\title{
ESTUDO DAS ALTERAÇÕES SAGITAIS, VERTICAIS E TRANSVERSAIS DECORRENTES DA DISTALIZAÇ̃̃O DOS MOLARES SUPERIORES COM O APARELHO PENDULUM
}

\section{Acácio Fuziy}

Tese apresentada à Faculdade de Odontologia de Bauru, da Universidade de São Paulo, como parte dos requisitos para obtenção do título de Doutor em Odontologia, na Área de Ortodontia.

$$
\text { (EDIÇÃO REVISADA) }
$$




\section{ESTUDO DAS ALTERAÇÕES SAGITAIS, VERTICAIS E TRANSVERSAIS DECORRENTES DA DISTALIZAÇ̃̃O DOS MOLARES SUPERIORES COM O APARELHO PENDULUM}

\section{Acácio Fuziy}

Tese apresentada à Faculdade de Odontologia de Bauru, da Universidade de São Paulo, como parte dos requisitos para obtenção do título de Doutor em Odontologia, na Área de Ortodontia.

Orientador: Prof. Dr. Renato Rodrigues de Almeida

(Edição Revisada)

Bauru

2001 


\section{Fuziy, Acácio}

F989e Estudo das alterações sagitais, verticais e transversais decorrentes da distalização dos molares superiores com o aparelho Pendulum./

Acácio Fuziy. - Bauru, 2001;

283p + apêndices: il.; $30 \mathrm{~cm}$

Tese (Doutorado) - Faculdade de Odontologia de Bauru. USP.

Orientador: Prof. Dr. Renato Rodrigues de Almeida

Autorizo, exclusivamente para fins acadêmicos e científicos, a reprodução total ou parcial desta tese, por processos fotocopiadores e outros meios eletrônicos.

\section{Acácio Fuziy}

Assinatura: 


\section{DADOS PESSOAIS}

\section{ACÁCIO FUZIY}

11 de outubro de 1965

1983-1987

1988-1992

1993

1994-1997

1998

Associações
Nascimento

Curso de Odontologia na Faculdade de Odontologia de Lins.

Curso de Especialização em Ortodontia na Faculdade de Odontologia de Londrina Universidade Estadual de Londrina - PR Professor Assistente da Faculdade de Ciências Odontológicas de Marília - Universidade de Marília.

Curso de Pós-graduação em Ortodontia, em nível de Mestrado, na Faculdade de Odontologia de Araraquara da Universidade Estadual Paulista.

Curso de Pós-graduação em Ortodontia, em nível de Doutorado, na Faculdade de Odontologia de Bauru da Universidade de São Paulo. Associação Brasileira de Ortodontia

Sociedade Paulista de Ortodontia Associação Paulista de Cirurgiões Dentistas. 
DEDICATÓRIA 
De dic atória

À Evelyn, minfa querida esposa, pela constante compreensãa, apoio e amor a mim dedicados durante essa longa jornada; pelos momentos dificeis em que abdicou da minha compantia e com paciência, soube esperar por um minuto de atenção. Com carinfo, amor e gratidão dedico-lhe esse trabalto. Consegui trilhar esse caminfo, e graças a seu incentivo alcanceio me u obje tivo. 
Ao meu filho César Henrique, que passou a integrar a minha vida, dedico esse trabalfo com muito amor. 
Aos meus pais, Iukio (in memorian) e Yoshiko, que incutiram na minha formação,o exemplo de amor, fronestidade, paciência e trabalfo.

Aos meus irmãos, Clarice e Eduardo pelos momentos compartilfados e por acreditarem em mim, dedico também esse trabalfo. 
AGRADECIMENTOS 
Agradecimento Especial,

Me u agradecimento especial ao $\operatorname{Prof}$. Dr.

Renato Rodrigues de Almeida, pela orientação precisa na realização dessa pesquisa, pela confiança depositada na mintra pessoa, pelo exemplo de luta e perseverança, pelos ensinamentos transmitidos e, acima de tudo, pela amizade.

A minha gratidão. 
Ao Professor Dr. José Fernando Castanka Henriques, Coordenador do Curso de Pós-graduação em Ortodontia, nível Doutorado, pela forma segura e pelo rigor na condução do Curso e pela experiência clínica e ensinamentos transmitidos, no decorrer desses três anos.

Meu sincero reconfecimento e agradecimento. 
Meus agradecimentos:

À Faculdade de Odontologia de Bauru - USP, representada nas pessoas de seu Diretor, Prof. Dr. Aymar Pavarini, e Prof. Dr. Luis Fernando Pegoraro, Presidente da Comissão de Pós-graduação, pela oportunidade que me foi concedida;

À coordenação do Curso de Pós-graduação em Ortodontia, representada na pessoa de seu Coordenador Prof. Dr. Iosé Fernando Castanfa Henriques;

Aos demais professores doutores da equipe da Disciplina de Ortodontia, Marcos Roberto de Freitas; Arnaldo Pinzan; Guilherme dos Reis Pereira Janson e Décio Rodrigues Martins, pelos confecimentos transmitidos, apoio e amizade.

Aos sogros gulio e Francisca pela confiança em mim depositada e pelo apoio nos momentos difice is;

$\mathcal{A}$ toda minfra familia pelo estimulo e carinfo; 
Aos amigos Prof. Dr. Iúlio de Araújo Gurgel e Prof. Paulo César Tukasan pela continua amizade e confiança em mim de positada;

Ao Prof. Antônio Vicente Fernandes, dire tor da Faculdade de Ciências Odontológicas da Universidade de Marília, pelo apoio e incentivo durante o desenvolver desse Curso;

Aos colegas de turma, Alexandre, Ricardo, Maria Helena, Liliana e Márcio pelos momentos inesquecíveis compartilfados e que o tempo torne eterna a amizade estabelecida durante a nossa caminfrada;

Aos colegas de "República", Alexandre e Cláudio pelas dificuldades que juntos enfrentamos e pela amizade durante os anos de convívio;

Aos funcionários da Disciplina de Ortodontia, Tia Maria, Sérgio, Cristina e Cristiane pela paciência e apoio durante o decorrer do Curso;

$\mathcal{A}$ Vera, em especial pela orientação precisa, paciência e amizade dedicada durante essa caminfada; 
Ao amigo Daniel, pela grande contribuição na elaboração das tabelas, refinamento das figuras, formatação final e impress ão da tese, o meu agradecimento especial e reconfecimento pela sua de dic açãa;

Às professoras Yolanda Matsuda e Lidia Scuracio pelas correções gramaticais e ortográficas;

Ao Prof. Dr. Iosé Eduardo Corrente pela paciência no desenvolvimento da análise estatística dos dados obtidos e pela precisão na elaboração do relatório estatístico;

Aos funcionários da Biblioteca e, em especial a Vera e Rita pelas orientações durante o desenvolver do Curso;

Às funcionárias da Pós-graduação e, em especial a Geane e Aurélio pela atenção e simpatia;

À professora Kïmie Nakagawa pelo auxílio na versãa do resumo para a língua inglesa; 
A FAPESP, pela bolsa de estudo concedida, viabilizando o curso de pós-graduação;

$\mathcal{A}$ Deus, pela sua continua proteção e por permitir que o sonho da Pós-graduação (Doutorado) realmente se tornasse re alidade;

E a todos aqueles que de alguma forma contribuiram para a realização desse trabalho,

Muito Obrigado! 
SUMÁRIO 


\section{SUMÁRIO}

Lista de figuras --------------------------------------------------------------- xvii

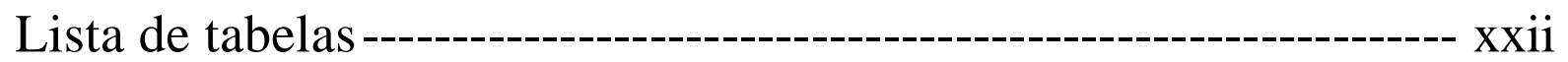

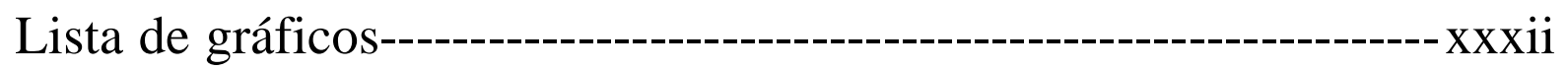

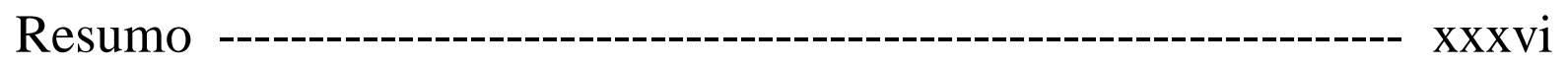

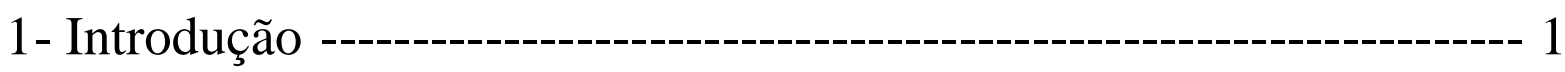

2- Revisão de literatura ------------------------------------------------------- 8

3- Proposição -------------------------------------------------------------------86

4- Material e métodos ------------------------------------------------------- 88

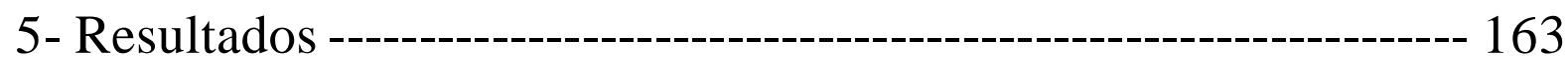

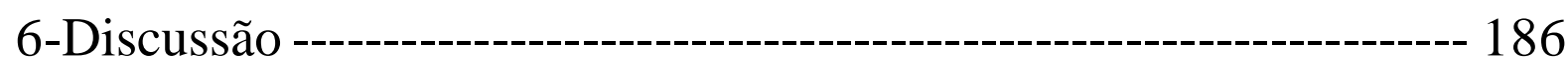

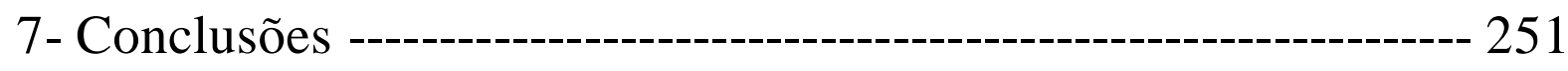

Referências bibliográficas --------------------------------------------------- 256

Abstract--------------------------------------------------------------------------- 281

Apêndices --------------------------------------------------------------------- 284 
LISTA DE FIGURAS 


\section{LISTA DE FIGURAS}

FIGURA 1- Fotografias extrabucais iniciais, de um paciente 90 apresentando as características da amostra;

FIGURA 2- Fotografia frontal intrabucal inicial, de um paciente da 90 amostra;

FIGURA 3- Fotografia intrabucal lateral direita inicial;

FIGURA 4- Fotografia intrabucal lateral esquerda inicial;

FIGURA 5- Início da fase clínica, com a separação dos primeiros molares e primeiros pré-molares superiores;

FIGURA 6- Bandagem do primeiro molar superior direito;

FIGURA 7- Bandagem do primeiro molar superior esquerdo; 92

FIGURA 8- Vista oclusal mostrando a adaptação do tubo lingual; 93

FIGURA 9- Vista oclusal mostrando a adaptação do tubo lingual; 93

FIGURA 10- Adaptação da banda do primeiro pré-molar superior; 93

FIGURA 11- Vista lateral direita, mostrando a banda do primeiro 93 pré-molar adaptada;

FIGURA 12- Vista lateral esquerda, mostrando a banda do primeiro pré-molar adaptada;

FIGURA 13- Dobra na extremidade do fio ortodôntico 0,9 mm para a construção do grampo de apoio oclusal;

FIGURA 14- Grampo adaptado na crista marginal mesial do 94 primeiro pré-molar superior;

FIGURA 15- Região de retenção do grampo;

FIGURA 16- Grampos de apoio oclusal finalizados; 95

FIGURA 17- Construção da região de retenção da mola 96 distalizadora; 
FIGURA 18- Posicionamento da mola, paralela à sutura palatina 96 mediana;

FIGURA 19- Construção do helicóide; 96

FIGURA 20- Construção da alça horizontal de ajuste; 96

FUGURA 21- Dimensões da mola distalizadora; 97

FIGURA 22- Mola recurvada para melhor adaptação no palato; 98

FIGURA 23- Adaptação do segmento intratubo; 98

FIGURA 24- Fixação dos elementos constituintes do aparelho para a 99 acrilização do botão palatino de Nance;

FIGURA 25- A construção do aparelho Pendex finalizada; 99

FIGURA 26- A construção do aparelho Pendulum finalizada; 99

FIGURA 27- Dobras de pré-ativação das molas distalizadoras; 100

FIGURA 28- Dobra de antiinclinação de $15^{\circ}$, em direção ao plano 100 oclusal;

FIGURA 29- Desenho esquemático da mola distalizadora com a 101 dobra de antiinclinação;

FIGURA 30- Aparelho Pendulum fixado por meio dos grampos de 102 apoio oclusal;

FIGURA 31- Aparelho Pendulum fixado por meio de bandas nos 102 primeiros pré-molares superiores;

FIGURA 32- Vista lateral direita da fixação do aparelho; 102

FIGURA 33- Vista hateral esquerda da fixação do aparelho; 102

FIGURA 34- Fotografias extrabucais iniciais; 103

FIGURA 35- Fotografia intrabucal frontal inicial; 103

FIGURA 36- Vista lateral direita e esquerda inicial; 104

FIGURA 37- Vista oclusal superior inicial; 104 
FIGURA 38- Fotografia intrabucal frontal pós-distalização dos 104 molares superiores;

FIGURA 39- Fotografias intrabucais laterais direita e esquerda, pós- 105 distalização dos molares superiores;

FIGURA 40- Fotografia intrabucal oclusal superior, pós-distalização 105 dos molares, com o botão palatino de Nance como forma de contenção;

FIGURA 41- Fotografias extrabucais iniciais;

FIGURA 42- Vista lateral direita e esquerda inicial;

106

FIGURA 43- Fotografia intrabucal oclusal superior inicial; 107

FIGURA 44- Fotografias intrabucais laterais, direita e esquerda, pós- 107 distalização dos molares superiores;

FIGURA 45- Fotografia intrabucal oclusal superior, pós-distalização dos molares;

FIGURA 46- Sistema de forças;

FIGURA 47- Sistema de forças;

FIGURA 48- Trajetória descrita pela mola;

FIGURA 49- Telerradiografias em norma lateral inicial e final;

FIGURA 50- Telerradiografias em normal lateral de $45^{\circ}$ inicial e final;

FIGURA 51- Desenho das estruturas anatômicas de interesse;

FIGURA 52- Pontos cefalométricos de interesse em tecido duro;

FIGURA 53- Pontos cefalométricos de interesse em tecido mole;

FIGURA 54- Linhas e planos cefalométricos utilizados;

FIGURA 55- Posição ântero-posterior da maxila; 
FIGURA 57- Relação maxilomandibular; 130

FIGURA 58- Padrão do esqueleto cefálico; 137

FIGURA 59- Alterações dentárias; 138

FIGURA 60- Padrão do perfil mole; 139

FIGURA 61- Desenho anatômico de interesse; 141

FIGURA 62- Pontos cefalométricos para o cefalograma de $45^{\circ}$; 143

FIGURA 63- Linhas e planos utilizados no cefalograma de 45\% 145

FIGURA 64- Alterações angulares no cefalograma de 45'; 147

FIGURA 65- Alterações dentárias verticais pela telerradiografia em 149 norma lateral de $45^{\circ}$;

FIGURA 66- Vista oclusal do modelo inicial; 151

FIGURA 67- Vista oclusal do modelo final; 151

FIGURA 68- Representação esquemática da localização dos pontos 153 cefalométricos;

FIGURA 69- Linhas de referência; 156

FIGURA 70- Medidas das alterações ântero-posteriores e 159

FIGURA 71- Medidas das alterações transversais. 160 


\section{LISTA DE TABELAS}




\section{LISTA DE TABELAS}

Tabela 1- Resultado do teste de Kruskal-Wallis para análise das 167 medidas da amostra total versus remedição para as fases inicial e final, em 10 pacientes;

Tabela 2- Resultado do teste de Kruskal-Wallis para análise de 168 erro, amostra total versus remedição para as fases inicial e final em 10 pacientes (lado direito);

Tabela 3- Resultado do teste de Kruskal-Wallis para análise de 169 erro, amostra total versus remedição para as fases inicial e final em 10 pacientes (lado esquerdo);

Tabela 4 Resultado do teste de Kruskal-Wallis para análise das 170 medidas da amostra total versus remedição dos modelos de estudo para as fases inicial e final, em 10 pacientes;

Tabela 5- Resultado do teste de Wilcoxon para dados pareados, 172 referente à análise da telerradiografia em norma lateral convencional para 31 pacientes;

Tabela 6- Resultado do teste de Wilcoxon para dados pareados, referente à análise da telerradigrafia em norma lateral de $45^{\circ}$ para 31 pacientes (lado direito); 
Tabela 7- Resultado do teste de Wilcoxon para dados pareados, 177 referente à análise da telerradigrafia em norma lateral de $45^{\circ}$ para 31 pacientes (lado esquerdo);

Tabela 8- Resultado do teste de Wilcoxon para dados pareados, 180 referente à análise oclusal de 31 pacientes;

Tabela 9- Valores obtidos para as diferenças entre as medidas 182 inicial e final para os dentes 15 e 16, valores absolutos para essas diferenças e porcentagem de abertura para o lado direito para esses dentes;

Tabela 10- Valores obtidos para as diferenças entre as medidas 183 inicial e final para os dentes 25 e 26 , valores absolutos para essas diferenças e porcentagem de abertura para o lado esquerdo para esses dentes;

Tabela 11- Taxa de distalização mensal para os lados direito e esquerdo;

Tabela 12- Idade inicial e final em meses dos pacientes da amostra;

Tabela 13- Tempo de tratamento em dias para a distalização dos molares superiores; 
Tabela 14- Dados referentes à avaliação da telerradiografia em norma lateral convencional (Fase inicial);

Tabela 15- Dados referentes à avaliação da telerradiografia em norma lateral convencional (Fase inicial);

Tabela 16- Dados referentes à avaliação da telerradiografia em norma lateral convencional (Fase inicial);

Tabela 17- Dados referentes à avaliação da telerradiografia em norma lateral convencional (Fase inicial);

Tabela 18- Dados referentes à avaliação da telerradiografia em norma lateral convencional (Fase final);

Tabela 19- Dados referentes à avaliação da telerradiografia em norma lateral convencional (Fase final);

Tabela 20- Dados referentes à avaliação da telerradiografia em norma lateral convencional (Fase final);

Tabela 21- Dados referentes à avaliação da telerradiografia em norma lateral convencional (Fase final); 
Tabela 22- Dados referentes à avaliação da telerradiografia em norma lateral convencional de 10 pacientes selecionados ao acaso (Valores retirados da amostra total da fase inicial);

Tabela 23- Dados referentes à remedição da telerradiografia em norma lateral convencional (Fase inicial);

Tabela 24- Dados referentes à avaliação da telerradiografia em norma lateral convencional de 10 pacientes selecionados ao acaso (Valores retirados da amostra total da fase inicial);

Tabela 25- Dados referentes à remedição da telerradiografia em norma lateral convencional (Fase inicial);

Tabela 26- Dados referentes à avaliação da telerradiografia em norma lateral convencional de 10 pacientes selecionados ao acaso (Valores retirados da amostra total da fase inicial);

Tabela 27- Dados referentes à remedição da telerradiografia em norma lateral convencional (Fase inicial); 
Tabela 28- Dados referentes à avaliação da telerradiografia em norma lateral convencional de 10 pacientes selecionados ao acaso (Valores retirados da amostra total da fase inicial);

Tabela 29- Dados referentes à remedição da telerradiografia em norma lateral convencional (Fase inicial);

Tabela 30- Dados referentes à avaliação da telerradiografia em norma lateral convencional de 10 pacientes selecionados ao acaso (Valores retirados da amostra total da fase final);

Tabela 31- Dados referentes à remedição da telerradiografia em norma lateral convencional (Fase final);

Tabela 32- Dados referentes à avaliação da telerradiografia em norma lateral convencional de 10 pacientes selecionados ao acaso (Valores retirados da amostra total da fase final);

Tabela 33- Dados referentes à remedição da telerradiografia em norma lateral convencional (Fase final); 
Tabela 34- Dados referentes à avaliação da telerradiografia em norma lateral convencional de 10 pacientes selecionados ao acaso (Valores retirados da amostra total da fase final);

Tabela 35- Dados referentes à remedição da telerradiografia em norma lateral convencional (Fase final);

Tabela 36- Dados referentes à avaliação da telerradiografia em norma lateral convencional de 10 pacientes selecionados ao acaso (Valores retirados da amostra total da fase final);

Tabela 37- Dados referentes à remedição da telerradiografia em norma lateral convencional (Fase final);

Tabela 38- Dados referentes à avaliação da telerradiografia em norma lateral de $45^{\circ}$, lados direito e esquerdo (Fase inicial);

Tabela 39- Dados referentes à avaliação da telerradiografia em norma lateral de $45^{\circ}$, lados direito e esquerdo (Fase inicial); 
Tabela 40- Dados referentes à avaliação da telerradiografia em norma lateral de $45^{\circ}$, lados direito e esquerdo (Fase final);

Tabela 41- Dados referentes à avaliação da telerradiografia em norma lateral de $45^{\circ}$, lados direito e esquerdo (Fase final);

Tabela 42- Dados referentes à avaliação da telerradiografia em norma lateral de $45^{\circ}$ de 10 pacientes selecionados ao acaso (Valores retirados da amostra total da fase inicial);

Tabela 43- Dados referentes à remedição da telerradiografia em norma lateral de $45^{\circ}$ de 10 pacientes (Fase inicial);

Tabela 44- Dados referentes à avaliação da telerradiografia em norma lateral de $45^{\circ}$ de 10 pacientes selecionados ao acaso (Valores retirados da amostra total da fase final);

Tabela 45- Dados referentes à remedição da telerradiografia em norma lateral de $45^{\circ}$ de 10 pacientes (Fase final);

Tabela 46- Dados referentes às posições iniciais dos dentes visualizadas pela análise de modelos, de 31 pacientes; 
Tabela 47- Dados referentes às posições iniciais dos dentes visualizadas pela análise de modelos, de 31 pacientes;

Tabela 48- Dados referentes às posições finais dos dentes visualizadas pela análise de modelos, de 31 pacientes;

Tabela 49- Dados referentes às posições finais dos dentes visualizadas pela análise de modelos, de 31 pacientes;

Tabela 50- Dados referentes à análise de modelos de 10 pacientes selecionados ao acaso (Valores retirados da amostra total da fase inicial);

Tabela 51- Dados referentes à remedição dos modelos de 10 pacientes (Fase inicial);

Tabela 52- Dados referentes à análise de modelos de 10 pacientes selecionados ao acaso (Valores retirados da amostra total da fase inicial);

Tabela 53- Dados referentes à remedição dos modelos de 10 pacientes (Fase inicial);

Tabela 54- Dados referentes à análise de modelos de 10 pacientes selecionados ao acaso (Valores retirados da amostra total da fase final); 
Tabela 55- Dados referentes à remedição dos modelos de 10 pacientes (Fase final);

Tabela 56- Dados referentes à análise de modelos de 10 pacientes selecionados ao acaso (Valores retirados da amostra total da fase final);

Tabela 57- Dados referentes à remedição dos modelos de 10 pacientes (Fase final) e

Tabela 58- Abertura de espaço medido diretamente nos modelos para o cálculo da taxa de distalização mensal. 
LISTA DE GRÁFICOS 


\section{LISTA DE GRÁFICOS}

Gráfico 1- Posição ântero-posterior da maxila avaliada pelo ângulo 201 SNA médio inicial e final;

Gráfico 2- Posição ântero-posterior da maxila avaliada pela 201 distância A-NPerp média inicial e final;

Gráfico 3- Posição ântero-posterior da mandíbula avaliada pelos 203 ângulos SNB e SND médio inicial e final;

Gráfico 4- Posição ântero-posterior da mandíbula avaliada pela 204 distância Pg-NPerp média inicial e final;

Gráfico 5- Relação vertical avaliada pelos valores médios iniciais e 206 finais de: AFAI, SN.GoGn, FMA, Frank.Ocl, Frank.Pal., Frank.GoGn, SN.PlOcl e SN.Gn;

Gráfico 6- Relação maxilomandibular avaliada pelos valores 209 médios iniciais e finais de ANB e Wits;

Gráfico 7- Alterações sagitais avaliadas pelas distâncias médias iniciais e finais de 4-PTV e 6-PTV;

Gráfico 8- Alterações angulares avaliadas pelos valores médios iniciais e finais de 1.Pal; 4.Pal; 5.Pal; 6.Pal e 7.Pal, referentes ao lado direito;

Gráfico 9- Alterações angulares avaliadas pelos valores médios iniciais e finais de 1.Pal; 4.Pal; 5.Pal; 6.Pal e 7.Pal, referentes ao lado esquerdo;

Gráfico 10- Alterações dentárias angulares avaliadas pelos valores médios iniciais e finais de 1.NA, Frank.4 e Frank.6; 
Gráfico 11- Alterações sagitais avaliadas pela análise de modelos, apresentando as distâncias médias iniciais e finais: Dist11, Dist-13, Dist-14, Dist-15, Dist-16 e Dist-17;

Gráfico 12- Alterações sagitais avaliadas pela análise de modelos, 228 apresentando as distâncias médias iniciais e finais: Dist21, Dist-23, Dist-24, Dist-25, Dist-26 e Dist-27;

Gráfico 13- Alterações sagitais dos incisivos superiores avaliadas 230 pelos valores médios iniciais e finais de 1-NA e 1-AV;

Gráfico 14- Alterações sagitais dos incisivos superiores avaliadas pelo valor médio inicial e final de 1-PTV;

Gráfico 15 - Alterações no trespasse vertical e horizontal observadas pelos valores médios iniciais e finais de Sobrem. e Sobres.;

Gráfico 16- Alterações no ângulo interincisivos 1.1, segundo os valores médios inicial e final;

Gráfico 17- Alterações verticais analisadas pelas medidas médias iniciais e finais de 1-Pal, 4-Pal, 5-Pal, 6-Pal e 7-Pal (lado direito);

Gráfico 18- Alterações verticais analisadas pelas medidas médias iniciais e finais de 1-Pal, 4-Pal, 5-Pal, 6-Pal e 7-Pal (lado esquerdo);

Gráfico 19- Alterações transversais analisadas pelas medidas lineares médias iniciais e finais: Expans-13, Expans-14, Expans-15, Expans-16 e Expans-17; 
Gráfico 20- Alterações transversais analisadas pelas medidas 243 lineares médias iniciais e finais: Expans-23, Expans-24, Expans-25, Expans-26 e Expans-27;

Gráfico 21- Alterações do perfil facial avaliadas pelas distâncias 249 médias iniciais e finais do Lábio superior/E e lábio inferior/E e

Gráfico 22- Alterações do perfil facial analisadas pelo ângulo 249 nasolabial médio inicial e final. 
RESUMO 


\section{RESUMO}

Nessa pesquisa, foram estudados 32 pacientes, 23 do sexo feminino e 9 do masculino, leucodermas, brasileiros, naturais da cidade de Bauru, estado de São Paulo, com idade variando de 11 anos e 6 meses a 17 anos e 9 meses, idade média de 14 anos e 7 meses, portadores de más oclusões de Classe II, $1^{\text {a }}$ divisão de Angle e presença de todos os dentes permanentes de segundo a segundo molar do lado oposto. Todos os indivíduos selecionados receberam como mecanismo para a distalização dos molares superiores, o aparelho Pendulum de Hilgers, que foi empregado por um período de 5,87 meses.

Foram feitas as telerradiografias em norma lateral convencional, lateral de $45^{\circ}$ e modelos de estudo, antes e depois das distalizações dos molares superiores. Foram obtidas as medidas cefalométricas e as medidas dos modelos de estudo e as diferenças entre as médias iniciais e finais do experimentos foram submetidas ao teste estatístico de Wilcoxon para dados pareados. Essa avaliação possibilitou verificar as alterações esqueléticas e os efeitos da distalização sobre os molares, pré-molares, caninos e incisivos superiores.

Com base nos resultados obtidos e na metodologia empregada, no que tange as alterações esqueléticas e dentárias decorrentes da distalização de primeiros e segundos molares superiores com o aparelho Pendulum, julga-se lícito concluir que a força leve e contínua das molas distalizadoras do aparelho e o intervalo de tempo não alteraram significativamente o posicionamento ânteroposterior da maxila e mandíbula.

Observou-se uma taxa de distalização mensal dos molares de 1,06 mm e 1,07 mm, respectivamente para os lados direito e esquerdo. Essa distalização foi acompanhada da inclinação distal das coroas dos molares que acarretou a 
rotação mandibular no sentido horário, refletindo diretamente no aumento da altura facial ântero-inferior.

O efeito recíproco do aparelho Pendulum sobre a unidade de ancoragem acarretou o movimento mesial dos primeiros e segundos pré-molares e dos caninos. Outro efeito negativo constatado foi o movimento vestibular dos incisivos superiores e a sua conseqüência para a alteração no perfil facial.

Associado a distalização dos molares superiores foi observado também alterações verticais e transversais em molares, pré-molares e caninos. 
INTRODUÇÃO 


\section{1 - INTRODUÇÃO}

Com a introdução da classificação das más oclusões, por ANGLE $^{07}$, em 1899, a Ortodontia recebeu um grande impulso na padronização das terminologias das anomalias. Assim sendo, a má oclusão de Classe II foi definida, nessa ocasião, como: “ a relação mesiodistal anormal dos arcos dentários com o arco inferior posicionado dorsalmente ao superior, resultando na desarmonia das linhas faciais e dos incisivos ". O autor atribuía a etiologia dessa má-oclusão somente para a mandíbula.

Posteriormente, $\mathrm{CASE}^{34}$, em 1907, mencionado como um notável crítico de Angle, considerou a classificação de Angle muito simplista e propôs a sua classificação em: Classe II, $1^{\text {a }}$ divisão, na qual se enquadravam os casos de

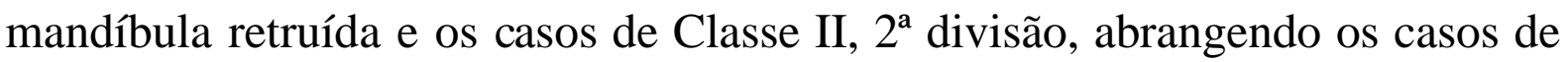
protrusão maxilar. Já nesse período nota-se a preocupação em definir os componentes envolvidos na determinação do referido problema, aceitando-se inclusive a participação da maxila na etiologia da má oclusão.

SILVA FILHO et al. ${ }^{137}$, em 1989, observaram que $42 \%$ das crianças naturais da cidade de Bauru-SP, na faixa etária de 7 a 11 anos, apresentavam a má oclusão de Classe II. Essa alta prevalência é um resultado comum nos levantamentos epidemiológicos de más oclusões, o que explica o interesse dos pesquisadores no seu estudo e nas tentativas de elaborar formas mais adequadas de tratamento.

A grande controvérsia está em definir a participação dos componentes esqueléticos e dentários, envolvidos nessa má-oclusão, com intuito de estabelecer planos de tratamento mais adequados. Na sua maioria, as pesquisas observam a posição ântero-posterior, basal e dento-alveolar, da maxila e 
mandíbula, além dos padrões esqueléticos no sentido vertical dos pacientes portadores de Classe II.

Quanto à posição esquelética da maxila em relação à base craniana, os resultados são bastante divergentes. Alguns pesquisadores relatam uma porcentagem de retrusão (RENFROE ${ }^{124}$, 1948; HARRIS et al. ${ }^{68}$, 1972; McNAMARA Jr. ${ }^{100}$, 1981; SIMPLÍCIO ${ }^{138}$, 1995), outros a protrusão (ELSASSER; WYLIE $^{45}$, 1948; ROTHSTEIN ${ }^{130}$, 1971; McNAMARA Jr. ${ }^{100}$, 1981; VALE; MARTINS ${ }^{147}$, 1987; SIMPLÍCIO $^{138}$, 1995) e, por fim, os que verificaram a maxila em posição normal (ELSASSER; WYLIE ${ }^{45}, 1948$; RIEDEL $^{125}$, 1952; HUNTER ${ }^{79}$, 1967; HITCHCOCK ${ }^{77}$, 1973; McNAMARA Jr. $\left.^{100}, 1981\right)$.

Com relação à mandíbula, a maioria dos autores relata uma maior frequiência de retrusão em relação à base do crânio (ELSASSER; WYLIE ${ }^{45}$, 1948; RENFROE ${ }^{124}, 1948$; GILMORE ${ }^{58}, 1950$; RIEDEL ${ }^{125}, 1952$ HUNTER $^{79}$, 1967; HTCHCOCK ${ }^{77}, 1973$; McNAMARA Jr. ${ }^{100}$, 1981, SIMPLÍCIO $^{138}$, 1995); alguns observaram um posicionamento normal (ELSASSER; WYLIE ${ }^{45}, 1948$; CALCOTE $^{28}$, 1960; ROTHSTEIN ${ }^{130}$, 1971; McNAMARA Jr. ${ }^{100}$, 1981; SIMPLÍCIO $^{138}$, 1995) e nenhuma citação de protrusão.

Outro componente que normalmente contribui para a má oclusão de Classe II é a posição dos dentes superiores em relação à estrutura esquelética da maxila. Sendo praticamente unânime entre os pesquisadores a constatação da protrusão dos dentes superiores (RENFROE ${ }^{124}$, 1948; RIEDEL ${ }^{125}$, 1952; HUNTER $^{79}$, 1967; ROTHSTEIN ${ }^{130}$, 1971; HARRIS et al. ${ }^{68}, 1972$; HITCHCOCK $^{77}$, 1973; SIMPLÍCIO ${ }^{138}$, 1995).

Quanto à participação da dentição inferior na má oclusão de Classe II, verifica-se com maior freqüência o posicionamento normal (THOMAZINHO ${ }^{143}$, 1970; HITCHCOCK ${ }^{77}$, 1971; MOYERS et al. ${ }^{106}$, 1980, MOYERS ${ }^{105}, 1948$; 
MOYERS; RIOLO ${ }^{107}$, 1991; McNAMARA Jr. ${ }^{100}$, 1981; SIMPLÍCIO ${ }^{138}$, 1995), e a protrusão foi verificada por SIMPLÍCIO ${ }^{138}$, em 1995. Enquanto que a retrusão também foi mencionada por $\left(\mathrm{HUNTER}^{79}, 1967\right.$; $\mathrm{HITCHCOK}^{77}, 1973$; HARRYS et al. ${ }^{68}$, 1972; VALE; MARTINS ${ }^{147}, 1987$ e SIMPLÍCIO ${ }^{138}$, 1995).

MOYERS et al. ${ }^{106}$, em 1980, identificaram, dentro de uma amostra de Classe II, levando-se em consideração o plano horizontal, seis subgrupos reconhecidos pelas letras $\mathrm{A}, \mathrm{B}, \mathrm{C}, \mathrm{D}, \mathrm{E}$ e $\mathrm{F}$ e que foram chamados de tipos. Entre esses, quatro são verdadeiras síndromes de Classe II (B,C, D e E), possuindo características esqueléticas e dentárias distintas, padrões morfológicos e de crescimento individuais. O tipo F, o maior observado, apresenta menos características esqueléticas de Classe II; porém, não se enquadra na má oclusão de Classe I. E, finalmente, o subgrupo tipo A, sem características esqueléticas, apenas dentárias.

Como podemos observar, as más oclusões de Classe II, $1^{\text {a }}$ divisão, não são todas iguais, suas etiologias diferem e seus prognósticos não são similares, e nem elas necessitam da mesma forma de tratamento.

Atualmente, muitas estratégias de tratamento estão disponíveis para os ortodontistas obterem a correção do relacionamento oclusal de Classe II. Entre essas, podemos citar os vários tipos de tração extrabucal, expansores, ortopedia funcional dos maxilares, aparelho fixo com e sem extrações dentárias. Entretanto, ainda é comum encontrar, entre os profissionais, aqueles que empregam apenas uma ou duas dessas opções, dependendo da sua preferência pessoal, experiência ou sucesso. Cada abordagem, porém, difere em seu efeito sobre as diversas regiões craniofaciais, estimulando, inibindo ou redirecionando o seu crescimento (McNAMARA Jr ${ }^{100}, 1981$ ).

É de fundamental importância a elaboração correta do diagnóstico diferencial para a determinação dos componentes que estão envolvidos na má- 
oclusão de Classe II, para que o tratamento seja direcionado segundo as necessidades dos casos em questão (MOYERS; RIOLO ${ }^{107}, 1991$ ).

As más oclusões do tipo A, apresentadas por MOYERS et al. ${ }^{106}$, em 1980, devem ser tratadas com a retração dos dentes superiores para uma relação molar e de incisivos normais, sem alterar a relação esquelética favorável, a dimensão vertical ou deslocar o arco inferior. Assim sendo, nesses casos está indicado o movimento distal dos molares superiores.

O método mais comumente utilizado é o aparelho extrabucal de ancoragem cervical, que oferece possibilidades de alterações ortopédicas e ortodônticas, porém, a grande desvantagem observada é a falta de cooperação durante o tratamento, o que poderá acarretar no insucesso.

O fator cooperação é o mais significante problema encontrado na distalização de molares superiores,o que pode ser verificado pela grande maioria dos ortodontistas. Dessa forma foram introduzidos os sistemas distalizadores intrabucais, dentre os quais os aparelhos removíveis. De acordo com CETLIN; TEN HOEVE ${ }^{36}$ (1983); JECKEL; RAKOSI ${ }^{83}$ (1991), porém, ainda dependiam da cooperação dos pacientes quanto ao uso dos mecanismos.

Mais recentemente, surgiram as modalidades de tratamento que não dependem dessa cooperação, dentre as quais os primeiros sistemas a serem introduzidos foram os magnetos (GIANELLY et al. ${ }^{57}$, 1988; BONDEMARK; $\left.\mathrm{KUROL}^{18}, 1992\right)$.

A característica da propriedade mecânica dos fios de níquel-titânio foi aproveitada no sistema apresentado por GIANELLY; BEDNAR; DIETZ ${ }^{55}$, 1991, que utilizou segmentos de molas comprimidas entre os segundos prémolares e os primeiros molares e por JONES; WHITE ${ }^{85}$, 1992, no aparelho Jones Jig, que também era composto por uma mola de níquel-titânio. 
Com o propósito de se aproveitar da propriedade de superelasticidade dos fios, surgiram outros métodos que incorporavam arcos de níquel-titânio com essa característica mecânica, estabelecendo uma deflexão entre os pré-molares e molares e resultando na força distalizadora (LOCATELLI et al. ${ }^{94}$, em $1992 \mathrm{e}$ GIANCOTTI; COZZA ${ }^{53}$, em 1998).

Outros sistemas foram apresentados, tais como o distalizador bimétrico de Wilson (WILSON; WILSON ${ }^{155}$, em 1980); o distal jet (CARANO; TESTA; SICILIANI $^{32}$, em 1996); aparelho de Nance modificado (REINER ${ }^{123}$, em 1992); alça em K (KALRA ${ }^{87}$, em 1995); hexahélice (REINA; MENDOZA ${ }^{122}$, em 1999); Pendulum modificado (ALMEIDA et al. ${ }^{05}$, em 1999).

Todos os aparelhos propostos desenvolvem sistemas de forças que atuam externamente ao centro de resistência dos molares, acarretando o estabelecimento de momentos que tendem a produzir efeitos rotacionais nos molares e dentes da unidade de ancoragem. Associadas a essas alterações sagitais existem ainda as forças verticais, que promovem os movimentos extrusivos e intrusivos desses elementos dentários. Pode-se ressaltar também a possibilidade de ocorrerem as mudanças no sentid o transversal, manifestando-se as expansões e contrações dos referidos dentes. Portanto, a grande preocupação dos profissionais é que esses efeitos indesejáveis sejam controlados ao máximo.

Independentemente do sistema, existe uma unanimidade de pensamento em relação à magnitude de força necessária para a distalização dos molares superiores. O ideal seria empregar as forças leves e contínuas e, considerando-se esse raciocínio, os sistemas que foram sendo apresentados procuraram explorar as propriedades mecânicas dos materiais que compunham os aparelhos, na tentativa de se obter a máxima distalização com o mínimo de efeitos indesejáveis na unidade de ancoragem. Porém, nos métodos intrabucais, sempre nos defrontaremos com algum potencial de ação sobre os pré-molares, 
caninos e incisivos, em razão de todos os métodos recorrerem ao botão palatino de Nance, ancorado ao palato, e em primeiros pré-molares, como alternativa de se tentar bloquear a ação recíproca das forças distalizadoras nesses elementos dentários.

HILGERS $^{74}$, em 1992, desenvolveu um novo tipo de aparelho, de simples construção e sem o custo elevado, denominado Pendulum, cuja função era promover a distalização dos primeiros molares e ou segundos molares superiores, em pacientes não colaboradores. Era um aparelho composto por um botão acrílico de Nance, apoiado no palato para a ancoragem, e molas construídas com fio de titânio-molibdênio e que produzem maior facilidade de controle e manuseio do aparelho, com a conseqüente rapidez em se alcançar a meta proposta, de distalização dos molares superiores.

Entretanto, desde a introdução do aparelho Pendulum, poucos relatos na literatura foram feitos com a preocupação de se quantificarem as alterações esqueléticas e dentárias, decorrentes da distalização dos molares superiores, com a utilização deste sistema. De tal forma a existirem dúvidas, principalmente sobre os efeitos dentários sagitais, verticais e transversais, nos primeiros e segundos molares e a ação recíproca sobre os primeiros e segundos pré-molares, caninos e incisivos.

Os objetivos desse trabalho foi elucidar as dúvidas existentes: a) no emprego do aparelho Pendulum, avaliando as alterações sagitais e verticais nos molares, pré-molares, caninos e incisivos, decorrentes da utilização do aparelho Pendulum, na distalização dos molares superiores em telerradiografias em norma de $45^{\circ}$; b) verificar as alterações esqueléticas e dentárias, sagitais e verticais, nas telerradiografias em norma lateral convencional; e c) as alterações sagitais e transversais, em modelos de estudo, obtidos no início do tratamento e após um período de 5,87 meses de aplicação desses mecanismos. 



\section{REVISÃO DA LITERATURA}

A má oclusão, de Classe II, pode apresentar diferentes componentes esqueléticos e dentários envolvidos no seu estabelecimento, podendo ser observadas alterações na posição ântero-posterior, basal e dentoalveolar, da maxila e mandíbula, além das manifestações em sentido vertical e que podem agravar a severidade do problema. Assim, o tratamento deve ser idealizado, buscando-se, especificamente, a correção dos componentes que apresentarem alterações.

Como já dissemos, muitas estratégias de tratamento estão, hoje, disponíveis para os ortodontistas obterem a correção da relação oclusal, de Classe II. Dentre essas, frisamos os vários tipos de tração extrabucal, expansores, a ortopedia funcional dos maxilares e extrações dentárias. Devemos ainda comentar sobre a distalização dos molares superiores, que pode proporcionar o alcance da relação molar, de Classe I, e assegurar a obtenção de espaços adicionais nos arcos dentários, quando as extrações não estão indicadas.

Justifica-se, portanto que a revisão da literatura abranja os seguintes aspectos:

2.1.- Componentes determinantes da má oclusão de Classe II e

2.2.- Distalização de molares superiores.

\section{1.- Componentes determinantes da má oclusão de Classe II}

O posicionamento dos primeiros molares superiores com a face e o crânio também tem sido motivo de estudo na literatura ortodôntica. BALDRIDGE $^{14}$, em 1941, analisou a posição da mandíbula e dos primeiros molares superiores, em relação à sua base óssea, em uma amostra de 50 
indivíduos com Classe I, 32 indivíduos com Classe II, $1^{\text {a }}$ divisão e 21 com Classe II, $2^{\mathrm{a}}$ divisão. $\mathrm{O}$ autor ${ }^{14}$ concluiu que os primeiros molares permanentes superiores assumiam a mesma relação com a face e crânio, nas más oclusões estudadas. Por outro lado, foi constatado que a mandíbula se posicionava corretamente nas más oclusões, de Classe I e Classe II, 2ª divisão, mas apresentava posicionada mais posterior em relação à base do crânio, na Classe II, $1^{\text {a }}$ divisão.

As características da má oclusão, de Classe II, foram abordadas por RENFROE $^{124}$, em 1948, ao estudar cefalometricamente 43 indivíduos com má oclusão, de Classe II, $1^{\text {a }}$ divisão, e 16 com Classe II, $2^{\text {a }}$ divisão. O autor ${ }^{124}$ verificou que a mandíbula não mostrava deficiência de desenvolvimento, mas se posicionava mais dorsalmente nas más oclusões, de Classes II, assim como os primeiros molares superiores apresentavam, nessa má oclusão, um posicionamento distal, ao invés de mesial. Enquanto a maxila caracterizava-se, na Classe I e Classe II, $2^{\text {a }}$ divisão, por uma posição mais ventral em relação à Classe II, $1^{\text {a }}$ divisão.

No mesmo ano, HIGLEY ${ }^{72}$, em 1948, preconizou a análise individual dos casos, como critério para se estabelecer o diagnóstico estrutural. Por meio da literatura, o autor apresentou algumas características que poderiam estar presentes na má oclusão, de Classe II, $1^{\text {a }}$ divisão de Angle: 1) a mandíbula e arcos dentários normais em forma e tamanho, mas posicionados dorsalmente em relação à maxila e ao crânio devido às seguintes razões: (a) os côndilos situados para cima e para trás na fossa mandibular e (b) a fossa mandibular localizada para cima e para trás, no crânio, com os côndilos em posição normal ou dorsal; 2) mandíbula apresentando corpo e ramo com tamanhos reduzidos; 3) mandíbula normal, mas os dentes inferiores posicionados distalmente; 4) ângulo goníaco muito agudo, causando um encurtamento aparente da mandíbula; 5) dentes 
póstero-superiores posicionados mesialmente ao normal e 6) combinação de dois ou mais desses fatores. Para o autor ${ }^{72}$, o mais importante seria analisar as estruturas craniofaciais de cada indivíduo e não estabelecer comparações com as médias de normalidade.

$\mathrm{Na}$ tentativa de analisar a natureza do prognatismo facial, BJÖRK ${ }^{17}$, em 1948, realizou um extenso estudo cefalométrico em 322 jovens suecos com 12 anos de idade, 281 recrutas do exército e um grupo controle de 20 indivíduos, com oclusão normal. Com relação a distoclusão, o pesquisador ${ }^{17}$ mostrou evidências de que essa má oclusão pode estar associada à maxila protruída, à posição dorsal da mandíbula, ou a uma combinação dos dois fatores. Como causas dessas alterações foram citadas: 1) a diferença relativa no tamanho dos maxilares, devido a um aumento no comprimento da maxila e à diminuição no comprimento mandibular; 2) diferença no prognatismo alveolar; 3) inclinação exagerada dos incisivos e 4) mobilidade da mandíbula na articulação têmporomandibular.

Empregando telerradiografias em norma lateral de dois grupos, o primeiro, constituído de indivíduos com má oclusão, de Classe II, $1^{\text {a }}$ divisão, dividido em 48 do gênero feminino e 45 do masculino; o outro grupo, denominado de controle, constituído de indivíduos com má oclusão, de Classe I, de ambos os gêneros, ELSASSER; WYLIE ${ }^{45}$, em 1948, verificaram que existia dimorfismo sexual, pois, estatisticamente, a Classe II, nos homens, apresentava protrusão maxilar, enquanto, nas mulheres, se verificava retrusão mandibular. Além disso, comprovaram que os homens, com Classe II, apresentavam maior comprimento total maxilar e mandibular do que as mulheres, mas quando comparados indivíduos do mesmo gênero, observaram que os homens, com Classe II, possuíam maior comprimento maxilar e os primeiros molares superiores, mais à frente. Da mesma forma, as mulheres, com Classe II, 
caracterizavam-se por um menor comprimento mandibular e incisivos centrais superiores com inclinação vestibular e protrusão mais acentuadas.

Utilizando a eletromiografia para avaliar o papel da articulação temporomandibular na etiologia da má oclusão de Classe II, MOYERS ${ }^{105} \mathrm{em}$ 1948, comparou a análise eletromiográfica da articulação temporomandibular de 16 indivíduos com má oclusão, de Classe II, $1^{\text {a }}$ divisão, com a análise de indivíduos com desenvolvimento normal. $\mathrm{O}$ autor ${ }^{105}$ constatou que os vários tipos existentes, de Classe II, $1^{\text {a }}$ divisão, possuíam atividades musculares diferentes, e, portanto, não poderiam receber a mesma forma de tratamento. $\mathrm{O}$ resultado dessa pesquisa demonstrou que nenhum desses casos com Classe II apresentava uma função muscular completamente normal e que o tratamento ortodôntico poderia alterar esse funcionamento.

A morfologia da má oclusão, da Classe II, $1^{\text {a }}$ divisão, foi analisada por GILMORE $^{58}$, em 1950, quando comparou as medições realizadas em telerradiografias de 67 indivíduos, portadores de más oclusões, de Classe II, $1^{\text {a }}$ divisão, dos quais 37 do gênero masculino e 30 do feminino, com medições feitas em telerradiografias de 61 ndivíduos com oclusão normal, sendo 31 do gênero masculino e 30 do feminino. $\mathrm{O}$ autor $^{58}$ verificou que a mandíbula no grupo da má oclusão, de Classe II, $1^{\text {a }}$ divisão, apresentava-se significantemente menor que do que nos casos de oclusão excelente, sendo mais crítica no gênero feminino, porém não havia diferença no tamanho da base anterior do crânio.

O padrão esquelético das más oclusões, de Classe I e Classe II, $1^{\text {a }}$ divisão, em telerradiografias em norma lateral, foi avaliado por $\mathrm{CRAIG}^{41}$, em 1951. Nessa pesquisa, comparou as características cefalométricas de dois grupos, com 12 anos de idade, sendo que 34 se enquadravam na má oclusão de

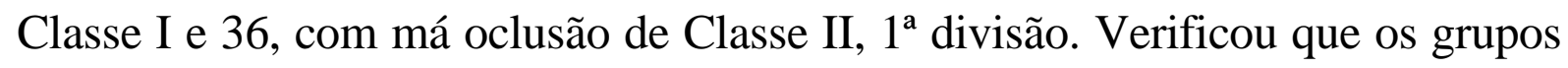
possuíam o mesmo padrão esquelético, exceto que o grupo da má oclusão de 
Classe II, apresentava menor comprimento mandibular e o primeiro molar posicionado mais posteriormente.

Vários componentes podem contribuir para a determinação da má oclusão, de Classe II. HEYDT ${ }^{71}$, em 1951, apresentou as diferentes condições que resultariam na anomalia, destacando as seguintes: 1) deslocamento mandibular, geralmente em decorrência de interferências dentárias que forçam a mandíbula dorsalmente, da posição de repouso à relação cêntrica; 2) arco dentário inferior retruído; 3) protrusão maxilar com deficiência mandibular; 4) potencial de protrusão maxilar; 5) retrusão mandibular estrutural; 6) protrusão bimaxilar e 7) potencial de protrusão bimaxilar. Ressaltou a importância da correta diferenciação dessas condições, para o direcionamento dos tratamentos adequados.

O tamanho e a posição ântero-posterior da maxila, em relação ao complexo craniofacial, têm sido um dos problemas principais da Ortodontia e Antropologia. RIEDEL ${ }^{125}$, em 1952, tentou determinar a existência da constância ou variação na relação da maxila com o crânio e mandíbula, em 52 adultos e 24 crianças com oclusão excelente, 38 indivíduos com má oclusão de Classe II, $1^{\text {a }}$ divisão, 10 com má oclusão de Classe II, $2^{\text {a }}$ divisão e 9 com Classe III. Verificou que não havia diferença significante na posição ântero-posterior da maxila com a base do crânio, em pacientes com oclusão excelente e má oclusão, porém havia uma tendência de a maxila tornar-se mais prognática com o crescimento. Constatou também que a mandíbula era menos prognática na má oclusão, de Classe II, $1^{\text {a }}$ divisão, do que nas oclusões normais. Observou que o ângulo ANB, nas más oclusões, variou consideravelmente e que o plano mandibular apresentava uma relativa inclinação com relação à linha SN. O autor $^{125}$ notou que a inclinação dos incisivos superiores com o plano horizontal de Frankfurt era de aproximadamente $111^{\circ}$ e $110^{\circ}$, respectivamente, nos adultos 
e crianças; entretanto, na Classe II, o valor era de $118^{\circ}$. Citou que a posição dos incisivos superiores era de 5,5 a 6,5 mm anterior ao plano facial, nas oclusões normais, e duas vezes mais nas más oclusões, de Classe II, $1^{\text {a }}$ divisão.

Provavelmente, a má oclusão de Classe II seja a anomalia que mais referência tem recebido na literatura ortodôntica; entretanto, ainda existem pontos contraditórios sobre a morfologia e fisiologia dessa variação. FISK et al. $^{50}$, em 1953, realizaram uma revisão da literatura, com o intuito de abordar as opiniões divergentes e propor estudos para esclarecer as dúvidas existentes sobre essa anomalia. Observaram que a maxila, na má oclusão de Classe II, $1^{\text {a }}$ divisão, poderia estar posicionada mais dorsalmente que na Classe I. Outros estudos relataram a não existência de diferenças e ainda um posicionamento mais ventral. Quanto ao comprimento da maxila, os autores ${ }^{50}$ citaram que a literatura apresenta trabalhos que constataram que a maxila era mais longa, curta ou sem diferença com o comprimento maxilar, na Classe I. Considerando-se a relação dos dentes com a maxila, observaram pontos divergentes, sendo que a grande maioria das pesquisas afirmaram que os dentes superiores encontravam-se posicionados mesialmente na maxila, porém também poderiam estar posicionados mais distalmente, ou, ainda, não apresentar diferença com as características da Classe I. Comentaram, então, que outras áreas do complexo craniofacial também contribuíam para a determinação da má oclusão. Os autores $^{50}$ constataram uma preponderância de opiniões de que a mandíbula era menor e posicionada mais dorsalmente em relação à base do crânio, na Classe II, $1^{\text {a }}$ divisão. A posição dos primeiros molares inferiores era variável, tanto na Classe I quanto na Classe II. Os autores ${ }^{50}$ verificaram que a contração muscular, principalmente do temporal, era a responsável pelo posicionamento mandibular. As alterações verticais e horizontais no complexo craniofacial têm sido motivo de estudo; assim sendo, ALTEMUS ${ }^{06}$, em 1955, comparou as 
telerradiografias de 20 meninas com oclusão normal, com as de 20 meninas que apresentavam má oclusão, de Classe II, $1^{\text {a }}$ divisão. Observou que as diferenças nas proporções das partes individuais eram pequenas nos grupos avaliados.

Com o objetivo de determinar as diferenças no comprimeto mandibular em pacientes com más oclusões, de Classe I e Classe II e pacientes com oclusão normal, CALCOTE ${ }^{28}$, em 1960, avaliou cefalometricamente 90 jovens com 12 anos de idade. Compôs a amostra com 30 casos para cada grupo, divididos eqüitativamente quanto ao gênero. Conforme os resultados do estudo, o autor $^{28}$ comprovou que não havia diferença significante com relação ao tamanho da mandíbula, entre os tipos de oclusão ou gênero.

Em 1964, ARAÚJO ${ }^{09}$, em sua tese de livre docência, estudou cefalometricamente 80 indivíduos, sendo cinco casos com oclusão normal; 50 com má oclusão de Classe I (18 do gênero masculino e 32 do feminino) e 25 com má oclusão de Classe II, $1^{\text {a }}$ divisão ( 8 do gênero masculino e 17 do feminino). Verificou que a maxila não apresentava diferença de posição entre os grupos, mas a mandíbula posicionava-se mais dorsalmente e possuía dimensões reduzidas na Classe II, $1^{\text {a }}$ divisão.

A dimensão vertical da face foi motivo de estudo na pesquisa de HUNTER $^{79}$, em 1967, que comparou um grupo de 50 pacientes com má oclusão

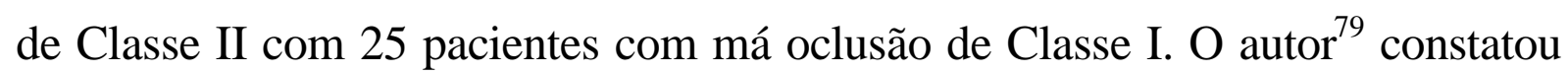
que nos casos de Classe II, o ângulo do plano mandibular apresentava-se levemente aumentado, a mandíbula era menor e posicionada posteriormente, entretanto, não observou diferenças de tamanho, no posicionamento da maxila.

Utilizando-se da análise arqueal, SASSOUNI ${ }^{134}$, em 1970, propôs quatro variações para a má oclusão de Classe II, combinando as alterações ântero-posteriores com as verticais, dentre as quais citou: a) dois tipos de Classe II, com mordida profunda, uma com retrusão mandibular e outra com protrusão 
maxilar e b) dois tipos de Classe II, com mordida aberta, uma associada a retrusão mandibular e outra com a protrusão maxilar. Concluiu que a simplificação do tratamento da má oclusão de Classe II, era muito perigosa e que o diagnóstico diferencial conduziria ao sucesso na correção dos verdadeiros problemas e na melhoria facial.

Em 1970, THOMAZINHO ${ }^{143}$, desenvolveu um estudo cefalométrico radiográfico em 120 indivíduos, leucodermas, com idade média de 12,5 anos, de ambos os gêneros, divididos em três grupos, um composto por indivíduos com oclusão normal; outro com más oclusões de Classe I e finalmente, um grupo com más oclusões de Classe II, $1^{a}$ divisão. A comparação dos grupos entre si, permitiu ao autor ${ }^{142}$ confirmar que a maxila apresentava-se posicionada de forma similar nos três grupos; a mandíbula, entretanto, diferiu nos casos de Classe II, assumindo uma posição retruída em relação à base do crânio. A inclinação dos incisivos superiores e inferiores em relação às suas bases ósseas, não apresentou diferenças entre os grupos, e na má oclusão de Classe II predominou um padrão vertical de crescimento.

Um estudo cefalométrico comparativo realizado por ROTHSTEIN ${ }^{130}$, em 1971, entre 273 indivíduos, com oclusão normal e 335 indivíduos, com más oclusões de Classe II, $1^{\text {a }}$ divisão, na faixa etária de 10 a 14 anos, revelou que os casos de Classe II apresentavam maior comprimento da base do crânio; a maxila mostrava-se protruída; o plano palatino inclinado superiormente e a mandíbula com dimensão normal e bem posicionada.

Avaliando os problemas que envolvem a má oclusão, de Classe II, $\mathrm{COBEN}^{40}$, em 1971, relatou que essa má oclusão poderia relacionar-se tanto com problemas na maxila quanto na mandíbula, e destacou a importância do diagnóstico diferencial, para que tratamentos eficientes pudessem ser implantados. Essa eficiência na condução desses tratamentos dependia, 
fundamentalmente, do pleno conhecimento de crescimento e desenvolvimento craniofacial, ou seja, saber a intensidade, forma, direção e época em que ocorrem as alterações nas diversas regiões do complexo craniofacial.

Empregando telerradiografias em norma lateral de 96 crianças com oclusão normal, e 63 com má oclusão de Classe II, $1^{\text {a }}$ divisão, de ambos os gêneros, na faixa etária de 10 a 12 anos, HARRIS et al. ${ }^{68}$, em 1972, aplicaram a análise de Steiner para avaliar os dois grupos e verificaram que: 1) a maxila apresentava a mesma posição ântero-posterior; 2) a mandíbula encontrava-se com maior retrusão, na Classe II; 3) os incisivos superiores eram mais protruídos na má oclusão, de Classe II e 4) os incisivos inferiores apresentavam uma inclinação semelhante. Os autores ${ }^{68}$ concluíram que as variáveis de Steiner mostram limitações na discriminação entre o normal e a má oclusão de Classe II.

Algumas características mandibulares em más oclusões de Classe I e Classe II, $1^{\text {a }}$ divisão, de Angle, foram estudadas por VIGORITO ${ }^{149}$, em 1973, numa amostra de 30 indivíduos que apresentavam má oclusão de Classe I, e 26 com Classe II, $1^{a}$ divisão. Concluiu que a mandíbula apresentou uma posição mais retruída em relação à base do crânio, nos casos de Classe II, $1^{\text {a }}$ divisão; a borda inferior do corpo mandibular mostrou tendência de exibir uma maior inclinação, na Classe II; o ângulo goníaco não caracterizou diferencialmente nenhum dos grupos estudados; a imagem radiográfica da sínfise mandibular exibiu uma inclinação lingual mais acentuada nos casos de Classe II, $1^{\text {a }}$ divisão; a projeção ortogonal da imagem da mandíbula, sobre a linha da sela-násio não demonstrou serem os segmentos anterior e posterior à sela túrcica, proporcionalmente, característicos das respectivas Classes de más oclusões a que pertencem; a dimensão da eminência mentoniana era maior nos casos de Classe II, $1^{\text {a }}$ divisão; a distância do ponto médio, do segmento oclusal dos primeiros molares inferiores permanentes, à borda inferior do corpo mandibular, 
não era caráter diferencial entre as más oclusões estudadas; a relação centesimal, estabelecida entre as dimensões longitudinais do ramo e do corpo mandibular, permite concluir ser, o primeiro, comparativamente menor, nos casos de Classe II, $1^{a}$ divisão; o comprimento mandibular, expresso pela soma de distâncias específicas do ramo e do corpo, era menor nos casos de Classe II, $1^{\text {a }}$ divisão.

Comparando-se uma amostra de 109 indivíduos com má oclusão de Classe II, $1^{\text {a }}$ divisão com um grupo de 40 indivíduos com oclusão normal, de ambos os gêneros, na faixa etária de 7 a 28 anos. HITCHCOCK ${ }^{77}$, em 1973, observou que a posição da maxila não apresentava diferença nos dois grupos estudados, mas por outro lado, a mandíbula encontrava-se retruída na Classe II. No aspecto dentário, verificou-se que os incisivos superiores mostravam uma maior protrusão na Classe II, enquanto que os incisivos inferiores, uma inclinação semelhante nos grupos.

Incentivados por suas observações clínicas e pesquisas anteriores, MOYERS et al. ${ }^{106}$, em 1980, tentaram desenvolver um sistema de diagnóstico diferencial e descrição dos tipos de más oclusões de Classe II. Com esse propósito, estudaram uma amostra de 697 crianças, sendo 540 selecionadas de clínicas privadas, 100 de clínicas de faculdades e 57, do arquivo do Centro de Crescimento e Desenvolvimento Humano da Universidade de Michigan. Na seleção das crianças, os autores ${ }^{106}$ empregaram os exames dos modelos de estudos, para não excluírem os tipos de Classe II, estritamente dentários. A avaliação das variáveis, nos planos horizontal e vertical, permitiu a divisão das crianças em diferentes tipos horizontais, denominados de: A, B, C, D, E e F.

O tipo A se caracterizava por um perfil esquelético e posição ânteroposterior dos maxilares normais. Os dentes inferiores encontravam-se com bom posicionamento em suas bases ósseas, mas a protrusão dos dentes superiores é 
que era a responsável pelo estabelecimento da relação molar de Classe II e pelo aumento na sobressaliência e sobremordida.

O tipo B mostrava um perfil excessivamente convexo, devido à proeminência da face média, associada a uma mandíbula de tamanho e relação ântero-posterior normal.

$\mathrm{O}$ tipo $\mathrm{C}$ caracterizava-se pelas dimensões faciais menores que dos outros tipos. O perfil era acentuadamente convexo e tanto a maxila quanto a mandíbula encontravam-se retruídas em relação à base do crânio. Os incisivos inferiores apresentavam-se inclinados vestibularmente e os superiores mostravam-se verticalizados ou inclinados para fora das suas bases ósseas, dependendo da categoria vertical. A mandíbula e maxila eram menores que o normal, sendo esse tipo mais prevalente no gênero feminino.

$\mathrm{O}$ tipo $\mathrm{D}$ apresentava o perfil esquelético retrognático, com a mandíbula menor que o normal. A face média encontrava-se normal ou levemente diminuída. Os incisivos inferiores mostravam-se verticalizados ou inclinados lingualmente, enquanto que os superiores se apresentavam vestibularizados.

O tipo E mostrava um perfil acentuadamente convexo, devido à proeminência da face média e à mandíbula normal ou, até, levemente prognática. Os incisivos superiores e inferiores geralmente eram protruídos em relação às suas bases ósseas.

O tipo F compreendia o maior subgrupo, sendo mais heterogêneo, com características suaves de Classe II. Foi considerado uma forma mais branda e não sintomática dos tipos $\mathrm{B}, \mathrm{C}, \mathrm{D}$ ou $\mathrm{E}$.

Os autores ${ }^{106}$ distribuíram a ocorrência dos tipos em: tipo A com 7,4\%; tipo $\mathrm{B}$, com $11,4 \%$; tipo $\mathrm{C}$, totalizando $12 \%$; tipo $\mathrm{D}$, manifestando-se em $26,5 \%$; 
tipo E, com $9,9 \%$; tipo F, com o total de $27,3 \%$; sem classificação, apenas $1,7 \%$ e dados incompletos em $3,6 \%$.

Com o intuito de determinar a frequiência com que os componentes principais da má oclusão de Classe II, de Angle, ocorrem, McNAMARA Jr. ${ }^{100}$, em 1981, analisou cefalometricamente 277 indivíduos, de ambos os gêneros, com idades entre 8 e 10 anos. $\mathrm{O}$ autor ${ }^{100}$ concluiu que essa anomalia poderia ser o resultado da combinação de vários componentes esqueléticos e dentários. $\mathrm{Na}$ maioria dos casos, foi observado que a maxila se encontrava em posição normal, mas, quando alterada, grande parte se apresentava retruída. Por outro lado, os dentes superiores mostravam-se protruídos, mais que as constatações feitas por outros estudos prévios na literatura. A retrusão mandibular caracterizou-se como sinal mais comum dessa amostra, apresentando, geralmente, os incisivos inferiores bem posicionados. Aproximadamente metade dos casos demonstraram desenvolvimento vertical acentuado. $\mathrm{O}$ autor ${ }^{100}$ destacou a importância do diagnóstico diferencial no direcionamento do tratamento que atue na região do complexo craniofacial afetada.

Discutindo sobre as vantagens e desvantagens das extrações dentárias no tratamento das más oclusões de Classe II, MUIR ${ }^{108}$, em 1982, comentou que essa má oclusão é uma anomalia com diferentes formas de manifestações de convexidade facial e posicionamentos dentários. Ressaltou que a análise adequada da face e da oclusão é necessária para direcionar o plano de tratamento satisfatório. Diante de uma protrusão facial suave associada ao apinhamento severo, as extrações dentárias estarão incluídas no plano de tratamento. Em outras situações, a má oclusão pode ser tratada sem extrações. O tratamento sem extrações deveria ser considerado nos casos em que há um bom padrão esquelético, com perfil facial equilibrado, ou a proporção ósseo-dentária é favorável e existe a possibilidade de se aproveitar o potencial de crescimento. 
Os registros longitudinais proporcionam informações sobre as características da oclusão normal e má oclusão. BUSCHANG et al. ${ }^{23}$, em 1986, estudaram um grupo de 40 indivíduos do gênero masculino, dos quais 20 apresentavam-se com oclusão normal e 20 com má oclusão de Classe II (12 com $1^{\text {a }}$ divisão e 8 , com $2^{\mathrm{a}}$ divisão). A amostra foi composta de uma série completa de registros longitudinais, em telerradiografias tomadas em norma lateral, dos 40 indivíduos nas idades de 11, 12, 13 e 14 anos. Os autores ${ }^{23}$ demonstraram que havia um maior crescimento da base do crânio, na Classe II, $2^{\text {a }}$ divisão, em relação à $1^{\mathrm{a}}$ divisão. A Classe II, $1^{\mathrm{a}}$ divisão, apresentou o comprimento mandibular extremamente menor e maior discrepância ântero-posterior das bases ósseas.

Realizando uma avaliação cefalométrica das estruturas dentoesqueléticas, em 50 indivíduos, com má oclusão de Classe II, $1^{\text {a }}$ divisão de Angle, sendo 23 do gênero masculino e 27 do feminino, na faixa etária de 9 a 15 anos, VALE; MARTINS ${ }^{147}$, em 1987, revelaram que a maxila se apresentou bastante variável, com uma discreta tendência para a protrusão, enquanto a mandíbula variou do normal para retrognática. No aspecto dentário, os incisivos superiores demonstraram uma excessiva inclinação vestibular, porém os incisivos inferiores, uma posição mais lingual. Evidenciaram também uma acentuada predisposição para o desenvolvimento vertical excessivo do complexo craniofacial e o conseqüente aumento da altura facial ântero-inferior. Não observaram a manifestação do dimorfismo sexual.

O acompanhamento de indivíduos com más oclusões de Classe II, $1^{\text {a }}$ divisão, não tratados, proporciona informações sobre as alterações dentofaciais que ocorrem com o decorrer do tempo. CARTER ${ }^{33}$, em 1987, apresentou as medidas cefalométricas de 30 indivíduos, sendo 15 do gênero feminino e 15 do masculino, com más oclusões de Classe II, $1^{\text {a }}$ divisão. Utilizou dois conjuntos de 
telerradiografias, o primeiro obtido quando os pacientes apresentavam a idade média de 12 anos e um mês e o segundo, aos 17 anos e cinco meses. Comparou os valores médios de 38 parâmetros esqueléticos e dentários entre os grupos do gênero feminino e masculino. Constatou que a maxila era normal, enquanto que a mandíbula suavemente retruída em relação à base do crânio. $\mathrm{O}$ autor $^{33}$ observou também que o ângulo ANB mostrava uma considerável variação e que houve maior protrusão dos incisivos superiores, no grupo da Classe II. As dimensões lineares eram três vezes maiores no gênero masculino do que no feminino. Os resultados demonstraram a ocorrência de maior rotação mandibular no sentid o horário no gênero feminino.

Em 1989, AIDAR; SCANAVINI ${ }^{01}$ estudaram, cefalometricamente, o padrão de crescimento facial, segundo os dados de SIRIWAT; JARABAK, de pacientes com oclusão normal e das más oclusões de Classe I, Classe II, $1^{\mathrm{a}}$ e $2^{\mathrm{a}}$ divisões, e Classe III. A amostragem constou de 200 telerradiografias divididas, eqüitativamente, em cinco grupos de acordo com o tipo de oclusão. Os autores ${ }^{01}$ constataram para a má oclusão de Classe II, $1^{\text {a }}$ divisão, um predomínio do padrão de crescimento facial neutro, com a maxila de tamanho normal ou ligeiramente retruída, enquanto que a mandíbula se apresentava excessivamente retruída em relação à base anterior do crânio e reduzida em tamanho, quando comparada aos outros grupos estudados.

Segundo MOYERS; RIOLO ${ }^{107}$, em 1991, a definição dos tipos clínicos de más oclusões de Classe II facilitou a elaboração das estratégias de tratamento, pois possibilitou condições de: 1) agrupar os casos com características semelhantes e que, portanto, necessitavam de planos de tratamentos comuns; 2) localizar as regiões craniofaciais em desequilíbrio; 3) estimar, de maneira mais precisa, os efeitos do crescimento das estruturas craniofaciais; 4) determinar a melhor abordagem terapêutica para as 
necessidades específicas individuais. Comentaram que a melhor estratégia de tratamento consistia em retrair os dentes superiores para uma relação molar e de incisivos normais, sem alterar a relação esquelética favorável, a dimensão vertical ou deslocamento do arco inferior. Portanto, deveriam: 1) girar, inclinar e transladar os molares permanentes superiores, sem extruir, usando o aparelho extrabucal; 2) retrair os incisivos superiores, intruindo quando necessário; 3) ajustar a inclinação e a posição dos incisivos superiores ao perfil esquelético e 4) coordenar as formas dos arcos superior e inferior.

Estudando as características cefalométricas da má oclusão de Classe II, $1^{\text {a }}$ divisão de Angle, em 200 leucodermas brasileiros da região Nordeste, eqüitativamente distribuídos quanto ao gênero, com idade variando de 6 anos e 11 meses a 19 anos e nove meses, MAIA ${ }^{96}$, em 1993 observou o seguinte: predomínio do vetor vertical de crescimento facial; a dominância do perfil facial convexo, com a maxila normal ou protruída e a mandíbula com definida tendência retrusiva; os incisivos superiores e inferiores inclinados para a vestibular e protruídos; o trespasse horizontal aumentado e o vertical, normal.

Uma análise da posição sagital da maxila e mandíbula é essencial para o planejamento do tratamento ortopédico e ortodôntico-cirúrgico. ROSENBLUM $^{129}$, em 1995, avaliou o envolvimento da retrusão mandibular e protrusão maxilar, na definição da má oclusão de Classe II, fundamentando-se em quatro indicadores cefalométricos para cada base óssea. Com esse objetivo, o autor ${ }^{129}$ analisou as telerradiografias de 103 indivíduos com padrão esquelético de Classe II, de ambos os gêneros, em vários níveis de maturação óssea. Os resultados demonstraram que a protrusão maxilar era responsável pela determinação da Classe II e que a mandibula se apresentava normal.

A aplicação do método de diagnóstico diferencial e a classificação proposta por MOYERS et al. ${ }^{106}$, em 1980, para a má oclusão de Classe II, foi 
motivo de enfoque no estudo realizado por SIMPLÍCIO ${ }^{138}$, em 1995. O autor $^{138}$ procurou verificar os componentes dento-esqueléticos, nos sentidos horizontal e vertical, que mais freqüentemente determinaram a má oclusão de Classe II, em 100 indivíduos leucodermas, com idade variando de oito a 12 anos, naturais de Teresina-Piauí, distribuídos igualmente quanto ao gênero. Concluiu que a maxila protruída predominou no gênero masculino, sendo a classificação normal a mais prevalente no gênero feminino; a posição da mandíbula, em ambos os gêneros, variou entre normal e retruída, assim como os incisivos inferiores apresentaram-se, na maioria dos casos, normais e os superiores, protruídos. $\mathrm{O}$ padrão vertical normal foi o mais observado.

O crescimento craniofacial em pacientes apresentando más oclusões de Classe II e oclusão normal, entre os 10 e 12 anos de idade, foi avaliado por URSI; McNAMARA Jr ${ }^{146}$, em 1997. Para tanto, selecionaram 29 indivíduos que apresentavam essa má oclusão e 30 com oclusão normal, que foram acompanhados dos 10,6 aos 12,6 anos. Concluíram que os pacientes com distoclusão apresentavam uma base craniana mais alongada, que a maxila encontrava-se posicionada sagitalmente de maneira semelhante aos dos indivíduos com oclusão normal. Entretanto, os pacientes com más oclusões de Classe II possuíam a mandíbula mais retrognática, a altura facial ântero-inferior maior, que era provavelmente, resultante do crescimento craniofacial mais vertical.Os incisivos e molares superiores eram mias extruídos e os incisivos inferiores mais protruídos e extruídos. O crescimento craniofacial dos dois grupos foi, durante o período avaliado de 24 meses, muito semelhante em todos os aspectos, indicando que as diferenças observadas devem ser atribuídas ao crescimento na primeira década de vida.

Investigando o comportamento de determinadas estruturas dentárias e esqueléticas em telerradiografias em norma lateral, de 45 crianças brasileiras (23 
meninos e 22 meninas), com idade entre oito e 12 anos, portadoras de má oclusão de Classe II, $1^{\text {a }}$ divisão, MISAKA; FANTINI ${ }^{102}$, em 1997, concluíram que: 1) a maxila encontrou-se, no geral, bem posicionada, com tendência à protrusão; 2) o arco dentário superior mostrava-se protruído e o arco inferior, retruído; 3) a mandíbula apresentava uma nítida propensão ao retrognatismo e 4) o padrão esquelético da face indicou a tendência ao desenvolvimento vertical.

As modificações que ocorriam no comprimento mandibular e na relação maxilomandibular, da dentadura decídua à permanente, foram abordados por BISHARA ${ }^{16}$, em 1998. O autor ${ }^{16}$ empregou uma amostra de 30 indivíduos (15 do gênero masculino e 15 do feminino), e comparou com 35 indivíduos (20 do gênero masculino e 15 do feminino) do grupo controle com oclusão normal. $\mathrm{O}$ autor ${ }^{16}$ constatou que os casos de Classe II apresentavam a mandíbula com posicionamento dorsal e comprimento diminuído. Acrescentou, ainda, que havia uma maior convexidade esquelética facial nessa má oclusão, devido à retrusão mandibular.

O diagnóstico diferencial dos componentes horizontais da Classe II, $1^{\mathrm{a}}$ divisão, de acordo com o método proposto por MOYERS et al. ${ }^{106}$, foi abordado por TUKASAN $^{145}$, em 1999, num estudo cefalométrico realizado em 120 indivíduos leucodermas, com má oclusão de Classe II, $1^{\text {a }}$ divisão de Angle, de ambos os gêneros (60 do masculino e 60 do feminino), na faixa etária de 12 a 15 anos. Baseado nos resultados obtidos da amostra, concluiu que: 1) o tipo $\mathrm{F}$ foi o mais freqüente, seguido do tipo B. Os demais tipos demonstraram porcentagens muito próximas, entre si; 2) não houve diferença estatisticamente significativa na distribuição dos tipos horizontais de Classe II entre os dois gêneros; 3) a protrusão maxilar foi mais freqüente, em ambos os gêneros; 4) o retrognatismo mandibular foi mais freqüente no gênero feminino, enquanto o gênero masculino mostrou valores estatisticamente semelhantes para a normalidade e 
retrognatismo mandibular; 5) a posição normal dos incisivos inferiores foi a mais freqüente no gênero feminino, enquanto o gênero masculino apresentou valores iguais para a posição normal e vestibular e, 6) a posição vestibular dos incisivos superiores foi a mais freqüente em ambos os gêneros.

\section{2.- Distalização dos molares superiores}

Tentativas têm sido feitas para esclarecer dúvidas existentes em relação às forças extrabucais, tais como: 1) redireciona o crescimento maxilar?; 2) afeta o crescimento alveolar?; 3) o movimento que prevalece é de inclinação?; 4) libera as interferências oclusais, liberando o crescimento mandibular?; 5) são fisiológicas?; 6) podem causar impacções dos segundos e terceiros molares?; 7) provocam a inclinação lingual excessiva dos incisivos superiores? e 8) qual a melhor tração?. GRABER ${ }^{61}$, em 1955, verificou que não havia evidências de que o crescimento maxilar fosse afetado, porém o crescimento alveolar era influenciado por alterações ântero-posteriores das bases apicais. Com relação à distalização de molares superiores, o autor ${ }^{61}$ afirmou que o movimento de translação poderia ser alcançado mais facilmente com as extrações de segundos molares e que na maioria dos casos, o que se observava era a excessiva inclinação distal dos molares. Em 100 casos tratados, observou que poderia ocorrer uma impacção temporária dos segundos molares, pela excessiva inclinação distal dos primeiros molares, mas após a remoção das forças extrabucais e a conseqüente verticalização desses elementos, os segundos molares irromperiam sem problemas. Entretanto, em casos severos, comentou que os desvios das posições dos segundos molares e as impacções dos terceiros molares eram manifestações que deveriam ser consideradas com cautela.

Os efeitos esqueléticos e dentários das forças extrabucais na correção da má oclusão de Classe II devem ser analisados isoladamente para se verificar a 
participação de cada componente na correção do problema. KLEIN ${ }^{88}$, em 1957, analisou as alterações sagitais dos molares e se as respostas variaram, segundo o padrão de crescimento facial com o uso da ancoragem cervical. Empregou uma amostra composta de 24 indivíduos, sendo treze meninos e onze meninas, com idade média de oito anos e seis meses, caracterizados pela má oclusão de Classe II, $1^{\text {a }}$ divisão. Todos foram tratados com aparelhos extrabucais com ancoragem cervical. Verificou um aumento médio no eixo Y de crescimento de $4 \mathrm{~mm}$ e uma variação anual de $2,8 \mathrm{~mm}$, associado a abertura de $3^{\circ}$. Observou uma redução na convexidade facial de $2,8^{\circ}$ e no ângulo SNA de $1,3^{\circ}$. Na amostra estudada, houve um aumento na angulação do plano palatal em relação à $\mathrm{SN}$ de $1,75^{\circ}$ e a alteração do plano oclusal com o mandibular foi insignificante. Constatou, neste estudo, a taxa de 1 a $3 \mathrm{~mm}$ de distalização dos molares, inclinação distal de 1,2 ${ }^{\circ}$ e extrusão de 2,3 mm. Concluiu que: 1) a inclinação dos molares poderia ser controlada pela manipulação adequada do aparelho; 2) o movimento distal ocorreu na maioria dos casos; 3) a extrusão dos molares não era problemática; 4) o ponto A sofreu um movimento para trás e 5) o plano palatal inclinou-se para baixo, sugerindo alterações na estrutura da maxila.

Um dos requisitos essenciais para se alcançar a cooperação quanto ao uso dos aparelhos extrabucais é que seja confortável e aceito pela maioria dos pacientes. O aparelho extrabucal de tração cervical preenche esses requisitos. $\mathrm{KLOEHN}^{89}$, em 1961, apresentou os resultados do tratamento de sete pacientes, portadores de más oclusões de Classe II para ilustrar as variações individuais de respostas ao tratamento. O objetivo de tratamento foi distalizar os dentes superiores, estabelecendo uma relação funcional com os seus antagonistas, sem movimentar os dentes inferiores mesialmente. A resposta alcançada no alinhamento de todos os dentes, assim como o equilíbrio facial, variou em cada caso. O tempo de tratamento também diferiu entre os casos, não sendo possível 
determinar uma regra fixa. Concluiu que houve evidências suficientes da distalização dos dentes superiores, com a força de ancoragem cervical. O crescimento para frente do arco dentário e do processo alveolar foi redirecionado em muitos casos.

Examinando a distalização de molares superiores com aparelhos extrabucais de ancoragem occipital, BAALACK; POULSEN ${ }^{11}$, em 1966, empregaram uma amostra de 29 pacientes, dos quais nove do gênero masculino e vinte do feminino, apresentando a idade média de 11 anos, os quais foram tratados com ancoragem occipital durante um ano, para a distalização de molares superiores. Analisaram modelos de estudo iniciais, seis meses após o início do tratamento e totalizando 12 meses de tratamento. Avaliaram os seguintes aspectos: 1) tempo de tratamento; 2) importância do grau de irrupção dos segundos molares; 3) modificação na relação molar, comparada ao movimento distal dos molares; 4) sobressaliência e 5) migração mesial de molares superiores em casos não tratados. O movimento distal foi medido usando-se uma linha de referência horizontal, pela rugosidade palatina, na região de primeiros pré-molares e outra linha, de referência vertical, pela papila palatina. A distalização média foi $0,95 \mathrm{~mm}$ e a expansão, de $0,37 \mathrm{~mm}$, após o período de um ano. Observaram que o movimento distal foi maior nos casos onde os segundos molares não estavam presentes. O movimento mesial dos primeiros molares superiores, no grupo não tratado, foi $0,9 \mathrm{~mm}$. Concluíram que o prognóstico do movimento distal dos primeiros molares superiores seria maior, quando o tratamento fosse realizado antes da irrupção dos segundos molares.

As rugosidades palatinas são de especial interesse na avaliação dos movimentos dos dentes superiores. PEAVY Jr; KENDRICK ${ }^{115}$, em 1967, analisaram os efeitos do reposicionamento dentário sobre as rugosidades 
palatinas. Empregaram modelos de estudo, pré e pós-tratamento, de 15 indivíduos que foram submetidos ao tratamento ortodôntico, com extrações de pré-molares e retração dos dentes ântero-superiores. Observaram ligeiras alterações morfológicas em 127 rugosidades, como resultado do movimento dentário, indicando que o padrão das rugosidades não era alterado.

A cooperação dos pacientes durante o tratamento ortodôntico é um dos fatores importantes na obtenção do sucesso no resultado final. ALLAN; HODGSON $^{02}$, em 1968, tentaram relacionar a cooperação do paciente no tratamento ortodôntico com características padronizadas da personalidade. Segundo os resultados dessa pesquisa, os autores ${ }^{02}$ verificaram que os pacientes mais cooperadores eram aqueles com idade de 14 anos ou menos. Eram pacientes mais entusiásticos, saudáveis, bem-controlados, responsáveis e confiantes. Os pacientes acima de 14 anos eram menos cooperadores, independentes, indiferentes, nervosos, temperamentais, impacientes, individualistas, intolerantes para atividades dependentes de esforço pessoal ou atenção prolongada.

O sucesso no tratamento com aparelhos extrabucais depende do controle da magnitude, direção, duração da força e a compreensão da mecânica envolvida. ARMSTRONG ${ }^{10}$, em 1971, estudou como esses fatores poderiam ser explorados para aumentar a efetividade no tratamento das más oclusões. Considerou de extrema importância o domínio da direção da força aplicada, em relação ao centro de resistência dos incisivos e molares superiores, para que movimentos dentários mais controlados fossem alcançados. Dessa forma haveria resultados melhores, obtendo-se não somente as inclinações distais dos molares, mas também o movimento distal de translação com pouco efeito extrusivo. Recomendou, na maioria dos casos, a aplicação de forças paralelas ao plano oclusal, sendo que a magnitude ideal da força distal seria de $1262 \mathrm{~g}$, em cada 
molar. Salientou que o tempo de utilização dos aparelhos está diretamente ligado à duração do tratamento, assim como aos resultados finais. Comentou que o uso da força extrabucal, por 14 horas, em pacientes no estágio da dentadura mista, proporciona resultados em um período de tempo de aproximadamente quatro a seis meses, desde que a cooperação, quanto à utilização do aparelho, seja adequada.

A cooperação dos pacientes, quanto ao uso dos aparelhos extrabucais e elásticos intermaxilares, foi avaliada por CRAWFORD ${ }^{42}$, em 1974, em 49 pacientes submetidos ao tratamento ortodôntico. Informações sobre as características da personalidade dos pacientes, motivação e interesse quanto ao tratamento foram obtidas a partir de questionários que foram aplicados aos pacientes e responsáveis. As variáveis que mais se relacionaram à boa cooperação foram a idade e características de personalidade. Os questionários revelaram que os pacientes e responsáveis estavam mais preocupados com a melhoria das características faciais do que com o posicionamento dentário, e que os pacientes não consideravam a manutenção da boa higiene bucal um aspecto de cooperação importante no tratamento ortodôntico.

É comumente aceito que o crescimento exerce grande importância no tratamento ortodôntico, particularmente nos casos que necessitam de melhoria na posição ântero-posterior da maxila e mandíbula. Na correção das más oclusões de Classe II, a tração cervical é freqüentemente indicada na dentadura mista. WIESLANDER ${ }^{152}$, em 1975, estudou um grupo de 23 pacientes, com más oclusões de Classe II, que foram tratados com a tração cervical na dentadura mista. Uma força de 286,9 a $430,3 \mathrm{~g}$ foi aplicada nos primeiros molares permanentes, por 12 a 14 horas por dia. Os resultados indicaram que a quantidade e direção de crescimento contribuíram para um efetivo tratamento. $\mathrm{O}$ crescimento vertical mostrou-se correlacionado à melhoria na relação 
maxilomandibular. A maior redução no ângulo ANB foi verificada quando o tratamento era realizado na dentadura mista. Observou-se que o movimento distal dos molares foi mais evidente no tratamento precoce.

A motivação psicológica e social foi avaliada por DORSEY; $\mathrm{KORABIK}^{44}$, em 1977, quando analisaram, por meio de questionários, os pacientes e seus respectivos pais, da clínica de Ortodontia da Universidade de Saint Louis e de dois consultórios particulares. Os pacientes eram predominantemente do gênero feminino, a decisão pelo tratamento geralmente era feita pela mãe, e os tratamentos eram mais importantes para os pais do que para os filhos. A motivação principal era a melhoria na aparência, acreditando que isso proporcionaria novas oportunidades sociais e ocupacionais. As pessoas da classe média-baixa atribuíram maior importância ao tratamento do que as pessoas da classe média-alta. Isso pode ser atribuído à maior necessidade de aceitação social e por maiores aspirações para os seus filhos.

O conceito de sistema modular utiliza módulos bimétricos internos e externos, coordenados com qualquer outro aparelho, para facilitar as funções dos mecanismos. WILSON ${ }^{153}$, em 1978, apresentou o sistema de $\operatorname{arcos} 3 \mathrm{D}$, que possibilita o controle do nivelamento, distorções do arco, dobras de terceira ordem, distalização rápida dos molares sem o uso de aparelhos extrabucais, expansão e fechamento de espaços. Na distalização dos molares, empregou tubos duplos, sendo que um tubo de diâmetro .045" e 6,3 mm de comprimento era posicionado cervicalmente. Essa posição era responsável pela distalização dos molares superiores, controlando-se a inclinação axial. O sistema ainda era composto pelo arco bimétrico, que consiste de extremidades de diâmetro .040", o qual proporcionava a rigidez necessária e o suporte para aparelhos extrabucais. Complementando o mecanismo de distalização, um tubo de diâmetro .045" deslizava-se livremente sobre o arco bimétrico e, quando ativado por meio de 
elásticos intermaxilares, de Classe II, comprimia a secção de mola contra os molares, produzindo a força distalizadora. Recomendou o uso dos elásticos de Classe II, 12 horas por dia, por um período aproximado de seis semanas, para se estabelecer a neutroclusão. Concluiu que a presença dos segundos molares deveria ser determinada antes da distalização, para se evitar a impactação vestibular desses elementos dentários. Os primeiros molares poderiam ser distalizados diante da evidenciação radiográfica da existência de espaço, caso contrário seria prudente aguardar a irrupção dos segundos molares.

O estudo da migração normal dos dentes posteriores, durante o crescimento, é de fundamental importância para desenvolver as referências úteis ao plano de tratamento e para a avaliação dos resultados finais de tratamento. VAN DER LINDEN ${ }^{148}$, em 1978, tentou: 1) estabelecer as mudanças dimensionais e posicionais das rugosidades palatinas, que ocorriam com o crescimento e desenvolvimento normais; 2) analisar as relações entre os dentes posteriores e as rugosidades palatinas projetadas no plano médio-sagital, em indivíduos que não haviam sido submetidos ao tratamento ortodôntico e, 3) investigar a possibilidade de utilizar as rugosidades palatinas como referência para avaliar os resultados de tratamento. Com esse objetivo, analisou 65 crianças com idade variando de 6 a 16 anos e seis casos tratados com a aplicação de força distal sobre os primeiros molares superiores. Realizou medições empregando-se as demarcações laterais e mediais das rugosidades anterior e intermediária, ponto posterior da rugosidade medial, ponto posterior da rugosidade lateral, ponto médio na rugosidade anterior e ponto médio da parte dorsal do palato, ponto distal dos caninos decíduos ou permanentes, ponto mesial dos primeiros molares permanentes. Concluiu que os pontos da rugosidade palatina lateral não se alteram consideravelmente, e portanto, podem ser usadas como referências para se analisar as mudanças de posições dos dentes posteriores. 
Algumas pesquisas defendem a eficácia dos aparelhos extrabucais no controle ortopédico. MILLS; HOLMAN; GRABER ${ }^{101}$, em 1978, investigaram as mudanças no complexo dentofacial, em decorrência da aplicação da tração cervical, com força pesada intermitente, na maxila de pacientes em crescimento, com má oclusão. A amostra consistiu em 135 indivíduos, sendo 51 meninos com idade média de 11,55 anos e 84 meninas com idade média de 10,40 anos. Todos os indivíduos foram caracterizados com más oclusões de Classe II, $1^{\text {a }}$ divisão, distoclusão maior que 4 a $6 \mathrm{~mm}$. O tratamento restringiu-se ao arco superior, empregando-se a força extrabucal cervical pesada e intermitente, de $941 \mathrm{~g}$ por lado. A direção da tração foi ajustada em aproximadamente $22^{\circ}$ abaixo do plano oclusal, produzindo um componente vertical de força, de $380 \mathrm{~g}$. Orientaram os pacientes a usarem os aparelhos de 10 a 12 horas por dia. Utilizaram as telerradiografias laterais, iniciais e finais, para verificarem as alterações individuais e as do grupo. Constataram que a alteração significante ocorreu no ponto A, afetando o ângulo SNA que, para baixo e para trás. Observaram ainda, o aumento do ângulo SN.SGn, em comparação ao grupo controle. O tratamento teve um efeito de contenção sobre a irrupção normal dos molares superiores, para baixo e para frente. Verificaram que os molares superiores sofreram a inclinação distal durante o tratamento, e que recidivou um pouco, após a remoção dos aparelhos.

A cooperação do paciente quanto ao uso dos dispositivos mostra uma relação direta com o sucesso do tratamento. CLEMMER; HAYES ${ }^{39}$, em 1979, estudaram a cooperação de vinte pacientes no uso dos aparelhos extrabucais. Observaram que os contrastes estavam no dimorfismo sexual e na interrelação da má oclusão com a atitude do paciente. Pacientes que mais necessitavam dos aparelhos extrabucais apresentavam um maior potencial para desenvolver atitudes problemáticas, como o baixo aproveitamento escolar. As meninas eram 
mais cooperadoras no uso dos aparelhos extrabucais, sendo motivadas mais pela estética dentofacial do que os meninos. Objetivando melhorar a motivação dos meninos, os ortodontistas deveriam conscientizá-los de suas responsabilidades nos resultados dos tratamentos. Concluíram que os profissionais poderiam sensibilizar os pacientes quanto à severidade das más oclusões, aumentando, dessa forma, o interesse pela terapia ortodôntica.

Os primeiros molares superiores são as chaves para a análise do comprimento do arco, diagnóstico e plano de tratamento. As possibilidades de distalizar os molares, mesmo que seja em poucos milímetros, protruir os incisivos e promover uma ligeira expansão, produzem novos parâmetros para o aumento do comprimento de arco. WILSON; WILSON ${ }^{155}$, em 1980, afirmaram que, quando os molares eram distalizados, a rotação ocorria próxima ao centro das raízes, e o arranjo das fibras periodontais da porção distal das raízes resistia à intrusão. Concomitantemente, não se observava o controle adequado das rotações o que forçava o rearranjo das fibras periodontais por mesial, causando a extrusão das cúspides mesiais e um efeito de dobras de segunda ordem sobre as cúspides distais. Comentaram que o posicionamento dos tubos, cervicalmente, mostrava uma diferença marcante na inclinação distal com a aplicação da força. Quando o movimento distal era tentado com arcos contínuos, os momentos e a inclinação distal aumentavam a fricção e o atrito, tornando a distalização em massa, dos segmentos posteriores, uma tarefa muito difícil. Por essa razão, os autores ${ }^{155}$ recomendaram o emprego de arcos seccionados, nas fases iniciais, e a montagem progressiva dos aparelhos.

O valor dos modelos de estudo na avaliação tridimensional das más oclusões, auxiliando no diagnóstico e elaboração do plano de tratamento foi explorado por WHITE ${ }^{151}$, em 1982, por meio do emprego dos oclusogramas. Segundo o autor $^{151}$ o oclusograma proporciona a reprodução de 1:1 das 
superfícies oclusais dos modelos de estudo, sendo útil clinicamente na individualização das formas dos arcos, na análise de modelos, nas simulações oclusais, na análise da discrepância de Bolton, na avaliação do plano de tratamento. Concluiu que os oclusogramas representam instrumentos de precisão que auxiliam no diagnóstico e na definição do plano de tratamento.

Recentes avanços na mecanoterapia reduziram a necessidade das extrações na correção das más oclusões de Classe I e II. CETLIN; TEN $\operatorname{HOEVE}^{36}$, em 1983, comentaram que o movimento distal de corpo era essencial para prevenir a recidiva dos molares inclinados e para evitar a necessidade futura da verticalização radicular. Recomendaram para o movimento distal de corpo, dos molares superiores, a combinação do aparelho extrabucal com a força intrabucal de um aparelho removível, composto por grampos de retenção, molas distalizadoras e uma placa de resina acrílica. A ancoragem para o aparelho removível era proporcionada pela correta adaptação no palato da placa de resina acrílica que deveria se estender até os incisivos, formando um plano para liberação da oclusão. A retenção era oferecida pelos grampos de Adams nos primeiros pré-molares, e o aparelho extrabucal deveria ser usado, 24 horas por dia. As molas eram ativadas 1 a 1,5 mm, gerando uma força distal de $30 \mathrm{~g}$. No plano vertical, a mola era direcionada o mais próximo possível da gengiva, sem causar a irritação para minimizar a inclinação dos dentes. O aparelho removível distalizava as coroas com relativa facilidade, e o aparelho extrabucal complementava o sistema, exercendo uma força distal de $150 \mathrm{~g}$ por lado, devendo ser usado 12 a 14 horas por dia. $\mathrm{O}$ controle adequado das asas externas produzia o momento que deslocava as raízes dos molares. Verificaram a ocorrência da expansão dos caninos, segundos pré-molares e primeiros molares, respectivamente, de 3,0; 4,6 e 5,0 $\mathrm{mm}$. 
As molas abertas são ativadas por compressão e exercem forças, simultaneamente, em duas direções. Os ortodontistas tentam quantificar as forças produzidas, para que possam controlar melhor o tempo de tratamento, assim como selecionar as molas mais adequadas ao movimento dentário desejado. CHACONAS; CAPUTO; HARVEY ${ }^{37}$, em 1984, analisaram e compararam a produção de força nas curvas de carga-deflexão, para molas construídas com fios de vários diâmetros e produzidas por três diferentes fabricantes, auxiliando, portanto, os clínicos na seleção das molas ideais para uma determinada aplicação. Observaram que para as molas abertas, diminuindose o diâmetro, aumentava-se a força produzida para uma determinada ativação, enquanto que aumentando-se o diâmetro do fio, proporcionavam-se os mesmos efeitos no comportamento das molas. Isso significava que molas construídas com diâmetro maior, e com fio de menor calibre, seriam indicadas para uso ortodôntico, pois as forças seriam mais constantes. Verificaram que, quando as molas eram comprimidas, um terço do seu comprimento original, ou $6 \mathrm{~mm}$, resultaria em força dentro do limite de 270 a 540 g. Os clínicos deveriam certificar-se de que as forças produzidas estariam dentro dos níveis adequados aos movimentos dentários.

Um dos problemas associados com a força extrabucal cervical, para a correção da má oclusão, de Classe II, é a extrusão dos molares superiores. CANGLIALOSI et al. $^{30}$, em 1988, estudaram os efeitos do tratamento sem extrações, da má oclusão de Classe II, com a terapia Edgewise e o aparelho extrabucal cervical. Avaliaram as telerradiografias laterais de 43 pacientes, que foram submetidos ao tratamento, por um período de dois anos e oito meses. Observaram que: 1) o crescimento da maxila foi redirecionado e a mandíbula continuou com o seu crescimento normal; 2) a redução no ângulo SNB contribuiu para a diminuição do ANB; 3) a parte anterior do palato inclinou-se 
para baixo; 4) os incisivos superiores inclinaram-se para a lingual; 5) a convexidade facial sofreu redução e 6) os primeiros molares superiores sofreram extrusão e movimento mesial.

A superelasticidade e as propriedades mecânicas das ligas de níqueltitânio japonês também têm sido exploradas na fabricação das molas abertas e fechadas. MIURA et al. ${ }^{103}$, em 1988, realizaram ensaios mecânicos com molas abertas e fechadas, fabricadas com ligas de níquel-titânio e compararam com as de aço. Observaram que as molas de níquel-titânio exibiam propriedades de memória superior e de superelasticidade similar às propriedades dos arcos de níquel-titânio japonês. Mostraram que a atividade de superelasticidade poderia ser efetivamente controlada pela alteração no diâmetro do fio, diâmetro da luz da mola e por transformações martensíticas de temperatura. Citaram, como característica importante das molas, a capacidade de exercer forças constantes e contínuas, sendo possível usá-las seletivamente na obtenção de um ótimo movimento dentário. Verificaram que a superelasticidade era evidente, quando as molas abertas eram comprimidas de 75 a $15 \%$. Observaram também que as molas abertas mostraram valores de cargas de superelasticidade mais constantes e, portanto, as forças contínuas poderiam ser alcançadas mais com as molas abertas do que com as molas fechadas. Entretanto, consideraram de difícil controle, o estágio final da deflexão, pois a força remanescente não era suficiente ao movimento dentário. Conseqüentemente, as molas abertas deveriam ser um pouco maiores que à distância desejada do movimento a ser alcançado.

O uso de magnetos, associado a outros aparelhos, tem mostrado as suas vantagens na distalização de molares. GIANELLY; VAITAS; THOMAS ${ }^{56}$, em 1989, analisaram modelos de estudo, pré e pós-tratamento, de oito pacientes que utilizaram magnetos de repulsão, para distalizar os molares superiores, 
ancorados por um botão palatino de Nance, cimentado em primeiros prémolares. Os magnetos foram reativados semanalmente. Verificaram a boa adaptação dos pacientes com relação aos aparelhos e, na remoção, constatava-se geralmente uma ligeira irritação na mucosa do palato, sob o acrílico do botão palatino, que persistia por uma a duas semanas. Quando os segundos molares não estavam presentes, observava-se um movimento mais rápido dos molares para uma relação de Classe I, dentro de um período de dois a cinco meses. Quando os segundos molares estavam presentes, o tempo de tratamento aumentava um pouco, sendo que, nos adultos, o resultado era menos previsível. Concluíram que essa forma de abordagem proporcionava uma menor perda de ancoragem. Consistentemente, $80 \%$ do espaço criado era representado pelo movimento distal dos molares e, portanto, a cada $5 \mathrm{~mm}$ de espaço aberto, os molares eram movimentados, posteriormente, $4 \mathrm{~mm}$, enquanto que os prémolares e incisivos movimentavam-se $1,0 \mathrm{~mm}$.

Devido à falta de cooperação dos pacientes, os tratamentos podem ser encerrados precocemente, ou não ser possível alcançar o sucesso ao final. BRATTSTRÖM; INGELSSON; ABERG ${ }^{21}$, em 1991, incluíram nesse estudo, pacientes que haviam utilizado aparelhos extrabucais, ativadores, aparelhos removíveis e aparelhos fixos. Observaram que a falta de cooperação e a finalização precoce do tratamento relacionava-se com possíveis desconfortos, sendo que em $26 \%$ dos pacientes a razão era a dor.

As fotocópias dos modelos de estudo foram empregadas por $\mathrm{YEN}^{157}$ em 1991, na análise de Bolton, na mensuração das distâncias intercaninos e intermolares, na medição do comprimento do arco e na definição da forma dos arcos e na determinação do espaço disponível. O autor ${ }^{157}$ concluiu que a utilização do método computadorizado simplifica a tarefa das medições e reduz o tempo para a finalização dessas análises. 
A superelasticidade das ligas de níquel-titânio também tem sido aproveitada na distalização de molares superiores. GIANELLY; BEDNAR; DIETZ $^{55}$, em 1991, descreveram que as molas superelásticas de níquel-titânio podem ser empregadas, independente da cooperação dos pacientes, exercendo força distalizadora de $100 \mathrm{~g}$ e produzindo a taxa mensal de movimento de $1 \mathrm{a}$ $1,5 \mathrm{~mm}$. Utilizaram um arco superior de aço inoxidável .016" X .022”, com molas superelásticas, comprimidas de 8 a $10 \mathrm{~mm}$, por meio de um gancho do tipo Gurin contra os primeiros molares. A ancoragem era obtida por meio de um aparelho de Nance, modificado e associado a uma mola verticalizadora, construída com fio de aço inoxidável .018”, posicionada nas ranhuras verticais dos braquetes dos primeiros pré-molares, direcionando as coroas distalmente. Comentaram que em $25 \%$ dos pacientes, com a presença dos segundos molares superiores, era necessário o emprego de elásticos de Classe II, para se controlar a posição dos incisivos. $\mathrm{O}$ controle no arco inferior era proporcionado por um arco .018" x .022", com $10^{\circ}$ de torque lingual de raiz nos incisivos.

Para HILGERS ${ }^{73}$, em 1991, as correções das más oclusões de Classe II geralmente requereram uma expansão da maxila. Introduziu um aparelho de expansão maxilar que apresentava como vantagem a possibilidade de se realizar a disjunção palatina e a correção da relação oclusal de Classe II, com uma mínima cooperação do paciente. Esse aparelho consistia de duas bandas nos primeiros molares, uma extensão de fio com helicóide soldada nas bandas, um segmento de fio servindo como apoio oclusal nos primeiros pré-molares ou primeiros molares decíduos, uma placa de resina acrílica e um parafuso expansor. A extensão de fio com helicóide promoveria uma rotação e distalização dos molares superiores, aproveitando-se da ancoragem oferecida pela resina. O parafuso expansor produziria a disjunção palatina, sendo ativado um quarto de volta por dia. Realizou pequenos desgastes nas extremidades da 
resina para se evitar a compressão da mucosa e o aparelho era cimentado nos molares. Posteriormente, era colado com resina acrílica nos primeiros prémolares. A pré-ativação do aparelho consistia de três etapas:1) girar as bandas dos primeiros molares distalmente por meio dos helicóides, aproximadamente duas vezes a rotação necessária; 2) colocar uma dobra em direção lingual na porção vertical do fio que se estendia do acrílico e se dirigia para as bandas; 3) incorporar uma dobra de segunda ordem nos molares. Recomendou que os pacientes fossem avaliados a cada duas semanas, e após a correção, um período de três meses de estabilização.

Os magnetos podem proporcionar a força contínua necessária para estabelecer a relação molar, de Classe I, na dentadura mista. ITOH et al. ${ }^{80}$, em 1991, estudaram a distalização dos molares com magnetos. O sistema de distalização era composto por dois magnetos em cada quadrante posterior. O magneto mesial de cada par movimentava-se livremente ao longo de um segmento de fio e a força magnética, de aproximadamente $230 \mathrm{~g}$, era liberada quando a barra deslizante contactava-se com o magneto mesial, levando-o de encontro ao magneto distal. A distalização dos molares resultava da separação dos magnetos. A ancoragem era estabelecida por um botão palatino de Nance. As reativações eram realizadas a cada duas semanas. A distalização dos molares variava de $0,5 \mathrm{~mm}$ a $3,7 \mathrm{~mm}$, com uma média de $2,1 \mathrm{~mm}$, e a inclinação distal, de $0^{\circ}$ a $16,0^{\circ}$, com média de $7,4^{\circ}$. O movimento vestibular dos incisivos ocorria de $0,5 \mathrm{~mm}$ a $2,4 \mathrm{~mm}$, com uma média de $1,2 \mathrm{~mm}$ e inclinação de $0,5^{\circ}$ a $12,0^{\circ}$, sendo, a média, de $3,8^{\circ}$. A rotação molar variava de $0^{\circ}$ a $29,0^{\circ}$, e média de $6,2^{\circ}$. Verificaram que a força magnética diminuía de $50-70 \%$ a cada 0,5 a $1,0 \mathrm{~mm}$ de movimento dos molares e, portanto, aconselharam a realização das reativações a cada duas semanas. 
A falta de cooperação no uso das forças extrabucais, para promover a distalização dos molares, faz com que a procura por mecanismos alternativos seja grande. ROSÉ ${ }^{128}$, em 1992, apresentou um novo sistema composto por bandas, com tubos nos segundos pré-molares e primeiros molares. A ancoragem era constituída pelas bandas nos segundos pré-molares e uma estrutura de fio de aço inoxidável de 1,0 mm, soldada a essas bandas e que se estendia anteriormente. Uma cobertura de resina acrílica envolvia essa estrutura metálica e contactava os elementos dentário s de segundo pré-molar a segundo pré-molar. O elemento ativo consistia de uma mola de níquel-titânio ou de aço inoxidável, que pressionava diretamente as bandas dos primeiros molares superiores, promovendo a distalização dos mesmos.

Os efeitos dentofaciais na distalização simultânea dos primeiros e segundos molares, com magnetos de repulsão, foram estudados por BONDEMARK; KUROL ${ }^{18}$, em 1992. Nessa pesquisa, selecionaram dez indivíduos, nove do gênero feminino e um do masculino, portadores de más oclusões, de Classe II, apresentando uma deficiência de espaço total de 2 a 5 mm, com idade média aproximada de 13 anos e cinco meses. Todos foram tratados com magnetos de samário-cobalto, que produzia força inicial de $225 \mathrm{~g}$. As reativações eram realizadas a cada três semanas, ou seja, quando a separação das faces dos magnetos atingia cerca 1,5 a 2,0 mm. Esse protocolo de reativações evitava que a força atingisse uma magnitude inferior a $60 \mathrm{~g}$. O tempo de tratamento foi de 16,6 semanas, até que os molares alcançassem a relação molar de Classe I. Os movimentos dentários foram analisados por meio de medições em modelos de estudo, fotografias laterais dos modelos e telerradiografias em norma lateral, das fases inicial e final de distalização dos molares. O movimento médio da coroa do molar foi de 4,2 $\mathrm{mm}$, e os primeiros molares inclinaram-se distalmente e sofreram rotação distovestibular de 8,0 e 
$8,5^{\circ}$, respectivamente. A inclinação distal e a rotação distovestibular dos segundos molares foi de 5,6 e 7,0 $0^{\circ}$, respectivamente. As forças recíprocas resultaram no ligeiro aumento da inclinação vestibular dos incisivos superiores. A perda de ancoragem ocorreu em aproximadamente $1,5 \mathrm{~mm}$. Concluíram que a distalização simultânea de primeiros e segundos molares poderia ser uma alternativa de tratamento ortodôntico, que cumpria os objetivos, num período de tempo relativamente curto. Recomendaram a realização da verticalização, a correção das rotações dos molares e os ajustes oclusais, na fase pós-distalização.

A superelasticidade dos fios de níquel-titânio com forma de memória Neosentalloy também foi explorada como um recurso alternativo na distalização dos molares. LOCATELLI et al. ${ }^{94}$, em 1992, empregaram arcos de níquel-titânio com três delimitadores de segmentos, posicionados, o primeiro m distal dos braquetes dos primeiros pré-molares; o segundo, de 5 a $7 \mathrm{~mm}$, distalmente ao tubo do molar e o terceiro, entre incisivos laterais e caninos superiores. $\mathrm{O}$ arco apresentava um comprimento de 5 a $7 \mathrm{~mm}$ maior do que o espaço disponível no segmento e, como consequiência, defletia o excesso para a região gengival entre os primeiros molares e primeiros pré-molares. Ao retornar para a forma original, o arco exercia uma força distalizadora de $100 \mathrm{~g}$ e um componente mesial de reação sobre os primeiros pré-molares, caninos e incisivos. Usaram, como reforço de ancoragem, elásticos de Classe II, de 100 a 150 g, adaptados do gancho, entre os incisivos laterais e caninos, aos molares inferiores, ou um botão palatino de Nance. Constataram que, se os segundos molares não estivessem irrompidos, a taxa de distalização mensal seria de 1 a $2 \mathrm{~mm}$, com pouca perda de ancoragem. Verificaram que a perda de ancoragem era maior nos casos em que os segundos molares estavam presentes. Aconselharam, para proporcionar uma maior distalização nesses casos, o uso de arcos Neosentalloy .018 X .025", de $200 \mathrm{~g}$, conjuntamente com os procedimentos de reforço da ancoragem. 
A importância do botão palatino de Nance tem sido ressaltada nos casos de distalização dos molares superiores. REINER ${ }^{123}$, em 1992, avaliou a eficiência do aparelho de Nance modificado no tratamento das más oclusões, de Classe II, subdivisões. Com esse propósito, analisou doze pacientes com idade de 13 a 17 anos, apresentando relação molar, de Classe II, de 2 a $6 \mathrm{~mm}$. O aparelho era composto de bandas,em primeiros molares e no primeiro pré-molar do lado, da Classe II, e uma estrutura metálica de fio de aço inoxidável .036", dobrada em forma de um quadrihélice. No lado da Classe I, era soldada à banda do primeiro molar e estend ia-se mesialmente, e no lado da Classe II, o braço deslizava-se por um tubo de .045", presente na banda do primeiro molar, cujo extremo mesial era soldado à banda do primeiro pré-molar. Uma alça em forma de ômega, construída com fio de aço .020", com a porção anterior soldada na banda do pré-molar. A extremidade distal da alça movimentava-se livremente, pressionando a mola de secção, aberta contra o molar. A força distalizadora produzida pelo sistema era de $150 \mathrm{~g}$ e os molares movimentaram-se em média $0,19 \mathrm{~mm}$ por semana, com um desvio padrão de $0,5 \mathrm{~mm}$. Concluiu que o aparelho produz uma significante rotação distal do molar, estabelecendo-se a Classe I.

Muitos estudos recomendam o emprego dos oclusogramas para a avaliação dos requisitos de espaço. $\mathrm{FABER}^{47}$, em 1992, ressaltaram que o oclusograma poderia ser utilizado para definir a linha média de tratamento, para analisar a simetria dos arcos e estabelecer a forma dos arcos e contribuir com a visualização dos planos de tratamentos e também na observação dos resultados de tratamento.

Estudando os efeitos ortopédicos e ortodônticos do aparelho extrabucal de tração alta no tratamento das más oclusões de Classe II, $1^{\text {a }}$ divisão, FIROUZ; ZERNIK; NANDA ${ }^{48}$, em 1992, realizaram um estudo prospectivo 
cefalométrico, utilizando uma amostra de doze indivíduos, portadores de más oclusões, de Classe II, $1^{\text {a }}$ divisão. A distoclusão era de 3,0 a 7,0 mm, ao início do tratamento. Todos os pacientes empregaram os aparelhos extrabucais de tração alta, por um período de seis meses, em média doze horas por dia. Usaram um grupo controle, composto por indivíduos com as mesmas características de más oclusões do grupo tratado. Observaram que a força direcionada através do centro de resistência dos molares superiores proporcionou o movimento distal dos molares, de 2,56 mm, assim como a intrusão de 0,54 mm. No grupo controle, o movimento mesial dos molares foi de $0,23 \mathrm{~mm}$ e a extrusão, de 0,42 $\mathrm{mm}$. Os resultados demonstraram que a força de $500 \mathrm{~g}$ era suficiente para produzir os efeitos ortopédicos sobre a maxila. Verificaram a ocorrência do redirecionamento do crescimento da maxila em sentido horizontal e vertical, constatável pelo movimento posterior do ponto A, de $0,33 \mathrm{~mm}$. Concluíram que essa abordagem dependia da cooperação dos pacientes, na correção da relação molar de Classe II.

Muitos dispositivos foram introduzidos para movimentar os dentes sem a necessidade da cooperação dos pacientes, dentre os quais destaca-se o Jones Jig. JONES; WHITE ${ }^{85}$, em 1992, apresentaram o aparelho Jones Jig, que era composto de um botão palatino de Nance que buscava a ancoragem no palato, uma extensão de fio de aço que se adaptava no tubo do primeiro molar e uma mola de níquel-titânio. Essa mola era comprimida de 1 a $5 \mathrm{~mm}$, contra o primeiro molar por meio de um cursor que se unia ao braquete do segundo prémolar com um segmento de amarril, acionando o sistema com a força produzida de 70 a 75 g. Segundo os autores ${ }^{85}$ o aparelho Jones Jig acarretava o movimento distal dos molares para a relação de Classe I, com ou sem os segundos molares irrompidos, na dentadura mista ou permanente, uni ou bilateralmente, e em pacientes em crescimento ou não. 
Métodos de tratamento da má oclusão de Classe II, que não comprometa o arco inferior e não dependa da cooperação dos pacientes têm sido propostos na literatura ortodôntica. HILGERS ${ }^{74}$, em 1992, descreveu dois novos mecanismos para a correção da relação oclusal de Classe II. O primeiro aparelho, era composto de grampos de apoios oclusais que se apoiavam nas cristas marginais mesiais dos primeiros pré-molares e nas cristas marginais distais dos segundos pré-molares, e eram incorporados na placa de resina acrílica do botão palatino de Nance. Esses grampos proporcionavam a fixação do aparelho pela adesão com resina acrílica nessas regiões. Ocasionalmente, os grampos dos primeiros pré-molares eram substituídos pelas bandas ortodônticas. Complementando o aparelho, o autor construiu duas molas distalizadoras com fio de titânio-molibdênio, de diâmetro .032", que se adaptavam no palato, e eram finalizadas com uma alça que se ajustava nos tubos linguais, de diâmetro .036”, presentes nas bandas dos primeiros molares superiores. Essas molas apresentavam como conformação básica: um helicóide de diâmetro de 2,29 mm, alça horizontal de raio $1,14 \mathrm{~mm}$, a região de retenção da mola de 9,91 mm de comprimento, e um segmento intratubo de, aproximadamente, $6,0 \mathrm{~mm}$ de extensão. Embora, as molas pudessem ser ativadas intrabucalmente, o autor recomendou por questão de maior controle que fossem pré-ativadas, externamente, até que ficassem paralelas a linha média do palato, ou seja, perpendicular ao corpo do botão de Nance. Segundo o autor, as reativações deveriam ser executadas a cada três semanas, verificando-se a magnitude da força residual, e, se necessário, essas eram realizadas, intrabucalmente, empregando-se dois alicates 139, mantendo-se o padrão de ativação inicial. Diante da necessidade de se realizar a expansão, o autor ${ }^{74}$ incorporava um parafuso expansor, e o aparelho, então, recebia a denominação de Pend-x, transformando-se no segundo tipo de aparelho. A ativação do expansor deveria 
ser executada a cada três dias, produzindo-se uma expansão lenta, o que favoreceria a distalização dos molares. $\mathrm{O}$ autor $^{74}$ verificou uma taxa de distalização dos molares de $5,0 \mathrm{~mm}$, num período de três a quatro semanas, e que resultados melhores seriam alcançados, se o aparelho fosse empregado, antes da irrupção dos segundos molares permanentes. Recomendou para os casos que necessitavam de grandes distalizações, as extrações dos segundos molares, desde que os terceiros molares estivessem favoráveis a irrupção, em bom posicionamento. Concluiu que esse aparelho era eficiente na distalização dos molares e que não deveria ser utilizado em pacientes com padrão vertical de crescimento, especialmente, associado aos hábitos bucais deletérios, pois o aparelho tenderia a causar uma abertura na mordida.

Desde a introdução do aparelho Pendulum, em 1992, tem sido provada a sua eficiência, como abordagem que não depende da cooperação do paciente, na correção da Classe II. HILGERS ${ }^{75}$, em 1993, comentou sobre as modificações que foram incorporadas para melhorar o conforto ao paciente, facilitar a colocação e ativação do aparelho, simplificar o desenho e melhorar a aceitabilidade. No modelo inicial, as molas localizavam-se no centro do botão palatino de Nance, podendo gerar alguma irritação na língua. As molas foram curvadas, acompanhando a morfologia do palato e inseridas 6 a $8 \mathrm{~mm}$ dentro do botão acrílico, aproximando-se do palato. Quando a língua do paciente tocava no aparelho, durante a fala ou deglutição, o contato ocorria somente no acrílico, proporcionando um maior conforto na sua utilização.Um parafuso expansor passou a incorporar todos os aparelhos, eliminando a necessidade das alças horizontais, de ajuste nas molas, pois a expansão dos molares era executada pela ativação dos parafusos expansores. Para o controle de torque, os segmentos intratubos deveriam formar uma alça, que poderia ser inserida justamente nos tubos linguais. $\mathrm{O}$ aparelho era sempre fixado por quatro grampos de apoio 
oclusal, embora no modelo inicial, em algumas situações, a bandagem de primeiros pré-molares e grampos nos segundos pré-molares fossem empregados como a única forma de retenção do botão palatino, ocasionando, freqüentemente, a inclinação dos pré-molares e provocando a irritação do tecido do palato, na região anterior. Portanto, os grampos de apoio oclusal, em dentes decíduos ou permanentes, resultariam em maior estabilidade e simplificação na construção do aparelho. A construção poderia ser realizada com o modelo do paciente, sem a bandagem dos primeiros molares, pois a posição dos tubos linguais poderia ser estimada precisamente e o aparelho instalado na consulta de cimentação das bandas, reduzindo o número de visitas. As molas eram ativadas com uma dobra de $90^{\circ}$, no centro do helicóide, de forma que ficassem paralelas à linha média do palato, e os segmentos intratubos eram ajustados aos tubos linguais, usando o alicate Weingart. As reativações intrabucais das molas eram desconfortáveis, porém, uma vez ativadas, seguindo o esquema recomendado, não haveria necessidade de reativações e o profissional apenas deveria esperar o aparelho atuar. HILGERS ${ }^{75}$ aconselhou iniciar a ativação do parafuso expansor, após a terceira semana, a cada três dias. Subseqüentemente à remoção do aparelho, era utilizado um aparelho, Quick-Nance, para a manutenção dos molares nas suas posições, durante a distalização dos pré-molares.

Desde que Haas introduziu o seu sistema de expansão rápida da maxila, esse aparelho tem sido combinado com outras mecânicas. WARREN ${ }^{150}$, em 1993, descreveu um método de correção, da Classe II, associando-se o aparelho disjuntor com o aparelho extrabucal. Nessa abordagem, o aparelho disjuntor convencional era empregado, promovendo-se uma expansão inicial e, depois, o paciente era instruído a usar o aparelho extrabucal, associado a uma tração cervical ou combinada cervical-occipital, por 12 a 16 horas diárias. Essa forma de tratamento era realizada em duas etapas, ou continuamente, com a 
expansão intercalada pela distalização de molares. Concluíram que, por meio desse procedimento, havia uma economia de tempo, pois a distalização era realizada com o expansor ainda em posição, e a expansão da maxila liberava a mandíbula de possíveis interferências oclusais, permitindo o seu posicionamento anterior.

Existem muitos métodos destinados à correção da má oclusão de Classe II. MUSE et al. ${ }^{109}$, em 1993, determinaram as alterações nos molares e incisivos superiores e inferiores, decorrentes da correção da relação molar, de Classe I, com a distalização rápida, empregando-se o arco de Wilson, por um período de 16 semanas. Procuraram determinar:1) a direção e a magnitude do movimento dos molares superiores; 2) a ocorrência ou não de movimento de corpo e 3) a estabilidade na posição dos incisivos e primeiros molares inferiores. Com esse propósito, selecionaram 19 pacientes, sendo 13 meninas com idade média de 12 anos e quatro meses e 6 meninos com idade média de 13 anos e dois meses, da clínica do departamento de Ortodontia da Universidade de Loma Linda. Todos os indivíduos apresentavam má oclusão de Classe II, ângulo do plano mandibular com o plano horizontal de Frankfurt, de $27^{\circ}$, distância do incisivo inferior à linha A-pogônio, menor ou igual a 3,5 mm, ângulo do eixo facial maior ou igual a $85^{\circ}$ e a convexidade menor que $6,0 \mathrm{~mm}$, e não necessitavam de tratamentos com extrações. Foram tratados com arcos distalizadores bimétricos, e, no arco inferior, um arco utilidade .016" X .016", ou arco Edgewise .018” X .025”, para estabilização. Os arcos distalizadores foram ativados com as molas abertas, reduzindo-se o comprimento da alça ômega para 3,0 mm e associada ao uso dos elásticos intermaxilares, de Classe II, obedecendo-se ao princípio da redução da carga elástica, sendo que, na primeira semana, a força deveria ser de $172,14 \mathrm{~g}$; na segunda, $114,76 \mathrm{~g}$; na terceira, 57,38 g, permanecendo até o retorno para consulta. Um total de cinco ativações foram 
completadas, ou até que a inspeção visual revelasse a presença da sobrecorreção de 1,0 mm, na relação molar, de Classe I. As telerradiografias em norma lateral inicial foram comparadas com as finais, para quantificar as alterações dentárias, ocorridas com a distalização dos molares. A correção da relação molar média foi de 4,1 mm. A distalização dos molares superiores foi de 2,16 mm, ou seja 50,7\% da correção da Classe II, com inclinação de $7,8^{\circ}$, sendo, a proporção de movimento, 0,56 $\mathrm{mm}$ por mês. O movimento mesial dos molares inferiores foi de $1,38 \mathrm{~mm}$, ou $39,8 \%$ da correção. A protrusão e extrusão média dos incisivos superiores foi de $0,3 \mathrm{~mm}$ e 1,6 mm, respectivamente. Exceto para amostra Edgewise, todos os indivíduos apresentaram um movimento dos molares inferiores maior que o dos incisivos, reduzindo o comprimento do arco inferior. A presença dos segundos molares irrompidos não se correlacionou com a taxa de movimento dos primeiros molares superiores, magnitude ou quantidade de inclinação. Concluíram que: 1) a relação molar, de Classe I, pode ser alcançada em 16 semanas ou menos; 2) a taxa de distalização molar não era previsível; 3) os molares superiores inclinaram-se para a distal em todos os casos e, 4) uma significante proporção de correção, da Classe II, ocorreu com o movimento dos molares inferiores para a mesial.

O erro na reprodutibilidade das medidas das análises cefalométricas de Steiner e de Ricketts foi estudado por MARTINS ${ }^{99}$, em 1993, numa amostra de 30 telerradiografias. Os traçados foram realizados por um professor, e um aluno de pós-graduação, em duas oportunidades, com intervalos de tempo de 1 mês para cada conjunto de traçados. Nesse estudo, determinou o erro sistemático aplicando-se um teste t- Student ao conjunto das diferenças entre as primeiras e segundas mensurações de cada traçador, nos dois métodos e para as análises estudadas. Como critério para a determinação do erro casual, utilizou o valor de erro de Dahlbergh e considerou os valores das respectivas variâncias. Observou 
que o erro em cefalometria é uma constante, mesmo quando o traçador é experiente e, como conseqüência, se evidenciou a necessidade de replicar as mensurações com finalidade de diagnóstico, plano de tratamento ou de pesquisa científica. $\mathrm{O}$ uso do computador não reduziu significantemente os erros sistemáticos ou casuais que ocorreram nas duas análises estudadas. Constatou que os erros significantes, cometidos pelos traçadores com ambos os métodos, principalmente com medidas que envolvem os traçados dos incisivos. Concluiu que todo trabalho científico, utilizando o método cefalométrico, deveria incluir mensurações duplicadas e uma análise dos erros, para inferir seus resultados com validade e precisão.

Combinando os aparelhos removíveis com as forças extrabucais, JOHNSON $^{84}$, em 1994, decreveu um sistema que viabilizava alcançar o movimento distal de corpo dos molares superiores, na fase inicial de tratamento das más oclusões, de Classe II. Segundo o autor ${ }^{84}$, esse aparelho está indicado para a distalização de molares superiores, em pacientes em crescimento e com uma boa relação esquelética.

Comparando os magnetos de repulsão com as molas superelásticas de níquel-titânio, no movimento distal simultâneo de primeiros e segundos molares superiores, BONDEMARK; KUROL; BERNHOLD ${ }^{19}$, em 1994, avaliaram os efeitos clínicos e dentofaciais do tratamento realizado, empregando-se esses sistemas em 18 indivíduos, com a idade de 12,5 a 18,3 anos, apresentando más oclusões de Classe II, mordida profunda, deficiência moderada de espaço na maxila e presença dos germes dos terceiros molares. Todos os pacientes foram tratados com magnetos em um lado e, no oposto, com molas superelásticas de níquel-titânio, para a distalização dos molares superiores. Os magnetos e as molas foram calibrados a produzir $225 \mathrm{~g}$ de força e as reativações executadas, a cada quatro semanas. Observaram que as forças magnéticas declinaram mais 
rapidamente, de 225 para $100 \mathrm{~g}$, enquanto as forças médias das molas de 225 para 180 g. Os movimentos dentários foram medidos em modelos de estudos, fotografias laterais de modelos, telerradiografias em norma lateral das fases, inicial e seis meses após o início do tratamento. O movimento distal dos molares foi de 3,2 mm para as molas e de 2,2 $\mathrm{mm}$ para os magnetos. A inclinação distal média dos primeiros molares foi baixa, em torno de $1,0^{\circ}$ e a dos segundos molares, de $3,8^{\circ}$. A rotação distovestibular dos primeiros molares foi de $2,9^{\circ}$ para as molas e de $2,0^{\circ}$ para os magnetos. A sobressaliência aumentou 1,5 mm, como resultado do aumento na inclinação vestibular dos incisivos superiores, de $4,4^{\circ}$. A inclinação vestibular dos incisivos superiores foi associada com o movimento mesial dos dentes da unidade de ancoragem, caninos e pré-molares. Essa perda de ancoragem foi causada pelas forças recíprocas, direcionadas mesialmente no sistema de forças. Verificaram que a redução na sobressaliência foi de 3,6 mm. Concluíram que: as molas superelásticas de níquel-titânio foram mais efetivas do que os magnetos, para a distalização simultânea dos molares superiores; as molas foram mais constantes e mais confortáveis do que os magnetos; o aumento na inclinação vestibular dos incisivos foi decorrente das forças recíprocas, e a abertura da mordida estava associada com a distalização.

A distalização dos molares superiores, com o emprego do aparelho Pendulum, não é uma tarefa difícil, porém a manutenção e a estabilização dos molares, nas novas posições durante a retração dos demais dentes, representa um grande desafio. Segundo HILGERS; BENNETT ${ }^{76}$, em 1994, há basicamente 13 formas alternativas de conservar os molares em suas posições. São elas: 1) a sobrecorreção; 2) aparelho Quick-Nance; 3) aparelho extrabucal do tipo arco facial com braços curtos; 4) arcos contínuos com alças em ômegas; 5) arco utilidade superior; 6) molas comprimidas entre primeiros pré-molares e caninos; 7) colagem precoce dos dentes superiores; 8) elásticos de Classe II; 9) placa 
lábio-ativa superior; 10) placas do tipo Hawley, ou do tipo acrílico de cobertura; 11) aparelho Bionator; 12) aparelho Herbst apoiado em pré-molares inferiores, ou seja, curto e 13) aparelho Herbst com apoio em molares inferiores, ou seja, longo.

O uso do oclusograma foi introduzido na década de cinqüenta, visando a análise e o planejamento ortodôntico no plano transversal. SAKIMA et al. ${ }^{133}$, em 1995, descreveram a técnica utilizada no curso de pós-graduação em Ortodontia, da Faculdade de Odontologia de Araraquara, suas aplicações e vantagens. Inicialmente, os modelos eram devidamente preparados e recortados e eram obtidas as fotocópias, evitando-se o aparecimento de sombras, cobrindose toda a superfície em torno do modelo com uma folha de papel recortado. A máquina de xerox era regulada, variando-se as tonalidades, selecionando-se a que apresentasse maior riqueza de detalhes. Sobre a fotocópia era fixada uma folha de papel acetato transparente, de tamanho 10 por $10 \mathrm{~cm}$. Com um lápis $3 \mathrm{H}$ eram traçadas as estruturas oclusais, os limites gengivais dos dentes, as rugosidades palatinas do modelo superior, bem como a base posterior, delimitando a canaleta de orientação. Por meio dos oclusogramas torna-se possível realizar a visualização da oclusão, determinação da linha média de tratamento, cálculo da discrepância de modelos, avaliação das estratégias de tratamento, confecção do arco ideal e avaliação de resultados pós-tratamento. Concluíram que a reprodução das superfícies oclusais dos modelos de estudo do paciente, na proporção de 1:1, dinamizava a manipulação dos traçados oclusais.

Os aparelhos distalizadores geralmente provocam a inclinação distal das coroas, exigindo o emprego de sistemas de forças suplementares, para verticalizar os molares após a distalização, acarretando na perda de ancoragem e algum grau de recidiva. GREENFIELD ${ }^{62}$, em 1995, apresentou o aparelho Piston, que mantém o controle dos movimentos dos molares, com pouca perda 
de ancoragem. Esse aparelho era constituído de: bandas com tubos .036" e .030" em primeiros molares e primeiros pré-molares, respectivamente; botão palatino de Nance, reforçado com fio de aço inoxidável .040"; sistema de fio que se desliza pelos tubos; molas de níquel-titânio ajustadas por vestibular e lingual dos molares. As molas eram pressionadas contra os molares por meio de delimitadores prensáveis, a cada seis ou oito semanas, gerando força distalizadora de 25 a $50 \mathrm{~g}$ por segmento de fio deslizante. Concluíram que o sistema emprega forças leves e, portanto, reduz a possibilidade de perda de ancoragem e compressão na mucosa do palato.

O aparelho Pendulum é um dos mais novos e eficientes aparelhos distalizadores de molares superiores, que pode proporcionar o espaço para a irrupção seqüencial de caninos e pré-molares. RONDEAU ${ }^{127}$, em 1995, descreveu uma modificação para o aparelho Pendulum, cuja fixação deveria ser realizada com tubos linguais horizontais, ou por meio de um sistema de encaixe, do tipo Mershon, nas bandas dos primeiros pré-molares, assim, o botão palatino de Nance seria removível. As molas foram construídas com fio de aço inoxidável .032", e deveriam ser ativadas de 45 a $60^{\circ}$, gerando uma força distalizadora leve. Devido à trajetória de força, descrita pelo braço da mola, em forma de semi-círculo, aconselhou que as molas tivessem alças horizontais, que poderiam ser ajustadas, permitindo uma ligeira expansão dos molares durante a distalização. Outro recurso, também empregado para controle da tendência de cruzamento da mordida, foi a incorporação do parafuso expansor. Os segmentos intratubos poderiam ser ajustados para o controle rotacional dos molares. $\mathrm{O}$ autor $^{127}$ considerou, como indicações precisas para o emprego desse tipo de aparelho, os casos de padrão esquelético, de Classe I, perfil reto, adequado suporte do lábio superior, relações esqueléticas transversais e verticais normais, padrão braquicefálico, onde a deficiência no comprimento do arco era o 
problema principal, devido à relação, de Classe II, mordida profunda, molares superiores inclinados para a mesial, casos de perda do comprimento do arco, resultante da perda precoce de segundos molares decíduos, pacientes com boa saúde da ATM, pacientes não cooperadores e, preferencialmente, antes da irrupção dos segundos molares permanentes. Citou, como contra-indicações: más oclusões, de Classe II, caracterizada pela maxila normal e mandíbula retrognática, mordida aberta anterior, altura facial anterior inferior aumentada, maxila atrésica, padrão dolicocefálico, relação oclusal de Classe I e III, molares inclinados para a distal, perfil retrognático, suporte do lábio superior inadequado, pacientes com sinais e sintomas de disfunção da ATM. Segundo o autor $^{127}$, dentre as vantagens incluem-se: 1) é um aparelho fixo e, portanto, efetivo em obter a distalização dos molares em período relativamente de tempo curto; 2) favorece a motivação do paciente com a terapêutica; 3) não prejudica a dicção; 4) não dificulta a mastigação. Apresentou como desvantagens: 1) movimentos indesejáveis dos molares, resultantes de distorções, incorporadas durante a ativação das molas; 2) acúmulo de resíduo alimentar sob o botão de acrílico, causando irritação no tecido mole do palato e 3) a irritação geralmente ocorre quando o botão palatino de Nance é de tamanho reduzido. Comentou sobre a ativação, que, quando realizada fora da cavidade bucal, aproximadamente $30 \%$ dela é perdida, no momento da inserção dos segmentos intratubos. Diante de uma ativação de $30^{\circ}, 10 \%$ é perdida, permanecendo apenas $20^{\circ} ; 45^{\circ}$ de ativação, $15 \%$ é perdida, ficando $30^{\circ}$ e, $60^{\circ}$ de ativação, $20 \%$ perdese e permanece $40^{\circ}$. Recomendou como protocolo de ativação: $45^{\circ}$, antes da irrupção dos segundos molares permanentes e de $60^{\circ}$, na presença dos segundos molares. Comparou os efeitos do aparelho Pendulum com os do arco distalizador de Wilson e comentou que o aparelho atua apenas na maxila, sem causar alguma ação sobre a mandíbula e, por ser fixo, não depende da 
cooperação do paciente. Quanto ao arco distalizador de Wilson, busca a ancoragem nos dentes ântero-superiores para distalizar os molares e os elásticos, de Classe II, devem ser utilizados para neutralizar o componente anterior de força, gerado sobre os incisivos. Se o paciente não colaborasse quanto ao uso dos elásticos, resultaria na inclinação mesial dos molares inferiores e na vestibularização indesejável dos incisivos

$\mathrm{Na}$ elaboração dos aparelhos distalizadores, deveremos considerar alguns princípios, tais como: magnitude de força, momentos, a proporção momento/força, constância das forças e dos momentos, fricção dos braquetes, facilidade de uso e custo. $\mathrm{KALRA}^{87}$, em 1995, descreveu um aparelho para o tratamento da má oclusão de Classe II, que obedecia aos princípios citados. Esse aparelho era construído com fio de titânio-molibdênio, .017" X .025", apresentava uma alça em forma da letra $\mathrm{k}$ e proporcionava força e momento, ancorado em um botão palatino de Nance. Na construção da alça com fio de titânio-molibdênio, o aparelho pode ser ativado duas vezes mais que com o aço inoxidável, antes que sofra a deformação permanente. As alças foram construídas com 8,0 mm de comprimento e 1,5 mm de largura e dobradas em $20^{\circ}$, depois de prontas, eram inseridas nos tubos molares e braquetes dos prémolares. $\mathrm{O}$ fio era demarcado na mesial do tubo molar e mesial do braquete do pré-molar. Posteriormente, era dobrado 1,0 $\mathrm{mm}$ distal, evitando o contato do aparelho com tecidos moles e permitindo, também, a ativação em 2,0 mm. As dobras em $20^{\circ}$ produzem momentos que neutralizam a tendência de inclinação dos molares, durante a distalização. Portanto, o molar sofrerá um movimento translatório, ao invés de inclinação. O movimento radicular continua, mesmo após a dissipação da força. Para o movimento adicional dos molares, o aparelho deverá ser reativado mais $2,0 \mathrm{~mm}$, após seis semanas. Para um bom controle das forças verticais, a alça deveria ser posicionada no centro do espaço, entre o 
primeiro molar e o pré-molar. Concluíram que os pré-molares sofrem o movimento mesial de 1,0 mm para cada 4,0 mm de distalização dos molares.

Muitos trabalhos têm relatado experiências com os magnetos de repulsão. STEGER; BLECHMAN ${ }^{140}$, em 1995, relataram a aplicação dos magnetos, com dois casos clínicos. Notaram que: 1) os magnetos de repulsão, com certas características, distalizam os molares, rapidamente, sem efeitos adversos que sejam discerníveis clinicamente. A redução da necessidade de cooperação para a aplicação da força, a mobilidade reduzida, o desconforto e o movimento de translação foram demonstrados clinicamente; 2) a ancoragem pôde ser controlada pelo uso de técnicas convencionais de aumento da ancoragem ou redução de força; 3) o tratamento pôde ser satisfatoriamente concluído; 4) os efeitos biológicos desses mecanismos continuam desconhecidos. Entretanto, hipotetizaram que a redução rápida da mobilidade e desconforto durante a distalização eram atribuídas à propriedade sinergística dos campos magnéticos que rompem o equilíbrio local.

A estabilidade das rugosidades palatinas, como referência para a análise dos modelos de estudo, de pacientes tratados com e sem extrações dentárias. BAILEY; ESMAILNEJAD; ALMEIDA ${ }^{13}$, em 1996, com o intuito de determinar se as posições das rugosidades palatinas eram afetadas pelo tratamento ortodôntico, avaliaram os modelos de estudo, pré e pós-tratamento, de 57 pacientes adultos tratados com e sem extrações, na clínica de Ortodontia da Universidade da Carolina do Norte. Os resultados desse estudo, indicaram que os pontos laterais e mediais da terceira rugosidade palatina eram estáveis para a construção de planos de referência, para a avaliação dos movimentos dentários em direção ântero-posterior e transversal, em pacientes tratados com e sem extrações. A estabilidade da primeira e segunda rugosidade palatina era limitada e dependente do tipo de tratamento. Concluíram que as rugosidades 
poderiam ser empregadas como referências, mesmo nos casos que envolviam os movimentos transversais dos dentes.

Em, 1996, SNODGRASS ${ }^{139}$ apresentou um aparelho disjuntor palatino que incorporava os componentes de rotação e distalização do aparelho Pendulum, e que poderia ser usado na dentadura mista e permanente, como um adjunto, nos tratamentos das más oclusões de Classe II. O aparelho consistia de um parafuso expansor de $11 \mathrm{~mm}$, apoios oclusais e molas de titânio-molibdênio, de diâmetro .032". O parafuso expansor e as molas eram envolvidos pelo acrílico, pois o fio de titânio-molibdênio não era passível de soldagem. As molas eram pré-ativadas 8 a $10 \mathrm{~mm}$ distalmente. Os parafusos expansores eram soldados na região mesial dos molares. Os apoios oclusais deveriam ser colados em todos os molares decíduos na dentadura mista, enquanto que, na permanente, os primeiros pré-molares deveriam ser bandados e os apoios colados nos segundos pré-molares.

Em muitos sistemas, as forças ortodônticas são aplicadas nas coroas, e o movimento distal dos primeiros molares superiores ocorre, associado às inclinações e rotações das coroas. CARANO; TESTA; SICILIANI ${ }^{32}$, em 1996, apresentaram os resultados obtidos em dois pacientes, tratados com o novo distalizador lingual. Os componentes ativos do distalizador são tubos de $0,9 \mathrm{~mm}$, bilaterais, conectados ao aparelho de Nance. Um fio, dobrado em forma de uma baioneta, era inserido nos tubos linguais dos primeiros molares. Em cada tubo, eram ajustadas as molas de aço e anéis metálicos. Os anéis deslizam-se em direção aos molares e pressionam as molas, exercendo uma força distalizadora de $150 \mathrm{~g}$, que diminuía, conforme os espaços vão sendo abertos. As ativações foram realizadas uma vez por mês. Em ambos os pacientes, os segundos molares estavam presentes. Os molares superiores foram distalizados de 3 a $5 \mathrm{~mm}$, em 4 meses, igualando-se aos magnetos e ao Jones Jig. Os pré-molares e incisivos 
permaneceram estáveis nos dois casos, e a distalização dos primeiros e segundos molares foi caracterizada pela translação dos dentes. Concluíram que esse aparelho poderia ser manipulado com facilidade, tolerado pelos pacientes e, não dependia da cooperação dos mesmos.

Os aparelhos removíveis têm sido amplamente usados para produzir o movimento distal dos molares superiores e, em muitos casos, associados aos aparelhos extrabucais. LEWIS; FOX ${ }^{93}$, em 1996, descreveram uma técnica, empregada na Universidade e Hospital Dentário de Manchester e Hospital Geral Bolton, para alcançar a distalização dos molares superiores com os aparelhos removíveis, sem o uso dos aparelhos extrabucais, na maioria dos casos. Esse aparelho caracterizava-se pela presença de um arco vestibular com esporões, que permitiriam o ajuste de aparelhos extrabucais. As molas não deveriam ser estendidas até a face vestibular dos molares. Os desgastes na placa de resina acrílica deveriam permitir a distalização espontânea dos segundos pré-molares. Os molares distalizam-se, girando em torno de suas raízes palatinas, permitindo a correção da relação molar em dois a três meses. Nesse movimento, as cúspides mesiovestibulares movimentam-se distalmente, e a resina acrílica deveria permitir, à superfície distopalatina, o movimento em direção palatina, enquanto o elemento dentário sofre rotação. Se o molar tem o seu movimento dificultado, ocorre um aumento na sobressaliência. Concluíram que essa técnica era efetiva, particularmente quando os molares apresentavam rotação mesiopalatina, ao início do tratamento.

Discutindo os procedimentos de distalização dos molares superiores, MARTINS; MELO; MARTINS ${ }^{98}$, em 1996, descreveram os aparelhos Pendulum e Pend-x, como originalmente apresentado por Hilgers, na Ortodontia contemporânea, para a correção das más oclusões de Classe II e, introduziram algumas modificações que tornaram o aparelho mais eficiente. A 
extensão do apoio oclusal dos primeiros pré-molares para os caninos, possibilitava a movimentação dos pré-molares sem que se necessitasse remover o aparelho, o qual se tornava uma ancoragem maxilar. Os autores ${ }^{98}$ sugeriram, por motivos de preservação de ancoragem, a utilização das molas de titâniomolibdênio inicialmente nos segundos molares, seguidos da sua estabilização com fios de aço inoxidável para aumento da unidade de ancoragem. A seguir, as molas, anteriormente empregadas, nos segundos molares, eram ajustadas nos tubos dos primeiros molares para propocionar o movimento desses dentes.

O tratamento da má oclusão, de Classe II, freqüentemente requer a distalização dos molares superiores para uma relação molar de Classe I. GHOSH; NANDA ${ }^{60}$, em 1996, determinaram os efeitos do aparelho Pendulum na distalização dos molares superiores e os seus efeitos recíprocos na ancoragem, composta pelos pré-molares e incisivos superiores. Analisaram as radiografias cefalométricas, iniciais e finais, de 41 pacientes, sendo 26 do gênero feminino e 15 do masculino, que foram tratados com o aparelho Pendulum, para a distalização bilateral dos primeiros molares superiores, para a correção da relação molar, de Classe II, ou para a obtenção de espaço no arco superior. Avaliaram também os modelos de estudo de 31 pacientes. Determinaram as alterações de tecido mole, esqueléticas e dentárias. A distalização média dos primeiros molares superiores foi de $3,37 \mathrm{~mm}$, com a inclinação distal de $8,36^{\circ}$. Os segundos molares foram distalizados $2,27 \mathrm{~mm}$ e inclinados distalmente, $11,99^{\circ}$. Somente as coroas dos terceiros molares eram visíveis radiograficamente, e os efeitos sobre a distalização foram variáveis, mostrando 2,49 ${ }^{\circ}$ de inclinação distal e $0,19 \mathrm{~mm}$ de distalização. A irrupção dos segundos molares teve um mínimo efeito sobre a distalização dos primeiros molares. $\mathrm{O}$ movimento mesial médio recíproco foi de $2,55 \mathrm{~mm}$, com a inclinação mesial de $1,29^{\circ}$. Portanto, para cada milímetro de distalização dos molares ocorreu um 
movimento mesial, dos pré-molares, de $0,75 \mathrm{~mm}$. A intrusão dos primeiros, segundos e terceiros molares foi de $0,1 \mathrm{~mm}, 0,47 \mathrm{~mm}$ e $0,22 \mathrm{~mm}$, respectivamente. Os primeiros pré-molares extruíram 1,70 mm. A distância transversal entre as cúspides mesiovestibulares dos primeiros e segundos molares aumentou 1,40 e 2,33 mm. A expansão dos segundos pré-molares aumentou $1,95 \mathrm{~mm}$. A sobressaliência aumentou $1,30 \mathrm{~mm}$, e a sobremordida diminuiu $1,39 \mathrm{~mm}$, como resultado do tratamento. Os incisivos centrais superiores tiveram a sua inclinação vestibular aumentada em $2,40^{\circ}$, em relação à linha SN. Os lábios superior e inferior foram protruídos 0,31 e $0,95 \mathrm{~mm}$, respectivamente, em consequiência da perda de ancoragem. $\mathrm{O}$ aparelho Pendulum causou mudanças insignifcantes na inclinação dos planos palatino e oclusal. O plano mandibular, por sua vez, sofreu uma rotação, para trás de $1,09^{\circ}$, o que proporcionou a diminuição na sobremordida. A extrusão dos primeiros molares inferiores, de $0,5 \mathrm{~mm}$, associada à rotação mandibular, acarretou no aumento da altura facial ântero-inferior, de 2,79 $\mathrm{mm}$. Esse aumento foi mais acentuado nos pacientes que apresentavam as maiores medições, do ângulo do plano mandibular, com o plano horizontal de Frankfurt. A perda de ancoragem foi medida nos primeiros pré-molares, e a unidade de ancoragem consistia dos primeiros e segundos pré-molares, que eram conectados pelos grampos de apoios oclusais e da cobertura de resina acrílica, no palato. Os resultados desse estudo mostraram que o aparelho Pendulum era um método efetivo e seguro na distalização dos molares superiores; entretanto, essa distalização, geralmente, era acompanhada de uma moderada perda de ancoragem. Como a ancoragem era composta dos primeiros e segundos pré-molares, conectados pelos grampos de apoios oclusais e pela cobertura de resina acrílica no palato, aconselharam estender essa cobertura por todo o palato incluir todos os elementos dentários. Creditaram como sendo as maiores vantagens desse sistema: a mínima 
dependência dos pacientes, a facilidade na construção dos aparelhos, a ativação única e, a possibilidade de ajustes das molas, se necessário, para corrigir problemas transversais e verticais, nas posições dos molares, e a aceitação dos pacientes.

Tentativas de definir as técnicas que proporcionam melhores resultados de distalização de molares superiores têm conduzido algumas pesquisas. ERVERDI; KOYUTÜRK; KÜÇÜKKELES ${ }^{46}$, em 1997, compararam dois procedimentos intrabucais de distalização de molares superiores, envolvendo quinze casos com relação molar, de Classe II. Os magnetos foram aplicados nos primeiros molares do lado direito, em cada caso, enquanto que as molas abertas de níquel-titânio foram usadas nos primeiros molares do lado oposto, por um período de três meses. Medições foram realizadas em telerradiografias em norma lateral, e fotocópias de modelos de estudo, obtidas antes e ao final da distalização. Por meio dos resultados, os autores ${ }^{46}$ verificaram que a distalização dos primeiros molares, com magnetos, foi em média 2,1 mm, quando medidos nos cefalogramas laterais, e $2,7 \mathrm{~mm}$, nas fotocópias. A inclinação distal foi de $7,6^{\circ}$ e a rotação distopalatina, de $9,9^{\circ}$. As molas de níquel-titânio produziram uma distalização média de $3,8 \mathrm{~mm}$ e de 4,2 $\mathrm{mm}$, medidas nos cefalogramas e fotocópias, respectivamente. A inclinação distal foi de $9,8^{\circ}$ e a rotação, de $8,6^{\circ}$. Concluíram que, apesar da distalização ter sido facilmente alcançada pelas duas técnicas, as molas de níquel-titânio mostraram superioridade nos movimentos resultantes.

Realizando um estudo clínico e radiográfico, BYLOFF; DARENDELILER $^{26}$, em 1997, avaliaram os efeitos esqueléticos e dentários do aparelho Pendulum e a sua influência sobre a dimensão vertical. Com esse propósito, empregaram uma amostra de treze pacientes, dos quais nove do gênero feminino e quatro do masculino, com idade média de 11 anos e 1 mês, 
caracterizados, clinicamente pela relação dentária, de Classe II, com uma moderada deficiência de espaço no arco superior e ausência de mordida aberta. Todos os pacientes foram tratados com o aparelho Pendulum, com grampos de apoios oclusais em pré-molares ou molares decíduos, para a distalização dos molares superiores. As molas foram ativadas $45^{\circ}$ no centro dos helicóides, em relação ao plano sagital, produzindo uma força inicial de 200 a $250 \mathrm{~g}$. Dependendo do movimento requerido, a ativação foi repetida intrabucalmente, uma ou duas vezes, durante o tratamento. Instruíram os pacientes a realizarem as ativações dos parafusos expansores a cada três dias, por um período de quatro semanas e, nos pacientes com tendência à mordida cruzada posterior, ou com mordida cruzada posterior, essa ativação deveria permanecer por um tempo total de doze semanas. Os aparelhos foram usados por aproximadamente 16,6 semanas (aproximadamente 4 meses), até a sobrecorreção da relação molar, de Classe I. Avaliaram as telerradiografias laterais, iniciais e finais dos pacientes e verificaram que o movimento distal dos primeiros molares foi de $3,39 \mathrm{~mm}$, com inclinação distal de $14,5^{\circ}$ e intrusão de 1,68 e 1,17 mm, em relação aos planos palatino e oclusal, respectivamente. O movimento mesial dos segundos prémolares foi de $1,63 \mathrm{~mm}$ e a extrusão, de 0,78 e 0,42 mm, em relação aos planos palatino e oclusal. A abertura de espaço entre o primeiro molar e o segundo prémolar foi de $5,53 \mathrm{~mm}$, sendo que $71 \%$ foi atribuída à distalização dos molares. O movimento anterior do centro da coroa dos incisivos foi de $0,74 \mathrm{~mm} \mathrm{e}$, da borda incisal, de $0,92 \mathrm{~mm}$, com uma inclinação vestibular de $1,71^{\circ}$. O estágio de desenvolvimento dos segundos molares não afetou a distalização e o movimento de inclinação dos molares. Observaram, com relação às alterações esqueléticas, que o ângulo SNA não apresentou diferenças estatisticamente significantes, sugerindo que o ponto A não foi afetado pelas forças de reação, num curto período de tempo. Concluíram que o aparelho Pendulum promoveu a 
distalização dos molares, sem estabelecer a mordida aberta, dentária ou esquelética, e com pouca perda de ancoragem e que a inclinação dos molares deveria ser considerada no emprego desses aparelhos.

Preocupados com o controle da inclinação axial dos molares, durante a distalização, BYLOFF et al. ${ }^{27}$, em 1997, analisaram a distalização dos molares com o aparelho Pendulum modificado e também procuraram verificar se a expansão lenta preservaria a ancoragem anterior. Nessa pesquisa, os autores ${ }^{27}$ modificaram o aparelho, incorporando-se as dobras de verticalização nos segmentos intratubos, na segunda fase da distalização, com o intuito de reduzir a excessiva inclinação distal dos molares superiores. A amostra consistiu de vinte indivíduos, sendo oito do gênero feminino e doze do masculino, com idade média de 13,11 anos. Desse total, 8 foram submetidos à expansão lenta da maxila de 2 a $4 \mathrm{~mm}$. A ativação dos aparelhos seguiu o protocolo adotado na pesquisa anterior, ou seja, na parte I, porém, a diferença encontrava-se na execução de uma segunda fase, na qual foram incorporadas as dobras de antiinclinação nos segmentos intratubos de $15^{\circ}$, em relação ao plano oclusal. As molas foram mantidas ativas no sentido sagital, mantendo as posições das coroas dos molares superiores. Os efeitos esqueléticos e dentários foram avaliados por meio das telerradiografias iniciais e finais. Os resultados mostraram que a sobrecorreção da relação molar foi alcançada num período de tempo médio, de seis semanas a três meses. Desse tempo total, quatro meses foram destinados à distalização e dois meses e três semanas, para a fase de verticalização. Constataram que o movimento distal das coroas foi de 4,14 mm, com a translação mensal de $1,20 \mathrm{~mm}$, se somente o movimento distal fosse considerado e de $0,69 \mathrm{~mm}$, se o experimento total fosse abordado. Os ápices radiculares movimentaram-se distalmente, $2,81 \mathrm{~mm}$, com a taxa mensal de 1,01 mm. A abertura de espaço entre os primeiros molares e segundos pré-molares 
foi atribuída em $64,16 \%$ ao movimento distal dos molares. Verificaram que antiinclinação distal dos molares foi de $6,07^{\circ}$, o que demonstrou que o propósito de controle da inclinação axial foi alcançado. Os autores ${ }^{27}$ comentaram que a força distalizadora das molas poderia estar ativa na fase em que as dobras de verticalização foram incorporadas e, portanto as forças mesiais e distais continuaram atuantes, causando o movimento distal dos molares, o movimento mesial e a inclinação dos incisivos, assim como o aumento da perda de ancoragem dos pré-molares. Concluíram que: 1) a introdução das dobras de verticalização aumentou o tempo de tratamento; 2) ocorreu uma perda de ancoragem ligeiramente maior na borda incisal; 3) não houve diferença na perda de ancoragem, em pacientes com ou sem expansão maxilar e 4) a posição do segundo molar não influenciou na quantidade de movimento distal, no movimento mesial de pré-molares e na perda de ancoragem dos incis ivos.

Muitas modificações do aparelho de Nance, para a correção das más oclusões, de Classe II, têm sido propostas. PIERINGER; DROSCHL; PERMANN $^{116}$, em 1997, avaliaram os efeitos do aparelho de Nance, combinado às molas Sentalloy. Empregaram esse sistema em oito pacientes, com idade de 13 a 34 anos e que requeriam a distalização de molares e pré-molares superiores. O aparelho consistia de duas bandas, em pré-molares, conectadas por uma estrutura metálica e um botão de resina acrílica. Esse aparelho era cimentado aos pré-molares e proporcionava a ancoragem necessária para a aplicação das molas Sentalloy, com força distalizadora de 150 a $200 \mathrm{~g}$. Em cinco pacientes, os primeiros e segundos molares foram distalizados juntos. Observaram que o movimento distal máximo dos molares foi de $10,5 \mathrm{~mm}$, em dez meses de tratamento. Quatro dentes foram movimentados 5 a $10 \mathrm{~mm}$, e os sete remanescentes, menos do que 5,0 $\mathrm{mm}$. Todos os dentes foram distalizados, com a inclinação das coroas, que variou de 6 a $22^{\circ}$. Oito dentes foram movimentados 
vestibularmente e também oito dentes foram intruídos, sendo que a intrusão observada nas cúspides distais foi de 3 a $5 \mathrm{~mm}$. A rotação horizontal, mínima e máxima, foi de 5 e $27^{\circ}$, respectivamente. A protrusão média dos incisivos durante a distalização foi de aproximadamente $6,0^{\circ}$. Concluíram que o aparelho de Nance era um método efetivo na distalização dos molares superiores e não exigia a cooperação dos pacientes. Os resultados indicaram que não havia possibilidade de estabelecer correlações entre a distalização ou a duração de tratamento, com a inclinação, rotação ou protrusão dos incisivos.

O aparelho ortodôntico removível pode ser utilizado como coadjuvante no tratamento ortodôntico com a ancoragem extrabucal, da má oclusão de Classe II, $1^{\text {a }}$ divisão de Angle com protrusão maxilar ou falta de espaço no arco superior. HENRIQUES et al. ${ }^{70}$, em 1997, descreveram o aparelho removível que era composto de uma placa de resina acrílica, grampos de retenção e molas digitais incluídas no acrílico para distalizar os segundos molares. O braço dessa mola deveria adaptar-se à região cervical interproximal, entre os primeiros e segundos molares permanentes sem causar irritação à gengiva. Esse procedimento minimiza o efeito da inclinação da coroa, pelo posicionamento mais superior (cervical) do braço da mola. Para tanto, torna-se de fundamental importância realizar o desgaste interproximal no modelo de trabalho, antes da confecção da mola, permitindo assim, uma adaptação adequada na região interproximal. Concluíram que a aplicação simultânea do aparelho removível com molas digitais e a ancoragem extrabucal cervical mostrou-se eficiente no tratamento da má oclusão de Classe II, $1^{\text {a }}$ divisão com protrusão maxilar e falta de espaço no arco superior. O aparelho propicia a distalização da coroa e a ancoragem extrabucal promove a correção radicular dos molares. Constataram, ainda, que esse método proporciona a correção da 
relação molar de forma rápida e efetiva, porém, esses resultados favoráveis dependem dos pacientes na utilização dos aparelhos.

Revisando a literatura ortodôntica sobre os erros em cefalometria, GOLDREICH et al. ${ }^{59}$, em 1998, constataram que o erro era uma constante nos dados advindos dos traçados cefalométricos. Embora fosse impossível evitá-los totalmente, existem cuidados que se iniciam já na tomada da telerradiografia e finalizam com as mensurações, diminuindo a possibilidade do erro do método cefalométrico. Os autores ${ }^{59}$ observaram que após o registro dos pontos cefalométricos, certas medidas lineares e angulares são utilizadas para se analisar o cefalograma. A confiabilidade desses pontos cefalométriocs afetam diretamente essas medidas. Os erros de mensuração são divididos em três tipos: o primeiro é o erro de projeção e se relaciona à medida verdadeira; o segundo e o terceiro são erros em localização de pontos cefalométricos e erros mecânicos durante o traçado das linhas entre os pontos e/ou na mensuração com a régua e transferidor. Esse último erro tornou-se bastante reduzido com a utilização do computador eletrônico, que faz as mensurações diretamente dos pontos digitados. Sem o conhecimento do posicionamento tridimensional dos pontos cefalométricos, não é possível ter controle completo do erro de projeção. Pelo uso de medidas angulares no lugar das medidas lineares pode-se tentar minimizar o impacto do erro de projeção. Isso pode se tornar útil, pois as medidas angulares permanecem constantes, independente do fator de magnificação. As medidas lineares são, freqüentemente, de estruturas da linha média que apresentam um fator de aumento uniforme e, portanto, todos os pontos desse plano têm fatores de aumentos similares e padronizados.

O movimento distal dos molares superiores, sem a cooperação dos pacientes, foi abordado por RUNGE; MARTIN; BUKAI ${ }^{131}$, em 1998, quando avaliaram os efeitos do tratamento com aparelho Jones Jig, na distalização de 
molares superiores. $\mathrm{O}$ aparelho produzia a força distalizadora contra os molares, suportada pelo botão palatino, de Nance, eliminando a necessidade de cooperação dos pacientes. Compararam as telerradiografias, em norma lateral, de 13 pacientes que foram tratados em 26 semanas com o aparelho Jones Jig, para determinar se houve diferenças nas variáveis esqueléticas, dentárias e de tecido mole, pré e pós-tratamento. Verificaram a ocorrência de movimento mesial e a inclinação dos pré-molares. Houve também um significante aumento na sobressaliência e na altura facial ântero-inferior, indicando que a ancoragem era insuficiente para neutralizar as forças recíprocas, produzidas pela compressão da mola contra o botão palatino, de Nance. Os molares superiores foram distalizados e sofreram rotações distolinguais.

As molas superelásticas de níquel-titânio têm sido utilizadas na distalização de molares superiores. GIANCOTTI; COZZA ${ }^{53}$ em 1998, apresentaram um sistema que proporciona a distalização simultânea de primeiros e segundos molares, usando-se fios superelásticos de níquel-itânio Neosentalloy. O aparelho é montado com bandagem dos primeiros e segundos molares e segundos pré-molares inferiores e colagem dos demais elementos dentários. Empregaram como dispositivo de estabilização do arco inferior a placa-lábio-ativa. Após o alinhamento e nivelamento prévio dos dentes superiores, um arco superior Neosentalloy de $80 \mathrm{~g}$ é colocado com ganchos prensáveis na distal de primeiro pré-molar e $5 \mathrm{~mm}$ distal ao tubo do primeiro molar superior. Outro segmento de fio é preparado colocando-se dois ganchos, um na distal do segundo pré-molar e outro $5 \mathrm{~mm}$ distal ao tubo do segundo molar superior. Os arcos são inseridos promovendo uma deflexão na região dos primeiros e segundos molares superiores. As molas verticalizadoras foram adaptadas nas ranhuras verticais dos braquetes dos primeiros pré-molares e no arco principal e os elásticos de Classe II de diâmetro 5/16"com força de 172,14 
$\mathrm{g}$ foram usadas entre o tubo do primeiro molar inferior e os ganchos dos caninos. Segundo os autores a força distalizadora produzida era de $80 \mathrm{~g}$ e não exigia a utilização de barra transpalatina ou de botão de Nance e que o sistema era eficiente, pois as forças eram direcionadas aos primeiros e segundos molares distintamente.

O distal jet é um aparelho lingual fixo, que pode produzir a distalização uni ou bilateral dos molares e a correção das rotações, num período de quatro a nove meses, sem depender da cooperação dos pacientes. Dentre as vantagens desse sistema, incluem-se a estética, conforto, simplicidade de manipulação e ativação e facilidade de ajustes do botão palatino de Nance, para manter as posições dos molares. BOWMAN ${ }^{20}$, em 1998, descreveu as modificações do aparelho. A primeira delas consiste em colocar uma porção de resina acrílica ao redor da mola, após a distalização dos molares, para prevenir o movimento distal adicional, ou a perda de ancoragem. Outro método alternativo é amarrar um fio de ligadura do segmento intratubo ao gancho mesial da extensão de ativação. A terceira modificação incorporou a colocação de dois parafusos: um mesial, que era fixado ao tubo, e um segundo, fixado ao segmento intratubo, para prevenir o movimento molar. A quarta modificação incorporou os helicóides, para produzir a rotação distal dos molares, ou verticalizar os molares inclinados mesialmente. A quinta modificação sugeria a colocação do parafuso expansor no botão palatino, de Nance, propiciando a expansão do arco simultaneamente a distalização dos molares.

Preocupando-se com a construção laboratorial, passo-a-passo, do aparelho Pendulum, MORGANTI ${ }^{104}$, em 1998, descreveu o método de confecção e também relatou sobre as indicações, contra-indicações, instalação, consolidação e manutenção do espaço obtido, orientações ao paciente e os efeitos colaterais que podem advir do uso dessa técnica. A construção 
laboratorial, assim como os cuidados e orientações aos pacientes e, mesmo a consolidação e manutenção do espaço, baseavam-se nos preceitos descritos por Hilgers, em, 1992, 1993 e 1994. Comentou que os efeitos começam a se manifestar depois de oito semanas, aproximadamente, mas é na $12^{\mathrm{a}}$ semana que o espaço se abre, significativamente, sendo que, nos adultos, as respostas são mais lentas. Recomendou a remoção prévia dos terceiros molares antes da aplicação do dispositivo. Segundo a autora ${ }^{103}$, o aparelho é capaz de distalizar os molares em apenas quatro meses de uso, em jovens em crescimento.

As extrações de segundos molares para a correção das más oclusões de Classe II têm sido reportadas na literatura ortodôntica, HARNICK ${ }^{67}$, em 1998, relatou o tratamento de um caso clínico de uma menina de 13 anos e 4 meses portadora de uma má oclusão de Classe II severa, caracterizada por uma sobressaliência de $14 \mathrm{~mm}$ e uma mordida aberta de $3 \mathrm{~mm}$, apinhamento suave, incisivos superiores protruídos e inferiores verticalizados e curva de Spee moderada. A paciente foi tratada com aparelho fixo e arco distalizador bimétrico de Wilson após as extrações dos segundos molares. Comentou que esse caso clínico demonstra a eficiência do sistema e que a relação molar foi corrigida em 4,5 meses e o tempo de tratamento total foi de 22 meses. Concluiu que $100 \%$ dos terceiros molares superiores irrompem após as extrações dos segundos molares. Os elásticos de Classe II combinados com o arco distalizador de Wilson subseqüentes às extrações dos segundos molares podem ser utilizados no tratamento da má oclusão de Classe II.

Poucos estudos enfocaram o movimento distal simultâneo dos primeiros e segundos molares superiores, com aparelhos distalizadores; assim sendo, GULATI; KHARBANDA; PARKASH ${ }^{64}$, em 1998, avaliaram a eficácia do aparelho distalizador seccional Jones Jig na distalização de molares superiores e seus efeitos dentários e esqueléticos. Conduziram o estudo, 
utilizando uma amostra composta de dez pacientes, com idade de doze a quinze anos, os quais apresentavam todos os elementos dentários, os segundos molares eram clinicamente visíveis e não haviam sido submetidos a tratamento ortodôntico prévio. Eram caracterizados pela má oclusão, de Classe II, $1^{\text {a }}$ divisão, ou Classe I, com apinhamento anterior suave. Os molares foram distalizados, com o aparelho Jones Jig, com molas superelásticas Sentalloy, exercendo força distal de $150 \mathrm{~g}$. Os pacientes foram reavaliados a cada quatro semanas, por um período total de doze semanas.Os registros incluíam modelos de estudo, fotografias clínicas e telerradiografias. Compararam as telerradiografias e modelos iniciais com os da fase pós-tratamento. Observaram o movimento distal dos primeiros molares, de 2,75 $\mathrm{mm}+/-0,85$, e dos segundos molares, de 2,70 mm+/- 0,82, associados à inclinação distal de 3,50 +/- 1,85 e de $3,30^{\circ}+/-2,20$, respectivamente. Os primeiros pré-molares sofreram movimento mesial de $1,10 \mathrm{~mm}+/-0,87$, com inclinação mesial $2,60^{\circ}+/-1,17$. A sobressaliência aumentou $1,05 \mathrm{~mm}+/-0,83$ e a sobremordida diminuiu $0,95 \mathrm{~mm}$ $+/-1,21$. Os primeiros molares extruíram 1,60 mm +/-1,25 e sofreram uma rotação distopalatina de $2,40^{\circ}$. As mudanças esqueléticas envolveram um aumento significante no ângulo do plano mandibular com o plano horizontal, de Frankfurt, de 1,30 +/- 0,94. As mensurações nos modelos de estudo mostraram que a distalização dos primeiros e segundos molares, no lado direito, foi de 2,95 $\mathrm{mm}+/-0,89$ e 2,61 mm +/- 0,85, e no lado esquerdo, de 2,60 mm +/- 1,04 e 2,05 $\mathrm{mm}+/-1,13$, respectivamente. A taxa de distalização foi de $0,86 \mathrm{~mm}+/-0,33$ por mês, no lado direito, e de $0,79 \mathrm{~mm}+/-0,30$, no lado esquerdo. Concluíram que o aparelho distaliza os molares, com uma insignificante taxa de inclinação e rotação dos molares, associado ao movimento mesial de pré-molares e incisivos e aumento do plano mandibular. 
Preocupando-se com a obtenção de resultados reproduzíveis, na correção das más oclusões, de Classe II, sem extrações, CARANO; TESTA; ROTUNNO $^{31}$, em 1999, apresentaram o aparelho Distal Jet como sendo um aparelho que possibilitava a rápida distalização dos molares superiores, sem a cooperação dos pacientes. Comentaram que, por meio do uso desses aparelhos, tornava-se possível obter resultados consistentes na correção da má oclusão, da Classe II. Descreveram o sistema, que era composto de bandas com tubos linguais nos primeiros molares, nos quais se inseria um fio dobrado, em forma de baioneta. A retenção do aparelho era proporcionada por uma estrutura de fio, soldado às bandas dos primeiros pré-molares e incorporado à resina acrílica do botão palatino, de Nance. Esse aparelho apresentava ainda dois tubos, nos quais deslizavam-se molas de níquel-titânio e uma fixação. A força distalizadora era obtida pela compressão das molas, por meio da fixação deslizante. A máxima ativação das molas gerava a força de $180 \mathrm{~g}$, para a distalização dos primeiros molares, e de $240 \mathrm{~g}$, para os primeiros e segundos molares. Após a distalização dos molares, o Distal Jet era convertido em retentor simplesmente. Verificaram, num estudo em que o aparelho havia sido aplicado em 25 pacientes, que: 1) o Distal Jet produziu a distalização em massa dos molares superiores, com uma inclinação distal de $6^{\circ}$ para cada milímetro de movimento; 2) a perda de ancoragem foi de $20 \%$ da abertura de espaço; 3) a distalização dos molares não acarretou a divergência mandibular; 5) o aparelho era confortável aos pacientes e, portanto, não requeria a cooperação dos mesmos quanto à sua utilização.

Empregando-se um aparelho de distalização intrabucal que era composto por um botão palatino, de Nance, conectado às bandas dos primeiros pré-molares e primeiros molares e apresentando dois braços em forma da letra "L", composto, também por três helicóides, REINA; MENDOZA ${ }^{122}$, em 1999, apresentaram o aparelho hexahélice. Construíram os braços com fio de aço 0,8 
$\mathrm{mm}$, e os helicóides encontravam-se dispostos de tal forma, que os dois últimos posicionavam-se 2,0 $\mathrm{mm}$ distalmente às bandas dos molares e separadas, entre si, por $6,0 \mathrm{~mm}$. A ação dessas molas gerava uma distalização rápida dos molares, com inclinação distal das coroas, porém como os segundos helicóides situavam-se próximo ao centro de resistência do primeiro molar, isso proporcionava uma boa distribuição das forças. Compensaram as rotações excessivas dos molares e a tendência de expansão, por meio dos terceiros e primeiros helicóides, respectivamente. Os aparelhos deveriam ser reativados a cada seis semanas. Observaram uma abertura de espaço de aproximadamente 7,0 mm, num período de quatro meses. Quando a relação molar, de Classe I, era alcançada, as conexões do aparelho aos primeiros pré-molares eram cortadas, transformado-o em botão acrílico, de Nance, simplesmente. Após a distalização progressiva dos pré-molares, o aparelho era removido, permitindo a retração dos incisivos.

Nem sempre os pacientes estão preparados para cooperar com a terapia ortodôntica. Assim sendo, FIGUEIREDO; FIGUEIREDO; NOBUYASU ${ }^{48}$, em 1999, descreveram ordenadamente a utilização do aparelho Pendulum/Pendex, de Hilgers, na distalização dos molares superiores. Observaram que em apenas três a quatro meses de terapia era possível distalizar os molares em $5 \mathrm{~mm}$ ou mais, facilitando sobremaneira a correção da Classe II, quando o diagnóstico exigia esse tipo de soulção. Concluíram que esses aparelhos produzem forças monomaxilares que, além de promoverem o movimento distal e o giro de molares, podem expandir o arco superior. Isso poderia liberar a maxila de um eventual travamento e permitir o posicionamento anterior da mandíbula.

Visando aprimorar o desenho do aparelho Pendulum e dessa forma melhorar a eficência na distalização dos molares superiores, SCUZZO; PISANI; TAKEMOTO $^{136}$, em 1999, descreveram uma modificação, que consistia na 
colocação de alças horizontais invertidas, proprocionando o controle dos movimentos das coroas e raízes dos molares. Recomendavam que após a distalização dos molares, as alças deveriam ser abertas e isso produziria a verticalização radicular, resultando no movimento de translação, com menor efeito indesejável de rotação e inclinação. Utilizavam, inicialmente, a ativação de $45^{\circ}$ das molas com força distalizadora de $125 \mathrm{~g}$ de cada lado.

Objetivando descrever um método alternativo para a correção da má oclusão de Classe II. ALMEIDA; ALMEIDA; INSABRALDE ${ }^{04}$, em 1999, preconizaram o tratamento em duas fases, na primeira era empregado o aparelho Jones Jig e na segunda fase, a ancoragem extrabucal e aparelhagem fixa. Comentaram que essa mecânica de distalização requeria a mínima cooperação dos pacientes e que possibilitava a condução de um tratamento de forma rápida e consistente, sendo, portanto uma abordagem viável dentro das técnicas ortodônticas convencionais para a correção das discrepâncias dentárias. Entretanto, fatores como o padrão de crescimento, discrepância dentoesquelética, estágio de desenvolvimento dentário e idade do paciente deveriam ser considerados, pois o grau de dificuldade, bem como o prognóstico dessa terapia encontrava-se associada aos fatores supracitados. Dessa forma, a maior distalização dos molares pode ser esperada, quando o dispositivo era utilizado, antes da irrupção dos segundos molares.

Visando facilitar o mecanismo de ativação e reativação das molas dos aparelhos Pendulum/Pendex, ALMEIDA et al. ${ }^{05}$, em 1999, apresentaram uma modificação na construção desses aparelhos. Mostraram a construção, passo-apasso, do aparelho Pendulum/Pendex original e, posteriormente, a alteração incorporada. Os autores ${ }^{05}$ sugeriram iniciar pela bandagem dos primeiros molares, com tubos linguais. Após a cimentação dessas bandas, foram selecionadas e adaptadas as bandas dos primeiros pré-molares e realizada a 
moldagem de trabalho. As bandas dos primeiros pré-molares são transferidas para a moldagem, para a obtenção do modelo de trabalho. A confecção dos grampos de fixação e das molas seguem os princípios preconizados por HILGERS $^{74}$. Entretanto, as molas apresentam algumas diferenças em suas dimensões: 1) o helicóide possui um diâmetro de aproximadamente $5 \mathrm{~mm}$; 2) a alça horizontal é construída $3 \mathrm{~mm}$ distante do helicóide; 3) a conformação da alça envolve $4 \mathrm{~mm}$ de largura por $5 \mathrm{~mm}$ de comprimento e 4) o segmento intratubo não é finalizada com uma alça. Na modificação proposta, o botão palatino, de Nance, foi acrilizado com dois segmentos de tubos telescópicos, de $10 \mathrm{~mm}$ de comprimento, posicionados paralelos à sutura palatina mediana. As molas foram construídas de maneira a se adaptarem a esses tubos, tornando-se removíveis. Concluíram que a grande vantagem verificada nessa modificação encontrava-se relacionada à possibilidade de remoção das molas e a sua posterior ativação fora da cavidade bucal. No aparelho original, realizam-se as ativações, intrabucalmente, com o emprego de dois alicates, simultaneamente, sendo de difícil execução, em função do acesso reduzido, acarretando lesões na mucosa da região do palato mole e falta de controle dos movimentos dos molares. Desse modo, deve-se remover o aparelho e reativá-lo fora da cavidade bucal, e, então, fixá-lo novamente, implicando o aumento do tempo de atividade clínica. Assim, no aparelho modificado, as molas são reativadas extrabucalmente, permitindo uma avaliação mais precisa das dobras de préativação, proporcionando um maior controle durante a distalização dos molares.

Buscando minimizar o problema da perda de ancoragem na distalização dos molares superiores com os métodos intrabucais, CHUNG; PARK; $\mathrm{KO}^{38}$, em 2000, apresentaram uma forma alternativa que era composta de uma estrutura de fio de aço 0,9 $\mathrm{mm}$ com uma dobra, formando um helicóide, na região de caninos e estendia-se posteriormente até os tubos dos primeiros 
molares. Uma mola era soldada distalmente ao helicóide e quando a estrutura metálica era inserida ao tubo, essa mola exercia a força distalizadora sobre o molar. Como ancoragem, empregaram uma placa de resina acrílica que recobria as faces vestibulares dos incisivos e para proporcionar um controle maior da protrusão dos incisivos, acrescentaram ganchos na região anterior para permitir a utilização de elásticos de Classe II, ou mesmo o aparelho extrabucal do tipo gancho em J. As molas quando comprimidas exercem a força distal de $200 \mathrm{~g}$, movimentando os molares na taxa mensal de 1 a 1,5 $\mathrm{mm}$. O controle vertical é mantido pelo ajuste da estrututra de fio oclusalmente ou gengivalmente. As reavaliações deveriam ser realizadas a cada três semanas. Aconselharam a sobrecorreção de 2,0 mm para se evitar a recidiva, na fase de verticalização dos molares.

Comparando os efeitos dos aparelhos extrabucais e Jones Jig na distalização dos molares superiores, HAYDAR; ÜNER ${ }^{69}$, em 2000, avaliaram 20 pacientes, no estágio final da dentadura mista com padrão esquelético de Classe I e Classe II suave e Classe II dentária. Desse total, dez foram tratados com o aparelho Jones Jig e seguidos por aparelhos fixos, e dez foram tratados com aparelhos extrabucais e finalizados com aparelhos fixos. A idade média para o grupo do aparelho Jones Jig e com aparelho extrabucal foi de 10,1 anos e 10,5 anos, respectivamente. Os aparelhos extrabucais foram empregados por 16 horas/diárias com força de 600 g. O tempo médio de tratamento para esse grupo foi de 10,7 meses. O aparelho Jones Jig foi ativado 5,0 $\mathrm{mm}$, produzindo força de $75 \mathrm{~g}$, totalizando um tempo médio de 2,5 meses. Como resultado, os molares foram distalizados efetivamente em ambos os grupos. Observaram que a principal desvantagem entre os dois grupos era o controle da ancoragem, sendo que o movimento mesial e a protrusão da unidade de ancoragem ocorreu no grupo tratado com o aparelho Jones Jig. Entretanto, comentaram que a grande 
vantagem desse aparelho foi o tempo reduzido para se alcançar a distalização, quando comparado com o aparelho extrabucal. Não verificaram a irritação no tecido mole do palato como conseqüência do uso do botão palatino de Nance.

Em 2000, ZANELATO; TREVISI; ZANELATO ${ }^{158}$, apresentaram uma nova abordagem terapêutica para a correção da má oclusão de Classe II, em pacientes adolescentes não cooperadores. Para desenvolver essa proposta de tratamento, era necessário o conhecimento do tamanho e posição dos terceiros molares. Recomendaram a realização das exodontias dos segundos molares superiores antes do início da distalização dos primeiros molares. Utilizaram para a distalização dos primeiros molares superiores, as molas abertas que eram posicionadas entre os primeiros molares e segundos pré-molares, sendo 3,0 $\mathrm{mm}$ maior que esse espaço. As molas eram substituídas a cada 21 dias. Como forma de ancoragem empregaram o botão palatino de Nance.

O emprego do aparelho extrabucal, de tração cervical, é evidenciado na correção esquelética e dentária da má oclusão de Classe II, expansão lenta da base apical, como alternativa para aumentar o comprimento do arco e como ancoragem na correção da mordida profunda e durante a fase de retração dos dentes anteriores nos casos de extrações, e também para aplicação direta no arco inferior. HAAS $^{65}$, em 2000, comentou sobre a utilização do aparelho extrabucal cervical, na correção dentária da má oclusão de Classe II, sem deslocar o arco inferior. Citou que a variação na magnitude de força poderia acarretar alterações esqueléticas e dentárias. Assim sendo, a força de 688,56 a 1377,12 g deveria ser usada no tratamento de más oclusões de Classe II esqueléticas; de 459,04 a $688,56 \mathrm{~g}$, no controle do desenvolvimento anterior da maxila e de 172,14 a $286,9 \mathrm{~g}$, para produzir efeitos dentoalveolar com pouca ou nenhuma ação sobre o crescimento maxilar. 
A barra transpalatina de Goshgarian é um aparelho que permite o aumento no comprimento do arco pela rotação, expansão e distalização dos molares, independentemente da cooperação do paciente. HAAS; CISNEROS ${ }^{66}$, em 2000, examinaram os efeitos desse aparelho na correção da má oclusão de Classe II, e determinaram as características da força-ativação do aparelho, com um modelo laboratorial. Avaliaram as telerradiografias em norma lateral e modelos de 11 pacientes com más oclusões de Classe II. Os resultados revelaram que a correção era alcançada pela inclinação distal e rotação distovestibular do molar ativado. O movimento distal das cúspides mesiovestibulares e mesiolinguais foi de aproximadamente 1,8 e $0,9 \mathrm{~mm}$, respectivamente. A rotação dos molares ativados foi de $12^{\circ}$ e a inclinação distal foi de $4^{\circ}$. Os efeitos negativos eram visualizados no movimento mesial de 1,3 mm dos molares não ativados. As distâncias intermolares e intercaninos tiveram um aumento substancial com torque vestibular de raiz. Observaram também a expansão dos segundos pré-molares. Não ocorreu a intrusão e extrusão dos molares. Os resultados laboratoriais mostraram a linearidade das forças, sendo que a força gerada pela deflexão distal era de $16 \mathrm{~g} / \mathrm{mm}$, ou seja, um quarto a um oitavo da força gerada pelos aparelhos extrabucais, e a força média de expansão era de $260 \mathrm{~g} / \mathrm{mm}$. Quando a ativação distal excedia $35^{\circ}$, resultava no comportamento não elástico.

$\mathrm{O}$ arco distalizador bimétrico de Wilson é um sistema que promove a distalização rápida dos molares, com o uso controlado da força para maximizar os movimentos, minimizando as forças reacionárias. RANA; BECHER ${ }^{121}$, em 2000, realizaram um estudo retrospectivo, para avaliar os resultados do tratamento, após o emprego do arco distalizador de Wilson e mecânica Edgewise. A amostra consistiu de 18 pacientes, quatro do gênero masculino e 14 do feminino, com a idade média de 13 anos, caracterizados pela má oclusão 
de Classe II, sobressaliência menor que 8,0 $\mathrm{mm}$, incisivos superiores verticalizados ou com inclinação normal, apinhamento suave nos arcos superior e inferior. Todos os pacientes foram tratados com o arco distalizador bimétrico para corrigir a relação molar de Classe II. Utilizaram as molas de níquel-titânio e o esquema de redução da força dos elásticos. Instruíram os pacientes para efetuarem as substituições dos elásticos da seguinte forma: 172,14 g por três semanas; $114,76 \mathrm{~g}$ por duas semanas e 57,38 g por uma semana. Os molares foram distalizados até se obter a sobrecorreção e o tratamento, finalizado com mecânica Edgewise. Compararam as telerradiografias iniciais e finais. A correção resultou da distalização dos molares superiores e movimento mesial dos molares inferiores. Os molares superiores inclinaram-se distalmente $2,3^{\circ}$, distalizaram $0,8 \mathrm{~mm}$ e extruíram em média $1,1 \mathrm{~mm}$, em relação ao plano palatino. Verificaram também a ocorrência da protrusão dos incisivos superiores e inferiores. A inclinação vestibular e protrusão dos incisivos superiores foi em média $3,5^{\circ}$ e $1,4 \mathrm{~mm}$, respectivamente. A extrusão dos incisivos superiores foi de 0,6 mm. Concluíram que os primeiros molares poderiam ser distalizados unilateral ou bilateralmente e que a seleção do paciente era imperativo para se alcançar o sucesso com essa terapia. Consideraram como pacientes ideais para esse tipo de aparelho: pacientes adolescentes, relação molar de Classe II suave, incisivos superiores verticalizados, padrão de crescimento normodivergente e mínimo apinhamento.

Na correção da má oclusão de Classe II, devem ocorrer uma ou mais variedades de alterações ântero-posteriores, incluindo a distalização de molares superiores, movimento mesial de dentes inferiores, crescimento e/ou mudanças ortopédicas das bases ósseas. As alterações esqueléticas e dentoalveolares, promovidas pelo aparelho Herbst, contribuem para a correção da má oclusão de Classe II. LAI ${ }^{91}$, em 2000, avaliou os efeitos dentários do aparelho Herbst, 
assim como os seus efeitos a longo-prazo sobre a dentição. O sistema telescópico do aparelho Herbst aplica uma força distalizadora e intrusiva sobre os molares superiores e o vetor de força passa oclusalmente ao centro de resistência. Esse sistema produz o movimento dos molares superiores para trás e para cima, associado à inclinação distal da coroa. Observaram que o aparelho Herbst, assim como os outros mecanismos intra-arcos, tais como os elásticos de Classe II e os arcos de Wilson, utilizam a ancoragem do arco inferior, na distalização dos molares superiores. As forças recíprocas deslocam a dentição inferior anteriormente e protruem os incisivos inferiores. Embora todos esses aparelhos sejam efetivos na correção da relação sagital, as mudanças verticais resultantes diferem. Os elásticos de Classe II tendem a extruir os incisivos superiores e molares que ocasionam a rotação horária mandibular. $\mathrm{O}$ aparelho Herbst, por sua vez, proporciona a força intrusiva sobre os molares superiores e dentes inferiores, gerando um aumento no ângulo do plano oclusal e sem reflexo para o plano mandibular. Em geral, a distalização dos molares superiores contribui com 25 a $40 \%$ da correção molar, com o aparelho de Herbst bandado, e de 20 a 25\%, com o aparelho suportado por resina acrílica. Concluíram que o reestabelecimento parcial ocorre após a terapia Herbst e os efeitos podem persistir no arco inferior.

$\mathrm{O}$ interesse pela terapia sem extrações tem acelerado o uso e desenvolvimento de muitos aparelhos distalizadores, que requerem o mínimo efeito da cooperação dos pacientes. $\mathrm{O}$ aparelho desenvolvido por Hilgers, tem se tornado um dos mais populares. JOSEPH; BUTCHART ${ }^{86}$, em 2000, avaliaram o desempenho desse aparelho na correção da má oclusão de Classe II, pela distalização dos molares superiores, em sete pacientes. Realizaram medições em telerradiografias laterais iniciais e após a remoção dos aparelhos. A distalização dos molares superiores, com a sobrecorreção além da relação molar de Classe I, 
foi alcançada em 3,4 meses. O movimento distal médio dos primeiros molares superiores foi de 5,1 mm. Esse movimento foi acompanhado da alteração média, na angulação de $15,7^{\circ}$. A perda de ancoragem foi evidente, com o aumento na angulação dos incisivos de $4,9^{\circ}$ e a protrusão média de $3,7 \mathrm{~mm}$. A dimensão vertical foi mantida. Concluíram que esse aparelho era efetivo na distalização dos molares para a relação de Classe I, com pouca cooperação dos pacientes; também que apresentavam alguns efeitos visíveis de perda de ancoragem, tais como o aumento da sobressaliência e na inclinação dos molares.

Considerando-se as vantagens do aparelho Distal Jet, QUICK; HARRIS $^{119}$, em 2000, descreveram algumas modificações para eliminar algumas dificuldades observadas na utilização destes sistemas. A modificação básica era que a secção deslizante passou a ser inserida, de distal para a mesial, nos tubos linguais dos molares. A extensão da presilha deveria ser mais longa, para facilitar a amarração com elásticos ou ligaduras metálicas. Comentaram que molas comprimidas também poderiam ser acrescentadas por vestibular, proporcionando uma força adicional. Verificaram que um espaço de 4,0 mm poderia ser aberto entre os molares e pré-molares, num período de três meses e meio. Constataram que o uso simultâneo de molas por vestibular acarretou algum grau de inclinação distal dos molares, enquanto o Distal Jet produzia o movimento de translação.

A mecânica de distalização, para a correção das más oclusões de Classe II, é uma modalidade de tratamento comum. Assim sendo, BUSSICK; McNAMARA $\mathrm{Jr}^{24}$, em 2000, examinaram os efeitos esqueléticos e dentoalveolares, a magnitude e a direção do movimento dos primeiros molares superiores e a perda da ancoragem, ou seja, o movimento mesial de primeiros pré-molares e incisivos, com a utilização do aparelho Pendulum em pacientes de Classe II, apresentando variados estágios de desenvolvimento dentário 
(presença ou ausência dos segundos molares decíduos, segundos molares permanentes superiores, irrompidos ou não) e com distintos padrões faciais, caracterizados pelo ângulo do plano mandibular com o plano horizontal de Frankfurt (MPA) baixo $\left(<\right.$ que $21^{\circ}$ ), alto (> que $26^{\circ}$ ) e neutro (entre 21 e $26^{\circ}$ ). Verificaram também se os efeitos do aparelho variavam com os diferentes estágios de desenvolvimento dentário. Com esse propósito, empregaram telerradiografias iniciais e finais de 101 pacientes, dos quais 56 eram do gênero feminino, com idade média de 12 anos e um mês e 45 do masculino, com a mesma idade média. Os indivíduos incluídos nesse estudo foram tratados por 13 diferentes profissionais dos Estados Unidos, com o aparelho Pendulum/Pendex, similar ao descrito por Hilgers, em 1992. As molas foram ativadas 60 a $90^{\circ}$, produzindo a força distal de 200 a 250 g. Quando necessário, os segmentos intratubos eram ajustados, para controle da rotação durante a distalização dos molares. Geralmente, o monitoramento dos pacientes era efetuado a cada três a quatro semanas, por um período total de ativação de, aproximadamente, oito a 12 semanas. As telerradiografias finais eram obtidas quando os molares alcançavam a relação próxima de Classe III. Os resultados desse estudo indicaram que o aparelho Pendulum afeta, primariamente, a dentição superior, entretanto, com efeitos menos pronunciados sobre as estruturas esqueléticas craniofaciais e tecidos moles associados. Os efeitos esqueléticos sagitais podem ser observados no aumento de $0,4^{\circ}$ e aumento no comprimento da face média de 0,6 mm. O comprimento mandibular aumentou e houve uma diminuição no ângulo SNB e na distância Pg-NPerp. A distalização dos primeiros molares superiores, média, foi de $5,7 \mathrm{~mm}$, com uma inclinação distal de $10,6^{\circ}$. Os dentes da unidade de ancoragem sofreram movimento mesial, como indicado pelo movimento anterior, de $1,8 \mathrm{~mm}$ dos primeiros pré-molares, com inclinação mesial de $1,5^{\circ}$. A distalização dos molares representou $76 \%$ das mudanças 
sagitais dos molares e o movimento anterior recíproco dos primeiros prémolares $24 \%$. A relação molar demonstrou $6,4 \mathrm{~mm}$ de correção da Classe II para a Classe I. Os primeiros molares superiores intruíram $0,7 \mathrm{~mm}$ e os primeiros pré-molares extruíram 1,0 $\mathrm{mm}$. Os primeiros molares permanentes inferiores extruíram 0,7 mm, com mesialização de $0,2 \mathrm{~mm}$. As alterações verticais mostraram que o plano palatino permaneceu inalterado durante o período. $\mathrm{O}$ plano oclusal sofreu uma abertura e o ângulo do plano mandibular (MPA) e a altura facial ântero-inferior (AFAI) aumentaram significantemente. A mandíbula sofreu uma rotação horária de $1,0^{\circ}$, a sobremordida diminuiu $1,7 \mathrm{~mm}$ e a sobressaliência aumentou $0,8 \mathrm{~mm}$. A altura facial ântero-inferior aumentou 2,2 mm e não havia diferença entre pacientes com ângulos do plano mandibular baixo, alto e neutro. Esse aumento foi atribuído a extrusão de $0,7 \mathrm{~mm}$ dos molares inferiores, associado ao movimento distal dos molares superiores para dentro do arco de fechamento. Considerando-se a ancoragem proporcionada por molares decíduos, em relação aos pré-molares, verificaram que ocorreu uma extrusão maior no último grupo, produzindo também um aumento na AFAI de 2,4 mm contra 1,6 mm, no primeiro grupo. Não notaram nenhuma diferença na quantidade de distalizaçã, na presença ou não dos segundos molares permanentes, porém observaram um aumento maior na AFAI e no MPA, em comparação aos pacientes sem segundos molares, sendo de 1,2 e 2,7 mm, respectivamente. Constataram a ocorrência da protrusão do lábio superior de 0,6 $\mathrm{mm}$ e do lábio inferior de $1,0 \mathrm{~mm}$ em relação ao plano estético. $\mathrm{O}$ ângulo nasolabial diminuiu $2,5^{\circ}$ e a inclinação do lábio superior acentuou $2,0^{\circ}$. Essas alterações foram atribuídas à perda de ancoragem anterior. Sugeriram que, para a obtenção da máxima distalização dos molares, com o mínimo aumento da AFAI, o aparelho Pendulum deveria ser empregado com os segundos molares 
decíduos como ancoragem e na ausência dos segundos molares permanentes, embora nenhuma abertura significante da mordida tenha sido constatada.

Os aparelhos ortodônticos removíveis também podem ser utilizados na correção da Classe II. ARAS $^{08}$, em 2000, descreveu o uso clínico de um aparelho sagital, combinado com aparelho extrabucal com ganchos em forma da letra J. Essa técnica foi usada para distalizar os segmentos posteriores, após as extrações dos segundos molares, no tratamento de pacientes com más oclusões de Classe II com caninos superiores em vestibuloversão. $\mathrm{O}$ aparelho extrabucal foi empregado por 10 a 12 horas por dia. Esse método mostrou ser efetivo na distalização dos dentes posteriores, sem causar efeitos indesejáveis de vestibularização dos dentes anteriores.

O problema enfrentado na realização das reativações do aparelho Pendulum foi eliminado por SCUZZO et al. ${ }^{135}$, em 2000, com uma modificação estabelecida, por meio da qual as molas passaram a ser removíveis. A extremidade de retenção da mola era soldada a um outro segmento de fio de titânio-molibdênio, e durante a construção do botão de acrílico essa extremidade era inserida na resina acrílica na fase plástica, promovendo a formação de um tubo interno. Os autores ${ }^{134}$ relataram que essa modificação reduziu o tempo de cadeira para o atendimento dos pacientes e o movimento distal mensal dos molares de 1,5 mm e com um controle maior, pois os efeitos indesejáveis poderiam ser neutralizados.

Dentre os inúmeros mecanismos distalizadores intrabucais, destaca-se o aparelho Jones Jig. SUGINO; FURQUIM; RAMOS ${ }^{141}$, em 2000, descreveram a construção laboratorial do aparelho passo-a-passo e realizaram algumas considerações clínicas sobre a aplicação clínica do aparelho. Comentaram sobre os efeitos dentários e esqueléticos resultantes da distalização dos molares com esse sistema. Verificaram que o mvoimento distal mensal dos primeiros molares 
era de 1,0 mm, embora pudesse manifestar as variações individuais. Recomendram a realização das reativações a cada 4 a 5 semanas e verificaram que apesar desses mecanismos proporcionarem a distalização rápida dos molares,em 120 -180 dias e sem a necessidade de cooperação dos pacientes, também promovem a perda de ancoragem dos dentes anteriores.

Os efeitos do aparelho Pendulum na distalização de molares superiores em indivíduos apresentando vários padrões de crescimento facial e as alterações durante o curto período de estabilização de três meses foram estudados por TOROGLU et al. ${ }^{144}$, em 2001, numa amostra de 30 pacientes, divididos em dois grupos, baseados nos valores do ângulo FMA. O grupo denominado alto ângulo (grupo 1), composto de 14 pacientes, sendo 10 do gênero feminino e 4 do masculino, com a idade média de 13,14 anos e ângulo FMA maior ou igual a $29^{\circ}$. O grupo considerado de baixo ângulo (grupo 2), foi constituído por 16 pacientes, sendo distribuídos igualmente nos gêneros masculino e feminino, com idade média de 12,9 anos. Empregaram as telerradiografias iniciais e finais para avaliar as alterações decorrentes da distalização dos molares. Em relação às alterações esqueléticas, observaram que os ângulos SNA, SNB e ANB sofreram ligeiras modificações, porém não significantes. Verificaram que não houve diferença estatisticamente significante na quantidade da distalização dos molares nos dois grupos, sendo de 5,9 mm no grupo 1 e de 4,1 $\mathrm{mm}$ no grupo 2 . Os autores $^{143}$ explicaram a ocrrência dessa pequena diferença na quantidade de distalização, pelo fato de que em $75 \%$ dos pacientes do grupo 2 , os segundos molares se encontravam irrompidos e no grupo 1, em apenas $57 \%$. A perda de ancoragem foi de $4,8 \mathrm{~mm}$ e $6,6 \mathrm{~mm}$, respectivamente nos grupos 1 e 2 . O movimento mesial dos incisivos superiores foi de 2,1 $\mathrm{mm}$ no grupo 1 , e de 4,1 $\mathrm{mm}$ no grupo 2, resultando no aumento da sobressaliência. Constataram que no perídodo de estabilização, a perda de ancoragem dos molares foi de $1,5 \mathrm{~mm}$ e de 
$1,7 \mathrm{~mm}$, nos grupos 1 e 2, e que os segundos pré-molares e incisivos tendiam a retornar as posições iniciais. Concluíram que o aparelho Pendulum distalizava os molares num curto período de tempo, entretanto, havia a necessidade de estabilizá-los por pelo menos três meses com o intuito de se evitar a perda de ancoragem. 



\section{PROPOSIÇÃO}

Esta pesquisa propõe-se analisar, cefalometricamente e em modelos de estudo, as possíveis alterações decorrentes da distalização de primeiros e segundos molares superiores, com o aparelho Pendulum em jovens brasileiros leucodermas, com má oclusão de Classe II, $1^{\text {a }}$ divisão de Angle, para:

1) Examinar os efeitos dentários e esqueléticos após o uso do aparelho Pendulum, a curto prazo;

2) Determinar a taxa de movimento distal dos molares superiores, assim como as alterações em suas inclinações axiais;

3) Avaliar a perda de ancoragem por meio do movimento mesial dos pré-molares e incisivos;

4) Verificar a alteração nas inclinações axiais de pré-molares e incisivos;

5) Calcular a porcentagem de movimento dos molares e prémolares, responsável pela abertura de espaço entre segundos pré-molares e primeiros molares;

6) Analisar as alterações sagitais e transversais dos molares, prémolares, caninos e incisivos superiores, em modelos de estudo, decorrentes da distalização dos molares;

7) Examinar as alterações verticais dos molares, pré-molares, caninos e incisivos superiores e;

8) Determinar a taxa de distalização mesial dos molares. 



\section{MATERIAL E MÉTODOS}

\subsection{MATERIAL}

A amostra utilizada no presente estudo consistiu de 32 indivíduos, de ambos os sexos (23 do sexo feminino e 9 do masculino), leucodermas, brasileiros, naturais da cidade de Bauru, estado de São Paulo, com idade variando de 11 anos e 6 meses a 17 anos e 9 meses, idade média de 14 anos e 7 meses. Do total de 32 pacientes, foram empregados: 1) telerradiografias em norma lateral de 31 pacientes, envolvendo as fases inicial e final; 2) telerradiografias em norma lateral de $45^{\circ}$ de 31 pacientes, dos lados direito e esquerdo, para as fases inicial e final e 3) modelos de estudo de 31 pacientes para as etapas já referidas. Foi descartado um paciente pela falta de documentação completa que possibilitasse a avaliação pela metodologia desenvolvida.

Os pacientes foram selecionados na Clínica de Ortodontia da Faculdade de Odontologia de Bauru - Universidade de São Paulo e em Escolas Estaduais, respeitando-se os seguintes critérios:

1) relação molar de Classe II de Angle;

2) presença de todos os dentes permanentes, do segundo ao segundo molar do lado oposto;

3) observação clínica dos relacionamentos dos caninos e incisivos de Classe II (Figuras 1 a 4).

Todos os indivíduos selecionados receberam, como mecanismo para a distalização dos molares superiores, o aparelho Pendulum de Hilgers, que foi empregado por um período de 5,87 meses (5meses e 26 dias). Foram analisadas as telerradiografias cefalométricas, em norma lateral convencional e de $45^{\circ}$ e os 
modelos de estudo desses pacientes obtidos antes e após a fase de distalização dos molares.
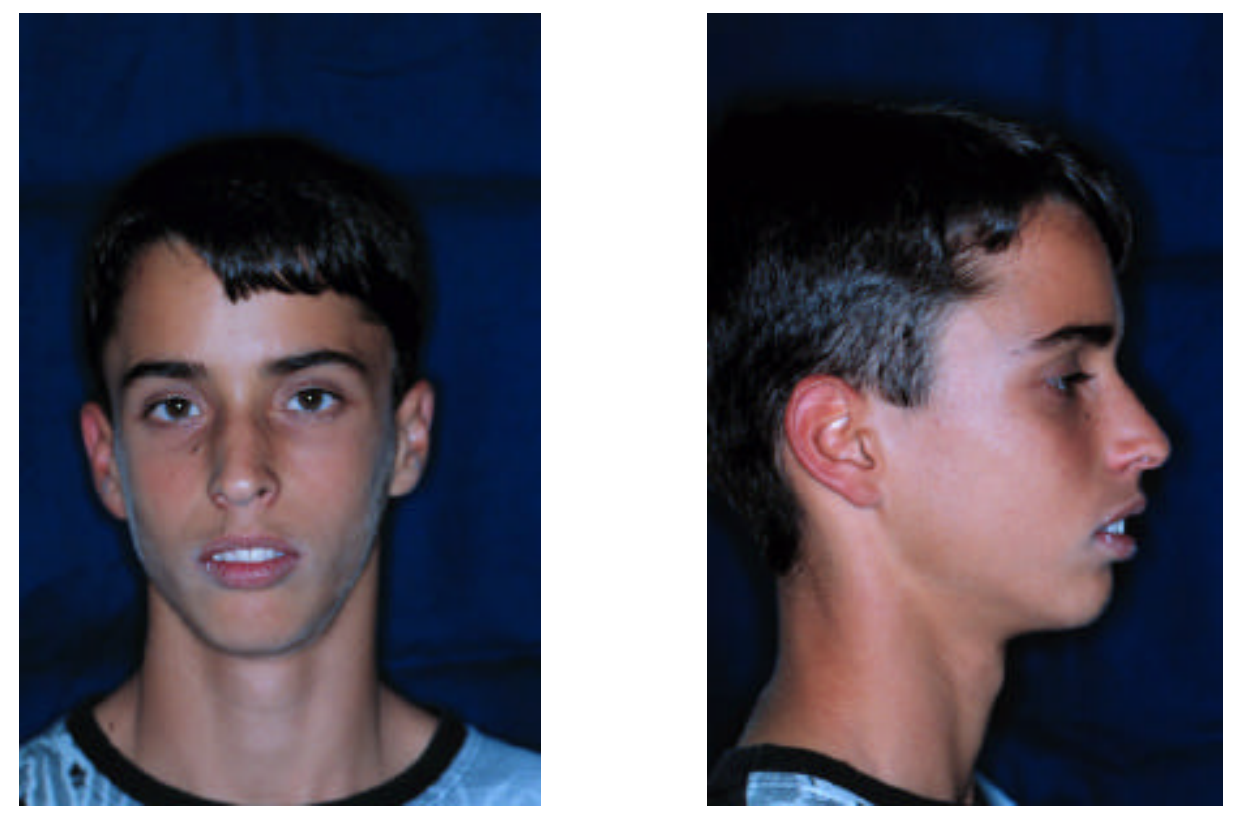

FIGURA 1- Fotografias extrabucais iniciais, de um paciente apresentando as características da amostra.

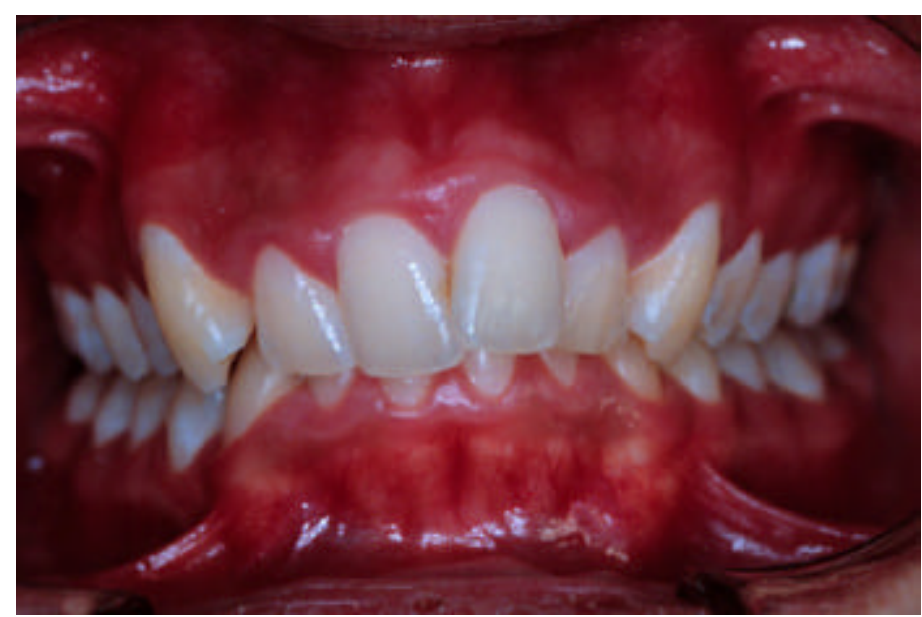

FIGURA 2 - Fotografia frontal intrabucal inicial, de um paciente da amostra. 


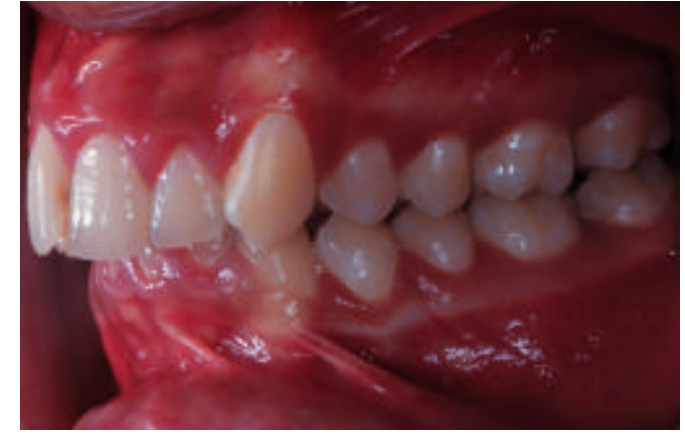

FIGURA 3- Fotografia intrabucal lateral direita inicial.

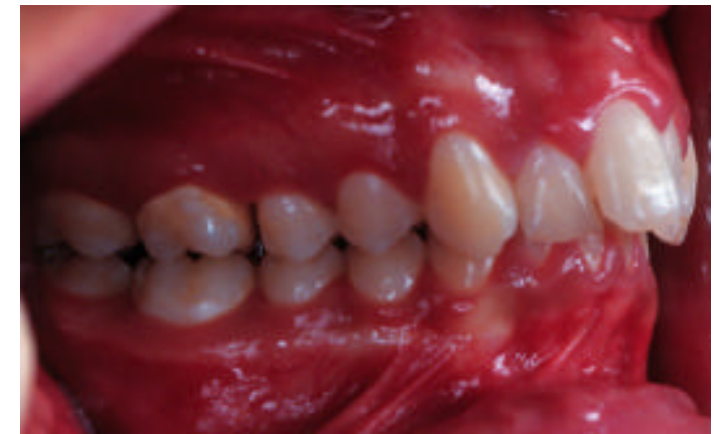

FIGURA 4 - Fotografia intrabucal lateral esquerda inicial.

\subsection{MÉTODO}

Para uma melhor organização, dividiu-se o método em:

4.2.1) Tratamento ortodôntico;

4.2.2) Método radiográfico;

4.2.3) Elaboração dos cefalogramas em norma lateral convencional;

4.2.4) Elaboração dos cefalogramas em norma lateral de $45^{\circ}$;

4.2.5) Análise de modelos;

4.2.6) Controle de erro e

4.2.7) Análise estatística.

\subsubsection{TRATAMENTO ORTODÔNTICO}

\subsubsection{CONSTRUÇÃO DOS APARELHOS}

Os pacientes selecionados receberam, como mecanismos distalizadores dos molares superiores, o aparelho Pendulum de Hilgers. A construção desse aparelho seguiu os passos descritos por ALMEIDA et al. ${ }^{05}$, em 1999, envolvendo basicamente duas fases: uma laboratorial (Figuras 13 a 24) e outra clínica (Figuras 5 a 12). 
Inicialmente foram adaptadas as bandas dos primeiros molares superiores com tubos duplos ou triplos por vestibular e linguais pela palatina da marca ORMCO (código 672-3672) ou similar nacional MORELLI (código T1L08) por palatina, figuras 6 a 9). Após a cimentação das bandas nos primeiros molares, eram adaptadas as bandas nos primeiros pré-molares e obtinham-se os modelos de trabalho (Figuras 10 a 12).

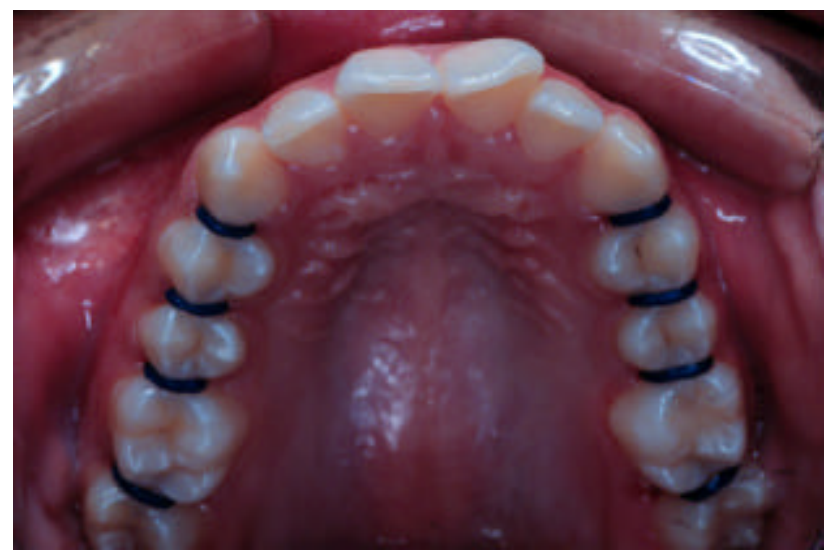

FIGURA 5 - Início da fase clínica, com a separação dos primeiros molares e primeiros pré-molares superiores.

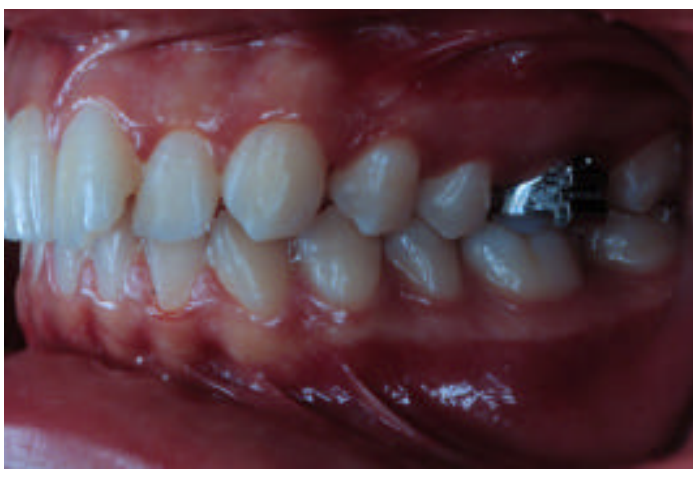

FIGURA 6 - Bandagem do primeiro molar superior direito.

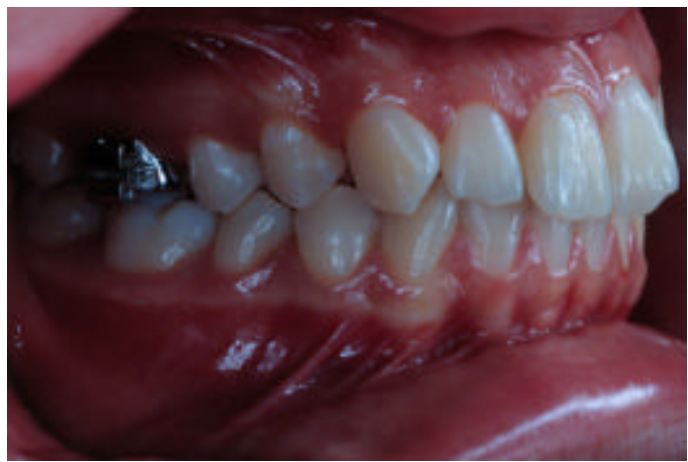

FIGURA 7 - Bandagem do primeiro molar superior esquerdo. 


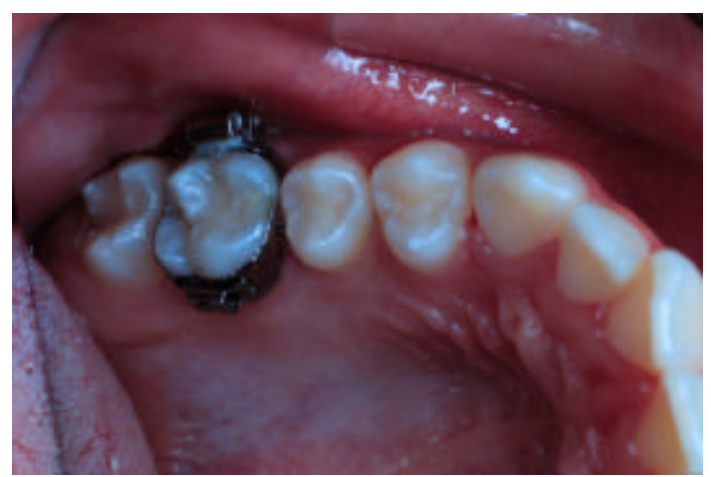

FIGURA 8 - Vista oclusal mostrando a adaptação do tubo lingual.

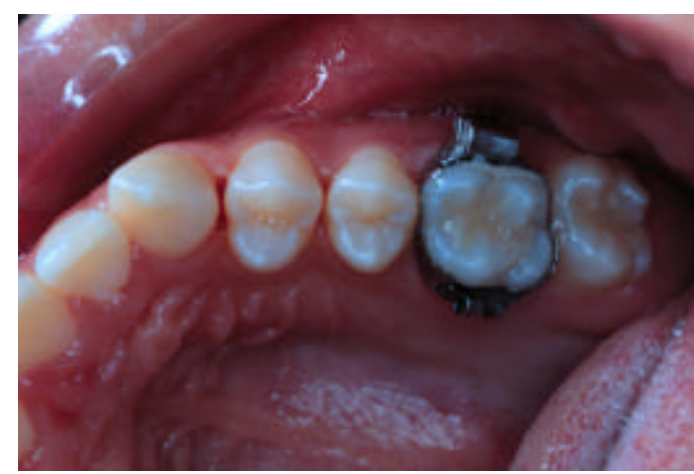

FIGURA 9 - Vista oclusal mostrando a adaptação do tubo lingual.

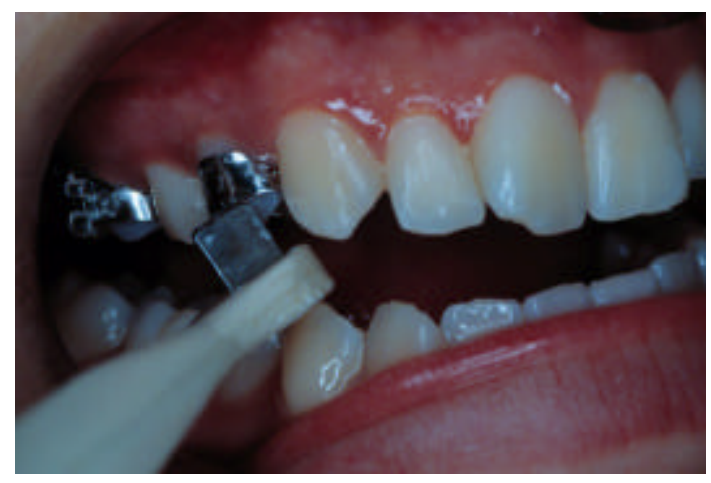

FIGURA 10 - Adaptação da banda do primeiro pré-molar superior.

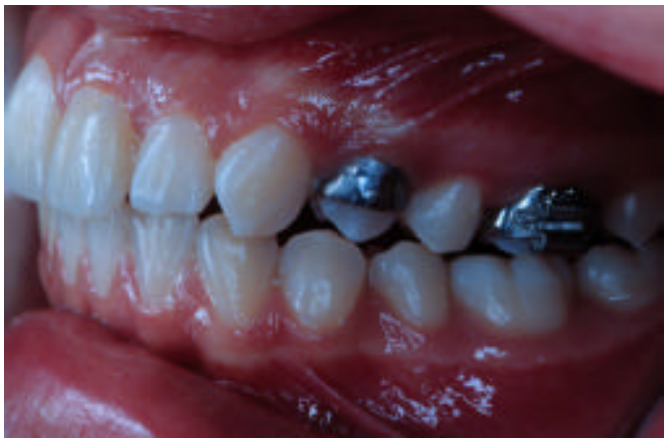

FIGURA 11 - Vista lateral direita, mostrando a banda do primeiro pré-molar adaptada.

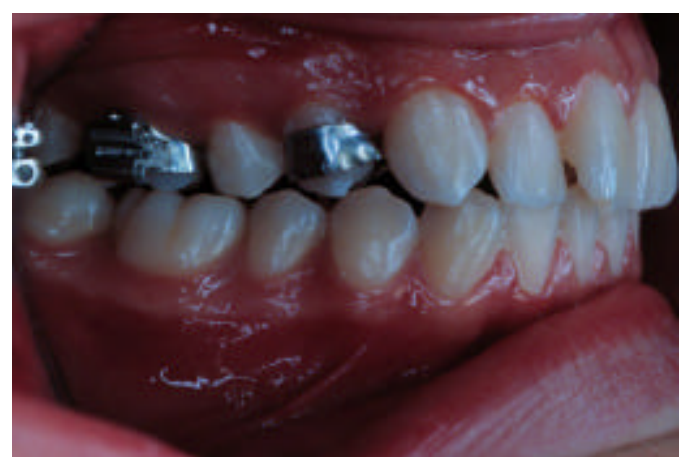

FIGURA 12 - Vista lateral esquerda, mostrando a banda do primeiro pré-molar adaptada. 
A fase laboratorial principiava com a construção dos grampos de apoio oclusais. Utilizando-se o alicate "Bird beak" ou 139, dobrava-se a extremidade de um segmento de $5 \mathrm{~cm}$ de fio ortodôntico $0,9 \mathrm{~mm}$ sobre a ponta piramidal para obter uma dobra menor que $90^{\circ}$, que deveria ser ajustada às cristas marginais mesial dos primeiros pré-molares e distal dos segundos pré-molares (Figuras 13 a 16). Entretanto, visando um maior controle na estabilidade dos aparelhos e eliminar os riscos de fratura das resinas utilizadas para a fixação dos grampos nas áreas das cristas marginais, optou-se pela substituição dos grampos dos primeiros pré-molares por bandas metálicas. Dessa forma, os grampos de apoio oclusais passaram a ser soldados nas faces palatinas dessas bandas, conservando-se apenas os grampos de apoio oclusais dos segundos pré-molares (Figuras 30 e 31). Assim sendo, convencionalmente, HILGERS ${ }^{74}$ utilizava a fixação por meio dos grampos de apoio oclusais, embora comentasse dessa outra possibilidade de retenção do aparelho.

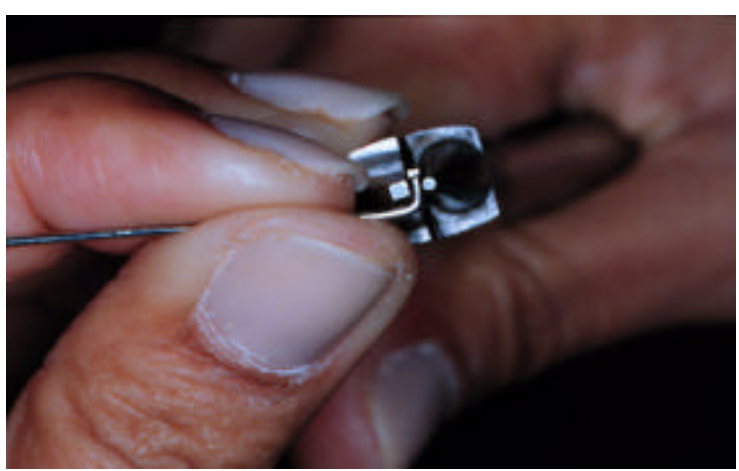

FIGURA 13 - Dobra na extremidade do fio ortodôntico $0,9 \mathrm{~mm}$ para a construção do grampo de apoio oclusal.

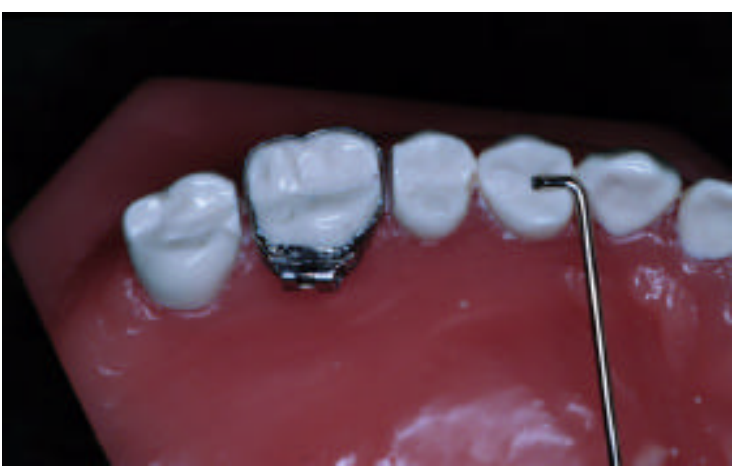

FIGURA 14 - Grampo adaptado na crista marginal mesial do primeiro pré-molar superior. 


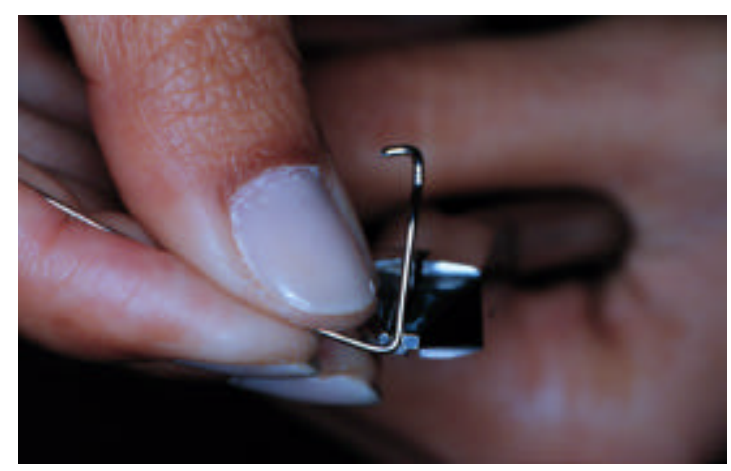

FIGURA 15- Região de retenção do grampo.

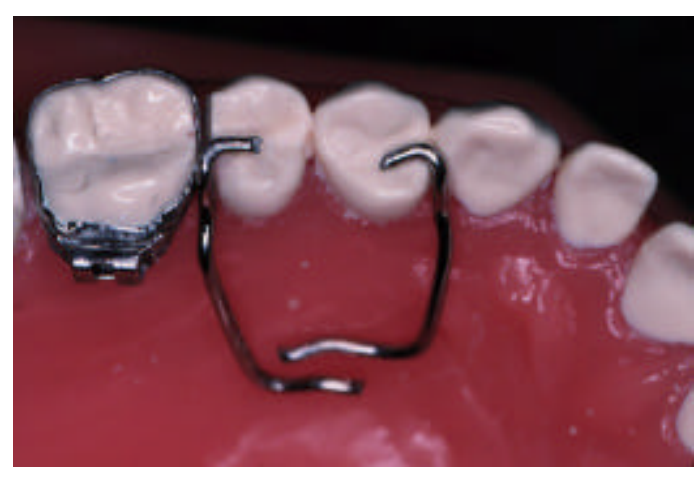

FIGURA 16- Grampos de apoio oclusal finalizados.

O passo subseqüente era a construção das molas distalizadoras com fio de titânio-molibdênio (TMA) .032”. Com o alicate 139 ou alicate 0423 da marca AEZ/ORMCO, realizava-se, inicialmente, uma dobra em forma de gota que constituiria a parte de retenção das molas, figura 17.

Posteriormente, com o fio posicionado paralelo à sutura palatina mediana (Figura 18), fazia-se uma demarcação na região do primeiro molar a partir do qual era construído o helicóide, que deveria ter aproximadamente 4,0 mm de diâmetro interno, figura 19.

O próximo passo consistia em confeccionar, $3,0 \mathrm{~mm}$ distante do helicóide, as alças horizontais de ajuste, apresentando 4,0 $\mathrm{mm}$ de largura e 4,0 $\mathrm{mm}$ de altura, com o objetivo de aumentar o comprimento de fio, reduzindo, assim, a relação carga/deflexão e aumentando a flexibilidade da mola, figura 20. Esse procedimento facilitava a inserção dos segmentos intratubos das molas nos tubos linguais, assim como permitia a condução de pequenos ajustes verticais e transversais durante a avaliação da pré-ativação da mola 


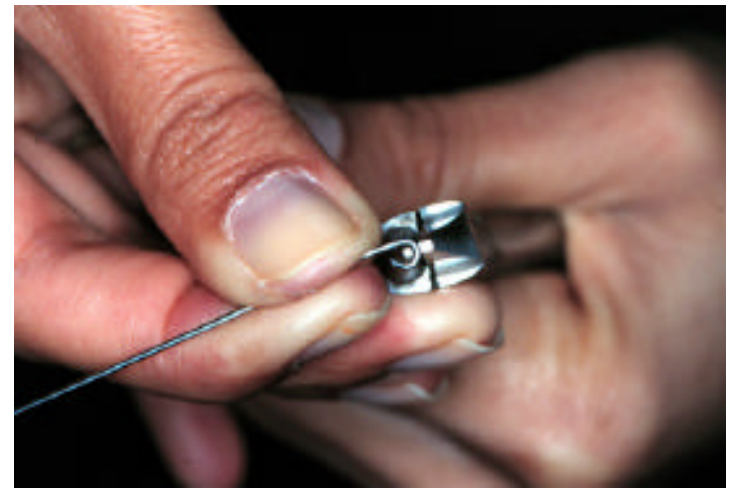

FIGURA 17- Construção da região de retenção da mola distalizadora.

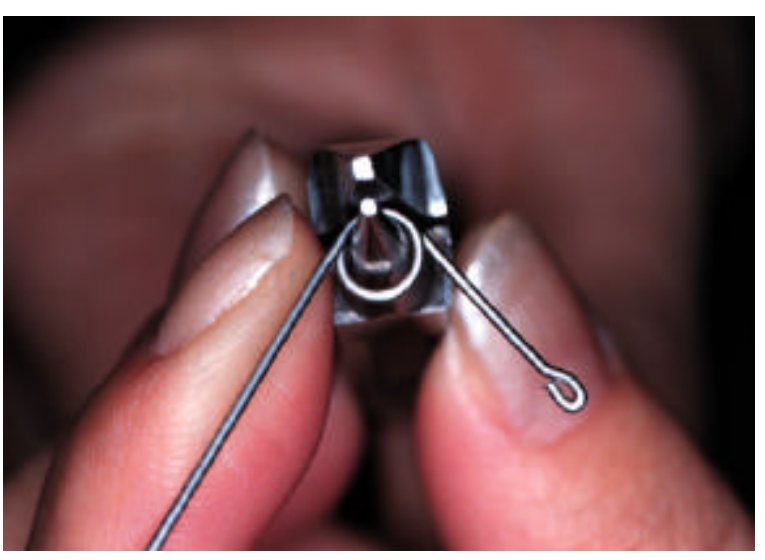

FIGURA 19- Construção do helicóide.

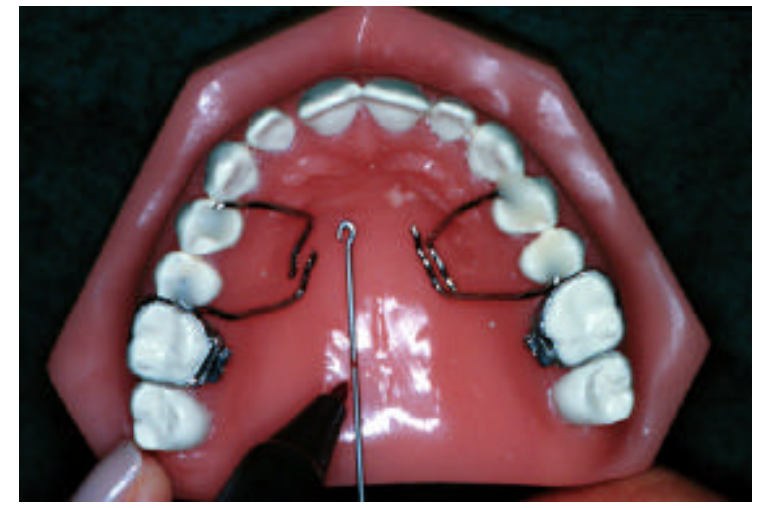

FIGURA 18- Posicionamento da mola, paralela à sutura palatina mediana.

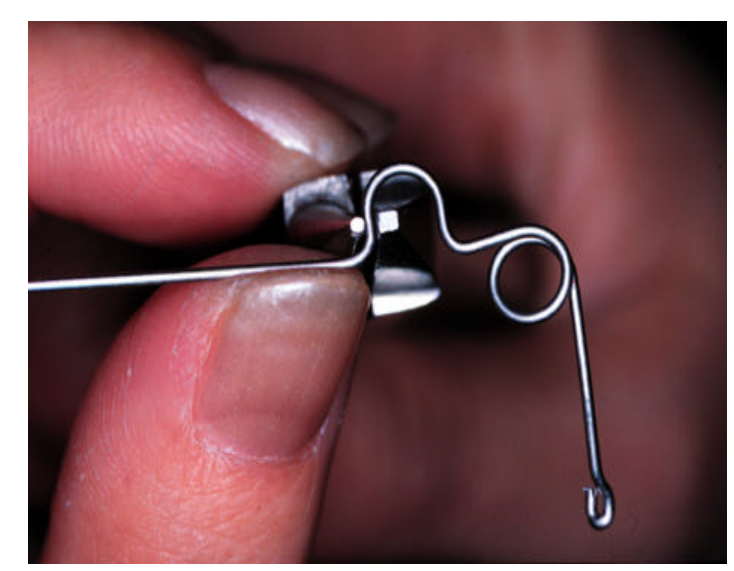

FIGURA 20- Construção da alça horizontal de ajuste. 


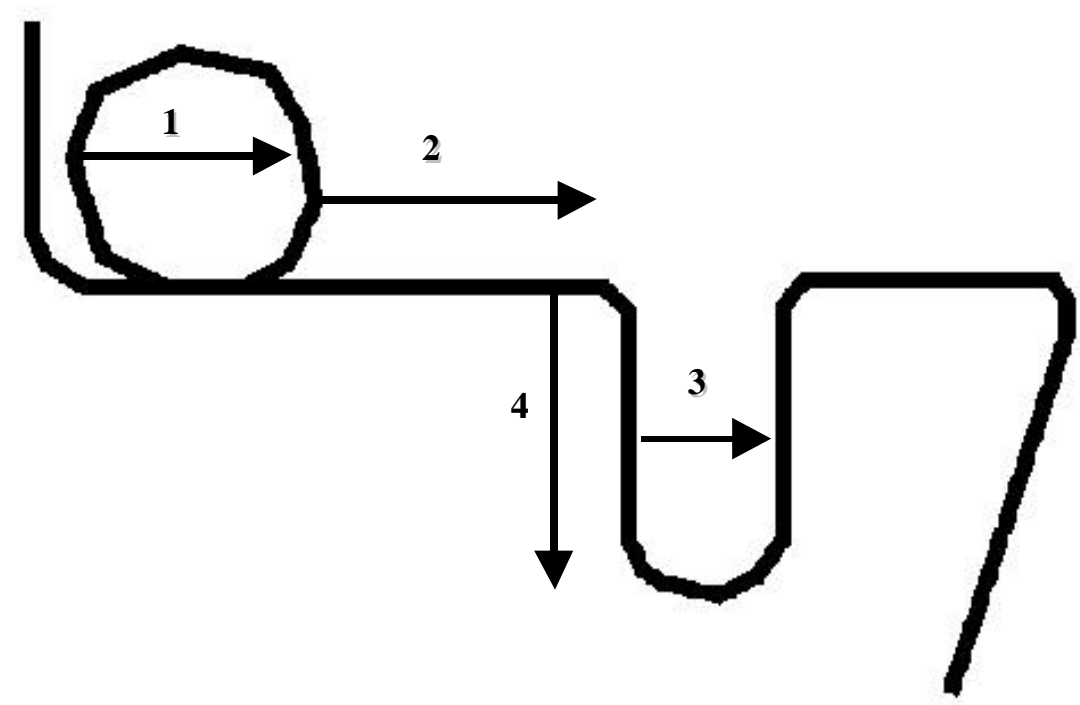

1- Helicóide de diâmetro 4,0 mm, 2- Distância de 3,0 mm,

3- Largura da alça de 4,0 mm e 4- Altura da alça de 4,0 $\mathrm{mm}$

FIGURA 21 Dimensões da mola distalizadora

Confeccionada a alça, toda a extensão devia ser recurvada para uma melhor adaptação no rebordo alveolar do palato, figura 22. Com a mola posicionada, fazia-se uma marcação na altura da luz do tubo lingual e finalizavase, simplesmente, com uma dobra, formando-se o segmento intratubo, figura 23. Essa extensão é que era inserida no tubo lingual, portanto, era ajustada para que permanecesse passiva, tanto no sentido vestibulolingual quanto no vertical, para evitar a ocorrência de movimentos indesejáveis dos primeiros molares permanentes, durante a distalização.

Para a obtenção da mola do lado oposto repetiam-se os procedimentos anteriormente citados, com a preocupação de preservar a simetria com a mola construída primeiramente (Figura 21). 
$\mathrm{Na}$ construção das molas, era fundamental evitar as dobras muito agudas, pois o fio TMA era mais suscetível às fraturas nos locais onde recebia uma pressão muito grande.

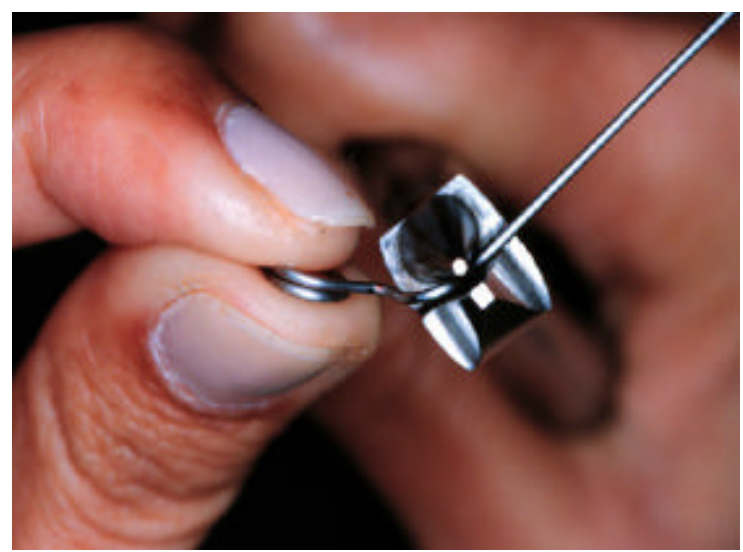

FIGURA 22- Mola recurvada para melhor adaptação no palato.

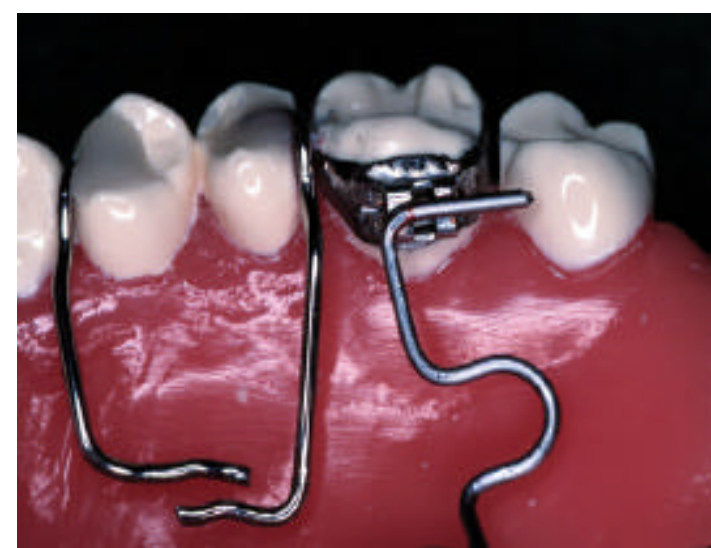

FIGURA 23- Adaptação do segmento intratubo.

Todos os elementos constituintes do aparelho eram fixados no modelo de trabalho em suas corretas posições com cera pegajosa. Os helicóides foram protegidos com cera 7 ou pegajosa para não ocorrer a incorporação na resina acrílica, figura 24.

Na seqüência, construía-se o botão palatino de Nance que se estendia 5 $\mathrm{mm}$ abaixo da gengiva marginal e envolvia o palato, englobando todos os elementos do aparelho. A técnica utilizada para a construção desse botão consistia no polímero previamente saturado em um pote de vidro que no início da fase plástica era incorporado na região estabelecida do palato. Ocasionalmente, nos casos que necessitam de uma expansão da maxila, pode ser incorporado o parafuso ou torno expansor, recebendo a denominação de 
Pendex, figura 25. Nesse estudo, foram empregados o aparelho Pendulum, segundo HILGERS ${ }^{74}$ e ALMEIDA et al. ${ }^{05}$, figura 26.

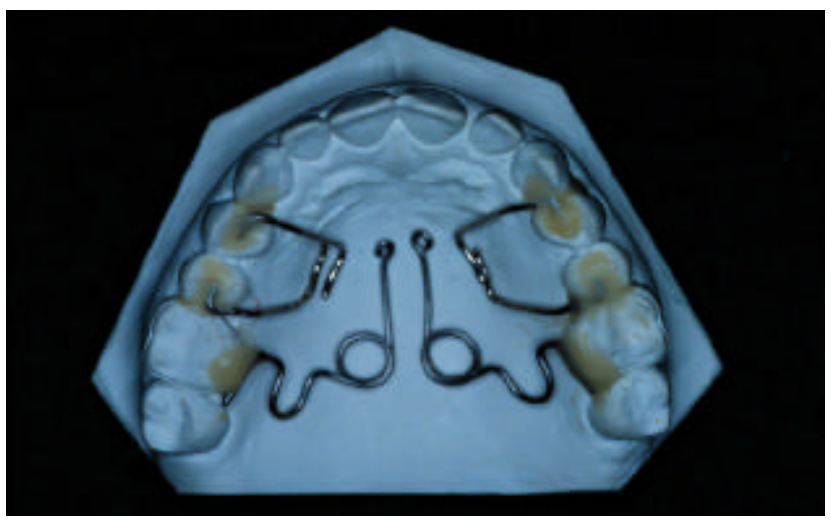

FIGURA 24 - Fixação dos elementos constituintes do aparelho para a acrilização do botão palatino de Nance.

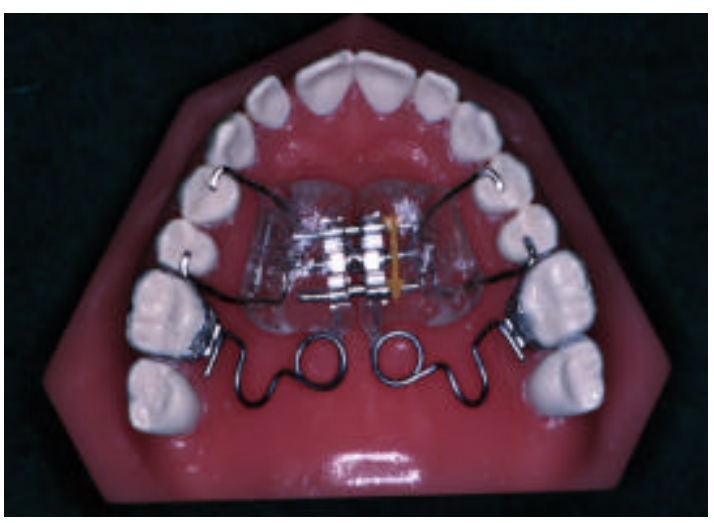

FIGURA 25- A construção do aparelho Pendex finalizada.

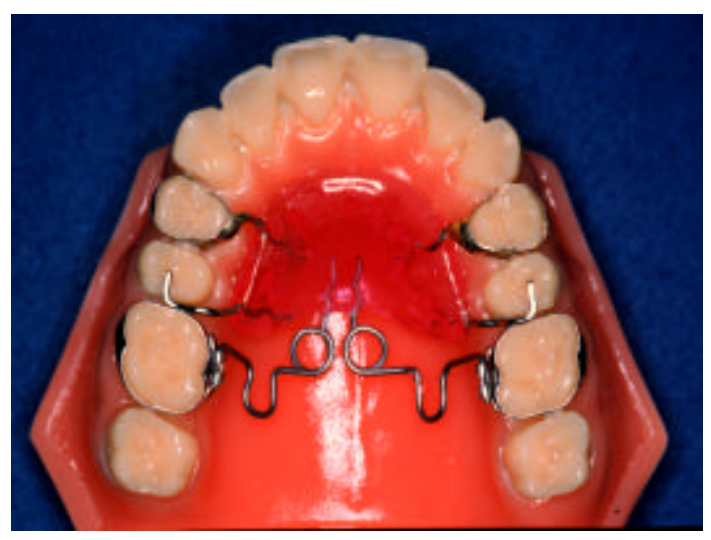

FIGURA 26- A construção do aparelho Pendulum finalizada 
Após o acabamento e o polimento do aparelho, as molas eram ativadas, estabelecendo uma pequena dobra no helicóide, até que ficassem paralelas à sutura palatina mediana, conforme estabelecido por HILGERS ${ }^{74}$, em 1992, como sendo uma ativação de $60^{\circ}$, figura 27. Também deviam ser realizadas as dobras de antiinclinação, de tal forma que o segmento intratubo formasse um ângulo de $15^{\circ}$ em direção oclusal para se ter um maior controle sobre a inclinação distal das coroas dos molares que normalmente ocorria durante a distalização com esses mecanismos, figura 28 e 29.

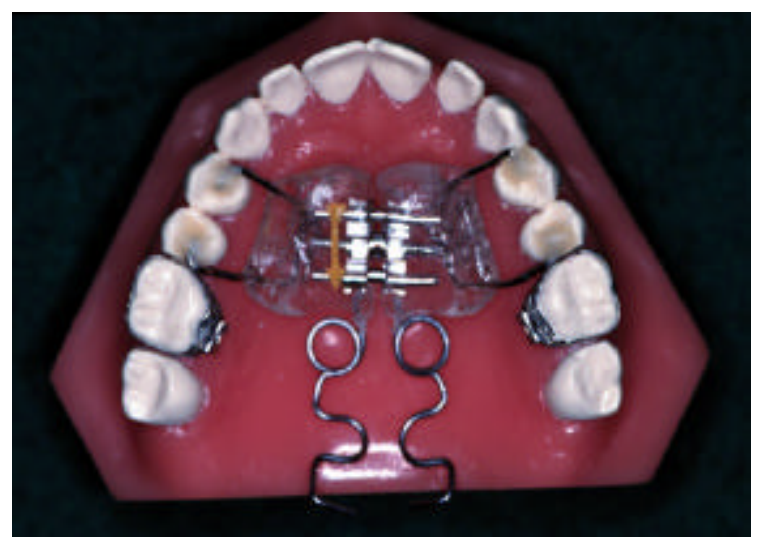

FIGURA 27 - Dobras de préativação das molas distalizadoras.

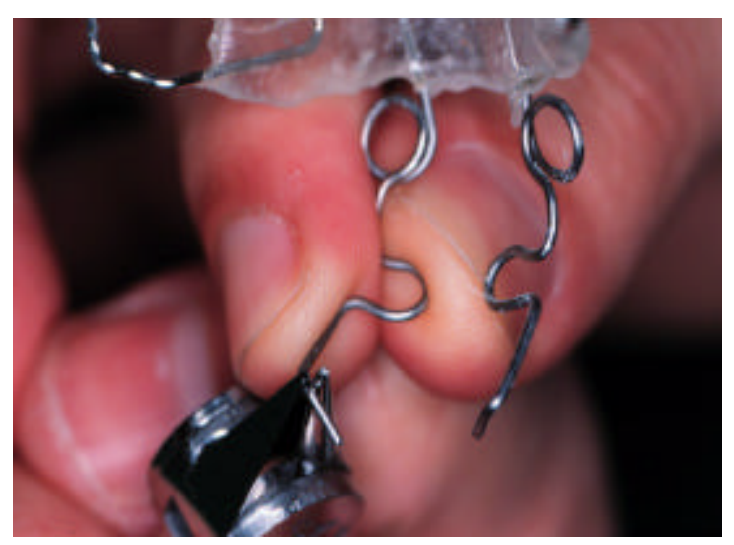

FIGURA 28 - Dobra de antiinclinação de $15^{\circ}$, em direção ao plano oclusal. 


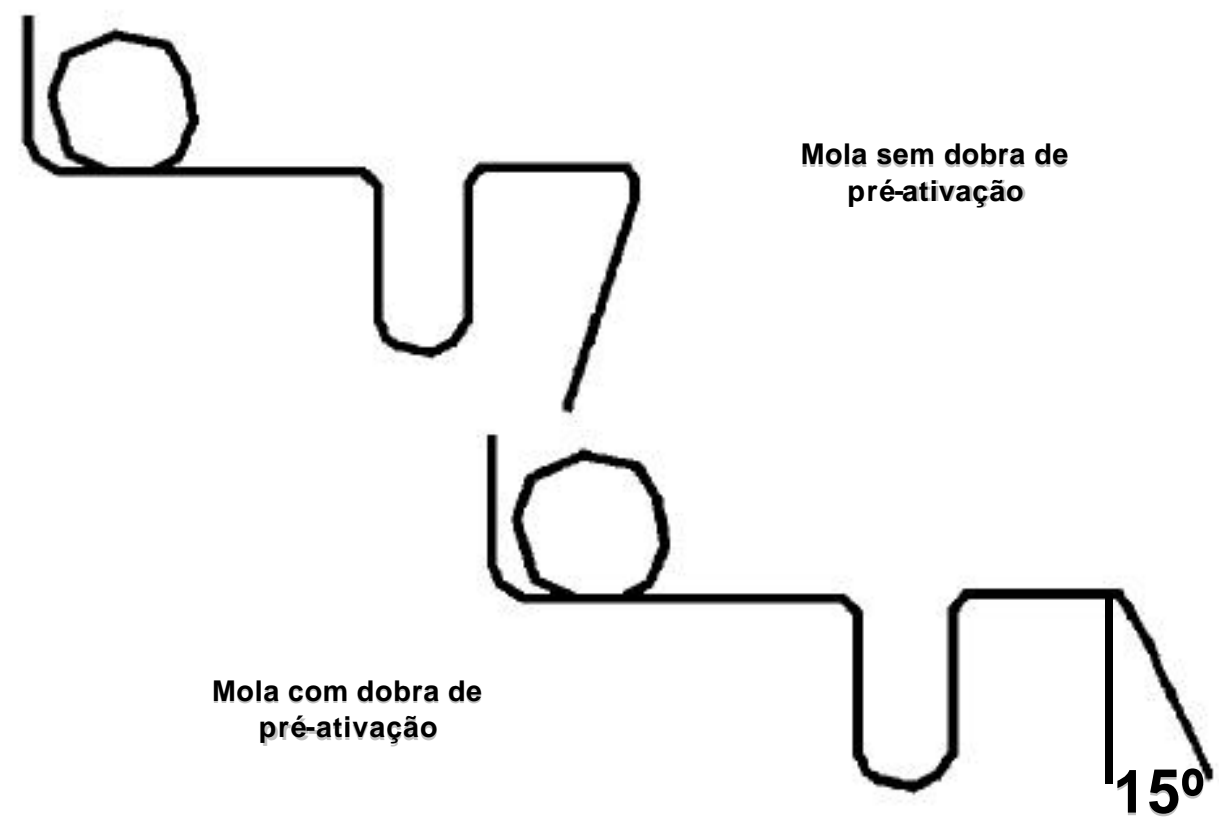

FIGURA 29 - Desenho esquemático da mola com a dobra de antiinclinação

O aparelho pré-ativado era testado no modelo de trabalho, verificandose se não ocorreu qualquer distorção nas molas que resultariam em movimentos indesejáveis. Em seguida, fixava-se com resina fotopolimerizável sobre os apoios, nas cristas marginais distais dos segundos pré-molares, figuras 30 a 33 . Essa resina produzia um levantamento da oclusão, o que facilitaria a distalização dos molares superiores pelo alívio das intercuspidações desses elementos dentários.

Os pacientes foram avaliados mensalmente para se conferir a magnitude de força residual, porém mantendo-se uma única ativação durante o período do tratamento ativo. Os primeiros molares foram distalizados para a relação molar normal num período médio de 5,87 meses, figuras 34-45. 


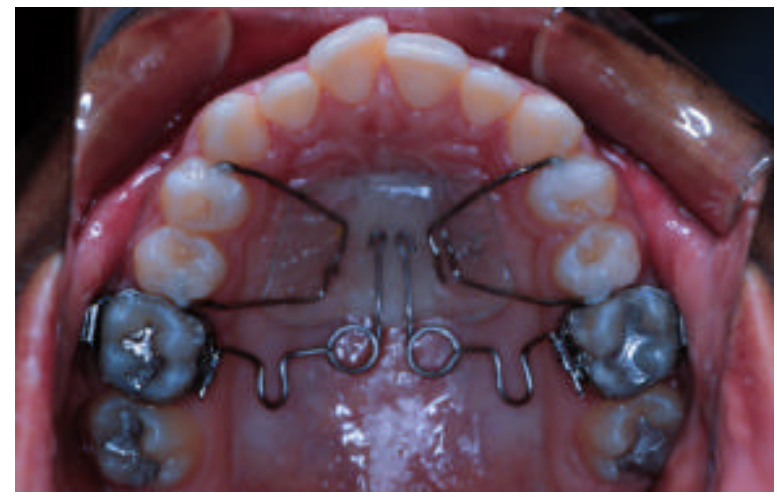

FIGURA 30 - Aparelho Pendulum fixado por meio dos grampos de apoio oclusal.

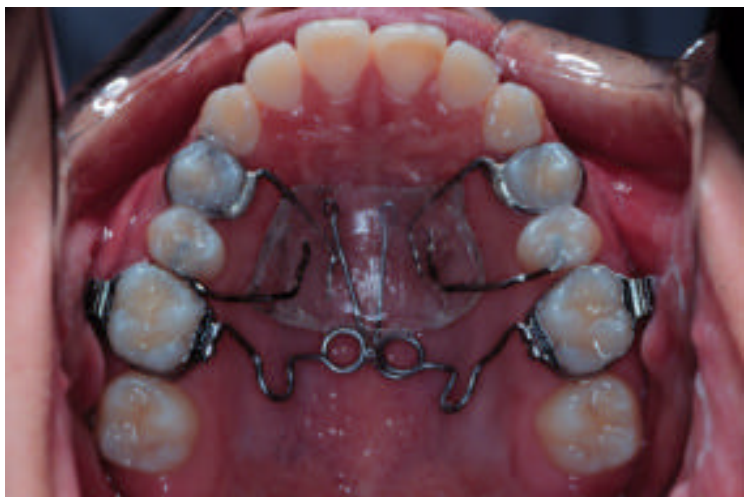

FIGURA 31 - Aparelho Pendulum fixado por meio de bandas nos primeiros pré-molares superiores.

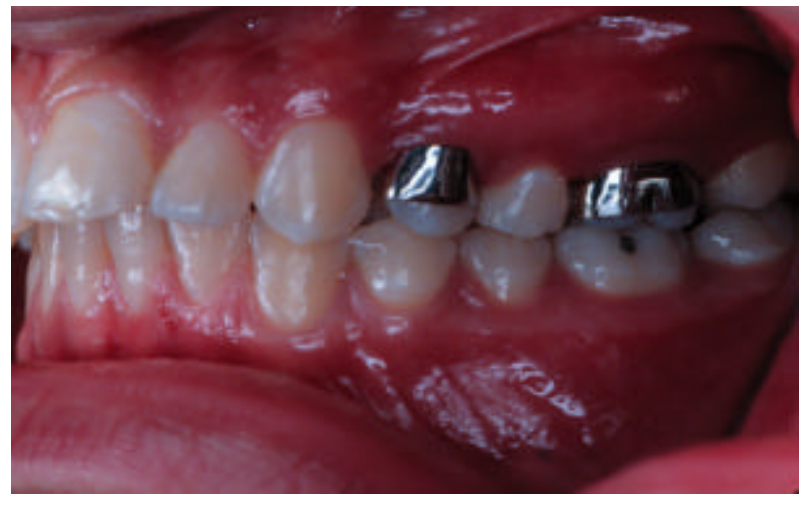

FIGURA 32 - Vista lateral direita da fixação do aparelho.

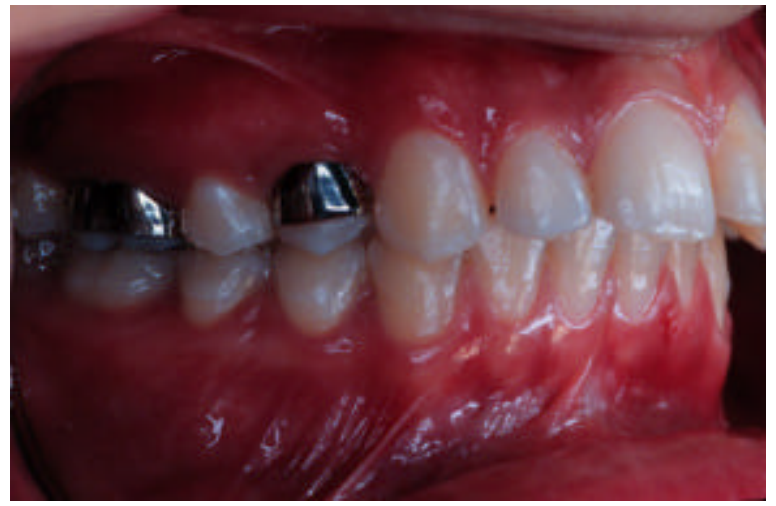

FIGURA 33 - Vista lateral esquerda da fixação do aparelho. 

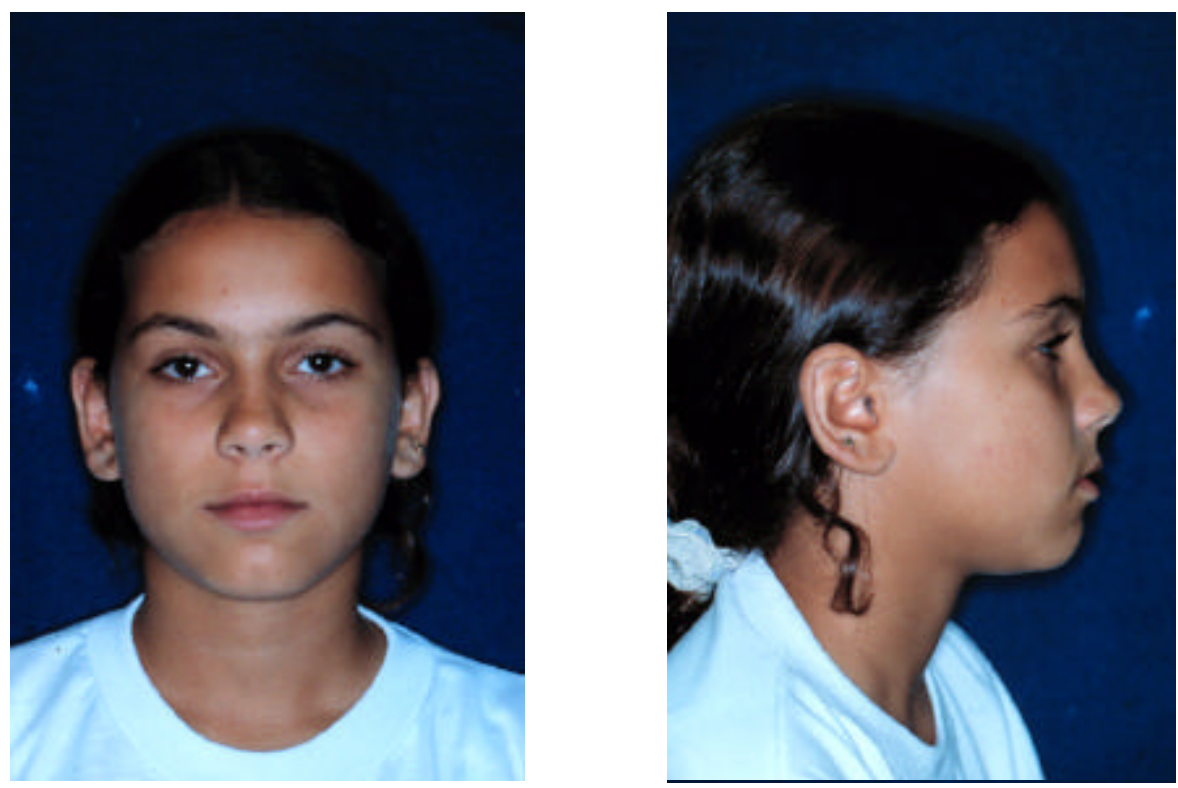

FIGURA 34 - Fotografias extrabucais iniciais.

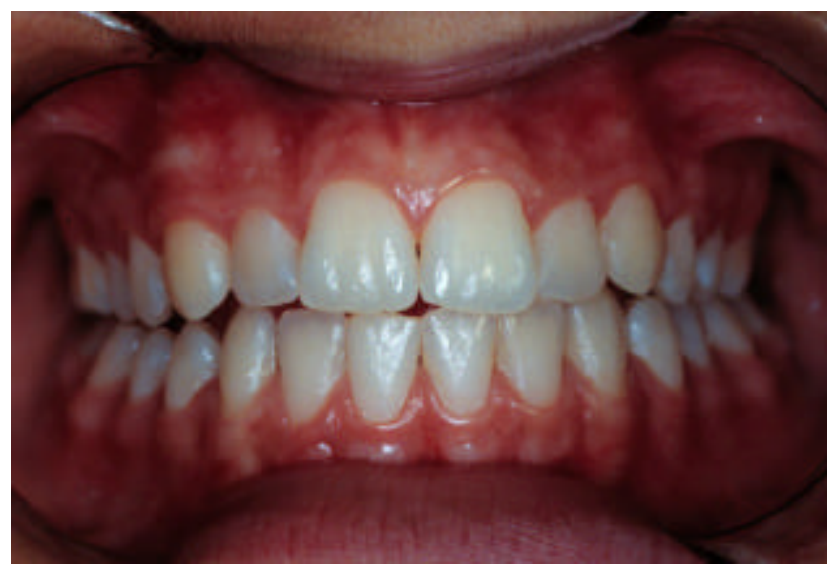

FIGURA 35 - Fotografia intrabucal frontal inicial. 

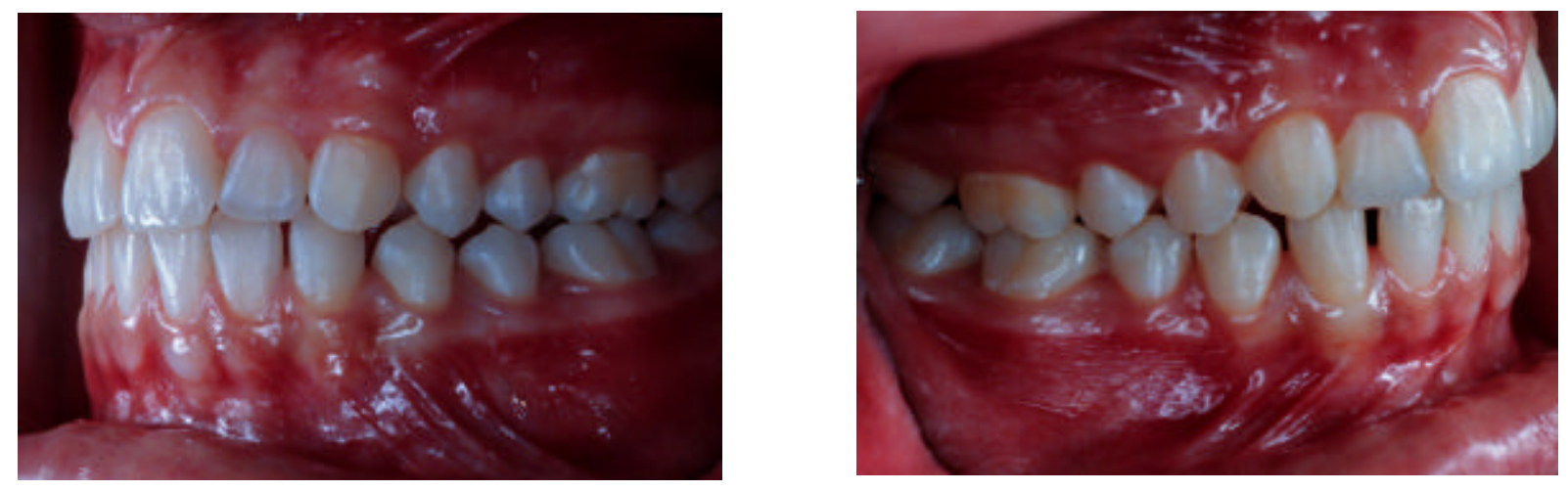

FIGURA 36- Vista lateral direita e esquerda inicial.

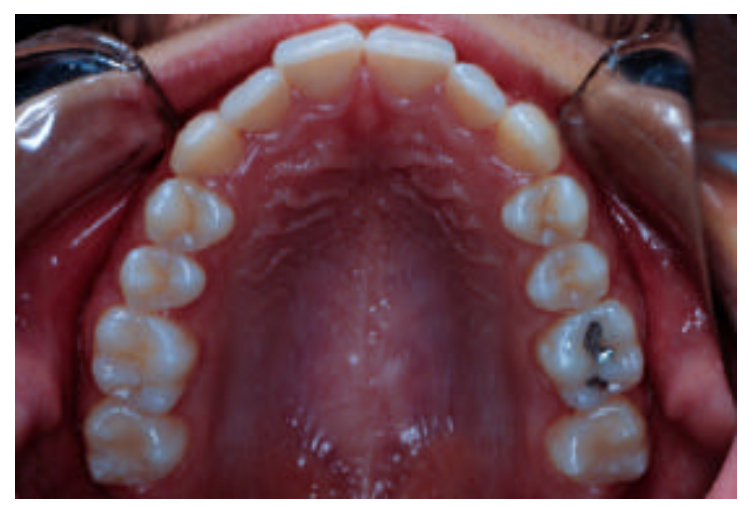

FIGURA 37 - Vista oclusal superior inicial.

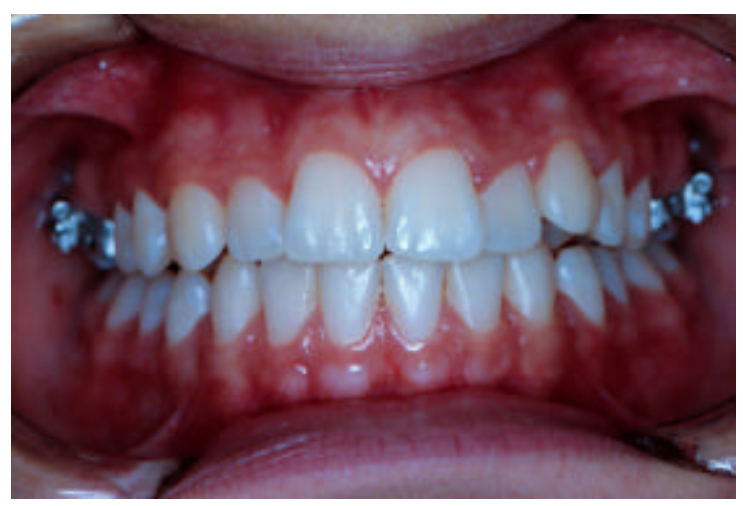

FIGURA 38 - Fotografia intrabucal frontal pós-distalização dos molares superiores. 

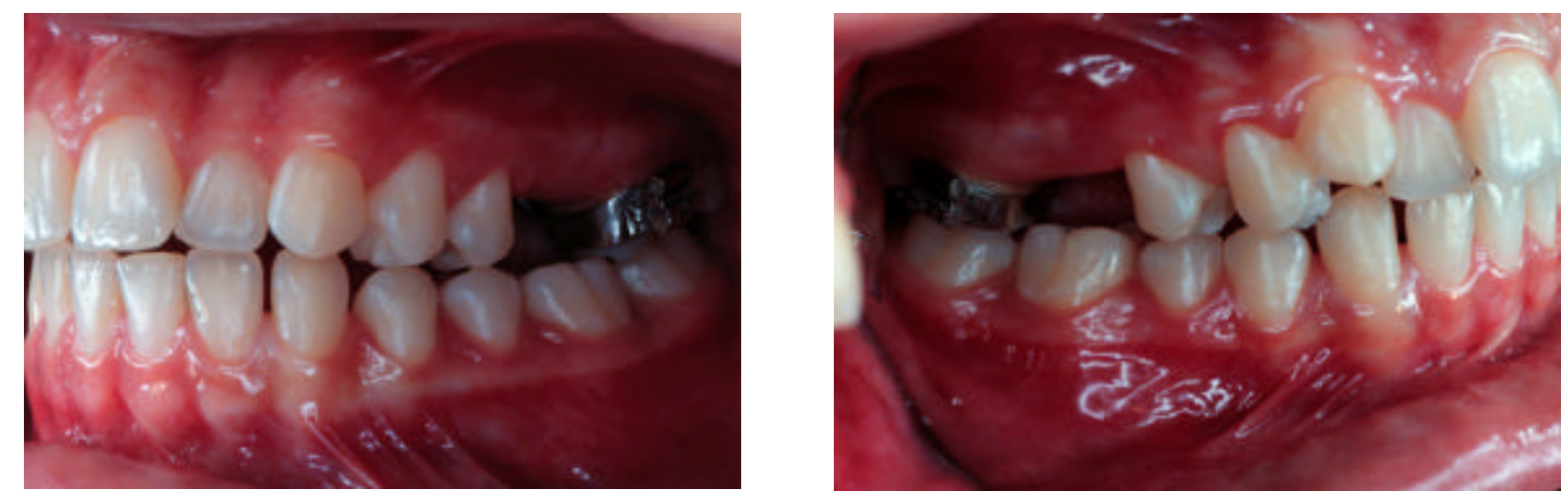

FIGURA 39 - Fotografias intrabucais laterais direita e esquerda, pósdistalização dos molares superiores.

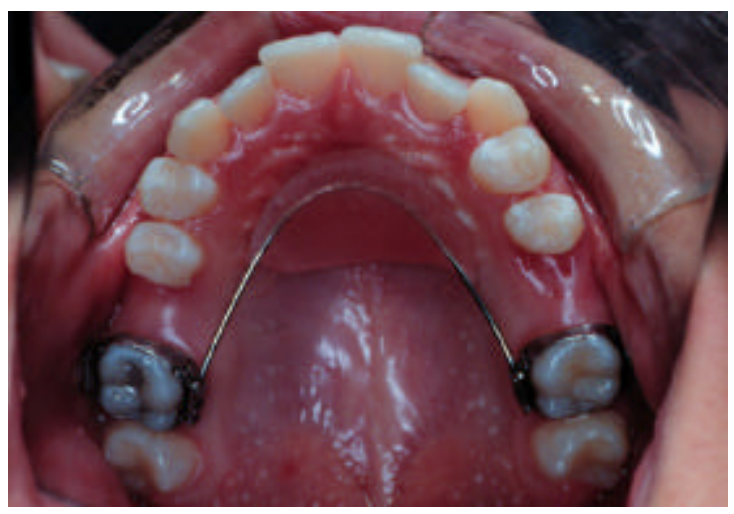

FIGURA 40 - Fotografia intrabucal oclusal superior, pós-distalização dos molares, com o botão palatino de Nance como forma de contenção. 

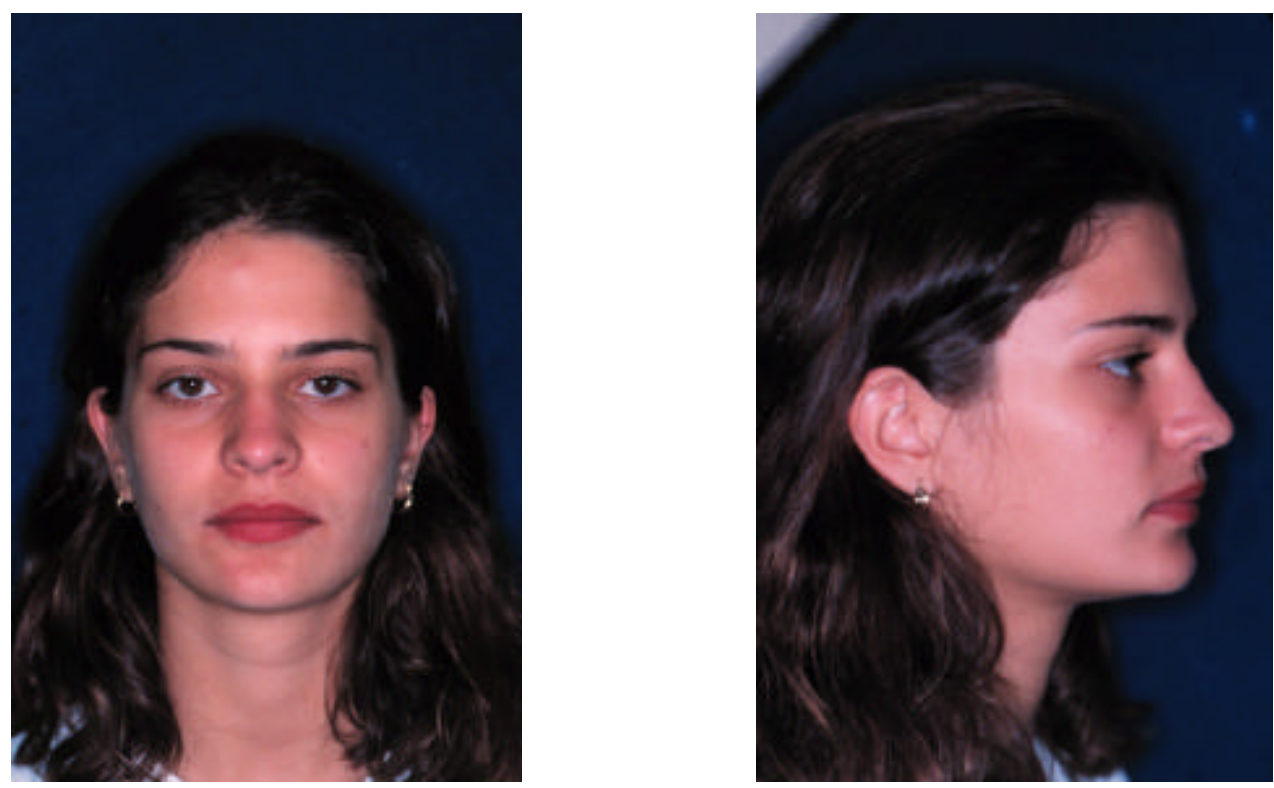

FIGURA 41 - Fotografias extrabucais iniciais.
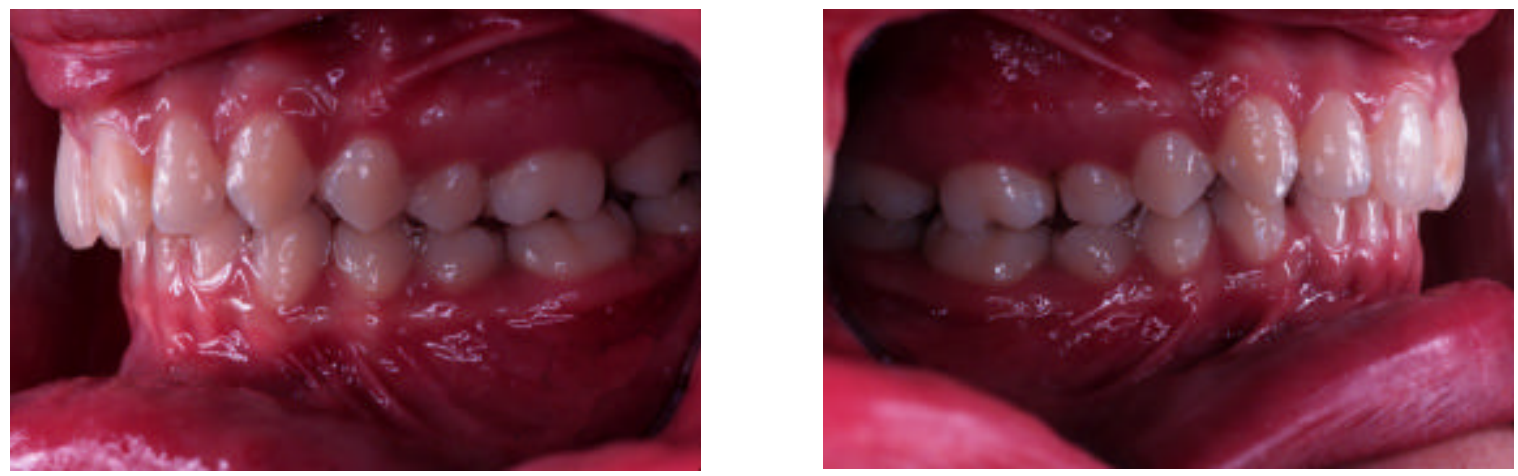

FIGURA 42 - Vista lateral direita e esquerda inicial. 


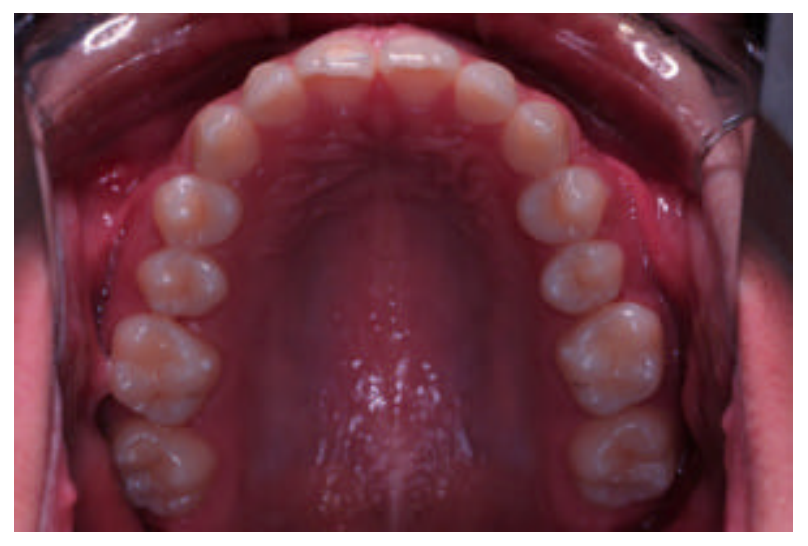

FIGURA 43 - Fotografia intrabucal oclusal superior inicial.
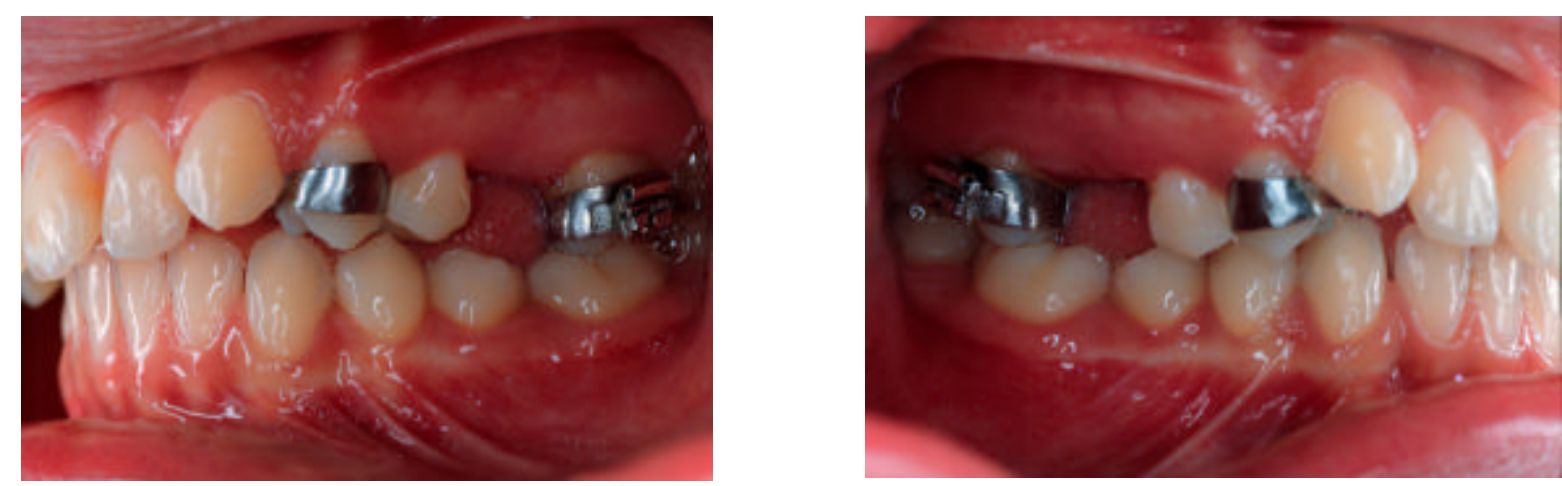

FIGURA 44 - Fotografias intrabucais laterais, direita e esquerda, pósdistalização dos molares superiores.

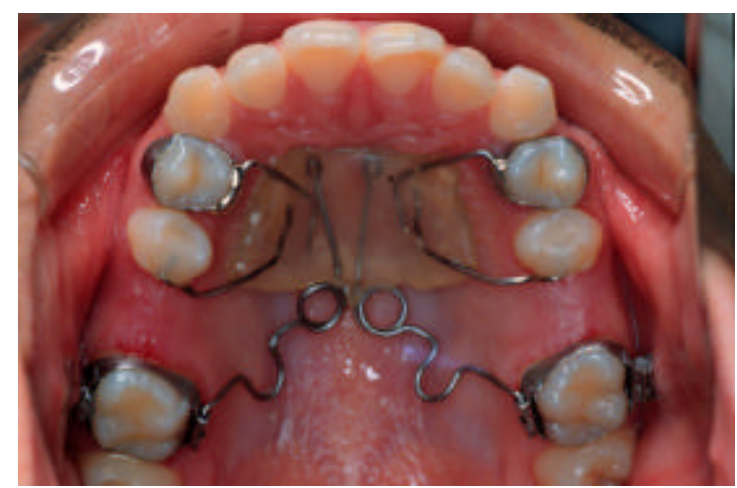

FIGURA 45 - Fotografia intrabucal oclusal superior, pós-distalização dos molares. 


\subsubsection{SISTEMA DE FORÇA PRODUZIDO}

As molas eram ativadas realizando-se uma pequena dobra no helicóide, de tal forma que o braço da mola ficasse paralela à sutura palatina mediana, produzindo a força distalizadora de 253,3g, figura 27 e 46 . Essa magnitude de força foi comprovada mediante um ensaio mecânico laboratorial prévio.

Além da força distalizadora que acarretaria o movimento distal dos molares, notava-se também, pela atuação das molas lingualmente ao centro de resistência, a possibilidade da trajetória do braço da mola produzir uma rotação distopalatina dos molares, resultando na tendência à mordida cruzada, segundo HILGERS $^{74}$, figura 47 e 48.

Verticalmente as molas liberavam a força distalizadora nas coroas dos molares e a uma certa distância do centro de resistência, produzindo um momento responsável pela inclinação distal das coroas, segundo HILGERS ${ }^{74}$. Considerando-se essa tendência optou-se por incorporar no segmento intratubo a dobra de antiinclinação de $15^{\circ}$ como tentativa de neutralizar esse efeito indesejável e proporcionar um melhor controle durante a distalização, figura 28 e 29 .

Como pode ser observado, as molas distalizadoras também geravam forças verticais que causariam alterações de extrusão e intrusão nos molares que representavam a unidade receptora da força e nos pré-molares, caninos e incisivos que pertenciam à unidade de ancoragem, segundo HILGERS ${ }^{74}$.

Assim sendo, percebe-se por meio da literatura, que o aparelho Pendulum determina um sistema de força que proporciona alterações sagitais, transversais e verticais e que, além das forças aplicadas nos molares, haveria simultaneamente as forças recíprocas correspondentes atuando sobre os prémolares, caninos e incisivos. 


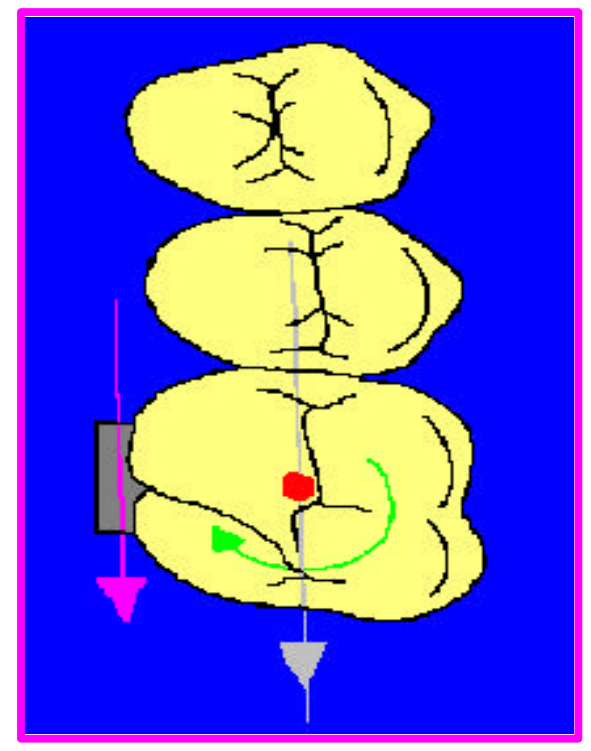

FIGURA- 46- Sistema de forças

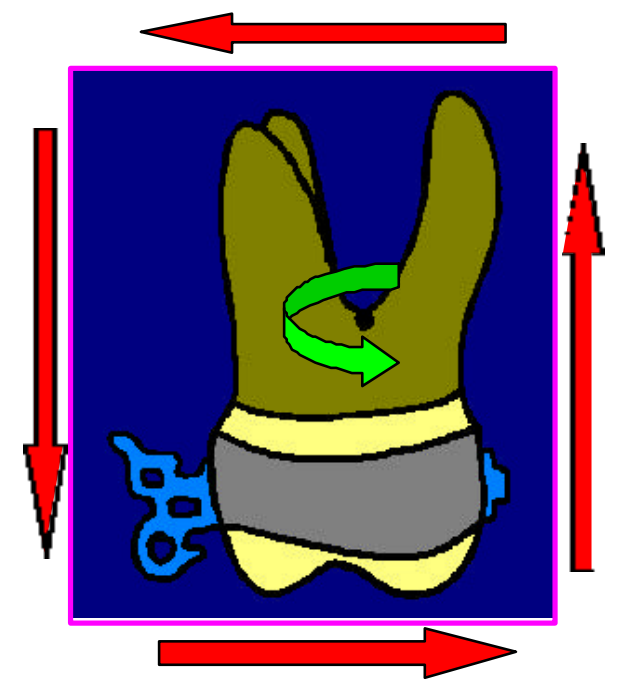

FIGURA 47- Sistema de forças

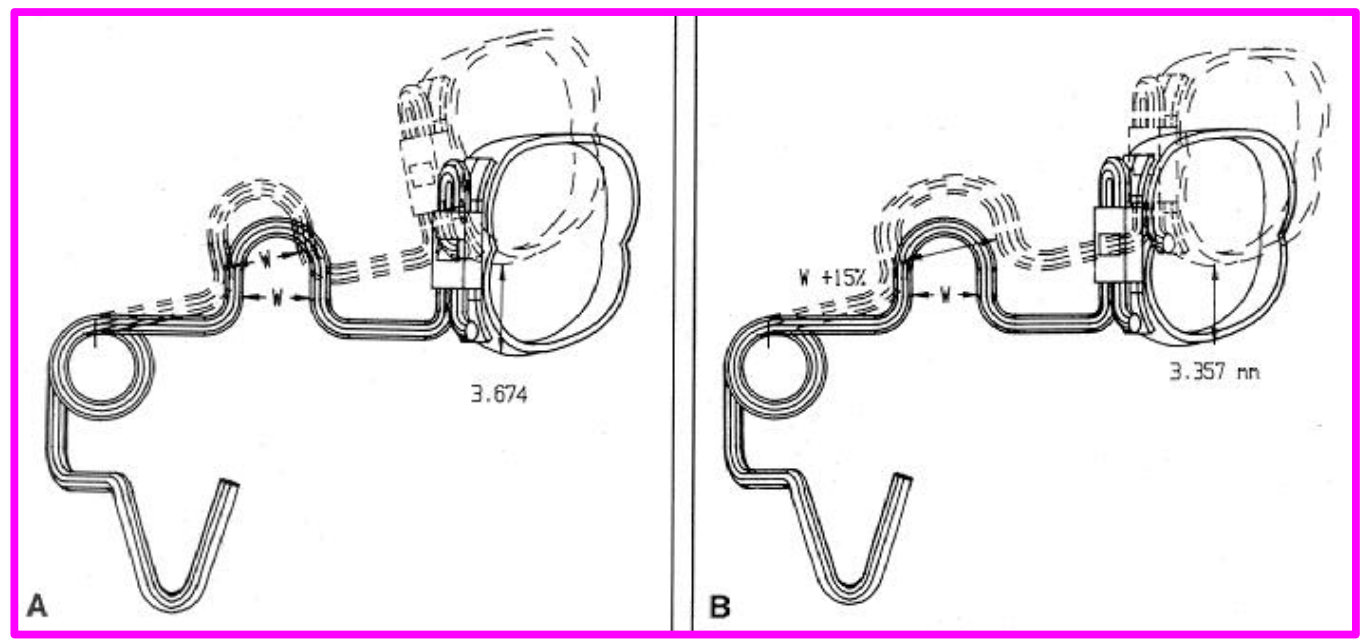

FIGURA 48- Trajetória descrita pela mola 


\subsubsection{MÉTODO RADIOGRÁFICO}

\subsubsection{OBTENÇÃO DAS TELERRADIOGRAFIAS EM NORMA LATERAL CONVENCIONAL}

As telerradiografias em norma lateral convencional foram realizadas no Centro de Diagnóstico Bucal (CDB) de Bauru, por um técnico em Radiologia treinado previamente para a padronização da técnica de obtenção, permitindo que as radiografias apresentassem a mesma qualidade.

Foram empregados filmes extrabucais TMS-1, 18 X $24 \mathrm{~cm}$ da marca KODAK ${ }^{*}$, e chassi metálico, tamanho 20,8 X 26,8 cm, equipado com écran intensificador Lanex Regular**.

Como fonte produtora de raios $\mathrm{X}$, utilizou-se um aparelho Orthophos CD, marca SIEMENS, com braço do conjunto cefalostato, e fatores de exposição regulados para $80 \mathrm{KVp}, 15 \mathrm{~mA}$ e tempo de 1,6 segundos. A distância foco-filme usada foi de $1,53 \mathrm{~m}$ e para se obter uma boa imagem do perfil de tecido mole, um filtro de alumínio foi justaposto ao chassi.

Para o posicionamento dos pacientes no momento da tomada radiográfica, empregou-se o cefalostato do tipo Margolis, onde o chassi era acoplado paralelamente ao plano sagital mediano, aproximando ao máximo a cabeça do indivíduo, para que houvesse o maior contato possível entre o objeto e o filme. Todos os pacientes foram orientados para permanecerem com os dentes em máxima intercuspidação habitual e com os lábios em posição de repouso.

Todos os filmes foram revelados pelo mesmo operador, utilizando-se o método de processamento automático, em câmara escura sob a luz de segurança. Essas telerradiografias foram obtidas na fase inicial e após a distalização dos

\footnotetext{
* KODAK Brasileira Comércio e Indústria LTDA, São Paulo, Brasil.

** EASTMAN KODAK COMPANY, Rochester, N.Y., U.S.A.
} 
molares superiores, figura 49. Uma correção para magnificação de $6 \%$ foi utilizada para todas as telerradiografias.
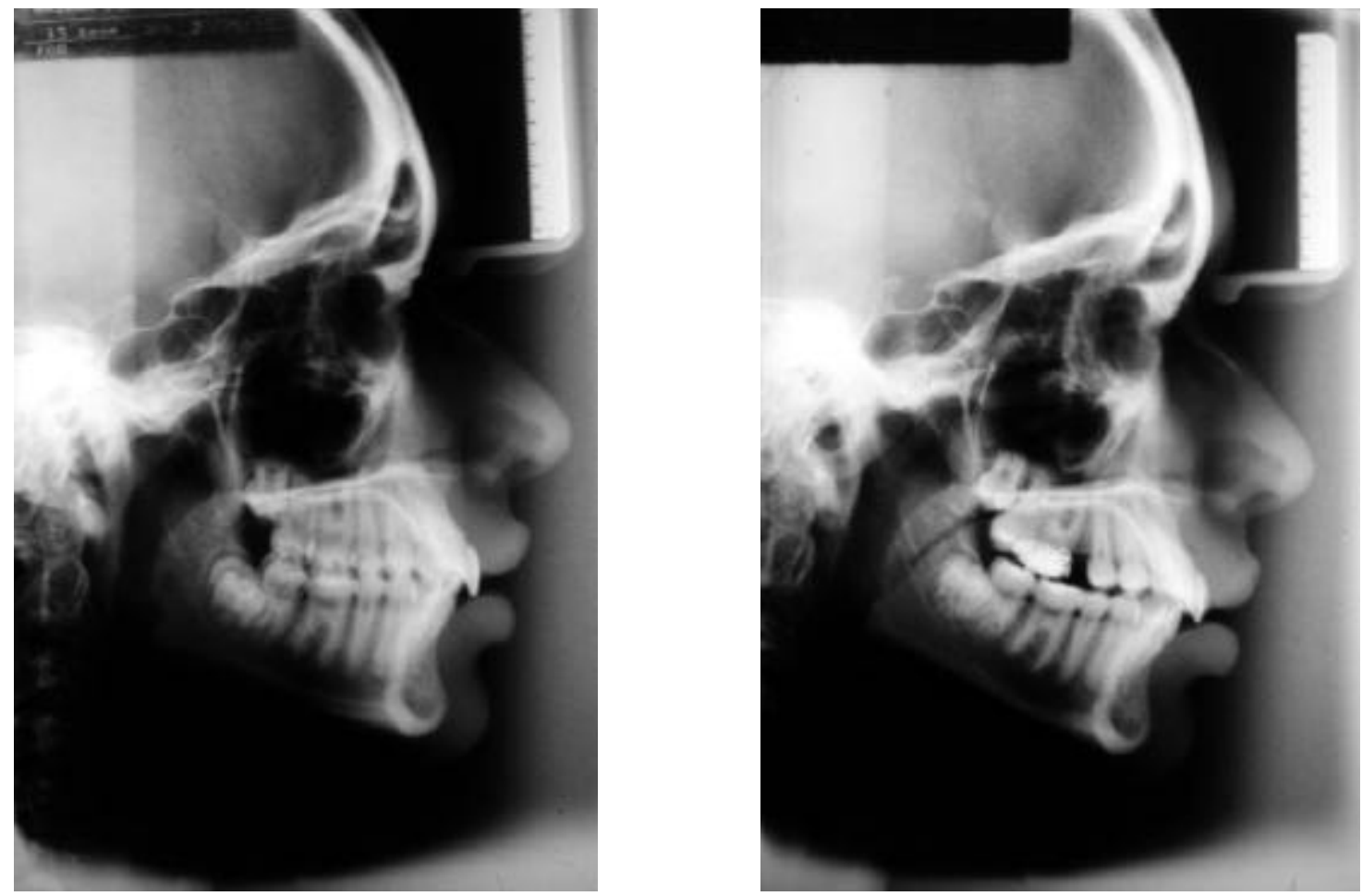

FIGURA 49- Telerradiografias em norma lateral inicial e final.

\subsubsection{OBTENÇÃO DAS TELERRADIOGRAFIAS EM} NORMA LATERAL DE $45^{\circ}$

As telerradiografias em norma lateral de $45^{\circ}$ foram obtidas na Clínica de Radiologia, do Hospital de Reabilitação de Anomalias Craniofaciais, da Universidade de São Paulo, na Clínica de Ortodontia do Prof. Dr. Renato Rodrigues de Almeida e no Centro de Diagnóstico Bucal de Bauru (CDB).

Foram empregados filmes extrabucais T-MAT, na dimensão de $18 \mathrm{X}$ $24 \mathrm{~cm}$, da marca Kodak, e chassi metálico, tamanho 20,8 X 26,8 cm, equipado com écran intensificador Lanex Regular. Na Clínica de Radiologia do Hospital 
de Reabilitação de Anomalias Craniofaciais da USP, o aparelho utilizado foi o Roentax ${ }^{*}$, modelo 50/90, série 44.0688, e na Clínica de Ortodontia foi utilizado como fonte produtora de raios $\mathrm{X}$ o aparelho Panoura, e no Centro de Diagnóstico Bucal de Bauru (CDB) o aparelho modelo Orthophos CD, da marca SIEMENS, associado a um cefalostato.

A técnica radiográfica empregada no Centro de Diagnóstico Bucal para a obtenção dessas telerradiografias envolveu os seguintes parâmetros: 1) distância chassi/paciente de $1,49 \mathrm{~m}$; 2) ângulo de rotação do cefalostato de $45^{\circ}$; 3) fatores de exposição de $80 \mathrm{KVp}$ e $14 \mathrm{~mA}$; 4) tempo de exposição de 0,64 segundos; 5) utilização do colimador 4 , deslocando-se $0,5 \mathrm{~cm}$ para a posição anterior à posição normal na obtenção da radiografia do lado direito e para o lado esquerdo na posição normal.

Na Clínica de Radiologia do Hospital de Reabilitação de Anomalias Craniofaciais e na Clínica de Ortodontia foram empregados com padronização da técnica radiográfica os seguintes procedimentos: 1) para o posicionamento da cabeça dos pacientes foi empregado um cefalostato do tipo Margolis; 2) colocação de uma rotação de $45^{\circ}$, entre o plano sagital mediano e chassi, 3) aproximação do chassi com a cabeça do indivíduo, para que houvesse o maior contato possível entre o objeto e o filme; 4) a distância foco-filme foi de 1,53 m e 5) tempo de exposição de 0,5 ou 0,6 segundos.

As radiografias obtidas foram reveladas pelo método de processamento automático na câmara escura e controle de luz.

Essas telerradiografias foram realizadas nos seguintes períodos: inicial e após o período de distalização que foi de 5,87 meses, figura 50. Os fatores de correção da magnificação empregados foram de $1,4 \%, 1,2 \%$ e $0,45 \%$ para as telerradiografias obtidas respectivamente no Centro de Diagnóstico Bucal de

\footnotetext{
* Eletromedicina Indústria LTDA (EMIC), Brasil.
} 
Bauru (CDB), Clínica de Ortodontia e no Hospital de Reabilitação de Anomalias Craniofaciais.
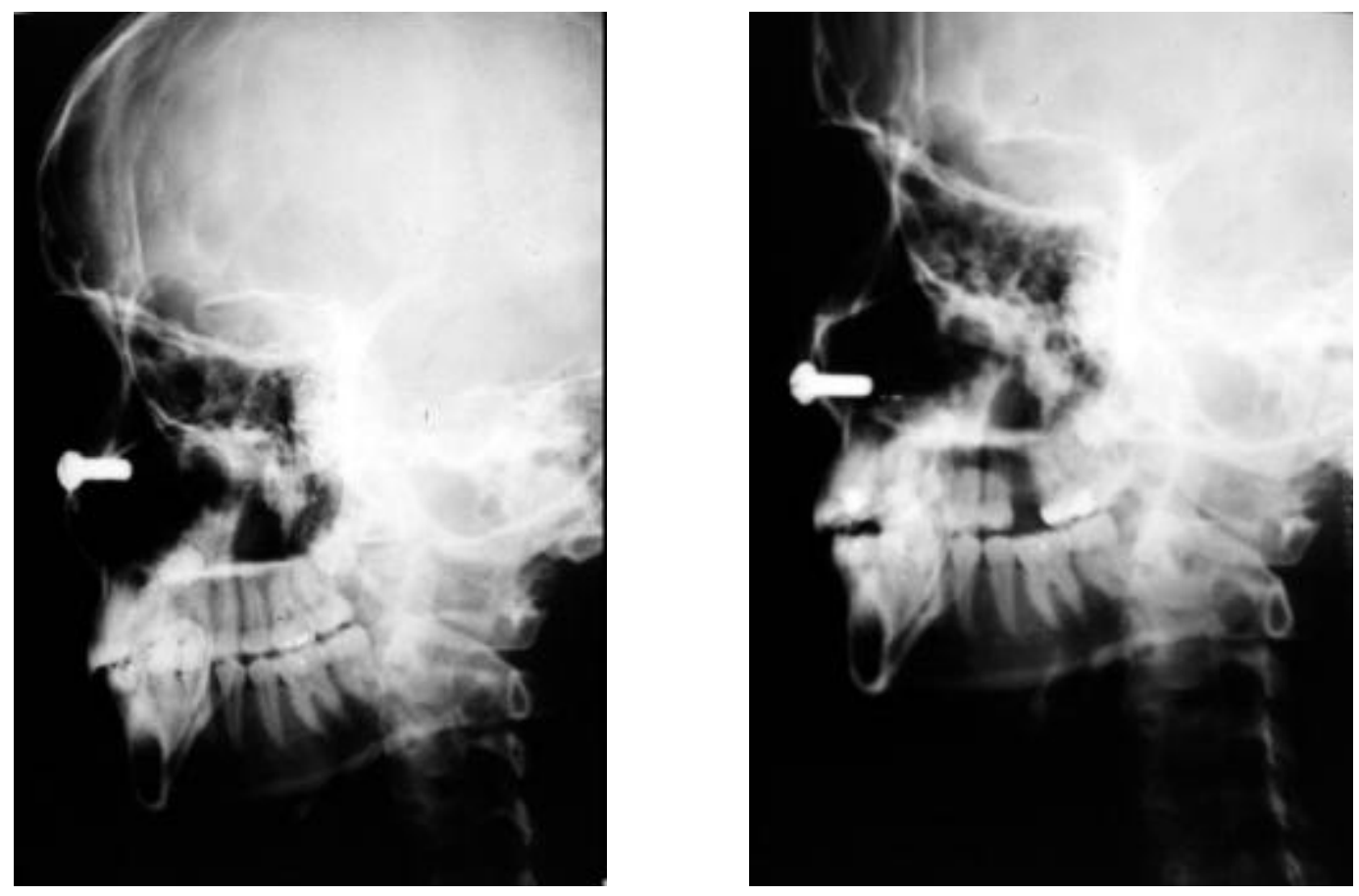

FIGURA 50 Telerradiografias em norma lateral de $45^{\circ}$ inicial e final.

\subsubsection{ELABORAÇÃO DOS CEFALOGRAMAS EM NORMA LATERAL CONVENCIONAL}

Para melhor visualização das estruturas anatômicas de interesse, os traçados foram realizados em sala obscurecida. Em cada telerradiografia foi adaptada uma folha de papel acetato, de dimensão de $17,5 \times 17,5 \mathrm{~cm}$ e espessura de 0,07 $\mathrm{mm}$. Em seguida, com lapiseira e grafite preto 0,3 $\mathrm{mm}$, foram realizados os cefalogramas sobre um negatoscópio, sempre pelo mesmo operador numa posição ereta e com a lapiseira empunhada o mais vertical possível para que o desenho resultasse em linhas finas e uniformes.

A elaboração dos cefalogramas consistiu nas seguintes etapas: 
4.2.3.1. Desenho das estruturas anatômicas;

4.2.3.2. Definição dos pontos cefalométricos;

4.2.3.3. Estabelecimento das linhas e planos cefalométricos;

4.2.3.4. Método de padronização do desenho anatômico dos dentes e

4.2.3.5. Obtenção das medidas cefalométricas.

\subsubsection{Desenho das estruturas anatômicas (Figura 51)}

O traçado constituiu-se do contorno das linhas radiopacas das seguintes estruturas, no seu limite externo e superficial:

A - Perfil mole;

B- Base anterior do crânio, média e posterior (apenas para compor o desenho);

C - Sela túrcica;

D - Perfil anterior do osso frontal e ossos próprios do nariz;

E - Borda póstero-inferior das órbitas;

F - Fissura pterigomaxilar;

G - Meato acústico externo;

$\mathrm{H}$ - Maxila: linha do assoalho da fossa nasal, espinha nasal anterior e posterior, rebordo alveolar anterior e palato ósseo;

I - Mandíbula: rebordo alveolar anterior, corticais interna e externa na região da sínfise, borda inferior do corpo mandibular, borda posterior do ramo, processos condilar e coronóide;

L - Incisivo central superior;

M - Primeiro pré-molar superior;

$\mathrm{N}$ - Primeiro molar permanente superior;

O- Incisivo central inferior e

P- Primeiro molar inferior. 


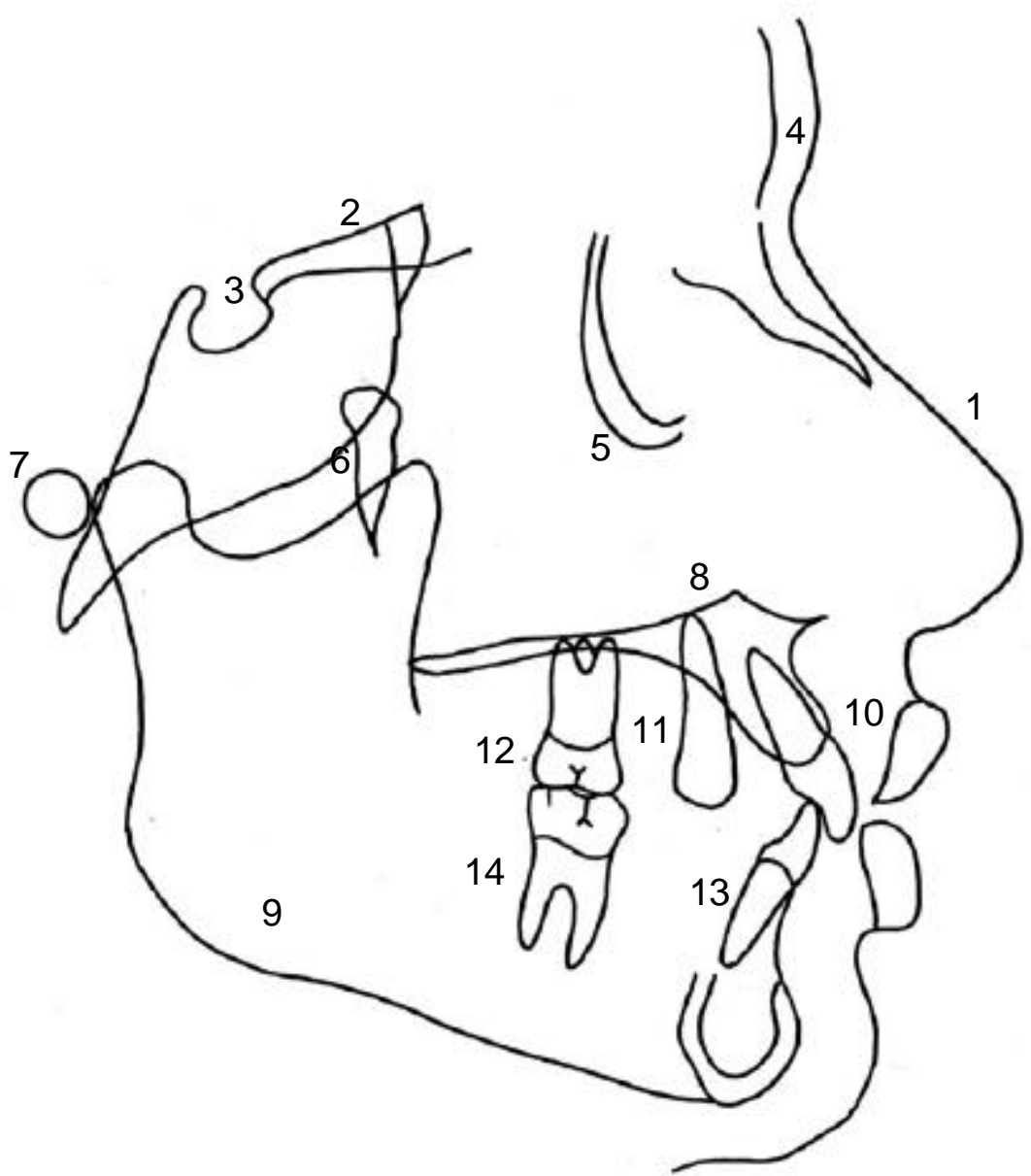

1- Perfil mole; 2- base anterior do crânio, média e posterior; 3- sela túrcica; 4-perfil anterior do osso frontal e ossos próprios do nariz; 5- borda pósteroinferior das órbitas; 6- fissura pterigomaxilar; 7-meato acústico externo; 8- maxila; 9- mandíbula; 10- incisivo central superior; 11-primeiro pré-molar superior; 12- incisivo central inferior e 13- primeiro molar inferior

FIGURA 51 - Desenho das estruturas anatômicas de interesse. 


\subsubsection{Definição dos pontos cefalométricos (Figura 52)}

Os pontos cefalométricos de interesse para as análises foram os seguintes:

1 - Sela (S) - ponto que representa o centro geométrico da sela túrcica, determinado por inspeção visual;

2 - Násio $(\mathrm{N})$ - ponto mais anterior da sutura frontonasal;

3 - Orbitário (Or) - ponto mais inferior da margem infraorbitária;

4 - Pório (Po) - ponto mais superior do meato acústico externo;

5 - Subespinhal (A) - ponto mais profundo da concavidade anterior da maxila, entre a espinha nasal anterior e o próstio;

6 - Supramentoniano (B) - ponto mais profundo na concavidade anterior da mandíbula, entre o pogônio e o infradentário;

7 - Ponto D - ponto situado no centro do contorno da secção transversal da sínfise mandibular;

8 - Pogônio (Pog) - ponto mais anterior do contorno da sínfise mandibular, determinado por inspeção;

9 - Gnátio (Gn) - ponto mais inferior e anterior do contorno do mento, definido pela bissetriz do ângulo formado pela linha NP e pela linha da borda inferior do corpo mandibular;

10 - Mentoniano (Me) - ponto mais inferior do contorno da sínfise mentoniana, na confluência da margem inferior da sínfise com a linha da base mandibular;

11 - Gônio (Go) - ponto mais inferior e mais posterior do contorno do ângulo goníaco, definido pela bissetriz do ângulo formado pela tangente à borda inferior do corpo da mandíbula e outra tangente à borda posterior do ramo ascendente da mandíbula; 
12 - Espinha nasal anterior - (ENA) - ponto mais anterior da maxila ao nível do palato;

13 - Espinha nasal posterior - (ENP) - ponto localizado na extremidade da espinha nasal posterior;

14 - Ponto CF - ponto localizado na intersecção da tangente à físsura pterigomaxilar;

15 - Cúspide do primeiro molar superior- ponto médio da cúspide mesiovestibular do primeiro molar permanente superior;

16 - Ápice radicular do primeiro molar superior- ponto localizado no ápice radicular mesial do primeiro molar permanente superior;

17 - Cúspide do primeiro pré-molar superior - ponto localizado na cúspide vestibular do primeiro pré-molar superior;

18 - Ápice radicular do primeiro pré-molar superior - ponto do ápice radicular do primeiro pré-molar superior;

19 - Incisal do incisivo central superior - ponto da borda incisal do incisivo central superior;

20 - Ápice radicular do incisivo central superior - ponto do ápice radicular do incisivo central superior;

21 - Cúspide do primeiro molar inferior - ponto médio da cúspide mesiovestibular do primeiro molar permanente inferior;

22 - Ápice radicular do primeiro molar inferior - ponto localizado no ápice radicular mesial do primeiro molar inferior;

23 - Incisal do incisivo central inferior - ponto da borda incisal do incisivo central inferior;

24 - Ápice radicular do incisivo central inferior - ponto localizado no ápice radicular do incisivo central inferior;

25 - Ponto AO - projeção do ponto A perpendicular no plano oclusal; 
26 - Ponto BO - projeção do ponto B perpendicular no plano oclusal;

Associados aos pontos cefalométricos em tecido duro destacam-se alguns pontos que se localizam em tecido mole (Figura 53), dentre os quais:

1- Lábio superior (Ls) - ponto na região mais anterior do lábio superior;

2 - Lábio inferior $(\mathrm{Li})$ - ponto localizado na região mais anterior do lábio inferior;

3 - Pogônio mole (Pog') - ponto mais anterior no contorno do mento mole;

4 - Pronasal - ponto mais anterior do nariz;

5 - Subnasal - ponto em que a columela se intersecta com o lábio superior no plano médio sagital.

Visando a facilitar a demarcação dos pontos e a posterior digitalização dos mesmos, cada ponto foi identificado por meio de duas linhas de referência, uma horizontal e outra vertical, sendo que o referido ponto cefalométrico se localizaria na intersecção dessas linhas. $O$ cursor de digitalização foi posicionado de maneira a enquadrar corretamente essas referências durante o procedimento de digitalização 


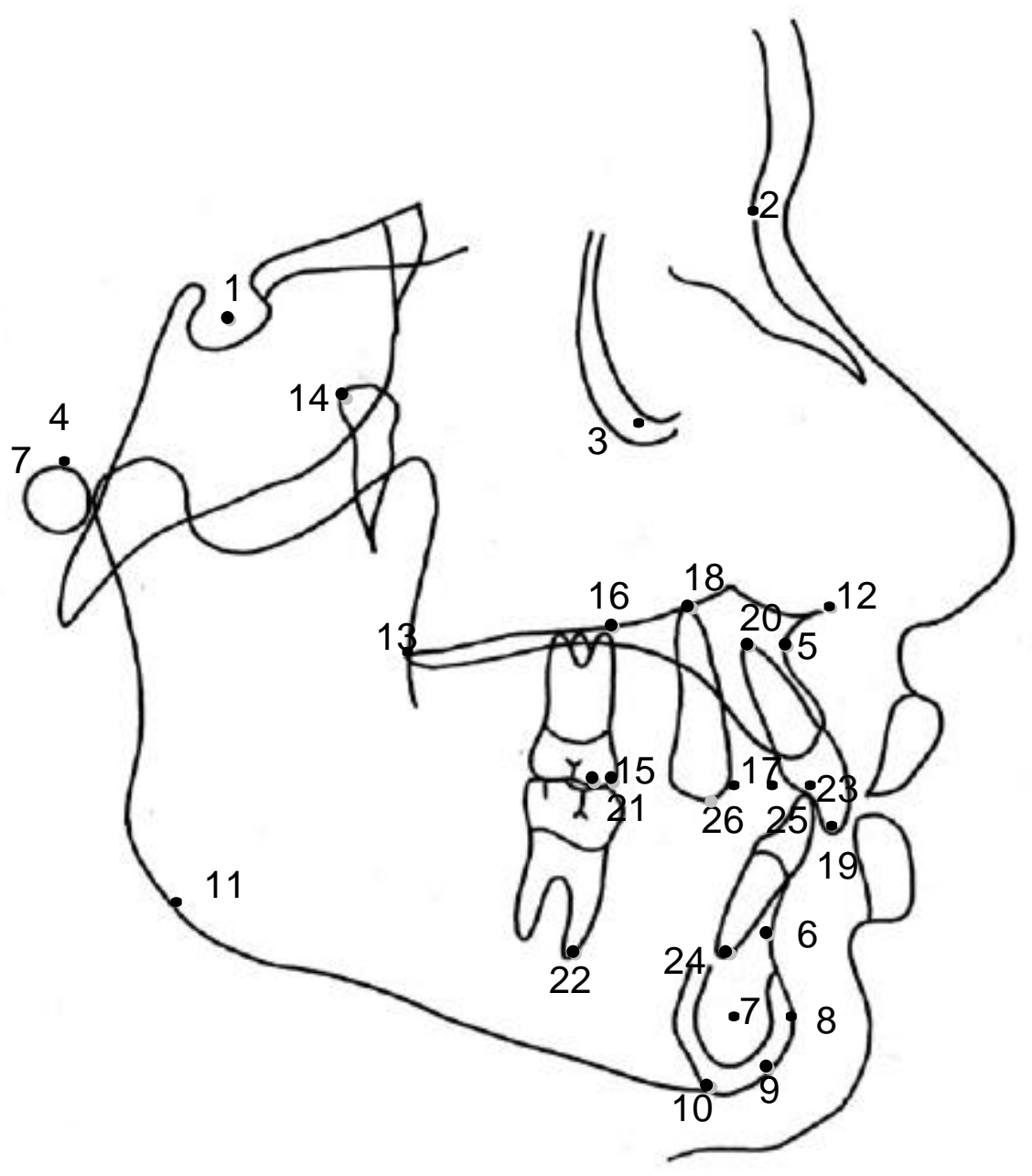

1- Sela (S); 2- Násio (N); 3- Orbitário (Or); 4- Pório (Po); 5- Subespinhal (A); 6- Supramentoniano (B); 7- Ponto D; 8- Pogônio (Pog); 9- Gnátio (Gn); 10Mentoniano (Me); 11- Gônio (Go); 12-Espinha nasal anterior (ENA); 13 Espinha nasal posterior (ENP); 14- Ponto CF; 15-Cúspide do primeiro molar superior; 16- Ápice radicular do primeiro molar superior; 17- Cúspide do primeiro pré-molar superior; 18- Ápice radicular do primeiro pré-molar superior; 19- Incisal do incisivo central superior; 20- Ápice radicular do incisivo central superior; 21-Cúspide do primeiro molar inferior; 22- Ápice radicular do primeiro molar inferior; 23- Incisal do incisivo central inferior; 24- Ápice radicular do incisivo central inferior; 25- Ponto AO; 26- Ponto BO

\section{FIGURA-52- Pontos cefalométricos de interesse em tecido duro}




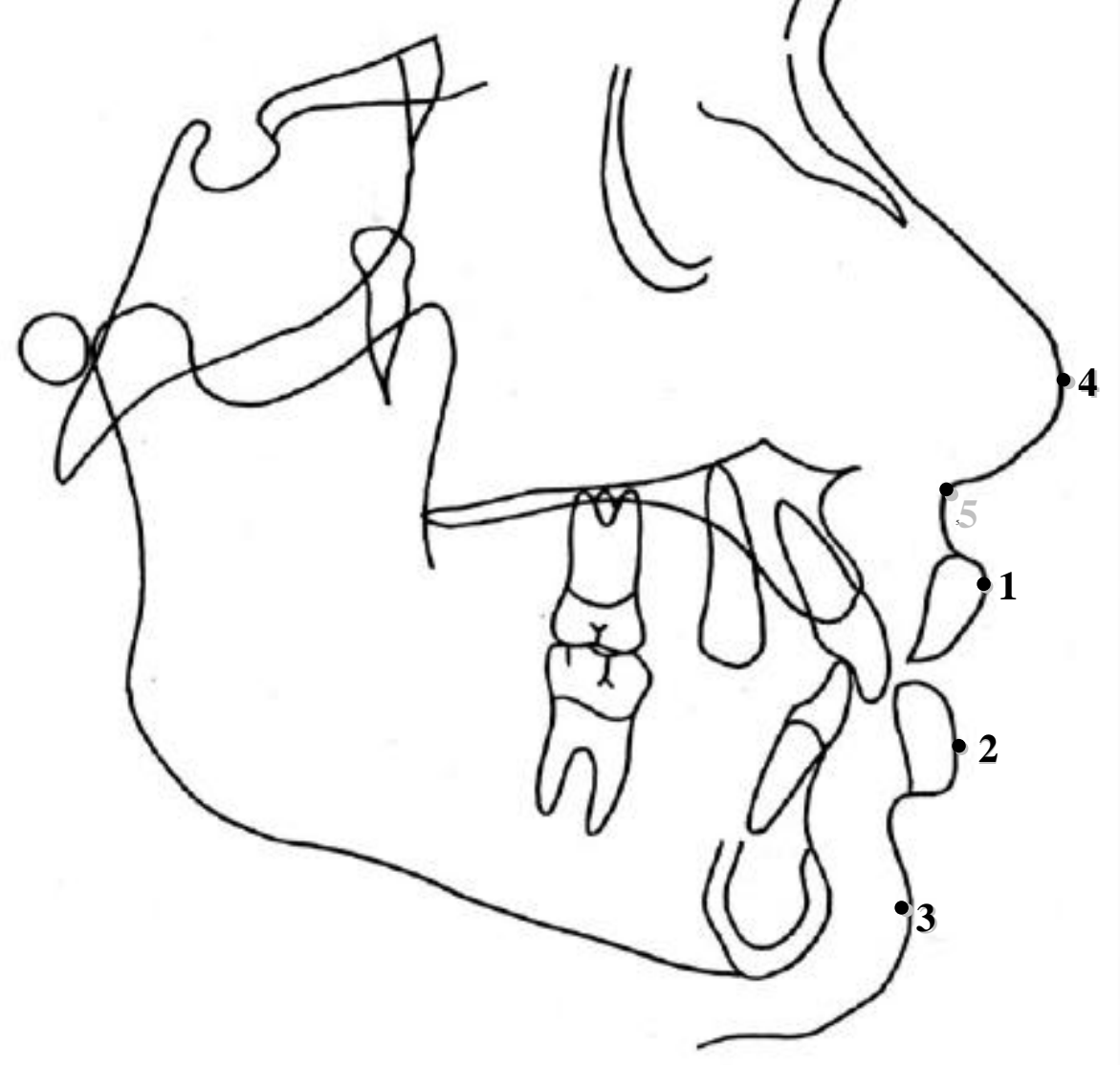

1- Lábio superior; 2- Lábio inferior; 3- Pogônio mole; 4- Pronasal e 5- Subnasal

FIGURA 53- Pontos cefalométricos de interesse em tecido mole 


\subsubsection{ESTABELECIMENTO DAS LINHAS E PLANOS (Figura 54)}

As linhas de interesse foram as seguintes:

1- Linha SN - linha que passa pelos pontos S e N, situados no plano mediosagital e na base do crânio;

2- Linha NA - linha que une os pontos N e A;

3- Linha NB - linha que une os pontos $\mathrm{N}$ e B;

4- Linha ND - linha que une os pontos N e D;

5- Linha Násio Perpendicular - linha vertical traçada de násio perpendicular ao plano horizontal de Frankfurt;

6- Linha A Vertical - linha vertical desenhada passando pelo ponto A paralelo à linha násio perpendicular;

7- Linha SGn (Eixo Y de crescimento) - linha que une os pontos S e $\mathrm{Gn}$;

8- Longo eixo do incisivo central superior - linha que segue o eixo longitudinal do incisivo central superior;

9- Longo eixo do incisivo central inferior - linha que segue o longo eixo do incisivo central inferior;

10- Longo eixo do primeiro molar superior - linha que segue o eixo longitudinal do primeiro molar superior;

11- Longo eixo do primeiro pré-molar superior - linha que une os pontos da cúspide e ápice do primeiro pré-molar permanente superior;

12- Linha vertical pterigóide (PTV) - linha tangente ao ponto CF e perpendicular ao plano horizontal de Frankfurt;

13- Linha $\mathrm{E}$ - linha que une os pontos pronasal e pogônio mole;

14- Linha que une a espinha nasal anterior ao mentoniano;

15- Linha que passa pela columela nasal até o ponto subnasal; 
16- Linha que se estende do ponto subnasal até o ponto do lábio superior.

Os planos cefalométricos empregados foram:

1- Plano oclusal funcional (POcl.) - passa pelo ponto oclusal médio dos molares e dos pré-molares;

2- Plano mandibular (GoGn) - é a representação da base mandibular por meio de uma linha que corta os pontos Go e Gn;

3- Plano mandibular (GoMe) - é o plano que une os pontos Go e Me.

4- Plano horizontal de Frankfurt - é o plano conhecido por órbitomeático e une os pontos de referência Po e Or;

5- Plano palatino - plano que une os pontos ENA e ENP; 


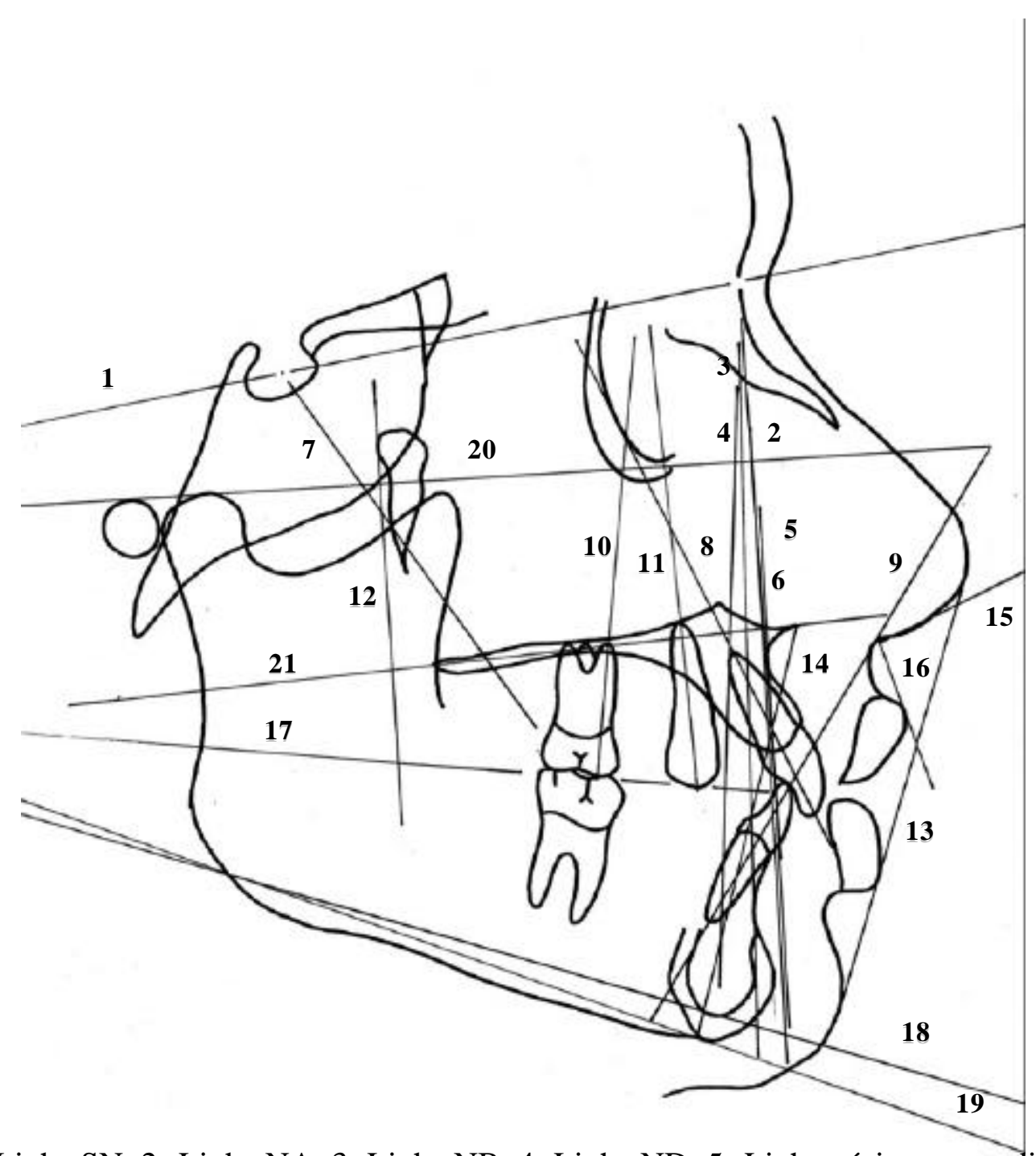

1-Linha SN; 2- Linha NA; 3- Linha NB; 4- Linha ND; 5- Linha násio perpendicular; 6- Linha A vertical; 7- Linha SGn; 8- Longo eixo do incisivo central superior; 9Longo eixo do incisivo central inferior; 10- Longo eixo do primeiro molar superior; 11- Longo eixo do primeiro pré-molar superior; 12- Linha vertical PTV; 13-Linha E; 14- Linha da espinha nasal anterior ao mentoniano; 15- Linha da columela nasal; 16Linha subnasal lábio superior; 17- Plano oclusal; 18- Plano mandibular GoGn; 19Plano mandibular GoMe; 20- Plano horizontal de Frankfurt; 21- Plano palatino.

\section{FIGURA 54- Linhas e planos cefalométricos utilizados}




\subsubsection{Método de padronização do desenho anatômico dos dentes}

Posteriormente à execução dos cefalogramas iniciais, como critério de padronização do desenho anatômico dos elementos dentários analisados, os desenhos do incisivo central, primeiro pré-molar e primeiro molar superior contidos nos traçados iniciais foram utilizados como modelos para o estabelecimento dos contornos desses dentes nos traçados finais.

A cada telerradiografia final foi adaptada uma nova folha de acetato e abaixo dessa foi fixado o traçado inicial, procurando-se justapor primeiramente o desenho do incisivo central superior do traçado inicial sobre a imagem desse referido dente observada na telerradiografia final, para se esboçar o contorno do incisivo final, respeitando-se o modelo inicial. Em seguida, obedecendo-se ao mesmo princípio, estabeleceram-se os desenhos dos demais dentes. Dessa maneira padronizou-se a dimensão dos elementos dentários presentes nos traçados iniciais e finais, eliminando-se as variáveis que poderiam comprometer a análise das alterações dentárias decorrentes da distalização dos molares superiores.

Os traçados iniciais e finais de $30 \%$ da amostra foram repetidos num intervalo de 15 dias para compor um segundo conjunto de traçados que posteriormente a suas digitalizações permitiriam a análise de erro.

\subsubsection{OBTENÇÃO DAS MEDIDAS CEFALOMÉTRICAS}

As medidas cefalométricas foram adquiridas por meio de um método computadorizado, mediante o emprego de um computador IBM - PC, e uma mesa digitalizadora, da marca NUMONICS, modelo 2200, com resolução de cem linhas e precisão de $0,1 \mathrm{~mm}$. 
O programa Dentofacial Planner Plus 4.0 foi adaptado para a execução das digitalizações dos pontos cefalométricos de interesse nos cefalogramas laterais convencionais previamente executados e com o auxílio de um cursor da marca NUMONICS.

Esse programa permitiu a realização da construção das linhas e planos necessários para se obterem as medidas lineares e angulares que demonstraram as variações sagitais e verticais decorrentes da aplicação dos mecanismos dis talizadores. Foram divididas em:

1- Posição ântero-posterior da maxila;

2- Posição ântero-posterior da mandíbula;

3- Relação maxilomandibular;

4- $\quad$ Padrão do esqueleto cefálico;

5- $\quad$ Alterações dentárias e

6- Padrão do perfil mole.

Para a obtenção dos valores normativos das medidas cefalométricas angulares e lineares, referentes aos pacientes do gênero masculino e feminino, com idade de 15 anos, usados como parâmetro de comparação com as variáveis do estudo em questão, foi empregado o Atlas de Crescimento Craniofacial de MARTINS et al. ${ }^{97}$, em 1998.

\section{1- Posição ântero-posterior da maxila (Figura 55)}

As variáveis que mostram as alterações na posição da maxila são:

1 - Ângulo SNA - determinado pela intersecção das linhas SN e NA, sendo o valor normal para a idade dos 15 anos, de $82,3^{\circ}$ e desvio padrão de $2,7^{\circ}$ para o gênero masculino, e de $81,6^{\circ}$ e desvio padrão de $3,2^{\circ}$ para o gênero feminino. Expressa o grau de protrusão ou retrusão da maxila em relação à base do crânio. As medidas acima indicam a protrusão e abaixo a retrusão maxilar e 
2- Distância A-NPerp - determina a posição ântero-posterior da maxila em relação à base do crânio e é medida da linha násio perpendicular ao Plano Horizontal de Frankfurt ao ponto A. O ponto A posicionado anteriormente a essa linha mostra um valor positivo e quando posicionado posteriormente, um valor negativo. Em faces equilibradas, essa medição é de $1 \mathrm{~mm}$ no adulto e de 0 mm na dentadura mista. Para a idade de 15 anos, essa medida deve ser de $-1,4$ com desvio padrão de $2,9 \mathrm{~mm}$, para o gênero masculino, e de $-0,7$ com desvio padrão de 3,4 mm no gênero feminino. Os valores acima e abaixo indicam a protrusão e retrusão maxilar, respectivamente.

\section{2- Posição ântero-posterior da mandíbula (Figura 56)}

1- Ângulo SNB - formado pelas linhas SN e NB, sendo o valor normal para a idade de 15 anos, de $79,5^{\circ}$ e desvio padrão de $2,9^{\circ}$ para o gênero masculino, e de $79,8^{\circ}$ e desvio padrão de $2,8^{\circ}$ para o feminino. Define a posição ântero-posterior da mandíbula, representada pelo ponto $\mathrm{B}$, em relação à base do crânio (linha SN). Medidas acima mostram a protrusão mandibular e, abaixo, a retrusão mandibular;

2- Ângulo SND - determinado pela intersecção das linhas SN e $\mathrm{ND}$, sendo o valor normal $76^{\circ}$, segundo JACOBSON ${ }^{81}$. Estabelece com mais exatidão o posicionamento mandibular durante a mecanoterapia. Os valores altos indicam a protrusão mandibular e ângulos baixos a retrusão mandibular e

3- Distância Pg-NPerp - a relação da mandíbula com a base do crânio é determinada pela medição da distância do pogônio à linha násio perpendicular ao Plano Horizontal de Frankfurt. O posicionamento do ponto pogônio posteriormente à linha násio perpendicular é interpretado por uma medida negativa. Para pacientes do gênero masculino, na idade de 15 anos, essa 
medida deveria ser $-6,5 \mathrm{~mm}$, com desvio padrão de $4,6 \mathrm{~mm}$. No gênero feminino, na mesma faixa etária, a média deveria ser de $-2,7 \mathrm{~mm}$, com desvio padrão de 4,9 mm. Os valores acima e abaixo indicam a ocorrência de uma protrusão e retrusão mandibular, respectivamente.

\section{3- Relação maxilomandibular (Figura 57)}

1- Ângulo ANB - determinado pela intersecção das linhas NA e NB. Corresponde à diferença matemática entre os ângulos SNA e SNB, sendo o valor normal para a idade de 15 anos, de $2,8^{\circ}$ e $1,7^{\circ}$, respectivamente nos gêneros masculino e feminino. Revela a relação ântero-posterior entre a maxila e a mandíbula e o verdadeiro relacionamento das bases apicais. O ANB de 0 a $4,5^{\circ}$ refere-se à Classe I, enquanto que valores acima de 4,5 indicam a Classe II, e valores negativos, a Classe III e

2- Distância WITS - identifica a verdadeira relação ânteroposterior dos maxilares. No adulto do gênero masculino com oclusão excelente, o ponto $\mathrm{BO}$ deve estar posicionado aproximadamente $1 \mathrm{~mm}$ para trás do ponto $\mathrm{AO}$ e no gênero feminino o ponto $\mathrm{BO}$ deveria coincidir com o ponto $\mathrm{AO}$. Assim, essa distância encontra-se aumentada na má oclusão de Classe II, e na Classe III essa distância é negativa. 


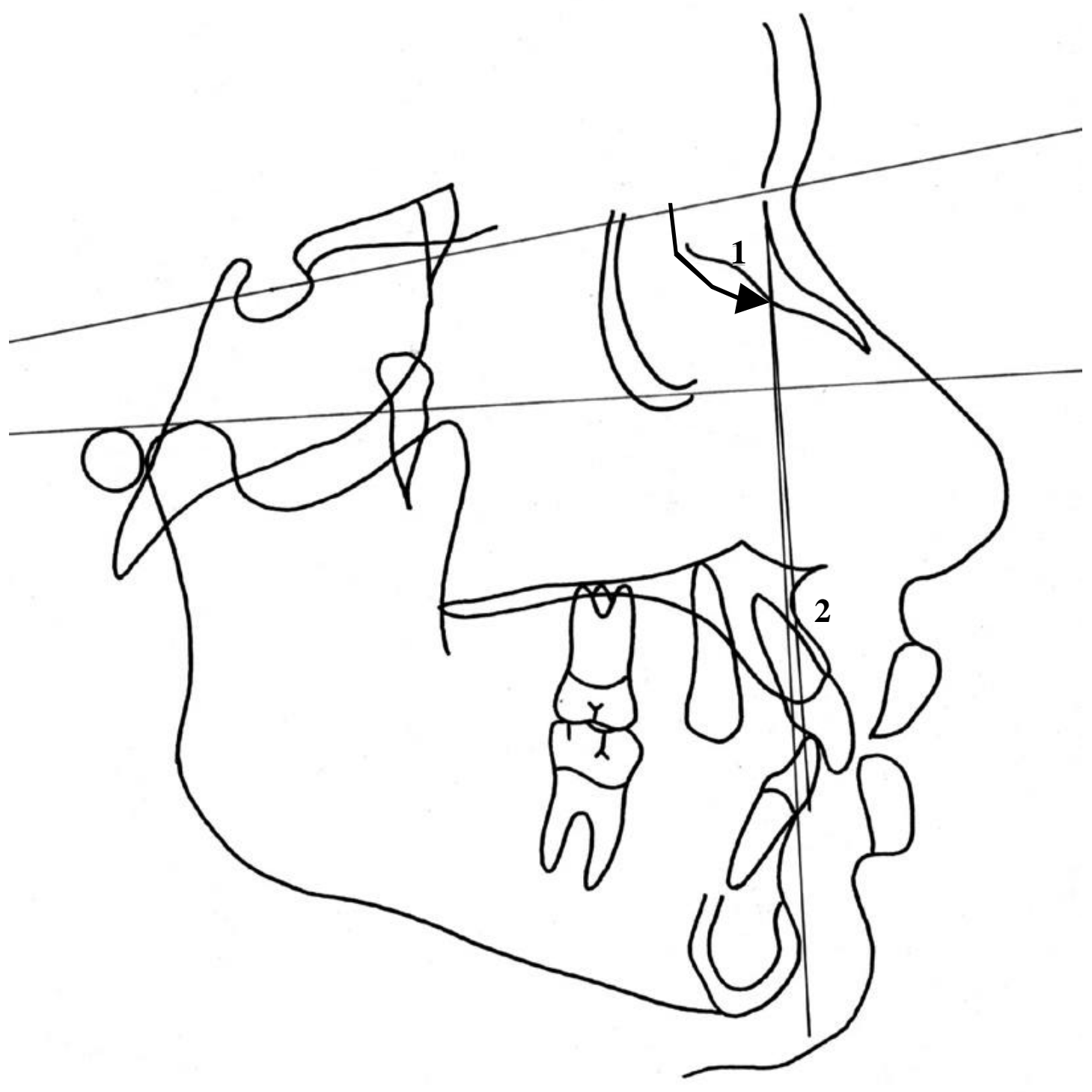

1 - Ângulo SNA e 2- Distância A-NPerp

FIGURA 55- Posição ântero-posterior da maxila 


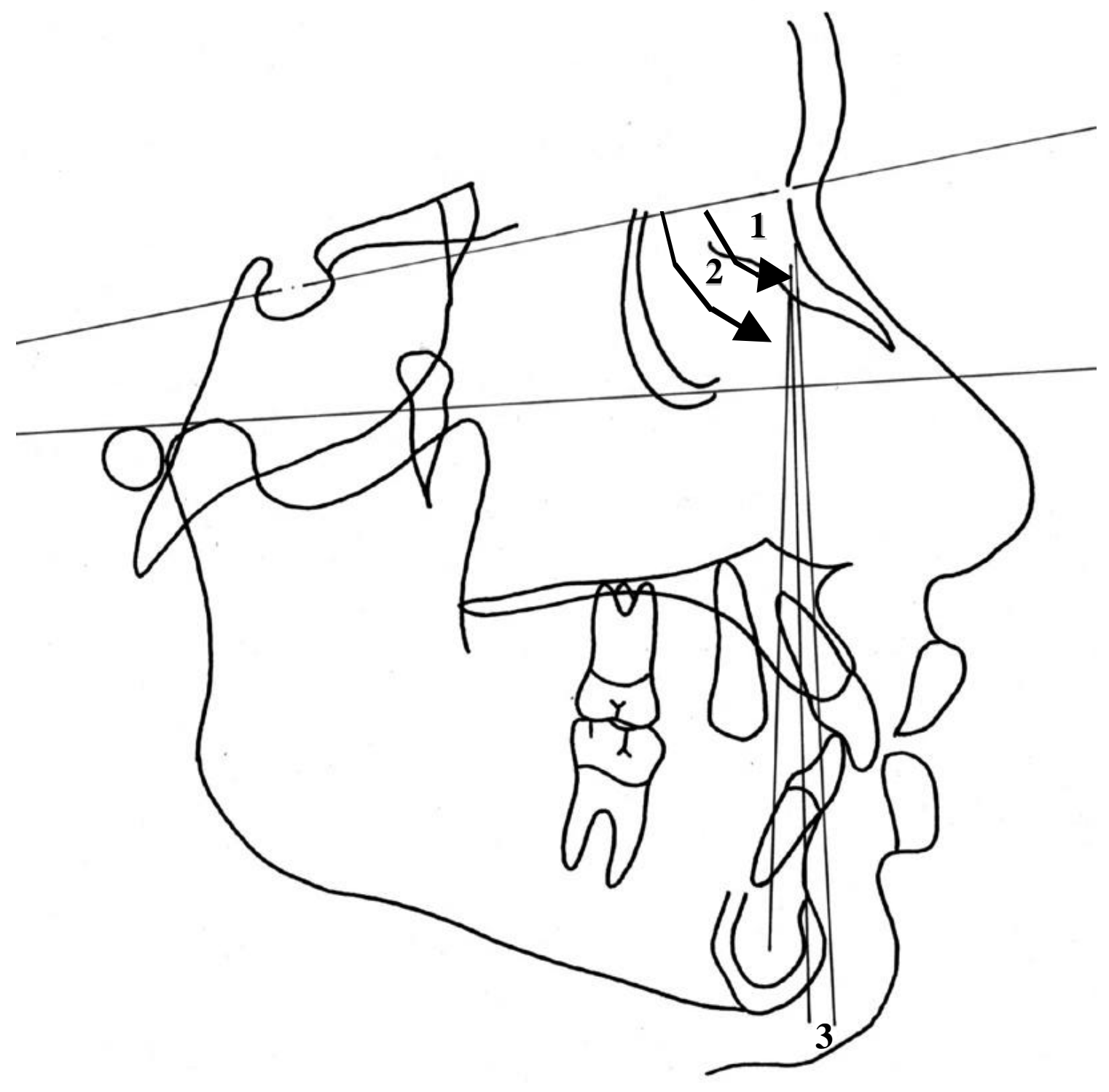

1- Ângulo SNB; 2- Ângulo SND e 3- Distância Pg-

FIGURA 56- Posição ântero-posterior da mandíbula 


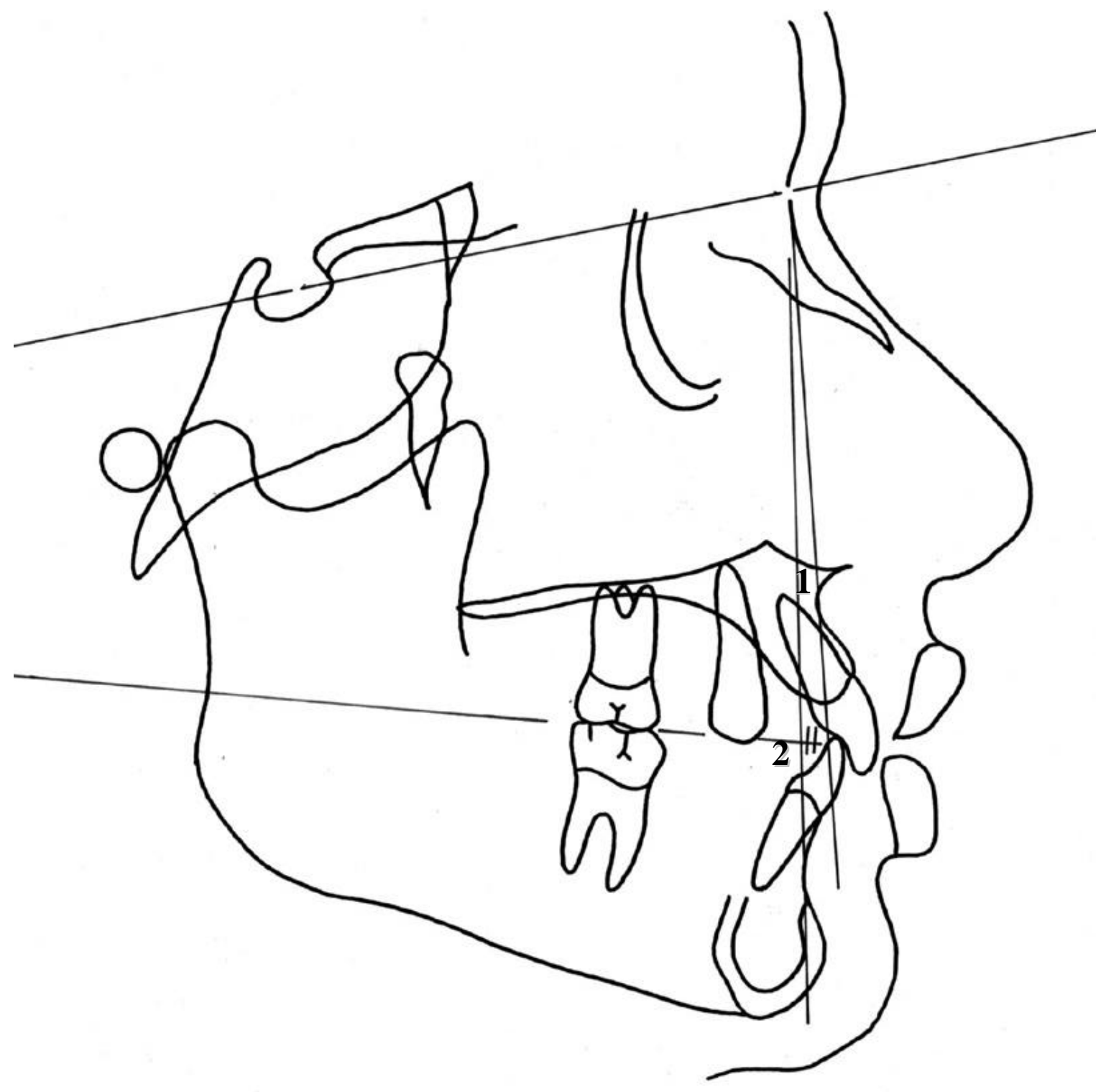

1- Ângulo ANB e 2- Distância Wits

FIGURA 57- Relação maxilomandibular 


\section{4- PADRÃO DO ESQUELETO CEFÁLICO (Figura 58)}

1- Distância da altura facial ântero-inferior (AFAI) - é medida da espinha nasal anterior (ENA) ao mentoniano (Me). Em faces equilibradas, essa dimensão correlaciona-se com o comprimento efetivo da face média (CondílioPonto A). Assim sendo, na dentadura mista, com o comprimento da face média de $85 \mathrm{~mm}$, a AFAI deveria ser de 60 a $62 \mathrm{~mm}$, segundo JACOBSON ${ }^{81}$. Para a idade dos 15 anos, a média considerada ideal para os gêneros masculino e feminino é de 71,2 $\mathrm{mm}$ e $67,1 \mathrm{~mm}$, respectivamente.

2- Ângulo SN.GoGn - ângulo formado pela linha SN e o Plano Mandibular GoGn. Considerando-se que GoGn representa o corpo mandibular, esse ângulo elucida o comportamento da base mandibular em relação à base do crânio. Significa dizer que o tipo de crescimento facial é predominantemente vertical ou horizontal. $\mathrm{O}$ valor preestabelecido para a idade de 15 anos é $32,9^{\circ}$ para o gênero masculino e de $31,0^{\circ}$ para o feminino. As variações acima ou abaixo de $2^{\circ}$ indicam que o padrão do esqueleto cefálico é desfavorável. Valores acima da norma mostram que há uma divergência dos planos horizontais, com predominância do crescimento no sentido vertical. Os valores abaixo da norma demonstram que o crescimento está se processando no sentido horizontal;

3- Ângulo FMA - ângulo súpero-posterior, determinado pela intersecção dos Planos Horizontal de Frankfurt e o Mandibular, sendo a norma para a idade de 15 anos do gênero masculino de $27,0^{\circ}$ e do feminino de $23,6^{\circ}$. Esse ângulo proporciona a informação do sentido predominante do crescimento facial. $\mathrm{O}$ valor acima do normal indica um crescimento predominantemente no sentido vertical e quando se encontra abaixo da norma o crescimento está ocorrendo mais no sentido horizontal; 
4- $\quad$ Ângulo do Plano Horizontal de Frankfurt com o Plano Oclusal (Frank.Ocl)- ângulo obtido pela intersecção dos Planos Oclusal e Horizontal de Frankfurt. Relaciona a superfície oclusal com a base do crânio. A norma para a idade de 15 anos do gênero masculino e feminino é respectivamente $19,0^{\circ} \mathrm{e}$ 17,8 $8^{\circ}$ Esse ângulo sofre reflexo direto das alterações do Plano Oclusal: se o Plano Oclusal inclinar-se para baixo, o valor mostrará um aumento e se o Plano Oclusal inclinar-se para cima, o ângulo será menor que a norma;

5- Ângulo do Plano Horizontal de Frankfurt com o Plano Palatino (Frank.Pal) - ângulo definido pela intersecção dos Planos Palatino e Horizontal de Frankfurt. Não possui valor normativo, sendo que o Plano Palatino inclinado para baixo mostra um valor negativo e o inclinado para cima um valor positivo;

6- Ângulo do Plano Horizontal de Frankfurt com o Plano Mandibular (Frank.GoGn) - ângulo determinado pela intersecção dos Planos Mandibular e Horizontal de Frankfurt. Expressa a relação da mandíbula com a base do crânio. O padrão preestabelecido para a idade de 15 anos, do gênero masculino e feminino é $28,8^{\circ}$ e $30,4^{\circ}$, respectivamente. O ângulo do Plano Mandibular demonstra a complicação a ser encarada no tratamento e o prognóstico. Em uma má oclusão de Classe II, $1^{\text {a }}$ divisão, encontra-se aumentado e na Classe II, $2^{\text {a }}$ divisão, esse ângulo apresenta-se diminuído;

7- $\quad$ Ângulo SN.POcl. - ângulo estabelecido pela linha SN e o Plano Oclusal. O padrão preestabelecido para indivíduos do gênero masculino com 15 anos de idade é $25,3^{\circ}$ e para o feminino com idade equivalente é $25,5^{\circ}$. O significado clínico desse ângulo é baseado na importância de mantê-lo constante durante o tratamento e

8- $\quad$ Ângulo SN.Gn - ângulo formado pela intersecção das linhas SN e SGn (eixo Y de crescimento). Define a resultante vetorial de crescimento anterior e inferior da mandíbula. O valor normal para indivíduos do gênero 
masculino e feminino com idade de 15 anos é de $66,5^{\circ}$ mais $3,0^{\circ}$. Essa grandeza tende a suprir a deficiência que SN.GoGn nos fornecia, assim esses dois ângulos se complementam. O ângulo SN.Gn é mais sensível às variações ânteroposteriores. O valor acima e abaixo da norma relacionam-se ao vetor de crescimento facial mais no sentido vertical e horizontal, respectivamente.

\section{5- ALTERAÇÕES DENTÁRIAS (Figura 59)}

1- Ângulo do incisivo central superior (1.NA) - formado pela linha do longo eixo do incisivo central superior com a linha NA, sendo a norma $21,2^{\circ}$ para indivíduos do gênero masculino com idade de 15 anos, e do feminino de idade equivalente $24,6^{\circ}$. Os valores acima, dentro da norma e abaixo, indicam que os incisivos superiores se encontram inclinados para a vestibular, verticalizados e inclinados para a lingual, respectivamente. Ângulo maior que $22^{\circ}$ é geralmente observado na Classe II, $1^{\text {a }}$ divisão e na Classe III; ângulo menor que o normal é característico da Classe II, $2^{a}$ divisão. Clinicamente esse ângulo é importante no controle de torque quando da retração ou projeção dos incisivos superiores;

2- Distância do incisivo central superior (1-NA) - distância do ponto mais vestibular da coroa do incisivo central superior até a linha NA. Expressa, em milímetros, a relação ântero-posterior do incisivo central superior com a linha NA, cujo valor normal é de 3,6 mm para o gênero masculino e 4,5 mm, para o feminino, de idade média de 15 anos. Os valores acima, dentro da norma e abaixo indicam que os incisivos superiores encontram-se protruídos, bem posicionados e retruídos, respectivamente;

3- Distância do incisivo central superior a Linha A Vertical (1AV)- essa medida determina se os incisivos superiores estão protruídos ou 
retruídos, sendo medida a distância do ponto mais vestibular da coroa do incisivo superior à linha A vertical, cujo valor deve ser de 4 a 6mm;

4- Ângulo do Plano Horizontal de Frankfurt com o primeiro prémolar superior (Frank.4) - ângulo formado pela linha que representa o longo eixo do primeiro pré-molar superior com o Plano Horizontal de Frankfurt. Não possui valor normativo e a sua leitura deve ser feita no ângulo complementar anterior;

5- $\quad$ Ângulo do Plano Horizontal de Frankfurt com o primeiro molar superior (Frank.6)- ângulo definido pela linha do longo eixo do primeiro molar superior com o Plano Horizontal de Frankfurt. Não apresenta padrão preestabelecido, sendo a leitura feita também no ângulo complementar anterior;

6- Distância do incisivo central superior à Linha PTV (1-PTV)distância medida da face vestibular do incisivo central superior à linha vertical pterigóide (PTV). Define a posição ântero-posterior do incisivo superior. Não apresenta um valor padrão, devendo apenas ser avaliado por comparação entre os valores iniciais e finais para quantificar o deslocamento sofrido por esse elemento dentário, durante o procedimento de distalização dos molares. Essa medida mostra a perda de ancoragem visualizada pelo movimento mesial dos incisivos centrais superiores;

7- Distância do primeiro pré-molar superior à Linha PTV (4-PTV)distância do primeiro pré-molar superior à linha vertical pterigóide (PTV). Estabelece a posição ântero-posterior do primeiro pré-molar superior, porém não possui valor normativo, apenas define por meio da comparação entre os valores inicial e final o movimento mesial sofrido por esse elemento dentário, durante a distalização dos molares. Essa distância denota a perda de ancoragem dos prémolares superiores; 
8- $\quad$ Distância do primeiro molar superior à Linha PTV (6-PTV)distância do primeiro molar superior à linha vertical pterigóide (PTV). Mostra a posição ântero-posterior do primeiro molar superior, entretanto não possui valor normativo. A comparação dos valores inicial e final define o movimento distal sofrido pelo primeiro molar;

9- Ângulo interincisivos (1.1) - ângulo interincisivos é estabelecido pela intersecção dos longos eixos dos incisivos centrais superior e inferior. O padrão preestabelecido para indivíduos do gênero masculino com idade de 15 anos é $132^{\circ}$, e do feminino com idade equivalente é $129,3^{\circ}$. Os valores acima e abaixo da norma relacionam-se a biprotrusão e birretrusão, respectivamente;

10- Sobremordida (Sobrem.) - a sobremordida é medida verticalmente do ponto médio da incisal do incisivo central superior ao ponto médio da incisal do incisivo central inferior e

11- Sobressaliência (Sobress.) - a sobressaliência é medida do ponto médio da incisal do incisivo central superior ao ponto médio da incisal do incisivo central inferior. Essa medida mostrará a quantidade de trespasse horizontal e deve ser analisada comparando-se os valores das telerradiografias inicial e final.

\section{6- PADRÃO DO PERFIL MOLE (Figura 60)}

1- Distância do Lábio Superior à Linha E - distância do lábio superior para a linha traçada tangente ao nariz e ao tecido mole do mento. Mostra a ocorrência de alterações na protrusão do lábio superior. Essa distância tende a diminuir quando há protrusão do lábio superior;

2-Distância do Lábio inferior à Linha E - distância do lábio inferior para a linha traçada tangente ao nariz e ao tecido mole do mento. Essa distância 
é de $-2+/-2 \mathrm{~mm}$, segundo JACOBSON ${ }^{81}$. Devemos observar se a mecanoterapia causou alguma alteração na estética facial;

3- Ângulo nasolabial - esse ângulo é formado pela linha tangente à base do nariz e pela linha do subnasal ao lábio superior. A norma em adultos do gênero masculino e feminino com faces equilibradas é $102^{\circ}$, segundo JACOBSON $^{81}$. O ângulo abaixo da norma é o reflexo da protrusão dentoalveolar, assim como o valor acima do padrão indica que o incisivo superior se apresenta retruído ou verticalizado.

Os valores obtidos para as medidas angulares e lineares foram dispostos em quadros do programa Excel e encaminhados para a análise estatística, para se avaliarem as alterações esqueléticas, dentárias e do perfil do tecido mole decorrentes da distalização dos molares superiores. 


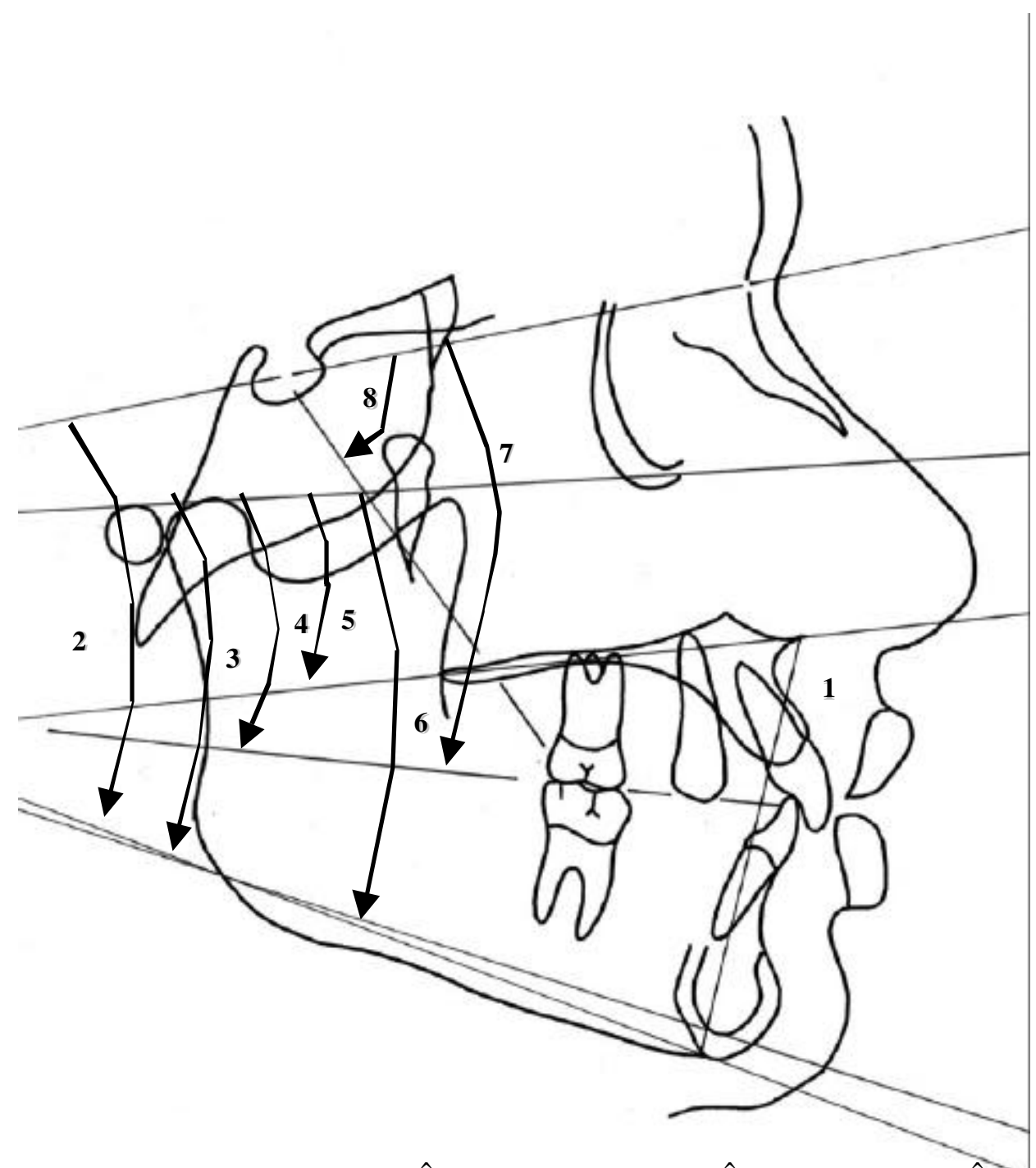

1- Altura ântero-inferior (AFAI); 2- Ângulo SN.GoGn; 3- Ângulo FMA; 4- Ângulo do Plano Horizontal de Frankfurt com o Plano oclusal; 5-Ângulo do Plano Horizontal de Frankfurt com o Plano palatino; 6- Ângulo do Plano Horizontal de Frankfurt com o Plano mandibular; 7- Ângulo SN.PlOcl; 8- Ângulo SN.

FIGURA 58 - Padrão do esqueleto cefálico 


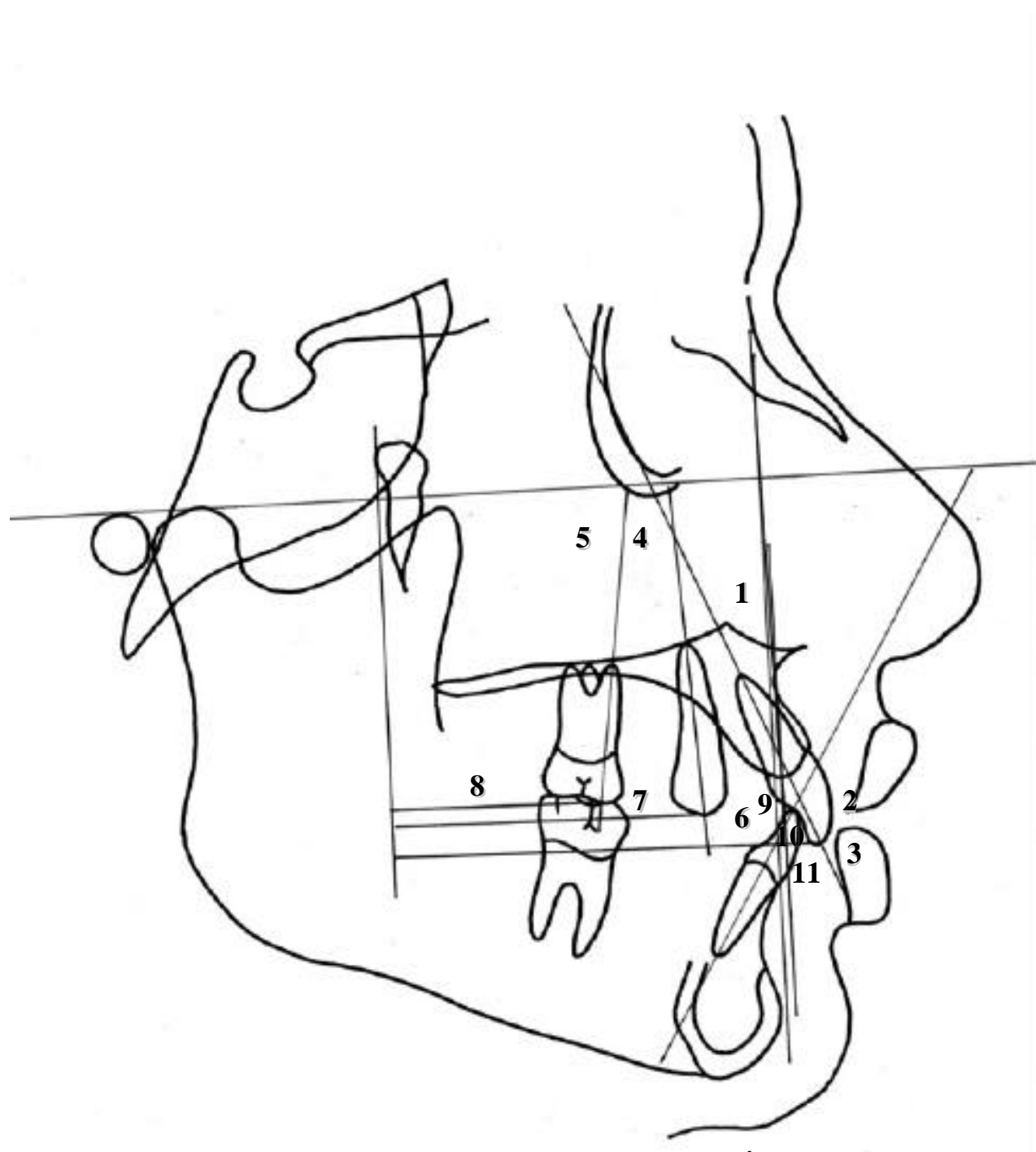

1- Ângulo 1.NA; 2- Distância 1-NA; 3- Distância 1-AV; 4- Ângulo do Plano horizontal de Frankfurt com o primeiro pré-molar superior; 5- Ângulo do Plano horizontal de Frankfurt com o primeiro molar superior; 6- Distância do incisivo superior à linha PTV; 7- Distância do primeiro pré-molar superior à linha PTV; 8- Distância do primeiro molar superior à linha PTV; 9- Ângulo interincisivos; 10- Sobremordida; 11-

FIGURA 59 - Alterações dentárias 


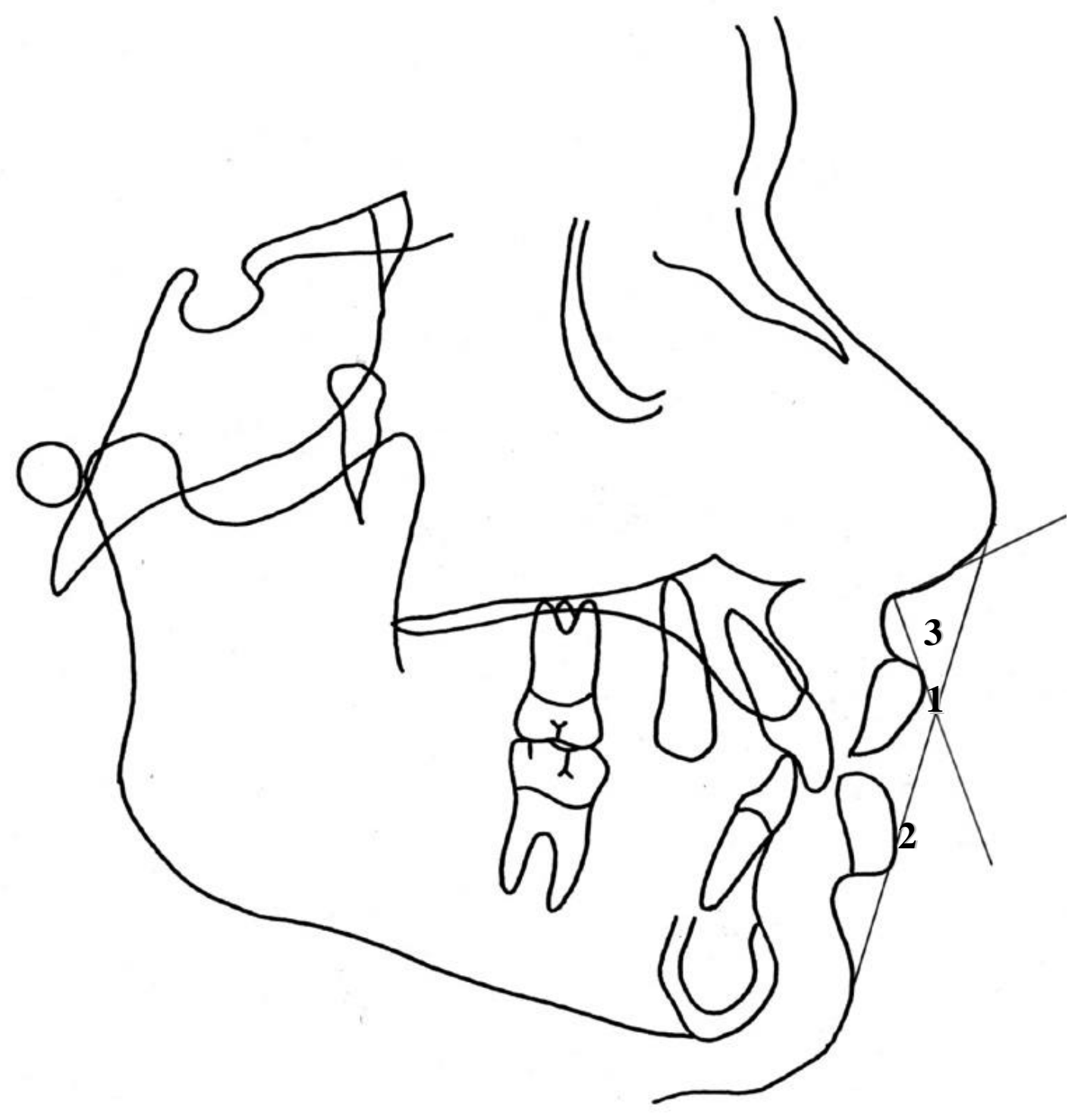

1- Distância do lábio superior à linha E, 2- Distância do lábio inferior à linha E e 3- Ângulo nasolabial 


\subsubsection{ELABORAÇÃO DOS CEFALOGRAMAS EM NORMA}

\section{LATERAL DE $45^{\circ}$}

Em cada telerradiografia em norma lateral de $45^{\circ}$, foi adaptada uma folha de papel acetato transparente "Tercron", de dimensão de 12,5 cm X 10,0 $\mathrm{cm}$ e espessura de 0,07 $\mathrm{mm}$. Em seguida, o desenho anatômico foi delineado, sempre pelo mesmo operador, com auxílio de uma lapiseira e grafite preto HB 0,3 mm, sobre um negatoscópio. Para melhor visualização das estruturas de interesse, esses traçados foram realizados utilizando-se o recurso da sala obscurecida, e para a obtenção de contornos mais precisos e regulares a lapiseira foi mantida na posição vertical durante a execução do desenho anatômico.

Os traçados foram efetuados nas telerradiografias da fase inicial e após o período de distalização dos molares superiores. Decorrido um intervalo de tempo de 15 dias, foram repetidos os traçados em $30 \%$ da amostra, envolvendo as telerradiografias das fases inicial e final, obtendo-se um segundo conjunto de traçados para a avaliação do erro de método.

A elaboração dos cefalogramas consistiu em:

4.2.4.1. Desenho anatômico;

4.2.4.2. Definição dos pontos cefalométricos;

4.2.4.3. Estabelecimento das linhas e planos cefalométricos;

4.2.4.4. Método de padronização do desenho anatômico dos dentes e

4.2.4.5. Obtenção das medidas cefalométricas.

\subsubsection{Desenho anatômico (Figura 61)}

Foram delineadas as linhas radiopacas das seguintes estruturas anatômicas:

1- Maxila: linha do assoalho da fossa nasal, espinha nasal anterior e posterior, rebordo alveolar anterior e palato ósseo; 
2- Incisivo central superior;

3- Primeiro pré-molar superior;

4- Segundo pré-molar superior;

5- Primeiro molar superior e

6- Segundo molar superior.

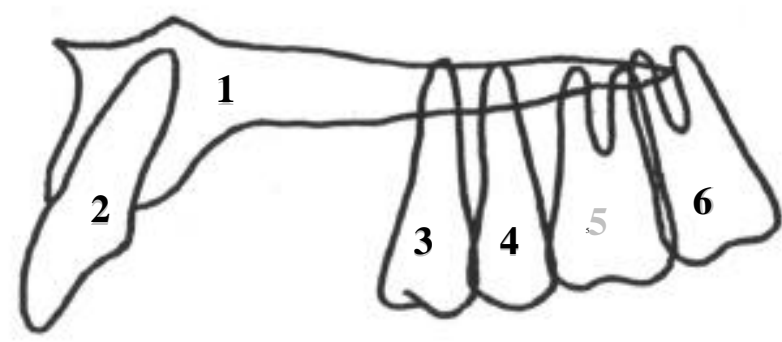

1- Maxila; 2 - Incisivo central superior; 3 - Primeiro pré-molar superior; 4- Segundo pré-molar superior; 5- Primeiro molar superior e 6- Segundo molar superior

FIGURA 61 - Desenho Anatômico de interesse.

\subsubsection{Definição dos pontos cefalométricos (Figura 62)}

Após o desenho das estruturas anatômicas de interesse, fez-se a demarcação dos pontos cefalométricos:

1- Espinha nasal anterior (ENA) - ponto localizado na extremidade da espinha nasal anterior;

2- Espinha nasal posterior (ENP) - ponto situado na extremidade da espinha nasal posterior; 
3- Borda incisal do incisivo central superior - ponto estabelecido na borda incisal do incisivo central superior;

4- Ápice radicular do incisivo central superior - ponto definido no ápice radicular do incisivo central superior;

5- Cúspide do primeiro pré-molar superior - ponto localizado no ponto médio da cúspide vestibular do primeiro pré-molar superior;

6- Ápice radicular do primeiro pré-molar superior - ponto situado no ápice radicular do primeiro pré-molar superior;

7- Cúspide do segundo pré-molar superior - ponto estabelecido no ponto médio da cúspide vestibular do segundo pré-molar superior;

8- Ápice radicular do segundo pré-molar superior - ponto situado no ápice radicular do segundo pré-molar superior;

9- Cúspide do primeiro molar superior - ponto localizado no ponto médio das cúspides vestibulares do primeiro molar superior;

10- Ápice radicular do primeiro molar superior - ponto estabelecido no ápice radicular do primeiro molar superior;

11- Cúspide do segundo molar superior - ponto situado no ponto médio das cúspides vestibulares do segundo molar superior e

12- Ápice radicular do segundo molar superior - ponto localizado no ápice radicular do segundo molar superior.

Para facilitar o procedimento de digitalização dos pontos cefalométricos, foram traçadas duas linhas de referência, uma horizontal e outra vertical, sendo que o referido ponto cefalométrico se localizava na intersecção dessas duas linhas. As linhas de referência presentes no cursor de digitalização foram ajustadas de tal forma a coincidirem com as linhas previamente 
estabelecidas nos traçados cefalométricos, permitindo uma digitalização dos pontos de interesse com maior segurança e critério.

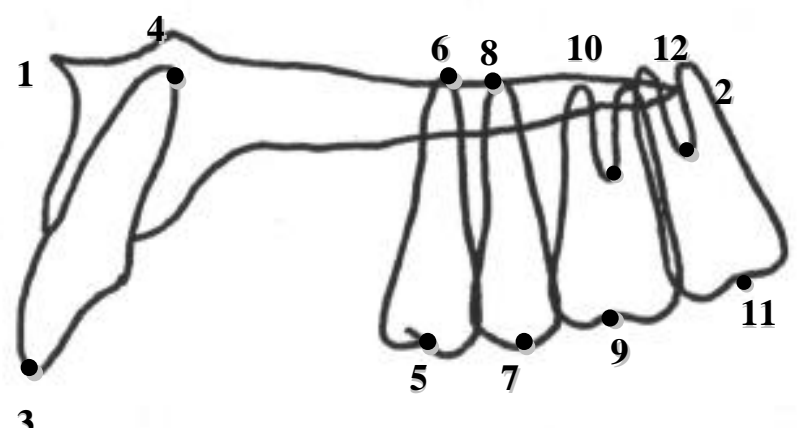

1- Espinha nasal anterior, 2 - Espinha nasal posterior, 3- Borda incisal do incisivo central superior, 4-Ápice radicular do incisivo central superior, 5- Cúspide do primeiro pré-molar superior, 6- Ápice radicular do primeiro pré-molar superior, 7-Cúspide do segundo pré-molar superior, 8- Ápice radicular do segundo pré-molar superior, 9- Cúspide do primeiro molar superior, 10- Ápice radicular do primeiro molar superior, 11-Cúspide do segundo molar superior e 12- Ápice radicular do segundo molar superior

FIGURA 62- Pontos cefalométricos para o cefalograma de $45^{\circ}$

\subsubsection{Estabelecimento das linhas e planos cefalométricos (Figura 63)}

1- Linha do longo eixo do incisivo central superior - linha que segue o eixo longitudinal do incisivo central superior; 
2- Linha do longo eixo do primeiro pré-molar superior - linha que segue o longo eixo do primeiro pré-molar superior;

3- Linha do longo eixo do segundo pré-molar superior - linha que segue o eixo longitudinal do segundo pré-molar superior;

4- Linha do longo eixo do primeiro molar superior - linha do eixo longitudinal do primeiro molar superior;

5- Linha do longo eixo do segundo molar superior - linha que segue o eixo longitudinal do segundo molar superior;

6- Plano palatino - plano que une os pontos ENA e ENP e

7- Plano oclusal funcional - plano que passa pelo ponto oclusal médio dos molares e dos pré-molares.

\subsubsection{Método de padronização do desenho anatômico dos dentes}

Após a execução dos cefalogramas iniciais, abrangendo os quadrantes direito e esquerdo, isoladamente, os desenhos do incisivo, do primeiro e segundo pré-molares, do primeiro e segundo molares superiores dos traçados iniciais foram utilizados como modelos para o estabelecimento dos contornos desses elementos dentários nos traçados finais.

A cada telerradiografia de $45^{\circ}$ final foi adaptada uma nova folha de acetato e sobre essa foi fixado o cefalograma inicial, procurando-se ajustar primeiramente o desenho do incisivo do traçado inicial sobre a imagem observada nessa telerradiografia, para se esboçar o contorno do incisivo da telerradiografia final, respeitando-se o modelo inicial. Em seguida, foi estabelecido o desenho final dos demais elementos dentários analisados, obedecendo-se ao mesmo princípio. Dessa maneira, padronizou-se a dimensão dos elementos dentários presentes nos traçados iniciais e finais, minimizando os 
problemas com os tamanhos dentários entre traçados e que pudessem comprometer a interpretação dos resultados, principalmente das variações verticais decorrentes da distalização dos molares.

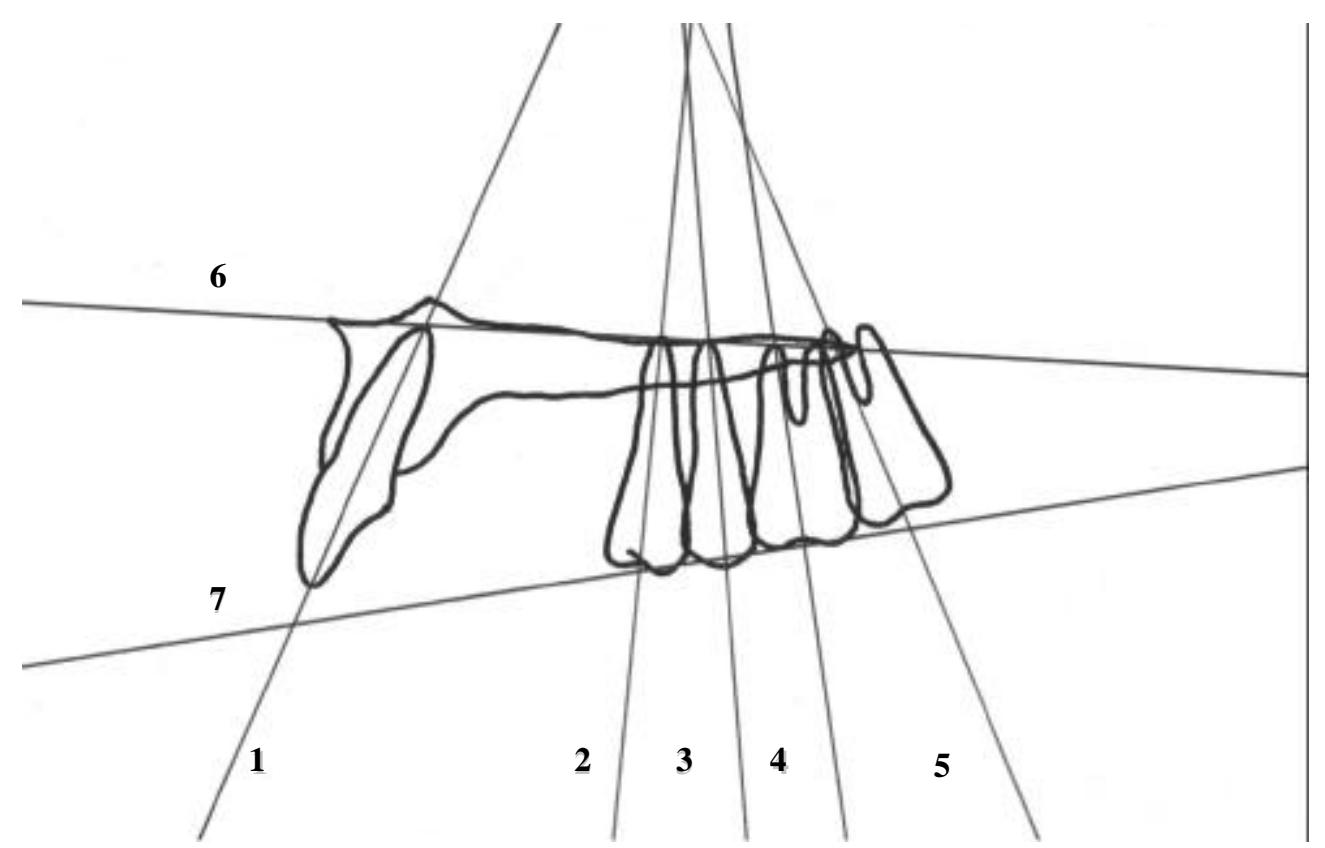

1- Linha do longo eixo do incisivo central superior, 2 - Linha do longo eixo do primeiro pré-molar superior,

3- Linha do longo eixo do segundo pré-molar superior, 4- Linha do longo eixo do primeiro molar superior,

4- Linha do longo eixo do segundo molar superior, 5- Plano palatino e 6- Plano oclusal funcional

FIGURA 63- Linhas e planos utilizados no cefalograma de $45^{\circ}$

\subsubsection{Obtenção das medidas cefalométricas}

Utilizou-se o método computadorizado para a obtenção das medidas cefalométricas, mediante o emprego de um computador IBM - PC, e de uma mesa digitalizadora, da marca NUMONICS, modelo 2200, com a resolução de cem linhas por milímetro e precisão de $0,1 \mathrm{~mm}$.

O programa Dentofacial Planner Plus 4.0 foi adaptado para as digitalizações dos pontos cefalométricos de interesse nos cefalogramas laterais 
de $45^{\circ}$ previamente executados e com o auxílio de um cursor da marca NUMONICS.

Esse programa permitiu a realização da construção das linhas e dos planos necessários para se obterem as medidas lineares e angulares que demonstraram as variações sagitais e verticais decorrentes da aplicação dos mecanismos distalizadores. Dividiu-se em:

1- Alterações sagitais e

2- Alterações verticais.

\section{1- $\quad$ Alterações sagitais (Figura 64)}

A- Ângulo do incisivo central superior com o Plano palatino (1.Pal) - formado pela intersecção do longo eixo do incisivo central superior com o Plano palatino;

B- Ângulo do primeiro pré-molar superior com o Plano palatino (4.Pal) - determinado pela intersecção do longo eixo do primeiro pré-molar superior com o Plano palatino;

C- Ângulo do segundo pré-molar superior com o Plano palatino (5.Pal) - formado pela intersecção do longo eixo do segundo pré-molar superior com o Plano palatino;

D- Ângulo do primeiro molar superior com o Plano palatino (6.Pal)determinado pela intersecção do longo eixo do primeiro molar superior com o Plano palatino e

E- Ângulo do segundo molar superior com o Plano palatino (7.Pal)formado pela intersecção do longo eixo do segundo molar superior com o Plano palatino. 


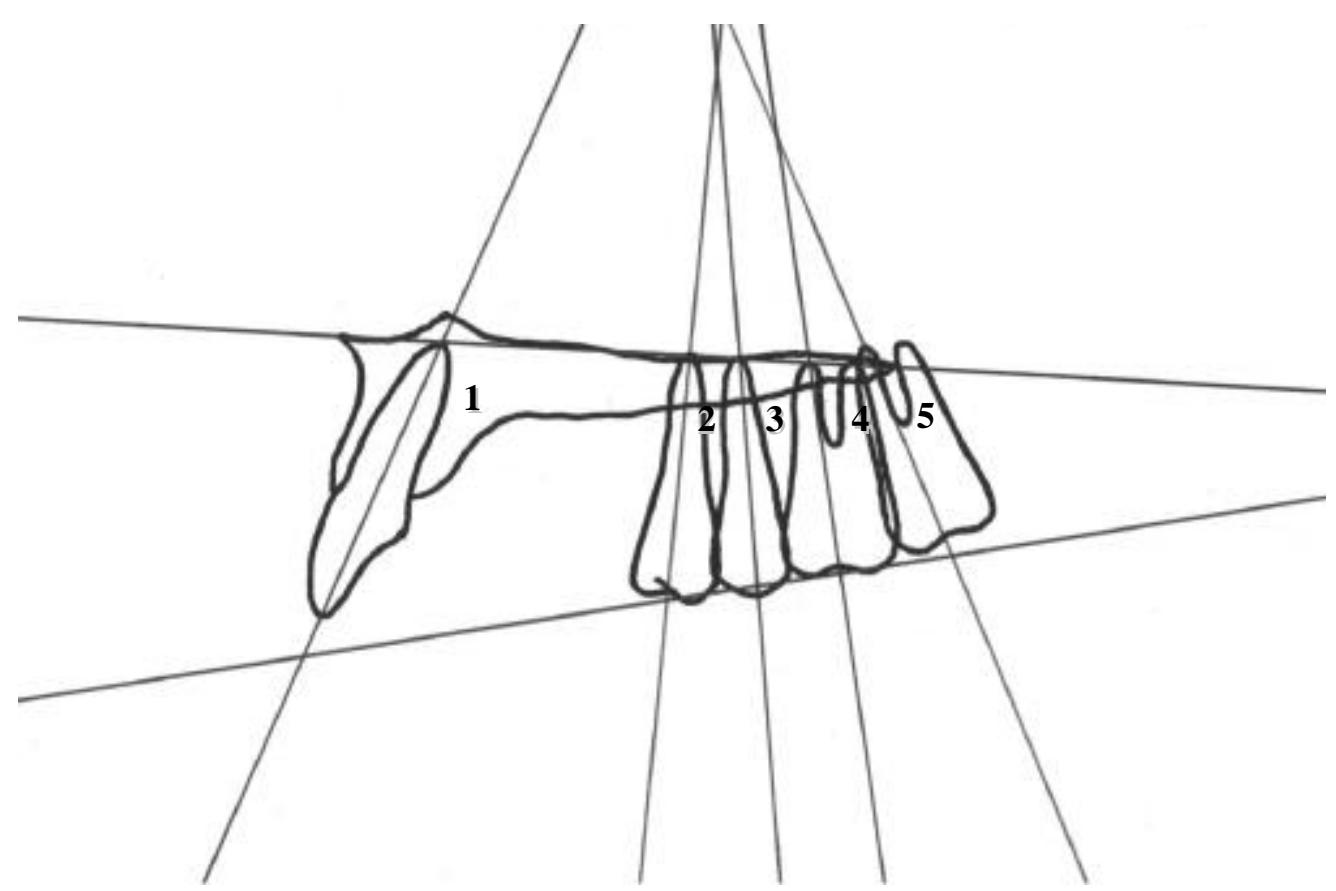

1- Ângulo do incisivo central superior com o Plano palatino, 2- Ângulo do primeiro pré-molar superior com o Plano palatino, 3- Ângulo do segundo pré-molar superior com o Plano palatino, 4-Ângulo do primeiro molar superior com o Plano palatino e 5- Ângulo do segundo molar superior com o Plano palatino

FIGURA 64 - Alterações angulares no cefalograma de $45^{\circ}$

\section{2- Alterações verticais (Figura 65)}

Os movimentos verticais dos elementos dentários decorrentes da distalização dos molares superiores também foram quantificados por meio das seguintes medidas:

1- Distância do incisivo central superior ao Plano palatino (1-Pal)distância medida da borda incisal do incisivo central superior ao Plano palatino; 
2- Distância do primeiro pré-molar superior ao Plano palatino (4Pal)- distância medida do ponto cúspide do primeiro pré-molar superior ao Plano palatino;

3- Distância do segundo pré-molar superior ao Plano palatino (5Pal)- distância medida do ponto cúspide do segundo pré-molar superior ao Plano palatino;

4- Distância do primeiro molar superior ao Plano palatino (6-Pal)distância do ponto cúspide do primeiro molar superior ao Plano palatino;

5- Distância do segundo molar superior ao Plano palatino (7-Pal)distância do ponto cúspide do segundo molar superior ao Plano palatino.

Torna-se necessário relembrar que foram consideradas as correções das magnificações das telerradiografias obtidas nos diferentes aparelhos, sendo de $0,45 \%$ para as telerradiografias obtidas no Hospital de Reabilitação de Anomalias Craniofaciais, de 1,2\% para as telerradiografias oriundas da Clínica de Ortodontia e de 1,4\% para aquelas obtidas no Centro de Diagnóstico Bucal de Bauru (CDB). Essas correções foram empregadas no programa Dentofacial Planner, que automaticamente ajustou os valores das medidas cefalométricas angulares e lineares decorrentes da digitalização.

Deve-se ressaltar que os mesmos procedimentos de elaboração dos cefalogramas, determinação dos pontos de referência, estabelecimento das linhas e planos cefalométricos e método de padronização do desenho dos dentes foram repetidos para a obtenção das medidas cefalométricas, empregando-se as telerradiografias do lado esquerdo. 
Os valores observados para as medidas angulares e lineares foram dispostos em quadros do programa Excel para o encaminhamento à análise estatística e para se avaliar a significância das alterações dentárias do lado direito e esquerdo resultantes da distalização dos molares superiores.

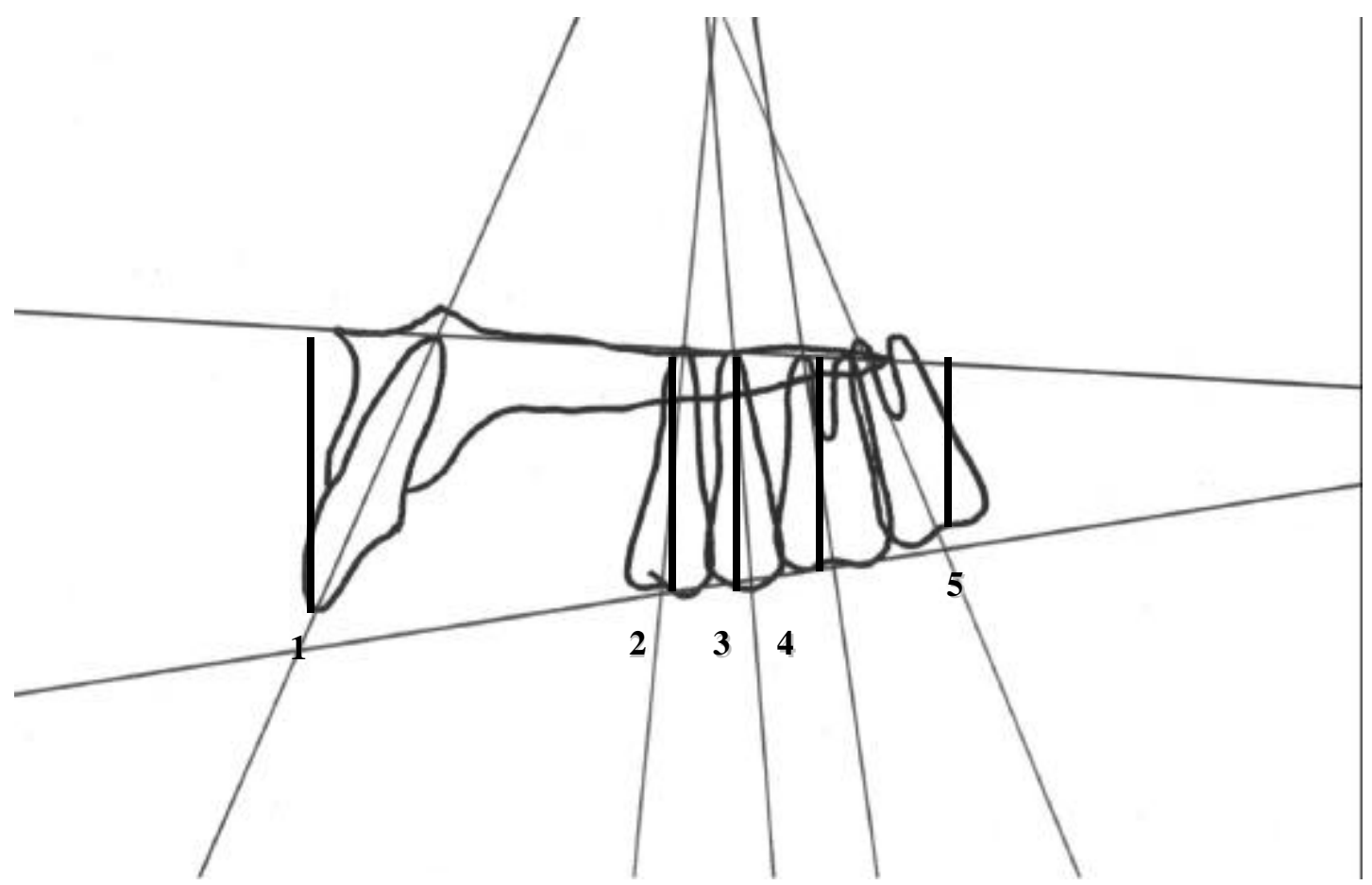

1 - Distância do incisivo central superior ao Plano palatino, 2- Distância do primeiro pré-molar superior ao Plano palatino, 3 - Distância do segundo pré-molar superior ao Plano palatino, 4Distância do primeiro molar superior ao Plano palatino e 5-Distância do segundo molar superior

FIGURA 65- Alterações dentárias verticais pela telerradiografia em norma lateral de $45^{\circ}$ 


\subsubsection{ANÁLISE DE MODELOS}

Foram utilizados os modelos de estudo iniciais e finais de 31 pacientes para se analisarem as alterações transversais e sagitais dos primeiros e dos segundos molares e dentes da unidade de ancoragem, que foi composta pelos primeiros e segundos pré-molares, caninos e incisivos centrais, com o emprego do aparelho Pendulum na distalização dos molares superiores.

Nos modelos foram demarcados dois pontos localizados nas extremidades laterais da terceira rugosidade do palato com uma lapiseira e grafite $0,3 \mathrm{~mm}$, objetivando facilitar a localização desses pontos nas imagens dos modelos obtidas nas fases avaliadas. Esse cuidado foi de fundamental importância, pois as linhas de referência horizontais empregadas nas mensurações deveriam passar por esses pontos.

Os modelos superiores foram adaptados com a sua vista oclusal apoiada e centralizada sobre a plataforma do Scanner e submetidas ao processo de captura da imagem, permitindo a fidelidade de $100 \%$ do tamanho real. Essas imagens foram submetidas aos processos de filtragem e melhoria de suas definições e posteriormente impressas em papel sulfite, figuras 66 e 67.

Para facilitar no processo de digitalização dos pontos cefalométricos e para a melhor padronização da técnica, nas imagens da vista oclusal dos modelos superiores foram traçadas linhas de referência horizontais e verticais pelos pontos de interesse. Os pontos se localizavam na intersecção dessas linhas. 


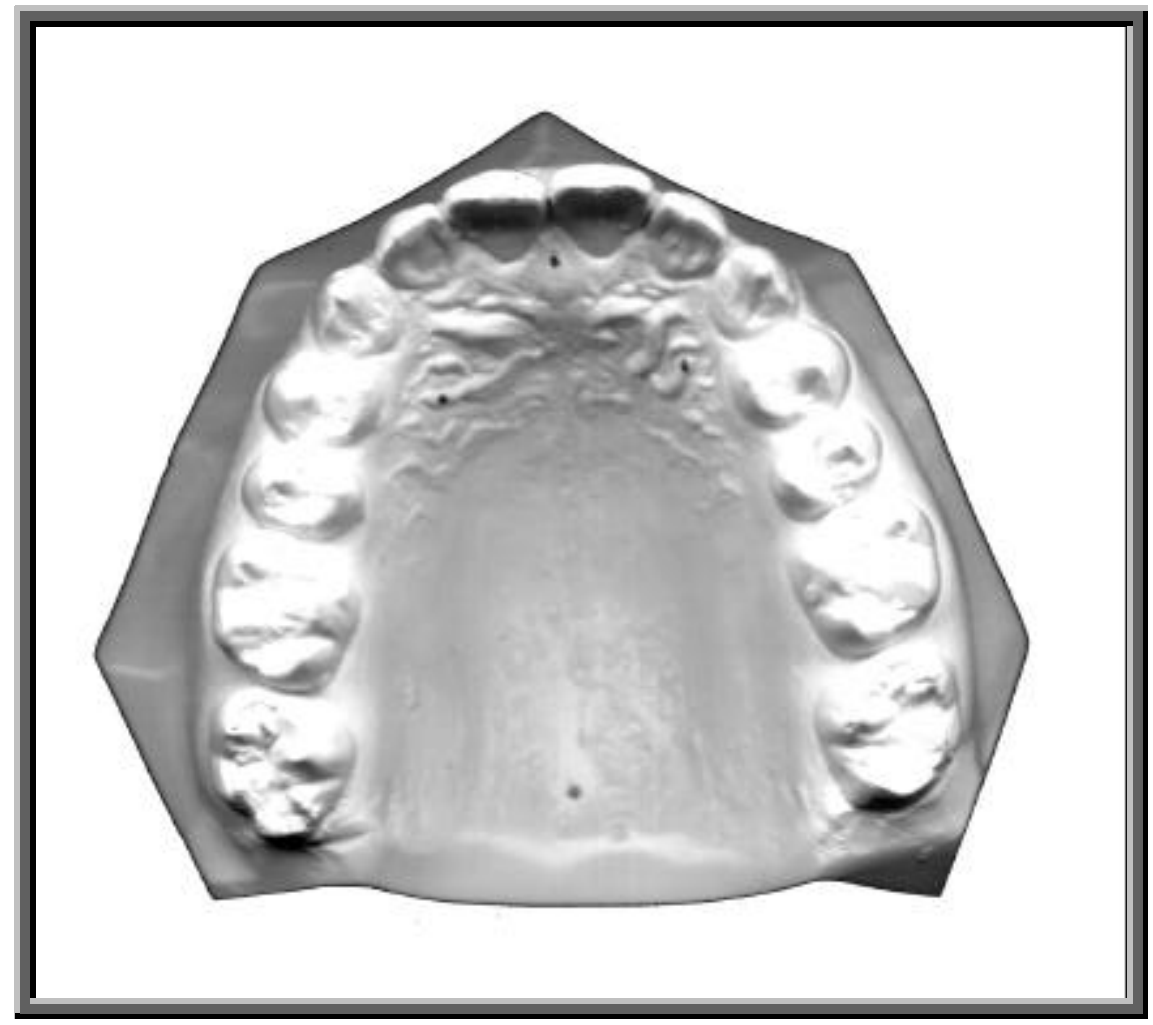

FIGURA 66 - Vista oclusal do modelo inicial

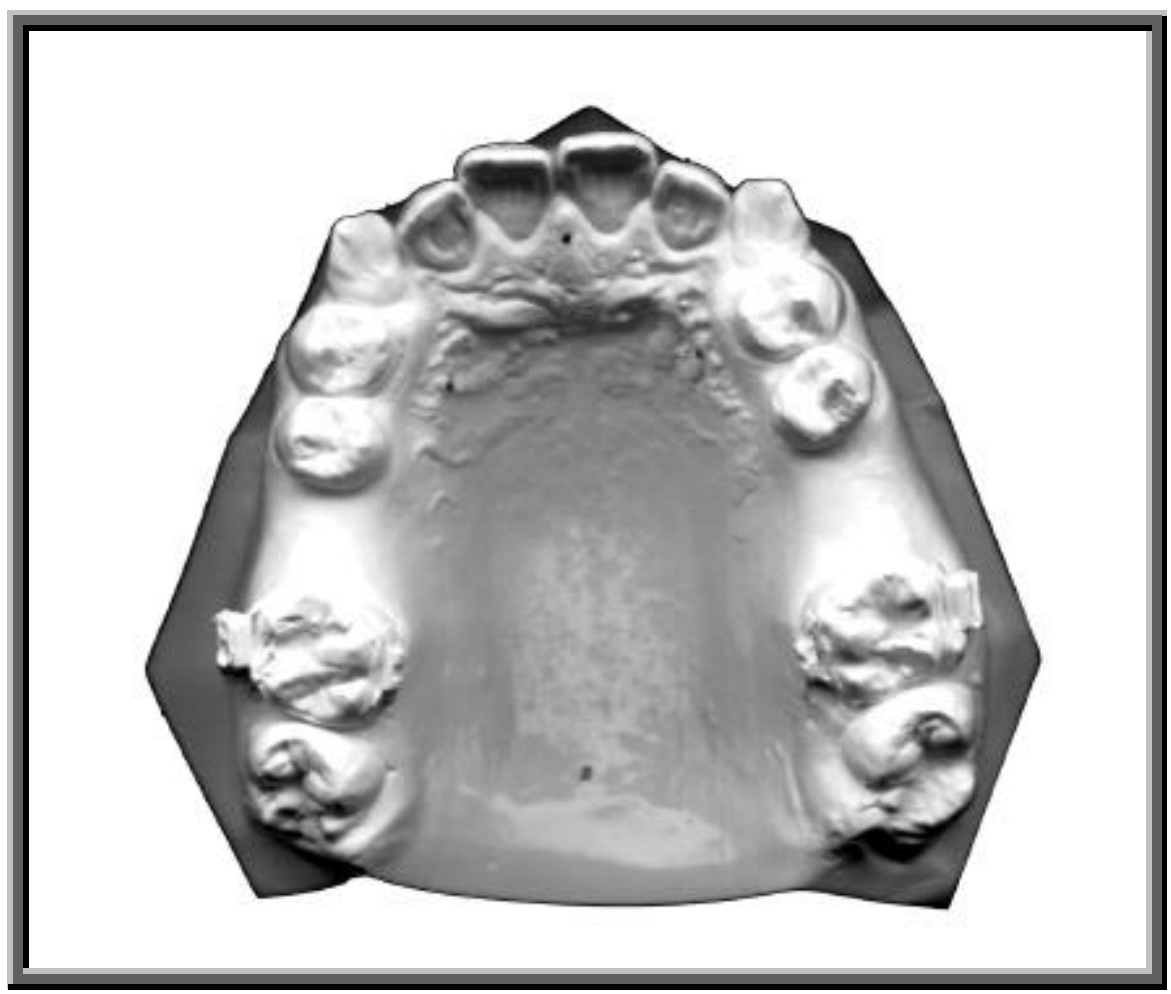

FIGURA 67 - Vista oclusal do modelo final 


\subsection{1 - Pontos cefalométricos (Figura 68)}

Nessas imagens impressas em papel foram definidos alguns pontos cefalométricos:

1- Ponto da $3^{\text {a }}$ rugosidade palatina direita - ponto localizado na extremidade da $3^{a}$ rugosidade palatina do lado direito;

2- Ponto da $3^{\text {a }}$ rugosidade palatina esquerda - ponto localizado na extremidade da $3^{\text {a }}$ rugosidade palatina do lado esquerdo;

3- Ponto da papila palatina - ponto localizado na papila palatina;

4- Ponto posterior do palato - ponto situado na parte posterior do palato, na região dos segundos molares;

5- Ponto do incisivo central superior - ponto situado na face vestibular do incisivo central superior;

6- Ponto mesial do canino superior - ponto situado na mesial do canino superior;

7- Ponto vestibular do canino superior - ponto localizado na face vestibular do canino superior;

8- Ponto mesial do primeiro pré-molar superior - ponto situado na mesial do primeiro pré-molar superior;

9- Ponto do sulco central do primeiro pré-molar superior - ponto situado no sulco central do primeiro pré-molar superior;

10- Ponto mesial do segundo pré-molar superior - ponto localizado na mesial do segundo pré-molar superior;

11- Ponto do sulco central do segundo pré-molar superior - ponto localizado no sulco central do segundo pré-molar superior;

12- Ponto mesial do primeiro molar superior - ponto localizado na mesial do primeiro molar superior; 
13- Ponto do sulco central do primeiro molar superior - ponto localizado no sulco central do primeiro molar superior;

14- Ponto mesial do segundo molar superior - ponto situado na mesial do segundo molar superior e

15- Ponto do sulco central do segundo molar superior - ponto situado no sulco central do segundo molar superior.

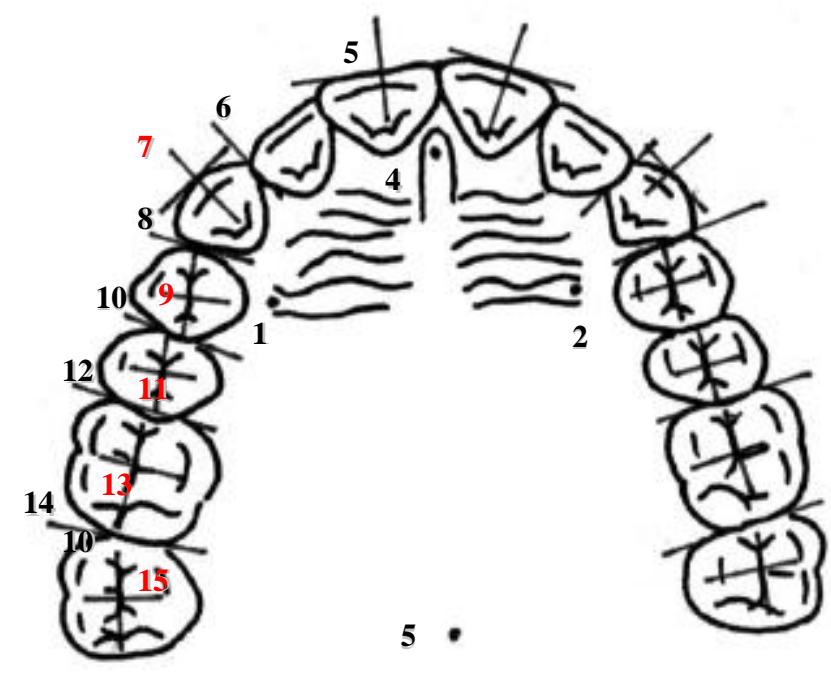

1-Ponto da $3^{\text {a }}$ rugosidade do palato do lado direito, 2- Ponto da $3^{\text {a }}$ rugosidade do palato do lado esquerdo, 3- Ponto da papila palatina, 4- Ponto posterior do palato, 5- Ponto do incisivo central superior, 6- Ponto mesial do canino, 7- Ponto vestibular do canino, 8Ponto mesial do primeiro pré-molar superior, 9- Ponto do sulco central do primeiro pré-molar superior, 10- Ponto mesial do segundo pré-molar superior, 11- Ponto do sulco central do segundo pré-molar superior, 12- Ponto mesial do primeiro molar superior, 13- Ponto do sulco central do primeiro molar superior, 14- Ponto mesial do segundo molar superior e 15- Ponto do sulco central do segundo molar superior.

FIGURA 68 - Representação esquemática da localização dos pontos cefalométricos 
Os pontos dentários são bilaterais e para a demarcação dos pontos homólogos do lado esquerdo, repete-se os procedimentos e as determinações de definição dos pontos cefalométricos estabelecidos para o lado direito.

\subsubsection{Linhas de referência (Figura 69)}

1- Linha de referência horizontal - essa linha foi traçada passando-se pelas extremidades laterais da $3^{\text {a }}$ rugosidade do palato e foi utilizada para a análise das alterações dentárias ântero-posteriores;

2- Linha de referência vertical - linha desenhada passando-se pelo ponto da papila palatina e pelo ponto posterior; foi empregada para a avaliação das alterações dentárias transversais;

3- Linha vertical oclusal do segundo molar superior - linha que se estende do ponto mesial do segundo molar superior até a linha de referência horizontal;

4- Linha horizontal oclusal do segundo molar superior - linha que se estende do ponto do sulco central do segundo molar superior até a linha de referência vertical;

5- Linha vertical oclusal do primeiro molar superior - linha que se estende do ponto mesial do primeiro molar superior até a linha de referência horizontal;

6- Linha horizontal oclusal do primeiro molar superior - linha que se prolonga do ponto do sulco central do primeiro molar superior até a linha de referência vertical;

7- Linha vertical oclusal do segundo pré-molar superior- linha que se prolonga do ponto mesial do segundo pré-molar superior até a linha de referência horizontal; 
8- Linha horizontal oclusal do segundo pré-molar superior- linha que se estende do sulco central do segundo pré-molar superior até a linha de referência vertical;

9- Linha vertical oclusal do primeiro pré-molar superior - linha que se prolonga do ponto mesial do primeiro pré-molar superior até a linha de referência horizontal;

10- Linha horizontal oclusal do primeiro pré-molar superior - linha que se estende do sulco central do primeiro pré-molar superior até a linha de referência vertical;

11- Linha vertical da cúspide do canino superior - linha que se prolonga da cúspide do canino superior até a linha de referência horizontal;

12- Linha horizontal da cúspide do canino superior - linha horizontal que se estende da cúspide do canino superior até a linha de referência vertical e

13- Linha vertical do incisivo central superior - linha que se estende da vestibular do incisivo central superior até a linha de referência horizontal.

Para os dentes homólogos foram determinadas as linhas de referência horizontal e vertical, seguindo-se o mesmo princípio de construção. 


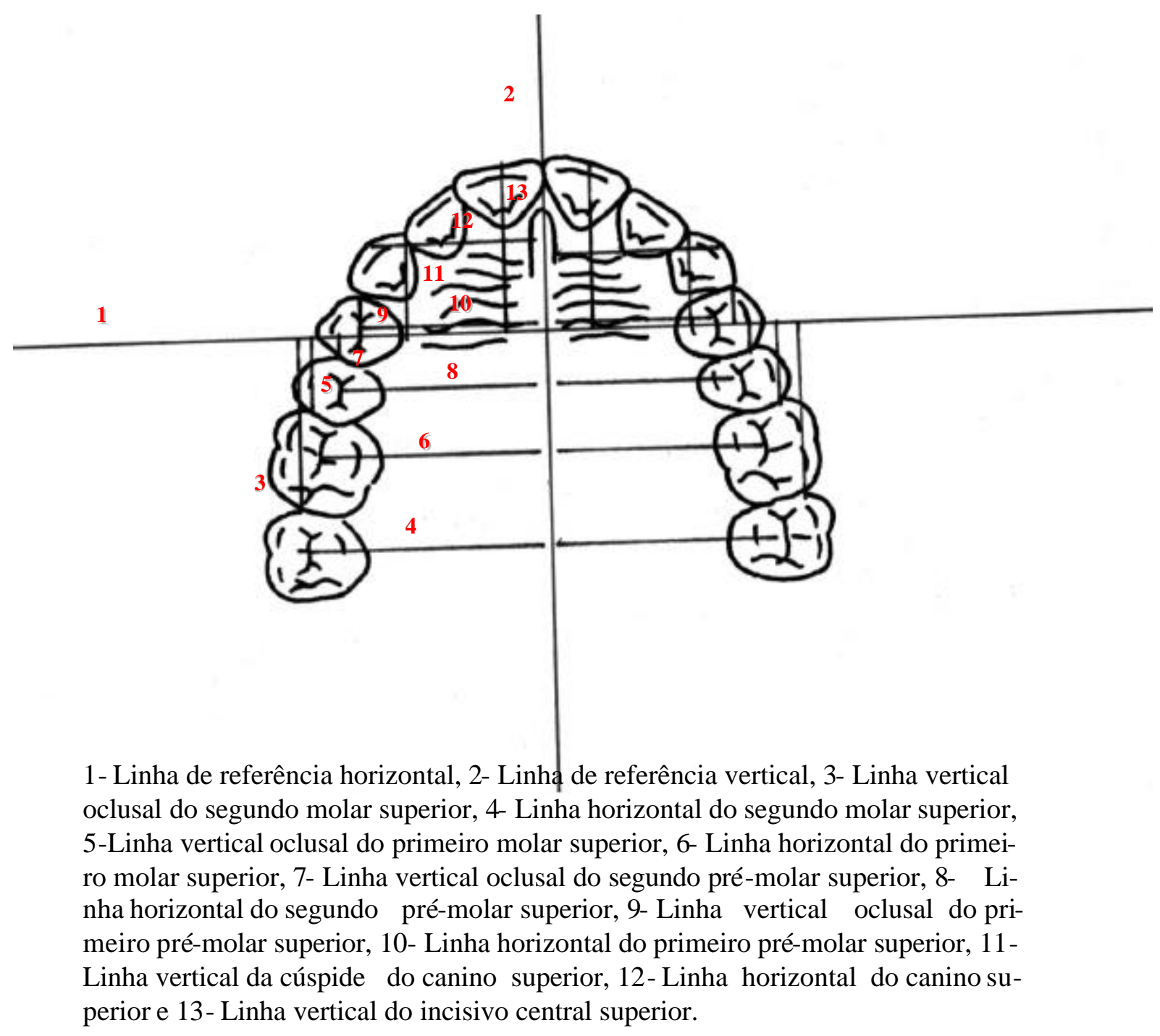

FIGURA 69 - Linhas de referência

\subsubsection{Obtenção das medidas cefalométricas}

O programa Dentofacial Planner Plus 4.0 foi adaptado para permitir as digitalizações e a leitura dos pontos referenciais acima mencionados. Esse programa construiu as coordenadas X e X', direcionadas pela linha de referência horizontal e Y e Y' pela linha vertical e calculou todas as distâncias dos pontos, perpendicularmente a essas linhas de orientação estabelecidas. 
Considerando-se a linha de referência horizontal, obtiveram-se as alterações ântero-posteriores, distribuídas nos quadrantes direito e esquerdo do arco dentário superior. Essas distâncias foram medidas perpendicularmente do ponto de referência dentário à linha de referência horizontal, sendo as seguintes (Figura 70):

1- Distal. 11- distância do ponto vestibular do incisivo central direito à linha de referência horizontal;

2- Distal. 13 - distância do ponto mesial do canino direito à linha de referência horizontal;

3- Distal. 14 - distância do ponto mesial do primeiro pré-molar direito à linha de referência horizontal;

4- Distal. 15 - distância do ponto mesial do segundo pré-molar direito à linha de referência horizontal;

5- Distal. 16 - distância do ponto mesial do primeiro molar direito à linha de referência horizontal;

6- Distal. 17 - distância do ponto mesial do segundo molar direito à linha de referência horizontal;

7- Distal. 21 - distância do ponto vestibular do incisivo central superior esquerdo à linha de referência horizontal;

8- Distal. 23 - distância do ponto mesial do canino à linha de referência horizontal;

9- Distal. 24 - distância do ponto mesial do primeiro pré-molar esquerdo à linha de referência horizontal;

10- Distal. 25 - distância do ponto mesial do segundo pré-molar esquerdo à linha de referência horizontal;

11- Distal. 26 - distância do ponto mesial do primeiro molar esquerdo à linha de referência horizontal; 
12- Distal. 27 - distância do ponto mesial do segundo molar à linha de referência horizontal.

As distâncias ântero-posteriores dos segundos pré-molares, primeiros e segundos molares foram expressas com sinal negativo, pois localizam-se no quadrante inferior da coordenada X X' e, portanto, considerouse apenas o valor numérico.

Empregando-se a linha de referência vertical obtiveram-se as medidas das alterações transversais dos molares e dentes da unidade de ancoragem diante da distalização dos molares superiores. Essas distâncias foram avaliadas perpendicularmente do ponto dentário a essa linha de referência, sendo as seguintes medidas (Figura 71):

1- Expans. 13 - distância do ponto vestibular do canino direito à linha de referência vertical;

2- Expans. 14 - distância do ponto do sulco central do primeiro prémolar direito à linha de referência vertical;

3- Expans. 15 - distância do ponto do sulco central do segundo prémolar direito à linha de referência vertical;

4- Expans. 16 - distância do ponto do sulco central do primeiro molar direito à linha de referência vertical;

5- Expans. 17 - distância do ponto do sulco central do segundo molar direito à linha de referência vertical;

6- Expans. 23 - distância do ponto vestibular do canino esquerdo à linha de referência vertical;

7- Expans. 24 - distância do ponto do sulco central do primeiro prémolar esquerdo à linha de referência vertical;

8- Expans. 25 - distância do ponto do sulco central do segundo prémolar esquerdo à linha de referência vertical; 
9- Expans. 26 - distância do ponto do sulco central do primeiro molar esquerdo à linha de referência vertical e

10- Expans. 27 - distância do ponto do sulco central do segundo molar esquerdo à linha de referência vertical.

As medidas do quadrante superior direito foram expressas com sinal negativo, pois localizam-se no lado esquerdo da coordenada YY' e consideraram-se apenas os seus valores numéricos.

Os valores obtidos foram dispostos em quadros do programa Excel e encaminhados para a análise estatística.

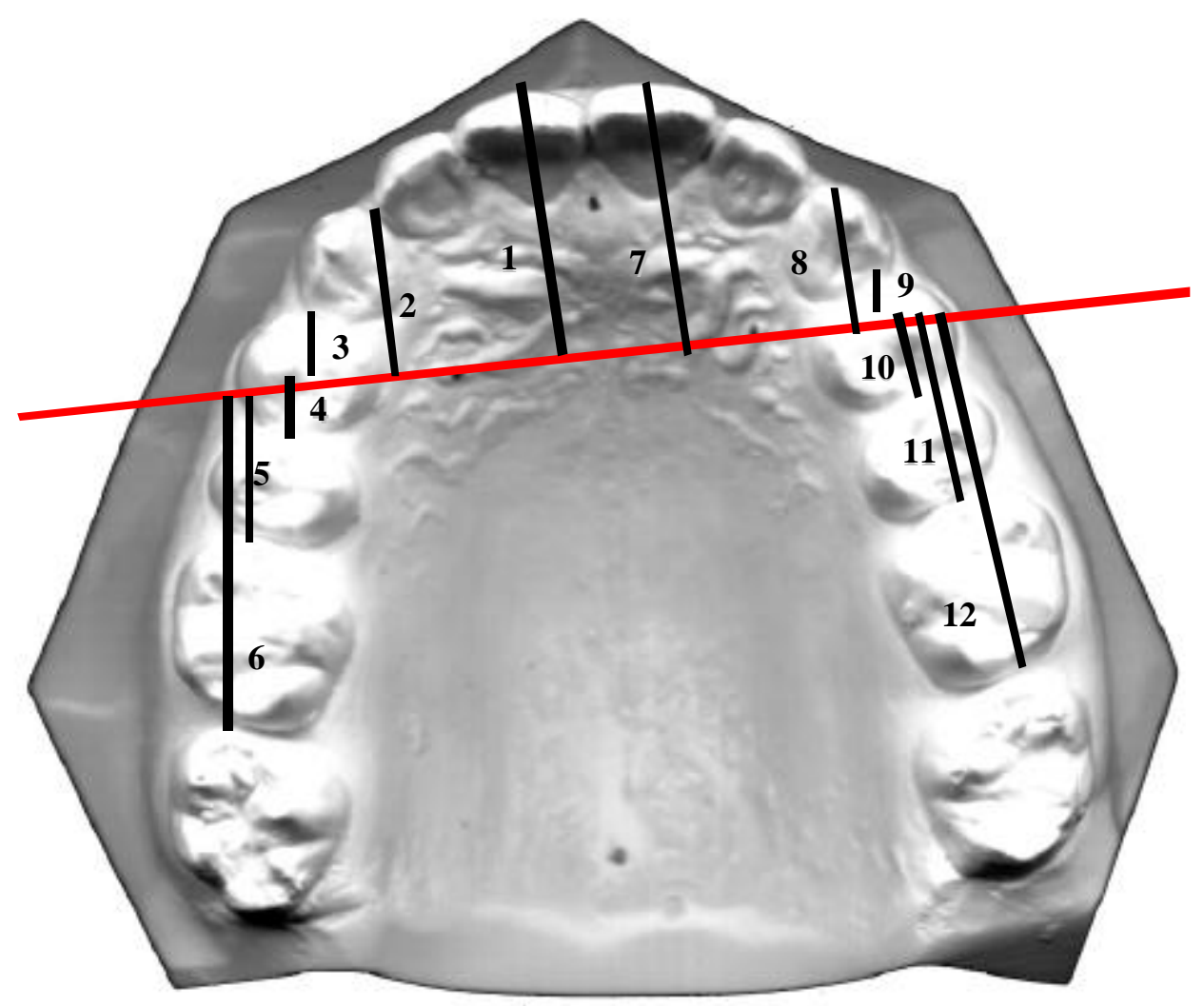

1- Distal-11; 2- Distal-13; 3- Distal-14; 4- Distal-15; 5- Distal-16; 6- Distal-17; 7- Distal-21;

8- Distal-23; 9- Distal-24; 10- Distal-25; 11- Distal-26 e 12- Distal-27

FIGURA 70- Medidas das alterações ântero-posteriores 


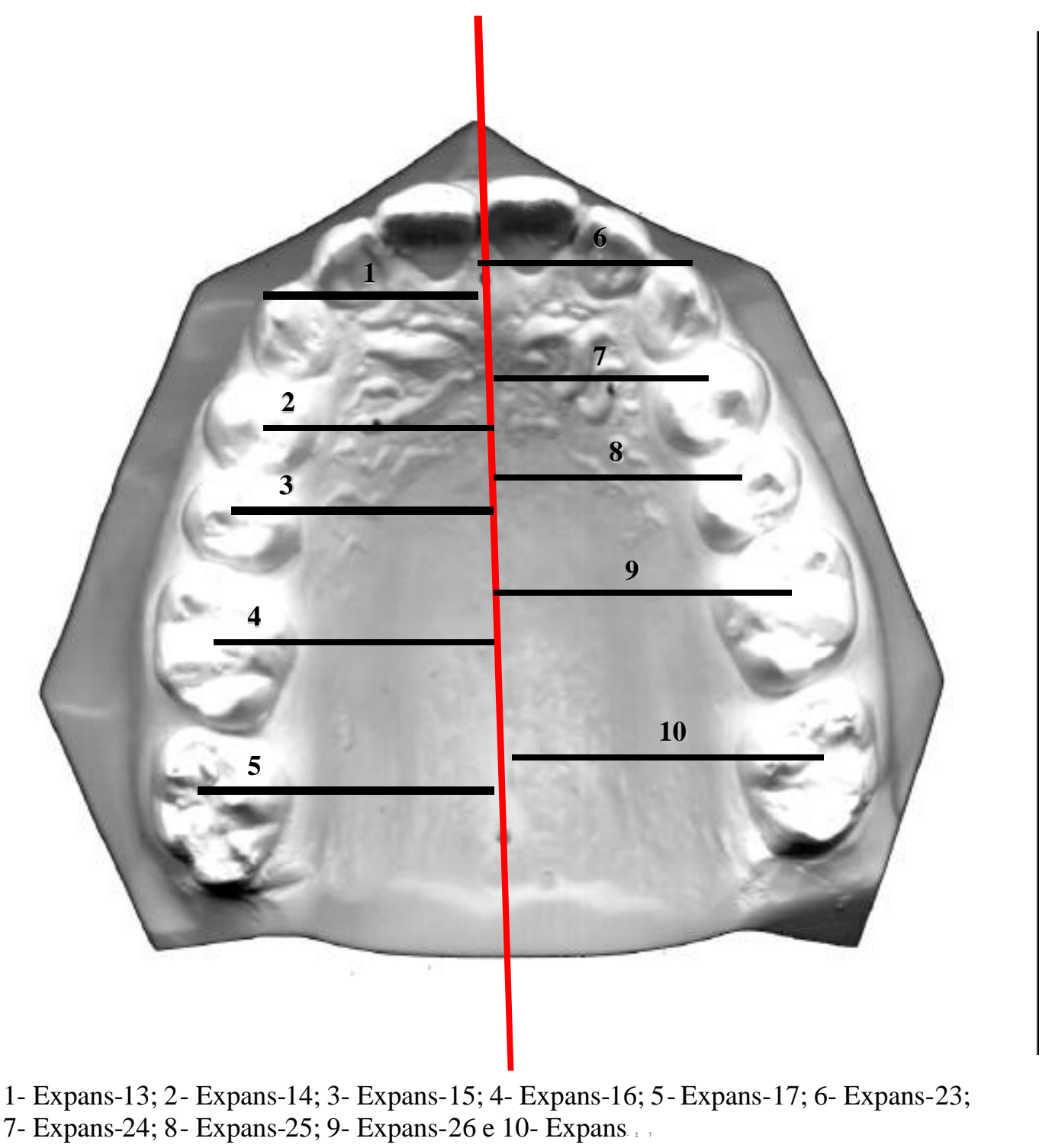

FIGURA 71- Medidas das alterações transversais

\subsection{CONTROLE DE ERRO}

Como forma de padronização, a seleção dos pacientes foi executada com o rigor de se obedecer ao critério estabelecido nessa pesquisa, ou seja, eles deveriam apresentar as mesmas características das más oclusões.

Após a definição do grupo de pacientes, as telerradiografias foram obtidas sempre pelo mesmo operador, no Centro de Diagnóstico Bucal de 
Bauru, na Clínica de Radiologia do Hospital de Reabilitação de Anomalias Craniofaciais da Universidade de São Paulo e na Clínica de Ortodontia.

A fase de execução dos tratamentos ortodônticos foi realizada pelo mesmo operador com o objetivo de se padronizar a construção e a ativação do aparelho Pendulum. Durante a fase experimental, todos os pacientes foram avaliados mensalmente para se verificar a magnitude da força distalizadora remanescente, conferindo-se se a mola permanecia com a morfologia de ativação inicial, paralela à linha média do palato e, mesmo, observar se havia ocorrido algum acidente de quebra do aparelho que poderia comprometer os resultados finais da pesquisa.

Na elaboração dos cefalogramas, os traçados foram realizados sempre pelo mesmo operador, empregando-se uma lapiseira com grafite preto $0,3 \mathrm{~mm}$, que permitia a definição de contornos mais precisos. Foi utilizado também o recurso da sala obscurecida, para melhor visualização das estruturas de interesse.

Para a obtenção de valores mais fiéis, durante os procedimentos de digitalização, a mesa digitalizadora foi calibrada previamente.

A validade e a precisão do processo de mensuração foram examinadas mediante a repetição de $30 \%$ da amostra do estudo para cada uma das análises empregadas na pesquisa (telerradiografias em norma lateral convencional e de $45^{\circ}$ e modelos de estudo). Dessa forma obtiveram-se dois conjuntos de medidas, a primeira contendo os valores da amostra total e a segunda com as medidas de apenas $30 \%$ da amostra e que foram comparadas estatisticamente para a verificação da presença de diferenças significantes ou não.

\subsection{ANÁLISE ESTATÍSTICA}

A análise estatística foi realizada empregando-se o "Software Statistica", v 5.0 e foi dividida em duas etapas: na primeira procurou-se observar 
a existência ou não de diferenças entre as mensurações quando realizadas em ocasiões diferentes, e na segunda verificar o efeito da distalização nos dentes da unidade receptora da força e na unidade de ancoragem por meio da comparação dos valores iniciais e finais.

Inicialmente, os valores obtidos nas mensurações dos dois conjuntos independentes: o primeiro representa a amostra total, da qual foram selecionadas apenas as medidas dos 10 pacientes que foram escolhidos aleatoriamente para a obtenção de novos traçados e o segundo, composto das medidas de $30 \%$ da amostra, obtidas por meio de novos cefalogramas e denominado de remedição. Os valores desses dois conjuntos de medidas foram submetidos ao teste estatístico não paramétrico de Kruskal-Wallis.

Essa análise é útil quando se deseja avaliar se amostras independentes são diferentes e, portanto avaliaram-se dessa forma a validade e precisão do processo de mensuração das variáveis nas fases inicial e final. Essa análise foi aplicada para cada um dos métodos de medição: telerradiografias em norma lateral convencional, de $45^{\circ}$ e modelos de estudo.

Na segunda etapa, foi realizada uma análise intragrupo das diferenças entre as médias iniciais e finais das grandezas cefalométricas e das medições nos modelos de estudo pelo teste de Wilcoxon para dados pareados. Essa análise é poderosa para definir se duas medidas pareadas são diferentes ou uma melhor do que a outra.

Os dados obtidos em todas as medidas cefalométricas para as fases inicial e final do experimento foram computados para a verificação da hipótese nula de que os efeitos do aparelho nas fases avaliadas eram semelhantes.

O valor crítico foi construído ao nível de significância de 5\% e 1\% para todas as análises empregadas. 
RESULTADOS 


\section{5- RESULTADOS}

Os resultados avaliados compreenderam as diferenças das médias iniciais e finais do experimento. Avaliaram-se os efeitos da distalização com o aparelho Pendulum sobre os molares superiores e a ação recíproca sobre a unidade de ancoragem composta pelos pré-molares, caninos e incisivos centrais.

Para uma melhor compreensão dividiu-se o capítulo em:

\section{1 - Análise de erro:}

5.1.1- Análise de erro para a telerradiografia lateral convencional;

5.1.2- Análise de erro para a telerradiografia lateral de $45^{\circ}$;

5.1.3- Análise de erro para a avaliação dos modelos de estudo;

\section{2 - Análise dos efeitos da distalização:}

5.2.1- Análise da telerradiografia em normal lateral convencional;

5.2.2- Análise da telerradiografia em norma lateral de $45^{\circ}$;

5.2.3- Análise de modelos de estudo;

5.3 - Porcentagem de abertura atribuída ao movimento dos prémolares e molares e

\section{4 - Taxa de distalização mensal}

Na seção 5.1, fez-se uma análise do erro sistemático e aleatório, onde se discutiu o processo de mensuração das variáveis, comparando as medidas obtidas nos dois conjuntos de valores cefalométricos e dos modelos de estudo (Tabelas 1 a 4). Na secção 5.2, descrevem-se os efeitos da distalização sobre os molares e a unidade de ancoragem (Tabelas 5 a 8). Os resultados estatísticos são apresentados considerando os níveis de significância de 5 e $1 \%$.

Para a análise dos efeitos da distalização, empregando-se as telerradiografias em norma lateral convencional e de $45^{\circ}$ e modelos de estudo, foram utilizados os dados iniciais e finais de 31 pacientes. 
Foram realizadas medições da abertura de espaço diretamente nos modelos de estudo finais usando-se um paquímetro da marca Dentaurum, modelo 042-751 com precisão de $0,1 \mathrm{~mm}$. Os valores obtidos foram combinados aos dados da análise oclusal para se calcular a porcentagem de abertura atribuída ao movimento mesial dos pré-molares e ao movimento distal dos molares superiores. Essas informações estão contidas na Tabela 9 presentes na secção 5.3 e são referentes aos lados direito e esquerdo.

Finalmente, na seção 5.4, considerando-se as medidas de abertura de espaço entre o primeiro molar e o segundo pré-molar nos lados direito e esquerdo e o tempo total médio de distalização, foram apresentadas as taxas mensais de distalização.

Os valores individuais, de cada paciente, referentes às grandezas cefalométricas e das medições dos modelos de estudo encontram-se dispostos nas tabelas do apêndice.

\subsection{Análise dos erros}

Nessa seção, estudaram-se as diferenças entre as mensurações obtidas em dois conjuntos diferentes de cefalogramas dos mesmos pacientes e realizados em intervalos de tempo de 15 dias entre o primeiro conjunto e o segundo. Assim, a principal questão da análise de erros é verificar para quais variáveis houve diferenças significativas entre as medidas alcançadas a partir de cefalogramas diferentes. As análises foram feitas considerando-se as medições inicial e final separadamente.

Do total de 29 variáveis na análise da telerradiografia lateral convencional, de 10 variáveis na análise da telerradiografia lateral de $45^{\circ}$ e de 22 variáveis na análise oclusal, não foi constatada diferença significativa pelo teste não paramétrico de Kruskal-Wallis para quaisquer diferenças entre as 
mensurações dos 10 pacientes, tanto para a fase inicial e como para a final do experimento (Tabelas 1 a 4 ).

\subsubsection{Análise de erro para a telerradiografia lateral convencional}

Para garantir a precisão das medidas, ou seja, do instrumento de mensuração, foi feita uma amostragem com 10 pacientes selecionados aleatoriamente da amostra total com os seus respectivos valores cefalométricos. Para esses 10 pacientes foram traçados novos cefalogramas e realizada a remedição. Para avaliar essa precisão, foi utilizado o teste de Kruskal-Wallis, considerando esses dois grupos: grupo 1, valores para os 10 pacientes da amostra total e grupo 2, a remedição. As análises foram feitas envolvendo as fases inicial e final, separadamente. Os resultados constam da tabela 1. 
Tabela 1. Resultado do teste de Kruskal-Wallis para análise das medidas da amostra total versus remedição para as fases inicial e final em 10 pacientes.

\begin{tabular}{|c|c|c|c|c|}
\hline \multirow[b]{2}{*}{ Variáveis } & \multicolumn{2}{|c|}{$\begin{array}{c}\text { Erro } x \text { remedição - } \\
\text { Inicial }\end{array}$} & \multicolumn{2}{|c|}{$\begin{array}{c}\text { Erro } x \text { remedição- } \\
\text { Final }\end{array}$} \\
\hline & $\boldsymbol{H}$ & $\boldsymbol{P}$ & $\boldsymbol{H}$ & $\boldsymbol{P}$ \\
\hline SNA & 0,0128 & $0,9097(\mathrm{NS})$ & 0,2416 & $0,6230(\mathrm{NS})$ \\
\hline SNB & 0,0915 & $0,7622(\mathrm{NS})$ & 0,3219 & $0,5705(\mathrm{NS})$ \\
\hline$\overline{\mathrm{SND}}$ & 0,0128 & $0,9096(\mathrm{NS})$ & 0,5161 & $0,4725(\mathrm{NS})$ \\
\hline A-NPerp & 0,0514 & $0,8026(\mathrm{NS})$ & 0,0014 & $0,9698(\mathrm{NS})$ \\
\hline Pg-NPerp & 0,3662 & $0,5451(\mathrm{NS})$ & 0,0057 & $0,9397(\mathrm{NS})$ \\
\hline ANB & 0,0000 & $1,0000(\mathrm{NS})$ & 0,0702 & $0,7910(\mathrm{NS})$ \\
\hline AFAI & 0,1735 & $0,6770(\mathrm{NS})$ & 0,0057 & $0,9397(\mathrm{NS})$ \\
\hline$\overline{\text { SN.GOGN }}$ & 0,2060 & $0,6499(\mathrm{NS})$ & 0,1158 & $0,7336(\mathrm{NS})$ \\
\hline FMA & 0,1428 & $0,7055(\mathrm{NS})$ & 0,0128 & $0,9097(\mathrm{NS})$ \\
\hline FRANK.Ocl & 0,2808 & $0,5962(\mathrm{NS})$ & 0,4628 & $0,4960(\mathrm{NS})$ \\
\hline FRANK.Pal. & 0,0000 & $1,0000(\mathrm{NS})$ & 0,0014 & $0,9697(\mathrm{NS})$ \\
\hline FRANK.GOGn & 0,2802 & $0,5966(\mathrm{NS})$ & 0,0057 & $0,9397(\mathrm{NS})$ \\
\hline SN.PlOCL & 0,2800 & $0,5967(\mathrm{NS})$ & 0,1729 & $0,6775(\mathrm{NS})$ \\
\hline SN.GN & 0,0917 & $0,7620(\mathrm{NS})$ & 0,1729 & $0,6775(\mathrm{NS})$ \\
\hline 1.NA & 0,1729 & $0,6775(\mathrm{NS})$ & 0,1159 & $0,7334(\mathrm{NS})$ \\
\hline $1-\mathrm{NA}$ & 0,0128 & $0,9097(\mathrm{NS})$ & 0,0057 & $0,9397(\mathrm{NS})$ \\
\hline $1-\mathrm{AV}$ & 0,0129 & 0,9095 (NS) & 0,0000 & $1,0000(\mathrm{NS})$ \\
\hline FRANK.4 & 0,0700 & $0,7913(\mathrm{NS})$ & 0,0000 & $1,0000(\mathrm{NS})$ \\
\hline FRANK.6 & 0,2058 & $0,6500(\mathrm{NS})$ & 0,0357 & $0,8500(\mathrm{NS})$ \\
\hline 1-PTV & 0,0014 & $0,9698(\mathrm{NS})$ & 0,2057 & $0,6502(\mathrm{NS})$ \\
\hline 4-PTV & 0,0000 & $1,0000(\mathrm{NS})$ & 0,0057 & $0,9397(\mathrm{NS})$ \\
\hline 6-PTV & 0,1158 & 0,7335 (NS) & 0,0057 & 0,9397 (NS) \\
\hline SOBREMORDIDA & 0,2068 & $0,6493(\mathrm{NS})$ & 0,0057 & $0,9397(\mathrm{NS})$ \\
\hline SOBRESSAL. & 0,0358 & $0,8498(\mathrm{NS})$ & 0,2066 & $0,6494(\mathrm{NS})$ \\
\hline LABIOSUP-E & 0,0014 & $0,9698(\mathrm{NS})$ & 0,0014 & $0,8798(\mathrm{NS})$ \\
\hline 1.1 & 0,0014 & $0,9698(\mathrm{NS})$ & 0,0228 & $0,8798(\mathrm{NS})$ \\
\hline LABIOINF-E & 0,0014 & $0,9698(\mathrm{NS})$ & 0,0701 & $0,7912(\mathrm{NS})$ \\
\hline NASOLABIAL & 0,0357 & $0,8501(\mathrm{NS})$ & 0,3657 & $0,5454(\mathrm{NS})$ \\
\hline WITS & 0,0357 & $0,8580(\mathrm{NS})$ & 1,5592 & $0,2118(\mathrm{NS})$ \\
\hline
\end{tabular}


De acordo com o teste estatístico empregado, não se identificaram diferenças significantes a $5 \%$ e $1 \%$ para as 29 variáveis estudadas pela análise da telerradiografia lateral convencional para os 10 pacientes, avaliando-se as medições das fases inicial e final, separadamente.

\subsubsection{Análise de erro para a telerradiografia lateral de $\mathbf{4 5}^{\circ}$}

Da mesma forma que já feito anteriormente e para assegurar a precisão no processo de mensuração, foi feita uma amostragem com 10 pacientes, tendo dois conjuntos de medidas, o grupo 1, composto dos valores da mostra total para esses 10 pacientes e grupo 2, contendo as medidas obtidas a partir dos novos cefalogramas, para ambos os lados, direito e esquerdo. Para avaliar essa precisão foi aplicado o teste não paramétrico de Kruskal-Wallis, considerando-se os grupos 1 e 2. As medições foram feitas para os valores das fases inicial e final, isoladamente. Os resultados constam das Tabelas 2 e 3.

Tabela 2. Resultado do teste de Kruskal-Wallis para análise de erro, amostra total versus remedição para as fases inicial e final em 10 pacientes (lado direito)

\begin{tabular}{l|l|l|l|l|c}
\hline & \multicolumn{2}{|c|}{$\begin{array}{c}\text { Erro } x \text { Remedição - } \\
\text { Inicial }\end{array}$} & & \multicolumn{2}{c}{$\begin{array}{c}\text { Erro } x \text { Remedição - } \\
\text { Final }\end{array}$} \\
\hline \hline Variáveis & $\boldsymbol{H}$ & $\boldsymbol{p}$ & & $\boldsymbol{H}$ & $\boldsymbol{p}$ \\
\hline 1.PAL & 0,2808 & $0,5962(\mathrm{NS})$ & & 0,0514 & $0,8206(\mathrm{NS})$ \\
\hline 4.PAL & 0,4642 & $0,4956(\mathrm{NS})$ & & 0,0128 & $0,9097(\mathrm{NS})$ \\
\hline 5.PAL & 1,1208 & $0,2897(\mathrm{NS})$ & & 0,4131 & $0,5204(\mathrm{NS})$ \\
\hline 6.PAL & 0,0514 & $0,8206(\mathrm{NS})$ & & 0,4131 & $0,5204(\mathrm{NS})$ \\
\hline 7.PAL & 0,0228 & $0,8798(\mathrm{NS})$ & & 0,9657 & $0,3258(\mathrm{NS})$ \\
\hline 1_PAL & 0,0128 & $0,9097(\mathrm{NS})$ & & 0,0229 & $0,8797(\mathrm{NS})$ \\
\hline 4_PAL & 0,1735 & $0,6770(\mathrm{NS})$ & & 0,1430 & $0,7052(\mathrm{NS})$ \\
\hline 5_PAL & 0,3219 & $0,5705(\mathrm{NS})$ & & 0,2064 & $0,6495(\mathrm{NS})$ \\
\hline 6_PAL & 0,0228 & $0,8798(\mathrm{NS})$ & & 0,0515 & $0,8205(\mathrm{NS})$ \\
\hline 7_PAL & 0,0014 & $0,9698(\mathrm{NS})$ & & 0,0128 & $0,9096(\mathrm{NS})$ \\
\hline
\end{tabular}


O teste estatístico aplicado revelou que não houve diferenças estastiticamente significantes a $5 \%$ e $1 \%$ para as 10 variáveis empregadas na análise da telerradiografia em norma lateral de $45^{\circ}$, entre as medições do grupo 1 e 2, para o lado direito. Considerações foram feitas para as fases inicial e final, independentemente.

Tabela 3. Resultado do teste de Kruskal-Wallis para análise de erro, amostra total versus remedição para as fases inicial e final em 10 pacientes (lado esquerdo).

\begin{tabular}{|c|c|c|c|c|}
\hline \multirow[b]{2}{*}{ Variáveis } & \multicolumn{2}{|c|}{$\begin{array}{c}\text { Erro } x \text { Remedição- } \\
\text { Inicial }\end{array}$} & \multicolumn{2}{|c|}{$\begin{array}{c}\text { Erro } x \text { Remedição } \\
\text { Final }\end{array}$} \\
\hline & $\boldsymbol{H}$ & $\boldsymbol{P}$ & $\boldsymbol{H}$ & $p$ \\
\hline 1.PAL & 0,0357 & $0,8501(\mathrm{NS})$ & 0,0000 & $1,0000(\mathrm{NS})$ \\
\hline 4.PAL & 0,2961 & $0,6498(\mathrm{NS})$ & 0,2802 & 0,5966 (NS) \\
\hline 5.PAL & 0,2804 & 0,5964 (NS) & 0,0000 & $1,0000(\mathrm{NS})$ \\
\hline 6.PAL & 0,1428 & $0,7055(\mathrm{NS})$ & 0,0914 & $0,7624(\mathrm{NS})$ \\
\hline$\overline{7 . P A L}$ & 0,2800 & 0,5967 (NS) & 0,1428 & 0,7055 (NS) \\
\hline 1_PAL & 0,4628 & $0,4963(\mathrm{NS})$ & 0,0701 & $0,7912(\mathrm{NS})$ \\
\hline 4_PAL & 0,0014 & 0,9698 (NS) & 0,4628 & 0,4963 (NS) \\
\hline 5_PAL & 0,0128 & 0,9097 (NS) & 0,3657 & 0,5454 (NS) \\
\hline 6_PAL & 0,0014 & $0,9698(\mathrm{NS})$ & 0,0358 & $0,8498(\mathrm{NS})$ \\
\hline 7_PAL & 0,0357 & $0,8501(\mathrm{NS})$ & 0,0228 & $0,8797(\mathrm{NS})$ \\
\hline
\end{tabular}

Nota-se, novamente que, em ambos os lados, a comparação entre os dados para análise dos valores da amostra total e remedição, para os valores inicial e final não apresentaram qualquer diferença significativa a $5 \%$ e $1 \%$, para o quadrante esquerdo. 


\subsubsection{Análise de erro para a avaliação dos modelos de estudo}

Para garantir a precisão das medidas, foi feita uma amostragem com 10 pacientes com dois conjuntos de medidas, o grupo 1 com os valores da amostra total para os 10 pacientes e o grupo 2, com medidas oriundas das remedições dos modelos. Aplicou-se o teste de Kruskal-Wallis, comparando-se as medidas decorrentes dos grupos 1 e 2, para as fases inicial e final, separadamente. Os resultados constam da Tabela 4.

Tabela 4. Resultado do teste de Kruskal-Wallis para análise das medidas da amostra total versus remedição dos modelos de estudo para as fases inicial e final, em 10 pacientes.

\begin{tabular}{|c|c|c|c|c|}
\hline \multirow[b]{2}{*}{ Variáveis } & \multicolumn{2}{|c|}{ Erro x Remedição - Inicial } & \multicolumn{2}{|c|}{ Erro $x$ Remedição - Final } \\
\hline & $\boldsymbol{H}$ & $p$-valor & $\boldsymbol{H}$ & $p$-valor \\
\hline DIST11 & 0,4639 & $0,4958(\mathrm{NS})$ & 0,0228 & $0,8797(\mathrm{NS})$ \\
\hline DIST13 & 0,1158 & $0,7335(\mathrm{NS})$ & 0,0128 & $0,9097(\mathrm{NS})$ \\
\hline DIST14 & 0,2072 & $0,6478(\mathrm{NS})$ & 0,1158 & $0,7335(\mathrm{NS})$ \\
\hline DIST15 & 0,0057 & $0,9397(\mathrm{NS})$ & 0,1430 & $0,7052(\mathrm{NS})$ \\
\hline DIST16 & 0,0128 & $0,9097(\mathrm{NS})$ & 0,0922 & $0,7613(\mathrm{NS})$ \\
\hline DIST17 & 0,1158 & $0,7336(\mathrm{NS})$ & 0,0915 & $0,7622(\mathrm{NS})$ \\
\hline DIST21 & 0,3221 & $0,5703(\mathrm{NS})$ & 0,0128 & $0,9096(\mathrm{NS})$ \\
\hline DIST23 & 0,0014 & $0,9698(\mathrm{NS})$ & 0,0000 & $1,0000(\mathrm{NS})$ \\
\hline DIST24 & 0,0702 & $0,7910(\mathrm{NS})$ & 0,0515 & $0,8205(\mathrm{NS})$ \\
\hline DIST25 & 0,1159 & $0,7334(\mathrm{NS})$ & 0,0228 & $0,8797(\mathrm{NS})$ \\
\hline DIST26 & 0,0358 & $0,8499(\mathrm{NS})$ & 0,0701 & $0,7911(\mathrm{NS})$ \\
\hline DIST27 & 0,0514 & $0,8206(\mathrm{NS})$ & 0,1161 & $0,7332(\mathrm{NS})$ \\
\hline EXP13 & 0,6333 & $0,4261(\mathrm{NS})$ & 0,2061 & $0,6498(\mathrm{NS})$ \\
\hline EXP14 & 0,0223 & $0,8794(\mathrm{NS})$ & 0,0703 & $0,7908(\mathrm{NS})$ \\
\hline EXP15 & 0,0515 & $0,8205(\mathrm{NS})$ & 0,0057 & $0,9397(\mathrm{NS})$ \\
\hline EXP16 & 0,6333 & $0,4261(\mathrm{NS})$ & 0,2061 & $0,6479(\mathrm{NS})$ \\
\hline EXP17 & 0,0360 & $0,8493(\mathrm{NS})$ & 0,0057 & $0,9397(\mathrm{NS})$ \\
\hline EXP23 & 0,1439 & $0,7044(\mathrm{NS})$ & 0,0357 & $0,8501(\mathrm{NS})$ \\
\hline EXP24 & 0,0014 & $0,9698(\mathrm{NS})$ & 0,0229 & $0,8795(\mathrm{NS})$ \\
\hline EXP25 & 0,0057 & $0,9396(\mathrm{NS})$ & 0,1735 & $0,6770(\mathrm{NS})$ \\
\hline EXP26 & 0,0057 & $0,9396(\mathrm{NS})$ & 0,0917 & $0,7619(\mathrm{NS})$ \\
\hline EXP27 & 0,0129 & $0,9095(\mathrm{NS})$ & 0,0057 & 0,9397 (NS) \\
\hline
\end{tabular}


Como pode ser observado, não foram constatadas diferenças estatisticamente significantes a $5 \%$ e $1 \%$ para as 22 variáveis da análise oclusal entre as médias da amostra total e da remedição para os 10 pacientes, tanto para as fases inicial e como para a final do experimento.

\subsection{Análise dos efeitos da distalização}

As alterações esqueléticas e dentárias sagitais e verticais da distalização dos molares superiores com o aparelho Pendulum foram avaliadas por meio das análises das telerradiografias em norma lateral convencional e de $45^{\circ}$. As alterações sagitais e transversais foram avaliadas pela análise dos modelos de estudo. Para tanto, foram obtidas as grandezas cefalométricas e medições de modelos das fases inicial e final do experimento.

Essas medidas foram analisadas pelo Software Statistica, v. 5.0, utilizando-se o teste de Wilcoxon para dados pareados. Os resultados para os valores coletados dos pacientes encontram-se dispostos nas Tabelas 5 a 8 .

\subsubsection{Análise das telerradiografias em norma lateral convencional}

Os efeitos da distalização analisados pelas telerradiografias em norma lateral convencional estão dispostos na Tabela 5. 
Tabela 5. Resultado do teste de Wilcoxon para dados pareados referente à análise da telerradiografia em norma lateral convencional para 31 pacientes.

Teste de Wilcoxon para dados pareados Inicial e final

\begin{tabular}{l|l|l|l|l|l}
\hline \multicolumn{2}{l}{} & Valid & & \multicolumn{2}{l}{} \\
\hline & $\mathrm{N}$ & $\mathrm{T}$ & $\mathrm{Z}$ & $\mathrm{p}-$ level & \\
\hline SNA & 31 & 192 & 0,833018 & 0,404840916 & $(\mathrm{NS})$ \\
\hline SNB & 31 & 206 & 0,823055 & 0,410482943 & $(\mathrm{NS})$ \\
\hline SND & 31 & 226,5 & 0,12341 & 0,901783168 & $(\mathrm{NS})$ \\
\hline A-NPerp & 31 & 236 & 0,235159 & 0,814087212 & $(\mathrm{NS})$ \\
\hline Pg-NPerp & 31 & 136,5 & 2,384115 & 0,017126055 & \\
\hline ANB & 31 & 141 & 2,09683 & 0,036016423 & \\
\hline AFAI & 31 & 14 & 4,585591 & $4,54416 \mathrm{E}-06$ & \\
\hline SN.GoGn & 31 & 126 & 2,190528 & 0,028493136 & \\
\hline FMA & 31 & 95,5 & 3,150771 & 0,001629899 & \\
\hline Frank.Ocl & 31 & 198 & 0,709608 & 0,4779526 & \\
\hline Frank.Pal & 31 & 145,5 & 2,215824 & 0,026710536 & \\
\hline Frank.GoGn & 31 & 86 & 3,17464 & 0,001501645 & \\
\hline SN.PlOcl & 31 & 247 & 0,019597 & 0,984365344 & $(\mathrm{NS})$ \\
\hline SN.Gn & 31 & 123,5 & 2,43977 & 0,014702016 & \\
\hline 1.NA & 31 & 39 & 4,207262 & $2,59187 \mathrm{E}-05$ & \\
\hline 1-NA & 31 & 41,5 & 3,928553 & $8,56379 \mathrm{E}-05$ & \\
\hline 1-AV & 31 & 31,5 & 4,134236 & $3,57044 \mathrm{E}-05$ & \\
\hline Frank.4 & 31 & 145,5 & 2,215824 & 0,026710536 & \\
\hline Frank.6 & 31 & 0 & 4,93652 & $7,99285 \mathrm{E}-07$ & \\
\hline 1-PTV & 31 & 59 & 3,833283 & 0,000126686 & \\
\hline 4-PTV & 31 & 2 & 4,899122 & $9,67355 \mathrm{E}-07$ & \\
\hline 6-PTV & 31 & 1 & 4,917821 & $8,79462 \mathrm{E}-07$ & \\
\hline Sobremordida & 31 & 38 & 4,22596 & $2,38583 \mathrm{E}-05$ & \\
\hline Sobressaliência & 31 & 5 & 4,843025 & $1,28474 \mathrm{E}-06$ & \\
\hline Labio Superior/E & 31 & 136,5 & 1,974561 & 0,048326612 & \\
\hline 1.1 & 31 & 35,5 & 4,164266 & $3,13174 \mathrm{E}-05$ & \\
\hline Lábio Inferior/E & 31 & 118,5 & 2,720696 & 0,006517988 & \\
\hline Angulo Nasolabial & 31 & 171,5 & 1,729652 & 0,083702087 & $(\mathrm{NS})$ \\
\hline Wits & 31 & 147,5 & 1,748309 & 0,080420136 & $(\mathrm{NS})$ \\
\hline \hline & & & & & \\
\hline
\end{tabular}


O teste de Wilcoxon para dados pareados demonstrou que do total de 29 variáveis, apenas 7 revelaram ser não significativas a $5 \%$ e $1 \%$ de probabilidade. Dessas, 5 são grandezas cefalométricas angulares e referem-se aos ângulos: SNA, SNB, SND, SN.PIOcl e ao ângulo nasolabial. As outras duas representam as seguintes grandezas cefalométricas lineares: A-NPerp e Wits.

O ângulo SNA sofreu a variação do valor médio inicial de $81,77^{\circ}$ para $81,9^{\circ}$ ao final do experimento e isso demonstrou que o posicionamento ânteroposterior da maxila não foi influenciado pela mecanoterapia. Essa informação também pode ser confirmada pela medida de A-NPerp, cuja variação ocorreu de um valor médio inicial de $0,29 \mathrm{~mm}$ para $0,23 \mathrm{~mm}$ na fase final.

A posição ântero-posterior da mandíbula permaneceu constante segundo as observações feitas por meio do ângulo SNB, cuja média inicial de $77,73^{\circ}$ alterou-se para $77,58^{\circ}$. Isso pode ser confirmado também pelo ângulo SND de $74,9^{\circ}$ que se manteve em $74,9^{\circ}$.

O ângulo SN.PIOcl. demonstrou que não houve a rotação mandibular como conseqüência da distalização dos molares superiores, pois a média inicial alterou-se de $13,66^{\circ}$ para a final de $13,62^{\circ}$.

A grandeza cefalométrica de Wits mostrou que não houve mudança na relação maxilomandibular, pois o valor médio inicial de $3,2 \mathrm{~mm}$ foi alterado para $3,85 \mathrm{~mm}$ ao final.

O teste de Wilcoxon para dados pareados revelou diferenças significantes para a grandeza linear de Pg-NPerp, cuja média inicial sofreu a variação de $-4,16 \mathrm{~mm}$ para $-5,34 \mathrm{~mm}$. Essa ocorrência pode estar associada às alterações verticais que são verificadas pela significância nas diferenças para as grandezas cefalométricas de AFAI, SN.GoGn, FMA, Frank. Ocl, Frank.Pal, Frank.GoGn, SN.PlOcl, SN.Gn que mostraram aumentos em seus valores quando comparados às fases inicial e final do experimento. 
As alterações dentárias podem ser visualizadas pela distalização dos molares superiores associada a inclinação distal das coroas em cada paciente (Tabelas 16 e 20). A distalização média e a inclinação distal da coroa foi de 4,60 $\mathrm{mm}$ e $18,5^{\circ}$, respectivamente, sendo alterações significantes.

Os primeiros pré-molares sofreram um movimento mesial médio de 2,66 mm associado à inclinação mesial da coroa de $2,51^{\circ}$, enquanto que os incisivos centrais protruíram em média $1,51 \mathrm{~mm}$, segundo a medida de 1-PTV e de 1,11 mm, considerando-se 1-NA, e de 1,08 mm pela medida de $1-A V$ e a inclinação vestibular foi de $3,40^{\circ}$. $\mathrm{O}$ aumento na inclinação vestibular do incisivo central superior produziu a alteração significativa no ângulo interincisivos de $123,83^{\circ}$ para $119,9^{\circ}$. Como reflexo da perda de ancoragem, houve o aumento na sobressaliência de $5,37 \mathrm{~mm}$ para $6,93 \mathrm{~mm}$ e uma redução na sobremordida de $5,18 \mathrm{~mm}$ para $4,15 \mathrm{~mm}$.

A perda de ancoragem acarretou uma pequena protrusão do lábio superior de 0,29 $\mathrm{mm}$ e o ângulo nasolabial não mostrou diferença estatisticamente significante. O lábio inferior sofreu uma modificação de 0,21 mm (Tabelas 16 e 20).

\subsubsection{Análise da telerradiografia em norma lateral de $45^{\circ}$}

As alterações dentárias sagitais e verticais decorrentes da distalização dos molares superiores foram analisadas por meio das telerradiografias em norma lateral de $45^{\circ}$, isoladamente para os lados direito e esquerdo. Aplicandose o teste de Wilcoxon para dados pareados, foram obtidos os resultados que podem ser vistos na Tabelas 6 e 7 . 
Tabela 6. Resultado do teste de Wilcoxon para dados pareados, referente à análise da telerradiografia em norma lateral de $45^{\circ}$ para 31 pacientes (lado direito).

\begin{tabular}{l|l|l|l|l|l}
\hline $\begin{array}{l}\text { Teste de Wilcoxon para valores da fase inicial } \\
\text { versus final para o quadrante direito }\end{array}$ \\
\begin{tabular}{l|l|l|l|l|l}
\hline & Valid & & & & \\
\hline Variáveis & $\mathrm{N}$ & $\mathrm{T}$ & $\mathrm{Z}$ & $\mathrm{p}-$ level & \\
\hline 1.Pal I X 1.Pal F & 31 & 27,5 & 4,216509 & $2,49 \mathrm{E}-05$ & \\
\hline 4.Pal I X 4.Pal F & 31 & 30,5 & 4,154805 & $3,26 \mathrm{E}-05$ & \\
\hline 5.Pal I X 5.Pal F & 31 & 124,5 & 2,420173 & 0,015519 & \\
\hline 6.Pal I X 6.Pal F & 31 & 7,5 & 4,712969 & $2,45 \mathrm{E}-06$ & \\
\hline 7.Pal I X 7.Pal F & 31 & 0 & 4,859943 & $1,18 \mathrm{E}-06$ & \\
\hline 1-Pal I X 1-Pal F & 31 & 108 & 2,367741 & 0,017903 & \\
\hline 4-Pal I X 4-Pal F & 31 & 100,5 & 2,89049 & 0,003849 & \\
\hline 5-Pal I X 5-Pal F & 31 & 93,5 & 3,027666 & 0,002466 & \\
\hline 6-Pal I X 6-Pal F & 31 & 216,5 & 0,617291 & 0,537047 & $(\mathrm{NS})$ \\
\hline 7-Pal I X 7-Pal F & 31 & 118 & 2,547551 & 0,010853 & \\
\hline \hline
\end{tabular}
\end{tabular}

O resultado do teste de Wilcoxon para dados pareados comprovou que os molares superiores sofreram inclinação distal significante comprovada pela alteração angular significativa na média inicial de $83,08^{\circ}$ para $90,36^{\circ}$ para os primeiros molares, e de $66,44^{\circ}$ para $52,41^{\circ}$ para os segundos molares, resultando na inclinação distal de $7,28^{\circ}$ e $14,03^{\circ}$, respectivamente.

A ação recíproca da força distalizadora do aparelho Pendulum proporcionou a inclinação mesial significativa dos primeiros e segundos prémolares, confirmada pela variação nas médias iniciais de $86,30^{\circ}$ e 81,52 para 90,36 e 83,94 e conseqüentemente inclinações de $4,06^{\circ}$ e de $2,42^{\circ}$. 
Os incisivos centrais superiores também apresentaram uma significante inclinação vestibular da coroa, verificada pela alteração angular de 107,44 para $111,04^{\circ}$, com a diferença de $3,60^{\circ}$.

As alterações verticais analisadas segundo a distância dos pontos de referência localizados nas coroas dos elementos dentários ao plano palatino demonstrou que os primeiros molares superiores sofreram extrusão, pois o valor médio da medida 6-Pal aumentou de 20,42 para 20,70 mm, com movimento de $0,28 \mathrm{~mm}$, porém considerado não significativo. Os segundos molares intruíram, tendo a média de 7-Pal diminuído de 16,65 para 15,48 mm, ou seja um movimento significativo de $1,17 \mathrm{~mm}$.

Os primeiros e segundos pré-molares extruíram 1,72 mm e 1,62mm, segundo as variações nas médias das variáveis 4-Pal e 5-Pal, de 23,35 para 25,07 $\mathrm{mm}$ e de 22,73 para $24,35 \mathrm{~mm}$.

Verificou-se também um aumento na medida de 1-Pal de 27,32 para 28,46 mm, ou seja, uma diferença de $1,14 \mathrm{~mm}$. 
Tabela 7. Resultado do teste de Wilcoxon para dados pareados, referente à análise da telerradiografia em norma lateral de $45^{\circ}$ para 31 pacientes (lado esquerdo).

\begin{tabular}{|c|c|c|c|c|c|}
\hline \multicolumn{6}{|c|}{$\begin{array}{l}\text { Teste de Wilcoxon para valores da fase inicial } \\
\text { versus final para o quadrante direito }\end{array}$} \\
\hline & Valid & & & & \\
\hline & $\mathrm{N}$ & $\mathrm{T}$ & $\mathrm{Z}$ & p-level & \\
\hline 1.Pal I X 1.Pal F & 31 & 20 & 4,468012 & 7,92E-06 & \\
\hline 4.Pal I X 4.Pal F & 31 & 215,5 & 0,636888 & 0,524203 & \\
\hline 5.Pal I X 5.Pal F & 31 & 206 & 0,823055 & 0,410483 & (NS) \\
\hline 6.Pal I X 6.Pal F & 31 & 0 & 4,859943 & $1,18 \mathrm{E}-06$ & \\
\hline 7.Pal I X 7.Pal F & 31 & 0 & 4,859943 & $1,18 \mathrm{E}-06$ & \\
\hline 1-Pal I X 1-Pal F & 31 & 166,5 & \begin{tabular}{|l|}
1,597118 \\
\end{tabular} & 0,110249 & (NS) \\
\hline 4-Pal I X 4- Pal F & 31 & 86 & 3,17464 & 0,001502 & \\
\hline 5-Pal I X 5-Pal F & 31 & 101 & 2,880692 & 0,003971 & \\
\hline 6-Pal I X 6-Pal F & 31 & 204 & 0,586198 & \begin{tabular}{|l|}
0,557747 \\
\end{tabular} & $(\mathrm{NS})$ \\
\hline 7-Pal I X 7-Pal F & 31 & 29,5 & 4,065162 & $4,81 \mathrm{E}-05$ & \\
\hline
\end{tabular}

Nesse caso, as variáveis 5.Pal, 1-Pal e 6-Pal revelaram ser não significativas, ou seja, o segundo pré-molar não apresentou uma alteração na sua inclinação, assim como as alterações verticais do incisivo central e primeiro molar superior esquerdo não demonstraram variações.

O primeiro e segundo molar superior tiveram suas inclinações médias alteradas de 80,98 para $67,01^{\circ}$ e de 67,61 para $49,18^{\circ}$, resultando na inclinação distal significativa de $13,97^{\circ}$ e de $18,43^{\circ}$, respectivamente. A alteração vertical foi significante no segundo molar, que sofreu um movimento intrusivo de $1,92 \mathrm{~mm}$, segundo a sua variação de 17,17 para $15,25 \mathrm{~mm}$. A alteração da posição vertical do primeiro molar de $21,14 \mathrm{~mm}$ para $20,74 \mathrm{~mm}$ não foi significativo. 
A ação recíproca afetou mais o primeiro pré-molar que sofreu a alteração na sua inclinação média inicial de $89,93^{\circ}$ para $90,26^{\circ}$, com a inclinação mesial resultante de $0,33^{\circ}$. O segundo pré-molar não experimentou uma variação significativa, evidenciado pela alteração na sua inclinação axial de $85,31^{\circ}$ para $84,62^{\circ}$. As alterações verticais demonstraram a ocorrência de extrusão de 1,47 mm (variação de 24,25 para 25,72 $\mathrm{mm}$ ) e de 1,35 mm (variação de 23,65 para 25,0 $\mathrm{mm}$ ) para o primeiro e segundo pré-molar, respectivamente. Essas alterações verticais dos pré-molares observadas foram significativas.

O incisivo central mostrou um aumento na sua inclinação média inicial de 106,58 para $111,1^{\circ}$, ou seja, uma inclinação vestibular de $4,52^{\circ}$, porém o movimento vertical de $0,45 \mathrm{~mm}$ não foi significante (alteração de $28,58 \mathrm{~mm}$ para $29,03 \mathrm{~mm})$.

\subsubsection{Análise dos modelos de estudo.}

A análise das alterações dentárias sagitais decorrentes da distalização dos molares superiores e a ação recíproca sobre a unidade de ancoragem foi avaliada por meio das variáveis 1 a 12, denominadas (Dist 11 a Dist 27), e as variações transversais a partir das variáveis 13 a 22, denominadas (Exp 13 a Exp 27) para os valores inicial e final. Uitlizou-se o teste de Wilcoxon para dados pareados, cujos resultados para os dados coletados para os 31 pacientes se encontram dispostos na Tabela 8.

O teste de Wilcoxon revelou a distalização significativa dos molares superiores, segundo as seguintes alterações das médias in iciais para as finais: 1) primeiro molar superior direito, de $-8,47$ para $-12,92 \mathrm{~mm}$, com movimento de $4,45 \mathrm{~mm}$; 2) primeiro molar superior esquerdo, de $-10,55$ para $-15,77 \mathrm{~mm}$, com movimento de $5,2 \mathrm{~mm}$; 3) segundo molar superior direito, de $-18,79$ para - 
23,,01 mm, com movimento de 4,22 $\mathrm{mm}$ e 4) segundo molar superior esquerdo, de $-20,97$ para $-26,25 \mathrm{~mm}$, com movimento resultante de 5,28 $\mathrm{mm}$.

A unidade de ancoragem composta dos caninos, pré-molares e incisivos centrais sofreram o movimento mesial significativo, segundo as variações nas médias iniciais e finais: 1) segundo pré-molar direito, de $-2,09$ para $-0,41 \mathrm{~mm}$, movimento de 1,68 $\mathrm{mm}$; 2) segundo pré-molar esquerdo, de 4,04 para $-2,75 \mathrm{~mm}$, movimento de $1,29 \mathrm{~mm}$; 3) primeiro pré-molar direito, de 4,29 para $6,36 \mathrm{~mm}$, movimento de $2,07 \mathrm{~mm}$; 4) primeiro pré-molar esquerdo, de 2,76 para 4,43 mm, movimento de 1,67 $\mathrm{mm}$; 5) canino direito, de 11,25 para $13,02 \mathrm{~mm}$, movimento de $1,77 \mathrm{~mm}$; 6)canino esquerdo, de 10,3 para 11,69 $\mathrm{mm}$, movimento de 1,39 mm e 7) incisivo central direito, de 18,15 para 18,52 $\mathrm{mm}$, movimento de 0,37 mm. Entretanto, a alteração sagital sofrida pelo incisivo central esquerdo, de 17,96 para 18,2 mm com o movimento resultante de 0,24 $\mathrm{mm}$, não foi significativo.

Das alterações transversais avaliadas, apenas os segundos molares sofreram uma expansão significativa, segundo as variações de suas médias iniciais para as finais, de $-25,47$ para $-27,14 \mathrm{~mm}$ e de $-25,22$ para $26,76 \mathrm{~mm}$, sendo as alterações de 1,67 e 1,54mm, respectivamente para o segundo molar direito e esquerdo. O primeiro molar esquerdo sofreu uma expansão, conforme a modificação do valor médio inicial de 22,93 para 24,44mm, sendo a diferença de $1,51 \mathrm{~mm}$, porém o primeiro molar direito permaneceu constante segundo a sua variação de $17,63 \mathrm{~mm}$ para $17,55 \mathrm{~mm}$.

As demais alterações transversais não foram significativas segundo as suas variações: 1) do canino direito de $17,63 \mathrm{~mm}$ para 17,55 , movimento de 0,08 $\mathrm{mm}$; 2) do canino esquerdo, de 17,75 $\mathrm{mm}$ para $17,63 \mathrm{~mm}$,movimento de 0,12 $\mathrm{mm}$; 3) primeiro pré-molar direito, de $17,76 \mathrm{~mm}$ para $17,87 \mathrm{~mm}$, movimento de $0,11 \mathrm{~mm}$; 4) primeiro pré-molar esquerdo, de $17,64 \mathrm{~mm}$ para 17,77 , movimento 
de $0,13 \mathrm{~mm}$; 5) segundo pré-molar direito, de 20,56 $\mathrm{mm}$ para 20,76 $\mathrm{mm}$, movimento de 0,20 $\mathrm{mm}$ e 6) segundo pré-molar esquerdo, de 20,49 $\mathrm{mm}$ para 20,62 mm, movimento de $0,13 \mathrm{~mm}$.

Em resumo, as variáveis Dist-21, Expans-13, Expans-14, Expans-15, Expans-16, Expans-23, Expans-24 e Expans-25 foram não significativas ao nível de $5 \%$ e $1 \%$ de probabilidade, ou seja, não existem diferenças entre as medidas inicial e final para essas variáveis.

Tabela 8. Resultado do teste de Wilcoxon para dados pareados, referente à análise oclusal de 31 pacientes.

\begin{tabular}{|c|c|c|c|c|c|c|}
\hline & & Valic & & & & \\
\hline Variáveis & & $\mathrm{N}$ & $\mathrm{T}$ & $\mathrm{Z}$ & p-level & \\
\hline 1 & DISTI11 \& DISTF11 & 31 & 107 & 2,581326 & 0,009847 & \\
\hline 2 & DISTI13 \& DISTF13 & 31 & 29 & 4,291643 & $1,78 \mathrm{E}-05$ & \\
\hline 3 & DISTI14 \& DISTF14 & 31 & 5 & 4,761961 & $1,93 \mathrm{E}-06$ & \\
\hline$\overline{4}$ & DISTI15 \& DISTF15 & 31 & 24 & 4,389626 & $1,14 \mathrm{E}-05$ & \\
\hline 5 & DISTI16 \& DISTF16 & 31 & 4 & 4,781557 & $1,75 \mathrm{E}-06$ & \\
\hline 6 & DISTI17 \& DISTF17 & 31 & 7 & 4,722767 & $2,34 \mathrm{E}-06$ & \\
\hline 7 & DISTI21 \& DISTF21 & 31 & 138 & 1,719044 & 0,085616 & (NS) \\
\hline 8 & DISTI23 \& DISTF23 & 31 & 64 & 3,605764 & 0,000312 & \\
\hline 9 & DISTI24 \& DISTF24 & 31 & 55 & 3,65088 & 0,000262 & \\
\hline 10 & DISTI25 \& DISTF25 & 31 & 57 & 3,609744 & 0,000307 & \\
\hline 11 & DISTI26 \& DISTF26 & 31 & 0 & 4,859943 & $1,18 \mathrm{E}-06$ & \\
\hline 12 & DISTI27 \& DISTF27 & 31 & 0 & 4,859943 & $1,18 \mathrm{E}-06$ & \\
\hline 13 & EXPI13 \& EXPF13 & 31 & 163,5 & 0,612637 & 0,54012 & (NS) \\
\hline 14 & EXPI14 \& $\quad$ EXPF14 & 31 & 155,5 & 1,583762 & 0,113258 & (NS) \\
\hline 15 & EXPI15 \& EXPF15 & 31 & 132,5 & 1,837972 & 0,066076 & $(\mathrm{NS})$ \\
\hline 16 & EXPI16 \& EXPF16 & 31 & 163,5 & 0,612637 & 0,54012 & (NS) \\
\hline 17 & EXPI17 \& EXPF17 & 31 & 31 & 4,14452 & $3,41 \mathrm{E}-05$ & \\
\hline 18 & EXPI23 \& EXPF23 & 31 & 185,5 & 0,966712 & 0,333695 & (NS) \\
\hline 19 & EXPI24 \& EXPF24 & 31 & 197,5 & 0,719892 & 0,471597 & (NS) \\
\hline 20 & EXPI25 \& EXPF25 & 31 & 181 & 1,059269 & 0,289485 & $(\mathrm{NS})$ \\
\hline 21 & EXPI26 \& EXPF26 & 31 & 11 & 4,555887 & $5,24 \mathrm{E}-06$ & \\
\hline 22 & EXPI27 \& EXPF27 & 31 & 9 & 4,683574 & 2,83E-06 & \\
\hline
\end{tabular}




\subsection{Porcentagem de abertura atribuída ao movimento dos pré-}

\section{molares e molares superiores.}

Considerando a abertura de espaço para o lado direito, foram calculadas as diferenças entre os valores inicial e final contidos na análise oclusal para o dente 15, que representava a unidade de ancoragem, e o 16 que se relacionava à unidade receptora da força distalizadora. A seguir, foi calculada a diferença em valores absolutos entre as diferenças obtidas para os dentes 15 e 16 e desse valor pôde-se alcançar a porcentagem de abertura, relacionando-se com a abertura medida diretamente nos modelos de estudo finais, para cada um desses dentes. Esses dados podem ser observados na Tabela 9.

A porcentagem média de abertura para o dente 15 foi de $30,74 \%$, enquanto que para o dente 16 foi de $72,97 \%$. Além disso, notam-se alguns valores discrepantes de abertura para o dente 15 e descartando-se esses valores, obtém-se uma média de $24,81 \%$, como pode ser observado na Tabela 9. 
Tabela 9. Valores obtidos para as diferenças entre medidas inicial e final para os dentes 15 e 16, valores absolutos para essas diferenças e porcentagem de abertura do lado direito para esses dentes.

\begin{tabular}{|c|c|c|c|c|c|c|c|}
\hline Pacientes -31 & $\begin{array}{c}\text { Abertura } \\
\text { direita }\end{array}$ & $\begin{array}{l}\text { Dif.15 } \\
\text { In. Final }\end{array}$ & $\begin{array}{l}\text { Dif.16 } \\
\text { In. Final }\end{array}$ & $\begin{array}{c}\text { Abs } 1 \\
5\end{array}$ & $\begin{array}{c}\text { Abs } \\
16\end{array}$ & $\% 15$ & $\% 16$ \\
\hline 1 & 7 & 1.1 & -6.3 & 1.1 & 6.3 & 15.71 & 90.00 \\
\hline 2 & 7.7 & 2.6 & -5.5 & 2.6 & 5.5 & 33.77 & 71.43 \\
\hline 3 & 5 & 1.4 & -3.8 & 1.4 & 3.8 & 28.00 & 76.00 \\
\hline 4 & 6.8 & 0.5 & -7.8 & 0.5 & 7.8 & 7.35 & 114.71 \\
\hline 5 & 6 & 2.5 & -3.1 & 2.5 & 3.1 & 41.67 & 51.67 \\
\hline 6 & 7 & -0.5 & -7.9 & 0.5 & 7.9 & 7.14 & 112.86 \\
\hline 7 & 4 & -1 & -4.6 & 1 & 4.6 & 25.00 & 115.00 \\
\hline 8 & 5.2 & 0.1 & -5.7 & 0.1 & 5.7 & 1.92 & 109.62 \\
\hline 9 & 6 & 4.2 & -1.5 & 4.2 & 1.5 & 70.00 & 25.00 \\
\hline 10 & 6.5 & 1.1 & -4.8 & 1.1 & 4.8 & 16.92 & 73.85 \\
\hline 11 & 6 & 0.6 & -4.6 & 0.6 & 4.6 & 10.00 & 76.67 \\
\hline 12 & 5.5 & 2.7 & -2.8 & 2.7 & 2.8 & 49.09 & 50.91 \\
\hline 13 & 5 & 3.5 & -1.4 & 3.5 & 1.4 & 70.00 & 28.00 \\
\hline 14 & 5 & 1.3 & -4.7 & 1.3 & 4.7 & 26.00 & 94.00 \\
\hline 15 & 5 & 1.6 & -3.6 & 1.6 & 3.6 & 32.00 & 72.00 \\
\hline 16 & 7 & 2 & -4.5 & 2 & 4.5 & 28.57 & 64.29 \\
\hline 17 & 6.2 & 0.5 & -6.6 & 0.5 & 6.6 & 8.06 & 106.45 \\
\hline 18 & 4 & 1.6 & -0.9 & 1.6 & 0.9 & 40.00 & 22.50 \\
\hline 19 & 4.5 & 0.6 & -2.6 & 0.6 & 2.6 & 13.33 & 57.78 \\
\hline 20 & 6 & 2.3 & -3.1 & 2.3 & 3.1 & 38.33 & 51.67 \\
\hline 21 & 5 & 1.2 & -3.5 & 1.2 & 3.5 & 24.00 & 70.00 \\
\hline 22 & 7.2 & 1.9 & -5.7 & 1.9 & 5.7 & 26.39 & 79.17 \\
\hline 23 & 6.9 & 1.9 & -4.8 & 1.9 & 4.8 & 27.54 & 69.57 \\
\hline 24 & 7.5 & 1.9 & -6 & 1.9 & 6 & 25.33 & 80.00 \\
\hline 25 & 8.3 & 2.5 & -6 & 2.5 & 6 & 30.12 & 72.29 \\
\hline 26 & 7.5 & 3.1 & -3.4 & 3.1 & 3.4 & 41.33 & 45.33 \\
\hline 27 & 7.5 & 2 & -7.1 & 2 & 7.1 & 26.67 & 94.67 \\
\hline 28 & 7 & 1.8 & -5.1 & 1.8 & 5.1 & 25.71 & 72.86 \\
\hline 29 & 6.2 & -1.6 & -7.9 & 1.6 & 7.9 & 25.81 & 127.42 \\
\hline 30 & 6 & 7.1 & 2 & 7.1 & 2 & 118.33 & 33.33 \\
\hline 31 & 8.5 & 1.60 & -4.5 & 1.6 & 4.5 & 18.82 & 52.94 \\
\hline MÉDIA & 6.23 & & & & & 30.74 & 72.97 \\
\hline $\begin{array}{l}\text { Média descal } \\
\text { observações }\end{array}$ & ando & & & & & 24.81 & \\
\hline
\end{tabular}

O mesmo foi feito para a abertura de espaço no lado esquerdo. Os valores obtidos constam da Tabela 10. 
Tabela 10. Valores obtidos para as diferenças entre medidas inicial e final para os dentes 25 e 26, valores absolutos para essas diferenças e porcentagem de abertura para o lado esquerdo para esses dentes.

\begin{tabular}{|c|c|c|c|c|c|c|c|}
\hline Pacientes -31 & $\begin{array}{l}\text { Abertura } \\
\text { esquerda }\end{array}$ & \begin{tabular}{|c|} 
Dif 25 \\
Final-Inic
\end{tabular} & $\begin{array}{c}\text { Dif. } 26 \\
\text { Final-Inic }\end{array}$ & $\begin{array}{l}\text { Abs } \\
25\end{array}$ & $\begin{array}{c}\text { Abs } \\
26\end{array}$ & $\% 25$ & $\% 26$ \\
\hline 1 & 8 & 2.8 & -5.4 & 2.8 & 5.4 & 35.00 & 67.50 \\
\hline 2 & 5.9 & 1.6 & -4.6 & 1.6 & 4.6 & 27.12 & 77.97 \\
\hline 3 & 8 & 1.8 & -6.4 & 1.8 & 6.4 & 22.50 & 80.00 \\
\hline 4 & 5 & 1.2 & -4.9 & 1.2 & 4.9 & 24.00 & 98.00 \\
\hline 5 & 7 & 1.2 & -7 & 1.2 & 7 & 17.14 & 100.00 \\
\hline 6 & 5 & 2.9 & -1.3 & 2.9 & 1.3 & 58.00 & 26.00 \\
\hline 7 & 5 & 1.8 & -2.9 & 1.8 & 2.9 & 36.00 & 58.00 \\
\hline 8 & 5.3 & 1.7 & -4.2 & 1.7 & 4.2 & 32.08 & 79.25 \\
\hline 9 & 7 & 4.4 & -1.8 & 4.4 & 1.8 & 62.86 & 25.71 \\
\hline 10 & 6 & 2.1 & -3.3 & 2.1 & 3.3 & 35.00 & 55.00 \\
\hline 11 & 6.5 & 1.6 & -4 & 1.6 & 4 & 24.62 & 61.54 \\
\hline 12 & 6.2 & 1.9 & -4.7 & 1.9 & 4.7 & 30.65 & 75.81 \\
\hline 13 & 5.5 & 0.7 & -6 & 0.7 & 6 & 12.73 & 109.09 \\
\hline 14 & 5.5 & 1.3 & -5.3 & 1.3 & 5.3 & 23.64 & 96.36 \\
\hline 15 & 5 & 1.1 & -4.1 & 1.1 & \begin{tabular}{|l|}
4.1 \\
\end{tabular} & 22.00 & 82.00 \\
\hline 16 & 7.3 & 2.4 & -4.5 & 2.4 & 4.5 & 32.88 & 61.64 \\
\hline 17 & 5.5 & 0.7 & -4.8 & 0.7 & 4.8 & 12.73 & 87.27 \\
\hline 18 & 7 & 0.7 & -5 & 0.7 & 5 & 10.00 & 71.43 \\
\hline 19 & 5.5 & 0.4 & -5.3 & 0.4 & 5.3 & 7.27 & 96.36 \\
\hline 20 & 6 & 2.1 & -4.1 & 2.1 & 4.1 & 35.00 & 68.33 \\
\hline 21 & 3 & 0.8 & -1.9 & 0.8 & 1.9 & 26.67 & 63.33 \\
\hline 22 & 6.8 & 0 & -6.7 & 0 & 6.7 & 0.00 & 98.53 \\
\hline 23 & 6.9 & 1.8 & -5.5 & 1.8 & 5.5 & 26.09 & 79.71 \\
\hline 24 & 6.3 & 1.9 & -5.1 & 1.9 & 5.1 & 30.16 & 80.95 \\
\hline 25 & 10 & 4.8 & -6.8 & 4.8 & 6.8 & 48.00 & 68.00 \\
\hline 26 & 6.9 & 0.6 & -7 & 0.6 & 7 & 8.70 & 101.45 \\
\hline 27 & 5.5 & 1.6 & -4.6 & 1.6 & 4.6 & 29.09 & 83.64 \\
\hline 28 & 9 & 0.6 & -7.7 & 0.6 & 7.7 & 6.67 & 85.56 \\
\hline 29 & 5 & $\mid-4.3$ & $\mid-9.8$ & 4.3 & 9.8 & 86.00 & 196.00 \\
\hline 30 & 5.5 & \begin{tabular}{|l|}
-5.2 \\
\end{tabular} & -12.4 & 5.2 & 12.4 & \begin{tabular}{|l|}
94.55 \\
\end{tabular} & 225.45 \\
\hline 31 & 8 & 2.8 & -4.7 & 2.8 & 4.7 & 35.00 & 58.75 \\
\hline MÉDIA & 6.29 & & & & & 30.71 & 84.47 \\
\hline
\end{tabular}

Nesse caso, a porcentagem média de abertura de espaço atribuída ao elemento dentário 25 foi de $30,71 \%$, e 84,47 \% para o dente 26 . 


\subsection{Taxa de distalização mensal}

Aplicando-se a fórmula matemática da abertura pelo tempo total médio de distalização e considerando-se que os valores de abertura de espaço entre o primeiro molar e o segundo pré-molar diretamente nos modelos de estudo finais foram de 6,23 e 6,29mm, para os lados direito e esquerdo, respectivamente e; o tempo total médio de distalização de 176,28 dias, ou seja, 5,87 meses, obteve-se a taxa mensal de movimento dos molares de $1,06 \mathrm{~mm}$ e de $1,07 \mathrm{~mm}$ para os lados direito e esquerdo. Pôde ser observada uma similaridade nas taxas para os quadrantes analisados. 
Tabela 11- Taxa de distalização mensal para os lados direito e esquerdo.

\begin{tabular}{|c|c|c|c|}
\hline PACIENTES - 31 & $\begin{array}{l}\text { TEMPO DE TRATAMENTO } \\
\text { (DIAS) }\end{array}$ & $\begin{array}{c}\text { DIR } \\
6,23 / 5,87\end{array}$ & $\begin{array}{c}\text { ESQ } \\
6,29 / 5,87\end{array}$ \\
\hline 1 & 167 & & \\
\hline 2 & 154 & & \\
\hline 3 & 205 & & \\
\hline 4 & 174 & & \\
\hline 5 & 175 & & \\
\hline 6 & 157 & & \\
\hline 7 & 178 & & \\
\hline 8 & 176 & & \\
\hline 9 & 173 & & \\
\hline 10 & 180 & & \\
\hline 11 & 208 & & \\
\hline 12 & 198 & & \\
\hline 13 & 176 & & \\
\hline 14 & 159 & & \\
\hline 15 & 159 & & \\
\hline 16 & 176 & & \\
\hline 17 & 187 & & \\
\hline 18 & 169 & & \\
\hline 19 & 211 & & \\
\hline 20 & 168 & & \\
\hline 21 & 173 & & \\
\hline 22 & 167 & & \\
\hline 23 & 211 & & \\
\hline 24 & 167 & & \\
\hline 25 & 176 & & \\
\hline 26 & 174 & & \\
\hline 27 & 174 & & \\
\hline 28 & 170 & & \\
\hline 29 & 129 & & \\
\hline 30 & 192 & & \\
\hline 31 & 203 & & \\
\hline 32 & 153 & & \\
\hline MÉDIA & $\mathbf{1 7 6 , 2 1 8}$ & 1,061328 & $\mathbf{1 , 0 7 1 5 5 0}$ \\
\hline
\end{tabular}


DISCUSSÃO 


\section{DISCUSSÃO}

Almejando uma melhor interpretação e discussão dos resultados alcançados neste estudo, julga-se de importância fundamental tecer inicialmente alguns comentários sobre a amostra empregada, e posteriormente realizar as considerações sobre as alterações esqueléticas e dentárias decorrentes da distalização dos molares superiores com o aparelho Pendulum. Dessa forma, dividiu-se o capítulo em:

\section{1 - Precisão da metodologia}

6.2- Considerações sobre a amostra;

\section{3-Sistema de força;}

\section{4- Efeitos esqueléticos decorrentes da distalização com o} aparelho Pendulum e

\section{5- Efeitos dentários resultantes da distalização.}

\section{1 - Precisão da metodologia}

Nesse estudo, utilizou-se dos recursos necessários para o controle da pesquisa, iniciando-se com o cumprimento rigoroso dos critérios de seleção da amostra.

Para a padronização da técnica radiográfica, as telerradiografias foram obtidas sempre pelo mesmo operador.

A construção dos aparelhos, assim como as suas ativações foram executadas pelo mesmo profissional. 
Após a fase experimental, foram obtidas as telerradiografias e os modelos de estudo finais que propiciaram a avaliação dos efeitos do mecanismo de distalização.

Foram obtidos os cefalogramas, referentes às fases inicial e final do experimento. E para analisar os erros de metodologia, quinze dias após a obtenção do primeiro conjunto de cefalogramas, foram escolhidos aleatoriamente dez pacientes , o que correspondia a 30\% da amostra.Para esses pacientes selecionados, realizou-se um novo conjunto de cefalogramas, envolvendo as fases inicial e final do experimento.

De posse das medidas provenientes desses conjuntos de cefalogramas foi possível realizar a comparação das medidas do primeiro conjunto de cefalogramas com as remedições. Optou-se pelo teste não-paramétrico de Kruskal-Wallis e verificou-se que do total de 29 variáveis analisadas nas telerradiografias em norma lateral convencional (Tabela 1)e de 10 variáveis estudadas nas telerradiografias em norma lateral de $45^{\circ}$, não houve diferença estatisticamente significante em nível de 5\% e 1\% (Tabelas 2 e 3 ).

Para as medições em modelos, do total de 22 variáveis avaliadas não foi observado diferença estatisticamente significante em nível de 5\% e 1\% (Tabela 4).

Torna-se lícito concluir que as observações decorrentes desse estudo podem ser utilizadas com segurança, se considerarmos a precisão do instrumento de mensuração empregado

\section{2 - Considerações sobre a amostra.}

A má oclusão de Classe II apresenta uma alta prevalência de manifestação. SILVA FILHO et al. ${ }^{137}$, em 1989, constataram que, na cidade de 
Bauru, São Paulo, na faixa etária de 7 a 11 anos, 42\% das crianças eram portadoras dessa anomalia. Essa elevada ocorrência é uma observação comum nos levantamentos epidemiológicos de más oclusões.

Essa anomalia freqüente e que pode se manifestar com o envolvimento dos componentes esqueléticos e dentários, tem despertado o interesse de muitos pesquisadores em seu estudo e na elaboração de formas alternativas de tratamento, como pode ser visto nas inúmeras citações (NOUER ${ }^{110}$, em 1966; TAKAHASHI $^{142}$, em 1975; GANDINI ${ }^{52}$, em 1993 e RITTER et al ${ }^{126}$, em 1997).

O sucesso para a execução de um tratamento que atenda às necessidades do paciente depende fundamentalmente de um diagnóstico diferencial que defina a participação dos componentes envolvidos, sejam dentários ou esqueléticos. Na sua maioria, as pesquisas verificam a posição ântero-posterior, basal e dentoalveolar, da maxila e mandíbula, além das alterações verticais nos indivíduos com Classe II.

Quanto à posição esquelética da maxila em relação à base craniana, as constatações são divergentes. Alguns pesquisadores relatam uma maior porcentagem de retrusão (RENFROE ${ }^{124}$, em 1948; HARRYS et al ${ }^{68}$, em 1972), outros de protrusão (ROTHSTEIN ${ }^{130}$,em 1971; VALE; MARTINS ${ }^{147}$, em 1987; SIMPLÍCIO ${ }^{138}$, em 1995, no gênero masculino) e por fim há os que observaram a maxila bem posicionada (RIEDEL ${ }^{125}$, em 1952; McNAMARA Jr ${ }^{100}$, em 1980; SIMPLÍCIO $^{138}$, em 1995, no gênero feminino). No presente estudo, observa-se que a maxila encontrava-se normal em relação à base craniana, segundo o ângulo SNA médio inicial de $81,77^{\circ}$, comparando-se ao valor angular médio para a idade de 15 anos do gênero masculino de $82,3^{\circ}$, e do gênero feminino de $81,6^{\circ}$. Essa condição também pode ser confirmada pelo valor médio da medida A-NPerp de 0,29 mm, que demonstra um bom posicionamento ântero-posterior 
da maxila, pois a média para essa faixa etária é de $-1,4$ e de $-0,7$, respectivamente para os gêneros masculino e feminino.

Considerando-se os valores médios compatíveis com a idade inicial para os casos isoladamente, constatou-se para a amostra total de 31 pacientes, a distribuição de 48,38\% dos casos com a maxila normal, $16,12 \%$ de casos de retrusão, e 32,25\% de protrusão, segundo a grandeza cefalométrica SNA, enquanto que a medida de A-NPerp mostra a porcentagem de casos com protrusão, retrusão e maxila normal em 41,93\%, 29,03\% e 25,80\%, respectivamente.

Quanto à posição mandibular, a maioria dos autores relata uma maior frequiência de retrusão em relação à base do crânio (RENFROE ${ }^{124}$, em 1948; GILMORE $^{58}$, em 1950; CRAIG $^{41}$, em 1951; RIEDEL ${ }^{125}$, em 1952; HITCHCOCK $^{77}$, em 1973; MOYERS et al. ${ }^{106}$, em 1980; MCNAMARA Jr ${ }^{100}$, em1981; SIMPLÍCIO ${ }^{138}$, em 1995). Alguns estudos relataram um posicionamento normal (ALTEMUS ${ }^{06}$, em 1955; CALCOTE $^{28}$, em 1960; ROTHSTEIN $^{130}$, em 1971) e nenhuma citação de protrusão. O valor médio inicial do ângulo $\mathrm{SNB}$, de $77,7^{\circ}$, quando comparado aos valores médios relativos à idade de 15 anos para o gênero masculino e feminino, de $79,5^{\circ} \mathrm{e}$ $79,8^{\circ}$, possibilitou a observação de que $25,80 \%$ da amostra se enquadrava em casos de bom posicionamento mandibular e 54,83\% em retrusão mandibular.

Analisando-se a medida Pg-NPerp média inicial de $-4,16 \mathrm{~mm}$ e tendose o conhecimento de que para a idade média da amostra estudada, o valor deveria ser de $-6,5 \mathrm{~mm}$ para o gênero masculino e de $-2,7 \mathrm{~mm}$ para o feminino, pode-se perceber que $25,80 \%$ do total dos pacientes possuíam a mandíbula normal e $29,03 \%$ de retrusão mandibular.

Entretanto, avaliando-se o ângulo SND médio de $74,95^{\circ}$ e utilizandose a média apresentada por Steiner de $76^{\circ}\left(\mathrm{JACOBSON}^{81}\right)$, confirma-se a taxa 
de $48,38 \%$ de casos com a mandíbula bem posicionada, enquanto que $51,61 \%$ dos casos enquadram-se em retrusão mandibular, concordando com a literatura ortodôntica de que há uma maior prevalência para a retrusão mandibular ao se avaliar a posição ântero-posterior dessa base óssea em relação à base craniana.

Considerando-se a relação vertical, nota-se que os pacientes pertencentes à amostra apresentam um padrão do esqueleto cefálico horizontal, segundo as medidas médias de SN.GoGn de $30,71^{\circ}$, FMA de $24,52^{\circ}$, Frank. Ocl de $5,15^{\circ}$, SN.PIOcl de $13,66^{\circ}$ e SN.Gn de $67,17^{\circ}$. Comparando-se com as médias correspondentes à faixa etária envolvida e relacionando-se respectivamente aos gêneros masculino e feminino, temos: SN.GoGn (32,9 e 31,0 $0^{\circ}$; FMA (28,8 e

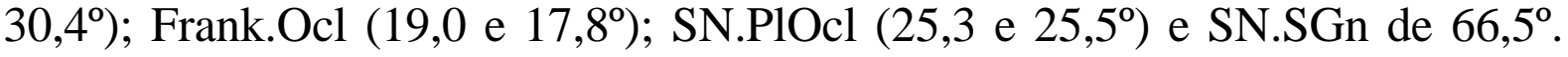
Comprova-se, portanto, por essa comparação, que os pacientes pertencentes a amostra apresentavam um padrão favorável para a distalização dos molares superiores.

A relação maxilomandibular é outro aspecto que deve ser analisado na determinação da forma adequada de tratamento para a Classe II. Assim sendo, conhecendo-se o ângulo ANB médio inicial da amostra de $4,05^{\circ}$ e sabendo-se que a média para a idade de 15 anos do gênero masculino é $2,8^{\circ}$ e do feminino de $1,7^{\circ}$, conclui-se que os pacientes apresentavam uma relação favorável das bases ósseas apicais. Porém, a medida média de Wits de 3,2 $\mathrm{mm}$ revela uma relação esquelética de Classe II.

Diante da possibilidade da má oclusão de Classe II ser resultante da combinação de vários componentes dento-esqueléticos, o planejamento do tratamento deve ser idealizado, buscando-se especificamente a correção dos componentes alterados. Essa preocupação é ressaltada por MOYERS ${ }^{105}$, em 1948, MOYERS et al. ${ }^{106}$, em 1980, McNAMARA Jr ${ }^{100}$, em 1981; MOYERS; RIOLO $^{107}$, em 1991. 
Torna-se necessário também definir a relação da dentição com o osso basal, podendo ser normal, protrusiva e retrusiva. Para definir a posição dos incisivos superiores utilizaram-se algumas medidas cefalométricas, tais como o ângulo 1.NA, cuja média verificada foi de $22,92^{\circ}$; a distância linear 1-NA inicial de 4,85 mm e 1-AV de 4,89 $\mathrm{mm}$. As médias consideradas ideais para pacientes dos gêneros masculino e feminino com a idade de 15 anos para as medidas acima citadas são: 1 .NA de $21,2^{\circ}$ e $24,6^{\circ}$; 1 -NA de $3,6 \mathrm{~mm}$ e 4,5 mm; 1 -AV de $3,1 \mathrm{~mm}$ e 4,2 $\mathrm{mm}$. Pode-se observar que os incisivos superiores encontram-se em posição normal, em relação à base óssea apical.

No segmento posterior, avaliando-se a posição dos molares superiores, a medida linear de 6-PTV inicial de 27,64 mm demonstra que os molares estão posicionados mesialmente ao normal que deveria ser de $17,6 \mathrm{~mm}$ para a referida idade média dos pacientes da amostra.

A mecânica de distalização dos molares superiores é uma modalidade de tratamento comumente empregada na correção da má oclusão de Classe II do tipo A de Moyers, que se caracteriza pelo bom relacionamento sagital e vertical da maxila e mandíbula, sendo que a protrusão dos dentes superiores é a responsável pela determinação da má oclusão. Entretanto, essa mecanoterapia tem a sua indicação também diante de casos de protrusão esquelética e dentoalveolar da maxila, assim como em situações clínicas em que não é permissível a realização de exodontias de dentes superiores ou do movimento mesial de dentes inferiores.

Portanto, as características da má oclusão de Classe II dos pacientes pertencentes à amostra desse estudo mostravam que a distalização poderia ser uma opção favorável de terapêutica para a correção da relação oclusal. 


\section{3 - Sistema de força}

Existe uma grande variedade de alternativas para a distalização dos molares que dependem fortemente da cooperação dos pacientes quanto ao uso ou controle dos mecanismos, dentre os quais se incluem: o aparelho extrabucal (GRABER $^{61}$, 1955 e WIESLANDER ${ }^{152}$, em 1975); aparelhos removíveis (CETLIN e TEN HOEVE ${ }^{36}$, em 1983); associação das duas; distalizador bimétrico de Wilson; mecânica com cursores e elásticos de Classe II.

Porém, tem-se questionado a possibilidade ou não de se alcançar o sucesso com esses sistemas, pois a cooperação dos pacientes é considerada o fator primordial para que os bons resultados de tratamento se manifestem (MIURA et al. ${ }^{103}$, em 1986; GIANELLY et al. ${ }^{57}$, em 1988; CANGLIALOSI et $\mathrm{al}^{30}$, em 1988; GIANELLY; VAITAS; THOMAS ${ }^{56}$, em 1989; GIANELLY; BEDNAR; DEITZ ${ }^{55}$, em 1991; REINER ${ }^{123}$, em 1992; HILGERS ${ }^{74}$, em 1992; BONDEMARK; KUROL; BERNHOLD ${ }^{19}$, em 1994; MUSE et al. ${ }^{109}$, em 1993; JOHNSON $^{84}$, em 1994; GOSH; NANDA ${ }^{60}$, em 1996; ERVERDI; KOYUTÜRK; KÜÇÜKKELES ${ }^{46}$, em 1997; BYLOFF; DARENDELILER ${ }^{26}$, em 1997; BYLOFF et al. ${ }^{27}$, em 1977; GULATI; KHARBANDA; PARKASH ${ }^{64}$, em 1998; CARANO; TESTA; ROTUNNO ${ }^{31}$, em 1999; REINA; MENDOZA ${ }^{122}$, em 1999; BUSSICK; McNAMARA JR ${ }^{25}$, em 2000; QUICK; HARRIS ${ }^{119}$, em 2000).

A constante preocupação dos profissionais com o fator cooperação dos pacientes quanto ao uso dos dispositivos conduziu à introdução dos aparelhos intrabucais, eliminando a necessidade da colaboração dos pacientes, exceto nos casos em que ainda se torna imprescindível o uso de elásticos de Classe II. Assim, surgiram os seguintes métodos: magnetos de repulsão (GIANELLY et al. ${ }^{57}$, em 1988 e BONDEMARK; KUROL ${ }^{18}$, em 1992); arcos transpalatinos (HAAS; CISNEROS ${ }^{66}$, em 2000); molas de compressão (JECKEL; RAKOSI ${ }^{83}$, 
em 1991); molas superelásticas de níquel-titânio (GIANELLY et al. ${ }^{57}$, em 1988 e LOCATELLI, et al. ${ }^{94}$, em 1992); aparelho distal jet (CARANO; TESTA; SICILIANI $^{32}$, em 1996); aparelho de Nance modificado (REINER ${ }^{123}$, em 1992); aparelhos Jones Jig (JONES ; WHITE ${ }^{85}$, em 1992).

A distalização dos molares superiores independente da inclinação distal das coroas e a possibilidade de mover simultaneamente os primeiros e segundos molares sem a necessidade da cooperação são as preocupações constantes quando nos referimos ao movimento distal de molares.

Os magnetos utilizados para a distalização dos molares proporcionam um sistema de força que atua vestibularmente ao centro de resistência dos molares, acarretando a possibilidade da distalização associada à tendência rotacional distopalatina dos molares (BONDEMARK; KUROL ${ }^{18}$, em 1992 e BONDEMARK; KUROL; BERNHOLD ${ }^{19}$, em 1994). A força distal inicial resultante da ativação horizontal era de 200-225 g, segundo GIANELLY, et al. ${ }^{57}$, em 1988 e para a manutenção dessa força dentro desse limite, GIANELLY; VAITAS; THOMAS ${ }^{56}$, em 1989 aconselharam que a reativação fosse realizada a cada três semanas. ITOH et al. $^{80}$, em 1991, por sua vez, recomendaram a reativação a cada duas semanas, pois a redução da força ocorria para 50 a $70 \%$ do valor inicial por milímetro de movimento dos molares. BONDEMARK; KUROL $^{18}$, em 1992, observaram a redução da força inicial de $220 \mathrm{~g}$ para $60 \mathrm{~g}$ conforme o movimento dos molares ocorria e os pólos magnéticos se afastavam, num período de três semanas. A força residual ao final desse período seria insuficiente para produzir o movimento dos molares. Portanto, BONDEMARK; KUROL; BERNHOLD ${ }^{19}$, em 1994, notaram que a redução da força de $225 \mathrm{~g}$ para $100 \mathrm{~g}$ num período de 4 semanas exigia que as reativações fossem realizadas a cada 4 semanas para se manter a magnitude dentro dos limites aceitáveis para a distalização dos molares. 
As molas superelásticas de níquel-titânio segundo GIANELLY; BEDNAR; DIETZ ${ }^{55}$, em 1991, ao serem ativadas em 8 a $10 \mathrm{~mm}$, geravam forças distalizadoras leves e contínuas de 100 g. BONDEMARK; KUROL; BERNHOLD $^{19}$, em 1994, empregaram as molas de níquel-titânio com força inicial de $225 \mathrm{~g}$ que declinava para $180 \mathrm{~g}$, num período de tempo de 5 a 6 semanas e aconselharam a reativação do sistema nesse intervalo de tempo para se manter a magnitude necessária para a distalização dos molares. Para ERVERDI; KOYUTÜRK; KÜÇÜKKELES ${ }^{46}$, em 1997, a força gerada pelas molas poderia alcançar o valor de 225 g. Entretanto, para GIANELLY; et al. ${ }^{57}$, em 1998, a força distal produzida pela ativação das molas era de 100 g. Por outro lado, LOCATELLI et al. ${ }^{94}$, em 1992, utilizaram arcos superelásticos de níquel-titânio que ao serem defletidos entre o primeiro molar e o primeiro prémolar produziam a força de 100 g. GIANCOTTI; COZZA ${ }^{53}$, em 1998, empregaram simultaneamente dois arcos superelásticos de níquel-titânio para os primeiros e segundos molares com força resultante de $80 \mathrm{~g}$ e comentaram que o estiramento das fibras transeptais contribuía para que forças mais leves pudessem ser empregadas na distalização dos primeiros molares. Contudo, todas as pesquisas que relataram a utilização das molas de níquel-titânio ou dos arcos superelásticos verificaram a necessidade da complementação do sistema com os elásticos de Classe II de 150 a 200 g para melhorar o controle da unidade de ancoragem e potencializar a distalização. Entretanto, o uso dos elásticos depende da cooperação dos pacientes. Esse sistema proporciona como resultado direto a distalização e a rotação distopalatina dos molares e possivelmente a ocorrência das alterações transversais, embora essas não tenham sido citadas na literatura.

$\mathrm{O}$ aparelho Jones Jig inclui duas unidades, uma de ativação e outra de ancoragem. A ancoragem é oferecida pelo botão palatino de Nance que se liga às bandas dos segundos pré-molares. A unidade de ativação envolve um 
segmento de fio de .030" com uma mola de níquel-titânio que desliza por esse segmento. A ativação é gerada por meio de um fio de ligadura que se une ao gancho mesial do segundo pré-molar e comprime de 1 a $5 \mathrm{~mm}$ as molas contra os molares, produzindo a força de 70-75 g (JONES; WHITE ${ }^{85}$, em 1992). RUNGE; MARTIN; BUKAI ${ }^{131}$, em 1998, recomendaram as reativações a cada 4 semanas.

O distalizador bimétrico de Wilson apresenta dois segmentos, um anterior e outro posterior que se ajusta ao tubo do aparelho extrabucal. Os pacientes devem ser orientados a utilizar elásticos de Classe II com a redução gradual da carga que comprime as alças em forma de ômega contra as molas de níquel-titânio, produzindo a força distal (WILSON; WILSON ${ }^{155}$, em 1980). Como se observa, esse sistema esbarra na dependência dos pacientes quanto ao uso dos elásticos de Classe II, iniciando-se com 172,14 g por 3 semanas, 114,76 g por 2 semanas e 57,38 g por 1 semana (RANA; BECHER ${ }^{121}$, em 2000). Os elásticos devem ser usados 24 horas por dia. Assim, para que resultados favoráveis se desenvolvam, existe a forte necessidade da cooperação dos pacientes.

Um novo distalizador foi introduzido por CARANO; TESTA; SICILIANI $^{32}$, em 1996, denominado distal jet, e tendo dois tubos de 0,9 mm conectados ao botão palatino de Nance. Um segmento de fio com uma dobra em forma de baioneta é inserido nos tubos linguais, comprimindo as molas contra os molares superiores e promovendo a distalização com a força de $150 \mathrm{~g}$. Entretanto, essa força demonstra um declínio rápido de sua magnitude, exigindo as reativações mensais.

A barra transpalatina de Goshgarian pode ser empregada na distalização dos molares com a força de $260 \mathrm{~g}$ resultante da deflexão que deve ser inferior a $35^{\circ}$, segundo HAAS; CISNEROS ${ }^{65}$, em 2000. BURSTONE; 
$\mathrm{KOENIG}^{22}$, em 1981, já haviam conferido que a constrição ou expansão de 1,9 $\mathrm{mm}$ era necessária para gerar a força de $200 \mathrm{~g}$. Essa força é aplicada lingualmente ao centro de resistência acarretando, além da distalização, a inclinação distal das coroas e a rotação distopalatina. $\mathrm{O}$ grande inconveniente que deve ser comentado é que o molar do lado oposto sofre um movimento mesial.

Aparelhos ortodônticos removíveis também podem ser utilizados na distalização dos molares superiores. Dentre eles, destaca-se o aparelho de resina acrílica cérvico-occipital, cujas molas, ao serem ativadas 3 a $4 \mathrm{~mm}$, produzem a força de 100 a $125 \mathrm{~g}$ e segundo $\mathrm{JOHNSON}^{84}$, em 1994, as reativações deveriam ser realizadas a cada 4 semanas, pois caso contrário a força residual seria insuficiente para distalizar os molares. LEWIS; FOX ${ }^{93}$, em 1996, concluíram que além da distalização poderia ocorrer a rotação mesiopalatina dos molares.

Em 1992, HLGERS ${ }^{74}$ descreveu dois novos aparelhos denominados Pendulum e Pendex, que não dependiam da cooperação dos pacientes para a distalização dos molares superiores. Esses aparelhos eram compostos por um botão palatino de Nance que se fixava por meio de grampos de apoio oclusais que se adaptavam nas cristas marginais mesiais e distais dos primeiros prémolares e segundos pré-molares, respectivamente. Eventualmente, os grampos de apoio oclusais dos primeiros pré-molares eram substituídos pelas bandas. A parte ativa do sistema era constituída pelas molas construídas com fio de liga de titânio-molibidênio (TMA) de diâmetro .032”. Essas molas eram ativadas em $60^{\circ}$, gerando a força distalizadora que era capaz de produzir a correção da relação oclusal de Classe II em aproximadamente 5 meses.

Estudos subseqüentes realizados por GOSH; NANDA ${ }^{60}$, em 1996, empregaram o aparelho Pendulum recomendando que as molas fossem ativadas em 60 a $70^{\circ}$, proporcionando a força distal de 230 g. Entretanto, BYLOFF; 
DARENDELILER ${ }^{26}$, em 1997 e BYLOFF et $\mathrm{al}^{27}$, em 1997, preconizaram a ativação das molas em $45^{\circ}$ no centro dos helicóides com a força resultante de 200 a 250 g. BUSSICK; McNAMARA JR ${ }^{25}$, em 2000, e JOSEPH; BUTCHART $^{86}$, em 2000, utilizaram o aparelho Pendulum com a ativação de 60 a $90^{\circ}$ com a força inicial de 200 a $250 \mathrm{~g}$.

Nesse estudo foi empregado o aparelho Pendulum segundo as recomendações de HILGERS ${ }^{74}$, em 1992, porém padronizando-se a construção das molas que deveriam apresentar a seguinte dimensão: a) helicóide com 4,0 $\mathrm{mm}$ de diâmetro e b) alças horizontais de ajuste com 4,0 $\mathrm{mm}$ de largura e 4,0 $\mathrm{mm}$ de altura. A ativação de $60^{\circ}$ gerou a força distal inicial de $253 \mathrm{~g}$ e como critério de compensação da inclinação distal das coroas foram incorporadas as dobras de antiinclinação de $15^{\circ}$ em direção oclusal.

As molas do aparelho promovem como efeito principal a distalização dos molares e por atuarem lingualmente ao centro de resistência, acarretam como efeito secundário a rotação distopalatina dos molares. Podem ser citados ainda como efeitos adversos, o movimento mesial dos dentes que compõem a unidade de ancoragem e as possíveis alterações transversais e verticais dos molares, pré-molares, caninos e incisivos. A distalização dos molares é acompanhada da inclinação distal das coroas destes elementos dentários.

\section{4 - Efeitos esqueléticos decorrentes da distalização de molares} superiores com o aparelho Pendulum

No que tange às alterações esqueléticas derivadas do tratamento, devese analisá-las considerando-se os planos sagital e vertical. Para essa avaliação, foram empregados os dados oriundos das comparações entre os valores iniciais e finais em telerradiografias em norma lateral. 
Dessa maneira, dividiram-se as alterações em:

\subsection{1 - Alterações sagitais da maxila;}

\subsection{2- Alterações sagitais da mandíbula;}

\subsection{3- Alterações verticais;}

\subsection{4- Alterações na relação maxilomandibular e}

\subsection{5- Alterações dentárias}

\subsection{6- Alterações do perfil facial e}

\subsection{7- Considerações clínicas.}

\subsection{1 - Alterações sagitais da maxila}

Com relação às alterações sagitais da maxila, os ângulos utilizados foram o SNA e A-NPerp e que proporcionam as informações sobre a posição ântero-posterior da maxila perante a base do crânio.

Quanto ao ângulo SNA, o seu valor médio inicial de $81,77^{\circ}$ alterou-se para $81,9^{\circ}$ ao final da distalização e isso demonstrou que o posicionamento ântero-posterior da maxila não foi influenciado significativamente pela mecanoterapia, confirmando os prévios estudos de BONDEMARK; KUROL ${ }^{18}$, em 1992; MUSE et al. ${ }^{109}$, em 1993; BONDEMARK; KUROL; BERNHOLD ${ }^{19}$, em 1994; BYLOFF; DARENDELILER ${ }^{26}$, em 1997; BYLOFF et al. ${ }^{27}$, em 1997 e HAYDAR; ÜNER ${ }^{69}$, em 2000. Entretanto, BUSSICK; McNAMARA Jr ${ }^{25}$, em 2000, constataram que o ângulo SNA teve um aumento significativo, assim como o comprimento maxilar avaliado pela distância do ponto condílio (Co) ao ponto A.

Ainda no que diz respeito à posição da maxila, essa observação pode ser vista também pela distância linear A-NPerp, cuja média inicial de 0,29 mm foi modificada para $0,23 \mathrm{~mm}$ na fase final. Isso sugere que o ponto A não foi afetado pelas forças que eram orientadas anteriormente, dentro de um tempo 
relativamente curto de 5 meses, e comprova a ocorrência principalmente de alterações dentárias na perda de ancoragem.

A segunda explicação para a não manifestação de alterações na posição da maxila foi que o aparelho Pendulum, por meio de sua ativação, proporcionava uma força distalizadora leve e contínua, sendo portanto, insuficiente para produzir as modificações ortopédicas na base óssea, pois espera-se a potencialização dos efeitos esqueléticos com a elevação do nível de força. Constatações feitas por $\mathrm{LEVIN}^{92}$, em 1985, com o emprego de forças extrabucais de $400 \mathrm{~g}$ por lado, em pacientes com má oclusão de Classe II, comprovaram a obtenção da relação molar de Classe I, num tempo de aproximadamente 12 meses, sendo que essa correção foi mais às custas da retração maxilar associada ao crescimento mandibular. É aconselhado um limite de força superior, de 24 a 48 onças $(688,58 \mathrm{~g}$ a 1377,16 g) para que as alterações ortopédicas aconteçam, enquanto que de 16 a 24 onças $(459,05 \mathrm{~g}$ a 688,58 g), apenas ocorre o controle do desenvolvimento anterior da maxila, segundo HAAS $^{65}$, em 2000. Porém, ao reduzir-se a magnitude da força extrabucal para 6 $(172,14 \mathrm{~g})$ a 10 onças $(286,91 \mathrm{~g})$, manifestavam-se os efeitos dentoalveolares, segundo BAUMRIND et al. ${ }^{15}$, em 1983; WIESLANDER ${ }^{152}$, em 1975; PANCHERZ ${ }^{113}$, em 1984; ÖZTÜRK; TANKUTER ${ }^{111}$, em 1994 e HAAS ${ }^{65}$, em 2000.

Durante o crescimento, o násio, a espinha nasal anterior e o ponto A deslocam-se anteriormente para a anterior na mesma proporção, enquanto que comparativamente, o pogônio movimenta-se em dobro. Assim, num período de 3 anos, tem-se que o deslocamento do násio e do ponto A foi de 2 a $3 \mathrm{~mm}$ e do pogônio de 5 a $6 \mathrm{~mm}$. Portanto, é justificável que o emprego de forças pesadas conduzem ao maior efeito ortopédico, reduzindo a diferença maxilomandibular, na Classe II, como consequiência da retração do ponto A, com reflexo direto na 
diminuição do ângulo SNA e aumento no ângulo SNB, segundo CANGLIALOSI et al. ${ }^{30}$, em 1993.

Esse comportamento da maxila pode ser facilmente visualizado por meio dos gráficos que representam as médias iniciais e finais dessas medidas, nos quais se nota apenas uma pequena variação que estatisticamente não foi significante em nível de 5\% (Gráficos 1 e 2)

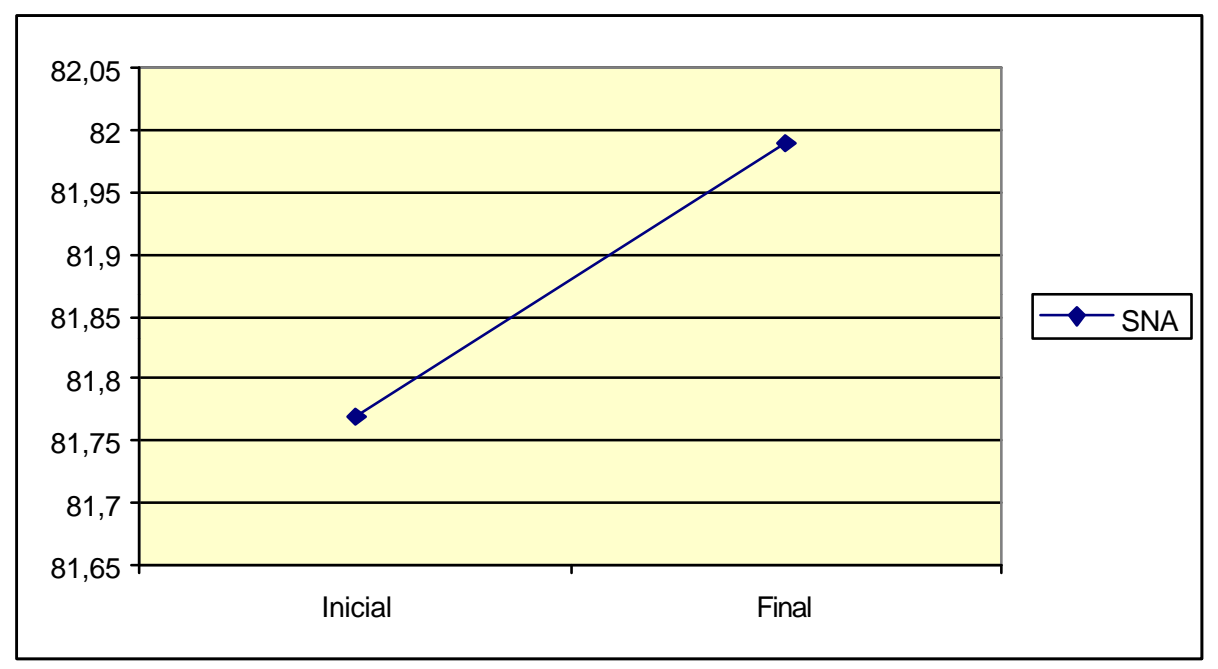

Gráfico1. Posição ântero-posterior da maxila avaliada pelo ângulo SNA médio inicial e final

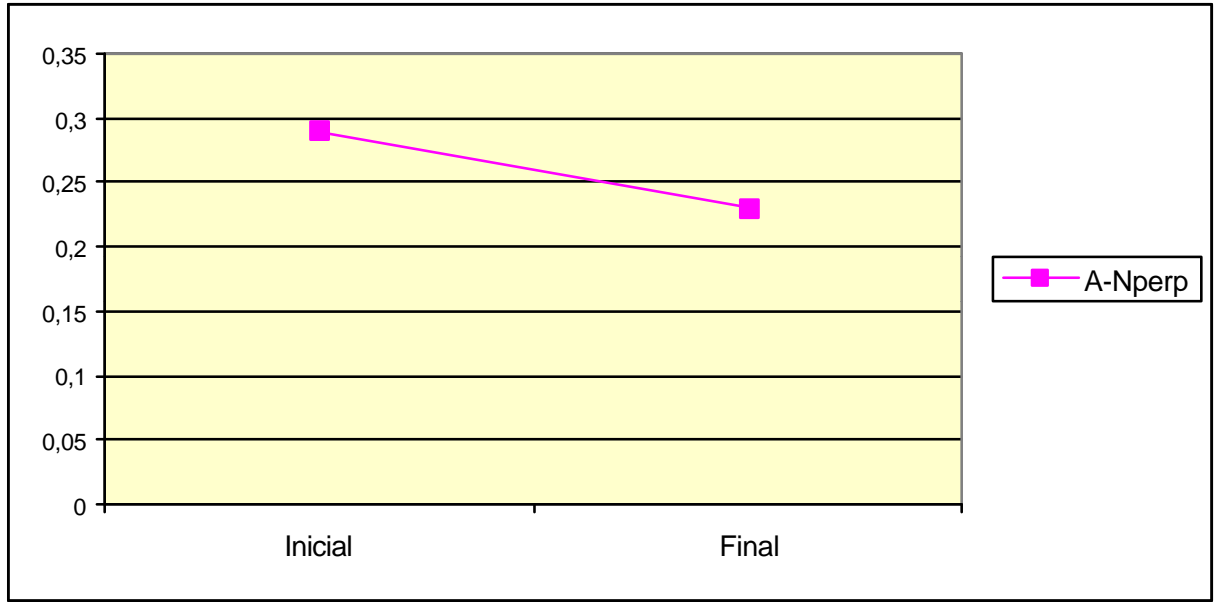


Gráfico 2. Posição ântero-posterior da maxila avaliada pela distância A-NPerp média inicial e final

\subsection{2- Alterações sagitais da mandíbula}

Para a determinação das alterações sagitais da mandíbula, foram empregados os ângulos SNB, SND e Pg-NPerp, por meio de comparações dos valores iniciais e finais.

A posição ântero-posterior da mandíbula permaneceu constante durante o período de avaliação, pois a média inicial do ângulo SNB de $77,73^{\circ}$ alterou-se para $77,58^{\circ}$, condição essa confirmada também pelo valor de SND que se manteve em $74,9^{\circ}$, nas duas fases do estudo. Essa observação foi verificada em outros estudos de distalização dos molares superiores, como os de BONDEMARK; KUROL ${ }^{18}$, em 1992; MUSE et al. ${ }^{106}$, em 1993; BONDEMARK; KUROL; BERNHOLD ${ }^{19}$, em 1994; BYLOFF; DARENDELILER $^{26}$, em 1997; BYLOFF et al. ${ }^{27}$, em, 1997; HAYDAR; ÜNER $^{69}$, em 2000. Entretanto, BUSSICK; McNAMARA $\mathrm{Jr}^{25}$, em 2000, confirmaram que o ângulo SNB diminuiu após a distalização, como reflexo da rotação mandibular para baixo e para trás, porém o comprimento mandibular medido pela distância do ponto condílio (CO) ao ponto Gn mostrou um aumento signific ativo.

Pela representação gráfica (Gráfico 3) observa-se que os valores médios iniciais e finais dos ângulos SNB e SND mantiveram-se constantes, demonstrando que a posição ântero-posterior da mandíbula não foi alterada significantemente pela distalização dos molares superiores com o aparelho

\section{Pendulum.}




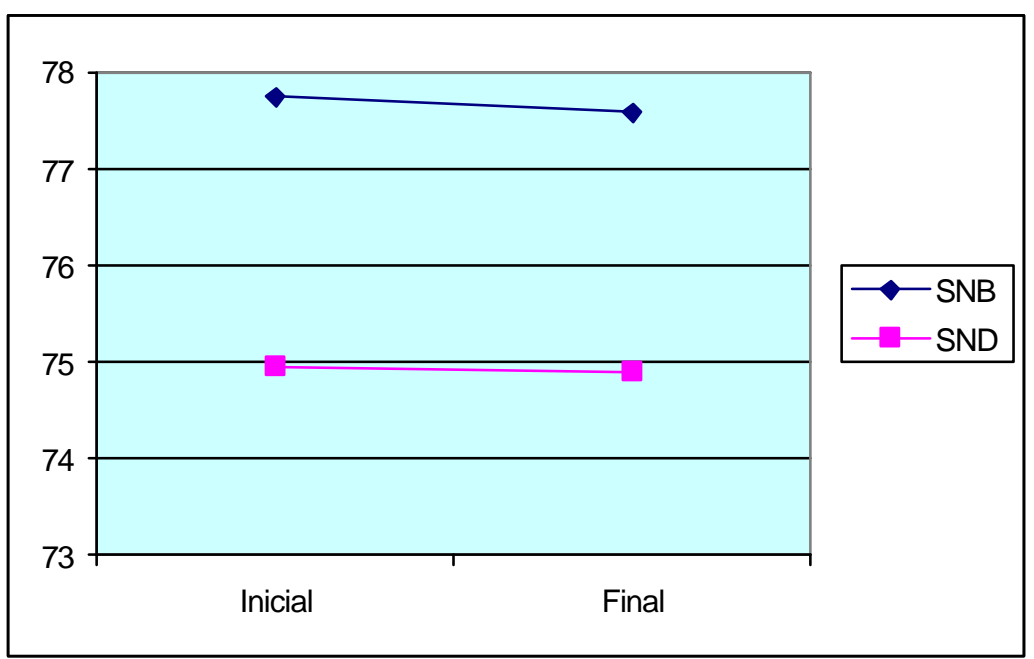

GRÁFICO 3. Posição ântero-posterior da mandíbula avaliada pelos ângulos SNB e SND médio inicial e final

Entretanto, nesse estudo, a distância Pg-NPerp média inicial de - 4,16 $\mathrm{mm}$ variou para $-5,34 \mathrm{~mm}$, sendo uma alteração significante e que corrobora com as informações obtidas por GOSH; NANDA ${ }^{60}$, em 1996 (Gráfico 4). Essa diminuição na distância Pg-NPerp pode ser explicada pela rotação do plano mandibular, visível na sobreposição das telerradiografias iniciais e finais, sendo que esse aspecto já havia sido ressaltado por outros estudos como o de GOSH; NANDA $^{60}$ em 1996; BYLOFF; DARENDELILER ${ }^{26}$, em 1997; BYLOFF et al ${ }^{27}$, em 1997; JOSEPH; BUTCHART ${ }^{86}$, em 2000 e BUSSICK; McNAMARA Jr ${ }^{25}$, em 2000. Porém, BUSSICK; McNAMARA Jr ${ }^{25}$, em 2000, observaram que a distância Pg-NPerp sofreu uma diminuição e que, apesar do aumento efetivo no comprimento mandibular, não houve uma compensação, mantendo-se essa redução.

A rotação mandibular decorrente da distalização dos molares superiores é uma consequiência do movimento de inclinação distal das coroas e isto também pôde ser verificado neste estudo. Entretanto, CARANO; TESTA; 
ROTUNNO ${ }^{31}$, em 1999, empregando o aparelho Distal Jet na distalização de molares superiores não constataram a divergência mandibular, apesar da inclinação distal dos molares.

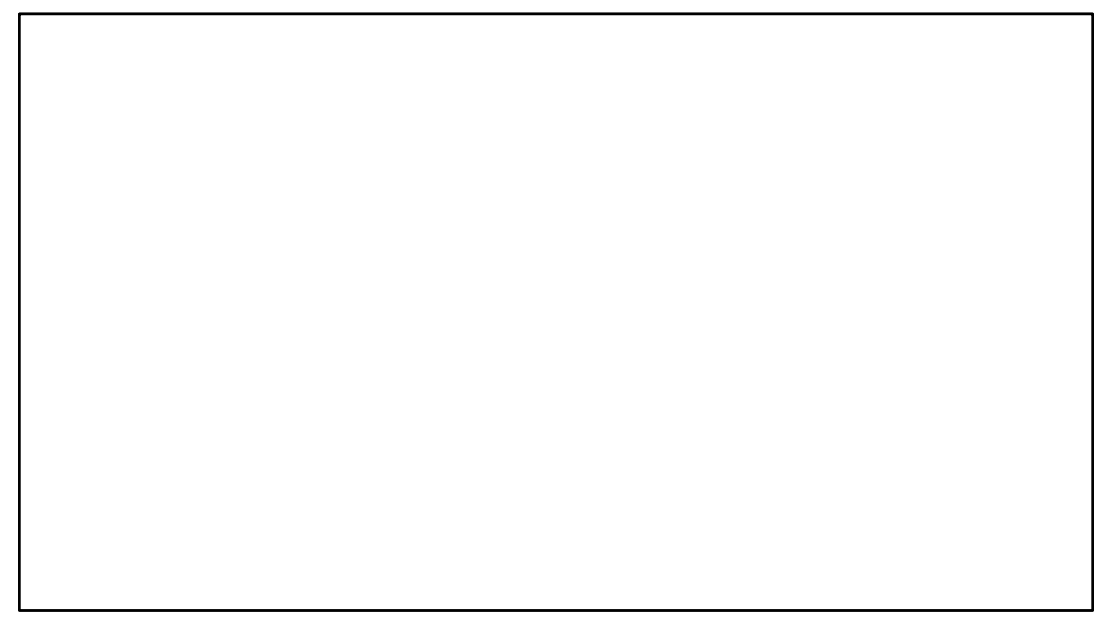

GRÁFICO 4. Posição ântero-posterior da mandíbula avaliada pela distância Pg-NPerp média inicial e final

\subsection{3- Alterações verticais}

O aparelho Pendulum produziu primariamente alterações dentoalveolares no arco superior e em menor extensão na maxila e mandíbula. A mandíbula sofreu uma ligeira rotação, o que explica alterações verticais significantes constatadas pelas grandezas cefalométricas de AFAI (de 65,98 mm para $67,92 \mathrm{~mm}$ ), SN.GoGn (de $30,71^{\circ}$ para $31,18^{\circ}$ ), FMA (de $24,52^{\circ}$ para $25,51^{\circ}$ ), Frank.Pal. (de $-1,23^{\circ}$ para $-0,61^{\circ}$ ), Frank.GoGn (de $22,25^{\circ}$ para $23,16^{\circ}$ ) e SN.Gn (de $67,17^{\circ}$ para $67,64^{\circ}$ ), que mostraram aumentos em seus valores quando comparadas as fases inicial e final do experimento. Os resultados dessa pesquisa concordaram com as alterações observadas por BUSSICK; McNAMARA $\mathrm{Jr}^{25}$, em 2000, que empregaram o aparelho Pendulum para a distalização de molares superiores, principalmente com relação às variações nas 
medidas: AFAI (de 65,4 para 67,6 mm), Frank.Pal (de $-0,9$ para $-0,9 \mathrm{~mm}$ ), Frank.PIOcl (de 8,3 para 9,4 $4^{\circ}$ ), Frank.GoGn (de 23,7 para 24,7 $)$. Entretanto, os resultados de GOSH; NANDA ${ }^{60}$, em 1996, comprovaram que a distância AFAI não se alterou de forma significante e que esse resultado poderia ter sido diferente caso a amostra de pacientes com alto ângulo do plano mandibular fosse maior.

A rotação mandibular foi observada por GOSH; NANDA ${ }^{60}$, em 1996, e por BUSSICK; McNAMARA $\mathrm{Jr}^{25}$, em 2000, que ao utilizarem o aparelho Pendulum para a distalização dos molares superiores verificaram que o plano mandibular sofreu uma rotação horária de $1,09^{\circ}$ e $1,0^{\circ}$, respectivamente, confirmada pelo ângulo SN.GoMe. Porém, para GOSH; NANDA ${ }^{60}$, em 1996, essa rotação mandibular não foi significante contrastando com as observações desse estudo, com relação ao ângulo SN.GoGn.

De um modo geral, os aparelhos distalizadores produzem forças que atuam distantes do centro de resistência, promovendo uma tendência rotacional dos molares, caracterizada pelas inclinações distais das coroas, o que explica a rotação mandibular e os aumentos observados nos valores cefalométricos de AFAI, SN.GoGn, FMA, Frank. Pal., Frank. GoGn, SN.Gn, neste estudo (Gráfico 5). Porém, estes aumentos não excederam o valor de $1^{\circ}$ para os ângulos e de 2,0 mm para o AFAI. Essa tendência de abertura anterior foi confirmada por HILGERS ${ }^{74}$, em 1992, quando o autor preconizou o aparelho Pendulum/Pendex, contraindicando a utilização do sistema em pacientes com padrão dolicocefálico e, especialmente nos casos de hábitos de sucção ou interposição lingual, devido à rotação mandibular para baixo e para trás que ocorre como conseqüência dessa mecanoterapia, o que foi também comprovado por BUSSICK; McNAMARA Jr ${ }^{25}$ em 2000, e JOHNSON ${ }^{84}$, em 1994, com o emprego do aparelho de resina acrílica cérvico-occipital. 


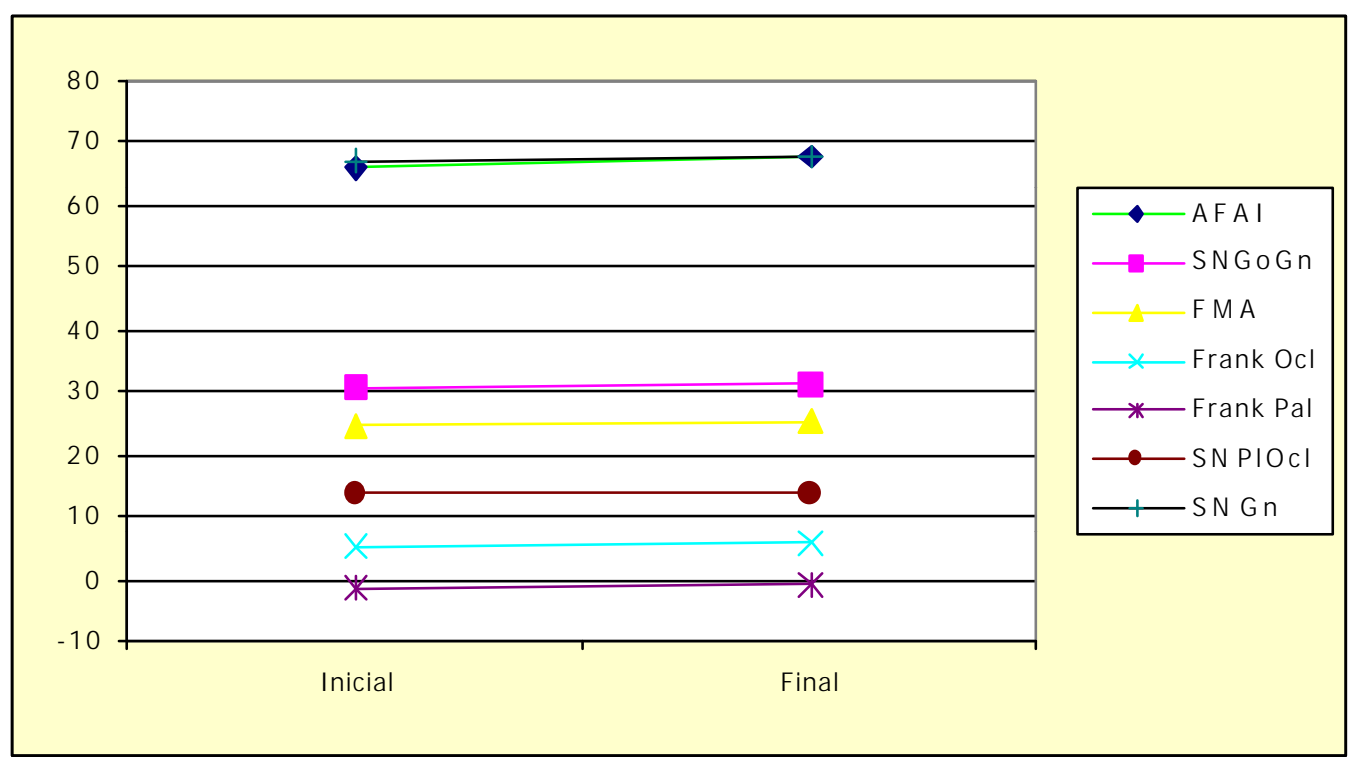

Gráfico 5. Relação vertical avaliada pelos valores médios iniciais e finais de: AFAI, SN.GoGn, FMA, Frank.Ocl, Frank.Pal, Frank.GoGn, SN.PlOcl e SN Gn.

A inclinação distal dos molares ocorre com o centro de rotação próximo do ápice radicular desses elementos dentários, possibilitando a manutenção do plano mandibular, segundo JOSEPH; BUTCHART ${ }^{86}$, em 2000.

Acredita-se que na fase de verticalização dos molares ocorra um retorno à situação inicial pela ação das forças oclusais, desde que o paciente possua um padrão do esqueleto cefálico favorável, segundo mencionado por HILGERS $^{74}$, em 1992, e MARTINS; MELO; MARTINS ${ }^{98}$, em 1996.

Porém, BYLOFF; DARENDELILER ${ }^{26}$, em 1997, revelaram que não ocorreram mudanças verticais significativas decorrentes da distalização dos molares superiores com o aparelho Pendulum empregado em pacientes com a presença ou não de segundos molares e tendo-se como padronização a ativação 
das molas, estabelecendo-se um ângulo de $45^{\circ}$ com o centro do helicóide. A força resultante dessa ativação foi de $250 \mathrm{~g}$. Na segunda parte da pesquisa, BYLOFF et $\mathrm{al}^{.27}$, em 1997, preconizaram que as molas deveriam receber as dobras de antiinclinação de $15^{\circ}$ na tentativa de se controlar a inclinação distal das coroas dos molares superiores, e constataram que não houve alterações verticais mesmo com a introdução dessa modificação.

Aumentos semelhantes aos resultados desse estudo foram constatados por BONDEMARK; KUROL; BERNHOLD ${ }^{19}$, em 1994, com o emprego de magnetos de repulsão e molas superelásticas de níquel-titânio para a distalização de molares superiores, principalmente no ângulo SN.GoMe que sofreu uma rotação horária de $1,0^{\circ}$. Tais observações foram verificadas também por GULATI; KHARBANDA; PARKASH ${ }^{64}$, em 1998, nos ângulos Frank. GoMe e SN.PIOcl na distalização de molares superiores com o aparelho Jones Jig.

Utilizando os magnetos para a distalização de molares, BONDEMARK; KUROL ${ }^{18}$, em 1992, não observaram alterações verticais significativas no ângulo SN. Plano mandibular.

A inclinação do plano palatino permaneceu inalterada, porém os planos oclusal e mandibular sofreram uma abertura, segundo BUSSICK; McNAMARA $\mathrm{Jr}^{25}$, em 2000. Entretanto, GOSH; $\mathrm{NANDA}^{60}$, em 1996; BYLOFF; DARENDELILER ${ }^{26}$, em 1997; BYLOFF et al. ${ }^{27}$, em 1997, observaram que a alteração na inclinação do plano palatino foi insignificante. Nesse estudo, constatou-se a inclinação significante do plano palatino para cima de $0,62^{\circ}$ (variação no valor de Frank.Pal de $-1,23^{\circ}$ para $-0,61^{\circ}$ ), assim como os planos oclusal e mandibular sofreram uma rotação para baixo e para trás, de $0,45^{\circ}$ (alteração no valor de Frank.Ocl de $5,15^{\circ}$ para 5,6 ) e $0,91^{\circ}$ (variação de Frank.GoGn de $22,25^{\circ}$ para $23,16^{\circ}$ ), respectivamente, confirmando nesses dois aspectos as observações de BUSSICK; McNAMARA $\mathrm{Jr}^{25}$ de abertura desses 
planos. No presente estudo, apesar da alteração na inclinação do plano oclusal constatada pelo valor de Frank.Ocl, a variação da medida SN.PlOcl de 13,66 para $13,62^{\circ}$, não foi significativa.

\subsection{4 - Alterações na relação maxilomandibular}

No presente estudo, a relação maxilomandibular foi avaliada pelo ângulo ANB e pela distância linear Wits (Gráfico 6). Por meio dos resultados, observou-se que o ângulo ANB sofreu um aumento significante da média inicial de $4,05^{\circ}$ para $4,41^{\circ}$. Esse efeito esquelético sagital pode ser justificado pelo movimento anterior da maxila entre as fases estudadas e pelo aumento no comprimento da face média. Porém, as alterações decorrentes da rotação mandibular para baixo e para trás provocou a diminuição do ângulo SNB e da distância Pg-NPerp, acarretando no final a alteração no ângulo ANB. Considerações semelhantes também foram realizadas por BUSSICK; McNAMARA $\mathrm{Jr}^{25}$, em 2000, que constataram um aumento médio de apenas $0,4^{\circ}$, entretanto considerado significante em seu estudo.

Por outro lado, nesse estudo, a distância Wits não mostrou uma variação significante, como pode ser verificado pelo aumento na medida inicial de 3,2 $\mathrm{mm}$ para $3,85 \mathrm{~mm}$ ao final da distalização dos molares. Essa mudança resulta do deslocamento anterior do ponto $\mathrm{A}$, em virtude do aumento da protrusão dos incisivos superiores e também pela rotação mandibular para baixo e para trás, conduzindo ao posicionamento posterior do ponto B. Na pesquisa de BUSSICK; McNAMARA Jr ${ }^{25}$, em 2000, os autores verificaram que a variação nessa medida não foi significante, sendo que o valor médio inicial de 1,6 mm alterou-se para $1,3 \mathrm{~mm}$.

Outra explicação que pode ser direcionada a essa situação é que a força produzida pelo aparelho Pendulum foi insuficiente para gerar a alteração 
ortopédica da maxila para a dorsal, e o resultado foi predominantemente dentoalveolar, com o ponto A sendo movimentado mais para a vestibular como conseqüência da perda de ancoragem. Entretanto, segundo pesquisas de BAUMRIND et al. ${ }^{15}$, em 1983; WIESLANDER ${ }^{152}$, em 1975; PANCHERZ ${ }^{13}$, em 1984; CANGLIALOSI et al. ${ }^{30}$, em 1988; ÖZTÜRK; TANKUTER ${ }^{111}$, em 1994, e HAAS $^{65}$, em 2000, a utilização de forças extrabucais pesadas sobre a maxila ocasionou a retração do ponto A, com influência direta no ângulo SNA e proporcionando um ligeiro aumento no ângulo SNB e a conseqüente redução do ângulo ANB. Portanto, comprovaram que a melhoria na relação maxilomandibular somente se manifestava com o emprego dessas forças pesadas.

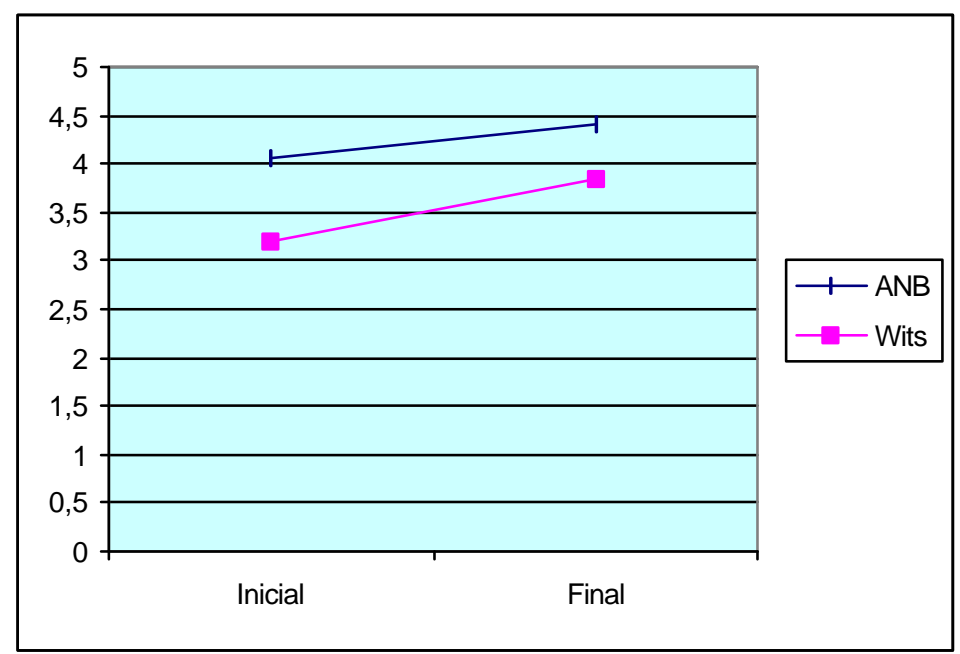

GRÁFICO 6. Relação maxilomandibular avaliada pelos valores médios iniciais e finais de ANB e WITS.

Clinicamente, notou-se um ligeiro aumento na sobressaliência, o que denota a alteração da relação maxilomandibular verificada nesse estudo e que é visualizada por meio do gráfico 6 que demonstra as variações nas médias 
iniciais e finais do ângulo ANB e da distância linear Wits. Pode ser constatado nesta representação que o ângulo ANB permaneceu praticamente constante durante a fase avaliada e que o aumento na medida de Wits foi maior, porém estatisticamente não significante.

\subsection{5 - Efeitos dentários resultantes da distalização}

Para a avaliação das alterações dentárias sagitais, foram empregadas as telerradiografias em norma lateral convencional, de $45^{\circ}$ e modelos de estudo. Foram consideradas as fases inicial e final de distalização dos molares superiores, que permitiram quantificar os deslocamentos dos molares que compuseram a unidade receptora da força distalizadora e os pré-molares, caninos e incisivos que pertencem à unidade de ancoragem.

Como a grande maioria dos aparelhos distalizadores recorrem a um botão palatino de Nance que se apóia sobre o palato e em pré-molares para que seja possível aplicar a força aos molares, teremos reciprocamente os deslocamentos dentários nas duas unidades, a receptora da força e a de ancoragem, sendo portanto, previsível que acabe resultando no movimento distal dos molares e mesial de pré-molares, caninos e incisivos. Porém, a grande dúvida a ser esclarecida é: "qual a quantidade de movimento efetivo dos molares que ocorrerá e quanto de perda de ancoragem estará relacionada simultaneamente a essa distalização?. 
O presente estudo apresenta a discussão das alterações dentárias divididas em:

\subsubsection{1 - Alterações dentárias sagitais;}

6.4.5.2 - Perda de ancoragem;

6.4.5.3 - Alterações dentárias verticais;

6.4.5.4 - Alterações dentárias transversais;

6.4.5.5 - Taxa de distalização mensal;

\subsubsection{1 - Alterações dentárias sagitais}

O aparelho Pendulum empregado nesse estudo teve uma padronização da ativação das molas em $60^{\circ}$, produzindo uma força distalizadora de $253 \mathrm{~g}$. Esse aparelho distalizou efetivamente os molares superiores até a sobrecorreção de Classe I num período médio de 5,87 meses. Essa distalização ocorreu sem a necessidade da cooperação dos pacientes e somente com uma única ativação das molas distalizadoras durante toda a fase estudada.

HILGERS $^{74}$, em 1992, observou que o aparelho poderia distalizar os molares superiores $5,0 \mathrm{~mm}$ em 4 meses de tratamento e que essa distalização estaria associada à inclinação distal das coroas, havendo, portanto, a necessidade da sobrecorreção, pois na fase da verticalização dos molares ocorreria a recidiva de aproximadamente 20 a $30 \%$ do movimento alcançado. GOSH; NANDA ${ }^{60}$, em 1996, empregando também o aparelho Pendulum com as molas ativadas em $60^{\circ}$, constataram que a distalização dos primeiros molares foi de $3,37 \mathrm{~mm}$, e associada à inclinação distal da coroa de $8,36^{\circ}$.

BYLOFF; DARENDELILER ${ }^{26}$, em 1997, utilizaram o aparelho Pendulum com a ativação das molas em $45^{\circ}$, gerando a força de 200 a $250 \mathrm{~g}$. 
Verificaram que a distalização dos molares superiores foi de 3,39 mm associada à inclinação distal da coroa de $14,50^{\circ}$, num período de 4 meses. Porém, no intuito de se controlar a inclinação distal excessiva resultante desse sistema, BYLOFF et al. ${ }^{27}$, em 1997, preconizaram a distalização dos molares em duas fases, sendo que na segunda fase foi incorporada uma dobra de antiinclinação de $15^{\circ}$ do segmento intratubo em relação ao plano oclusal, e perceberam que o movimento distal resultante foi de $4,14 \mathrm{~mm}$, com a inclinação distal da coroa de $6,07^{\circ}$. Apesar do controle da inclinação da coroa, houve um aumento significativo no tempo de tratamento para 6 meses e 3 semanas. BUSSICK; McNAMARA $\mathrm{Jr}^{25}$ empregaram o aparelho Pendulum com as molas ativadas em 60 a $90^{\circ}$, exercendo a força de 200 a 250 g sobre os molares superiores e verificaram uma mudança média na relação molar de $6,4 \mathrm{~mm}$, medida da face mesial dos primeiros molares ao longo do plano oclusal. A distalização média dos primeiros molares de $5,7 \mathrm{~mm}$, acompanhada da inclinação distal de $10,6^{\circ}$, foi alcançada num período de 7 meses. JOSEPH; BUTCHART ${ }^{86}$, em 2000, utilizando o aparelho Pendulum com as molas ativadas em $90^{\circ}$, constataram a distalização média dos primeiros molares de $5,1 \mathrm{~mm}$ associada à inclinação distal das coroas de $15,7^{\circ}$, num período de 1,5 a 5,0 meses de tratamento. TOROGLU et al. ${ }^{144}$, em 2001, usando o aparelho Pendulum com as molas ativadas paralelas a linha mediana do palato, em pacientes com ângulos FMA menor ou igual a $24^{\circ}$ e maior ou igual a $29^{\circ}$, respectivamente de $5,9 \mathrm{~mm}$ e 4,1 $\mathrm{mm}$.

Nesse estudo, por meio da alteração significante da distância 6PTV inicial de 27,64 mm para 23,04 mm, observou-se que a distalização média dos molares superiores foi de 4,60 mm, num período de 5,87 meses (Gráfico 7). Entretanto, essa distalização foi alcançada pela inclinação distal média da coroa de $18,50^{\circ}$, segundo a variação média do ângulo Frank.6 (Gráfico 10). Como 
pode ser visto, a distalização dos molares superiores alcançada nesse estudo foi semelhante à taxa citada por HILGERS ${ }^{74}$, em 1992, porém superior àquela atingida nas pesquisas de GOSH; NANDA ${ }^{60}$, em 1996; BYLOFF; DARENDELILER $^{26}$, em 1997 e BYLOFF et al. ${ }^{27}$, em 1997. Entretanto, a distalização observada nesse estudo foi inferior ao movimento dos molares conseguido por BUSSICK; McNAMARA $\mathrm{Jr}^{25}$, em 2000 e JOSEPH; BUTCHART $^{86}$, em 2000.

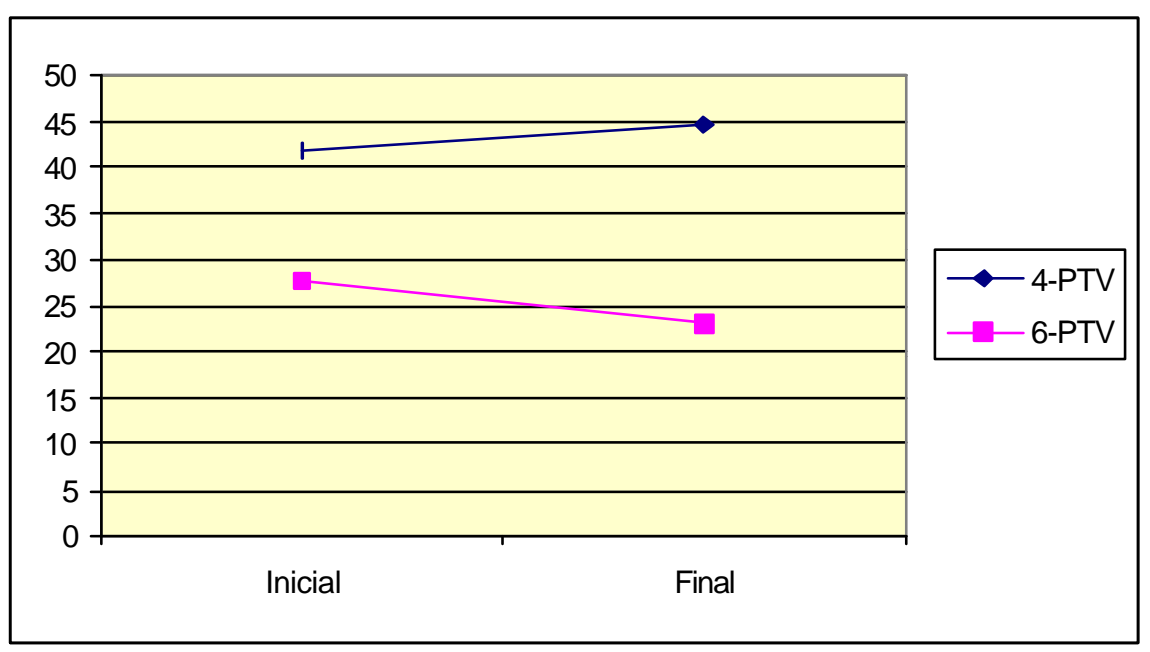

Gráfico 7. Alterações sagitais avaliadas pelas distâncias médias iniciais e finais de 4-PTV e 6-PTV.

Justifica-se a diferença na distalização dos primeiros molares dessa pesquisa em relação à taxa notada por BUSSICK; McNAMARA Jr ${ }^{25}$ e JOSEPH; BUTCHART $^{86}$, principalmente pelo fato de que nos referidos estudos, o aparelho foi utilizado numa amostra em que aproximadamente 50\% dos pacientes ainda não possuíam os segundos molares irrompidos e a idade média inicial dos indivíduos participantes era de aproximadamente 12 anos e portanto inferior à idade média inicial dos pacientes desse estudo, 14 anos e 7 meses e em 
que todos apresentavam os segundos molares irrompidos e a presença dos terceiros molares constatada radiograficamente. A presença dos segundos molares é considerada um obstáculo para a distalização dos molares superiores, principalmente quando se consideram os aparelhos extrabucais (JOSEPH; BUTCHART $^{86}$, em 2000), os magnetos de repulsão (GIANELLY; VAITAS; THOMAS $^{56}$, em 1989), as molas superelásticas de níquel-titânio (GIANCOTTI; COZZA $^{53}$, em 1998) e o aparelho Pendulum. Segundo HILGERS ${ }^{74}$, em 1992, o movimento distal dos molares superiores era mais eficiente antes da irrupção dos segundos molares. Além do fato de que algumas pesquisas complementam que a distalização dos primeiros molares superiores deveria ser realizada antes da irrupção dos segundos molares (GRABER ${ }^{61}$, em 1955; WILSON ${ }^{153}$, em 1978; ITOH $^{80}$, em 1991; HILGERS ${ }^{74}$, em 1992), ou caso os segundos molares já estivessem irrompidos, a distalização deveria ser efetuada em duas fases, primeiro conduzindo os segundos molares e finalmente os primeiros molares (GIANELLY; VAITAS; THOMAS ${ }^{56}$, em 1989; JECKEL; RAKOSI ${ }^{83}$, em 1991; HILGERS ${ }^{74}$, em 1992 e GIANCOTTI; COZZA ${ }^{53}$, em 1998). Nos casos em que fosse necessário a realização de uma grande distalização dos primeiros molares superiores, seria aconselhável a execução das exodontias dos segundos molares, desde que os germes dos terceiros molares estivessem em bom posicionamento e favoráveis a irrupção $\left(\right.$ QUINN $^{120}$, em 1985; MAGNESS ${ }^{95}$, em 1986; HILGERS ${ }^{74}$, em 1992; ZANELATO; TREVISI; ZANELATO ${ }^{158}$, em 2000)

Outro problema citado e que se relaciona com a presença dos segundos molares superiores na distalização é a possibilidade da maior perda de ancoragem, pois a área radicular aumenta e a distalização ocorre associada também com a acentuada inclinação das coroas (BONDEMARK; KUROL ${ }^{18}$, em 1992). Esse comentário já havia sido feito por GIANELLY; BEDNAR; 
DIETZ $^{55}$, em 1991, que complementaram ainda, que o tempo de tratamento aumentava diante da presença dos segundos molares.

A segunda explicação para a diferença relaciona-se ao tempo total de tratamento, pois nesse estudo a distalização foi de $4,60 \mathrm{~mm}$, porém conseguida num tempo de 5,87 meses e o trabalho de BUSSICK; McNAMARA $\mathrm{Jr}^{25}$ de 6,4 mm, em 7 meses. Portanto, proporcionalmente a quantidade de distalização em relação ao tempo total foi maior no presente estudo.

Nesse estudo, ainda a relação molar inicial era de Classe II completa e na pesquisa de JOSEPH; BUTCHART ${ }^{86}$, em 2000, do total de sete pacientes, quatro possuíam a distoclusão completa e os outros três, uma relação de Classe II de meia cúspide e ainda, no estudo de BUSSICK; McNAMARA $\mathrm{Jr}^{25}$ não foi mencionada a magnitude da relação oclusal de Classe II.

Outros estudos, tais como os de MUSE et al. ${ }^{109}$ em 1993; GOSH; NANDA $^{60}$, em 1996; BYLOFF; DARENDELILER ${ }^{26}$, em 1997; BYLOFF et al. $^{27}$, em 1997; HARNICK ${ }^{67}$, em 1998; BUSSICK; McNAMARA Jr ${ }^{25}$, em 2000, entretanto, comprovaram que a distalização poderia ser alcançada com sucesso independente da presença ou não dos segundos molares, da idade dos pacientes ou da relação molar. Nesse aspecto, compara-se à constatação feita por esse estudo, sendo que foi possível a correção da relação molar de Classe II, mesmo com a presença dos segundos molares e sem a extração prévia dos terceiros molares.

Nenhuma das pesquisas realizadas com o emprego do aparelho Pendulum se preocuparam em estabelecer valores de distalização para os primeiros e segundos molares isoladamente, utilizando-se modelos de estudo obtidos nas fases inicial e final. Assim sendo, nesse estudo foi constatado que o movimento distal dos molares ocorreu da segunite forma: 1) primeiros molares direito e esquerdo, respectivamente em $4,45 \mathrm{~mm}$ e $5,22 \mathrm{~mm}$ e 2) segundos 
molares direito e esquerdo, respectivamente em 4,22 e 5,28 mm (Gráficos 11 e 12).

Prévios estudos, recorrendo a outros recursos distalizadores, observaram resultados distintos. Assim sendo, KUROL; BJERKLIN ${ }^{90}$, em 1984, defenderam o emprego de forças extrabucais de tração cervical com $250 \mathrm{~g}$ de cada lado, e notaram que os molares movimentaram-se distalmente, num período de 9 a 12 meses. Ainda, considerando as forças extrabucais, HUBBARD; NANDA; CURRIER ${ }^{78}$, em 1994, recomendaram para a tração cervical, força de 650 a 770 g de cada lado e enfatizaram que a distalização somente era alcançada mediante a cooperação dos pacientes. Uma distalização dos molares superiores de 2,4 $\mathrm{mm}$ em quatro meses era possível, desde que se utilizasse a força extrabucal de tração alta com magnitude de 1135 a 1360 g por lado (BADELL ${ }^{12}$, em 1976).

Nota-se, com o emprego das forças extrabucais, a necessidade da atuação de forças pesadas e de um tempo de tratamento de aproximadamente 12 meses para que resultados se manifestem, divergindo totalmente dos sistemas distalizadores intrabucais que recomendam forças mais leves e contínuas, geralmente em torno de $250 \mathrm{~g}$ e um período de 5 meses de tratamento.

Por outro lado, os magnetos de repulsão com força inicial de $250 \mathrm{~g}$ podem mover os molares distalmente na taxa mensal de 0,75 a $1,0 \mathrm{~mm}$ (GIANELLY et al. ${ }^{57}$, em 1988), atingindo a distalização de aproximadamente 3,97 mm, num tempo de 5,53 meses (GIANELLY;VAITAS; THOMAS ${ }^{56}$, em 1989). Entretanto, para BONDEMARK; KUROL ${ }^{18}$, em 1992, a distalização mediante o emprego de magnetos era de $4,2 \mathrm{~mm}$, associada à inclinação distal da coroa de 8,0 ${ }^{\circ}$. BONDEMARK; KUROL; BERNHOLD ${ }^{19}$, em 1994, e ERVERDI; KOYUTÜRK; KÜÇÜKKELES ${ }^{46}$, em 1997, observaram a distalização de 2,2 mm e inclinação distal de 7,6 . Porém, ITOH et al. ${ }^{80}$, em 
1991, constataram uma maior efetividade quando o sistema era utilizado na dentadura mista, com a taxa de distalização de 2,1 mm em 2,5 meses.

Comparando-se os dados acima com os resultados do presente estudo, verificou-se um maior controle na inclinação distal da coroa dos primeiros molares com o emprego dos magnetos de repulsão. No entanto, a taxa de distalização foi metade da constatada com o emprego do aparelho Pendulum e, possivelmente, a razão para essa diferença é a constância da força distalizadora do aparelho Pendulum. Nos magnetos, a variação na força é relacionada à distância entre os pólos magnéticos; após o movimento inicial que normalmente é alcançado num período de 3 semanas a força decai bruscamente, mantendo-se a proporção da redução para $30 \%$ da força inicial para cada milímetro de separação dos pólos, o que conduz à conclusão de que a força residual de $60 \mathrm{~g}$ apresentava-se abaixo da ideal para a distalização dos molares, havendo, portanto a necessidade das reativações com maior frequiência (BONDEMARK; $\mathrm{KUROL}^{18}$, em 1992). Assim, ITOH et al. ${ }^{80}$, em 1991, recomendaram as reativações a cada duas semanas.

As molas superelásticas de níquel-titânio, exercendo força de $100 \mathrm{~g}$, promovem a taxa de distalização mensal de 1 a $1,5 \mathrm{~mm}$ com pouca ou nenhuma cooperação dos pacientes, porém GIANELLY; BEDNAR; DIETZ ${ }^{55}$, em 1991; ERVERDI; KOYUTÜRK; KUÇÜKKELES ${ }^{46}$, em 1997 e GIANELLY et al. ${ }^{57}$, em 1988, recomendaram a realização prévia das exodontias dos terceiros molares. Por outro lado, GIANCOTTI; COZZA $^{53}$, em 1998, verificaram a possibilidade da abertura de 1 a $2 \mathrm{~mm}$ de espaço, desde que a distalização fosse executada antes da irrupção dos segundos molares. Isso denota que, comparando-se os dois mecanismos, o aparelho Pendulum foi mais efetivo, pois proporcionou uma taxa de distalização maior para uma única ativação do sistema. 
O aparelho Jones Jig inclui um sistema composto de mola de compressão com a ativação de $5 \mathrm{~mm}$ e que produz a força de 70 a $75 \mathrm{~g}$ por lado, ancorado no palato por meio de um botão palatino de Nance, cuja reativação deve ser realizada em intervalos de 4 semanas. JONES; WHITE ${ }^{85}$, em 1992 , observaram que a correção da relação molar de Classe II geralmente ocorria num período de 120 a 180 dias. RUNGE; MARTIN; BUKAI ${ }^{131}$, em 1998, verificaram que o movimento distal dos molares superiores se processava num período de 6,50 meses. GULATI; KHARBANDA; PARKASH ${ }^{64}$, em 1998, comprovaram que o aparelho Jones Jig, com força de $150 \mathrm{~g}$ por um tempo de 12 meses produz a distalização dos molares de $2,78 \mathrm{~mm}$, com a inclinação distal de 3,50. HAYDAR; ÜNER ${ }^{69}$, em 2000, constataram uma distalização média de 2,80 mm em 2,5 meses de tratamento em pacientes com más oclusões suaves de Classe II e idade média inicial de 10,1 anos.

Comparando-se os resultados do presente estudo com as constatações feitas pelas pesquisas sobre a distalização dos molares superiores com o aparelho Jones Jig, percebe-se a nítida superioridade do aparelho Pendulum na taxa de distalização e no tempo para a correção da relação molar de Classe II.

Um outro sistema distalizador empregado denomina-se arco distalizador bimétrico de Wilson, controlado pela força de módulos elásticos, por meio da redução da carga elástica para se acionar a mola de níquel-titânio que é responsável pela distalização dos molares superiores, segundo WILSON; WILSON $^{155}$, em 1980. MUSE et $\mathrm{al}^{109}$, em 1993, constataram que os molares superiores foram distalizados 2,2 $\mathrm{mm}$ e inclinados distalmente aproximadamente $8,0^{\circ}$, e de acordo com RANA; BECHER ${ }^{121}$, em 2000, o movimento foi de 1,0 $\mathrm{mm}$, com inclinação maior do que $2,0^{\circ}$, sendo que a relação molar de Classe II foi corrigida em 4,5 meses (HARNICK ${ }^{67}$, em 1998). Isso contrasta com os presentes resultados, que demonstram que a distalização foi em dobro nesSe 
mesmo tempo de tratamento, podendo ser justificado pelo fato de que existe a dependência da colaboração dos pacientes na utilização dos elásticos de Classe II para o acionamento do sistema, o que contradiz com os objetivos dos sistemas intrabucais que foram introduzidos para se eliminar o fator colaboração no sucesso da terapia ortodôntica.

O componente ativo do aparelho Distal Jet incorpora dois tubos de 0,9 $\mathrm{mm}$ que se conectam ao botão palatino de Nance e um outro fio em forma de uma baioneta que é inserido no tubo lingual dos primeiros molares, por onde desliza uma mola de aço que, ao ser comprimida, exerce uma força de $150 \mathrm{~g}$, distalizando os molares na proporção de 3 a $5,0 \mathrm{~mm}$ em 4 meses, segundo CARANO; TESTA; SICILIANI ${ }^{32}$, em 1996. Para cada milímetro de distalização ocorrem $6^{\circ}$ de inclinação distal, de acordo com CARANO; TESTA ; ROTUNNO $^{31}$, em 1999. QUICK; HARRIS ${ }^{119}$, em 2000, complementaram o uso do aparelho Distal Jet com molas comprimidas por vestibular e verificaram um melhor controle na rotação molar.

A grande diferença notada entre o aparelho Distal Jet e o sistema utilizado nesse estudo é que as molas do Distal Jet podem ser de aço ou de níquel-titânio, e independente do material de composição das molas, necessitam de reativações mensais, pois a redução da força ocorre de forma acentuada principalmente nas molas de aço, cuja proporção carga-deflexão é muito elevada, não havendo a constância da força. Nas molas do aparelho Pendulum, isso não representa problema, pois as molas são ativadas uma única vez durante a distalização de $5 \mathrm{~mm}$. As molas do aparelho Pendulum foram construídas com liga de titânio-molibdênio, cuja carga-deflexão é inferior e conseqüentemente gera uma constância no nível de força.

Outra vantagem do uso do Pendulum é o melhor controle da inclinação distal dos molares superiores durante a distalização, pois com o 
emprego do aparelho Distal Jet, houve a inclinação de $6,0^{\circ}$ para cada milímetro de movimento dos molares (CARANO; TESTA; ROTUNNO ${ }^{31}$, em 1999), enquanto que com o parelho Pendulum neste estudo esta inclinação foi de $4,02^{\circ}$.

Os resultados laboratoriais comprovaram que a barra transpalatina de Goshgarian produz a força média de $16 \mathrm{~g} / \mathrm{mm}$ por milímetro de deflexão distal (HAAS; CISNEROS ${ }^{66}$, em 2000). Esse valor foi maior do que os valores citados por CETLIN ${ }^{35}$, em 1990, de 30 g por $3 \mathrm{~mm}$ de deflexão distal. Acima de $35^{\circ} \mathrm{e}$ 17,2 mm de deflexão distal, o material se deforma permanentemente. Para o movimento distal dos molares, seria exigida uma maior ativação, para compensar a quantidade relativamente pequena de força gerada pelas deflexões. Em resumo, os molares são submetidos a rotação, assim como a inclinação distal no lado da ativação do sistema. Como se pode perceber, para que seja produzida a força necessária para a distalização dos molares, é necessária a realização de uma quantidade de deflexão muito próxima da ocorrência da deformação permanente do material. Outra desvantagem verificada nesse sistema é a realização do movimento distal em etapas, ou seja, um molar por vez e a exposição do molar do lado oposto a um momento que tenderá a causar um efeito rotacional para a mesial. No estudo em questão, o aparelho Pendulum possibilitou a distalização simultânea dos molares sem os efeitos adversos de rotação mesial, como ocorreu com a barra transpalatina de Goshgarian.

O aparelho Herbst tem um pronunciado efeito na distalização dos molares superiores, segundo PANCHERZ ${ }^{112}$, em 1982; WINDMILLER ${ }^{156}$, em 1993; PANCHERZ; PANCHERZ ${ }^{114}$, em 1993, e FRANCHI; BACETTI; McNAMARA $\mathrm{Jr}^{51}$, em 1999. O mecanismo telescópico do aparelho exerce uma força intrusiva e distalizadora sobre os molares superiores e o vetor de força passa oclusalmente ao centro de resistência, produzindo um movimento para trás 
e para cima dos molares superiores, associado à inclinação distal da coroa (GREENSPAN $^{63}$, em 1970 e LAI $^{91}$, em 2000). Porém, comparativamente, os resultados desse estudo demonstram que o aparelho Pendulum produz uma maior taxa de distalização dos molares superiores e isso é atribuído ao fato de que originalmente o aparelho Herbst foi idealizado para redirecionar o crescimento das bases ósseas mais do que para distalizar especificamente os molares superiores.

Um meio alternativo de distalizar os molares superiores é a aplicação do aparelho acrílico cervical occipital que consiste em um aparelho ortodôntico removível com grampos de retenção nos pré-molares, arco vestibular e molas ativadas de 4 a $5 \mathrm{~mm}$ para produzir a força de 100 a $125 \mathrm{~g}$ contra a mesial dos primeiros molares, promovendo a distalização mais efetiva nos casos de molares com rotação mesiopalatina ao início do tratamento. JOHNSON ${ }^{84}$, em 1994; aconselhou nos casos de presença dos segundos molares a realização da distalização seqüencial, começando com os primeiros molares e depois os segundos molares. A taxa de distalização resultante do emprego desse tipo de sistema foi semelhante à dos magnetos, ou seja, de 1,0 mm mensal com uma grande inclinação das coroas para a distal, exigindo portanto a sobrecorreção como compensação para a fase de verticalização dos molares (LEWIS; FOX ${ }^{93}$, em 1996).

No entanto, esse é um sistema que depende da cooperação do paciente para que efeitos positivos sejam alcançados, pois a força gerada por esse sistema é intermitente e exige as reativações mensais, o que não foi necessário com o aparelho Pendulum, pois o mecanismo é isento da necessidade da cooperação do paciente e uma única ativação produziu a distalização simultânea dos primeiros e segundos molares de 4,60 mm em 5,87 meses. 
Visando a uma distribuição mais homogênea das forças pelo centro de resistência dos molares superiores, REINA; MENDOZA ${ }^{122}$, em 1999, desenvolveram um aparelho distalizador de molares que possuía uma mola com três helicóides construídos com fio de aço Elgiloy azul de diâmetro 0,8 mm. Esse aparelho proporciona uma grande distalização dos molares superiores, com uma acentuada inclinação distal das coroas. As reativações devem ser realizadas de quatro a seis semanas com o emprego do alicate de três pontas ou tridente.

Ao observarmos o desenho desse aparelho, verifica-se uma grande semelhança com o aparelho Pendulum, porém é construído com três helicóides, provavelmente com o intuito de reduzir a carga-deflexão, pois o fio utilizado é de aço e relativamente espesso. Em termos de propriedade mecânica, a liga de titânio-molibdênio é superior, pois apresenta um módulo de elasticidade de 0,42 do aço de mesmo diâmetro e proporção carga-deflexão menor, liberando uma força de aproximadamente $40 \%$ da do fio de aço de mesmo calibre, o que garante uma maior constância da força e resultados com certeza melhores (SACHDEVA et al. ${ }^{132}$, em 1990). E não podemos deixar de ressaltar que as reativações do aparelho hexahélice devem ser realizadas intrabucalmente com o emprego de alicates de três pontas, dificultando o controle da força resultante e possivelmente aumentando a ocorrência de efeitos indesejáveis, tais como as expansões e rotações dentárias.

Os aparelhos intrabucais distalizadores atuam nas coroas dentárias, a uma determinada distância do centro de resitência dos molares, e portanto é justificável que ocorra a inclinação distal das coroas desses dentes ao serem movimentados para a distal. A maioria dos estudos mencionados avaliaram as alterações sagitais e angulares dos molares por meio das telerradiografias em norma lateral convencional. Nesse estudo, observaram-se, por meio da avaliação das telerradiografias em norma lateral de $45^{\circ}$, as alterações angulares dos 
primeiros e segundos molares superiores distintamente. Assim sendo, o primeiro molar superior direito sofreu uma alteração na média inicial de $83,08^{\circ}$ para $71,72^{\circ}$ e o segundo molar superior direito de $66,44^{\circ}$ para $52,41^{\circ}$, sendo a inclinação distal média de $11,36^{\circ}$ e de $14,03^{\circ}$, respectivamente para o primeiro e segundo molar. No lado esquerdo, o primeiro molar superior variou a sua angulação de $80,98^{\circ}$ para $67,01^{\circ}$ e o segundo molar de $67,61^{\circ}$ para $49,18^{\circ}$, e portanto a inclinação distal média foi de $13,97^{\circ}$ e de $18,43^{\circ}$, respectivamente para o primeiro e segundo molar, gráficos 8 e 9.

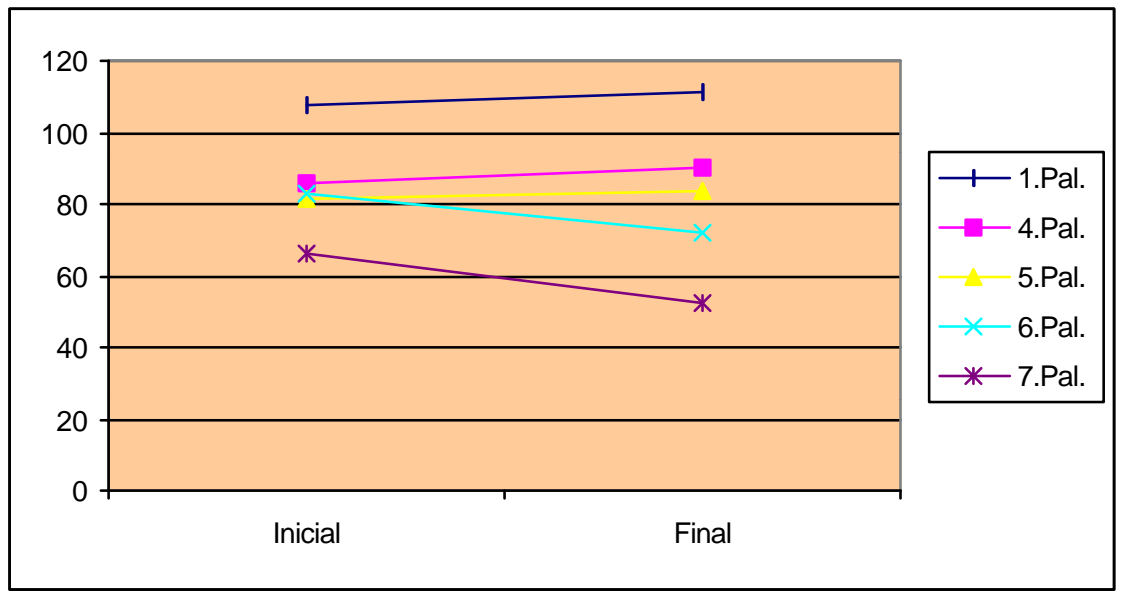

GRÁFICO 8. Alterações angulares avaliadas pelos valores médios iniciais e finais de 1.Pal, 4.Pal, 5.Pal, 6.Pal e 7.Pal, referentes ao lado direito. 


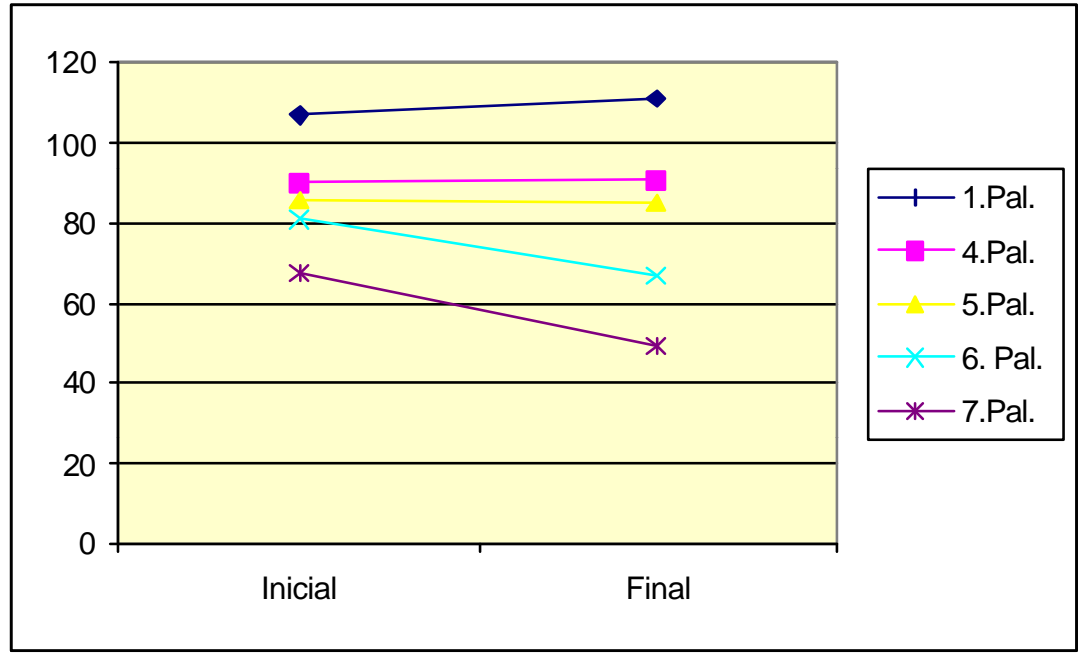

GRÁFICO 9. Alterações angulares avaliadas pelos valores médios iniciais e finais de 1.Pal, 4.Pal, 5.Pal, 6.Pal e 7.Pal, referentes ao lado esquerdo.

Nota-se que essas alterações nas inclinações axiais dos molares superiores apresentam-se próximas dos valores observados por outros estudos que também empregaram o aparelho Pendulum, porém com as constatações feitas em telerradiografias em norma lateral convencional e sem a preocupação de avaliar os primeiros e segundos molares separadamente. GOSH; NANDA ${ }^{60}$, em 1996 e BYLOFF; DARENDELILER ${ }^{26}$, em 1997 encontraram a inclinação de 8,3 e 14,5 ${ }^{\circ}$, respectivamente. BYLOFF; DARENDELILER ${ }^{26}$, em 1997, não constataram correlação significante entre a taxa de distalização dos molares e o grau de inclinação distal dos molares. BYLOFF et al. ${ }^{27}$, em 1997, tentaram minimizar a inclinação distal dos molares durante a distalização pela incorporação das dobras de antiinclinação de $15^{\circ}$ e verificaram uma maior verticalização das raízes dos molares. BUSSICK; McNAMARA Jr ${ }^{25}$, em 2000, observaram que a inclinação decorrente da distalização era de 10,6º , JOSEPH; 
BUTCHART $^{86}$, em 2000,a inclinação distal de 15,7 . TOROGLU et al, em 2001, verificaram que a inclinação distal dos primeiros molares foi de $13,4^{\circ}$ e $14,9^{\circ}$ em pacientes, respectivamente com baixo e alto valor do ângulo FMA.

\subsection{2 - Perda de ancoragem}

Define-se como perda de ancoragem o movimento dos elementos dentários que compõem a unidade de resistência quando um determinado dispositivo é aplicado para movimentar um ou mais elementos dentários. Como a grande maioria dos aparelhos distalizadores intrabucais buscam a ancoragem no palato por meio do botão palatino de Nance e esse por sua vez repousa sobre os pré-molares, observam-se os efeitos adversos do sistema de força sobre a unidade de ancoragem composta pelos pré-molares, caninos e incisivos.

Assim sendo, é provável a verificação do movimento mesial dos prémolares, caninos e incisivos superiores durante a distalização dos molares. E a grande dúvida a ser esclarecida é quanto à participação desses dentes na abertura do espaço entre os molares e pré-molares.

A perda de ancoragem foi medida pelo movimento dos primeiros prémolares que não resistiram à força mesial recíproca do aparelho Pendulum e foram mesializados $2,25 \mathrm{~mm}$ e inclinados mesialmente $1,29^{\circ}$. Para cada milímetro de movimento distal dos molares o pré-molar movimentou $0,75 \mathrm{~mm}$ (GOSH; NANDA ${ }^{60}$, em 1996). BYLOFF; DARENDELILER ${ }^{26}$, em 1997, verificaram que o segundo pré-molar se movimentou para a mesial 1,63 mm. O movimento distal representou $71 \%$ da abertura de espaço entre pré-molares e molares. BYLOFF et al. ${ }^{27}$, em 1997, aconselharam a incorporação das dobras de antiinclinação de $15^{\circ}$ nas molas para controlar a inclinação distal da coroa e constataram que houve um aumento de 0,61 $\mathrm{mm}$ na perda de ancoragem dos 
pré-molares e a porcentagem de distalização do molar reduziu para 70,92\%. BUSSICK; McNAMARA Jr ${ }^{25}$, em 2000, notaram que a distalização dos molares aconteceu para $76 \%$ da alteração na posição sagital entre os primeiros molares e pré-molares, sendo que $24 \%$ foi devido ao movimento anterior recíproco dos pré-molares. TOROGLU et al. ${ }^{144}$ compararam dois grupos distintos segundo os valores dos ângulos FMA e verificaram que nos pacientes com altos valores, a inclinação mesial dos segundos pré-molares foi de $3,9^{\circ}$ e o movimento mesial de 4,8 $\mathrm{mm}$, porém nos indivíduos com baixos valores de FMA, as variações foram de $5,9^{\circ}$ e $6,6 \mathrm{~mm}$.

Considerando-se a perda de ancoragem, pode-se constatar que os prémolares tiveram a sua inclinação média inicial pelo ângulo Frank.4 de 88,39 alterada para $85,88^{\circ}$, sendo essa variação de $2,51^{\circ}$ e a protrusão de $2,66 \mathrm{~mm}$, segundo a modificação do valor médio inicial de 4-PTV de 41,88 mm para 44,54 mm, gráfico 7e 10 .

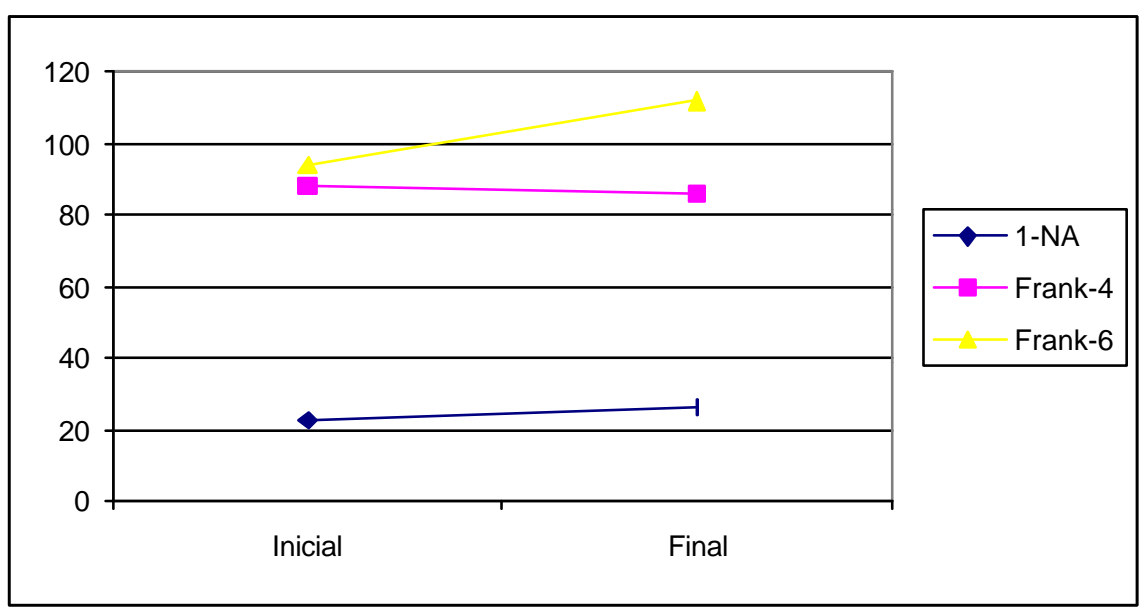

Gráfico 10. Alterações dentárias angulares avaliadas pelos valores médios iniciais e finais de 1.NA, Frank.4 e Frank.6. 
A informação sobre o efeito recíproco nos pré-molares foi complementada por meio das constatações feitas nas telerradiografias em norma lateral de $45^{\circ}$, que demonstrou a ocorrência da inclinação mesial, sendo que as variações angulares do primeiro e segundo pré-molar direito foram de $4,06^{\circ} \mathrm{e}$ $2,42^{\circ}$, respectivamente, enquanto que a do primeiro pré-molar esquerdo foi de $0,33^{\circ}$. Entretanto, o segundo pré-molar esquerdo apresentou uma inclinação distal de $0,69^{\circ}$ (Gráficos 8 e 9).

A avaliação da posição ântero-posterior inicial e final dos pré-molares, caninos e incisivos em modelos de estudo demonstrou as seguintes alterações: 1) os segundos pré-molares direito e esquerdo sofreram um movimento mesial de $1,68 \mathrm{~mm}$ e $1,29 \mathrm{~mm}$, respectivamente; 2) primeiros pré-molares direito e esquerdo, de 2,07 mm e 1,67 mm; 3) caninos direito e esquerdo, de 1,77 mm e $1,39 \mathrm{~mm}$ e 4) incisivos centrais direito e esquerdo, de $0,37 \mathrm{~mm}$ e $0,24 \mathrm{~mm}$. (Gráficos 11 e 12)

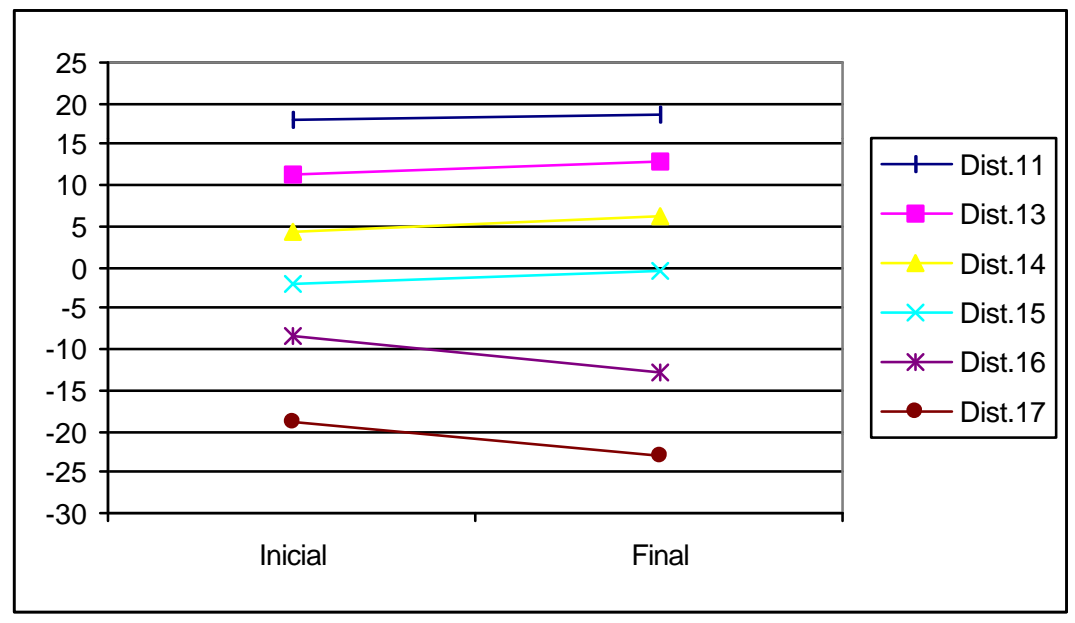

Gráfico 11. Alterações sagitais avaliadas pela análise de modelos, apresentando as distâncias médias iniciais e finais: Dist-11, Dist-13, Dist-14, Dist-15, Dist-16 e Dist-17. 


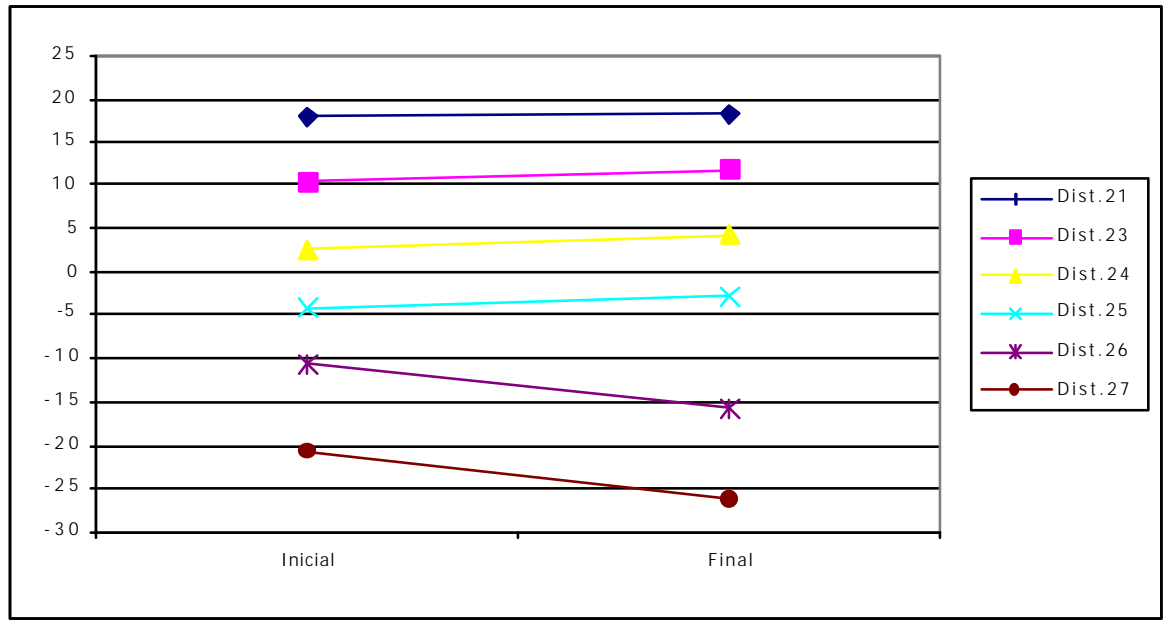

Gráfico 12. Alterações sagitais avaliadas pela análise de modelos, apresentando as distâncias médias iniciais e finais: Dist-21, Dist-23, Dist-24, Dist-25, Dist-26 e Dist-27.

Associando-se a abertura de espaço entre primeiros molares e segundos pré-molares medida diretamente nos modelos de estudo com a alteração proporcional dos referidos dentes na análise oclusal, constatou-se que a porcentagem de abertura do espaço atribuída ao movimento dos primeiros molares direito e esquerdo foi de $72,97 \%$ e de $84,47 \%$ e dos pré-molares direito e esquerdo de $30,74 \%$ e $30,71 \%$, gráficos 11 e 12 .

Como pode ser observado, a perda de ancoragem deste estudo analisada nos primeiros pré-molares foi inferior ao do estudo de GOSH; NANDA $^{60}$, em 1996. Entretanto, considerando-se os segundos pré-molares, nota-se que o movimento mesial desses dentes foi semelhante aos resultados verificados por BYLOFF; DARENDELILER ${ }^{26}$, em 1997. No entanto, no estudo atual, apesar da dobra de antiinclinação de $15^{\circ}$ incorporada nas molas, não houve um aumento na proporção da perda de ancoragem como foi mencionado por BYLOFF et al. ${ }^{27}$, em 1997. 
A justificativa para o fato de que seria esperado um aumento na perda de ancoragem com a incorporação das dobras de antiinclinação é que estariam sendo colocadas simultaneamente ativações em dois planos distintos, o vertical e o sagital, o que poderia de certa forma comprometer ou dificultar a distalização dos molares. Porém não foi verificada a quantidade de perda de ancoragem citada por BYLOFF et al. ${ }^{27}$, em 1997, demonstrando que a incorporação das dobras conjuntamente com a ativação sagital não reduz a efetividade do aparelho na distalização dos molares superiores.

Além do fato de observarmos a perda de ancoragem pelo movimento mesial dos pré-molares, foi evidenciado também o aumento da inclinação dos incisivos e da sobressaliência como conseqüência direta, segundo mencionado nos trabalhos de HILGERS ${ }^{74}$, em 1992 e BUSSICK; McNAMARA Jr ${ }^{25}$, em 2000. GOSH; NANDA ${ }^{60}$, em 1996, notaram que a sobressaliência aumentou $1,30 \mathrm{~mm}$ e a inclinação dos incisivos foi de $2,40^{\circ}$ em relação à linha SN. BYLOFF; DARENDELILER ${ }^{26}$, em 1997, por sua vez, constataram que os incisivos superiores inclinaram-se para a vestibular $1,71^{\circ}$ e o movimento anterior dos incisivos medido pelo centro da coroa foi $0,73 \mathrm{~mm}$ e da borda incisal de $0,92 \mathrm{~mm}$. Posteriormente, BYLOFF et al. ${ }^{27}$, em 1997, na tentativa de controlar a inclinação dos molares durante a distalização, incorporaram as dobras de antiinclinação de $15^{\circ}$ e perceberam um aumento de $0,62 \mathrm{~mm}$ no movimento anterior da borda incisal. JOSEPH; BUTCHART ${ }^{86}$, em 2000, verificaram que os incisivos superiores sofreram inclinação vestibular de $4,9^{\circ}$, com a protrusão da borda incisal de $3,7 \mathrm{~mm}$ e do ápice de $1,7 \mathrm{~mm}$. Finalmente, TOROGLU et al. ${ }^{144}$ observaram que os incisivos superiores inclinaram-se 3,6 em relação ao Plano de Frankfurt e protruíram 2,1mm, considerando-se a referência PTV nos pacientes com altos valores do ângulo FMA, enquanto que nos pacientes com baixos valores de FMA essas alterações foram de $8,7^{\circ}$ e $4,1 \mathrm{~mm}$. 
No entanto, neste estudo, os incisivos superiores inclinaram-se para a vestibular $3,40^{\circ}$ e posicionaram-se anteriormente $1,11 \mathrm{~mm}$, segundo as variações nas medidas iniciais e finais de 1.NA e 1-NA, respectivamente (Gráficos 10 e 13). A inclinação vestibular dos incisivos também foi confirmada pelas diferenças das medidas iniciais e finais de 1-AV e 1-PTV, de 1,08 mm e 1,51 mm (Gráficos 13 e 14). O ângulo interincisivos sofreu uma variação de 123,83 para $119,97^{\circ}$ (Gráficos 16). Como reflexo direto da alteração na inclinação dos incisivos, a sobressaliência aumentou de $5,37 \mathrm{~mm}$ para $6,93 \mathrm{~mm}$, com a diferença de 1,56 mm. A sobremordida diminuiu de $-5,18$ para $-4,15$, com a diferença de 1,03 mm (Gráfico 15).

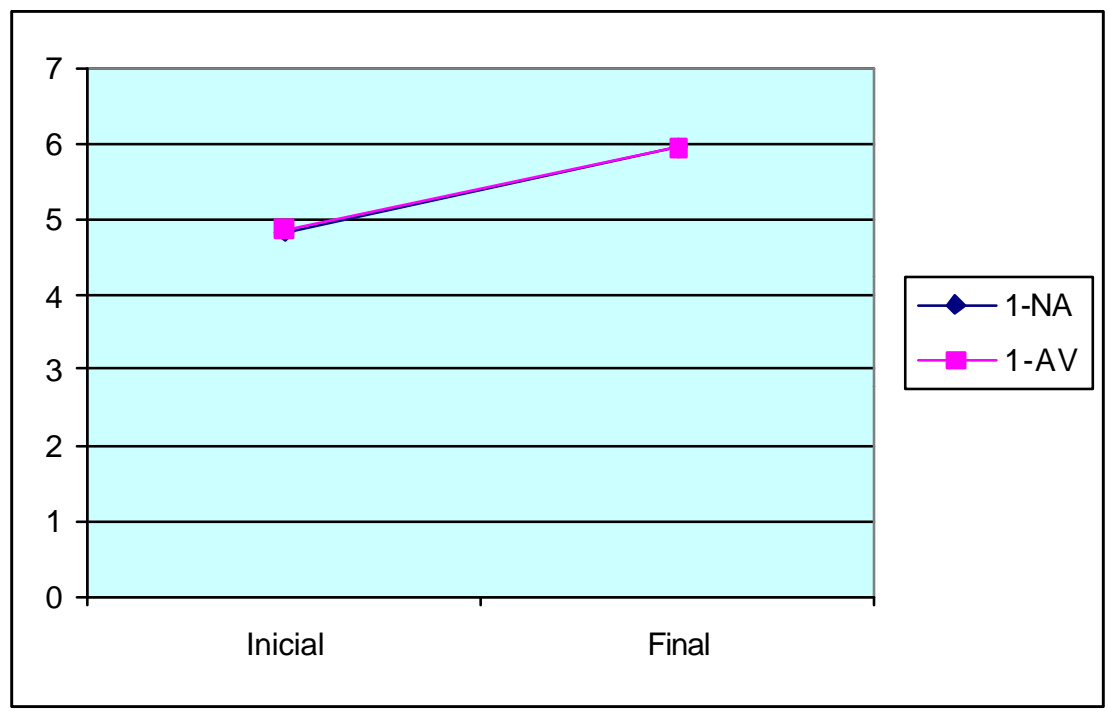

Gráfico 13. Alterações sagitais dos incisivos superiores avaliadas pelos valores médios iniciais e finais de1-NA e 1-AV. 


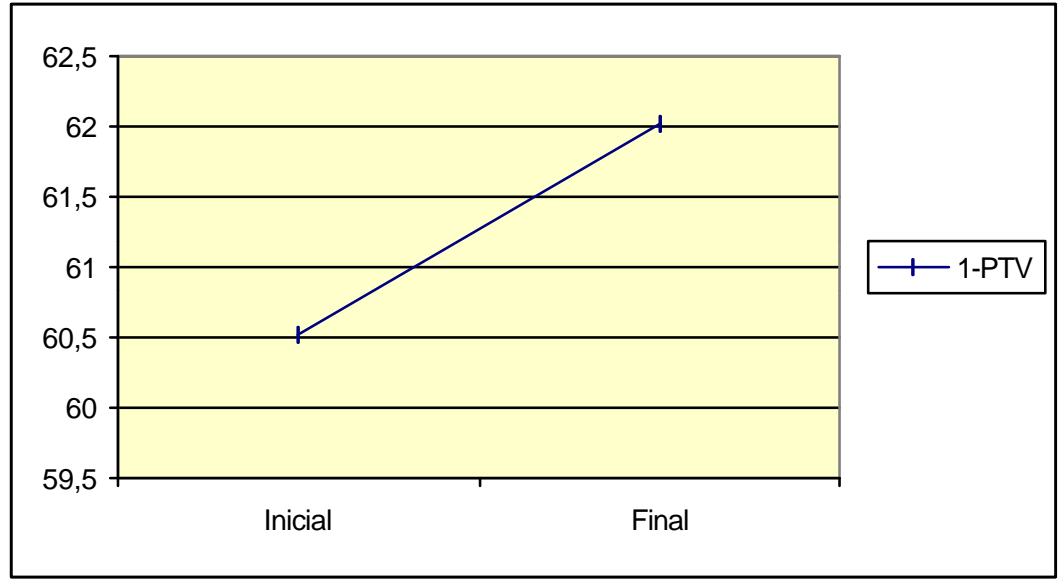

GRÁFICO 14. Alterações sagitais dos incisivos superiores avaliadas pelo valor médio inicial e final de 1-PTV.

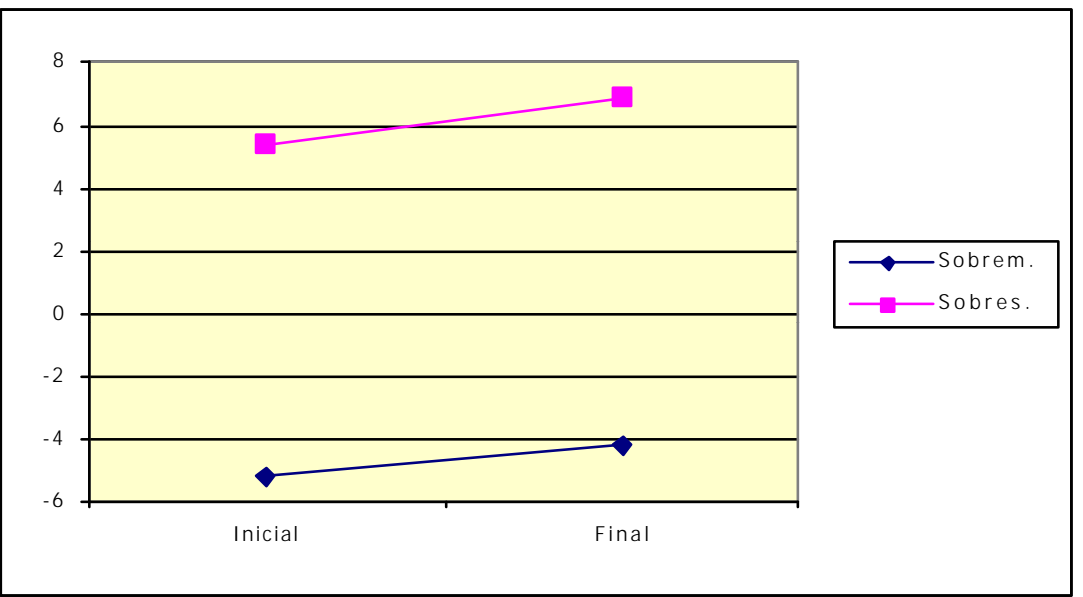

Gráfico 15. Alterações no trespasse vertical e horizontal observadas pelos valores médios iniciais e finais de Sobrem e Sobres. 


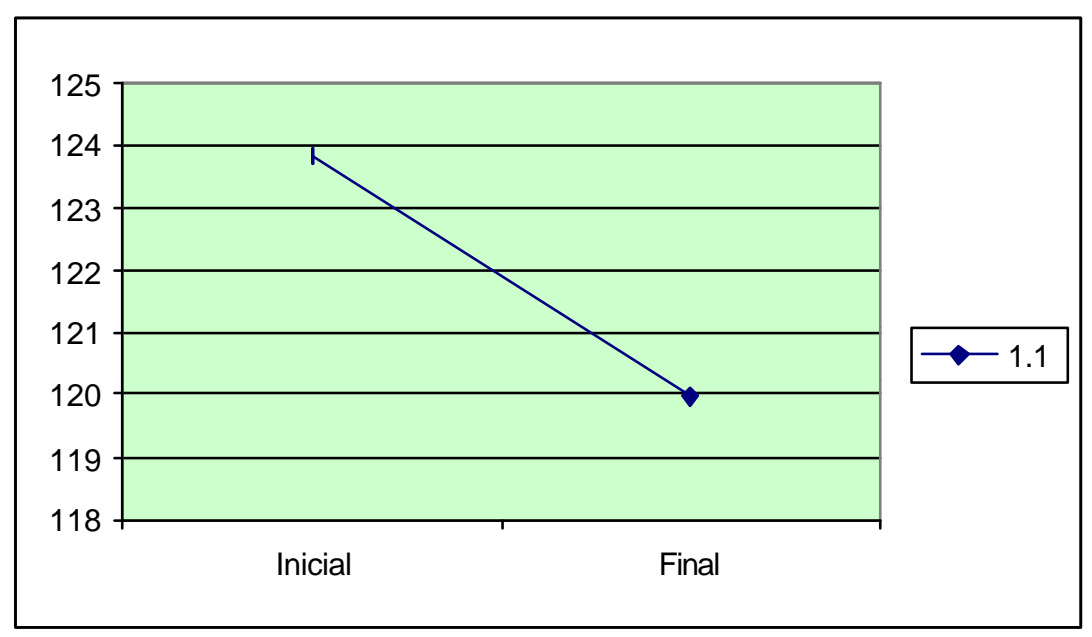

Gráfico 16. Alteração no ângulo interincisivos 1.1, segundo os valores médios iniciais e finais.

Mudanças significativas foram observadas após a distalização dos molares na inclinação e posição dos incisivos superiores. Usando as forças magnéticas, GIANELLY; VAITAS; THOMAS ${ }^{56}$, em 1989, observaram que, para cada 5,0 mm de distalização dos molares, ocorreu uma perda de ancoragem com o movimento anterior dos pré-molares e incisivos de $1,0 \mathrm{~mm}$, sendo que essa perda de ancoragem correspondeu a $20 \%$. GIANELLY et al. ${ }^{57}$, em 1992 , verificaram que o movimento anterior dos pré-molares alcançou a taxa de 33,3\%. O movimento anterior da borda incisal do incisivo superior foi de 1,8 $\mathrm{mm}$ e a inclinação vestibular acentuou-se em $6,0^{\circ}$, e dessa forma a perda de ancoragem correspondeu a 35,71\% segundo BONDEMARK; $\mathrm{KUROL}^{18}$, em 1992. BONDEMARK; KUROL; BERNHOLD ${ }^{19}$, em 1994, constataram que os incisivos superiores se posicionaram 1,5 a 2,0 $\mathrm{mm}$ mais anteriormente e se inclinaram vestibularmente 4,4. ERVERDI; KOYUTÜRK; KÜÇÜKKELES ${ }^{46}$, em 1997, observaram, em avaliações feitas em fotocópias de modelos de estudo, que os segundos pré-molares sofreram um movimento distal estatisticamente 
não significante de $0,5 \mathrm{~mm}$. Entretanto, como pode ser visualizado, a perda de ancoragem constitui-se num problema crítico, principalmente pelo aumento na sobressaliência e na inclinação dos incisivos e portanto, a indicação para o uso desse sistema deve ser bastante seletivo, sendo aconselhável usá-lo exclusivamente nos casos onde o efeito recíproco das forças possa ser aceitável ou neutralizado.

Provavelmente, o efeito mais marcante da perda de ancoragem relaciona-se com o movimento mesial dos pré-molares, sendo que as observações feitas nesse estudo com a utilização das imagens dos modelos iniciais e finais discordam com os resultados da pesquisa de ERVERDI; KOYUTÜRK; KÜÇÜKKELES ${ }^{46}$, em 1997, que verificaram o movimento distal dos segundos pré-molares. Essa diferença é justificável, pois o aparelho Pendulum, utiliza a ancoragem do botão palatino de Nance apoiado nas bandas dos primeiros pré-molares e grampos de apoio oclusais nos segundos prémolares, consolidando esses elementos dentários e impedindo que os segundos pré-molares acompanhassem em parte o movimento distal dos primeiros molares pela ação das fibras transeptais $\left(\right.$ HILGERS $^{74}$, em 1992 e HARNICK ${ }^{67}$, em 1998).

As molas superelásticas de níquel-titânio foram empregadas para a distalização dos molares superiores por GIANELLY; BEDNAR; DIETZ ${ }^{55}$, em 1991, que recomendaram a ativação de 8 a $10 \mathrm{~mm}$ para produzir a força de 100 g e verificaram que a força reacionária pode gerar algum efeito sobre os prémolares e incisivos. Para minimizar tal efeito utilizaram uma mola de verticalização que movimentava a coroa do primeiro pré-molar para a distal e aconselharam, em casos de perda de ancoragem em torno de 1,0 mm, o uso dos elásticos de Classe II. LOCATELLI et al. ${ }^{94}$, em 1992, comentaram que a perda de ancoragem era mais acentuada nos casos em que os segundos molares já 
estivessem irrompidos e recomendaram o emprego de elásticos de Classe II com força de 100 a $150 \mathrm{~g}$ ou ocorreria a perda de ancoragem de $1,0 \mathrm{~mm}$ ou mais. Discordando, ERVERDI; KOYUTÜRK; KÜÇÜKKELES ${ }^{46}$, em 1997, demonstraram que os segundos pré-molares sofreram um movimento distal de 0,8 mm. GIANCOTTI;COZZA ${ }^{53}$, em 1998, verificaram a necessidade de se reforçar a ancoragem com elásticos de Classe II. GIANELLY et al. ${ }^{57}$, em 1988 mostrou que a perda de ancoragem era evidente por meio do aumento na sobressaliência de aproximadamente 2,0 $\mathrm{mm}$. Comparando com os resultados do presente estudo, nota-se que o aparelho Pendulum, mesmo sendo utilizado sem qualquer forma alternativa de reforço da ancoragem, proporcionou um menor efeito reacionário nos incisivos em relação às molas superelásticas de níqueltitânio, principalmente no que diz respeito ao aumento da sobressaliência, cuja diferença alcançou o valor de $0,5 \mathrm{~mm}$.

O aparelho Jones Jig provoca como efeito recíproco da distalização dos molares superiores, a inclinação mesial dos pré-molares e vestibular dos incisivos, segundo JONES; WHITE ${ }^{85}$, em 1992, e HAYDAR; ÜNER ${ }^{69}$, em 2000. Conseqüentemente, o aumento na sobressaliência foi de $1,0 \mathrm{~mm}$ e na inclinação mesial de $2,60^{\circ}$ nos segundos pré-molares (GULATI; KHARBANDA; PARKASH ${ }^{64}$, em 1998). O movimento mesial e a inclinação mesial dos pré-molares foi quantificado em $3,23 \mathrm{~mm}$ e $9,47^{\circ}$, respectivamente, enquanto que o movimento mesial e a inclinação dos incisivos foi de $3,08 \mathrm{~mm}$ e $2,0^{\circ}$ e o aumento na sobressaliência resultante foi de 1,53 mm (RUNGE; MARTIN; BUKAI ${ }^{131}$, em 1998). Os resultados deste estudo constrastam com os valores de perda de ancoragem observados para os pré-molares e incisivos, quanto ao movimento mesial e inclinação vestibular de $2,51^{\circ}$ e $2,66 \mathrm{~mm}$ (Variações em Frank.4 e 4PTV) e 3,40 e 1,11 mm (Variações em 1.NA e 1- 
NA). Entretanto, a alteração na sobressaliência foi semelhante para os dois sistemas.

A força recíproca do distalizador bimétrico de Wilson é responsável pela protrusão média dos incisivos de $0,3 \mathrm{~mm}$ desde que o controle adequado seja realizado pelos pacientes no emprego de elásticos de Classe II, segundo MUSE et al. ${ }^{109}$, em 1993. Esses resultados favoráveis somente se manifestam diante da seleção correta dos pacientes e da cooperação quanto ao uso dos elásticos que neutralizem o componente anterior do sistema $\left(\mathrm{HARNICK}^{67}\right.$, em 1998). RANA; BECHER ${ }^{121}$, em 2000, observaram que a inclinação dos incisivos superiores com o plano palatino aumentou de $108,7^{\circ}$ para $112,2^{\circ}$, com a média de $3,5^{\circ}$. Portanto, nota-se a superioridade do aparelho Pendulum, que não depende da colaboração do paciente para que realmente o sistema demonstre todo o seu potencial na distalização dos molares. Apesar da menor perda de ancoragem constatada pelo distalizador bimétrico de Wilson, existe a dependência dos elásticos de Classe II para ativação das molas distalizadoras, produzindo uma certa neutralização dos efeitos recíprocos das forças direcionadas anteriormente. Entretanto, as forças somente atuarão com o uso dos elásticos, o que, explica a menor taxa de distalização alcançada.

Quando a distalização dos primeiros e segundos molares é realizada com o aparelho Distal Jet, ocorre a ação da força distal que tende a provocar uma pequena perda de ancoragem, segundo CARANO; TESTA; SICILIANI ${ }^{32}$, em 1996. Essa perda de ancoragem chega à proporção de 20\% (CARANO; TESTA; ROTUNNO ${ }^{31}$, em 1999). Porém, QUICK; HARRIS ${ }^{119}$, em 2000, utilizando o recurso da força adicional por vestibular, verificaram que a perda de ancoragem tornou-se visível pelo aumento da protrusão dos incisivos superiores. A quantidade de perda de ancoragem observada neste estudo concorda com a taxa verificada com o aparelho Distal Jet. 
A barra transpalatina de Goshgarian produz simultaneamente a distalização do molar do lado ativado e o movimento mesial do molar do lado oposto (HAAS; CISNEROS ${ }^{66}$, em 2000). Como pode ser verificado, a grande diferença no emprego da barra é que a perda de ancoragem acontece no lado oposto ao do movimento distal e neste estudo, o movimento mesial dos prémolares, caninos e incisivos é observado bilateralmente.

Outros sistemas distalizadores como a alça em forma da letra $\mathrm{K}$ (KALRA ${ }^{87}$, em 1995), o hexahélice (REINA; MENDOZA ${ }^{122}$, em 1999), o aparelho de Nance modificado (REINER ${ }^{123}$, em 1992) e o aparelho de resina acrílica cérvico-occipital (JOHNSON ${ }^{84}$, em 1994 e LEWIS; FOX ${ }^{93}$, em 1996) causam os movimentos mesiais recíprocos dos pré-molares e dos incisivos acentuando a sobressaliência. No entanto, esses estudos não quantificaram a perda de ancoragem, apenas ressaltaram a possibilidade dessa ocorrência e aconselharam a utilização de mecanismos de reforço da ancoragem.

\subsection{3 - Alterações dentárias verticais}

A distalização e a inclinação dos primeiros molares superiores pode resultar na intrusão dos molares em relação ao plano palatino. No presente estudo, analisando-se as telerradiografias em norma lateral de $45^{\circ}$, verificou-se que o primeiro molar superior direito extruiu $0,28 \mathrm{~mm}$ e o esquerdo intruiu 0,40 mm. Porém, essas alterações verticais dos primeiros molares não foram significantes. Os segundos molares direito e esquerdo intruíram 1,17 mm e 1,92 mm. GOSH; NANDA ${ }^{60}$, em 1996 e JOSEPH; BUTCHART ${ }^{86}$, em 2000, não notaram alteração vertical significante após a distalização com o aparelho Pendulum. BYLOFF; DARENDELILER ${ }^{26}$, em 1997, usando o aparelho Pendulum padrão, observaram que a intrusão do primeiro molar foi de $1,68 \mathrm{~mm}$ em relação ao plano palatino e de $1,17 \mathrm{~mm}$ em relação ao plano oclusal. 
Entretanto, BYLOFF et al. ${ }^{27}$ recorrendo a dobra de antiinclinação de $15^{\circ}$, verificaram que a intrusão foi menor, possivelmente devido ao componente extrusivo da dobra de antiinclinação. Contradizendo os resultados dos trabalhos anteriores, BUSSICK; McNAMARA $\mathrm{Jr}^{25}$, em 2000, confirmaram uma taxa de intrusão menor, de $0,7 \mathrm{~mm}$. Entretanto, complementaram que quando a ancoragem utilizava os dentes permanentes ao invés dos decíduos, ocorria uma maior extrusão dos primeiros molares e se acentuava quando os segundos molares encontravam-se irrompidos.

Apesar dos resultados do presente estudo demonstrarem que as alterações dos primeiros molares não foram significantes, três razões explicam a intrusão significativa dos molares observada em outros estudos de distalização dos molares com o aparelho Pendulum: a primeira relaciona-se ao fato de que o aparelho é ancorado rigidamente em pré-molares e isso pode contribuir para o controle do crescimento vertical dentoalveolar; a segunda, a força intrusiva exercida pela língua, e a terceira, a trajetória de ação descrita pela mola do aparelho Pendulum.

Contrariando as constatações deste estudo, de que os segundos molares sofreram intrusão, GULATI; KHARBANDA; PARKASH ${ }^{64}$, em 1998, notaram que os molares sofreram extrusão de 1,60 mm e BONDEMARK; KUROL; BERNHOLD $^{19}$, em 1994, com a utilização dos magnetos, verificaram que a extrusão dos molares superiores foi de 2,0 mm. RANA; BECHER ${ }^{121}$, em 2000, empregando o distalizador bimétrico de Wilson, observaram os primeiros molares sofrerem a extrusão de $1,1 \mathrm{~mm}$. Provavelmente, a justificativa para as diferenças observadas com os estudos acima citados se fundamentam no fato de que a não constância no sistema de força empregado nas outras pesquisas, possibilataram que a área radicular impusesse uma contraposição ao movimento 
distal dos molares e que os efeitos repercutissem também em movimentos de extrusão desses elementos dentários.

Os pré-molares extruíram, sendo que para os primeiros pré-molares direito e esquerdo, a extrusão média foi de $1,72 \mathrm{~mm}$ e $1,47 \mathrm{~mm}$, respectivamente. Os segundos pré-molares direito e esquerdo extruíram em média 1,62 mm e 1,35 mm. GOSH; NANDA ${ }^{60}$, em 1996, observaram que a extrusão dos primeiros pré-molares foi de 1,7 mm. BYLOFF; DARENDELILER $^{26}$, em 1997, reportaram que os segundos pré-molares extruíram 0,8 mm em relação ao plano palatino e $0,42 \mathrm{~mm}$ em relação ao plano oclusal. Porém, incorporando a dobra de antiinclinação, houve um aumento na extrusão dos pré-molares (BYLOFF et al. ${ }^{27}$ ). BUSSICK; McNAMARA Jr ${ }^{25}$, em 2000, demonstraram uma intrusão menor, de 1,0 mm. (Gráficos 16 e 17)

A extrusão dos pré-molares encontra a sua justificativa no fato de que o botão palatino de Nance apóia-se em pré-molares e a ativação do aparelho introduz um componente vertical de força que conduz à extrusão dos prémolares e à intrusão dos molares. Essa extrusão torna-se mais evidente quando se incorporam simultaneamente as dobras de antiinclinação e ativação horizontal das molas. Isso gera uma determinada restrição ao movimento sagital dos molares e acentua a extrusão dos pré-molares, como pode ser visto neste estudo e na pesquisa de BYLOFF et al. ${ }^{27}$, em 1997.

Os incisivos superiores extruíram em relação ao plano palatino, assim sendo os incisivos centrais superiores direito e esquerdo extruíram em média 1,14 mm e 0,45 mm, respectivamente. GOSH; NANDA ${ }^{60}$, em 1996, também constataram que apesar da inclinação vestibular dos incisivos houve uma ligeira extrusão. Entretanto, BYLOFF; DARENDELILER ${ }^{26}$, em 1997, calcularam a extrusão dos incisivos em $0,1 \mathrm{~mm}$ num período de observação de quatro meses. Na segunda parte da pesquisa, BYLOFF et al. ${ }^{27}$, em 1997, comprovaram um 
aumento da extrusão dos incisivos. HARNICK ${ }^{67}$, em 1998 observou que a extrusão dos incisivos foi de 1,6 mm com o emprego do distalizador bimétrico de Wilson. No entanto, RANA; BECHER ${ }^{121}$, em 2000, notaram uma menor extrusão de $0,6 \mathrm{~mm}$ dos incisivos superiores.

Como consequiência das alterações verticais, houve a redução na sobremordida segundo HILGERS ${ }^{74}$, em 1992; GOSH; NANDA ${ }^{60}$, em 1996; BYLOFF; DARENDELILER ${ }^{26}$, em 1997; BYLOFF et al. ${ }^{27}$, em 1997; BUSSICK; McNAMARA Jr ${ }^{25}$, em 2000 e JOSEPH; BUTCHART ${ }^{86}$, em 2000. A diminuição na sobremordida decorrente da distalização foi de 1,39 mm (GOSH; NANDA $^{60}$, em 1996). BUSSICK; McNAMARA Jr ${ }^{25}$, em 2000 confirmaram uma diminuição maior, sendo o valor de 1,7 mm. MUSE et al. ${ }^{109}$, em 1993, notaram que a extrusão dos incisivos com o distalizador bimétrico de Wilson foi de 1,6 mm. Porém, neste estudo em questão a sobremordida diminuiu $1,03 \mathrm{~mm}$, conforme a alteração de $-5,18 \mathrm{~mm}$ para $-4,15 \mathrm{~mm}$ (Gráfico 15).

A distalização dos molares superiores com outros sistemas também proporcionou a redução na sobremordida em 3,6 mm com o emprego dos magnetos (BONDEMARK; KUROL; BERNHOLD ${ }^{19}$, em 1994). Entretanto, GULATI; KHARBANDA; PARKASH ${ }^{64}$, em 1998, verificaram uma diminuição inferior, de $0,95 \mathrm{~mm}$.

Os fatores que colaboraram para a diminuição na sobremordida foram a extrusão dos molares inferiores associada à rotação horária mandibular em decorrência da distalização dos molares superiores e da inclinação distal das coroas. A inclinação vestibular dos incisivos também contribuiu para a diminuição da sobremordida. Essa extrusão dos molares inferiores foi quantificada em 0,7 mm segundo BUSSICK; McNAMARA Jr²5 em 2000. Porém, BONDEMARK; KUROL; BERNHOLD ${ }^{19}$, em 1994, constataram a 
extrusão dos molares inferiores em $0,8 \mathrm{~mm}$ associada à extrusão dos molares superiores em $2,0 \mathrm{~mm}$.

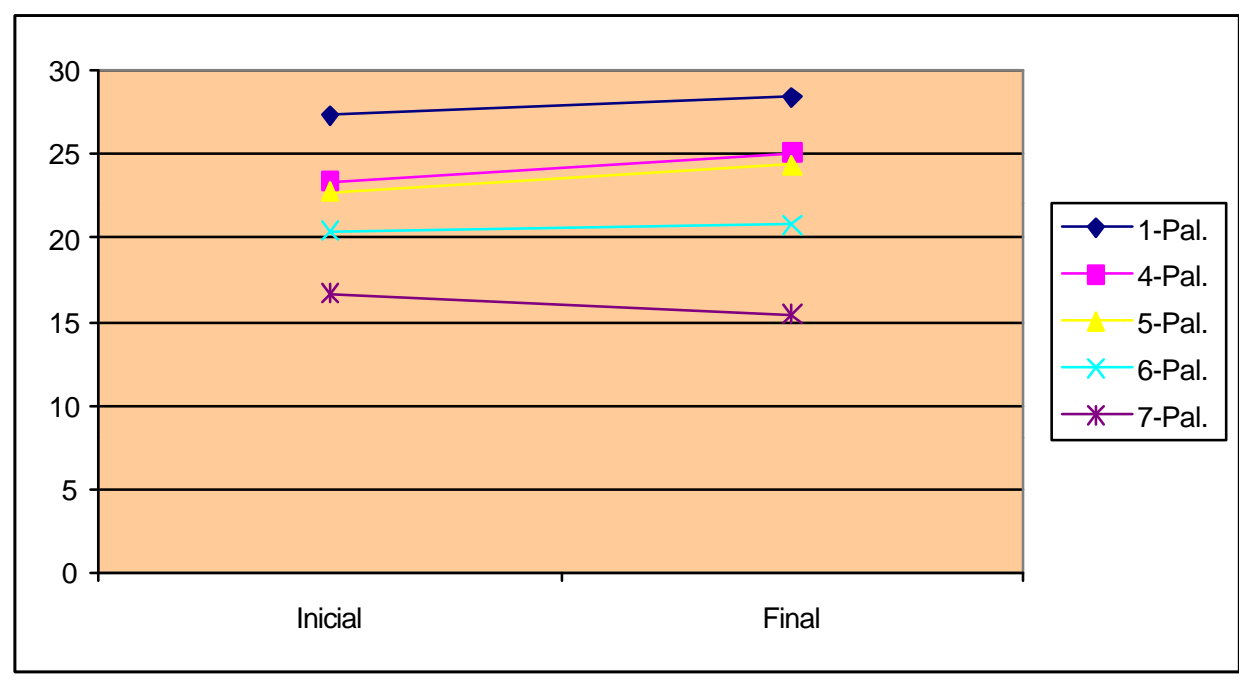

GRÁFICO 17. Alterações verticais analisadas pelas medidas médias iniciais e finais de 1-Pal., 4-Pal., 5-Pal., 6-Pal. e 7-Pal (lado direito).

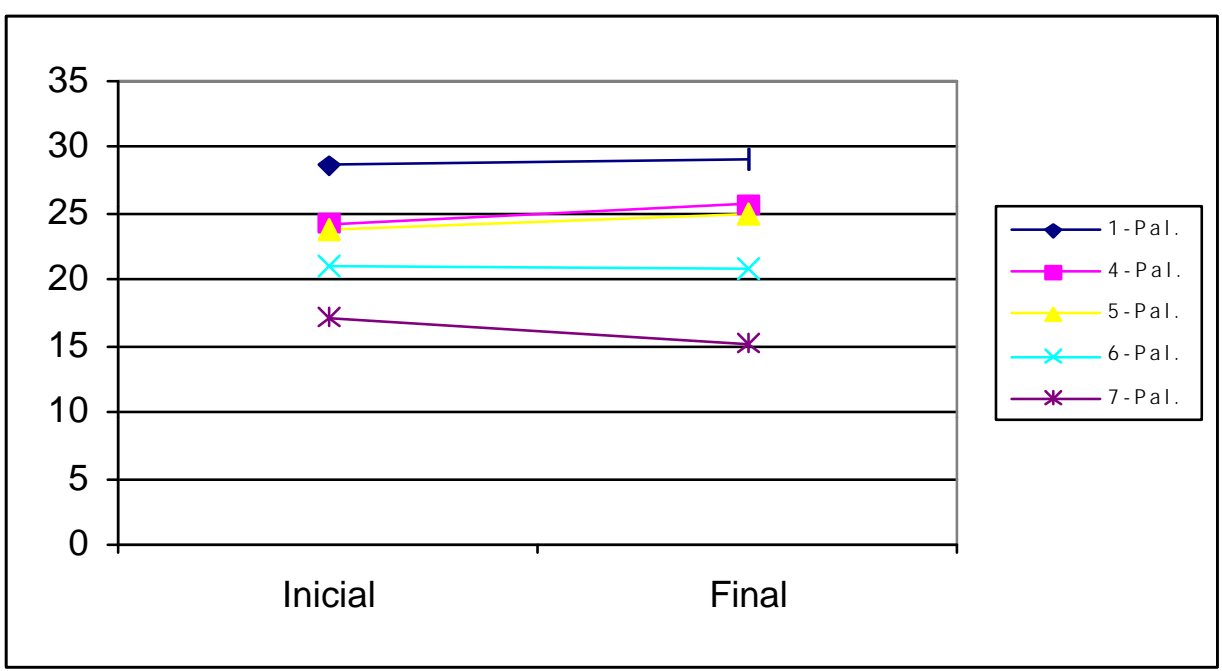

GRÁFICO 18. Alterações verticais analisadas pelas medidas médias iniciais e finais de 1 -Pal., 4-Pal., 5-Pal., 6-Pal. e 7-Pal. (lado esquerdo). 


\subsection{4 - Alterações dentárias transversais}

As molas distalizadoras atuam lingualmente ao centro de resistência dos molares, e portanto, existe a tendência de promover a rotação distopalatina, assim, como a possibilidade de ocorrer o estabelecimento da mordida cruzada dos molares. Da mesma forma que as forças causam alterações transversais, em molares, provavelmente ocorrerão efeitos recíprocos em pré-molares, devido à fixação do aparelho nesses elementos dentários.

No presente estudo, as alterações transversais medidas nos modelos demonstraram que houve uma contração de $0,08 \mathrm{~mm}$ e aumento de $1,51 \mathrm{~mm}$ entre o sulco central dos primeiros molares direito e esquerdo até a linha de referência vertical, passando pela papila palatina. Dividindo-se simetricamente, o aumento foi de $0,71 \mathrm{~mm}$ para cada molar. A expansão dos segundos molares direito e esquerdo foi de $1,67 \mathrm{~mm}$ e $1,54 \mathrm{~mm}$, sendo a média de 1,60 mm. A menor variação dos primeiros molares em relação aos segundos molares geralmente ocorre em virtude de as molas atuarem lingualmente nos primeiros molares, acarretando uma tendência constritiva, enquanto que os segundos molares respondem parcialmente às forças sagitais com o deslocamento para a vestibular (Gráficos 19 e 20).

Os pré-molares superiores sofreram expansão, destacando-se que os primeiros pré-molares direito e esquerdo tiveram o aumento de $0,11 \mathrm{~mm}$ e 0,13 $\mathrm{mm}$, sendo a média de $0,12 \mathrm{~mm}$. Os segundos pré-molares, por sua vez, mostraram aumentos de 0,20 $\mathrm{mm}$ e $0,13 \mathrm{~mm}$, com a média de $0,16 \mathrm{~mm}$. Como o aparelho era apoiado em pré-molares, por meio do botão palatino de Nance, o efeito recíproco da força distalizadora direcionava-se para os dentes da unidade de ancoragem provocando além do movimento mesial a tendência expansional desses dentes (Gráficos 19 e 20). 
Entretanto, os caninos direito e esquerdo tiveram uma diminuição de $0,08 \mathrm{~mm}$ e $0,12 \mathrm{~mm}$, medidos da face vestibular à linha de referência vertical, com a média distribuída de 0,10 mm. Os caninos foram movimentados para a mesial e passaram a ocupar uma região mais estreita do arco dentário, conduzindo a diminuição da dimensão transversal (Gráficos 19 e 20).

As alterações transversais ocorridas nos caninos, primeiros e segundos pré-molares e primeiro molar direito não foram estatisticamente significantes segundo a tabela 8 .

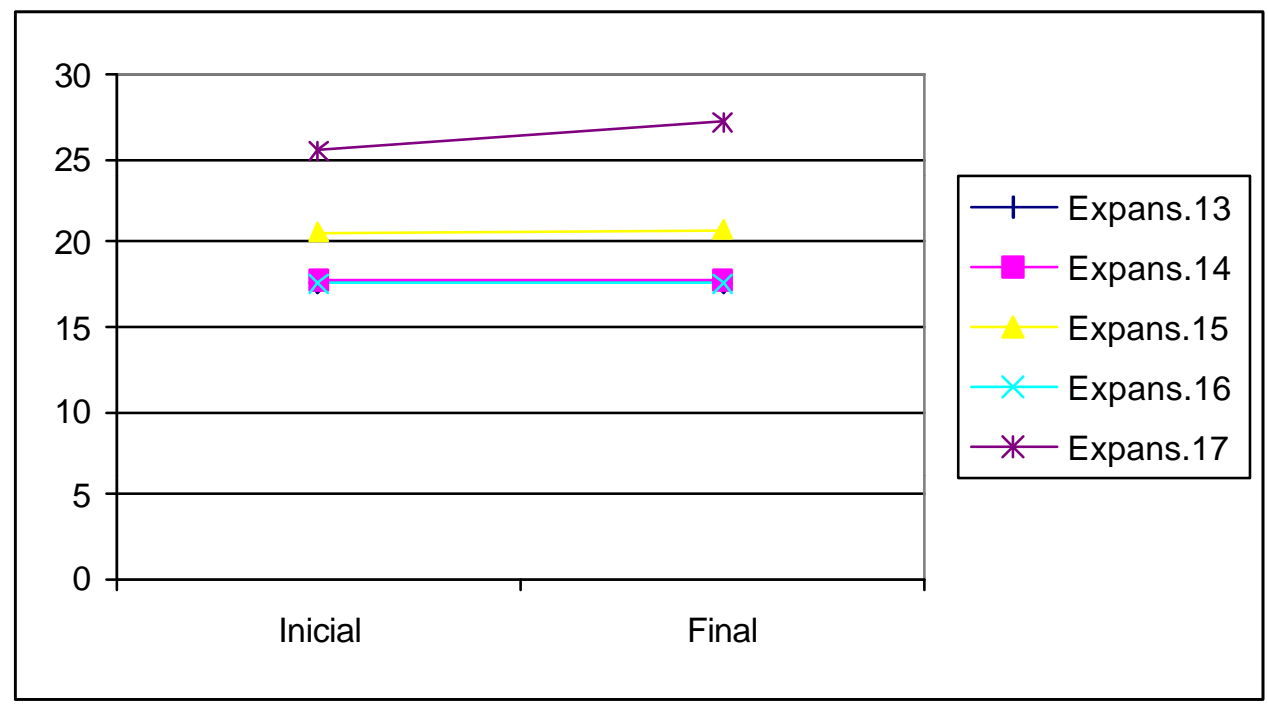

GRÁFICO 19. Alterações transversais analisadas pelas medidas lineares médias iniciais e finais: Expans.13, Expans.14, Expans.15, Expans.16 e Expans.17. 


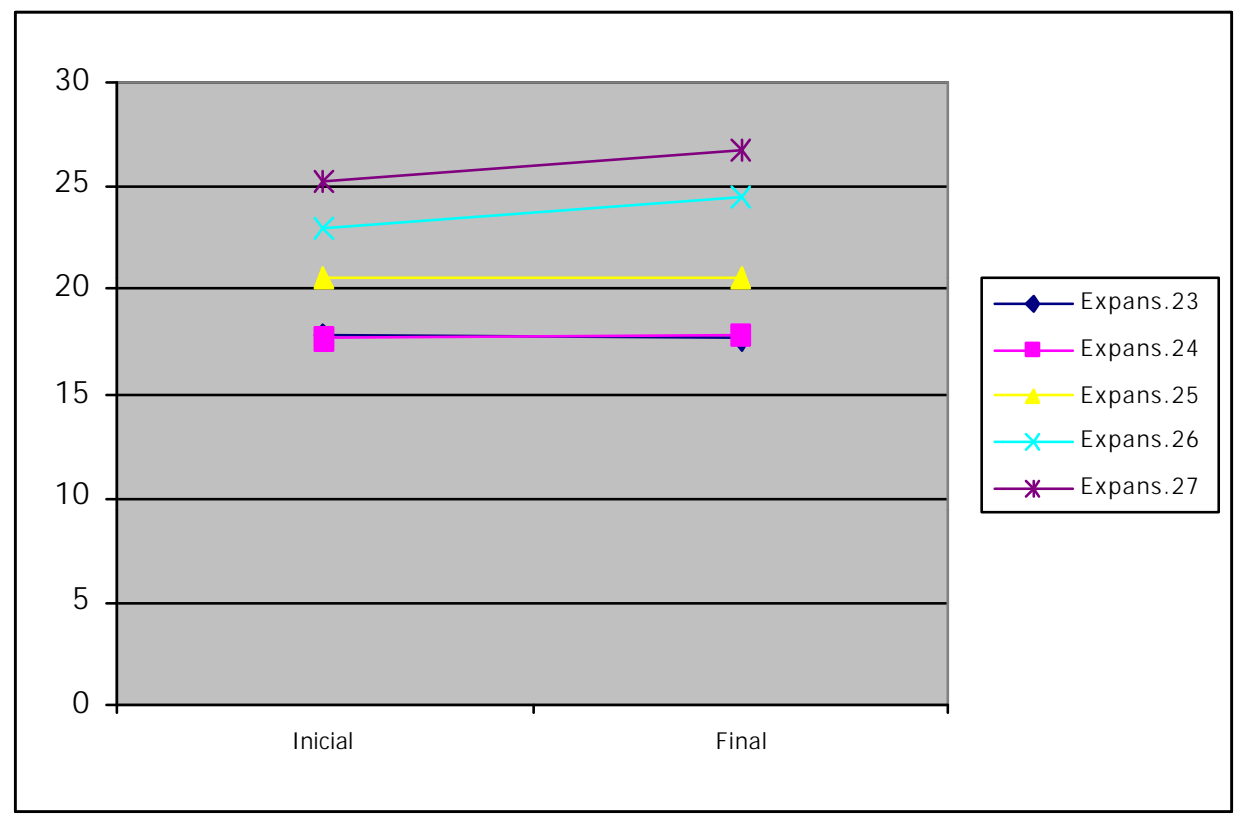

GRÁFICO 20. Alterações transversais analisadas pelas medidas lineares médias iniciais e finais: Expans.23, Expans.24, Expans.25, Expans.26 e Expans.27.

Essas alterações transversais já haviam sido comentadas por HILGERS $^{74}$, em 1992, quando o autor propôs a utilização do aparelho Pendulum. Posteriormente, GOSH; NANDA ${ }^{60}$, em 1996, constataram aumentos de $1,40 \mathrm{~mm}$ e de $2,33 \mathrm{~mm}$ entre as cúspides mesiovestibulares dos primeiros molares e dos segundos molares, respectivamente. No entanto, as demais pesquisas não fornecem dados sobre as alterações transversais de molares, prémolares e caninos. HAAS; CISNEROS ${ }^{66}$, em 2000, observaram o aumento de 2,0 mm na distância entre as cúspides mesiolinguais dos primeiros molares. Entetanto, a expansão dos primeiros molares foi maior com o emprego da barra transpalatina para a distalização dos molares superiores, sendo em média 4,50 $\mathrm{mm}$. 
Usando os magnetos, BONDEMARK; KUROL ${ }^{18}$, em 1992, verificaram que a alteração transversal foi mais acentuada entre as cúspides mesiovestibulares (de 1,59 $\mathrm{mm}$ ) dos segundos molares do que as distovestibulares (de 2,33 mm). Os autores encontraram a mesma tendência com os primeiros molares.

A expansão dos segundos pré-molares foi quantificada por GOSH; NANDA $^{60}$, em 1996, em 1,95 mm. CETLIN; TEN HOEVE ${ }^{36}$, em 1983, notaram uma expansão acentuada de 4,6 mm dos pré-molares. HAAS; CISNEROS ${ }^{66}$, em 2000, verificaram que a distância entre os segundos pré-molares aumentou 1,6 mm. A expansão dos primeiros pré-molares foi de 7,0 mm $\left(\right.$ HARNICK $^{67}$, em 1998).

Transversalmente, ainda deve ser citado que todos os sistemas distalizadores intrabucais produzem rotações distopalatinas dos primeiros e segundos molares. Para ITOH et al. $^{80}$, em 1991, essa rotação foi de $6,2^{\circ}$ e BONDEMARK; KUROL ${ }^{18}$, em 1992, comprovaram que essa rotação foi superior, sendo o valor de $8,5^{\circ}$ e de $7,0^{\circ}$ para os primeiros e segundos molares, respectivamente. Dois mais tarde, em outra pesquisa, BONDEMARK; KUROL; BERNHOLD $^{19}$ constataram um valor menor de rotação, de $2,0^{\circ}$ e $5,9^{\circ}$ para os primeiros e segundos molares. Porém, ERVERDI; KOYUTÜRK; KÜÇÜKKELES ${ }^{46}$, em 1997, observaram que a rotação dos primeiros molares foi de $9,9^{\circ}$.

Usando as molas de níquel-titânio, BONDEMARK; KUROL; BERNHOLD $^{19}$ em 1994, notaram que a rotação distopalatina foi inferior à dos magnetos, sendo para os primeiros molares de $2,9^{\circ}$ e para os segundos molares de 5,0. ERVERDI; KOYUTÜRK; KÜÇÜKKELES ${ }^{46}$, em 1997, demonstraram que a rotação foi menor que a dos magnetos, em torno de $8,6^{\circ}$, porém maior do 
que o valor mencionado por BONDEMARK ; KUROL; BERNHOLD ${ }^{19}$ em 1994.

Ainda RUNGE; MARTIN; BUKAI ${ }^{131}$, em 1998, comentaram que a rotação distopalatina dos primeiros molares superiores poderia ocorrer com a utilização do aparelho Jones Jig para a distalização dos molares. Essa rotação distopalatina dos primeiros molares superiores direito e esquerdo foi de 3,40 e 2,10 ${ }^{\circ}$, respectivamente, segundo GULATI; KHARBANDA; PARKASH ${ }^{64}$, em 1998.

\subsection{4 - Taxa de distalização mensal}

Os aparelhos distalizadores intrabucais são alternativas para o uso de forças leves e contínuas para o movimento distal dos molares superiores. Os magnetos exercendo a força de $225 \mathrm{~g}$ movimentaram os molares aproximadamente $0,75 \mathrm{~mm}$ a $1,5 \mathrm{~mm}$ por mês, sem a cooperação dos pacientes (GIANELLY et al. ${ }^{57}$, em 1988; GIANELLY; VAITAS; THOMAS ${ }^{56}$, em 1989 e GIANELLY $^{54}$, em 1998). ITOH et al. ${ }^{80}$, em 1991, observaram que desde que os magnetos fossem empregados na dentadura mista, poderia ser alcançada a distalização de $0,84 \mathrm{~mm}$ por mês dos molares. Porém, BONDEMARK; $\mathrm{KUROL}^{18}$, em 1992, constataram uma taxa de 1,01 mm de distalização mensal. BONDEMARK; KUROL; BERNHOLD ${ }^{19}$ em 1994 verificaram uma taxa de 0,36 mm de distalização mensal. ERVERDI; KOYUTÜRK; KÜÇÜKKELES ${ }^{46}$, em 1997, confirmaram que a taxa de distalização mensal dos molares em modelos era de $0,7 \mathrm{~mm}$ e em telerradiografias, a taxa de distalização era de 0,9 $\mathrm{mm}$.

As molas e os arcos superelásticos de níquel-titânio promovem a taxa de distalização mensal dos molares de 1,0 a 1,5 mm segundo GIANELLY; BEDNAR; DIETZ ${ }^{55}$, em 1991, e LOCATELLI et al. ${ }^{94}$, em 1992. Entretanto, 
BONDEMARK; KUROL; BERNHOLD ${ }^{19}$, em 1994 verificaram uma taxa mensal de $0,5 \mathrm{~mm}$ de distalização. ERVERDI; KOYUTÜRK; KÜÇÜKKELES $^{46}$, em 1997, comprovaram que as molas distalizavam os molares numa taxa mensal de 1,26 mm nos modelos de estudo e de 1,40 $\mathrm{mm}$ nas telerradiografias. GIANELLY et al. ${ }^{57}$, em 1988, constataram que os molares distalizavam $1,0 \mathrm{~mm}$ por mês.

Com o distalizador bimétrico de Wilson, MUSE et al. ${ }^{109}$, em 1993, notaram que a distalização mensal era de $0,56 \mathrm{~mm}$. No entanto, GULATI; KHARBANDA; PARKASH ${ }^{64}$, em 1998 observaram que o aparelho Jones Jig proporcionou a taxa de distalização mensal dos molares de 0,86 mm. CARANO; TESTA; SICILIANI ${ }^{32}$, em 1996, e QUICK; HARRIS ${ }^{119}$, em 2000, comprovaram que os molares eram distalizados $1,0 \mathrm{~mm}$ por mês com o emprego do aparelho Distal jet.

O aparelho Pendulum, por sua vez, distalizava os molares numa taxa mensal de 1,25 mm, segundo HILGERS ${ }^{74}$, em 1992. BYLOFF; DARENDELILER ${ }^{26}$, em 1997 e BUSSICK; McNAMARA Jr ${ }^{25}$, em 2000, confirmaram que a distalização dos molares foi de $0,81 \mathrm{~mm}$ por mês. BYLOFF et al. ${ }^{27}$, em 1997, se preocuparam em quantificar a distalização das coroas em 1,20 mm por mês e dos ápices em 1,01 mm. A maior taxa de distalização dos molares foi verificada por JOSEPH; BUTCHART ${ }^{86}$, em 2000, sendo 1,50 mm por mês.

No presente estudo, verificou-se nos modelos de estudo referentes à fase final do experimento que a abertura de espaço entre o segundo pré-molar e o primeiro molar foi de $6,23 \mathrm{~mm}$ no lado direito e de $6,29 \mathrm{~mm}$ no lado esquerdo. O tempo de tratamento médio de distalização foi de 5,87 meses e calculando-se a taxa de distalização mensal dos molares superiores, observou-se a taxa para os lados direito e esquerdo de 1,06 mm e 1,07 mm. Portanto, esta taxa aproxima-se 
das constatações de HILGERS ${ }^{74}$, em 1992; BYLOFF et al. ${ }^{27}$, em 1997; JOSEPH; BUTCHART ${ }^{86}$, em 2000. Entretanto, é superior aos resultados do estudo de BUSSICK; McNAMARA Jr ${ }^{25}$, em 2000.

\subsection{6 - Alterações do perfil facial}

Durante a distalização dos molares superiores, a perda de ancoragem influencia diretamente no posicionamento dos incisivos superiores com o reflexo sobre o perfil facial. (MUSE et al. ${ }^{109}$, em 1993; HARNICK $^{67}$, em 1998; GIANCOTTI; COZZA ${ }^{53}$, em 1998; GOSH; NANDA ${ }^{60}$, em 1996; BUSSICK; McNAMARA Jr ${ }^{25}$, em 2000; TOROGLU et al. ${ }^{144}$, em 2001). Entretanto, poucos estudos quantificaram as alterações faciais indesejáveis decorrentes da distalização dos molares, como pode ser observado nos estudos de MUSE et al. ${ }^{109}$, em 1993 e HARNICK $^{67}$, em 1998 com o emprego do distalizador bimétrico de Wilson, nos quais apenas comprovaram a ocorrência do aumento nas distâncias entre os lábios superior e inferior em relação à linha $\mathrm{E}$, porém, não apresentaram valores numéricos.

$\mathrm{Na}$ distalização de molares com o aparelho Jones Jig, RUNGE; MARTIN; BUKAI ${ }^{131}$, em 1998, constataram que além da perda de ancoragem, da protrusão dos incisivos e o aumento da altura facial ântero-inferior, incluíam ainda como efeitos negativos o aumento na projeção dos lábios superior e inferior de $0,38 \mathrm{~mm}$ e $1,0 \mathrm{~mm}$, respectivamente.

Dos estudos sobre a distalização dos molares com o aparelho Pendulum, apenas três quantificaram as alterações no perfil facial. GOSH; NANDA $^{60}$, em 1996, observaram que os lábios superior e inferior protruíram em relação à linha $\mathrm{E}$, durante o tratamento, em média, $0,31 \mathrm{~mm}$ e $0,95 \mathrm{~mm}$, respectivamente. BUSSICK; McNAMARA $\mathrm{Jr}^{25}$, em 2000, constatatram utilizando a mesma linha de referência que essas alterações foram de $0,6 \mathrm{~mm}$ e 
0,1 mm, respectivamente para os lábios superior e inferior. Notaram também, que o ângulo nasolabial diminuiu $2,5^{\circ}$ e a inclinação do lábio superior aumentou $2,0^{\circ}$, refletindo diretamente no aumento da protrusão do contorno do lábio superior. Entretanto, TOROGLU et al. ${ }^{144}$, em 2001 verificaram que os pacientes com o ângulo FMA menor ou igual a $24,0^{\circ}$ tiveram um aumento médio de $5,1^{\circ} \mathrm{e}$ de $6,2^{\circ}$, respectivamente nos ângulos nasolabial e mentolabial. Os pacientes com ângulo FMA maior ou igual a $29,0^{\circ}$, mostraram aumentos de $4,4^{\circ}$ e $2,6^{\circ}$, para as referidas grandezas angulares nasolabial e mentolabial.

No presente estudo, foi observado que os lábios superior e inferior protruíram em média $0,29 \mathrm{~mm}$ e $0,21 \mathrm{~mm}$, segundo as variações nas distâncias lábio superior-linha $\mathrm{E}$ de 1,45 mm para 1,16 e da distância lábio inferior-linha $\mathrm{E}$ de 0,07 $\mathrm{mm}$ para $0,28 \mathrm{~mm}$. Esses aumentos na protrusão dos contornos dos lábios superior e inferior foram significantes. Entretanto, apesar dos aumentos nas distâncias dos lábios superior e inferior até a linha E, o ângulo nasolabial sofreu uma variação não significativa de $106,31^{\circ}$ para $107,66^{\circ}$, com uma diferença média de $1,35^{\circ}$. Essa ocorrência das alterações no perfil facial é uma conseqüência direta da perda de ancoragem com a modificação no posicionamento dos incisivos superiores (Gráficos 21 e 22). 


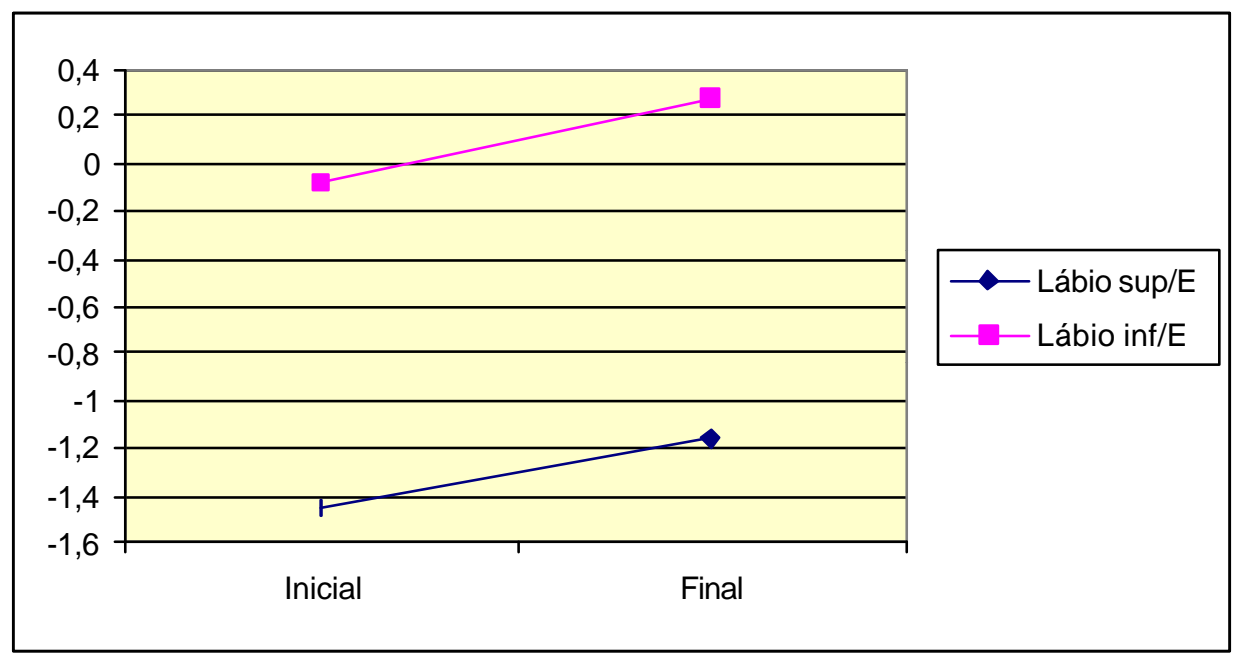

GRÁFICO 21. Alterações do perfil facial avaliadas pelas distâncias médias iniciais e finais do Lábio superior/E e lábioinferior/E.

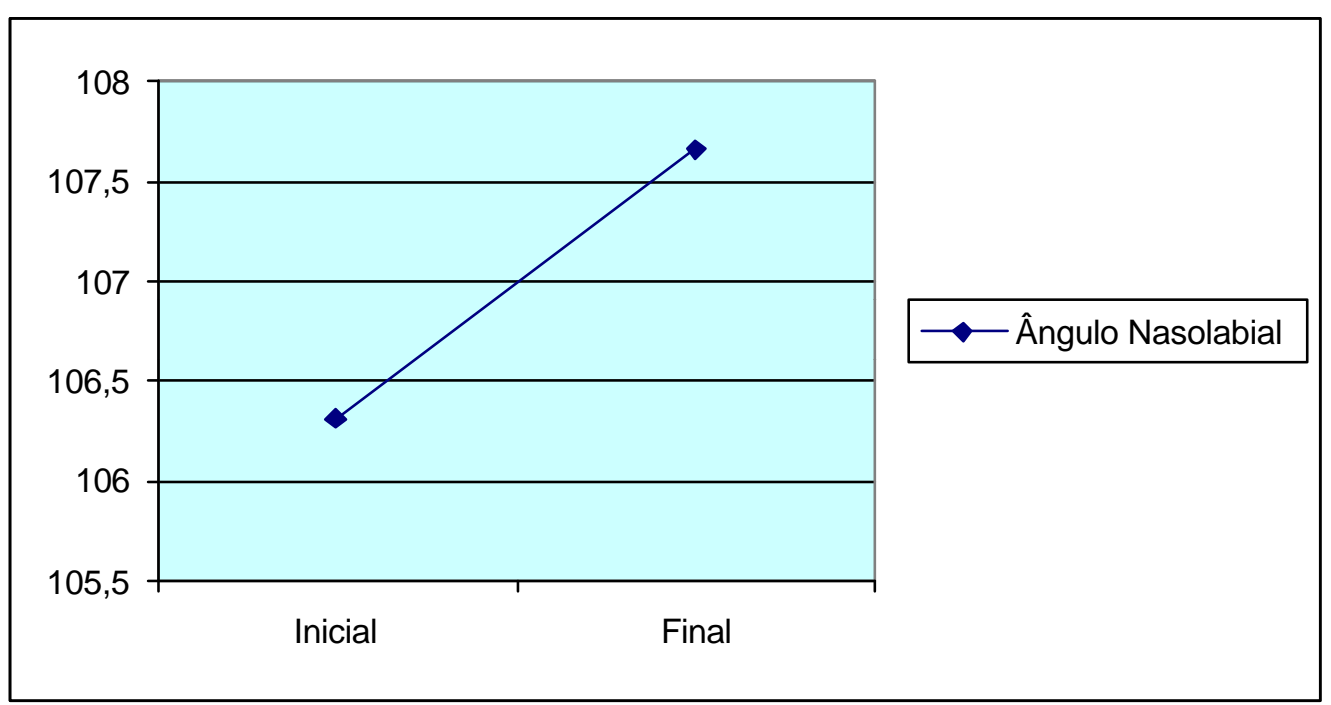

GRÁFICO 22. Alterações do perfil facial analisadas pelo ângulo nasolabial médio inicial e final

\subsection{7 - Considerações clínicas}


Os presentes resultados desta pesquisa sugerem que o aparelho Pendulum é efetivo na distalização dos molares superiores e no estabelecimento da relação oclusal de Classe I em um período de tempo relativamente curto, de 5,87 meses. Seria prudente aconselhar o controle adequado da inclinação distal das coroas dos molares, pois esta alteração sempre ocorrerá. Como cautela, recomenda-se o emprego das dobras de antiinclinação e mesmo, recorrer ao recurso da sobrecorreção, pois espera-se, no período de verticalização dos molares, alguma recidiva. Como controle da unidade de ancoragem, pode-se lançar mão dos elásticos de Classe II, ou até, da distalização seqüencial dos molares, iniciando-se com os segundos molares e finalmente, os primeiros molares. 



\section{CONCLUSÃO}

Com base nos resultados obtidos e na metodologia empregada, no que tange às alterações esqueléticas e dentárias, decorrentes da distalização de primeiros e segundos molares superiores, com o aparelho Pendulum, julga-se lícito concluir que:

\subsection{EM RELAÇÃO ÀS ALTERAÇÕES ESQUELÉTICAS:}

- A força leve e contínua das molas distalizadoras do aparelho Pendulum e o intervalo de tempo para a distalização não foram suficientes para alterar o posicionamento ântero-posterior da maxila;

A posição ântero-posterior da mandíbula não foi afetada pela mecanoterapia da distalização;

A distalização dos molares, associada à inclinação distal das coroas, contribuiu para a ocorrência da rotação mandibular, para baixo e para trás, refletindo-se diretamente nos aumentos significativos na altura facial ântero-inferior, de 1,94 mm e no ângulo SN.GoGn, de 0,47\%;

O plano palatino sofreu uma rotação anti-horária de $0,62^{\circ}$ e os planos oclusal e mandibular inclinaram-se no sentido horário, proporcionando as alterações significativas nos ângulos Frank.GoGn, Frank.Pal e Frank.Ocl.

\subsection{EM RELAÇÃO ÀS ALTERAÇÕES DENTÁRIAS:}

- O aparelho Pendulum afetou primariamente o arco dentário superior, os molares foram distalizados para uma relação molar de Classe I sobrecorrigida em um período de 5,87 meses; 
- Os primeiros molares foram distalizados 4,60 mm, segundo a distância 6-PTV e a inclinação distal das coroas foi de $18,5^{\circ}$ em relação ao plano palatino;

Apesar das dobras de antiinclinação de $15^{\circ}$, os primeiros molares superiores, direito e esquerdo, experimentaram uma inclinação distal das coroas de $11,36^{\circ}$ e de $13,97^{\circ}$, respectivamente. Os segundos molares superiores, direito e esquerdo, inclinaram-se distalmente $14,03^{\circ}$ e $18,43^{\circ}$;

$\mathrm{O}$ movimento distal dos primeiros molares, superiores direito e esquerdo, avaliado nos modelos de estudo, foi de 4,45 $\mathrm{mm}$ e 5,22 $\mathrm{mm}$, respectivamente, enquanto que o movimento distal dos segundos molares superiores, direito e esquerdo, foi de 4,22 $\mathrm{mm}$ e 5,35 mm;

$\mathrm{O}$ efeito recíproco do aparelho Pendulum, sobre a unidade de ancoragem, acarretou o movimento mesial dos primeiros pré-molares de 2,66 mm e a inclinação mesial das coroas de $2,51^{\circ}$;

As variações nas inclinações axiais dos primeiros pré-molares superiores, direito e esquerdo, foram de $4,30^{\circ}$ e $2,42^{\circ}$, respectivamente, enquanto que as dos segundos pré-molares superiores, direito e esquerdo, foram de $0,33^{\circ} \mathrm{e}$ $0,69^{\circ}$, respectivamente. Entretanto, as inclinações axiais dos segundos prémolares foram para a distal;

O movimento mesial dos primeiros pré-molares superiores, direito e esquerdo, foi de 2,07 $\mathrm{mm}$ e 1,67 mm, respectivamente, enquanto que o dos segundos pré-molares superiores, direito e esquerdo, foi de $1,68 \mathrm{~mm}$ e 1,29 $\mathrm{mm}$. Os caninos superiores, direito e esquerdo, movimentaram-se mesialmente $1,77 \mathrm{~mm}$ e 1,39 $\mathrm{mm}$, respectivamente.

O movimento mesial dos incisivos centrais superiores foi de $1,08 \mathrm{~mm}$, conforme a medida linear 1-PTV e inclinaram-se para a vestibular 
$3,40^{\circ}$, enquanto que o movimento avaliado nos modelos de estudo foi de 0,37 $\mathrm{mm}$ e de $0,27 \mathrm{~mm}$ para os incisivos centrais, direito e esquerdo;

Como conseqüência dessas alterações sagitais, verificou-se um aumento na sobressaliência de $1,56 \mathrm{~mm}$;

A distalização dos molares foi, ainda, acompanhada da alteração vertical não significativa dos primeiros molares superiores direito e esquerdo, enquanto os segundos molares, direito e esquerdo, intruíram 1,17 mm e 0,40 $\mathrm{mm}$;

Os primeiros pré-molares superiores, direito e esquerdo, sofreram a extrusão de 1,72 mm e 1,47 mm, enquanto os segundos pré-molares, direito e esquerdo, extruíram em média 1,62 mm e 1,35 mm, respectivamente;

- $\quad$ Em decorrência da rotação mandibular e das alterações verticais dos elementos dentários constatou-se a redução na sobremordida de $1,03 \mathrm{~mm}$;

As alterações transversais foram comprovadas pela expansão média: dos primeiros molares de $0,71 \mathrm{~mm}$; dos segundos pré-molares de 0,16 $\mathrm{mm}$; dos primeiros pré-molares de 0,12 $\mathrm{mm}$. Entretanto, os caninos sofreram uma contração de $0,10 \mathrm{~mm}$;

\subsection{EM RELAÇÃO À PROPORÇÃO DE DISTALIZAÇÃO E PERDA DE ANCORAGEM:}

No presente estudo, a taxa de distalização mensal foi de 1,06 $\mathrm{mm}$ e 1,07 mm, respectivamente, para os lados direito e esquerdo;

- Considerando-se a abertura de espaço entre os segundos prémolares e primeiros molares, observou-se que o movimento distal dos molares foi responsável por $78,72 \%$ dessa abertura e o dos pré-molares de $30,72 \%$. 


\subsection{EM RELAÇÃO ÀS ALTERAÇÕES NO PERFIL FACIAL:}

- Como reflexo do aumento da sobressaliência, houve um aumento, no ângulo nasolabial de $1,35^{\circ}$ e na diminuição da distância do lábio superior a linha E de $0,29 \mathrm{~mm}$; 


\section{REFERÊNCIAS}

\section{BIBLIOGRÁFICAS}




\section{REFERÊNCIAS BIBLIOGRÁFICAS:}

1. AIDAR, L. A . A ; SCANAVINI, M. A . Estudo comparativo cefalométrico radiográfico dos padrões de crescimento facial em pacientes portadores de oclusão normal e maloclusões de Classe I, Classe II, divisão 1, Classe II, divisão 2 e Classe III de Angle, de acordo com Siriwat \& Jarabak. Ortodontia, v. 22, p. 31-52, 1989.

2. ALLAN, T. K.; HODGSON, E. W. The use of personality measurements as a determinant of patient cooperation in an orthodontic practice. Amer. J. Orthodont., v. 54, n. 6, p. 433-40, Jun. 1968.

3. ALMEIDA, M. C. et al. Stability of the palatal rugae as landmarks for analysis of dental casts. Angle Orthodon., v. 65, n. 1, p. 43-8, 1995.

4. ALMEIDA, R. R.; ALMEIDA, M. R.; INSABRALDE, C. M. B. Um método alternativo de tratamento para a correção da Classe II de Angle utilizando o aparelho de Jones Jig. Relato de um caso clínico. Rev. Dental Press Ortodon. Ortop. Facial., v. 4, n. 4, p. 37-44, Jul/Ago. 1999.

5. ALMEIDA, R. R. et al. Modificação do aparelho Pendulum/Pend-x. Descrição do aparelho e técnica de construção. Rev Dental Press Ortodon Ortop Facial, v. 4, n. 6., p. 12-9, Nov./Dez. 1999. 
6. ALTEMUS, L. A. Horizontal and vertical dentofacial relationships in normal and Class II division 1 malocclusion in girls 11-15 years. Angle Orthodont.., v. 25, n.3, p. 120-37, Jul. 1955.

7. ANGLE, E. H. Classification of malocclusion. Dent. Cosmos, v. 41, p.246-64, 1899.

8. ARAS, A . Class II correction with the modified sagittal appliance and maxillary second molar extraction. Angle Orthodon., v. 70, n.4, p. 332-38, 2000.

9. ARAÚJO, M. C. M. Contribuição ao estudo dos desvios ânteroposteriores da mandíbula através das radiografias cefalométricas (Nos casos de Classe I e Classe II). Piracicaba, 1964. Tese (Livre Docência). Faculdade de Odontologia de Piracicaba.

10. ARMSTRONG, M. M. Controlling the magnitude, direction, and duration of extraoral force. Amer. J. Orthodon., v. 59, n. 3, p. 217 43, Mar. 1971.

11. BAALACK, I. B.; POULSEN, A. Occipital anchorage for distal movement of the maxillary first molars. Acta Odont. Scand., v. 24, n. 3, p. 307-25, Nov. 1966. 
12. BADELL, M. C. An evaluation of extraoral combined high-pull traction and cervical traction to the maxilla. Amer. J. Orthodon., v. 69, p. 431-446, 1976.

13. BAILEY, L. J.; ESMAILNEJAD, A.; ALMEIDA, M. A. Stability of the palatal rugae as landmarks for analysis of dental casts in extraction and nonextraction cases. Angle Orthodon., v. , n. 1, p. 73-8, 1996.

14. BALDRIDGE, J. P. A study of relation of the maxillary first permanent molars to the face in Class I and Class II malocclusions. Angle Orthodon., v. 11, n. 2, p. 100-9, Apr. 1941.

15. BAUMRIND, S. et al. Quantitative analysis of the orthodontic and orthopedic effects of maxillary traction. Amer. J. Orthodon., v. 84, p. 284-398, 1983.

16. BISHARA, S. E. Mandibular changes in persons with untreated and treated Class II, division 1. Amer. J. Orthodon. Dentofac. Orthoped., v. 113, n. 6, p. 661-73, Jun. 1998.

17. BJÖRK, A. The face in profile: an anthropological x-ray investigation on Swedish children and conscripts. Amer. J. Orthodon., v. 34, p. 619-29, 1948. 
18. BONDEMARK, L.; KUROL, J. Distalization of maxillary first and second molars simultaneously with repelling magnets. Europ. J. Orthodon., v. 14, p. 264-72, 1992.

19. BONDEMARK, L.; KUROL, J; BERNHOLD, M. Repelling magnets versus superelastic nickel-titanium coils in simultaneous distal movement of maxillary first and second molars. Angle Orthodon., v. 64, n. 3, p. 189-98, 1994.

20. BOWMAN, S. J. Modifications of the Distal Jet. J. Clin. Orthodon., v. 32, n. 9, p. 549-56, Sept. 1998.

21. BRATTSTRÖM, V.; INGELSSON, M.; ABERG, E. Treatment cooperation in Orthodontic patients. Brit. J. Orthodon., v. 18, n. 1, p. 37-41, Feb. 1991

22. BURSTONE, C.; KOENIG, H. Precision adjustment of the transpalatal lingual arch: computer arch form predermination. Amer. J. Orthodon., v. 79, p. 115-33, 1981.

23. BUSCHANG, P. H. et al. A polynomial approach to craniofacial growth: Description and comparison of adolescents males with normal occlusion and those with untreated Class II malocclusion. Amer. J. Orthodon. Dentofac. Orthop., v. 90, n. 5, p. 437-42, Nov. 1986. 
24. BUSSICK, T. J. A cephalometric evaluation of skeletal and dentoalveolar changes associated with maxillary molar distalization with the Pendulum appliance. Michigan, 1997. 103p. Tese (Mestrado) - The University of Michigan Ann Arbor, Michigan.

25. BUSSICK, T. J.; McNAMARA Jr, J. A. Dentoalveolar and skeletal changes associated with the pendulum appliance. Amer. J. Orthodon. Dentofac. Orthop., v. 117, n.3, p. 333-43, Mar. 2000.

26. BYLOFF, F. K.; DARENDELILER, M. A. Distal molar movement using the pendulum appliance. Part 1: Clinical and radiological evaluation. Angle Orthodon., v. 67, n. 4, p. 249-60, 1997.

27. BYLOFF, F. K. et al. Distal molar movement using the pendulum appliance. Part 2: The effects of maxillary molar root uprighting bends. Angle Orthodon., v. 67, n. 4, p. 261-70, 1997.

28. CALCOTE, C. E. A comparison of mandibular body lenght in normal occlusion, Class I malocclusion and Class II malocclusion in the 12 years-old group. Amer. J. Orthodon., v. 46, n. 2, p. 145, Feb.1960.

29. CAMPOS, H. Estatística experimental não-paramétrica. Piracicaba: Escola Superior de Agricultura "Luiz de Queiroz" da Universidade de São Paulo, 1983, 349p. 
30. CANGLIALOSI, T. J. et al. A cephalometric appraisal of edgewise Class II nonextraction treatment with extraoral force. Amer. J. Orthodon.Dentofac. Orthop., v. 93, n.4, p. 315-24, Apr 1988.

31. CARANO, A.; TESTA, M.; ROTUNNO, E. Corrección de la Clase II con el Distal Jet. Rev. Esp. Ortod., v. 29, p. 139-44, 1999.

32. CARANO, A.; TESTA, M.; SICILIANI, G. The lingual distalizer system. Europ. J. Orthodon., v. 18, p. 445-8, 1996.

33. CARTER, N. E. Dentofacial changes in untreated Class II division 1 subjects. Brit. J. Orthodon., v. 14, n. 4, p. 225-34, Nov. 1987.

34. CASE, C. S. Principles of occlusion and dentofacial relations. Dent. Items Interest., v. 27, p.485-527, 1905 apud KATZ, I. M.; INKFORD, J. C.; SANDERS JR., C. F. ref.

35. CETLIN, N. Course syllabus and lecture. Montefiore Medical Center, 1990.

36. CETlin, N.; TEN HOEVE, A. Nonextraction treatment. J. Clin. Orthodon., v. 17, n. 6, p. 396-13, Jun. 1983. 
37. CHACONAS, S. J.; CAPUTO, A. A.; HARVEY, K. Orthodontic force characteristics of open coil springs. Amer. J. Orthodon., v. 85, n. 6, p. 494-7, Jun. 1984.

38. CHUNG, K. R.; PARK, Y.G.; KO, S. J. C- space regainer for molar distalization. J. Clin. Orthodon., v. 34, n.1, p. 32-9, Jan. 2000.

39. CLEMMER, E. J.; HAYES, E. W. Patient cooperation in wearing orthodontic headgear. Amer. J. Orthodon., v. 75, n. 5, p. 517-24, May 1979.

40. COBEN, S. E. Growth and class II treatment. Amer. J. Orthodon., v. 59, n. 1, p. 5-26, Jan. 1971.

41. CRAIG, C. E. The skeletal patterns characteristic of class I and class II, division 1 malocclusis in norma lateralis. Angle Orthodon., v. 21, n.1, p. 44-56, Jan.1951

42. CRAWFORD, T. P. A multiple regression analysis of patient cooperation during orthodontic treatment. Amer. J. Orthodon., v. 65, n. 4, p. 436-7, Apr. 1974.

43. DAHLBERG, G. Statistical methods for medical and biological students. New York, Interscience, 1940. 
44. DORSEY, J.; KORABIK, K. Social and psychological motivations for orthodontic treatment. Amer. J. Orthodon., v. 72, n. 4, p. 460, Oct. 1977.

45. ELSASSER, W. A.; WYLIE, W. L. The craniofacial morphology of mandibular retrusion. Amer. J. Phys. Anthropol., v. 6, p. 461-74, 1948.

46. ERVERDI, N.; KOYUTÜRK, O.; KÜÇÜKKELES, N. Nickel-titanium coil springs and repelling magnets: a comparison of two different intra-oral molar distalization techniques. Brit. J. Orthodon., v.24, p.47-53, 1997.

47. FABER, R. D. Occlusograms in orthodontic treatment planning. J. Clin. Orthodon., v. 26, n. 7, p. 396- 9, Jul. 1992.

48. FIGUEIREDO, C. T. P.; FIGUEIREDO, M. A .; NOBUYASU, M. Distalização de molares superiores com o aparelho Pendulum/Pendex. Rev. APCD., v. 53, n. 1, p. 27-30, Jan/Fev. 1999.

49. FIROUZ, M.; ZERNIK, J.; NANDA, R. Dental and orthopedic effects of high-pull headgear in treatment of Class II, division 1 malocclusion. Amer. J. Orthodon. Dentofac. Orthop., v. 102, n. 3, p. 197-205, Sept 1992. 
50. FISK, G. V. et al. The morphology and physiology of distocclusion. Amer. J. Orthodon., Saint Louis, v. 39, p. 3-12, Jan. 1953.

51. FRANCHI, L.; BACCETTI, T.; McNAMARA Jr, J. A. Treatment and posttreatment effects of acrylic splint Herbst appliance therapy. Amer. J. Orthodon., v. 115, p. 429-38, 1999.

52. GANDINI, M. R. E. A. S. Estudo da oclusão dentária em escolares araraquarenses, na fase da dentadura mista, segundo sexo, região e planos. Araraquara, 1993. Tese (Doutorado), Faculdade de Odontologia de Araraquara, Universidade Estadual Paulista.

53. GIANCOTTI, A.; COZZA, P. Nickel titanium double-loop system for simultaneous distalization of first and second molars. J. Clin. Orthodon., v. 32, n. 4, p. 255-60, Apr. 1998.

54. GIANELLY, A. A. Distal movement of the maxillary molars. Amer. J. Orthodon. Dentofac. Orthop., v. 114, n. 1, p. 66-72, Jul. 1998.

55. GIANELLY, A. A.; BEDNAR, J.; DIETZ, V. S. Japanese ni-Ti coils used to move molars distally. Amer. J. Orthodon. Dentofac. Orthop., v. 99, n. 6, p. 564-6, Jun. 1991.

56. GIANELLY, A. A.; VAITAS, A. S.; THOMAS, W. M. The use of magnets to move molars distally. Amer. J. Orthodon. Dentofac. Orthop., v. 96, n. 2, p. 161-7, Aug. 1989. 
57. GIANELlY, A. A. et al. Distalization of molars with repelling magnets. J. Clin. Orthodon., v. 22, n. 1, p. 40-4, Jan. 1988.

58. GILMORE, W. A. Morphology of the adult mandible in Class II, division 1 malocclusion and in excellent occlusion. Angle Orthodon., v. 20, n.3, p. 137-46, Jul. 1950.

59. GOLDREICH, H. N. et al. Considerações sobre os erros em cefalometria. Rev. Dental Press Ortodon. Ortop. Facial., v. 3, n. 1, p. 81-90, Jan/Fev. 1998.

60. GOSH, J.; NANDA, R. S. Evaluation of an intraoral maxillary molar distalization technique. Amer. J. Orthodon. Dentofac. Orthop., v. 110, p. 639-46, Dec. 1996.

61. GRABER, T. M. Extraoral force - facts and fallacies. Amer. J. Orthodon., v. 41, n. 7, p. 490-505, Jul. 1955.

62. GREENFIELD, R. L. Fixed piston appliance for rapid Class II Correction. J. Clin. Orthodon., v. 29, n. 3, p. 174-83, Mar. 1995.

63. GREENSPAN, R. Reference charts for controlled extraoral force application to maxillary molars. Amer. J. Orthodon., v. 58, p. 48692, 1970. 
64. GULATI, S.; KHARBANDA, O. P.; PARKASH, H. Dental and skeletal changes after intraoral molar distalization with sectional jig assembly. Amer. J. Orthodon. Dentofac. Orthop., v. 114, n. 3, p. 319-27, Sept. 1998.

65. HAAS, A. J. Headgear therapy: The most efficient way to distalize molars. Seminars in Orthodontics, v. 6, n. 2, p. 79-90, Jun. 2000.

66. HAAS, S. E.; CISNEROS, G. J. The Goshgarian transpalatal bar: a clinical and an experimental investigation. Seminars in Orthodontics., v. 6, n.2, p. 98-105, Jun. 2000.

67. HARNICK, D. J. Case report: Class II correction using a modified Wilson bimetric distalizing arch and maxillary second molar extraction. Angle Orthodon., v. 68, n. 3, p. 275-80, 1998.

68. HARRIS, J. E. et al. Discrimination between normal and Class II individuals using Steiner's analysis. Angle Orthodon., v. 42, n. 3, p. 212-20, Jul. 1972.

69. HAYDAR, S.; ÜNER, O. Comparison of Jones Jig molar distalization appliance with extraoral traction. Amer. J. Orthodon. Dentofac. Orthop., v. 117, n. 1, p. 49-53, Jan. 2000. 
70. HENRIQUES, J. F. C. et al. Aparelho removível para a distalização dos $2^{\circ}$ s molares superiores, coadjuvante no tratamento com a ancoragem extrabucal. Descrição do aparelho e relato de um caso clínico. Rev. Dental Press Ortod. Ortop Maxilar., v. 2, n. 4, p. 55-64, Julho/Agosto 1997.

71. HEYDT, K. E. An analysis of the clinical entity, maxillary protrusion, with relation to classification, diagnosis, and treatment. Amer. J. Orthodon., v. 37, n. 11, p. 842-57, Nov. 1951.

72. HIGLEY, L. B. Cases analyses - indicated types of malocclusion. Amer. J. Orthodon., v. 34, p. 645-64, 1948.

73. HILGERS, J. J. Adjunts to Bioprogressive therapy - A palatal expansion appliance for non-compliance therapy. J. Clin. Orthodon., v. 25, n. 8, p. 491-7, Aug. 1991.

74. HILGERS, J. J. The Pendulum appliance for Class II non-compliance therapy. J. Clin. Orthodon., v. 26.n. 11, p. 706-14, Nov. 1992.

75. HILGERS, J. J. The Pendulum appliance ... An update. Clin. Impressions., v. 2, n. 1, p. 15-7, 1993.

76. HILGERS, J. J.; BENNETT, R. K. The Pendulum appliance, part II: Maintaining the gain. Clin. Impressions., v. 3. n. 4, p.6-9, 1994. 
77. HITCHCOCK, H. P. A cephalometric description of Class II, division 1 malocclusion. Amer. J. Orthodon., v. 63, n. 4, p. 414-23, Apr. 1973.

78. HUBBARD, G. W.; NANDA, R. S.; CURRIER, G. F. A cephalometric evaluation of nonextraction cervical headgear treatment in class II malocclusions. Angle Orthodon., v. 64, p. 359-70, 1994.

79. HUNTER, W. S. The vertical dimensions of the face and skeletodental retrognathism. Amer. J. Orthodon., v. 53, p. 586-95, 1967.

80. ITOH, T. et al. Molar distalization with repelling magnets. J. Clin. Orthodon., v. 25, n. 10, p. 611-17, Oct. 1991.

81. JACOBSON, A. Radiographic cephalometry. 1 ed., Quintessence Publishing Co. Inc., 1995, 322p.

82. JANSON, G. R. P. Estudo tridimensional das assimetrias dentárias e esqueléticas na má oclusão de Classe II, subdivisão. Bauru., 1998. 271p. Tese (Livre docência). Faculdade de Odontologia de Bauru, Universidade de São Paulo

83. JECKEL, N.; RAKOSI, T. Molar distalization by intraoral forces. Amer. J. Orthodon., v. 13, p. 43-6, 1991. 
84. JOHNSON, B. E. Distal movement of the maxillary molar using an active removable appliance and extraoral force: a case report. Quintessence International., v. 25, n. 1, p. 43-8, 1994.

85. JONES, R. D.; WHITE, J. M. Rapid Class II molar correction with an open-coil jig. J. Clin. Orthodon., v. 26, n. 10, p. 661-3, Oct. 1992.

86. JOSEPH, A. A.; BUTCHART, C. J. An evaluation of the Pendulum distalizing appliance. Seminars in Orthodontics., v. 6, n. 3, p. 12935, Jun. 2000.

87. KALRA, V. The K-loop molar distalizing appliance. J. Clin. Orthodon., v. 29, n. 5, p. 298-301, May 1995.

88. KLEIN, P. L. An evaluation of cervical traction on the maxilla and the upper first permanent molar. Angle Orthodon., v. 27, n. 1, p. 61-8, Jan. 1957.

89. KLOEHN, S. J. Evaluation of cervical anchorage force in treatment. Angle Orthodon., v. 31, n. 2, p. 91-104, Apr. 1961.

90. KUROL, J.; BJERKLIN, K. Treatment of children with ectopic eruption of the maxillary first permanent molar by cervical traction. Amer. J. Orthodon., v. 86, p. 483-92, 1984. 
91. LAI, M. Molar distalization with the Herbst appliance. Seminars in Orthodontics., v. 6, n. 2, p. 119-28, Jun. 2000.

92. LEVIN, R. I. Activator headgear therapy. Amer. J. Orthodon., v. 87, p. 91-109, 1985.

93. LEWIS, D. H.; FOX, N. A. Distal movement without headgear: the use of an upper removable appliance for the retraction of upper first molars. Brit, J. Orthodon., v. 23, p. 305-12, 1996.

94. LOCATELLI, R. et al. Molar distalization with superelastic NiTi wire. J. Clin. Orthodon., v. 26, n. 5, p. 277-9, May 1992.

95. MAGNESS, W. B. Extraction of second molars. J. Clin. Orthodon., v. 20, p. 519-22, 1986.

96. MAIA, F. A. Estudo cefalométrico da má olcusão de Classe II/1, em brasileiros da região Nordeste, em fase de dentadura mista (parte I). Ortodontia., v. 31, n. 2, p. 53-68, Mai/Jun/Jul/Ago. 1993.

97. MARTINS, D. R. et al. Atlas de crescimento craniofacial. 1 ed. São Paulo. Livraria Santos Editora, 1998. 280p.

98. MARTINS, J. C. R.; MELO, A .C. M.; MARTINS, L. P. "Pendex" modificado: um novo aparelho para distalização dos molares superiores no tratamento da má oclusão de Classe II. J. Bras. Ortodon. Ortop. Maxilar., v. 1, n. 4, p. 37-43, Julho-Agosto 1996. 
99. MARTINS, L. P. Erro de reprodutibilidade das medidas das análises cefalométricas de Steiner e de Ricketts pelos métodos convencionais e computadorizado. Araraquara, 1993. 121p. Tese (Mestrado). Faculdade de odontologia de Araraquara, Universidade Estadual Paulista.

100. McNAMARA, Jr., J. A. Components of class II malocclusion in children 810 years of age. Angle Orthodon., v. 51, p. 177-202, 1981.

101. MILLS, C. M.; HOLMAN, G.; GRABER, T. M. Heavy intermittent cervical traction in Class II treatment: A longitudinal cephalometric assessment. Amer. J. Orthodon., v.74, n. 4, p. 361-79, Oct. 1978.

102. MISAKA, M.; FANTINI, S. M. Análise telerradiográfica dos componentes da maloclusão de classe II, em norma lateral, em crianças brasileiras com idades entre 8 e 12 anos. Ortodontia., v.30, n. 3, p. 18-30, Set/Out/Nov/Dez. 1997.

103. MIURA, F. et al. The super-elastic Japanese NiTi alloy wire for use in orthodontics. Amer. J. Orthodon. Dentofac. Orthop., v. 94, n. 2, p. 89-96, Aug. 1988.

104. MORGANTI, L. Técnica de confecção dos aparelhos pêndulo e pendex de Hilgers. Ortodontia Gaúcha., v. II, n. 1, p.16-26, Jan/Jun. 1998. 
105. MOYERS, R. E. Temporomandibular muscle contraction patterns in Angle class II, division 1 malocclusions: an eletromyographic analysis. Amer. J. Orthodon., v. 35, p.837-57, 1948.

106. MOYERS, R. E. et al. Differential diagnosis of Class II malocclusions. Part 1. Facial types associated with Class II malocclusions. Amer. J. Orthodon., v. 78, p. 477-94, 1980.

107. MOYERS, R. E.; RIOLO, M. L. Tratamento precoce. In: Ortodontia. 4. ed. Rio de Janeiro: Guanabara Koogan, 1991. cap. 15, p.340-52.

108. MUIR, J. C. The non-extraction approach to the treatment of Class II malocclusions: diagnosis and treatment planning. New Zeland Dent. J., v. 78,n. 41, p. 41-51, Apr. 1982.

109. MUSE, D. S. et al. Molar and incisor changes with Wilson rapid molar distalization. Amer. J. Orthodon. Dentofac. Orthop., v. 104, n. 6, p. 556-65, Dec. 1993.

110. NOUER, D. F. Das maloclusões e alguns dos seus fatores etiológicos. Piracicaba, 1966. Tese (Doutorado), Faculdade de Odontologia de Piracicaba, Universidade Estadual de Campinas.

111. ÖZTÜRK, Y.; TANKUTER, N. Class II: a comparison of activator and activator headgear combination appliances. Europ. J. Orthodon., v. 16, p. 149-57, 1994. 
112. PANCHERZ, H. The mechanism of Class II correction in Herbst appliance treatment. A cephalometric investigation. Amer. J.Orthodon., v. 82, p. 104-13, 1982.

113. PANCHERZ, H. A cephalometric analysis of skeletal and dental changes contributing to Class II correction in activator treatment. Amer. J. Orthodon., v. 85, p. 125-34, 1984

114. PANCHERZ, H.; PANCHERZ, A. M. The headgear effect of the Herbst appliance: a cephalometric long-term study. Amer. J. Orthodon., v. 103, p. 510-20, 1993.

115. PEAVY Jr., D. C.; KENDRICK, G. S. The effects of tooth movement on the palatine ruggae. J. Pros. Dent., v. 18, n. 6, p. 536-42, Dec. 1967.

116. PIERINGER, M.; DROSCHL, H.; PERMANN, R. Distalization with a Nance appliance and coil springs. J. Clin. Orthodon., v. 31, n. 5, p. 321-6, May 1997.

117. PINZAN, A.; VARGAS NETO, J.; JANSON, G. R. P. O paciente ortodôntico quanto ao seu grau de informação e motivação, e suas expectativas acerca do tratamento. Ortodontia., v. 30, n. 3, p. 4044, Set/Out/Nov/Dez. 1997. 
118. PUENTE, M. Class II correction with an Edgewise-modified Nance appliance. J. Clin. Orthodon., v. 31, n. 3, p. 178-82, Mar. 1997.

119. QUICK, A. N.; HARRIS, A. M. P. Molar distalization with a modified distal jet appliance. J. Clin. Orthodon., v. 34, n. 7, p. 419-23, Jul. 2000.

120. QUINN, G. W. Extraction of four second molars. Angle Orthodon., v. 55, p. 58-69, 1985.

121. RANA, R.; BECHER, M. K. Class II correction using the Bimetric Distalizing Arch. Seminars in Orthodontics., v. 6, n.2, p. 106- 118, Jun. 2000.

122. REINA, E. S.; MENDOZA, A. M. Hexahelix: Distalador intraoral de doble función. Rev. Esp. Ortodon., v. 29, p. 17-26, 1999.

123. REINER, T. J. Modified Nance appliance for unilateral molar distalization. J. Clin. Orthodon., v. 26, n. 7, p. 402- 4, Jul. 1992.

124. RENFROE, E. W. A study of the facial patterns associated with Class I, Class II, division 1, and Class II, division 2 malocclusions. Angle Orthodon., v. 18, n.1-2, p. 12-5, Apr. 1948.

125. RIEDEL, R. The relation of maxillary structures to cranium in malocclusion and in normal occlusion. Angle Orthodon., v. 22, n. 3, p. 142-5, Jul. 1952. 
126. RITTER, D. E. et al. Prevalência das maloclusões de Angle em uma clínica de Ortodontia. Rev. Soc. Bras. Ortod., v. 3, n. 4, p. 123-5, Jul/Dez. 1997.

127. RONDEAU, B. H. M. The pendulum appliance. J. General Orthodon., v. 6, n. 1, p. 22-30, Mar. 1995.

128. ROSÉ, R. Aplicaciones clínicas del resorte espiral. Distalamiento molar. Sociedad Argent. Ortodon., v. 56, n. 111, p. 55-9, Enero 1992.

129. ROSENBLUM, R. E. Class II malocclusion: mandibular retrusion or maxillary protrusion? Angle Orthodon., v. 65, n. 1, p. 49-62, 1995.

130. ROTHSTEIN, T. L. Facial morphology and growth from 10 to 14 years of age in children presenting Class II, division 1 malocclusion: a comparative roentgenographic cephalometric study. Amer. J. Orthodon., v. 60, p. 619-20, 1971.

131. RUNGE, M. E.; MARTIN, J. T.; BUKAI, F. Analysis of rapid maxillary molar distal movement without patient cooperation. Amer. J. Orthodon. Dentofac. Orthop., v. 115, n. 2, p. 153-7, Feb. 1998.

132. SACHDEVA, R. et al. Ligas ortodônticas correntemente em uso. Revisão (Parte II). Rev. Odontol. USP., v. 4, n. 4, p. 343-8, Out/Dez. 1990 
133. SAKIMA, T. et al. Oclusograma: um método auxiliar no planejamento ortodôntico. Ortodontia., v. 28, n. 1, p. 46-52, Jan/Fev/Mar/Abr. 1995.

134. SASSOUNI, V. The Class II syndrome: differential diagnosis and treatment. Angle Orthod., v. 40, n. 4, p. 334-41, Oct. 1970.

135. SCUZZO, G. et al. The modified Pendulum appliance with removable arms. J. Clin.Orthodon., v. 34, n. 4, p. 244- 6, Apr. 2000

136. SCUZZO, G.; PISANI, F.; TAKEMOTO, K. Maxillary molar distalization with a modified Pendulum appliance. J. Clin.Orthodon., v. 33, n. 11, p. 645- 50, Nov. 1999.

137. SILVA FILHO et al. Prevalência de oclusão normal na dentadura mista em escolares na cidade de Bauru (São Paulo). Rev. Assoc. Paul. Cir. Dent., v. 43, p. 287-90, 1989.

138. SIMPlíCIO, A. H. M. Avaliação dos componentes horizontais e verticais da maloclusão Classe II, $1^{\text {a }}$ divisão (Angle), em pacientes de 8 a 12 anos. Araraquara, 1995. 127p. Tese (Mestrado), Faculdade de Odontologia de Araraquara, Universidade Estadual Paulista.

139. SNODGRASS, D. J. A fixed appliance for maxillary expansion, molar rotation, and molar distalization. J. Clin. Orthodon., v. 30, n.3, p. 156-9, Mar. 1996. 
140. STEGER, E. R.; BLECHMAN, A. M. Case reports: molar distalization with static repelling magnets. Part II. Amer. J. Orthodon. Dentofac. Orthop., v. 108, n. 5, p. 547-55, Nov. 1995.

141. SUGUINO, R.; FURQUIM, L.Z. O aparelho Jones Jig. Rev. Dental Press Ortodon. Ortop. Facial., v. 5, n. 3, p. 83-116, Mai/Jun. 2000.

142. TAKAHASHI, T. Prevalência de oclusão normal e má oclusão em mestiços. Londrina, 1975. Tese (Mestrado), Universidade Estadual de Londrina.

143. THOMAZINHO, A. Avaliação cefalométrica radiográfica como elemento do diagnóstico ortodôntico (Determinação do padrão facial nos casos de “oclusão normal”, Classe I e Classe II, divisão 1 de Angle). Ribeirão Preto, 1970. Tese (Doutorado), Faculdade de Farmácia e Odontologia de Ribeirão Preto, Universidade de São Paulo.

144. TOROGLU, M. S. et al. Cephalometric evaluation of the effects of pendulum appliance on various vertical growth patterns and of the changes during short-term stabilization. Clin. Orthod. Res., v. 4, p.15-27, 2001

145. TUKASAN, P. C. Diagnóstico diferencial dos componentes horizontais da Classe II, divisão 1 , de acordo com o método proposto por Moyers et al. (Estudo cefalométrico). Piracicaba, 1999. 109p. Tese (Mestrado), Faculdade de Odontologia de Piracicaba - Universidade Estadual de Campinas 
146. URSI, W.; McNAMARA JR, J. Crescimento craniofacial em pacientes apresentando maloclusões de Classe II e oclusão normal, entre os 10 e os 12 anos de idade. Rev. Dental Press Ortodon. Ortop. Facial., v. 2, n. 5, p. 49-59, Set/Out. 1997.

147. VALE, D. M. V.; MARTINS, D. R. Avaliação cefalométrica das estruturas dento-esqueléticas em jovens portadores de Classe II, divisão 1, brasileiros, leucodermas e de origem mediterrânea. Ortodontia., v. 20, p. 5-17, 1987.

148. VAN DER LINDEN, F. P. G. Changes in the position of posterior teeth in relation to ruga points. Amer. J. Orthodon., v. 74, n.2, p. 14261, Aug. 1978.

149. VIGORITO, J. W. Estudo comparativo de algumas características mandibulares em maloclusões de Classe I e Classe II, divisão 1, de Angle. Rev. Fac. Odont. São Paulo., v. 11, n. 1, p. 75-82, 1973.

150. WARREN, D. W. Rapid Class II correction with a headgear-expander. J. Clin. Orthodon., v. 27, n. 9, p. 503- 7, Sept. 1993.

151. WHITE, L. W. The clinical use of occlusograms. J. Clin. Orthodon., v. 16, n. 2, p. 92-103, Feb. 1982.

152. WIESLANDER. L. Early or late cervical traction therapy of Class II malocclusion in the mixed dentition. Amer. J. Orthodon., v. 67, n. 4, p. 432- 9, Apr. 1975. 
153. WILSON, W. L. Modular orthodontic systems. Prt 1, J. Clin. Orthodon., v. 12, n. 4, p. 259-78, Apr. 1978.

154. WILSON, W. L. Modular orthodontic systems. Part 2, J. Clin. Orthodon., v. 12, n. 4, p. 358-75, May 1978.

155. WILSON, W. L.; WILSON, R. C. New treatment dimensions with first phase sectional and progressive Edgewise mechanics. J. Clin. Orthodon., v. 14, n. 9, p. 607-26, Sept. 1980.

156. WINDMILLER, E. C. The acrylic-splint Herbst appliance: a cephalometric evaluation. Amer. J. Orthodon., v. 104, p. 73-84, 1993.

157. YEN, C. H. Computer-aided space analysis. J. Clin. Orthodon., v. 25, n. 4, p. 236-8, Apr. 1991.

158. ZANELATO, R. C.; TREVISI, H. J.; ZANELATO, A. C. T. Extração dos segundos molares superiores. Uma nova abordagem para os tratamentos da Classe II, em pacientes adolescentes. Rev. Dental Press Ortodon. Ortop. Facial., v. 5, n. 2, p. 64-75, Mar/Abr. 2000. 



\section{ABSTRACT}

In this study, 32 patients were studied. 23 females and 9 males, leucoderma, Brazilian, natural from Bauru, São Paulo state, with ages ranging from 11,06 years to 17,09 years, mean age 14,07 years, all carriers of Angle Class II division 1 malocclusions and presence of all permanent teeth from second molar to second molar in the same arch. To all the selected individuals were given for distalization of upper molars, the HILGERS Pendulum appliance which was used for a period of 5,87 months.

Lateral cephalometric radiographs, $45^{\circ}$ lateral cephalometric radiographs and dental casts were made before and after the upper molars distalizations. The cephalometric and the dental casts measurements were obtained and the differences between the initial and final measurements were submmited to the Wilcoxon statistical test for paired data. This evaluation possibilitated to verify the skeletal alterations and the effects of distalization on upper molars and premolars, canines and incisives.

On the basis of the obtained results and on the employed methodology concerning the skeletal and dental alterations caused by the distalization of upper first and second molars with the Pendulum appliance it can be concluded that the light and continued force of the distalization springs and the time spent did not alter significantly the maxila and mandible anteroposterior positioning.

A monthly distalization rate of $1,06 \mathrm{~mm}$ and $1,07 \mathrm{~mm}$ was observed, respectively for right and left sides. This distalization was followed by the distal inclination of the molar crown which caused a mandibular rotation in a clockwise direction, reflecting directly on the increase of the anteroinferior facial height. 
The reciprocal effect of Pendulum appliance over the anchorage unit caused the first and second premolars and canines mesial movement. Another negative effect proved was the vestibular movement of the upper incisives and its consequence on the facial profile alteration.

Associated to the upper molar distalization it was also observed the vertical and transverse alterations in molars, premolars and canines. 

Tabe la 12. Idade inicial e final em meses dos pacientes da amostra

\begin{tabular}{|c|c|c|}
\hline Pacientes-31 & Idade inicial em meses & Idade final em meses \\
\hline ALESSANDRA O & 162 & 168 \\
\hline ALESSANDRA V & 171 & 178 \\
\hline ANA LUCIA & 182 & 189 \\
\hline ARIELA & 186 & 192 \\
\hline$\overline{\text { BRUNA }}$ & 176 & 183 \\
\hline BRUNO & 144 & 150 \\
\hline CAMILA & 203 & 209 \\
\hline CASSIA & 211 & 216 \\
\hline$\overline{\text { CINIRA }}$ & 209 & 214 \\
\hline CRISTIAN & 186 & 191 \\
\hline DANIEL & 175 & 182 \\
\hline FABIO O & 211 & 217 \\
\hline FABIO P & 183 & 188 \\
\hline GABRIELLE & 169 & 175 \\
\hline HELOISA & 213 & 219 \\
\hline HENRIQUE & 148 & 155 \\
\hline HERMANO & 139 & 147 \\
\hline JEFFERSON & 181 & 186 \\
\hline JULIANA & 180 & 190 \\
\hline LETICIA & 177 & 183 \\
\hline LIVIA & 178 & 191 \\
\hline LUCIANA & 162 & 168 \\
\hline LUIZ HENRIQUE & 174 & 183 \\
\hline MARIANA & 169 & 175 \\
\hline MICHELLE & 181 & 188 \\
\hline NATHALIE & 144 & 151 \\
\hline PAMELA & 173 & 179 \\
\hline RAFAELA & 153 & 159 \\
\hline RAQUEL & 144 & 148 \\
\hline RENATHA & 151 & 156 \\
\hline STEFANI & 168 & 173 \\
\hline THAIZE & 193 & 199 \\
\hline MÉDIA & 174,88 & 181,31 \\
\hline
\end{tabular}


Tabela 13. Tempo de tratamento em dias para a distalização dos molares superiores

\begin{tabular}{l|c}
\hline PACIENTES -32 & TEMPO DE TRATAMENTO (DIAS) \\
\hline ALESSANDRA O & 167 \\
\hline ALESSANDRA V & 154 \\
\hline ANA LUCIA & 205 \\
\hline ARIELA & 174 \\
\hline BRUNA & 175 \\
\hline BRUNO & 157 \\
\hline CAMILA & 178 \\
\hline CASSIA & 176 \\
\hline CINIRA & 173 \\
\hline CRISTIAN & 180 \\
\hline DANIEL & 208 \\
\hline FABIO O & 198 \\
\hline FABIO P & 176 \\
\hline GABRIELLE & 159 \\
\hline HELOISA & 159 \\
\hline HENRIQUE & 176 \\
\hline HERMANO & 187 \\
\hline JEFFERSON & 169 \\
\hline JULIANA & 211 \\
\hline LETICIA & 168 \\
\hline LIVIA & 173 \\
\hline LUCIANA & 167 \\
\hline LUIZ HENRIQUE & 211 \\
\hline MARIANA & 167 \\
\hline MICHELLE & 176 \\
\hline NATHALIE & 174 \\
\hline PAMELA & 174 \\
\hline RAFAELA & 170 \\
\hline RAQUEL & 129 \\
\hline RENATA & 192 \\
\hline STEFANI & 203 \\
\hline THAIZE & 153 \\
\hline MEEDIA & $\mathbf{1 7 6 , 2 1 8 7 5}$ \\
\hline & \\
\hline & \\
\hline
\end{tabular}


Tabela 14. Dados referentes a avaliação da telerradiografia em norma lateral convencional (Fase inicial).

\begin{tabular}{l|c|c|c|c|c|c|c}
\hline Pacientes - 31 & SNA & SNB & SND & A-Nperp & Pg-Nperp & ANB & AFAI \\
\hline ALESSANDRA O. & 76,4 & 74,8 & 71,2 & $-2,5$ & $-6,2$ & 1,6 & 67,4 \\
\hline ALESSANDRA V. & 86,7 & 82,7 & 78 & 4,4 & $-2,2$ & 4 & 68,2 \\
\hline ANA LUCIA B. & 82,5 & 79,2 & 76,2 & 1,5 & $-0,8$ & 3,4 & 62,7 \\
\hline ARIELA G. & 83,4 & 80,3 & 77,8 & 0,2 & $-1,5$ & 3,1 & 65,2 \\
\hline BRUNA H. B. & 86,7 & 82,3 & 78,5 & 5 & 3,2 & 4,4 & 64 \\
\hline BRUNO D. F. & 82,4 & 79,8 & 76,7 & 1,3 & $-0,9$ & 2,6 & 58,4 \\
\hline CAMILLA D. & 82,2 & 77,7 & 74,8 & $-0,5$ & -6 & 4,5 & 65,4 \\
\hline CASSIA G. & 81,6 & 76,3 & 74,4 & $-1,3$ & $-8,1$ & 5,3 & 66,8 \\
\hline CINIRA R. & 74,7 & 70,7 & 69,9 & $-5,4$ & $-13,6$ & 4 & 70,7 \\
\hline CRISTIAN R. & 81,9 & 76,3 & 74,3 & $-1,1$ & $-10,1$ & 5,6 & 69,2 \\
\hline DANIEL U. & 84,5 & 80,1 & 76,5 & 2 & -2 & 4,3 & 71,6 \\
\hline FABIO O. & 84,3 & 76,8 & 74,2 & 3,5 & $-5,2$ & 7,5 & 72,3 \\
\hline FABIO P. G. & 82 & 78,2 & 77 & $-4,3$ & $-9,2$ & 3,8 & 70,6 \\
\hline GABRIELLE S. & 80,3 & 79,7 & 77,3 & -1 & 0,4 & 0,6 & 58,6 \\
\hline HELOISA CAS & 83,7 & 80,3 & 78,2 & $-2,6$ & $-7,4$ & 3,5 & 61,9 \\
\hline HENRIQUE P. & 77,6 & 76,3 & 74,3 & $-4,7$ & $-8,2$ & 1,4 & 69,6 \\
\hline HERMANO M. C. & 86,2 & 82,8 & 78,6 & 1,7 & $-1,9$ & 3,4 & 61,5 \\
\hline JEFERSON L. & 83,3 & 78,5 & 75 & 0,2 & $-7,6$ & 4,9 & 67,5 \\
\hline JULIANA D. & 80,6 & 77,4 & 75,6 & $-0,6$ & $-2,5$ & 3,2 & 59,2 \\
\hline LETICIA Q. & 78,7 & 76,3 & 74,2 & $-2,5$ & -2 & 2,3 & 64,3 \\
\hline LIVIA P. & 75 & 73 & 70,9 & $-1,7$ & $-3,1$ & 2 & 66,8 \\
\hline LUCIANA I. & 85,5 & 80,9 & 76,8 & 3,8 & $-0,4$ & 4,6 & 61 \\
\hline LUIZ H. S. & 85 & 79,2 & 76,1 & 5,3 & 2,1 & 5,8 & 62,5 \\
\hline MARIANA B.V. & 79,8 & 77,6 & 74,6 & $-4,3$ & -3 & 2,2 & 67,2 \\
\hline MICHELLE V. O. & 81 & 76,6 & 74 & 0,2 & -3 & 4,4 & 65,7 \\
\hline NATHALIE M. N. & 80,1 & 73,6 & 70,1 & 0,2 & -10 & 6,4 & 64,7 \\
\hline PAMELA S. M. & 79 & 74 & 72 & 0 & $-3,9$ & 5 & 63,3 \\
\hline RAFAELA O. & 86,8 & 79,8 & 76 & 5,1 & $-5,9$ & 7,1 & 78,7 \\
\hline RAQUEL I. & 80,8 & 76,5 & 73,8 & 1,2 & $-4,7$ & 4,3 & 66,7 \\
\hline STEFANI H. & 82,8 & 75,9 & 73,7 & 2,9 & $-4,3$ & 6,9 & 65,9 \\
\hline THAIZE Q. & 79,5 & 75,9 & 72,8 & 2,9 & $-1,1$ & 3,6 & 67,8 \\
\hline MEDIA & $\mathbf{8 1 , 7 7}$ & $\mathbf{7 7 , 7 3}$ & $\mathbf{7 4 , 9 5}$ & $\mathbf{0 , 2 9}$ & $-4,16$ & $\mathbf{4 , 0 5}$ & $\mathbf{6 5 , 9 8}$ \\
\hline & & & & & & & \\
\hline
\end{tabular}


Tabela 15. Dados referentes a avaliação da telerradiografia em norma lateral convencional (Fase inicial)

\begin{tabular}{c|c|c|c|c|c|c|c}
\hline SN.GoGn & FMA & FRANK.OcI & FRANK.PaI & FRANK.GoGn & SN.PIOcl. & SN.Gn & 1.NA \\
\hline 39,5 & 32 & 7,5 & 1,2 & 28,4 & 18,6 & 69,4 & 23,5 \\
\hline 30,8 & 25,5 & 1 & $-2,8$ & 23,9 & 9,5 & 65,6 & 26,2 \\
\hline 30 & 22,8 & 4,3 & $-5,5$ & 20,8 & 13,5 & 64,9 & 28,8 \\
\hline 27,6 & 23,7 & 7,7 & $-2,6$ & 20,8 & 14,5 & 65,8 & 22 \\
\hline 27,9 & 20,3 & 2,9 & $-0,4$ & 19,1 & 11,7 & 63,4 & 16,2 \\
\hline 25,5 & 18,5 & 0,8 & $-2,6$ & 16,5 & 9,8 & 62,6 & 33,1 \\
\hline 24,2 & 19 & 2,8 & 2,2 & 17,3 & 9,7 & 68,2 & 17,8 \\
\hline 29 & 24,3 & 4 & 0,1 & 21,9 & 11,2 & 67,2 & 17,1 \\
\hline 39,2 & 30,9 & 6,2 & -3 & 29,1 & 16,3 & 72 & 20,8 \\
\hline 32 & 27,5 & 6,6 & 1,6 & 24,9 & 13,6 & 69,4 & 21,9 \\
\hline 28,3 & 23,9 & 4,7 & $-2,6$ & 20,5 & 12,6 & 68,5 & 18,5 \\
\hline 34,4 & 26,9 & 4,4 & -1 & 25 & 13,8 & 67,9 & 12,3 \\
\hline 24,3 & 21,7 & 2,8 & 1 & 20,4 & 6,7 & 64,9 & 17,1 \\
\hline 25,3 & 20 & 2 & $-0,4$ & 17,4 & 9,9 & 62,5 & 30,2 \\
\hline 23,6 & 21,5 & 9,6 & 5,8 & 19,9 & 13,3 & 62,9 & 21,1 \\
\hline 36,2 & 31,2 & 3,8 & $-3,2$ & 28,5 & 11,4 & 68,7 & 28,8 \\
\hline 26,6 & 23,7 & 7,5 & $-6,9$ & 20,9 & 13,3 & 63,3 & 31 \\
\hline 36,2 & 31,6 & 4 & 1,1 & 29,4 & 10,7 & 68,7 & 28,6 \\
\hline 27,7 & 21,3 & 4,6 & $-0,5$ & 18,9 & 13,5 & 66 & 17,4 \\
\hline 29 & 22,6 & 5,3 & $-2,3$ & 20,2 & 14 & 67,9 & 37,6 \\
\hline 35 & 24 & 4,3 & $-0,9$ & 21,7 & 17,6 & 72,5 & 18 \\
\hline 27,9 & 22,1 & 7,2 & $-2,9$ & 19,5 & 15,6 & 65,2 & 22,6 \\
\hline 27,8 & 19,2 & $-1,5$ & $-3,5$ & 17,7 & 8,6 & 64,3 & 27,3 \\
\hline 29 & 26,4 & 5,1 & $-5,3$ & 23,9 & 10,2 & 65 & 33,7 \\
\hline 25,6 & 18,7 & 0,7 & $-1,9$ & 16,4 & 9,9 & 64,3 & 14,7 \\
\hline 37,2 & 29,4 & 10,3 & 0,5 & 27,1 & 20,5 & 73,2 & 18 \\
\hline 28 & 19 & 5,5 & 0 & 17 & 16,5 & 69,2 & 36,9 \\
\hline 36,9 & 31,6 & 8,6 & $-2,7$ & 29 & 16,5 & 68,7 & 15 \\
\hline 38,2 & 30,2 & 9,3 & -1 & 27,8 & 19,7 & 70,7 & 24,3 \\
\hline 34,6 & 26,6 & 10,1 & $-0,4$ & 24,3 & 20,4 & 68,1 & 14,3 \\
\hline 34,5 & 23,9 & 7,4 & 0,7 & 21,4 & 20,4 & 71,4 & 15,6 \\
\hline $\mathbf{3 0 , 7 1}$ & $\mathbf{2 4 , 5 2}$ & $\mathbf{5 , 1 5}$ & $\mathbf{- 1 , 2 3}$ & $\mathbf{2 2 , 2 5}$ & $\mathbf{1 3 , 6 6}$ & $\mathbf{6 7 , 1 7}$ & $\mathbf{2 2 , 9 2}$ \\
\hline & & & & & & & \\
\hline
\end{tabular}


Tabela 16. Dados referentes a avaliação da telerradiografia em norma lateral convencional (Fase inicial)

\begin{tabular}{c|c|c|c|c|c|c|c}
\hline 1-NA & 1-AV & FRANK.4 & FRANK.6 & 1-PTV & 4-PTV & $\mathbf{6 - P T V}$ & SOBREM. \\
\hline 5,1 & 4 & 96,9 & 101,8 & 61,5 & 42,9 & 31 & $-1,6$ \\
\hline 6,1 & 8 & 81,1 & 94,7 & 65,5 & 46 & 30,6 & $-4,2$ \\
\hline 5,9 & 6,5 & 85,3 & 99,1 & 61,4 & 41,6 & 27,7 & $-5,6$ \\
\hline 5,2 & 5,3 & 87,3 & 99,2 & 61,6 & 44,8 & 29,2 & $-5,6$ \\
\hline 5 & 5,4 & 87,9 & 93,1 & 63,9 & 45 & 30,4 & $-5,3$ \\
\hline 7,1 & 7,6 & 83 & 100,3 & 65 & 47,5 & 32,1 & $-4,3$ \\
\hline 2,8 & 2,4 & 87,1 & 99 & 58 & 40,3 & 24,1 & $-6,7$ \\
\hline 1,4 & 0,9 & 91,2 & 97,3 & 57 & 41,4 & 29,2 & $-6,8$ \\
\hline 6,5 & 4 & 96,3 & 102,3 & 57,2 & 37,1 & 24,5 & $-6,7$ \\
\hline 5,8 & 5,3 & 96,4 & 100,8 & 58 & 37,9 & 24,6 & $-6,6$ \\
\hline 3,9 & 5 & 89,3 & 101,2 & 61,7 & 42,6 & 27,8 & $-4,5$ \\
\hline 1,2 & 2,8 & 86,5 & 96,8 & 67,1 & 49,5 & 35,6 & $-8,3$ \\
\hline 2,8 & 1,1 & 91,6 & 100 & 55,6 & 38 & 23,3 & $-7,3$ \\
\hline 7,1 & 6,4 & 84,1 & 101,3 & 62,1 & 43,1 & 26,7 & $-4,9$ \\
\hline 5 & 3,9 & 94,5 & 100,1 & 60,9 & 41,9 & 28,2 & $-6,6$ \\
\hline 8,8 & 6,8 & 83,6 & 98,8 & 60,5 & 41,9 & 27,7 & $-4,6$ \\
\hline 6,4 & 7,1 & 83,3 & 100,3 & 61,7 & 43,5 & 30,1 & $-3,1$ \\
\hline 7,9 & 8 & 90,2 & 100,4 & 60,1 & 39,7 & 24,4 & $-4,5$ \\
\hline 2,8 & 2,6 & 94,8 & 97,7 & 57,9 & 39,7 & 25,9 & $-6,9$ \\
\hline 9,6 & 8,6 & 94,2 & 97,4 & 60,2 & 36,7 & 23,5 & $-5,3$ \\
\hline 3,5 & 2,7 & 86 & 100,4 & 53,8 & 38,6 & 23,6 & $-3,4$ \\
\hline 3,9 & 5,4 & 86,5 & 94,5 & 61,3 & 42,4 & 27,8 & $-4,7$ \\
\hline 4,4 & 6,3 & 83,8 & 98,7 & 65,7 & 44,7 & 29,4 & $-4,7$ \\
\hline 9,1 & 7 & 87,8 & 104,3 & 62,4 & 41,3 & 27,2 & $-5,5$ \\
\hline 1,5 & 1,6 & 87,8 & 95,7 & 62,1 & 43,7 & 27,8 & $-7,1$ \\
\hline 2 & 2,1 & 80,1 & 102,3 & 52,1 & 38 & 23,3 & -5 \\
\hline 7,3 & 7,3 & 86,8 & 96,2 & 62,4 & 39,9 & 25,2 & $-3,8$ \\
\hline 3,6 & 5,9 & 87,8 & 98,4 & 65,5 & 47,1 & 33,2 & $-3,8$ \\
\hline 6,5 & 7 & 88,2 & 99,8 & 59 & 39,4 & 26,4 & $-2,6$ \\
\hline 1,6 & 2,9 & 91,6 & 104,5 & 57,5 & 41,1 & 27,2 & $-4,6$ \\
\hline 0,6 & 1,7 & 89 & $-86,2$ & 57 & 41,1 & 29 & $-5,9$ \\
\hline $\mathbf{4 , 8 5}$ & $\mathbf{4 , 8 9}$ & $\mathbf{8 8 , 3 9}$ & $\mathbf{9 3 , 2 3}$ & $\mathbf{6 0 , 5 1}$ & $\mathbf{4 1 , 8 8}$ & $\mathbf{2 7 , 6 4}$ & $-\mathbf{5 , 1 8}$ \\
\hline & & & & & & & \\
\hline
\end{tabular}


Tabela 17. Dados referentes a avaliação da telerradiografia em norma lateral convencional (Fase inicial).

\begin{tabular}{|c|c|c|c|c|c|}
\hline SOBRES. & LÁBIO SUP/E & 1.1 & LÁBIO INF/E & NASOLABIAL & WITS \\
\hline 1,8 & $-0,3$ & 126,8 & 3,2 & 119,4 & 1,2 \\
\hline 5,8 & 0,6 & 115,1 & 3,4 & 96,8 & 3,5 \\
\hline 6,7 & -1 & 123,2 & 0,4 & 112,1 & 1,7 \\
\hline 3,9 & $-2,4$ & 124,8 & $-0,1$ & 104 & $-1,1$ \\
\hline 5,7 & $-4,1$ & 130,9 & $-3,3$ & 100 & 1,6 \\
\hline 4,6 & $-1,6$ & 110,8 & $-0,1$ & 106,1 & 2,2 \\
\hline 4,8 & $-2,4$ & 128,9 & $-1,5$ & 101,4 & 6 \\
\hline 6,1 & -1 & 136,3 & $-1,4$ & 120,9 & 6,6 \\
\hline 6,1 & $-2,8$ & 130,4 & $-1,1$ & 110,7 & 7 \\
\hline 5,7 & -1 & 123,5 & 2,3 & 92,1 & 5,5 \\
\hline 4,8 & -1 & 125,5 & 0,8 & 102,4 & 2,5 \\
\hline 6,6 & $-0,9$ & 130,9 & 1,2 & 105,8 & 7,3 \\
\hline 5,8 & $-2,7$ & 138 & $-4,2$ & 114,1 & 6,6 \\
\hline 5,2 & $-2,6$ & 122,6 & $-2,2$ & 100,1 & 1,5 \\
\hline 5,3 & -4 & 124,4 & $-2,2$ & 106,1 & 2 \\
\hline 5,4 & $-3,5$ & 120,6 & -1 & 106,9 & 4,5 \\
\hline 4,3 & 1,3 & 109,6 & 1,2 & 108 & $-1,7$ \\
\hline 7,2 & 4 & 113,5 & 5,8 & 106 & 4,6 \\
\hline 4,9 & $-3,6$ & 138,5 & $-2,3$ & 112,7 & 2,6 \\
\hline 10,1 & $-4,1$ & 116,5 & $-4,3$ & 104,1 & 2,2 \\
\hline 2,4 & $-4,2$ & 131,7 & $-1,7$ & 119,5 & 2,3 \\
\hline 4,7 & 0,4 & 117,5 & 1 & 99,2 & 0,3 \\
\hline 8,3 & $-2,2$ & 115,8 & $-3,5$ & 97,4 & 6,5 \\
\hline 7 & $-0,7$ & 115,9 & 1,3 & 107,1 & 2,8 \\
\hline 5,5 & $-5,2$ & 138,6 & $-4,9$ & 103 & 6,8 \\
\hline 3,1 & 1,4 & 120,8 & 5,1 & 120,8 & 3,8 \\
\hline 10 & $-2,2$ & 107,8 & $-2,5$ & 116,1 & 4,9 \\
\hline 2,8 & 1,2 & 119,6 & 3,9 & 86,9 & 2,1 \\
\hline 3,8 & 3,3 & 117,8 & 6 & 96,4 & 0,5 \\
\hline 4,6 & 0,4 & 124,5 & 1,5 & 112,4 & 2,1 \\
\hline 3,4 & $-3,9$ & 137,9 & -3 & 107,2 & 0,9 \\
\hline 5,37 & $-1,45$ & 123,83 & $-0,07$ & 106,31 & 3,2 \\
\hline
\end{tabular}


Tabela 18. Dados referentes a avaliação da telerradiografia em norma lateral convencional (Fase final).

\begin{tabular}{|c|c|c|c|c|c|c|c|}
\hline $\begin{array}{l}\text { Paci } \\
\text { ente } \\
\text { s - } \\
31\end{array}$ & SNA & SNB & SND & A-Nperp & Pg-Nperp & ANB & $\overline{\text { AFAl }}$ \\
\hline ALESSANDRA O. & 76,4 & 74,2 & 70,8 & $-2,8$ & -8 & 2,2 & 65,7 \\
\hline ALESSANDRA V. & 87,7 & 82,5 & 78,1 & 3,3 & $-4,2$ & 5,1 & 68,7 \\
\hline ANA LUCIA B. & 81,1 & 77,7 & 74,6 & 0,8 & $-2,7$ & 3,5 & 63,6 \\
\hline ARIELA G. & 84,1 & 81,4 & 78,7 & $-1,6$ & $-5,4$ & 2,7 & 65,8 \\
\hline BRUNA H. B. & 85,3 & 81,1 & 77,7 & 4,3 & 1,9 & 4,1 & 66,3 \\
\hline BRUNO D. F. & 83,4 & 80,2 & 77 & 2,6 & 0,6 & 3,1 & 61,2 \\
\hline CAMILLA D. & 84,6 & 79,3 & 76,7 & 1 & -4 & 5,3 & 67 \\
\hline CASSIA G. & 81,9 & 76,8 & 74,8 & $-0,8$ & $-6,9$ & 5,2 & 66,9 \\
\hline CINIRA R. & 75,4 & 70,5 & 69,9 & $-6,2$ & $-17,3$ & 5 & 73,3 \\
\hline $\begin{array}{l}\text { CRISTIAN R. } \\
\text {. }\end{array}$ & 81,9 & 75,5 & 73,5 & $-1,5$ & -13 & 6,4 & 71,4 \\
\hline DANIEL U. & 85,9 & 80,2 & 76,8 & 2,2 & $-3,8$ & 5,7 & 72,4 \\
\hline FABIO O. & 82,6 & 76,6 & 74,4 & 1,5 & -7 & 6 & 74,8 \\
\hline FABIO P. G. & 83 & 79,1 & 78 & $-2,8$ & $-6,6$ & 4 & 74,3 \\
\hline GABRIELLE S. & 81 & 80,2 & 77,8 & 0,6 & 3,3 & 0,8 & 60,5 \\
\hline HELOISA CAS & 84,1 & 80,3 & 78 & $-2,6$ & $-8,3$ & 3,8 & 61,9 \\
\hline HENRIQUE P. & 80,8 & 76,1 & 74,3 & $-1,6$ & $-9,2$ & 4,7 & 73,4 \\
\hline HERMANO M. C. & 87,4 & 82 & 78,7 & 2,5 & $-3,3$ & 5,4 & 64,9 \\
\hline JEFERSON L. & 82,8 & 78,8 & 75,5 & 1 & -5 & 4 & 73,9 \\
\hline JULIANA D. & 79,9 & 75,9 & 73,9 & $-0,4$ & $-3,9$ & 4 & 59,8 \\
\hline LETICIA Q. & 80,1 & 76,9 & 74,8 & $-2,8$ & $-2,9$ & 3,2 & 66 \\
\hline LIVIA P. & 75,3 & 72,7 & 70,8 & $-2,1$ & $-4,8$ & 2,6 & 67,4 \\
\hline LUCIANA I. & 84,5 & 78,8 & 75,1 & 2,9 & $-3,9$ & 5,7 & 63,2 \\
\hline LUIZ H. S. & 85,3 & 79,9 & 77,2 & 3,3 & $-0,4$ & 5,3 & 64,3 \\
\hline MARIANA B.V. & 78,6 & 78,2 & 75 & $-3,3$ & -2 & 0,4 & 69,1 \\
\hline MICHELLE V. O. & 80,2 & 75,5 & 73,3 & 1,5 & -7 & 4,7 & 69,4 \\
\hline NATHALIE M. N. & 79,7 & 72,4 & 69,5 & 1,2 & $-9,7$ & 7,3 & 68,3 \\
\hline PAMELA S. M. & 78,6 & 74,3 & 72,3 & $-2,8$ & $-7,8$ & 4,2 & 63,8 \\
\hline
\end{tabular}


Tabela 19. Dados referentes a avaliação da telerradiografia em norma lateral convencional (Fase final).

\begin{tabular}{|c|c|c|c|c|c|c|c|}
\hline SN.GoGn & FMA & FRANK.Ocl & FRANK.Pal. & FRANK.GoGN & SN.PI.Ocl & SN.Gn & 1.NA \\
\hline 39,1 & 32,3 & 6,8 & 4,7 & \begin{tabular}{|l|}
28,4 \\
\end{tabular} & 17,5 & 70 & 25,3 \\
\hline 30,5 & 27,5 & 5,1 & 0,1 & 24,8 & 10,8 & 66 & 25,1 \\
\hline 31,2 & 23,5 & 4,3 & $-4,7$ & 21,5 & 14,1 & 66,4 & 31,2 \\
\hline 27,6 & 26,2 & 9,4 & 0,4 & 23,2 & 13,7 & 65,3 & 26,7 \\
\hline 28,9 & 21 & 0,3 & $-0,5$ & 19,6 & 9,6 & 64,6 & 21,8 \\
\hline 25,3 & 17,8 & $-0,4$ & -4 & 15,9 & 9 & 62,6 & 34,4 \\
\hline 22,5 & 18,9 & 7,4 & 2,5 & 17 & 12,9 & 66,9 & 18,1 \\
\hline 28,7 & 24,7 & 5,8 & 0,9 & 22,6 & 11,9 & 66,7 & 21,8 \\
\hline 39,2 & 32,5 & 4,6 & $-2,1$ & 30,7 & 13 & 72,7 & 22,2 \\
\hline 33,7 & 29,5 & 8,4 & 1,7 & 27 & 15,1 & 70,2 & 30,5 \\
\hline 28,2 & 23,6 & 4,4 & $-2,2$ & 20,4 & 12,1 & 68 & 23 \\
\hline 35,5 & 30,3 & 8,4 & 1 & 28,5 & 15,4 & 68,6 & 16,1 \\
\hline 23,8 & 21,1 & 2,3 & 0,4 & 19,5 & 6,6 & 64,2 & 20,6 \\
\hline 25,6 & 19 & 0,6 & $-3,4$ & 16 & 10,2 & 62,3 & 35,7 \\
\hline 23,9 & 22 & 10 & 6,4 & 20,5 & 13,3 & 63,2 & 26 \\
\hline 38,1 & 32,8 & 6,3 & -3 & 30,5 & 14 & 69,5 & 29 \\
\hline 27,4 & 24,3 & 4,2 & $-3,7$ & 21,9 & 9,7 & 64 & 24,8 \\
\hline 37,4 & 31,3 & 4 & 0,4 & 29,1 & 12 & 70,1 & 34,9 \\
\hline 29,2 & 21,7 & 4,8 & $-0,9$ & 19,5 & 14,6 & 67,3 & 21,5 \\
\hline 28,3 & 24,1 & 7,3 & $-3,7$ & 21,3 & 14,4 & 67,3 & 43,2 \\
\hline 35,3 & 25,3 & 7,4 & $-0,4$ & 22,6 & 20,1 & 72,9 & 23,2 \\
\hline 30,5 & 24,8 & 6 & $-2,1$ & 22,1 & 14,4 & 67,1 & 26 \\
\hline 26,7 & 20,6 & 4,4 & $-2,1$ & 18,8 & 12,3 & 63,7 & 33,7 \\
\hline 28,5 & 23,8 & 2,5 & $-6,3$ & 20,9 & 10 & 64,9 & 38 \\
\hline 27,4 & 22,9 & 4,8 & 0,5 & 20,4 & 11,7 & 66,1 & 20,5 \\
\hline 39,2 & 30 & 7,6 & 0 & 27,8 & 19 & 75,6 & 16,7 \\
\hline 28,4 & 21,5 & 4,6 & 1,9 & 19,6 & 13,4 & 69,1 & 46,3 \\
\hline 37,9 & 34,2 & 7,9 & $-0,7$ & 31,6 & 14,3 & 69,8 & 14,7 \\
\hline 40,1 & 34,2 & 14,7 & $-0,6$ & 31,4 & 23,5 & 72,5 & 29,8 \\
\hline 35,9 & 26 & 4,3 & 0,1 & 23,7 & 16,5 & 69,4 & 18,1 \\
\hline 32,6 & 23,4 & 5,5 & 0,4 & 21,1 & 17 & 69,7 & 17 \\
\hline 31,18 & 25,51 & 5,6 & $-0,61$ & 23,16 & 13,62 & 67,64 & 26,32 \\
\hline
\end{tabular}


Tabela 20. Dados referentes a avaliação da telerradiografia em norma lateral convencional (Fase final).

\begin{tabular}{c|c|c|c|c|c|c|c}
\hline 1-NA & 1-AV & FRANK.4 & FRANK.6 & 1-PTV & 4-PTV & 6-PTV & SOBREM. \\
\hline 6,1 & 4,9 & 83,3 & 121,5 & 63,4 & 47,5 & 25,6 & $-1,1$ \\
\hline 6,1 & 7,6 & 77,6 & 109,5 & 65,2 & 47,9 & 23,9 & $-4,1$ \\
\hline 6,9 & 7,2 & 81,5 & 110 & 62,7 & 42,9 & 22,8 & $-4,9$ \\
\hline 6,5 & 6,6 & 82,4 & 116,9 & 63,3 & 46,6 & 24,2 & $-5,1$ \\
\hline 5 & 7 & 83,2 & 105 & 66,3 & 47,8 & 26 & $-4,3$ \\
\hline 7,3 & 8,4 & 81,6 & 105,1 & 67 & 48,8 & 27 & $-4,5$ \\
\hline 3 & 3 & 93,6 & 104,6 & 58,9 & 40,2 & 20,6 & $-5,7$ \\
\hline 2,2 & 1,5 & 83,7 & 110,3 & 57,9 & 44,3 & 24,1 & $-5,2$ \\
\hline 7,4 & 4,3 & 92,2 & 110,9 & 56,8 & 41,2 & 22 & $-5,2$ \\
\hline 8,5 & 7,9 & 98,8 & 117,8 & 61,6 & 41,1 & 21,1 & $-5,7$ \\
\hline 3,8 & 5 & 84,9 & 112,6 & 63,2 & 44,6 & 24 & $-3,7$ \\
\hline 3 & 2,8 & 86 & 110,8 & 64,7 & 49,6 & 29,7 & $-8,4$ \\
\hline 4,2 & 3,1 & 93,6 & 107,5 & 58,6 & 41 & 21,6 & $-5,2$ \\
\hline 8 & 8,2 & 71,1 & 109,2 & 65,3 & 48 & 24,7 & $-3,9$ \\
\hline 7,2 & 6,1 & 84,8 & 116,3 & 63,3 & 45,7 & 24,9 & $-6,3$ \\
\hline 7,3 & 6,7 & 84,8 & 112,1 & 63,3 & 45,4 & 22,3 & $-2,7$ \\
\hline 5 & 6,2 & 83,1 & 112,8 & 62,1 & 46,7 & 24,4 & $-1,5$ \\
\hline 11,1 & 11,5 & 94,6 & 106,5 & 67,3 & 46,4 & 25,3 & -2 \\
\hline 4,5 & 4,3 & 90 & 106,3 & 58,3 & 41,5 & 22,4 & $-6,8$ \\
\hline 10,3 & 9,3 & 86 & 109,2 & 60,9 & 38,7 & 18,7 & $-2,6$ \\
\hline 4,1 & 3,2 & 89,1 & 107,2 & 54,2 & 39 & 21,4 & $-4,6$ \\
\hline 5 & 6,2 & 82,8 & 105,8 & 61,9 & 45 & 23,2 & $-2,8$ \\
\hline 7 & 8,1 & 79,3 & 111,2 & 69,1 & 48,4 & 25,1 & $-2,5$ \\
\hline 12,6 & 10,9 & 74,2 & 111,7 & 66,1 & 47,8 & 24,3 & $-3,6$ \\
\hline 4,2 & 3 & 93,5 & 112,8 & 60,6 & 43,8 & 19,5 & $-4,8$ \\
\hline 2,7 & 3,2 & 87,9 & 116,2 & 53,9 & 40,4 & 18,8 & $-4,5$ \\
\hline 9,4 & 8,6 & 81,7 & 118,5 & 63,4 & 42,4 & 18,3 & $-3,1$ \\
\hline 3,7 & 5,1 & 89,3 & 127,4 & 64,1 & 48 & 23,2 & $-4,7$ \\
\hline 9,6 & 9,3 & 85,5 & 115,3 & 60 & 41 & 18,8 & $-0,3$ \\
\hline 2,5 & 4,2 & 100 & 109,9 & 61,9 & 44,9 & 25,8 & -4 \\
\hline 0,7 & 1,8 & 82,1 & 112,8 & 57,4 & 44,1 & 20,4 & -5 \\
\hline $\mathbf{5 , 9 6}$ & $\mathbf{5 , 9 7}$ & $\mathbf{8 5 , 8 8}$ & $\mathbf{1 1 1 , 7 3}$ & $\mathbf{6 2 , 0 2}$ & $\mathbf{4 4 , 5 4}$ & $\mathbf{2 3 , 0 4}$ & $-\mathbf{4 , 1 5}$ \\
\hline & & & & & & &
\end{tabular}


Tabela 21. Dados referentes a avaliação da telerradiografia em norma lateral convencional (Fase final).

\begin{tabular}{|c|c|c|c|c|c|}
\hline SOBRES. & LÁBIO SUP/E & 1.1 & LÁBIO INF/E & NASOLABIAL & WITS \\
\hline 3,8 & \begin{tabular}{|l|}
0,7 \\
\end{tabular} & 125,1 & \begin{tabular}{|l|}
3,3 \\
\end{tabular} & 118,7 & 1,2 \\
\hline 7 & 1,8 & 115,1 & 3,8 & 99,1 & 2,6 \\
\hline 8,2 & $-0,2$ & 121,1 & 1,3 & 113 & 2,1 \\
\hline 5 & $-2,1$ & 118,7 & 1,2 & 107,8 & $-0,4$ \\
\hline 6,9 & $-3,4$ & 125,2 & $-3,5$ & 104,2 & 3,4 \\
\hline 5,2 & $-1,9$ & 110,6 & 0,5 & 106,7 & 3,8 \\
\hline 5 & $-2,9$ & 126,1 & $-0,7$ & 95,2 & 3,6 \\
\hline 6,4 & $-1,4$ & 130,9 & $-1,5$ & 128,1 & 6,1 \\
\hline 8,1 & $-2,9$ & 129,1 & 0,2 & 118,8 & 11 \\
\hline 8,9 & $-0,1$ & 110,3 & 3,1 & 98,6 & 5,4 \\
\hline 7,1 & $-1,2$ & 117,5 & 1,1 & 108,7 & 5 \\
\hline 6,3 & -2 & 133,4 & -2 & 97,7 & 5,3 \\
\hline 8 & $-3,6$ & 135,8 & -5 & 115,1 & 6,1 \\
\hline 6,4 & $-2,1$ & 117,3 & $-0,7$ & 90,5 & 1,7 \\
\hline 6,1 & $-3,4$ & 115 & $-1,2$ & 110,6 & 2,7 \\
\hline 8,6 & -3 & 118,9 & $-2,9$ & 104,4 & 5 \\
\hline 6,1 & 1,3 & 115,3 & 2 & 114,1 & 2,5 \\
\hline 9,5 & 3,6 & 110,7 & 5,9 & 102,4 & 3,7 \\
\hline 7,1 & $-2,5$ & 128,9 & $-1,7$ & 122,3 & 4,2 \\
\hline 12 & $-2,2$ & 110 & $-2,5$ & 104,2 & 2,1 \\
\hline 3,6 & $-4,1$ & 123,8 & $-1,5$ & 126,2 & 1,3 \\
\hline 6,7 & 1 & 112,9 & 1,5 & 95,4 & 2 \\
\hline 10,8 & $-2,9$ & 113,3 & -3 & 95,6 & 5,5 \\
\hline 8,2 & $-0,7$ & 113,5 & 2,3 & 108,3 & 1,9 \\
\hline 7,9 & $-3,5$ & 133,3 & $-3,8$ & 103,7 & 6,8 \\
\hline 3,9 & 1,5 & 119,3 & 6,1 & 122,6 & 6,5 \\
\hline 11,7 & -2 & 104 & -2 & 111,9 & 5,3 \\
\hline 4 & 1,6 & 120,5 & 4,4 & 88,6 & 3,9 \\
\hline 7,2 & 4,2 & 110,7 & 6,6 & 95,4 & 1,4 \\
\hline 6 & $-0,2$ & 119,1 & 0,3 & 116,4 & 6,6 \\
\hline 3,2 & $-3,5$ & 133,6 & $-2,9$ & 113,3 & 1 \\
\hline 6,93 & $-1,16$ & 119,97 & 0,28 & 107,66 & 3,85 \\
\hline
\end{tabular}


Tabela 22. Dados referentes a avaliação da telerradiografia em norma lateral convencional de 10 pacientes selecionados ao acaso (Valores retirados da amostra total da fase inicial).

\begin{tabular}{l|c|c|c|c|c|c|c}
\hline Pacientes - 10 & SNA & SNB & SND & A-Nperp & Pg-Nperp & ANB & AFAI \\
\hline ALESSANDRA V. & 86,7 & 82,7 & 78 & 4,4 & $-2,2$ & 4 & 68,2 \\
\hline BRUNA H. B. & 86,7 & 82,3 & 78,5 & 5 & 3,2 & 4,4 & 64 \\
\hline CASSIA G. & 81,6 & 76,3 & 74,4 & $-1,3$ & $-8,1$ & 5,3 & 66,8 \\
\hline DANIEL U. & 84,5 & 80,1 & 76,5 & 2 & -2 & 4,3 & 71,6 \\
\hline JEFERSON L. & 83,3 & 78,5 & 75 & 0,2 & $-7,6$ & 4,9 & 67,5 \\
\hline JULIANA D. & 80,6 & 77,4 & 75,6 & $-0,6$ & $-2,5$ & 3,2 & 59,2 \\
\hline LIVIA P. & 75 & 73 & 70,9 & $-1,7$ & $-3,1$ & 2 & 66,8 \\
\hline PAMELA S. M. & 79 & 74 & 72 & 0 & $-3,9$ & 5 & 63,3 \\
\hline RAQUEL I. & 80,8 & 76,5 & 73,8 & 1,2 & $-4,7$ & 4,3 & 66,7 \\
\hline STEFANI H. & 82,8 & 75,9 & 73,7 & 2,9 & $-4,3$ & 6,9 & 65,9 \\
\hline MÉDIA & $\mathbf{8 2 , 1}$ & $\mathbf{7 7 , 6 7}$ & $\mathbf{7 4 , 8 4}$ & $\mathbf{1 , 2 1}$ & $\mathbf{- 3 , 5 2}$ & $\mathbf{4 , 4 3}$ & $\mathbf{6 6}$ \\
\hline
\end{tabular}

Tabela 23. Dados referentes a remedição da telerradiografia em norma lateral convencional (Fase inicial).

\begin{tabular}{l|c|c|c|c|c|c|c}
\hline Pacientes - 10 & SNA & SNB & SND & A-Nperp & Pg-Nperp & ANB & AFAI \\
\hline ALESSANDRA V. & 87,5 & 83,4 & 78,7 & 4 & -2 & 4,1 & 68,8 \\
\hline BRUNA H. B. & 87 & 82,7 & 78,8 & 4,6 & 3,3 & 4,3 & 64,1 \\
\hline CASSIA G. & 82,3 & 76,6 & 74,4 & -1 & $-8,9$ & 5,7 & 67,2 \\
\hline DANIEL U. & 83,3 & 79,4 & 75,7 & 1,8 & $-1,8$ & 3,8 & 71,2 \\
\hline JEFERSON L. & 85,9 & 79,3 & 75,5 & 1,6 & $-8,7$ & 6,6 & 69 \\
\hline JULIANA D. & 80,3 & 77,8 & 76,2 & $-1,5$ & $-2,9$ & 2,5 & 58,1 \\
\hline LIVIA P. & 75,9 & 73,2 & 71,3 & $-2,4$ & $-5,3$ & 2,7 & 66,8 \\
\hline PAMELA S. M. & 78,8 & 74,2 & 72 & 1,7 & $-0,2$ & 4,6 & 63,2 \\
\hline RAQUEL I. & 81,2 & 76,5 & 73,7 & 2,4 & $-3,1$ & 4,6 & 67,6 \\
\hline STEFANI H. & 80,9 & 75,1 & 72,4 & 3,3 & $-2,1$ & 5,8 & 65,9 \\
\hline MÉDIA & $\mathbf{8 2 , 3 1}$ & $\mathbf{7 7 , 8 2}$ & $\mathbf{7 4 , 8 7}$ & $\mathbf{1 , 4 5}$ & $\mathbf{- 3 , 1 7}$ & $\mathbf{4 , 4 7}$ & $\mathbf{6 6 , 1 9}$ \\
\hline
\end{tabular}


Tabela 24. Dados referentes a avaliação da telerradiografia em norma lateral convencional de 10 pacientes selecionados ao acaso (Valores retirados da amostra total da fase inicial).

\begin{tabular}{c|c|c|c|c|c|c|c}
\hline SN.GoGn & FMA & FRANK.Ocl & FRANK.Pal & FRANK.GoGn & SN.PIOcl. & SN.Gn & 1.NA \\
\hline 30,8 & 25,5 & 1 & $-2,8$ & 23,9 & 9,5 & 65,6 & 26,2 \\
\hline 27,9 & 20,3 & 2,9 & $-0,4$ & 19,1 & 11,7 & 63,4 & 16,2 \\
\hline 29 & 24,3 & 4 & 0,1 & 21,9 & 11,2 & 67,2 & 17,1 \\
\hline 28,3 & 23,9 & 4,7 & $-2,6$ & 20,5 & 12,6 & 68,5 & 18,5 \\
\hline 36,2 & 31,6 & 4 & 1,1 & 29,4 & 10,7 & 68,7 & 28,6 \\
\hline 27,7 & 21,3 & 4,6 & $-0,5$ & 18,9 & 13,5 & 66 & 17,4 \\
\hline 35 & 24 & 4,3 & $-0,9$ & 21,7 & 17,6 & 72,5 & 18 \\
\hline 28 & 19 & 5,5 & 0 & 17 & 16,5 & 69,2 & 36,9 \\
\hline 38,2 & 30,2 & 9,3 & -1 & 27,8 & 19,7 & 70,7 & 24,3 \\
\hline 34,6 & 26,6 & 10,1 & $-0,4$ & 24,3 & 20,4 & 68,1 & 14,3 \\
\hline $\mathbf{3 1 , 5 7}$ & $\mathbf{2 4 , 6 7}$ & $\mathbf{5 , 0 4}$ & $\mathbf{- 0 , 7 4}$ & $\mathbf{2 2 , 4 5}$ & $\mathbf{1 4 , 3 4}$ & $\mathbf{6 7 , 9 9}$ & $\mathbf{2 1 , 7 5}$ \\
\hline
\end{tabular}

Tabela 25. Dados referentes a remedição da telerradiografia em norma lateral convencional (Fase inicial).

\begin{tabular}{c|c|c|c|c|c|c|c}
\hline SN.GoGn & FMA & FRANK. OCL & FRANK.PAL. & FRANK.GoGn & SN.PIOcl. & SN.Gn & 1.NA \\
\hline 30,1 & 25,7 & 2 & $-2,7$ & 23,1 & 10,2 & 65,2 & 24 \\
\hline 28,3 & 21,2 & 3,8 & $-0,2$ & 25,5 & 11,8 & 63,6 & 15,7 \\
\hline 29,3 & 26,3 & 7 & 0,5 & 23,2 & 12,7 & 66,9 & 17 \\
\hline 29,1 & 25 & 5,5 & $-1,4$ & 21,5 & 13 & 68,8 & 21,5 \\
\hline 36,4 & 33 & 7 & 0,9 & 30,6 & 13,6 & 68,8 & 23,3 \\
\hline 28,2 & 22,3 & 7,1 & 0,4 & 20 & 15,2 & 65,7 & 17,1 \\
\hline 34,6 & 25,4 & 9 & 0,2 & 22,9 & 20,7 & 71,9 & 17,9 \\
\hline 27,8 & 17,3 & 1,1 & $-1,8$ & 14,9 & 13,9 & 69,3 & 37,9 \\
\hline 38,4 & 29,2 & 6,2 & -3 & 27 & 17,5 & 71 & 23,2 \\
\hline 35,4 & 25,2 & 4,6 & $-2,2$ & 22,9 & 17,1 & 68,8 & 15,3 \\
\hline $\mathbf{3 1 , 7 6}$ & $\mathbf{2 5 , 0 6}$ & $\mathbf{5 , 3 3}$ & $-\mathbf{0 , 9 3}$ & $\mathbf{2 3 , 1 6}$ & $\mathbf{1 4 , 5 7}$ & $\mathbf{6 8}$ & $\mathbf{2 1 , 2 9}$ \\
\hline
\end{tabular}


Tabela 26. Dados referentes a avaliação da telerradiografia em norma lateral convencional de 10 pacientes selecionados ao acaso (Valores retirados da amostra total da fase inicial).

\begin{tabular}{c|c|c|c|c|c|c|c}
\hline 1-NA & 1-AV & FRANK.4 & FRANK.6 & 1-PTV & 4-PTV & 6-PTV & SOBREM. \\
\hline 6,1 & 8 & 81,1 & 94,7 & 65,5 & 46 & 30,6 & $-4,2$ \\
\hline 5 & 5,4 & 87,9 & 93,1 & 63,9 & 45 & 30,4 & $-5,3$ \\
\hline 1,4 & 0,9 & 91,2 & 97,3 & 57 & 41,4 & 29,2 & $-6,8$ \\
\hline 3,9 & 5 & 89,3 & 101,2 & 61,7 & 42,6 & 27,8 & $-4,5$ \\
\hline 7,9 & 8 & 90,2 & 100,4 & 60,1 & 39,7 & 24,4 & $-4,5$ \\
\hline 2,8 & 2,6 & 94,8 & 97,7 & 57,9 & 39,7 & 25,9 & $-6,9$ \\
\hline 3,5 & 2,7 & 86 & 100,4 & 53,8 & 38,6 & 23,6 & $-3,4$ \\
\hline 7,3 & 7,3 & 86,8 & 96,2 & 62,4 & 39,9 & 25,2 & $-3,8$ \\
\hline 6,5 & 7 & 88,2 & 99,8 & 59 & 39,4 & 26,4 & $-2,6$ \\
\hline $\mathbf{1 , 6}$ & 2,9 & 91,6 & 104,5 & 57,5 & 41,1 & 27,2 & $-4,6$ \\
\hline $\mathbf{4 , 6}$ & $\mathbf{4 , 9 8}$ & $\mathbf{8 8 , 7 1}$ & $\mathbf{9 8 , 5 3}$ & $\mathbf{5 9 , 8 8}$ & $\mathbf{4 1 , 3 4}$ & $\mathbf{2 7 , 0 7}$ & $\mathbf{- 4 , 6 6}$ \\
\hline
\end{tabular}

Tabela 27. Dados referentes a remedição da telerradiografia em norma lateral convencional (Fase inicial).

\begin{tabular}{c|c|c|c|c|c|c|c}
\hline 1-NA & 1-AV & FRANK.4 & FRANK.6 & 1-PTV & 4-PTV & 6-PTV & SOBREM. \\
\hline 5 & 7,3 & 81,4 & 98 & 65,5 & 46,2 & 29,9 & $-4,8$ \\
\hline 5,5 & 5,5 & 88 & 95,4 & 63,3 & 44,8 & 29,7 & $-6,1$ \\
\hline 1 & $-0,2$ & 92,5 & 98,1 & 55,6 & 40,5 & 28 & $-6,1$ \\
\hline 5,2 & 5,6 & 89,3 & 100,2 & 60,5 & 40,9 & 26,7 & $-5,2$ \\
\hline 5,4 & 6,1 & 90,5 & 100,3 & 59,2 & 38,9 & 23,4 & $-4,5$ \\
\hline 3,6 & 2,9 & 94,7 & 101,4 & 56,7 & 38,7 & 23,4 & $-6,5$ \\
\hline 3 & 1,9 & 86,5 & 103,8 & 52,7 & 37,5 & 23,2 & $-4,4$ \\
\hline 7,6 & 8,2 & 85,4 & 92,2 & 64,2 & 41,5 & 27 & $-3,4$ \\
\hline 6,2 & 7,3 & 87,2 & 98,9 & 60,7 & 41 & 27,2 & $-2,6$ \\
\hline 2,7 & 4,2 & 89 & 102 & 59,4 & 42,9 & 28,8 & $-4,7$ \\
\hline $\mathbf{4 , 5 2}$ & $\mathbf{4 , 8 8}$ & $\mathbf{8 8 , 4 5}$ & $\mathbf{9 9 , 0 3}$ & $\mathbf{5 9 , 7 8}$ & $\mathbf{4 1 , 2 9}$ & $\mathbf{2 6 , 7 3}$ & $\mathbf{- 4 , 8 3}$ \\
\hline
\end{tabular}


Tabela 28. Dados referentes a avaliação da telerradiografia em norma lateral convencional de 10 pacientes selecionados ao acaso (Valores retirados da amostra total da fase inicial).

\begin{tabular}{c|c|c|c|c|c}
\hline SOBRES. & LÁBIO SUP/E & $\mathbf{1 . 1}$ & LÁBIO INF/E & NASOLABIAL & WITS \\
\hline 5,8 & 0,6 & 115,1 & 3,4 & 96,8 & 3,5 \\
\hline 5,7 & $-4,1$ & 130,9 & $-3,3$ & 100 & 1,6 \\
\hline 6,1 & -1 & 136,3 & $-1,4$ & 120,9 & 6,6 \\
\hline 4,8 & -1 & 125,5 & 0,8 & 102,4 & 2,5 \\
\hline 7,2 & 4 & 113,5 & 5,8 & 106 & 4,6 \\
\hline 4,9 & $-3,6$ & 138,5 & $-2,3$ & 112,7 & 2,6 \\
\hline 2,4 & $-4,2$ & 131,7 & $-1,7$ & 119,5 & 2,3 \\
\hline 10 & $-2,2$ & 107,8 & $-2,5$ & 116,1 & 4,9 \\
\hline 3,8 & 3,3 & 117,8 & 6 & 96,4 & 0,5 \\
\hline 4,6 & 0,4 & 124,5 & 1,5 & 112,4 & 2,1 \\
\hline $\mathbf{5 , 5 3}$ & $-\mathbf{0 , 7 8}$ & $\mathbf{1 2 4 , 1 6}$ & $\mathbf{0 , 6 3}$ & $\mathbf{1 0 8 , 3 2}$ & $\mathbf{3 , 1 2}$ \\
\hline
\end{tabular}

Tabela 29. . Dados referentes a remedição da telerradiografia em norma lateral convencional (Fase inicial).

\begin{tabular}{c|c|c|c|c|c}
\hline SOBRES. & LÁBIO SUP/E & $\mathbf{1 . 1}$ & LÁBIO INF/E & NASOLABIAL & WITS \\
\hline 5,8 & 0,8 & 117,8 & 3,5 & 98,1 & 3 \\
\hline 5,5 & $-4,2$ & 131,5 & $-3,3$ & 100,7 & 1,7 \\
\hline 5,7 & $-0,8$ & 135,7 & $-1,6$ & 115,9 & 6,4 \\
\hline 5,7 & $-0,6$ & 124,3 & 1,1 & 104,8 & 2,3 \\
\hline 7 & 4 & 114 & 5,4 & 107,1 & 3,7 \\
\hline 4,2 & $-4,1$ & 134,5 & $-2,4$ & 113,2 & 1,1 \\
\hline 2,7 & $-4,4$ & 134,5 & $-1,9$ & 120,4 & 1,1 \\
\hline 9,7 & -2 & 106,1 & $-2,4$ & 115,4 & 5,5 \\
\hline 4,5 & 3 & 119,4 & 6,1 & 99,3 & 1,8 \\
\hline 4,7 & 0,2 & 125,1 & 1,2 & 112,7 & 4,5 \\
\hline $\mathbf{5 , 5 5}$ & $-\mathbf{0 , 8 1}$ & $\mathbf{1 2 4 , 2 9}$ & $\mathbf{0 , 5 7}$ & $\mathbf{1 0 8 , 7 6}$ & $\mathbf{3 , 1 1}$ \\
\hline
\end{tabular}


Tabela 30. Dados referentes a avaliação da telerradiografia em norma lateral convencional de 10 pacientes selecionados ao acaso (Valores retirados da amostra total da fase final).

\begin{tabular}{l|c|c|c|c|c|c|c}
\hline Pacientes - 10 & SNA & SNB & SND & A-Nperp & Pg-Nperp & ANB & AFAI \\
\hline ALESSANDRA V. & 87,7 & 82,5 & 78,1 & 3,3 & $-4,2$ & 5,1 & 68,7 \\
\hline BRUNA H. B. & 85,3 & 81,1 & 77,7 & 4,3 & 1,9 & 4,1 & 66,3 \\
\hline CASSIA G. & 81,9 & 76,8 & 74,8 & $-0,8$ & $-6,9$ & 5,2 & 66,9 \\
\hline DANIEL U. & 85,9 & 80,2 & 76,8 & 2,2 & $-3,8$ & 5,7 & 72,4 \\
\hline JEFERSON L. & 82,8 & 78,8 & 75,5 & 1 & -5 & 4 & 73,9 \\
\hline LIVIA P. & 75,3 & 72,7 & 70,8 & $-2,1$ & $-4,8$ & 2,6 & 67,4 \\
\hline JULIANA D. & 79,9 & 75,9 & 73,9 & $-0,4$ & $-3,9$ & 4 & 59,8 \\
\hline PAMELA S. M. & 78,6 & 74,3 & 72,3 & $-2,8$ & $-7,8$ & 4,2 & 63,8 \\
\hline RAQUEL I. & 80,6 & 75,9 & 73,3 & $-0,6$ & $-9,2$ & 4,7 & 71,4 \\
\hline STEFANI H. & 82,1 & 75,2 & 72,7 & 4,4 & $-2,2$ & 6,9 & 68,9 \\
\hline MÉDIA & $\mathbf{8 2 . 0 1}$ & $\mathbf{7 7 . 3 4}$ & $\mathbf{7 4 . 5 9}$ & $\mathbf{0 . 8 5}$ & $\mathbf{- 4 . 5 9}$ & $\mathbf{4 . 6 5}$ & $\mathbf{6 7 . 9 5}$
\end{tabular}

Tabela 31. . Dados referentes a remedição da telerradiografia em norma lateral convencional (Fase final).

\begin{tabular}{l|c|c|c|c|c|c|c}
\hline PACIENTES - 10 & SNA & SNB & SND & A-Nperp & Pg-Nperp & ANB & AFAI \\
\hline ALESSANDRA V. & 87,8 & 82,7 & 78,4 & 3,1 & $-4,4$ & 5 & 70,9 \\
\hline BRUNA H. B. & 86 & 81,8 & 78,1 & 4,5 & 2,5 & 4,2 & 66,1 \\
\hline CASSIA G. & 81,2 & 76,7 & 74,9 & $-1,1$ & $-6,7$ & 4,5 & 67,2 \\
\hline DANIEL U. & 86,3 & 80,6 & 77,1 & 2,2 & -4 & 5,8 & 72,4 \\
\hline JEFERSON L. & 83,6 & 78,8 & 75,7 & 0,8 & -7 & 4,7 & 74,4 \\
\hline JULIANA D. & 81,7 & 77,2 & 75,3 & 0,4 & $-3,3$ & 4,6 & 60,2 \\
\hline LIVIA P. & 76,8 & 73,6 & 71,7 & $-1,7$ & -5 & 3,2 & 66,4 \\
\hline PAMELA S. M. & 78,5 & 75,4 & 73,6 & $-3,5$ & $-6,9$ & 3 & 64,5 \\
\hline RAQUEL I. & 82,1 & 76,9 & 74,1 & 0,6 & $-8,4$ & 5,2 & 71,9 \\
\hline STEFANI H. & 82,3 & 75,7 & 73,2 & 3,6 & -3 & 6,6 & 68,7 \\
\hline MÉDIA & $\mathbf{8 2 , 6 3}$ & $\mathbf{7 7 , 9 4}$ & $\mathbf{7 5 , 2 1}$ & $\mathbf{0 , 8 9}$ & $\mathbf{- 4 , 6 2}$ & $\mathbf{4 , 6 8}$ & $\mathbf{6 8 , 2 7}$ \\
\hline
\end{tabular}


Tabela 32. Dados referentes a avaliação da telerradiografia em norma lateral convencional de 10 pacientes selecionados ao acaso (Valores retirados da amostra total da fase final).

\begin{tabular}{c|c|c|c|c|c|c|c}
\hline SN.GoGn & FMA & FRANK.OcI & FRANK.Pal & FRANK.GoGn & SN.PIOcl. & SN.Gn & 1.NA \\
\hline 30,5 & 27,5 & 5,1 & 0,1 & 24,8 & 10,8 & 66 & 25,1 \\
\hline 28,9 & 21 & 0,3 & $-0,5$ & 19,6 & 9,6 & 64,6 & 21,8 \\
\hline 28,7 & 24,7 & 5,8 & 0,9 & 22,6 & 11,9 & 66,7 & 21,8 \\
\hline 28,2 & 23,6 & 4,4 & $-2,2$ & 20,4 & 12,1 & 68 & 23 \\
\hline 37,4 & 31,3 & 4 & 0,4 & 29,1 & 12 & 70,1 & 34,9 \\
\hline 35,3 & 25,3 & 7,4 & $-0,4$ & 22,6 & 20,1 & 72,9 & 23,2 \\
\hline 29,2 & 21,7 & 4,8 & $-0,9$ & 19,5 & 14,6 & 67,3 & 21,5 \\
\hline 28,4 & 21,5 & 4,6 & 1,9 & 19,6 & 13,4 & 69,1 & 46,3 \\
\hline 40,1 & 34,2 & 14,7 & $-0,6$ & 31,4 & 23,5 & 72,5 & 29,8 \\
\hline 35,9 & 26 & 4,3 & 0,1 & 23,7 & 16,5 & 69,4 & 18,1 \\
\hline $\mathbf{3 2 , 2 6}$ & $\mathbf{2 5 , 6 8}$ & $\mathbf{5 , 5 4}$ & $\mathbf{- 0 , 1 2}$ & $\mathbf{2 3 , 3 3}$ & $\mathbf{1 4 , 4 5}$ & $\mathbf{6 8 , 6 6}$ & $\mathbf{2 6 , 5 5}$ \\
\hline
\end{tabular}

Tabela 33. Dados referentes a remedição da telerradiografia em norma lateral convencional (Fase final).

\begin{tabular}{c|c|c|c|c|c|c|c}
\hline SN.GoGn & FMA & FRANK.OCL. & FRANK.PAL. & FRANK.GoGn & SN.PIOcl. & SN.Gn & 1.NA \\
\hline 30,7 & 27,9 & -6 & $-1,2$ & 25 & 12 & 66,1 & 25 \\
\hline 29 & 20,8 & 3,8 & $-1,3$ & 19,8 & 13 & 64,3 & 19,9 \\
\hline 29,3 & 23,9 & 5,4 & $-0,6$ & 21,6 & 13,2 & 66,8 & 23 \\
\hline 27 & 24,9 & 6,4 & 0,1 & 21,8 & 11,6 & 67,8 & 24,5 \\
\hline 37,4 & 32,5 & 8,1 & 1,4 & 30,2 & 15,4 & 70 & 33 \\
\hline 28 & 21,8 & 6,8 & $-1,5$ & 19,4 & 15,5 & 66,6 & 18,2 \\
\hline 34,3 & 25,2 & 7,5 & 0,9 & 22,7 & 19,1 & 72,2 & 19,3 \\
\hline 27,2 & 21,3 & 3,3 & 1 & 19 & 11,5 & 68,3 & 48,9 \\
\hline 40,4 & 34,2 & 10,8 & $-0,6$ & 31,9 & 19,4 & 72,5 & 26,4 \\
\hline 35,1 & 26,1 & 5,3 & 1 & 23,8 & 16,7 & 68,9 & 19,9 \\
\hline $\mathbf{3 1 , 8 4}$ & $\mathbf{2 5 , 8 6}$ & $\mathbf{5 , 1 4}$ & $-\mathbf{0 , 0 8}$ & $\mathbf{2 3 , 5 2}$ & $\mathbf{1 4 , 7 4}$ & $\mathbf{6 8 , 3 5}$ & $\mathbf{2 5 , 8 1}$ \\
\hline
\end{tabular}


Tabela 34. Dados referentes a avaliação da telerradiografia em norma lateral convencional de 10 pacientes selecionados ao acaso (Valores retirados da amostra total da fase final).

\begin{tabular}{c|c|c|c|c|c|c|c}
\hline 1-NA & 1-AV & FRANK.4 & FRANK.6 & 1-PTV & 4-PTV & 6-PTV & SOBREM. \\
\hline 6,1 & 7,6 & 77,6 & 109,5 & 65,2 & 47,9 & 23,9 & $-4,1$ \\
\hline 5 & 7 & 83,2 & 105 & 66,3 & 47,8 & 26 & $-4,3$ \\
\hline 2,2 & 1,5 & 83,7 & 110,3 & 57,9 & 44,3 & 24,1 & $-5,2$ \\
\hline 3,8 & 5 & 84,9 & 112,6 & 63,2 & 44,6 & 24 & $-3,7$ \\
\hline 11,1 & 11,5 & 94,6 & 106,5 & 67,3 & 46,4 & 25,3 & -2 \\
\hline 4,1 & 3,2 & 89,1 & 107,2 & 54,2 & 39 & 21,4 & $-4,6$ \\
\hline 4,5 & 4,3 & 90 & 106,3 & 58,3 & 41,5 & 22,4 & $-6,8$ \\
\hline 9,4 & 8,6 & 81,7 & 118,5 & 63,4 & 42,4 & 18,3 & $-3,1$ \\
\hline 9,6 & 9,3 & 85,5 & 115,3 & 60 & 41 & 18,8 & $-0,3$ \\
\hline 2,5 & 4,2 & 100 & 109,9 & 61,9 & 44,9 & 25,8 & -4 \\
\hline $\mathbf{5 , 8 3}$ & $\mathbf{6 , 2 2}$ & $\mathbf{8 7 , 0 3}$ & $\mathbf{1 1 0 , 1 1}$ & $\mathbf{6 1 , 7 7}$ & $\mathbf{4 3 , 9 8}$ & $\mathbf{2 3}$ & $\mathbf{- 3 , 8 1}$ \\
\hline
\end{tabular}

Tabela 35. Dados referentes a remedição da telerradiografia em norma lateral convencional (Fase final).

\begin{tabular}{c|c|c|c|c|c|c|c}
\hline 1-NA & 1-AV & FRANK.4 & FRANK.6 & 1-PTV & 4-PTV & 6-PTV & SOBREM. \\
\hline 6,2 & 7,6 & 75,9 & 109,7 & 64,6 & 48,1 & 23 & $-3,7$ \\
\hline 6 & 6,6 & 81,2 & 106,5 & 65,9 & 49,7 & 26,1 & $-4,4$ \\
\hline 3 & 2,6 & 85,3 & 110,6 & 58,5 & 44,3 & 23,8 & $-5,1$ \\
\hline 4,2 & 4,8 & 86,1 & 112,1 & 61,2 & 42,9 & 21,6 & $-4,1$ \\
\hline 9 & 9,3 & 92,3 & 106,2 & 66,1 & 47,2 & 23,8 & $-2,3$ \\
\hline 3,5 & 3,7 & 88,8 & 108,7 & 57,5 & 41,5 & 21,5 & $-6,6$ \\
\hline 3 & 2,3 & 90 & 107,7 & 52,5 & 37,4 & 19,7 & -5 \\
\hline 11,2 & 10,1 & 81,8 & 117,2 & 63,1 & 42,1 & 17,9 & $-2,6$ \\
\hline 8,6 & 8,9 & 89,1 & 109,4 & 60,9 & 41,4 & 20,8 & $-0,4$ \\
\hline 3,6 & 5,1 & 94,3 & 109,4 & 60,8 & 45 & 23,6 & $-3,5$ \\
\hline $\mathbf{5 , 8 3}$ & $\mathbf{6 , 1}$ & $\mathbf{8 6 , 4 8}$ & $\mathbf{1 0 9 , 7 5}$ & $\mathbf{6 1 , 1 1}$ & $\mathbf{4 3 , 9 6}$ & $\mathbf{2 2 , 1 8}$ & $\mathbf{- 3 , 7 7}$ \\
\hline
\end{tabular}


Tabela 36. Dados referentes a avaliação da telerradiografia em norma lateral convencional de 10 pacientes selecionados ao acaso (Valores retirados da amostra total da fase final).

\begin{tabular}{c|c|c|c|c|c}
\hline SOBRES. & LÁBIO SUP/E & $\mathbf{1 . 1}$ & LÁBIO INF/E & NASOLABIAL & WITS \\
\hline 7 & 1,8 & 115,1 & 3,8 & 99,1 & 2,6 \\
\hline 6,9 & $-3,4$ & 125,2 & $-3,5$ & 104,2 & 3,4 \\
\hline 6,4 & $-1,4$ & 130,9 & $-1,5$ & 128,1 & 6,1 \\
\hline 7,1 & $-1,2$ & 117,5 & 1,1 & 108,7 & 5 \\
\hline 9,5 & 3,6 & 110,7 & 5,9 & 102,4 & 3,7 \\
\hline 3,6 & $-4,1$ & 123,8 & $-1,5$ & 126,2 & 1,3 \\
\hline 7,1 & $-2,5$ & 128,9 & $-1,7$ & 122,3 & 4,2 \\
\hline 11,7 & -2 & 104 & -2 & 111,9 & 5,3 \\
\hline 7,2 & 4,2 & 110,7 & 6,6 & 95,4 & 1,4 \\
\hline 6 & $-0,2$ & 119,1 & 0,3 & 116,4 & 6,6 \\
\hline $\mathbf{7 , 2 5}$ & $-\mathbf{0 , 5 2}$ & $\mathbf{1 1 8 , 5 9}$ & $\mathbf{0 , 7 5}$ & $\mathbf{1 1 1 , 4 7}$ & $\mathbf{3 , 9 6}$ \\
\hline
\end{tabular}

Tabela 37. Dados referentes a remedição da telerradiografia em norma lateral convencional (Fase final).

\begin{tabular}{c|c|c|c|c|c}
\hline SOBRES. & LÁBIO SUP/E & $\mathbf{1 . 1}$ & LÁBIO INF/E & NASOLABIAL & WITS \\
\hline 7,3 & 1,3 & 118,9 & 3,3 & 94,3 & 1,5 \\
\hline 6 & $-3,2$ & 125,9 & $-3,6$ & 104 & 1,3 \\
\hline 6 & -2 & 127,4 & $-1,9$ & 115,3 & 4,2 \\
\hline 6,8 & -1 & 116,4 & 0,8 & 107,3 & 4,8 \\
\hline 8,3 & 3,3 & 111,8 & 6,2 & 105,4 & 2,3 \\
\hline 6,6 & $-1,8$ & 130,3 & $-1,6$ & 116,5 & 3,3 \\
\hline 3 & -4 & 128,3 & $-1,2$ & 125,5 & 2,5 \\
\hline 11,3 & $-2,2$ & 99,7 & $-1,8$ & 106,7 & 5 \\
\hline 7,3 & 3,9 & 112,5 & 6,6 & 98,3 & 1,1 \\
\hline 6,3 & $-0,1$ & 116,6 & 0,8 & 111,3 & 4,4 \\
\hline $\mathbf{6 , 8 9}$ & $-\mathbf{0 , 5 8}$ & $\mathbf{1 1 8 , 7 8}$ & $\mathbf{0 , 7 6}$ & $\mathbf{1 0 8 , 4 6}$ & $\mathbf{3 , 0 4}$ \\
\hline
\end{tabular}


Tabela 38. Dados referentes a avaliação da telerradiografia em norma lateral de $45^{\circ}$, lados direito e squerdo (Fase inicial).

\begin{tabular}{|c|c|c|c|c|c|c|c|c|c|c|c|}
\hline Pacientes - 31 & & 1.PAL. & 4.PAL. & 5.PAL. & 6.PAL. & 7.PAL. & 1-PAL. & 4-PAL. & 5-PAL. & 6-PAL. & 7-PAL. \\
\hline ALESSANDRA 0. & $\mathrm{D}$ & $-111,8$ & $-86,3$ & $-82,2$ & $-81,2$ & $-71,9$ & $-23,7$ & $-19,8$ & $-19,2$ & $-17,8$ & $-15,2$ \\
\hline ALESSANDRA 0. & $\mathrm{E}$ & 102,9 & 83,9 & 82,1 & 81,2 & 67,6 & 28,1 & 23,6 & 22 & 20,4 & 16,8 \\
\hline ALESSANDRA V. & $\mathrm{D}$ & $-109,6$ & -93 & $-83,9$ & -92 & $-69,7$ & $-27,2$ & $-23,8$ & $-22,9$ & $-21,7$ & $-18,8$ \\
\hline ALESSANDRA V. & $\mathrm{E}$ & 108,2 & 101,9 & 89,8 & 81 & 63,7 & 29,5 & 27,4 & 26,3 & 23,7 & 19,3 \\
\hline ANA LUCIA B. & $D$ & $-108,8$ & $-84,1$ & $-79,4$ & $-78,4$ & $-62,8$ & $-25,9$ & $-21,9$ & $-20,7$ & $-17,6$ & $-12,7$ \\
\hline ANA LUCIA B. & E & 108,4 & 90,5 & 82,8 & 72,9 & 58,6 & 27,9 & 24 & 22,6 & 20 & 13,8 \\
\hline ARIELA G. & $D$ & $-102,9$ & $-87,5$ & $-82,8$ & $-80,8$ & $-56,9$ & $-29,5$ & -24 & $-22,6$ & $-19,7$ & $-14,2$ \\
\hline ARIELA G. & $\mathrm{E}$ & 105,4 & 91,4 & 85,5 & 75 & 58,2 & 33,1 & 27,5 & 26,3 & 22,6 & 16,8 \\
\hline BRUNA H. B. & $D$ & $-110,6$ & $-83,6$ & $-90,7$ & $-90,8$ & $-69,1$ & $-24,1$ & $-22,8$ & $-21,3$ & $-20,9$ & $-18,6$ \\
\hline BRUNA H. B. & E & 108,6 & 89,3 & 90,7 & 84,6 & 77,1 & 24,1 & 18,8 & 19 & 19,5 & 17,9 \\
\hline BRUNO D. F. & $\mathrm{D}$ & $-109,5$ & $-87,4$ & -84 & $-86,3$ & $-67,8$ & $-21,9$ & $-18,5$ & -18 & $-16,4$ & $-12,5$ \\
\hline BRUNO D. F. & $\mathrm{E}$ & 114,1 & 88,2 & 85,7 & 78 & 64,4 & 26,2 & 21,1 & 20,3 & 17,2 & 12,5 \\
\hline CAMILLA D. & D & $-108,7$ & $-85,3$ & $-83,6$ & $-86,3$ & $-67,8$ & $-27,6$ & $-23,8$ & $-23,5$ & $-21,7$ & $-19,1$ \\
\hline CAMILLA D. & $\mathrm{E}$ & 103,1 & 89,3 & 86,2 & 84,8 & 69,9 & 28 & 21,2 & 22,2 & 19,9 & 16,8 \\
\hline CASSIA G. & $D$ & $-106,6$ & -91 & $-84,7$ & $-83,1$ & $-66,6$ & $-27,7$ & $-21,7$ & $-22,4$ & $-20,6$ & $-16,9$ \\
\hline CASSIA G. & $E$ & 108,3 & 94,5 & 90,3 & 86,3 & 64,3 & 29 & 24,7 & 24,7 & 22,4 & 18,6 \\
\hline CINIRA R. & $D$ & $-102,1$ & $-79,3$ & $-74,3$ & $-81,3$ & $-61,3$ & $-34,4$ & $-28,1$ & $-27,8$ & $-24,3$ & $-19,4$ \\
\hline CINIRA R. & $\mathrm{E}$ & 102,1 & 81,5 & 76,1 & 74,9 & 59,5 & 31,5 & 26,9 & 25,4 & 22,9 & 19 \\
\hline DANIEL U. & D & $-104,8$ & $-84,1$ & $-83,6$ & $-82,6$ & $-67,2$ & $-30,5$ & $-27,1$ & $-25,9$ & $-23,2$ & $-19,5$ \\
\hline DANIEL U. & E & 103,3 & 84,1 & 82,6 & 80,7 & 68,7 & 31,3 & 28 & 28 & 25,1 & 21,2 \\
\hline FABIO O. & D & $-107,2$ & $-89,5$ & $-86,4$ & $-86,7$ & $-79,3$ & $-29,9$ & $-28,7$ & $-25,6$ & $-24,1$ & $-22,2$ \\
\hline FABIO O. & $\mathrm{E}$ & 106,1 & 94,2 & 92,1 & 88,8 & 81,7 & 31,2 & 26,6 & 26 & 24,4 & 23,2 \\
\hline FABIO P. G. & $D$ & $-98,2$ & $-91,6$ & $-82,8$ & $-80,6$ & $-68,1$ & $-29,6$ & -24 & $-23,4$ & $-22,7$ & $-19,6$ \\
\hline FABIO P. G. & $\mathrm{E}$ & 104,7 & 90 & 84 & 87 & 71,1 & 33,3 & 30 & 28,8 & 26,6 & 22,2 \\
\hline GABRIELLES. & $\mathrm{D}$ & $-107,1$ & $-87,1$ & $-75,8$ & $-71,7$ & $-55,7$ & $-28,2$ & $-22,8$ & $-22,8$ & $-19,6$ & -15 \\
\hline GABRIELLE S. & $E$ & 112,5 & 91,4 & 86,2 & 79,6 & 66,6 & 26,7 & 24,6 & 24,5 & 21,1 & 16,6 \\
\hline HELOISA CAS & $D$ & $-104,7$ & -77 & $-80,3$ & $-90,7$ & $-80,5$ & $-30,5$ & $-25,9$ & $-25,4$ & $-22,5$ & $-19,6$ \\
\hline HELOISA CAS & $\mathrm{E}$ & 106,2 & 90,4 & 86,2 & 86,7 & 76,8 & 27,3 & 23,2 & 23,4 & 20,5 & 17,5 \\
\hline HENRIQUE P. & $\mathrm{D}$ & $-101,8$ & $-87,5$ & $-79,4$ & $-86,1$ & $-67,9$ & $-29,1$ & $-22,7$ & $-21,6$ & $-19,9$ & $-16,3$ \\
\hline HENRIQUE P. & E & 97,1 & 84,9 & 77,2 & 83,6 & 66,4 & 30,6 & 22,8 & 20,6 & 19,2 & 14,6 \\
\hline HERMANO M. C. & $D$ & $-115,4$ & $-95,8$ & $-80,9$ & $-87,7$ & $-64,9$ & $-23,7$ & -21 & $-20,4$ & $-17,3$ & $-13,5$ \\
\hline
\end{tabular}


Tabela 39. Dados referentes a avaliação da telerradiografia em norma lateral de $45^{\circ}$, lados direito e esquerdo (Fase inicial).

\begin{tabular}{|c|c|c|c|c|c|c|c|c|c|c|c|}
\hline JEFERSON L. & $\mathrm{D}$ & $-107,8$ & $-86,7$ & $-88,5$ & $-87,7$ & $-73,9$ & $-29,6$ & $-26,8$ & $-27,8$ & $-24,1$ & $-20,8$ \\
\hline JEFERSON L. & $\mathrm{E}$ & 108,1 & 87,8 & 87,5 & 86 & 69,9 & 32,6 & 31 & 30,9 & 26,4 & 21,5 \\
\hline JULIANA D. & $\mathrm{D}$ & $-103,8$ & $-86,7$ & $-76,6$ & -86 & $-69,5$ & $-27,5$ & $-21,5$ & $-20,3$ & $-18,3$ & $-14,5$ \\
\hline JULIANA D. & $E$ & 96,9 & 85,8 & 80,4 & 77,7 & 74,3 & 28,6 & 23 & 21 & 19,6 & 14,9 \\
\hline LETICIA Q. & $\mathrm{D}$ & $-111,5$ & $-89,5$ & $-82,8$ & $-84,8$ & -68 & $-25,3$ & $-20,1$ & $-19,3$ & $-17,8$ & $-14,8$ \\
\hline LETICIA Q. & $\mathrm{E}$ & 102,9 & 89,2 & 87,5 & 84,3 & 70,3 & 27,7 & 23,3 & 22,2 & 20 & 17,3 \\
\hline LIVIA P. & $\mathrm{D}$ & $-107,5$ & $-93,8$ & $-87,7$ & -88 & $-57,2$ & $-27,3$ & $-24,9$ & $-24,1$ & $-21,9$ & $-16,7$ \\
\hline LIVIA P. & $E$ & 103,6 & 95,1 & 84,5 & 81,2 & 61,1 & 32,7 & 31,6 & 29,9 & 27,4 & 21,8 \\
\hline LUCIANA I. & $\mathrm{D}$ & $-109,9$ & $-88,7$ & $-78,4$ & -78 & $-64,4$ & $-26,8$ & $-23,2$ & $-22,8$ & $-20,5$ & $-16,2$ \\
\hline LUCIANA I. & $E$ & 110,1 & 88,4 & 83 & 82,9 & 70,5 & 27,6 & 23,7 & 23 & 20,6 & 15,9 \\
\hline LUIZ H. S. & $\mathrm{D}$ & -109 & $-84,4$ & $-78,4$ & $-86,4$ & $-73,5$ & $-22,8$ & $-17,9$ & $-19,1$ & -17 & $-14,6$ \\
\hline LUIZ H. S. & $\mathrm{E}$ & 108,2 & 94,4 & 85,2 & 75,7 & 62,6 & 26,4 & 22,2 & 22,6 & 20,4 & 15,7 \\
\hline MARIANA B.V. & $\mathrm{D}$ & $-118,2$ & -85 & $-84,9$ & -83 & $-69,8$ & $-21,3$ & $-21,4$ & $-21,4$ & $-18,9$ & $-15,9$ \\
\hline MARIANA B.V. & $\mathrm{E}$ & 119,2 & 91,7 & 91 & 84,9 & 76,1 & 21,9 & 20 & 20,6 & 18,8 & 17 \\
\hline MICHELLE V. O. & $\mathrm{D}$ & $-103,5$ & $-86,2$ & $-82,8$ & $-79,9$ & $-70,5$ & $-25,2$ & $-22,1$ & $-23,6$ & -21 & $-17,5$ \\
\hline MICHELLE V. O. & $\mathrm{E}$ & 105,9 & 95,3 & 94,2 & 82,4 & 76,7 & 25,4 & 20,9 & 21,9 & 19,7 & 17,2 \\
\hline NATHALIE M. N. & $\mathrm{D}$ & $-106,6$ & $-83,7$ & $-79,6$ & $-74,1$ & $-51,3$ & -25 & $-21,3$ & $-20,4$ & -17 & $-10,6$ \\
\hline NATHA LIE M. N. & $E$ & 104,6 & 84,8 & 78,3 & 71,1 & 54,5 & 27,7 & 20,7 & 20,8 & 16,6 & 11,8 \\
\hline PAMELA S. M. & $\mathrm{D}$ & $-103,4$ & -87 & $-84,9$ & $-80,5$ & $-67,7$ & $-28,8$ & $-24,4$ & $-24,9$ & $-23,1$ & $-19,9$ \\
\hline PAMELA S. M. & $\mathrm{E}$ & 107 & 86 & 85,1 & 81,9 & 69,2 & 29,7 & 24,4 & 24,3 & 21,3 & 18,1 \\
\hline RAFAELA O. & $\mathrm{D}$ & -104 & $-81,7$ & $-82,3$ & $-81,9$ & $-70,4$ & $-33,4$ & $-28,8$ & $-27,8$ & $-24,4$ & $-20,5$ \\
\hline RAFAELA O. & $E$ & 109,6 & 89,8 & 78,1 & 77,3 & 66,3 & 36,1 & 30,6 & 30,1 & 25,6 & 21,2 \\
\hline RAQUEL I. & $\mathrm{D}$ & $-103,7$ & $-84,7$ & $-72,7$ & $-75,7$ & $-66,4$ & $-28,3$ & $-24,1$ & $-23,1$ & $-20,1$ & $-16,2$ \\
\hline RAQUEL I. & $\mathrm{E}$ & 109,7 & 89,5 & 83,7 & 75,5 & 64,5 & 28,2 & 21,6 & 21,5 & 18 & 14,1 \\
\hline RENATHA S. & $\mathrm{D}$ & $-116,5$ & $-82,1$ & $-76,4$ & $-73,1$ & $-57,6$ & $-28,2$ & $-24,4$ & $-22,2$ & $-19,3$ & $-14,1$ \\
\hline RENATHA S. & $E$ & 106,9 & 87,2 & 84,5 & 75,1 & 65,2 & 26,7 & 20,5 & 17,2 & 15,8 & 11,6 \\
\hline STEFANI $\mathrm{H}$. & $\mathrm{D}$ & $-107,6$ & $-84,1$ & $-78,9$ & $-81,2$ & $-58,8$ & $-27,1$ & $-24,1$ & -23 & -20 & $-15,2$ \\
\hline STEFANI H. & $\mathrm{E}$ & 105,9 & 98 & 92,5 & 91,6 & 73 & 25,9 & 23,7 & 24 & 21,6 & 17,9 \\
\hline THAIZE Q. & $\mathrm{D}$ & $-107,9$ & $-80,9$ & $-77,7$ & $-89,1$ & $-63,3$ & $-26,9$ & $-22,3$ & $-21,6$ & $-19,9$ & $-15,8$ \\
\hline THAIZE Q. & $E$ & 111,6 & 88 & 88 & 81,4 & 62,2 & 26,5 & 24 & 24,3 & 22 & 17,9 \\
\hline
\end{tabular}


Tabela 40. Dados referentes a avaliação da telerradiografia em norma lateral de $45^{\circ}$, lados direito e esquerdo (Fase final).

\begin{tabular}{|c|c|c|c|c|c|c|c|c|c|c|c|}
\hline PACIENTES - 31 & & 1.PAL. & 4.PAL. & 5.PAL. & 6.PAL. & 7.PAL. & 1-PAL. & 4-PAL. & 5-PAL. & 6-PAL. & 7-PAL. \\
\hline ALESSANDRA O. & $\mathrm{D}$ & $-116,5$ & $-86,7$ & $-85,8$ & $-65,5$ & $-49,1$ & -26 & $-23,5$ & -23 & $-18,3$ & $-12,9$ \\
\hline ALESSANDRA 0. & E & 109,3 & 91,8 & 88,5 & 59,3 & 41 & 28,3 & 25,7 & 24,8 & 19,4 & 13,8 \\
\hline ALESSANDRA V. & $\mathrm{D}$ & $-114,4$ & $-100,7$ & $-90,1$ & $-75,1$ & $-51,4$ & $-29,8$ & $-26,8$ & $-26,4$ & $-23,2$ & $-18,9$ \\
\hline ALESSANDRA V. & E & 111,7 & 99,3 & 88,2 & 64,6 & 43 & 30,8 & 30,6 & 30 & 24,4 & 18,3 \\
\hline ANA LUCIA B. & $\mathrm{D}$ & $-110,9$ & $-86,1$ & $-88,4$ & $-65,6$ & -52 & $-27,4$ & $-23,4$ & $-21,6$ & $-18,7$ & $-12,4$ \\
\hline ANA LUCIA B. & $\mathrm{E}$ & 110,6 & 98,2 & 99,8 & 57,4 & 45,5 & 29 & 26,3 & 24,3 & 18,7 & 11,1 \\
\hline ARIELA G. & $D$ & $-100,6$ & $-89,3$ & $-83,1$ & -61 & $-46,1$ & $-31,8$ & $-25,3$ & $-23,8$ & -18 & $-10,9$ \\
\hline ARIELA G. & $\mathrm{E}$ & 110,2 & 87,3 & 82,9 & 61,4 & 42,4 & 28,5 & 24,1 & 22,4 & 16,9 & 10,2 \\
\hline BRUNA H. B. & $\mathrm{D}$ & $-114,6$ & $-89,8$ & $-91,4$ & $-67,8$ & $-47,2$ & $-24,1$ & $-22,1$ & $-22,2$ & $-19,5$ & $-15,8$ \\
\hline BRUNA H. B. & $\mathrm{E}$ & 111,6 & 85,1 & 84,7 & 71,3 & 53,4 & 28,4 & 23,4 & 22,7 & 21,9 & 17,4 \\
\hline BRUNO D. F. & $D$ & $-110,7$ & $-88,1$ & $-82,9$ & $-65,3$ & $-47,6$ & $-27,4$ & $-26,8$ & $-25,8$ & $-20,8$ & $-14,6$ \\
\hline BRUNO D. F. & E & 114,3 & 93,3 & 85,3 & 75,6 & 54,3 & 26,1 & 21,2 & 20,4 & 17,6 & 12,8 \\
\hline CAMILLA D. & $D$ & $-109,8$ & $-92,2$ & $-83,1$ & $-85,6$ & $-58,7$ & $-28,9$ & $-29,4$ & $-29,1$ & $-25,9$ & $-21,3$ \\
\hline CAMILLA D. & E & 106,6 & 92,2 & 86,9 & 84,3 & 66,7 & 28,3 & 24 & 24,7 & 22,2 & 18 \\
\hline CASSIA G. & $D$ & $-112,1$ & $-95,3$ & $-89,4$ & $-76,1$ & $-52,5$ & $-27,7$ & $-20,1$ & $-21,6$ & $-19,9$ & $-14,9$ \\
\hline CASSIA G. & E & 115,6 & 95,8 & 92 & 70,9 & 45,8 & 29,3 & 26,4 & 26,6 & 21,9 & 16,2 \\
\hline CINIRA R. & $\mathrm{D}$ & $-102,5$ & $-85,6$ & $-79,7$ & $-82,1$ & $-55,6$ & $-31,5$ & $-25,9$ & $-26,4$ & $-22,6$ & -17 \\
\hline CINIRA R. & $\mathrm{E}$ & 110,1 & 90,9 & 84,1 & 74 & 47,2 & 33,6 & 27,6 & 27,4 & 24,5 & 18,4 \\
\hline DANIEL U. & $D$ & $-109,9$ & $-93,3$ & -91 & $-77,8$ & $-54,5$ & $-30,4$ & -28 & $-27,4$ & $-23,9$ & $-18,9$ \\
\hline DANIEL U. & E & 110,7 & 86,8 & 87,5 & 68,3 & 46,5 & 31,7 & 30 & 30,2 & 26,1 & 19,7 \\
\hline FABIO O. & $D$ & $-118,4$ & $-95,5$ & $-91,9$ & $-90,2$ & $-70,2$ & $-29,3$ & $-30,4$ & $-27,4$ & $-25,4$ & $-22,9$ \\
\hline FABIO O. & $\mathrm{E}$ & 110,8 & 95,2 & 89,2 & 75,5 & 64,6 & 32,1 & 30,2 & 30,6 & 27,4 & 24,2 \\
\hline FABIO P. G. & $D$ & $-104,8$ & $-93,7$ & $-88,2$ & $-67,9$ & $-56,6$ & $-33,9$ & $-28,8$ & $-28,9$ & $-25,4$ & $-20,7$ \\
\hline FABIO P. G. & $\mathrm{E}$ & 110,6 & 84,9 & 78,2 & 68 & 49,9 & 32,1 & 28,1 & 27 & 23,7 & 18 \\
\hline GABRIELLE S. & $\mathrm{D}$ & $-115,3$ & -99 & -78 & $-69,1$ & $-42,4$ & $-28,1$ & $-24,7$ & $-24,8$ & $-20,9$ & $-14,9$ \\
\hline GABRIELLE S. & $\mathrm{E}$ & 124,6 & 100,5 & 90,1 & 67,4 & 47,7 & 27,4 & 26,9 & 27,5 & 22,5 & $\overline{16,7}$ \\
\hline HELOISA CAS & $\mathrm{D}$ & $-106,1$ & $-91,5$ & -88 & -72 & $-60,9$ & $-29,4$ & $-24,6$ & -24 & $-19,7$ & $-15,5$ \\
\hline HELOISA CAS & $\mathrm{E}$ & 103 & 82 & 79,9 & 68,1 & 60,6 & 29 & 23,4 & 22,6 & 19 & 15 \\
\hline HENRIQUE P. & $D$ & $-107,8$ & $-90,4$ & $-87,6$ & $-70,7$ & $-51,7$ & $-29,6$ & $-25,5$ & $-23,1$ & $-18,7$ & -14 \\
\hline HENRIQUE P. & E & 108,2 & 84,6 & 80,9 & 68,2 & 51,2 & 29,2 & 23,2 & 21,3 & 16,8 & 12 \\
\hline HERMANO M. C. & $\mathrm{D}$ & $-117,6$ & $-102,3$ & -95 & $-69,5$ & $-51,8$ & -23 & -18 & $-18,9$ & $-15,5$ & $-9,6$ \\
\hline HERMANO M. C. & $E$ & 106,9 & 91,8 & 84,5 & 59,9 & 47,1 & 25,5 & 21,3 & 20,3 & 16,3 & 10,9 \\
\hline
\end{tabular}


Tabela 41. Dados referentes a avaliação da telerradiografia em norma lateral de $45^{\circ}$, lados direito e esquerdo (Fase final).

\begin{tabular}{|c|c|c|c|c|c|c|c|c|c|c|c|}
\hline JEFERSON L. & $\mathrm{D}$ & $-106,4$ & $-88,6$ & -90 & $-86,3$ & -54 & $-32,2$ & $-30,9$ & $-28,8$ & $-24,7$ & $-18,6$ \\
\hline JEFERSON L. & $E$ & 106,4 & 94,1 & 90,8 & 79,5 & 54,4 & 33,8 & 34,6 & 32,3 & 27,5 & 20,9 \\
\hline JULIANA D. & $\mathrm{D}$ & $-104,7$ & $-93,5$ & $-81,8$ & $-74,2$ & $-58,5$ & $-29,5$ & $-23,3$ & $-22,2$ & $-20,5$ & $-14,9$ \\
\hline JULIANA D. & $\mathrm{E}$ & 104,7 & 85,4 & 78,1 & 62,7 & 54,7 & 27,4 & 23,9 & 22 & 19,2 & 13,5 \\
\hline LETICIA Q. & $\mathrm{D}$ & $-117,5$ & $-89,5$ & $-81,6$ & $-73,1$ & $-59,3$ & $-25,5$ & $-21,8$ & $-21,1$ & $-18,5$ & $-14,2$ \\
\hline LETICIA Q. & $\mathrm{E}$ & 103,9 & 93,6 & 82,6 & 67,4 & 56,8 & 26,6 & 22,5 & 21,4 & 16,7 & 13,1 \\
\hline LIVIA P. & $\mathrm{D}$ & $-106,8$ & $-88,9$ & $-81,5$ & $-71,6$ & $-46,7$ & $-32,5$ & $-30,1$ & $-28,6$ & $-23,8$ & $-16,4$ \\
\hline LIVIA P. & $\mathrm{E}$ & 106,7 & 92,6 & 82,8 & 70,4 & 46,3 & 30 & 28,3 & 26,5 & 21,8 & 15,6 \\
\hline LUCIANA I. & $\mathrm{D}$ & -110 & $-92,9$ & $-81,2$ & $-68,1$ & $-50,5$ & -26 & $-21,6$ & $-21,6$ & $-17,5$ & $-11,7$ \\
\hline LUCIANA I. & $E$ & 116 & 85,6 & 77,3 & 62,1 & 47,8 & 26,2 & 23,9 & 22,4 & 16,9 & 11,4 \\
\hline LUIZ H. S. & $\mathrm{D}$ & $-111,5$ & $-87,9$ & $-80,2$ & $-79,7$ & -66 & $-26,2$ & $-22,2$ & $-22,5$ & $-19,2$ & -17 \\
\hline LUIZ H. S. & $E$ & 112,2 & 98,8 & 91,3 & 62,2 & 51,6 & 27,4 & 23,2 & 24,1 & 20,5 & 15 \\
\hline MARIANA B.V. & $\mathrm{D}$ & $-120,6$ & $-87,5$ & $-87,2$ & -68 & $-51,2$ & $-19,8$ & $-17,9$ & $-17,7$ & $-16,4$ & $-13,2$ \\
\hline MARIANA B.V. & $\mathrm{E}$ & 120,1 & 93,3 & 92,8 & 57,4 & 47,6 & 22 & 19,4 & 19,2 & 15,7 & 11,7 \\
\hline MICHELLE V. O. & $\mathrm{D}$ & -115 & $-86,7$ & $-82,3$ & -75 & $-54,1$ & $-27,5$ & $-27,4$ & $-27,1$ & $-24,4$ & $-18,7$ \\
\hline MICHELLE V. O. & $\mathrm{E}$ & 117,5 & 94,7 & 95 & 61,1 & 48,8 & 27,8 & 26,5 & 27,3 & 22,5 & 17,2 \\
\hline NATHALIE M. N. & $\mathrm{D}$ & $-106,6$ & $-82,2$ & $-69,8$ & -60 & $-31,6$ & $-27,4$ & $-24,3$ & -23 & $-16,9$ & $-8,8$ \\
\hline NATHALIE M. N. & $\mathrm{E}$ & 112,4 & 78,2 & 73,3 & 65 & 39,9 & 27,5 & 24,3 & 24,2 & 18,1 & 11,5 \\
\hline PAMELA S. M. & $\mathrm{D}$ & $-111,7$ & $-94,9$ & $-81,7$ & $-66,6$ & $-49,4$ & $-26,4$ & $-21,4$ & $-21,4$ & $-18,6$ & $-13,4$ \\
\hline PAMELA S. M. & $E$ & 115,7 & 83,5 & 79,9 & 64,1 & 47,7 & 29,3 & 24,5 & 24,2 & 18,9 & 13,8 \\
\hline RAFAELA O. & $\mathrm{D}$ & $-104,8$ & $-81,8$ & $-72,5$ & -60 & $-49,4$ & $-37,3$ & $-31,1$ & $-28,7$ & $-22,4$ & $-16,7$ \\
\hline RAFAELA O. & $\mathrm{E}$ & 110,1 & 94,5 & 74,8 & 62,6 & 45,7 & 37,9 & 33,9 & 33,1 & 26,3 & 20 \\
\hline RAQUEL I. & $\mathrm{D}$ & $-115,7$ & $-90,3$ & $-80,4$ & $-72,2$ & $-63,4$ & -28 & $-26,3$ & $-26,2$ & -22 & $-17,5$ \\
\hline RAQUEL I. & $\mathrm{E}$ & 109,4 & 85,2 & 79,3 & 68,2 & 47,3 & 29,3 & 24,7 & 23,9 & 19,4 & 14,3 \\
\hline RENATHA S. & D & $-118,5$ & $-89,6$ & $-80,4$ & $-68,1$ & $-48,9$ & $-28,7$ & $-25,4$ & $-22,9$ & -18 & $-12,5$ \\
\hline RENATHA S. & $\mathrm{E}$ & 111,7 & 86,9 & 83,8 & 59 & 41,5 & 29,1 & 25,6 & 23,2 & 17,3 & 11,6 \\
\hline STEFANI H. & $\mathrm{D}$ & $-108,1$ & $-82,1$ & $-74,3$ & -63 & $-47,5$ & $-31,1$ & $-26,1$ & $-25,9$ & $-22,2$ & $-16,6$ \\
\hline STEFANI H. & $\mathrm{E}$ & 106,4 & 82,1 & 76,1 & 72,2 & 42,9 & 29,3 & 26,8 & 25,7 & 22,3 & 15,6 \\
\hline THAIZE Q. & $\mathrm{D}$ & $-112,5$ & $-85,3$ & $-83,8$ & $-76,2$ & $-46,2$ & -26 & $-24,1$ & $-22,9$ & $-20,3$ & $-14,7$ \\
\hline THAIZE Q. & $\mathrm{E}$ & 116,1 & 90,1 & 82,7 & 69,5 & 44,9 & 27,3 & 23,1 & 23 & 20,7 & 15,1 \\
\hline
\end{tabular}


Tabela 42. Dados referentes a avaliação da telerradiografia em norma lateral de $45^{\circ}$ de 10 pacientes selecionados ao acaso (Valores retirados da amostra total da fase inicial).

\begin{tabular}{|c|c|c|c|c|c|c|c|c|c|c|c|}
\hline Pacientes - 10 & & 1.PAL. & 4.PAL. & 5.PAL. & 6.PAL. & 7.PAL. & 1-PAL. & 4-PAL. & 5-PAL. & 6-PAL. & 7-PAL. \\
\hline ALESSANDRA O. & D & $-111,8$ & $-86,3$ & $-82,2$ & $-81,2$ & $-71,9$ & $-23,7$ & $-19,8$ & $-19,2$ & $-17,8$ & $-15,2$ \\
\hline ALESSANDRA O. & $\mathrm{E}$ & 102,9 & 83,9 & 82,1 & 81,2 & 67,6 & 28,1 & 23,6 & 22 & 20,4 & 16,8 \\
\hline BRUNO D. F. & $\mathrm{D}$ & $-109,5$ & $-87,4$ & -84 & $-86,3$ & $-67,8$ & $-21,9$ & $-18,5$ & -18 & $-16,4$ & $-12,5$ \\
\hline BRUNO D. F. & $E$ & 114,1 & 88,2 & 85,7 & 78 & 64,4 & 26,2 & 21,1 & 20,3 & 17,2 & $\overline{12,5}$ \\
\hline CASSIA G. & $\bar{D}$ & $-106,6$ & -91 & $-84,7$ & $-83,1$ & $-66,6$ & $-27,7$ & $-21,7$ & $-22,4$ & $-20,6$ & $-16,9$ \\
\hline CASSIA G. & $\mathrm{E}$ & 108,3 & 94,5 & 90,3 & 86,3 & 64,3 & 29 & 24,7 & 24,7 & 22,4 & $\overline{18,6}$ \\
\hline DANIEL U. & $\mathrm{D}$ & $-104,8$ & $-84,1$ & $-83,6$ & $-82,6$ & $-67,2$ & $-30,5$ & $-27,1$ & $-25,9$ & $-23,2$ & $-19,5$ \\
\hline DANIEL U. & $\mathrm{E}$ & 103,3 & 84,1 & 82,6 & 80,7 & 68,7 & 31,3 & 28 & 28 & 25,1 & $\overline{21,2}$ \\
\hline GABRIELLE S. & $\mathrm{D}$ & $-107,1$ & $-87,1$ & $-75,8$ & $-71,7$ & $-55,7$ & $-28,2$ & $-22,8$ & $-22,8$ & $-19,6$ & $\overline{-15}$ \\
\hline GABRIELLE S. & $E$ & 112,5 & 91,4 & 86,2 & 79,6 & 66,6 & 26,7 & 24,6 & 24,5 & 21,1 & $\overline{16,6}$ \\
\hline HELOISA CAS & $\mathrm{D}$ & $-104,7$ & -77 & $-80,3$ & $-90,7$ & $-80,5$ & $-30,5$ & $-25,9$ & $-25,4$ & $-22,5$ & $\overline{-19,6}$ \\
\hline HELOISA CAS & $\mathrm{E}$ & 106,2 & 90,4 & 86,2 & 86,7 & 76,8 & 27,3 & 23,2 & 23,4 & 20,5 & $\overline{17,5}$ \\
\hline LUCIANA I. & $\mathrm{D}$ & $-109,9$ & $-88,7$ & $-78,4$ & -78 & $-64,4$ & $-26,8$ & $-23,2$ & $-22,8$ & $-20,5$ & $\overline{-16,2}$ \\
\hline LUCIANA I. & $E$ & 110,1 & 88,4 & 83 & 82,9 & 70,5 & 27,6 & 23,7 & 23 & 20,6 & $\overline{15,9}$ \\
\hline MARIANA B.V. & $\mathrm{D}$ & $-118,2$ & -85 & $-84,9$ & -83 & $-69,8$ & $-21,3$ & $-21,4$ & $-21,4$ & $-18,9$ & $\overline{-15,9}$ \\
\hline MARIANA B.V. & $E$ & 119,2 & 91,7 & 91 & 84,9 & 76,1 & 21,9 & 20 & 20,6 & 18,8 & 17 \\
\hline NATHALIE M. N. & $\mathrm{D}$ & $-106,6$ & $-83,7$ & $-79,6$ & $-74,1$ & $-51,3$ & -25 & $-21,3$ & $-20,4$ & -17 & $-10,6$ \\
\hline NATHALIE M. N. & $E$ & 104,6 & 84,8 & 78,3 & 71,1 & 54,5 & 27,7 & 20,7 & 20,8 & 16,6 & $\overline{11,8}$ \\
\hline RAQUEL I. & D & \begin{tabular}{|c|}
$-103,7$ \\
\end{tabular} & $-84,7$ & $-72,7$ & $-75,7$ & $-66,4$ & $-28,3$ & $-24,1$ & $-23,1$ & $-20,1$ & $\overline{-16,2}$ \\
\hline RAQUEL I. & $\mathrm{E}$ & 109,7 & 89,5 & 83,7 & 75,5 & 64,5 & 28,2 & 21,6 & 21,5 & 18 & 14,1 \\
\hline
\end{tabular}

Tabela 43. Dados referentes a remedição da telerradiografia em norma lateral de $45^{\circ}$ de 10 pacientes (Fase inicial).

\begin{tabular}{|c|c|c|c|c|c|c|c|c|c|c|c|}
\hline PACIENTES - 10 & & 1.PAL. & 4.PAL. & 5.PAL. & 6.PAL. & 7.PAL. & 1-PAL. & 4-PAL. & 5-PAL. & 6-PAL. & 7-PAL. \\
\hline ALESSANDRA O. & D & $-109,2$ & $-86,7$ & $-84,8$ & $-81,4$ & $-73,5$ & $-23,9$ & $-20,3$ & $-19,8$ & $-18,3$ & -15 \\
\hline ALESSANDRA O. & $\mathrm{E}$ & 102,1 & 88,1 & 87,7 & 81,7 & 64,9 & 26,5 & 23,5 & 21,8 & 20,5 & 16,2 \\
\hline BRUNO D. F. & $D$ & $-112,3$ & $-87,2$ & $-86,4$ & $-71,1$ & $-62,7$ & -25 & $-20,9$ & $-19,9$ & $-17,6$ & -13 \\
\hline BRUNO D. F. & E & 114,3 & 87,9 & 85,6 & 80,5 & 68,3 & 21,6 & 19 & 18,3 & 16,7 & 12,9 \\
\hline CASSIA G. & D & $-108,4$ & -90 & $-87,5$ & $-85,4$ & $-69,9$ & -27 & $-24,2$ & $-23,3$ & $-21,4$ & $-18,3$ \\
\hline CASSIA G. & E & 110,3 & 93,5 & 87,8 & 82 & 63,8 & 29,2 & 25,3 & 25,5 & 23,2 & 19,4 \\
\hline DANIEL U. & $D$ & $-107,3$ & $-86,6$ & $-83,9$ & -90 & $-73,4$ & $-29,3$ & $-27,1$ & $-26,4$ & $-24,8$ & $-21,2$ \\
\hline DANIEL U. & E & 107,8 & 87,7 & 87 & 81,8 & 72 & 29,4 & 28,2 & 28,5 & 26,1 & 21,8 \\
\hline GABRIELLE S. & $D$ & -108 & -87 & $-79,4$ & $-79,1$ & -64 & $-26,4$ & $-22,9$ & $-23,6$ & $-21,1$ & $-16,8$ \\
\hline GABRIELLE S. & E & 118 & 92,9 & 87 & 77,3 & 61,5 & 24,8 & 23,8 & 24 & 20,5 & 15,6 \\
\hline HELOISA CAS & $D$ & $-101,8$ & $-82,7$ & $-79,9$ & $-87,6$ & $-80,4$ & $-31,1$ & $-27,1$ & -26 & $-22,4$ & -20 \\
\hline HELOISA CAS & $\mathrm{E}$ & 105,6 & 91,7 & 89,8 & 84,1 & 76,9 & 27,9 & 23,7 & 23,8 & 20,6 & 17,8 \\
\hline LUCIANA I. & $D$ & $-110,9$ & -94 & $-82,1$ & $-79,7$ & $-65,5$ & $-24,9$ & $-21,7$ & $-21,8$ & $-19,3$ & $-15,7$ \\
\hline LUCIANA I. & E & 108,9 & 87,9 & 80,9 & 80,2 & 65,8 & 28,9 & 23,7 & 22,4 & 20,2 & 15,1 \\
\hline MARIANA B.V. & $\mathrm{D}$ & $-115,4$ & -85 & $-84,8$ & $-80,9$ & $-66,9$ & $-22,7$ & $-22,2$ & $-21,4$ & $-18,8$ & $-15,1$ \\
\hline MARIANA B.V. & E & 118,8 & 86,2 & 87,1 & 83,3 & 69,1 & 21,4 & 20 & 20,8 & 18,6 & 16,6 \\
\hline NATHALIE M. N. & $D$ & $-106,1$ & $-85,1$ & $-80,7$ & $-73,1$ & $-55,9$ & $-26,1$ & -21 & $-19,5$ & $-16,5$ & -10 \\
\hline NATHALIE M. N. & $\mathrm{E}$ & 104,6 & 82,1 & 79,3 & 75,4 & 59,5 & 27,2 & 20,7 & 21,3 & 17,8 & 12,8 \\
\hline RAQUEL I. & $D$ & $-106,6$ & -85 & $-76,2$ & $-76,5$ & $-66,2$ & $-27,9$ & $-23,9$ & $-23,2$ & $-19,8$ & $-15,4$ \\
\hline RAQUEL I. & E & 107,5 & 84,8 & 82,3 & 76,1 & 61,3 & 26,8 & 21,6 & 21,8 & 18,2 & 13,8 \\
\hline
\end{tabular}


Tabela 44. Dados referentes a avaliação da telerradiografia em norma lateral de $45^{\circ}$ de 10 pacientes selecionados ao acaso (Valores retirados da amostra total da fase final).

\begin{tabular}{|c|c|c|c|c|c|c|c|c|c|c|c|}
\hline Pacientes -10 & & 1.PAL. & 4.PAL. & 5.PAL. & 6.PAL. & 7.PAL. & 1-PAL. & 4-PAL. & 5-PAL. & 6-PAL. & 7-PAL. \\
\hline ALESSANDRA 0. & $\mathrm{D}$ & $-116,5$ & $-86,7$ & $-85,8$ & $-65,5$ & $-49,1$ & -26 & $-23,5$ & -23 & $-18,3$ & $-12,9$ \\
\hline ALESSANDRA O. & $\mathrm{E}$ & 109,3 & 91,8 & 88,5 & 59,3 & 41 & 28,3 & 25,7 & 24,8 & 19,4 & 13,8 \\
\hline BRUNO D. F. & $\mathrm{D}$ & $-110,7$ & $-88,1$ & $-82,9$ & $-65,3$ & $-47,6$ & $-27,4$ & $-26,8$ & $-25,8$ & $-20,8$ & $-14,6$ \\
\hline BRUNO D. F. & $\mathrm{E}$ & 114,3 & 93,3 & 85,3 & 75,6 & 54,3 & 26,1 & 21,2 & 20,4 & 17,6 & 12,8 \\
\hline CASSIA G. & $\mathrm{D}$ & $-112,1$ & $-95,3$ & $-89,4$ & $-76,1$ & $-52,5$ & $-27,7$ & $-20,1$ & $-21,6$ & $-19,9$ & $-14,9$ \\
\hline CASSIA G. & $\mathrm{E}$ & 115,6 & 95,8 & 92 & 70,9 & 45,8 & 29,3 & 26,4 & 26,6 & 21,9 & 16,2 \\
\hline DANIEL U. & $\mathrm{D}$ & $-109,9$ & $-93,3$ & -91 & $-77,8$ & $-54,5$ & $-30,4$ & -28 & $-27,4$ & $-23,9$ & $-18,9$ \\
\hline DANIEL U. & E & 110,7 & 86,8 & 87,5 & 68,3 & 46,5 & 31,7 & 30 & 30,2 & 26,1 & 19,7 \\
\hline GABRIELLE S. & $\mathrm{D}$ & $-115,3$ & -99 & -78 & $-69,1$ & $-42,4$ & $-28,1$ & $-24,7$ & $-24,8$ & $-20,9$ & $-14,9$ \\
\hline GABRIELLE S. & $\mathrm{E}$ & 124,6 & 100,5 & 90,1 & 67,4 & 47,7 & 27,4 & 26,9 & 27,5 & 22,5 & 16,7 \\
\hline HELOISA CAS & $\mathrm{D}$ & $-106,1$ & $-91,5$ & -88 & -72 & $-60,9$ & $-29,4$ & $-24,6$ & -24 & $-19,7$ & $-15,5$ \\
\hline HELOISA CAS & $\mathrm{E}$ & 103 & 82 & 79,9 & 68,1 & 60,6 & 29 & 23,4 & 22,6 & 19 & 15 \\
\hline LUCIANA I. & $\mathrm{D}$ & -110 & $-92,9$ & $-81,2$ & $-68,1$ & $-50,5$ & -26 & $-21,6$ & $-21,6$ & $-17,5$ & $-11,7$ \\
\hline LUCIANA I. & $\mathrm{E}$ & 116 & 85,6 & 77,3 & 62,1 & 47,8 & 26,2 & 23,9 & 22,4 & 16,9 & 11,4 \\
\hline MARIANA B.V. & $\mathrm{D}$ & $-120,6$ & $-87,5$ & $-87,2$ & -68 & $-51,2$ & $-19,8$ & $-17,9$ & $-17,7$ & $-16,4$ & $-13,2$ \\
\hline MARIANA B.V. & $\mathrm{E}$ & 120,1 & 93,3 & 92,8 & 57,4 & 47,6 & 22 & 19,4 & 19,2 & 15,7 & 11,7 \\
\hline NATHALIE M. N. & $\mathrm{D}$ & $-106,6$ & $-82,2$ & $-69,8$ & -60 & $-31,6$ & $-27,4$ & $-24,3$ & -23 & $-16,9$ & $-8,8$ \\
\hline NATHALIE M. N. & $\mathrm{E}$ & 112,4 & 78,2 & 73,3 & 65 & 39,9 & 27,5 & 24,3 & 24,2 & 18,1 & 11,5 \\
\hline$R \Delta \cap I I F I \quad I$ & $n$ & -1157 & $-9 \cap 2$ & $-8 \cap 4$ & -700 & -624 & -28 & -263 & -260 & -20 & -175 \\
\hline
\end{tabular}

Tabela 45. . Dados referentes a remedição da telerradiografia em norma lateral de $45^{\circ}$ de 10 pacientes (Fase final).

\begin{tabular}{|c|c|c|c|c|c|c|c|c|c|c|c|}
\hline & & & & & & & & & & & \\
\hline Pacientes - 10 & & 1.PAL. & 4.PAL. & 5.PAL. & 6.PAL. & 7.PAL. & 1-PAL. & 4-PAL. & 5-PAL. & 6-PAL. & 7-PAL. \\
\hline ALESSANDRA O. & D & $-115,5$ & $-83,1$ & $-80,8$ & $-61,2$ & -53 & $-24,6$ & $-22,8$ & $-22,2$ & $-18,1$ & $-14,1$ \\
\hline ALESSANDRA O. & $\mathrm{E}$ & 107,8 & 91,9 & 90,4 & 57,2 & 42,2 & 27,4 & 25,5 & 23,7 & 19,2 & 13 \\
\hline BRUNO D. F. & $D$ & $-112,2$ & $-92,2$ & -87 & $-78,3$ & $-60,1$ & $-26,1$ & $-21,6$ & $-20,6$ & $-18,5$ & $-13,3$ \\
\hline BRUNO D. F. & E & 109,8 & 83,1 & 76,3 & 64,8 & 53,3 & 28 & 26,5 & 25,2 & 19,8 & 13,8 \\
\hline CASSIA G. & $D$ & -114 & $-95,5$ & -88 & $-67,9$ & $-48,2$ & $-27,5$ & -23 & $-21,8$ & $-18,1$ & $-13,3$ \\
\hline CASSIA G. & E & 117,4 & 102 & 91,9 & 73,7 & 48,8 & 27,9 & 26,6 & 27,2 & 23,6 & 17,5 \\
\hline DANIEL U. & D & $-110,3$ & $-91,3$ & $-91,7$ & $-77,5$ & $-53,4$ & $-29,3$ & $-27,5$ & $-26,5$ & $-23,7$ & $-18,6$ \\
\hline DANIEL U. & $\mathrm{E}$ & 107,4 & 90,6 & 89,9 & 71,4 & 53,5 & 31,9 & 31,2 & 31,5 & 26,8 & 21,2 \\
\hline GABRIELLE S. & $D$ & $-121,7$ & $-97,8$ & $-84,9$ & $-71,2$ & $-55,6$ & $-26,5$ & $-23,8$ & $-25,2$ & $-21,6$ & $-16,2$ \\
\hline GABRIELLE S. & $\mathrm{E}$ & 125,3 & 94,1 & 91,5 & 69,5 & 50,9 & 26,8 & 27,3 & 27,6 & 22,5 & 16,2 \\
\hline HELOISA CAS & $\mathrm{D}$ & $-109,1$ & $-91,3$ & $-89,3$ & $-76,6$ & -68 & $-29,3$ & $-26,9$ & -26 & $-21,6$ & $-17,2$ \\
\hline HELOISA CAS & E & 106,5 & 79,6 & 80,5 & 60,8 & 55,6 & 29,1 & 23,2 & 22,9 & 17,7 & 13,4 \\
\hline LUCIANA I. & $D$ & $-109,7$ & $-90,3$ & $-81,3$ & $-68,1$ & $-52,3$ & $-26,9$ & $-22,6$ & $-22,8$ & $-18,7$ & $-12,7$ \\
\hline LUCIANA I. & $\mathrm{E}$ & 118 & 86,1 & 77,9 & 60 & 43,9 & 25,9 & 23,5 & 21,5 & 16,6 & 11,3 \\
\hline MARIANA B.V. & $D$ & -118 & $-93,1$ & $-92,2$ & $-80,3$ & $-63,7$ & -19 & $-17,6$ & $-18,3$ & $-17,3$ & $-14,8$ \\
\hline MARIANA B.V. & E & 121,7 & 91,2 & 90,7 & 61,2 & 50,4 & 21,6 & 20,1 & 19,8 & 16,6 & 13,2 \\
\hline NATHALIE M. N. & $\mathrm{D}$ & $-104,6$ & $-74,5$ & $-67,6$ & $-55,8$ & $-37,9$ & $-30,2$ & $-24,3$ & $-21,6$ & $-15,6$ & -7 \\
\hline NATHALIE M. N. & $\mathrm{E}$ & 109,2 & 76,5 & 72,9 & 62,4 & 37,8 & 31,2 & 25 & 24,6 & 17,3 & 10,8 \\
\hline RAQUEL I. & $D$ & $-115,6$ & $-90,7$ & $-84,1$ & $-69,7$ & $-48,1$ & $-28,8$ & $-26,1$ & $-25,7$ & -20 & $-14,6$ \\
\hline RAQUEL I. & $E$ & 116,8 & 84,6 & 83,4 & 69,1 & 43,3 & 26,5 & 25,2 & 25 & 19,4 & 14,1 \\
\hline
\end{tabular}


Tabela 46. Dados referentes às posições iniciais dos dentes visualizadas pela análise de modelos, de 31 pacientes.

\begin{tabular}{|c|c|c|c|c|c|c|}
\hline Pacientes & DISTAL.11 & DISTAL.13 & DISTAL.14 & DISTAL.15 & DISTAL.16 & DISTAL.17 \\
\hline 1 & 16,7 & 9,4 & 2,7 & $-3,4$ & $-8,8$ & $-18,6$ \\
\hline 2 & 19,8 & 11,7 & 5,2 & $-2,1$ & $-8,4$ & $-20,2$ \\
\hline 3 & 18 & 10,8 & 3,6 & $-3,7$ & $-11,2$ & -21 \\
\hline 4 & 19,2 & 11,1 & 3,6 & $-3,4$ & -10 & $-20,6$ \\
\hline 5 & 15,2 & 13,7 & 6,8 & 1,6 & $-3,9$ & $-13,3$ \\
\hline 6 & 19,1 & 10,7 & 2,5 & -5 & $-12,3$ & $-23,7$ \\
\hline 7 & 17,6 & 11,5 & 3,5 & $-2,7$ & $-9,4$ & $-20,4$ \\
\hline 8 & 16,8 & 9,3 & 3,4 & $-2,1$ & $-8,3$ & $-18,3$ \\
\hline 9 & 15,1 & 6,9 & $-0,2$ & -7 & $-13,1$ & -22 \\
\hline 10 & 18 & 12,8 & 5,1 & $-1,2$ & $-6,8$ & $-16,3$ \\
\hline 11 & 20,5 & 13 & 5,3 & -1 & $-7,4$ & $-17,6$ \\
\hline 12 & 20,5 & 15,3 & 7,4 & 2,1 & $-3,3$ & $-12,1$ \\
\hline 13 & 16,7 & 10,2 & 3,9 & $-2,2$ & -9 & $-19,8$ \\
\hline 14 & 18,4 & 10,8 & 3,5 & $-3,2$ & $-10,3$ & $-20,7$ \\
\hline 15 & 17,3 & 11,5 & 5,1 & $-0,6$ & $-6,8$ & $-15,9$ \\
\hline 16 & 18,1 & 10 & 3,5 & $-3,5$ & $-9,8$ & $-19,9$ \\
\hline 17 & 17,4 & 10,6 & 3,9 & $-2,3$ & $-8,9$ & $-18,6$ \\
\hline 18 & 23,8 & 16,1 & 9,2 & 2 & $-4,3$ & $-15,9$ \\
\hline 19 & 18,4 & 11,3 & 5,2 & $-0,9$ & $-6,7$ & $-16,6$ \\
\hline 20 & 18,5 & 14,2 & 6,8 & 0,3 & $-5,9$ & $-15,3$ \\
\hline 21 & 18,2 & 12,5 & 5,3 & $-0,3$ & -7 & $-17,3$ \\
\hline 22 & 18,4 & 12,6 & 6 & 0 & $-5,9$ & -17 \\
\hline 23 & 19,8 & 10,9 & 5,1 & -2 & $-9,2$ & $-20,7$ \\
\hline 24 & 16 & 8 & 0,1 & $-5,4$ & $-11,4$ & $-22,5$ \\
\hline 25 & 17,4 & 11,2 & 4,9 & $-2,3$ & $-9,2$ & $-21,6$ \\
\hline 26 & 18,4 & 11,5 & 5,3 & $-0,5$ & $-7,4$ & $-16,4$ \\
\hline 27 & 18 & 9,5 & 3,2 & $-2,3$ & $-8,8$ & $-18,6$ \\
\hline 28 & 16,9 & 8,8 & 1,6 & $-5,5$ & $-11,2$ & $-20,2$ \\
\hline 29 & 18,6 & 10,5 & 2,3 & $-4,5$ & $-10,8$ & $-21,2$ \\
\hline 30 & 16,8 & 7,9 & 2,1 & $-4,1$ & $-10,4$ & $-21,7$ \\
\hline 31 & 19 & 14,5 & 7 & 0,3 & $-6,8$ & $-18,4$ \\
\hline MÉDIA & 18,15 & 11,25 & 4,29 & $-2,09$ & $-8,47$ & $-18,79$ \\
\hline
\end{tabular}


Tabela 46. Dados referentes às posições iniciais dos dentes visualizadas pela análise de modelos, de 31 pacientes.

\begin{tabular}{|c|c|c|c|c|c|c|}
\hline Pacientes & DISTAL.21 & DISTAL.23 & DISTAL.24 & DISTAL.25 & DISTAL.26 & DISTAL.27 \\
\hline 1 & 17,1 & 10 & 3,3 & $-3,1$ & $-8,8$ & -18 \\
\hline 2 & 19,7 & 10,4 & 3,4 & $-3,8$ & $-10,3$ & $-21,2$ \\
\hline 3 & 18,2 & 12 & 4,3 & $-2,7$ & -10 & $-19,2$ \\
\hline 4 & 19,2 & 12,5 & 4,3 & $-2,2$ & $-8,5$ & $-18,9$ \\
\hline 5 & 14,7 & 4,1 & $-4,5$ & $-11,8$ & $-18,8$ & -30 \\
\hline 6 & 19,3 & 13,2 & 5,2 & $-1,8$ & $-8,2$ & $-18,7$ \\
\hline 7 & 17,6 & 9,7 & 1,7 & $-4,9$ & $-11,4$ & $-22,5$ \\
\hline 8 & 15,9 & 11,4 & 3,7 & $-2,8$ & -9 & $-18,6$ \\
\hline 9 & 14,9 & 7,5 & 0,7 & $-5,9$ & $-11,5$ & $-20,4$ \\
\hline 10 & 19,2 & 10 & 2,4 & $-4,7$ & $-10,7$ & $-20,2$ \\
\hline 11 & 19 & 11,5 & 3,9 & -3 & $-9,7$ & $-19,9$ \\
\hline 12 & 18,4 & 10,2 & 1,6 & $-5,4$ & $-12,5$ & $-22,6$ \\
\hline 13 & 16,8 & 11,9 & 4,9 & -2 & $-8,2$ & $-19,1$ \\
\hline 14 & 16,8 & 9,6 & 2,3 & $-5,1$ & $-12,4$ & $-23,2$ \\
\hline 15 & 17,2 & 7,9 & 0,1 & $-6,8$ & $-12,9$ & $-23,2$ \\
\hline 16 & 17,3 & 9 & 1,3 & $-5,8$ & $-12,2$ & $-22,9$ \\
\hline 17 & 18,3 & 11,4 & 3,2 & $-2,9$ & $-9,6$ & $-19,5$ \\
\hline 18 & 22,2 & 14,7 & 5,9 & $-1,6$ & $-8,3$ & $-20,4$ \\
\hline 19 & 18 & 10,4 & 3 & $-3,2$ & $-9,5$ & $-19,7$ \\
\hline 20 & 22,2 & 10,9 & 3,3 & $-4,1$ & -11 & $-21,1$ \\
\hline 21 & 17,6 & 11,3 & 3,3 & -3 & $-9,6$ & $-19,4$ \\
\hline 22 & 17,7 & 9,7 & 2,3 & $-4,4$ & $-11,1$ & $-22,3$ \\
\hline 23 & 21,3 & 14,4 & 7,7 & 1 & $-5,4$ & $-16,1$ \\
\hline 24 & 15,8 & 7,5 & 0,9 & $-4,8$ & $-11,3$ & $-21,8$ \\
\hline 25 & 17 & 9,1 & 2,7 & $-5,7$ & $-12,1$ & $-24,4$ \\
\hline 26 & 18 & 10 & 3,5 & $-2,8$ & $-9,7$ & $-19,6$ \\
\hline 27 & 16,9 & 5,8 & $-1,8$ & $-8,8$ & $-15,5$ & $-26,2$ \\
\hline 28 & 16,7 & 8,4 & 0,6 & $-6,5$ & -13 & $-22,1$ \\
\hline 29 & 18,1 & 10,5 & 3,3 & $-3,9$ & $-10,5$ & $-20,7$ \\
\hline 30 & 17 & 11,7 & 4 & $-0,9$ & $-6,7$ & $-17,7$ \\
\hline 31 & 18,6 & 12,7 & 5,2 & $-1,7$ & $-8,8$ & $-20,6$ \\
\hline MÉDIA & 17,96 & 10,3 & 2,76 & $-4,04$ & $-10,55$ & $-20,97$ \\
\hline
\end{tabular}


Tabela 47. Dados referentes às posições iniciais dos dentes visualizadas pela análise de modelos .

\begin{tabular}{|c|c|c|c|c|}
\hline EXPANS.13 & EXPANS.14 & EXPANS.15 & EXPANS.16 & EXPANS.17 \\
\hline$-17,4$ & $-18,1$ & $-20,2$ & $-17,4$ & $-24,2$ \\
\hline$-18,9$ & $-18,9$ & $-21,9$ & $-18,9$ & -26 \\
\hline$-16,7$ & $-15,9$ & -17 & $-16,7$ & $-23,2$ \\
\hline-17 & $-17,4$ & $-19,9$ & -17 & $-25,9$ \\
\hline$-17,2$ & $-15,6$ & $-17,8$ & $-17,2$ & $-21,7$ \\
\hline$-19,4$ & $-19,7$ & $-23,1$ & $-19,4$ & $-26,7$ \\
\hline-19 & -18 & $-20,7$ & -19 & $-24,7$ \\
\hline$-16,4$ & $-16,5$ & $-20,1$ & $-16,4$ & $-25,8$ \\
\hline$-17,6$ & $-17,1$ & $-19,1$ & $-17,6$ & -24 \\
\hline$-17,7$ & $-16,8$ & $-19,8$ & $-17,7$ & -24 \\
\hline$-18,8$ & $-19,3$ & -23 & $-18,8$ & $-28,4$ \\
\hline$-17,8$ & $-17,1$ & $-20,5$ & $-17,8$ & $-25,7$ \\
\hline$-18,2$ & $-17,7$ & $-21,6$ & $-18,2$ & $-26,3$ \\
\hline$-17,6$ & $-18,4$ & $-21,1$ & $-17,6$ & $-25,8$ \\
\hline$-16,4$ & $-17,8$ & $-20,6$ & $-16,4$ & $-24,6$ \\
\hline$-18,2$ & $-18,3$ & $-20,6$ & $-18,2$ & $-26,4$ \\
\hline$-18,9$ & $-16,9$ & $-20,5$ & $-18,9$ & $-26,7$ \\
\hline$-18,4$ & $-18,6$ & $-20,2$ & $-18,4$ & $-24,9$ \\
\hline$-16,7$ & $-17,9$ & -21 & $-16,7$ & $-25,4$ \\
\hline-17 & $-16,4$ & $-19,3$ & -17 & $-24,8$ \\
\hline-17 & -17 & $-20,1$ & -17 & $-25,9$ \\
\hline$-17,8$ & $-18,9$ & $-21,8$ & $-17,8$ & $-27,2$ \\
\hline$-18,5$ & -20 & -23 & $-18,5$ & $-27,5$ \\
\hline$-18,1$ & $-18,4$ & $-20,6$ & $-18,1$ & -24 \\
\hline$-18,8$ & $-19,3$ & $-20,9$ & $-18,8$ & $-24,5$ \\
\hline$-15,4$ & $-15,8$ & $-18,6$ & $-15,4$ & $-23,9$ \\
\hline$-18,1$ & $-18,4$ & $-22,1$ & $-18,1$ & $-26,7$ \\
\hline$-16,2$ & $-17,2$ & $-20,4$ & $-16,2$ & $-26,5$ \\
\hline$-15,4$ & $-16,9$ & $-19,8$ & $-15,4$ & $-24,7$ \\
\hline$-16,7$ & $-17,5$ & $-20,8$ & $-16,7$ & $-27,1$ \\
\hline$-19,1$ & $-18,9$ & $-21,2$ & $-19,1$ & $-26,5$ \\
\hline$-17,63$ & $-17,76$ & $-20,56$ & $-17,63$ & $-25,47$ \\
\hline
\end{tabular}


Tabela 47. Dados referentes às posições iniciais dos dentes visualizadas pela análise de modelos .

\begin{tabular}{|c|c|c|c|c|}
\hline EXPANS.23 & EXPANS.24 & EXPANS.25 & EXPANS.26 & EXPANS.27 \\
\hline 17 & 16,4 & 19,1 & 21,1 & 22,7 \\
\hline 17,5 & 17,4 & 20,7 & 23,8 & 25,5 \\
\hline 18 & 16,7 & 18,4 & 19,9 & 22,7 \\
\hline 19,6 & 18,1 & 20 & 21,9 & 24,4 \\
\hline 16,8 & 17,3 & 20,1 & 22 & 24,8 \\
\hline 19,2 & 19,3 & 21,4 & 23,6 & 25,1 \\
\hline 18,2 & 17,6 & 20,7 & 22,9 & 25,4 \\
\hline 17,7 & 17,7 & 21 & 24 & 26,1 \\
\hline 16,5 & 15,6 & 17 & 19,1 & 22 \\
\hline 15,3 & 14,4 & 17,8 & 21 & 23,1 \\
\hline 18,9 & 18,5 & 21,9 & 24,9 & 27,5 \\
\hline 18,2 & 17,4 & 21,3 & 24,7 & 27,5 \\
\hline 16,9 & 16,9 & 20,2 & 23,7 & 26,9 \\
\hline 17,2 & 16,9 & 20,3 & 22,4 & 24,8 \\
\hline 16,9 & 17,4 & 20 & 22,6 & 24,2 \\
\hline 20,3 & 19,7 & 22,4 & 25 & 28,4 \\
\hline 17,7 & 17,4 & 20,5 & 22,9 & 25,8 \\
\hline 20,1 & 19,6 & 22,3 & 23,1 & 23 \\
\hline 16,8 & 18,5 & 21,4 & 24 & 24,9 \\
\hline 15 & 14,2 & 17,1 & 19,4 & 22,3 \\
\hline 18,1 & 17,6 & 21 & 23,4 & 28,4 \\
\hline 18,8 & 20 & 22,6 & 24,8 & 26,1 \\
\hline 18 & 19,2 & 22,4 & 25,9 & 26,9 \\
\hline 17,9 & 18,3 & 20,3 & 23 & 23,9 \\
\hline 17,9 & 18,5 & 21,4 & 24,5 & 26,4 \\
\hline 15,6 & 16,2 & 18,2 & 20,7 & 23 \\
\hline 17 & 17,6 & 20,5 & 23,9 & 27,3 \\
\hline 18,4 & 18,4 & 20,9 & 22,8 & 26,3 \\
\hline 18,5 & 19,1 & 22,4 & 24,7 & 26,2 \\
\hline 16,7 & 15,5 & 20 & 21,2 & 24,4 \\
\hline 19,5 & 19,5 & 21,9 & 23,8 & 25,8 \\
\hline 17,75 & 17,64 & 20,49 & 22,93 & 25,22 \\
\hline
\end{tabular}


Tabela 48. Dados referentes às posições finais dos dentes visualizadas pela análise de modelo, de 31 pacientes.

\begin{tabular}{|c|c|c|c|c|c|c|}
\hline Pacientes & DISTAL.11 & DISTAL.13 & DISTAL.14 & DISTAL.15 & DISTAL.16 & DISTAL.17 \\
\hline 1 & 16,3 & 9,6 & 3,8 & $-2,3$ & $-15,1$ & $-24,7$ \\
\hline 2 & 20,5 & 13,9 & 7,5 & 0,5 & $-13,9$ & $-24,8$ \\
\hline 3 & 18,5 & 12 & 5,4 & $-2,3$ & -15 & $-24,8$ \\
\hline 4 & 19,4 & 12,9 & 5 & $-2,9$ & $-17,8$ & $-28,4$ \\
\hline 5 & 15,1 & 16,2 & 10,3 & 4,1 & -7 & $-16,3$ \\
\hline 6 & 17,9 & 10,4 & 1,7 & $-5,5$ & $-20,2$ & $-30,5$ \\
\hline 7 & 17,1 & 11,7 & 3,6 & $-3,7$ & -14 & $-25,6$ \\
\hline 8 & 17,1 & 10,6 & 4,3 & -2 & -14 & $-23,6$ \\
\hline 9 & 16 & 10,5 & 3,6 & $-2,8$ & $-14,6$ & $-24,5$ \\
\hline 10 & 18,2 & 13,2 & 6,3 & $-0,1$ & $-11,6$ & $-22,1$ \\
\hline 11 & 22 & 14,8 & 6,7 & $-0,4$ & -12 & $-23,3$ \\
\hline 12 & 20,3 & 17 & 10 & 4,8 & $-6,1$ & $-14,9$ \\
\hline 13 & 18,4 & 13,6 & 7,7 & 1,3 & $-10,4$ & $-21,3$ \\
\hline 14 & 18,4 & 12,2 & 5,1 & $-1,9$ & -15 & $-25,7$ \\
\hline 15 & 17,7 & 12,6 & 6,8 & 1 & $-10,4$ & $-19,1$ \\
\hline 16 & 19,4 & 12,3 & 5,9 & $-1,5$ & $-14,3$ & $-24,6$ \\
\hline 17 & 17,5 & 12,4 & 5,7 & $-1,8$ & $-15,5$ & $-25,3$ \\
\hline 18 & 24,9 & 19,1 & 11,8 & 3,6 & $-5,2$ & $-16,9$ \\
\hline 19 & 19,3 & 12,4 & 6,3 & $-0,3$ & $-9,3$ & $-20,3$ \\
\hline 20 & 18,3 & 16,3 & 9,7 & 2,6 & -9 & $-18,6$ \\
\hline 21 & 18,7 & 14,7 & 7,6 & 0,9 & $-10,5$ & -19 \\
\hline 22 & 18,6 & 14,3 & 7,8 & 1,9 & $-11,6$ & $-22,2$ \\
\hline 23 & 21,4 & 13,2 & 7,6 & $-0,1$ & -14 & $-25,6$ \\
\hline 24 & 17 & 9,9 & 3 & $-3,5$ & $-17,4$ & $-27,7$ \\
\hline 25 & 19 & 14,2 & 7,9 & 0,2 & $-15,2$ & $-26,4$ \\
\hline 26 & 18,3 & 14,1 & 8,4 & 2,6 & $-10,8$ & $-19,8$ \\
\hline 27 & 19,7 & 11,7 & 5,1 & $-0,3$ & $-15,9$ & $-22,3$ \\
\hline 28 & 16,6 & 10,2 & 3 & $-3,7$ & $-16,3$ & $-25,5$ \\
\hline 29 & 14,7 & 7,7 & 1,4 & $-6,1$ & $-18,7$ & $-28,2$ \\
\hline 30 & 18,5 & 12,6 & 9,1 & 3 & $-8,4$ & $-18,6$ \\
\hline 31 & 19,2 & 17,3 & 9,2 & 1,9 & $-11,3$ & $-22,7$ \\
\hline MÉDIA & 18,52 & 13,02 & 6,36 & $-0,41$ & $-12,92$ & $-23,01$ \\
\hline
\end{tabular}


Tabela 48. Dados referentes às posições finais dos dentes visualizadas pela análise de modelo, de 31 pacientes.

\begin{tabular}{|c|c|c|c|c|c|c|}
\hline Pacientes & DISTAL.21 & DISTAL.23 & DISTAL.24 & DISTAL.25 & DISTAL.26 & DISTAL.27 \\
\hline 1 & 17 & 10,1 & 5,8 & $-0,3$ & $-14,2$ & -24 \\
\hline 2 & 20 & 11,8 & 4,8 & $-2,2$ & $-14,9$ & -26 \\
\hline 3 & 18,7 & 13 & 5,8 & $-0,9$ & $-16,4$ & $-25,2$ \\
\hline 4 & 19 & 14,6 & 6,3 & -1 & $-13,4$ & $-23,6$ \\
\hline 5 & 14,7 & 5,1 & $-2,6$ & $-10,6$ & $-25,8$ & -36 \\
\hline 6 & 18,7 & 14,6 & 7,3 & 1,1 & $-9,5$ & $-19,9$ \\
\hline 7 & 18 & 12,5 & 3,7 & $-3,1$ & $-14,3$ & -26 \\
\hline 8 & 15,7 & 12,4 & 5,1 & $-1,1$ & $-13,2$ & $-23,3$ \\
\hline 9 & 15,3 & 12,1 & 4,7 & $-1,5$ & $-13,3$ & -23 \\
\hline 10 & 21 & 12,1 & 4,4 & $-2,6$ & -14 & $-24,6$ \\
\hline 11 & 20,3 & 13,7 & 6,3 & $-1,4$ & $-13,7$ & $-24,5$ \\
\hline 12 & 18,1 & 12,2 & 3,6 & $-3,5$ & $-17,2$ & $-28,2$ \\
\hline 13 & 18 & 14,2 & 6,2 & $-1,3$ & $-14,2$ & $-25,9$ \\
\hline 14 & 15,6 & 11,6 & 3,9 & $-3,8$ & $-17,7$ & $-28,7$ \\
\hline 15 & 17,7 & 9 & 1,5 & $-5,7$ & -17 & $-27,3$ \\
\hline 16 & 18,5 & 11 & 4 & $-3,4$ & $-16,7$ & $-27,3$ \\
\hline 17 & 17,5 & 11,7 & 5,1 & $-2,2$ & $-14,4$ & $-24,9$ \\
\hline 18 & 23,1 & 16,9 & 8,3 & $-0,9$ & $-13,3$ & $-24,4$ \\
\hline 19 & 18,6 & 11,4 & 4,6 & $-2,8$ & $-14,8$ & $-25,1$ \\
\hline 20 & 23,4 & 13,5 & 5,8 & -2 & $-15,1$ & $-25,1$ \\
\hline 21 & 17,9 & 12,9 & 4,8 & $-2,2$ & $-11,5$ & $-22,2$ \\
\hline 22 & 17,7 & 9,5 & 2,3 & $-4,4$ & $-17,8$ & $-28,6$ \\
\hline 23 & 23,6 & 16,9 & 10,5 & 2,8 & $-10,9$ & $-22,2$ \\
\hline 24 & 16,7 & 9,5 & 3,4 & $-2,9$ & $-16,4$ & $-26,9$ \\
\hline 25 & 19 & 13,2 & 7 & $-0,9$ & $-18,9$ & -30 \\
\hline 26 & 16,8 & 9,7 & 4,1 & $-2,2$ & $-16,7$ & $-25,8$ \\
\hline 27 & 18,7 & 8,3 & 0,1 & $-7,2$ & $-20,1$ & $-29,4$ \\
\hline 28 & 16,2 & 8,7 & 1,2 & $-5,9$ & $-20,7$ & $-30,5$ \\
\hline 29 & 13,7 & 6,4 & $-0,7$ & $-8,2$ & $-20,3$ & $-31,7$ \\
\hline 30 & 15,9 & 7,8 & 1,1 & $-6,1$ & $-19,1$ & $-29,8$ \\
\hline 31 & 19,1 & 15,9 & 8,8 & 1,1 & $-13,5$ & $-23,8$ \\
\hline MÉDIA & 18,2 & 11,69 & 4,43 & $-2,75$ & $-15,77$ & $-26,25$ \\
\hline
\end{tabular}


Tabela 49. . Dados referentes às posições finais dos dentes visualizadas pela análise de modelo, de 31 pacientes.

\begin{tabular}{|c|c|c|c|c|}
\hline EXPANS.13 & EXPANS.14 & EXPANS.15 & EXPANS.16 & EXPANS.17 \\
\hline$-17,4$ & $-18,1$ & $-20,2$ & $-17,4$ & $-24,2$ \\
\hline$-18,9$ & $-18,9$ & $-21,9$ & $-18,9$ & -26 \\
\hline$-16,7$ & $-15,9$ & -17 & $-16,7$ & $-23,2$ \\
\hline-17 & $-17,4$ & $-19,9$ & -17 & $-25,9$ \\
\hline$-17,2$ & $-15,6$ & $-17,8$ & $-17,2$ & $-21,7$ \\
\hline$-19,4$ & $-19,7$ & $-23,1$ & $-19,4$ & $-26,7$ \\
\hline-19 & -18 & $-20,7$ & -19 & $-24,7$ \\
\hline$-16,4$ & $-16,5$ & $-20,1$ & $-16,4$ & $-25,8$ \\
\hline$-17,6$ & $-17,1$ & $-19,1$ & $-17,6$ & -24 \\
\hline$-17,7$ & $-16,8$ & $-19,8$ & $-17,7$ & -24 \\
\hline$-18,8$ & $-19,3$ & -23 & $-18,8$ & $-28,4$ \\
\hline$-17,8$ & $-17,1$ & $-20,5$ & $-17,8$ & $-25,7$ \\
\hline$-18,2$ & $-17,7$ & $-21,6$ & $-18,2$ & $-26,3$ \\
\hline$-17,6$ & $-18,4$ & $-21,1$ & $-17,6$ & $-25,8$ \\
\hline$-16,4$ & $-17,8$ & $-20,6$ & $-16,4$ & $-24,6$ \\
\hline$-18,2$ & $-18,3$ & $-20,6$ & $-18,2$ & $-26,4$ \\
\hline$-18,9$ & $-16,9$ & $-20,5$ & $-18,9$ & $-26,7$ \\
\hline$-18,4$ & $-18,6$ & $-20,2$ & $-18,4$ & $-24,9$ \\
\hline$-16,7$ & $-17,9$ & -21 & $-16,7$ & $-25,4$ \\
\hline-17 & $-16,4$ & $-19,3$ & -17 & $-24,8$ \\
\hline-17 & -17 & $-20,1$ & -17 & $-25,9$ \\
\hline$-17,8$ & $-18,9$ & $-21,8$ & $-17,8$ & $-27,2$ \\
\hline$-18,5$ & -20 & -23 & $-18,5$ & $-27,5$ \\
\hline$-18,1$ & $-18,4$ & $-20,6$ & $-18,1$ & -24 \\
\hline$-18,8$ & $-19,3$ & $-20,9$ & $-18,8$ & $-24,5$ \\
\hline$-15,4$ & $-15,8$ & $-18,6$ & $-15,4$ & $-23,9$ \\
\hline$-18,1$ & $-18,4$ & $-22,1$ & $-18,1$ & $-26,7$ \\
\hline$-16,2$ & $-17,2$ & $-20,4$ & $-16,2$ & $-26,5$ \\
\hline$-15,4$ & $-16,9$ & $-19,8$ & $-15,4$ & $-24,7$ \\
\hline$-16,7$ & $-17,5$ & $-20,8$ & $-16,7$ & $-27,1$ \\
\hline$-19,1$ & $-18,9$ & $-21,2$ & $-19,1$ & $-26,5$ \\
\hline$-17,63$ & $-17,76$ & $-20,56$ & $-17,63$ & $-25,47$ \\
\hline
\end{tabular}


Tabela 49. . Dados referentes às posições finais dos dentes visualizadas pela análise de modelo, de 31 pacientes.

\begin{tabular}{|c|c|c|c|c|}
\hline EXPANS.23 & EXPANS.24 & EXPANS.25 & EXPANS.26 & EXPANS.27 \\
\hline 17 & 16,4 & 19,1 & 21,1 & 22,7 \\
\hline 17,5 & 17,4 & 20,7 & 23,8 & 25,5 \\
\hline 18 & 16,7 & 18,4 & 19,9 & 22,7 \\
\hline 19,6 & 18,1 & 20 & 21,9 & 24,4 \\
\hline 16,8 & 17,3 & 20,1 & 22 & 24,8 \\
\hline 19,2 & 19,3 & 21,4 & 23,6 & 25,1 \\
\hline 18,2 & 17,6 & 20,7 & 22,9 & 25,4 \\
\hline 17,7 & 17,7 & 21 & 24 & 26,1 \\
\hline 16,5 & 15,6 & 17 & 19,1 & 22 \\
\hline 15,3 & 14,4 & 17,8 & 21 & 23,1 \\
\hline 18,9 & 18,5 & 21,9 & 24,9 & 27,5 \\
\hline 18,2 & 17,4 & 21,3 & 24,7 & 27,5 \\
\hline 16,9 & 16,9 & 20,2 & 23,7 & 26,9 \\
\hline 17,2 & 16,9 & 20,3 & 22,4 & 24,8 \\
\hline 16,9 & 17,4 & 20 & 22,6 & 24,2 \\
\hline 20,3 & 19,7 & 22,4 & 25 & 28,4 \\
\hline 17,7 & 17,4 & 20,5 & 22,9 & 25,8 \\
\hline 20,1 & 19,6 & 22,3 & 23,1 & 23 \\
\hline 16,8 & 18,5 & 21,4 & 24 & 24,9 \\
\hline 15 & 14,2 & 17,1 & 19,4 & 22,3 \\
\hline 18,1 & 17,6 & 21 & 23,4 & 28,4 \\
\hline 18,8 & 20 & 22,6 & 24,8 & 26,1 \\
\hline 18 & 19,2 & 22,4 & 25,9 & 26,9 \\
\hline 17,9 & 18,3 & 20,3 & 23 & 23,9 \\
\hline 17,9 & 18,5 & 21,4 & 24,5 & 26,4 \\
\hline 15,6 & 16,2 & 18,2 & 20,7 & 23 \\
\hline 17 & 17,6 & 20,5 & 23,9 & 27,3 \\
\hline 18,4 & 18,4 & 20,9 & 22,8 & 26,3 \\
\hline 18,5 & 19,1 & 22,4 & 24,7 & 26,2 \\
\hline 16,7 & 15,5 & 20 & 21,2 & 24,4 \\
\hline 19,5 & 19,5 & 21,9 & 23,8 & 25,8 \\
\hline 17,75 & 17,64 & 20,49 & 22,93 & 25,22 \\
\hline
\end{tabular}


Tabela 50. Dados referentes à análise de modelos de 10 pacientes selecionados ao acaso (Valores retirados da amostra total da fase inicial).

\begin{tabular}{l|c|c|c|c|c|c}
\hline PACIENTES & DISTAL.11 & DISTAL.13 & DISTAL.14 & DISTAL.15 & DISTAL.16 & DISTAL.17 \\
\hline 1 & 17,6 & 11,5 & 3,5 & $-2,7$ & $-9,4$ & $-20,4$ \\
\hline 2 & 15,1 & 6,9 & $-0,2$ & -7 & $-13,1$ & -22 \\
\hline 3 & 20,5 & 13 & 5,3 & -1 & $-7,4$ & $-17,6$ \\
\hline 4 & 18,4 & 12,6 & 6 & 0 & $-5,9$ & -17 \\
\hline 6 & 16 & 8 & 0,1 & $-5,4$ & $-11,4$ & $-22,5$ \\
\hline 7 & 17,4 & 11,2 & 4,9 & $-2,3$ & $-9,2$ & $-21,6$ \\
\hline $\mathbf{8}$ & 18,4 & 11,5 & 5,3 & $-0,5$ & $-7,4$ & $-16,4$ \\
\hline 10 & 18 & 9,5 & 3,2 & $-2,3$ & $-8,8$ & $-18,6$ \\
\hline MÉDIA & 18,6 & 10,5 & 2,3 & $-4,5$ & $-10,8$ & $-21,2$ \\
\hline
\end{tabular}

Tabela 50. Dados referentes à análise de modelos de 10 pacientes selecionados ao acaso (Valores retirados da amostra total da fase inicial).

\begin{tabular}{l|c|c|c|c|c|c}
\hline PACIENTES & DISTAL.21 & DISTAL.23 & DISTAL.24 & DISTAL.25 & DISTAL.26 & DISTAL.27 \\
\hline 1 & 17,6 & 9,7 & 1,7 & $-4,9$ & $-11,4$ & $-22,5$ \\
\hline 2 & 14,9 & 7,5 & 0,7 & $-5,9$ & $-11,5$ & $-20,4$ \\
\hline 3 & 19 & 11,5 & 3,9 & -3 & $-9,7$ & $-19,9$ \\
\hline $\mathbf{5}$ & 17,7 & 9,7 & 2,3 & $-4,4$ & $-11,1$ & $-22,3$ \\
\hline 6 & 15,8 & 7,5 & 0,9 & $-4,8$ & $-11,3$ & $-21,8$ \\
\hline 7 & 17 & 9,1 & 2,7 & $-5,7$ & $-12,1$ & $-24,4$ \\
\hline $\mathbf{9}$ & 18 & 10 & 3,5 & $-2,8$ & $-9,7$ & $-19,6$ \\
\hline 10 & 16,9 & 5,8 & $-1,8$ & $-8,8$ & $-15,5$ & $-26,2$ \\
\hline MÉDIA & 18,1 & 10,5 & 3,3 & $-3,9$ & $-10,5$ & $-20,7$ \\
\hline
\end{tabular}


Tabela 51. Dados referentes à remedição dos modelos de 10 pacientes (Fase inicial).

\begin{tabular}{c|c|c|c|c|c|c}
\hline Pacientes & DISTAL.11 & DISTAL.13 & DISTAL.14 & DISTAL.15 & DISTAL.16 & DISTAL.17 \\
\hline 1 & 17,8 & 11,7 & 3,6 & -3 & $-9,7$ & $-20,6$ \\
\hline 2 & 16 & 8 & $-0,4$ & $-7,5$ & $-13,2$ & $-21,8$ \\
\hline 3 & 20 & 11,6 & 5,3 & $-1,4$ & $-7,6$ & $-18,2$ \\
\hline 4 & 19 & 12,7 & 5,6 & $-0,7$ & $-6,3$ & $-17,2$ \\
\hline 5 & 16,1 & 8,3 & 0,4 & $-5,5$ & $-11,4$ & $-22,1$ \\
\hline 6 & 17,3 & 11,1 & 5,3 & $-1,6$ & $-8,7$ & $-20,8$ \\
\hline 7 & 19,1 & 12,9 & 6,1 & $-0,5$ & $-7,1$ & -16 \\
\hline 8 & 19,3 & 10,8 & 3,8 & $-2,1$ & $-8,6$ & $-17,9$ \\
\hline 9 & 18,3 & 9,9 & 2,7 & $-3,6$ & $-9,8$ & $-20,5$ \\
\hline 10 & 19,2 & 15,1 & 7,2 & 0,3 & $-6,6$ & $-17,6$ \\
\hline MÉDIA & $\mathbf{1 8 , 2 1}$ & $\mathbf{1 1 , 2 1}$ & $\mathbf{3 , 9 6}$ & $\mathbf{- 2 , 5 6}$ & $\mathbf{- 8 , 9}$ & $\mathbf{- 1 9 , 2 7}$ \\
\hline
\end{tabular}

Tabela 51. Dados referentes à remedição dos modelos de 10 pacientes (Fase inicial).

\begin{tabular}{c|c|c|c|c|c|c}
\hline Pacientes & DISTAL.21 & DISTAL.23 & DISTAL.24 & DISTAL.25 & DISTAL.26 & DISTAL.27 \\
\hline 1 & 17,8 & 10,4 & 1,7 & $-4,9$ & $-11,5$ & $-22,1$ \\
\hline 2 & 15,8 & 8,8 & 1,1 & $-6,1$ & $-11,7$ & $-20,2$ \\
\hline 3 & 18,4 & 10,2 & 3,5 & $-2,8$ & $-9,4$ & -20 \\
\hline 4 & 18,6 & 10,1 & 2,2 & $-4,6$ & $-11,1$ & $-21,9$ \\
\hline 5 & 15,7 & 7,2 & 0,7 & -5 & $-11,3$ & $-22,2$ \\
\hline 6 & 16,8 & 8,8 & 2,1 & $-5,8$ & $-12,4$ & $-24,9$ \\
\hline 7 & 18,8 & 11,3 & 4,1 & -3 & $-9,8$ & $-19,4$ \\
\hline 8 & 18,3 & 6,9 & $-1,8$ & $-8,9$ & $-15,3$ & $-25,3$ \\
\hline 9 & 17,6 & 9,1 & 2,3 & $-4,2$ & $-10,8$ & $-21,7$ \\
\hline 10 & 18,9 & 13 & 5,1 & $-2,1$ & -9 & $-20,3$ \\
\hline MÉDIA & $\mathbf{1 7 , 6 7}$ & $\mathbf{9 , 5 8}$ & $\mathbf{2 , 1}$ & $\mathbf{- 4 , 7 4}$ & $\mathbf{- 1 1 , 2 3}$ & $\mathbf{- 2 1 , 8}$ \\
\hline
\end{tabular}


Tabela 52. Dados referentes a análise de modelos de 10 pacientes selecionados ao acaso (Valores retirados da amostra total da fase inicial).

\begin{tabular}{c|c|c|c|c}
\hline EXPANS.13 & EXPANS.14 & EXPANS.15 & EXPANS.16 & EXPANS.17 \\
\hline-19 & -18 & $-20,7$ & -19 & $-24,7$ \\
\hline$-17,6$ & $-17,1$ & $-19,1$ & $-17,6$ & -24 \\
\hline$-18,8$ & $-19,3$ & -23 & $-18,8$ & $-28,4$ \\
\hline$-17,8$ & $-18,9$ & $-21,8$ & $-17,8$ & $-27,2$ \\
\hline$-18,1$ & $-18,4$ & $-20,6$ & $-18,1$ & -24 \\
\hline$-18,8$ & $-19,3$ & $-20,9$ & $-18,8$ & $-24,5$ \\
\hline$-15,4$ & $-15,8$ & $-18,6$ & $-15,4$ & $-23,9$ \\
\hline$-18,1$ & $-18,4$ & $-22,1$ & $-18,1$ & $-26,7$ \\
\hline$-15,4$ & $-16,9$ & $-19,8$ & $-15,4$ & $-24,7$ \\
\hline$-19,1$ & $-18,9$ & $-21,2$ & $-19,1$ & $-26,5$ \\
\hline$-17,81$ & $-18,1$ & $-20,78$ & $-17,81$ & $-25,46$ \\
\hline
\end{tabular}

Tabela 52. Dados referentes a análise de modelos de 10 pacientes selecionados ao acaso (Valores retirados da amostra total da fase inicial).

\begin{tabular}{c|c|c|c|c}
\hline $\boldsymbol{E X P A N S . 2 3}$ & EXPANS.24 & EXPANS.25 & EXPANS.26 & EXPANS.27 \\
\hline 18,2 & 17,6 & 20,7 & 22,9 & 25,4 \\
\hline 16,5 & 15,6 & 17 & 19,1 & 22 \\
\hline 18,9 & 18,5 & 21,9 & 24,9 & 27,5 \\
\hline 18,8 & 20 & 22,6 & 24,8 & 26,1 \\
\hline 17,9 & 18,3 & 20,3 & 23 & 23,9 \\
\hline 17,9 & 18,5 & 21,4 & 24,5 & 26,4 \\
\hline 15,6 & 16,2 & 18,2 & 20,7 & 23 \\
\hline 17 & 17,6 & 20,5 & 23,9 & 26,2 \\
\hline 18,5 & 19,1 & 22,4 & 24,7 & 25,8 \\
\hline 19,5 & 19,5 & 21,9 & 23,8 & $\mathbf{2 5 , 3 6}$ \\
\hline $\mathbf{1 7 , 8 8}$ & $\mathbf{1 8 , 0 9}$ & $\mathbf{2 0 , 6 9}$ & $\mathbf{2 3 , 2 3}$ & \\
\hline
\end{tabular}


Tabela 53. Dados referentes a remedição dos modelos de 10 pacientes (Fase inicial).

\begin{tabular}{c|c|c|c|c}
\hline EXPANS.13 & EXPANS.14 & EXPANS.15 & EXPANS.16 & EXPANS.17 \\
\hline$-18,2$ & $-17,7$ & $-20,7$ & $-18,2$ & $-25,1$ \\
\hline$-16,2$ & $-15,9$ & $-18,2$ & $-16,2$ & $-24,2$ \\
\hline$-18,7$ & $-19,3$ & $-22,7$ & $-18,7$ & $-28,4$ \\
\hline$-17,2$ & $-18,6$ & $-21,7$ & $-17,2$ & $-27,3$ \\
\hline$-18,1$ & $-18,4$ & $-20,6$ & $-18,1$ & -24 \\
\hline$-18,4$ & $-19,4$ & -21 & $-18,4$ & $-24,5$ \\
\hline$-14,2$ & $-14,6$ & $-17,8$ & $-14,2$ & -24 \\
\hline$-16,8$ & $-17,6$ & $-21,4$ & $-16,8$ & $-27,2$ \\
\hline$-15,8$ & $-17,4$ & $-20,2$ & $-15,8$ & $-24,4$ \\
\hline-19 & -19 & $-21,3$ & -19 & $-26,4$ \\
\hline$-17,26$ & $-17,79$ & $-20,56$ & $-17,26$ & $-25,55$ \\
\hline
\end{tabular}

Tabela 53. Dados referentes a remedição dos modelos de 10 pacientes (Fase inicial).

\begin{tabular}{c|c|c|c|c}
\hline EXPANS.23 & EXPANS.24 & EXPANS.25 & EXPANS.26 & EXPANS.27 \\
\hline 18,3 & 18,2 & 21 & 23 & 25,3 \\
\hline 16,5 & 15,2 & 16,9 & 19 & 22 \\
\hline 19,5 & 18,8 & 22,1 & 24,9 & 27,5 \\
\hline 18,8 & 20,1 & 22,9 & 24,9 & 26,1 \\
\hline 18 & 18,4 & 20,4 & 23 & 26,3 \\
\hline 18 & 18,4 & 21,3 & 24,5 & 23 \\
\hline 15,3 & 15,7 & 17,8 & 20,5 & 26,8 \\
\hline 18,3 & 18,3 & 21,3 & 24,3 & 26,3 \\
\hline 18,3 & 18,8 & 22,1 & 24,3 & 26,2 \\
\hline 18,9 & 19 & 21,5 & 23,9 & $\mathbf{2 5 , 3 5}$ \\
\hline $\mathbf{1 7 , 9 9}$ & $\mathbf{1 8 , 0 9}$ & $\mathbf{2 0 , 7 3}$ & $\mathbf{2 3 , 2 3}$ & \\
\hline
\end{tabular}


Tabela 54. Dados referentes a análise de modelos de 10 pacientes selecionados ao acaso (Valores retirados da amostra total da fase final).

\begin{tabular}{c|c|c|c|c|c|c}
\hline PACIENTES & DISTAL.11 & DISTAL.13 & DISTAL.14 & DISTAL.15 & DISTAL.16 & DISTAL.17 \\
\hline 1 & 17,1 & 11,7 & 3,6 & $-3,7$ & -14 & $-25,6$ \\
\hline 2 & 16 & 10,5 & 3,6 & $-2,8$ & $-14,6$ & $-24,5$ \\
\hline 3 & 22 & 14,8 & 6,7 & $-0,4$ & -12 & $-23,3$ \\
\hline 4 & 18,6 & 14,3 & 7,8 & 1,9 & $-11,6$ & $-22,2$ \\
\hline 5 & 17 & 9,9 & 3 & $-3,5$ & $-17,4$ & $-27,7$ \\
\hline 6 & 19 & 14,2 & 7,9 & 0,2 & $-15,2$ & $-26,4$ \\
\hline 7 & 18,3 & 14,1 & 8,4 & 2,6 & $-10,8$ & $-19,8$ \\
\hline 8 & 19,7 & 11,7 & 5,1 & $-0,3$ & $-15,9$ & $-22,3$ \\
\hline 9 & 14,7 & 7,7 & 1,4 & $-6,1$ & $-18,7$ & $-28,2$ \\
\hline 10 & 19,2 & 17,3 & 9,2 & 1,9 & $-11,3$ & $-22,7$ \\
\hline MÉDIA & $\mathbf{1 8 , 1 6}$ & $\mathbf{1 2 , 6 2}$ & $\mathbf{5 , 6 7}$ & $\mathbf{- 1 , 0 2}$ & $\mathbf{- 1 4 , 1 5}$ & $\mathbf{- 2 4 , 2 7}$ \\
\hline
\end{tabular}

Tabela 54. Dados referentes a análise de modelos de 10 pacientes selecionados ao acaso (Valores retirados da amostra total da fase final).

\begin{tabular}{c|c|c|c|c|c|c}
\hline PACIENTES & DISTAL.21 & DISTAL.23 & DISTAL.24 & DISTAL.25 & DISTAL.26 & DISTAL.27 \\
\hline 1 & 18 & 12,5 & 3,7 & $-3,1$ & $-14,3$ & -26 \\
\hline 2 & 15,3 & 12,1 & 4,7 & $-1,5$ & $-13,3$ & -23 \\
\hline 3 & 20,3 & 13,7 & 6,3 & $-1,4$ & $-13,7$ & $-24,5$ \\
\hline 4 & 17,7 & 9,5 & 2,3 & $-4,4$ & $-17,8$ & $-28,6$ \\
\hline 5 & 16,7 & 9,5 & 3,4 & $-2,9$ & $-16,4$ & $-26,9$ \\
\hline 6 & 19 & 13,2 & 7 & $-0,9$ & $-18,9$ & -30 \\
\hline 7 & 16,8 & 9,7 & 4,1 & $-2,2$ & $-16,7$ & $-25,8$ \\
\hline 8 & 18,7 & 8,3 & 0,1 & $-7,2$ & $-20,1$ & $-29,4$ \\
\hline 9 & 13,7 & 6,4 & $-0,7$ & $-8,2$ & $-20,3$ & $-31,7$ \\
\hline 10 & 19,1 & 15,9 & 8,8 & 1,1 & $-13,5$ & $-23,8$ \\
\hline MÉDIA & $\mathbf{1 7 , 5 3}$ & $\mathbf{1 1 , 0 8}$ & $\mathbf{3 , 9 7}$ & $\mathbf{- 3 , 0 7}$ & $\mathbf{- 1 6 , 5}$ & $\mathbf{- 2 6 , 9 7}$ \\
\hline
\end{tabular}


Tabela 55. Dados referentes a remedição dos modelos de 10 pacientes (Fase final).

\begin{tabular}{c|c|c|c|c|c|c}
\hline Pacientes & DISTAL.11 & DISTAL.13 & DISTAL.14 & DISTAL.15 & DISTAL.16 & DISTAL.17 \\
\hline 1 & 16,9 & 11,2 & 3,7 & $-3,2$ & $-13,6$ & $-24,8$ \\
\hline 2 & 15,6 & 10,8 & 4 & $-2,6$ & $-15,2$ & -25 \\
\hline 3 & 22,2 & 14,4 & 7 & $-0,1$ & $-11,7$ & $-22,7$ \\
\hline 4 & 19 & 14,8 & 8,3 & 2 & -11 & $-21,2$ \\
\hline 5 & 16,8 & 9,8 & 3,2 & $-3,2$ & $-17,1$ & $-27,8$ \\
\hline 6 & 19,1 & 13,9 & 7,8 & 0,1 & $-15,2$ & $-26,4$ \\
\hline 7 & 19,7 & 14,5 & 9,1 & 3,2 & -10 & $-19,1$ \\
\hline 8 & 19,6 & 12,6 & 6,3 & $-0,2$ & $-15,2$ & $-21,5$ \\
\hline 9 & 15 & 7,8 & 1,7 & $-5,1$ & $-17,1$ & $-27,1$ \\
\hline 10 & 18,8 & 16,6 & 8,9 & 1,6 & $-11,6$ & $-23,1$ \\
\hline MÉDIA & $\mathbf{1 8 , 2 7}$ & $\mathbf{1 2 , 6 4}$ & $\mathbf{6}$ & $\mathbf{- 0 , 7 5}$ & $\mathbf{- 1 3 , 7 7}$ & $\mathbf{- 2 3 , 8 7}$ \\
\hline
\end{tabular}

Tabela 55. Dados referentes a remedição dos modelos de 10 pacientes (Fase final).

\begin{tabular}{c|c|c|c|c|c|c}
\hline Pacientes & DISTAL.21 & DISTAL.23 & DISTAL.24 & DISTAL.25 & DISTAL.26 & DISTAL.27 \\
\hline 1 & 17,6 & 11,5 & 2,9 & -4 & $-15,4$ & $-27,1$ \\
\hline 2 & 15 & 12,1 & 4,6 & $-1,6$ & $-14,7$ & $-24,1$ \\
\hline 3 & 20,4 & 13,5 & 6,2 & $-1,4$ & -14 & $-24,9$ \\
\hline 4 & 17,9 & 9,8 & 2,7 & $-4,8$ & $-18,4$ & $-28,7$ \\
\hline 5 & 16,7 & 9 & 3,1 & -3 & $-16,4$ & $-27,2$ \\
\hline 6 & 19 & 13,3 & 6,9 & $-0,8$ & $-18,9$ & -30 \\
\hline 7 & 18,4 & 11,2 & 4,7 & $-2,3$ & $-16,1$ & -25 \\
\hline 8 & 18,4 & 8,6 & 0,1 & $-8,1$ & $-21,5$ & -30 \\
\hline 9 & 13,7 & 6,3 & $-0,9$ & $-8,2$ & -20 & $-31,4$ \\
\hline 10 & 18,6 & 15,9 & 8,6 & 1,2 & $-13,5$ & $-23,8$ \\
\hline MÉDIA & $\mathbf{1 7 , 5 7}$ & $\mathbf{1 1 , 1 2}$ & $\mathbf{3 , 8 9}$ & $\mathbf{- 3 , 3}$ & $\mathbf{- 1 6 , 8 9}$ & $\mathbf{- 2 7 , 2 2}$ \\
\hline
\end{tabular}


Tabela 56. Dados referentes a análise de modelos de 10 pacientes selecionados ao acaso (Valores retirados da amostra total da fase final).

\begin{tabular}{c|c|c|c|c}
\hline EXPANS.13 & EXPANS.14 & EXPANS.15 & EXPANS.16 & EXPANS.17 \\
\hline$-18,4$ & $-18,8$ & -21 & $-18,4$ & $-26,6$ \\
\hline$-16,4$ & $-16,9$ & $-18,8$ & $-16,4$ & $-25,4$ \\
\hline$-18,9$ & -19 & $-22,7$ & $-18,9$ & -29 \\
\hline$-17,6$ & $-18,6$ & -21 & $-17,6$ & $-27,8$ \\
\hline$-17,4$ & $-18,1$ & $-20,2$ & $-17,4$ & $-25,3$ \\
\hline$-20,1$ & $-19,6$ & $-20,9$ & $-20,1$ & $-24,5$ \\
\hline$-16,8$ & -16 & $-18,5$ & $-16,8$ & $-26,5$ \\
\hline$-17,1$ & $-18,9$ & -23 & $-17,1$ & $-29,6$ \\
\hline$-15,5$ & $-16,7$ & $-19,7$ & $-15,5$ & $-26,2$ \\
\hline$-19,5$ & -19 & $-21,7$ & $-19,5$ & $-29,7$ \\
\hline$-17,77$ & $-18,16$ & $-20,75$ & $-17,77$ & $-27,06$ \\
\hline
\end{tabular}

Tabela 56. Dados referentes a análise de modelos de 10 pacientes selecionados ao acaso (Valores retirados da amostra total da fase final).

\begin{tabular}{c|c|c|c|c}
\hline EXPANS.23 & EXPANS.24 & EXPANS.25 & EXPANS.26 & EXPANS.27 \\
\hline 17,5 & 17,5 & 20,5 & 23,4 & 25,5 \\
\hline 15,8 & 15,5 & 17,3 & 20,6 & 23,7 \\
\hline 19,1 & 19 & 22,2 & 28 & 30,9 \\
\hline 19,8 & 20,5 & 23,2 & 26,9 & 28,4 \\
\hline 17,2 & 18,8 & 20,6 & 24,5 & 25,9 \\
\hline 18,5 & 18,3 & 20,9 & 25,6 & 28,5 \\
\hline 16,1 & 16,5 & 18,7 & 22,2 & 25 \\
\hline 18 & 18,6 & 21,2 & 24,9 & 29,8 \\
\hline 17,9 & 19,2 & 21,3 & 24,5 & 27,1 \\
\hline 20,5 & 19,5 & 21,7 & 25,2 & 27,2 \\
\hline $\mathbf{1 8 , 0 4}$ & $\mathbf{1 8 , 3 4}$ & $\mathbf{2 0 , 7 6}$ & $\mathbf{2 4 , 5 8}$ & $\mathbf{2 7 , 2}$ \\
\hline
\end{tabular}


Tabela 57. Dados referentes a remedição dos modelos de 10 pacientes (Fase final).

\begin{tabular}{c|c|c|c|c}
\hline EXPANS.13 & EXPANS.14 & EXPANS.15 & EXPANS.16 & EXPANS.17 \\
\hline-18 & $-18,7$ & -21 & -18 & $-26,7$ \\
\hline$-15,3$ & $-16,2$ & $-17,8$ & $-15,3$ & $-25,3$ \\
\hline$-18,8$ & -19 & $-22,8$ & $-18,8$ & $-28,8$ \\
\hline$-17,7$ & $-18,6$ & $-21,1$ & $-17,7$ & -28 \\
\hline$-17,5$ & $-18,1$ & $-20,1$ & $-17,5$ & $-25,3$ \\
\hline$-20,1$ & $-19,6$ & $-20,8$ & $-20,1$ & $-24,3$ \\
\hline$-15,3$ & -15 & $-17,6$ & $-15,3$ & $-26,8$ \\
\hline$-16,2$ & $-17,9$ & $-21,8$ & $-16,2$ & $-29,8$ \\
\hline$-15,5$ & $-17,2$ & $-20,4$ & $-15,5$ & $-26,3$ \\
\hline$-19,9$ & $-19,2$ & $-21,9$ & $-19,9$ & $-29,4$ \\
\hline$-\mathbf{1 7 , 4 3}$ & $-\mathbf{1 7 , 9 5}$ & $\mathbf{- 2 0 , 5 3}$ & $\mathbf{- 1 7 , 4 3}$ & $\mathbf{- 2 7 , 0 7}$ \\
\hline
\end{tabular}

Tabela 57. Dados referentes a remedição dos modelos de 10 pacientes (Fase final).

\begin{tabular}{c|c|c|c|c}
\hline EXPANS.23 & EXPANS.24 & EXPANS.25 & EXPANS.26 & EXPANS.27 \\
\hline 17,6 & 17,5 & 20,5 & 23,3 & 25,5 \\
\hline 16,2 & 15,5 & 17,6 & 21 & 23,9 \\
\hline 18,9 & 19 & 22,3 & 28,2 & 31,1 \\
\hline 19,4 & 20,4 & 23,2 & 26,8 & 28,3 \\
\hline 17,3 & 18,7 & 20,6 & 24,5 & 26 \\
\hline 18,6 & 18,4 & 21,1 & 25,7 & 28,6 \\
\hline 17 & 17,2 & 19,6 & 22,4 & 24,5 \\
\hline 19,1 & 19,4 & 22,2 & 25,4 & 29,8 \\
\hline 17,8 & 19,4 & 21,7 & 24,7 & 26,9 \\
\hline 19,6 & 19 & 21,6 & 25,4 & $\mathbf{2 7 , 2 3}$ \\
\hline $\mathbf{1 8 , 1 5}$ & $\mathbf{1 8 , 4 5}$ & $\mathbf{2 1 , 0 4}$ & $\mathbf{2 4 , 7 4}$ & \\
\hline
\end{tabular}


Tabela 58. Abertura de espaço medido diretamente nos modelos para o cálculo da taxa de distalização mensal.

\begin{tabular}{|c|c|c|}
\hline Pacientes & & \\
\hline 31 & $\begin{array}{l}\text { ABERTURA DE ESPAÇO LADO } \\
\text { DIREITO }\end{array}$ & $\begin{array}{c}\text { ABERTURA DE ESPAÇO LADO } \\
\text { ESQUERDO }\end{array}$ \\
\hline ALESSANDRA O & 7 & 8 \\
\hline ALESSANDRA V & 7,7 & 5,9 \\
\hline \begin{tabular}{l|} 
ANA LUCIA \\
\end{tabular} & 5 & 8 \\
\hline ARIELA & 6,8 & 5 \\
\hline BRUNA & 6 & 7 \\
\hline BRUNO & 7 & 5 \\
\hline$\overline{\text { CAMILA }}$ & 4 & 5 \\
\hline$\overline{C A S S I A}$ & 5,2 & 5,3 \\
\hline CINIRA & 6 & 7 \\
\hline CRISTIAN & 6,5 & 6 \\
\hline$\overline{D A N I E L}$ & 6 & 6,5 \\
\hline$\overline{F A B I O O}$ & 5,5 & 6,2 \\
\hline$\overline{\text { FABIO P }}$ & 5 & 5,5 \\
\hline GABRIELLE & 5 & 5,5 \\
\hline HELOISA & 5 & 5 \\
\hline HENRIQUE & 7 & 7,3 \\
\hline HERMANO & 6,2 & 5,5 \\
\hline JEFFERSON & 4 & 7 \\
\hline JULIANA & 4,5 & 5,5 \\
\hline LETICIA & 6 & 6 \\
\hline LIVIA & 5 & 3 \\
\hline LUCIANA & 7,2 & 6,8 \\
\hline LUIZ HENRIQUE & 6,9 & 6,9 \\
\hline \begin{tabular}{l|} 
MARIANA \\
\end{tabular} & 7,5 & 6,3 \\
\hline MICHELLE & 8,3 & 10 \\
\hline NATHALIE & 7,5 & 6,9 \\
\hline PAMELA & 7,5 & 5,5 \\
\hline RAFAELA & 7 & 9 \\
\hline RAQUEL & 6,2 & 5 \\
\hline STEFANI & 6 & 5,5 \\
\hline THAIZE & 8,5 & 8 \\
\hline MÉDIA & 6,23 & 6,29 \\
\hline
\end{tabular}

